\title{
"Remov[e] Us From the Bondage of South Africa:" Transnational Resistance Strategies and Subnational Concessions in Namibia's Police Zone, 1919-1962
}

\author{
Michael R. Hogan \\ West Virginia University, mrh0024@mix.wvu.edu
}

Follow this and additional works at: https://researchrepository.wvu.edu/etd

Part of the African History Commons

\footnotetext{
Recommended Citation

Hogan, Michael R., "'Remov[e] Us From the Bondage of South Africa:" Transnational Resistance Strategies and Subnational Concessions in Namibia's Police Zone, 1919-1962" (2021). Graduate Theses,

Dissertations, and Problem Reports. 8264.

https://researchrepository.wvu.edu/etd/8264

This Dissertation is protected by copyright and/or related rights. It has been brought to you by the The Research Repository @WVU with permission from the rights-holder(s). You are free to use this Dissertation in any way that is permitted by the copyright and related rights legislation that applies to your use. For other uses you must obtain permission from the rights-holder(s) directly, unless additional rights are indicated by a Creative Commons license in the record and/ or on the work itself. This Dissertation has been accepted for inclusion in WVU Graduate Theses, Dissertations, and Problem Reports collection by an authorized administrator of The Research Repository @ WVU. For more information, please contact researchrepository@mail.wvu.edu.
} 
"Remov[e] Us From the Bondage of South Africa:" Transnational Resistance Strategies and Subnational Concessions in Namibia's Police Zone, 1919-1962

Michael Robert Hogan

Dissertation submitted to the Eberly College of Arts and Sciences at West Virginia University in partial fulfillment of the requirements for the degree of

\author{
Doctor of Philosophy \\ In \\ History \\ Robert M. Maxon, Ph.D., Co-Chair \\ Tamba M'bayo, Ph.D., Co-Chair \\ Joseph M. Hodge, Ph.D. \\ James F. Siekmeier, Ph.D. \\ Jamie Shinn, Ph.D.
}

Department of History

Morgantown, West Virginia

2021

Keywords: Namibia, Transnational, Subnational, Resistance, Apartheid

Copyright 2021 Michael R. Hogan 


\section{ABSTRACT \\ "Remov[e] Us From the Bondage of South Africa:" Transnational Resistance Strategies and Subnational Concessions in Namibia's Police Zone, 1919-1962}

Michael R. Hogan

Between 1919 and 1962, the South African government implemented ever more restrictive segregationist and apartheid policies in South West Africa that attempted to control and monitor the social, political, and economic development of Namibians living in South West Africa's Police Zone. This dissertation examines the transnational resistance campaigns and strategies developed by Namibians living in the Police Zone and their attempts to dissolve and frustrate the colonial state's implementation of these policies. Particular focus is paid to such transnational institutions/actors as the League of Nations, the Universal Negro Improvement Association, the African Methodist Episcopal Church, the United Nations, and international student organizations across Scandinavia, the United States, and South Africa. This work argues that transnational resistance strategies were the primary tool used by Namibians in the Police Zone during the first half of the twentieth century and that these strategies were embraced because of the numerous opportunities created by centuries-old historical linkages connecting Namibians to the international community. Ideas, actors, resources, and institutions circulated across national boundaries and proved invaluable in Namibians' resistance campaigns. These transnational strategies ultimately helped Namibians secure subnational concessions and reforms from the colonial regime that improved their standard-of-living and counteracted the South African government's flagrant attempts to exploit and underdevelop Namibians living in the Police Zone. 


\section{Dedication}

To my fiancé Jaddah, who put her life on hold to support me in the pursuit of my dream. 


\section{ACKNOWLEDGEMENTS}

I would like to thank everyone that played a role in the completion of this dissertation. First, I would like to thank my co-chairs, Dr. Robert Maxon and Dr. Tamba M'bayo, for the countless hours they have put into directing and editing this dissertation. Their critical eye, quick responses, and suggestions have made this a truly enjoyable process. Without their help and insight this project could not have come to fruition. A special thank you to the other members of my dissertation committee, Dr. Jamie Shinn, Dr. Joseph Hodge, and Dr. James Siekmeier. Dr. Shinn's work with me through the geography department profoundly impacted my understanding of both physical and human geography and changed the way that I looked at issues of environmental security as they pertained to political and economic resistance strategies discussed in this dissertation. Similarly, Dr. Hodge's classes on the ideologies of empire and Dr. Siekmeier's suggestions surrounding my conceptualization of international diplomacy helped shape this study.

There are a few other professors on my academic journey that deserve some recognition for the completion of this work. I would like to thank Dr. Lamont King and Dr. David Owusu-Ansah of James Madison University for introducing me to African Studies and African History during my undergraduate years. It was your classes and teaching that placed me on this career path. Likewise, a heartfelt thank you is needed for Dr. Benedict Carton at George Mason University. He introduced me to Namibian history and was foundational in the beginning of this project. His class on a comparative history of the United States and South Africa was important in introducing me to Dr. Robert Vinson and Dr. Robert Edgar. The introduction to Dr. Vinson during the Fall 2015 semester was my first experience with transnational history as a concept and his guest lecture provided me with the conceptual framework that shaped this dissertation. Thank you to all of you for leading me to this moment.

The funding provided by the History Department at West Virginia University played an important role in facilitating this research project. The West Virginia University Dissertation Research Fellowship, the Doctoral Mini-Grant, and the African Studies Scholarship allowed me to travel to Windhoek, Geneva, Basel, Stockholm, Oxford, Chapel Hill, and New York to conduct this transnational study. Without this funding, this dissertation could not have come to fruition.

A countless number of librarians archivists made this dissertation possible. A special thank you to Beauty Matongo for her patience and granting me access to the archival collections at the National Archives of Namibia. I would also like to thank Martha Nakanyala for teaching me how to use the National Archives finding aids, Albertian Nekongo for helping reproduce images of archival documents, and Ralph Ntelamo for going into the archival stacks every day to retrieve my numerous document requests. I greatly appreciate Dr. Dag Henrichsen's communication with me throughout the summer of 2019 and the effort he put in to help me go through the documents at Basler Afrika Bibliographien. Your willingness to sit with me and go over foreign language documents saved me valuable time and your suggestions for further reading filled out some of the historiographical gaps in the dissertation. Lastly, I would like to thank the Wilson Library's Special Collections staff at the University of North Carolina-Chapel Hill for reproducing the 
audiotapes in the Allard Lowenstein Collection and Jacques Oberson for providing me with access to the League of Nations Archives on less than a week's notice.

Finally, I would like to thank my family for the emotional and financial support they have provided during this 11-year journey. I would like to thank my fiancé Jaddah for putting her life on hold and moving to Morgantown with me for the past 5 years. Thank you to my parents, Vickie and Michael, for their financial help throughout the pandemic and for the continued emotional support they have provided during the toughest days of this dissertation writing process. Lastly, I would like to thank my brother, Matthew, for encouraging me to continue on this academic path and for the interest that he has shown in my studies. His encouragement has been invaluable. 


\section{Table of Contents}

Chapter 1: South West Africa and Its Changing Colonial Context-Historical Background and Methodological Considerations .......................................................................................

South African Rule in South West Africa, 1921-1966 .....................................................4

The African Resistance Historiography and the Changing Conception

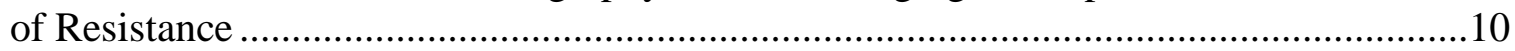

The Development of the Namibian Resistance Historiography and this

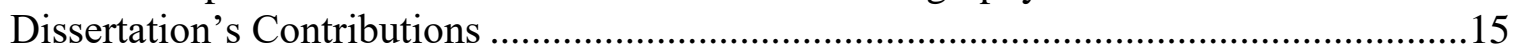

Transnational History as a Conceptual Framework for Namibian

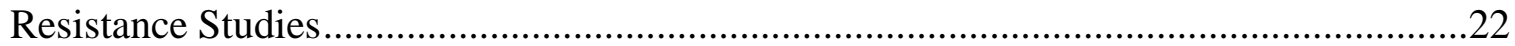

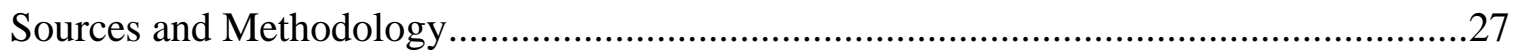

Temporal and Spatial Limitations of the Study ..............................................................36

Ethnicity and Geopolitics in Namibia's Police Zone........................................................40

Subnationalism and Nationalism in Namibia's Police Zone, 1919-1962 ..........................48

Structure of the Dissertation .......................................................................................57

Chapter 2-A New Type of Resistance: The Rehoboth Baster's Petition-Writing Campaign to

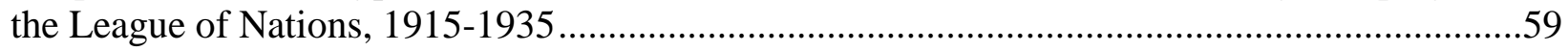

Establishment of the Rehoboth Baster Community in Namibia, 1870-1915.....................61

The Creation of the League of Nations and Mandate System in

South West Africa, 1916-1920 ......................................................................................71

The Extension of South African Rule and Conflicts in the Police Zone, 1920-1923 ........81

The Transnational Resistance Strategies of the Rehoboth basters, 1923-1935 ….............91

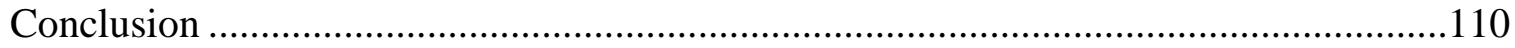

Chapter 3-“The Herero Claim it for Themselves Alone:" Subnationalism and the Rise and Fall of the UNIA in South West Africa, 1921-1924 ............................................115

Marcus Garvey: The Development of His Pan-African Thought ....................................120 
The UNIA: Its Structure and Growth in North America

The UNIA in South Africa

The UNIA Arrives in South West Africa: Racial Unity and Subnationalism in the Police Zone.

The Rise of Herero Leadership in the UNIA and the Problem of Subnationalism, 1922-1924. 154

Conclusion 168

Chapter 4 - Comparative White Politics and Apartheid in Southern Africa, 1919-1964.

Samsmelting and Changes in Late-Nineteenth- and Twentieth-Century

Afrikaner Politics..

Interwar White Politics in South West Africa, 1919-1939

The Incorporation of South West Africa and the Failed Referendum of 1946 198

The Rise of D.F. Malan and the Implementation of Apartheid in South Africa, 1945-1955

De Facto Incorporation and the Introduction of Apartheid in South

West Africa, 1949-1964.

Conclusion

Chapter 5-“They Do Not Want to be Dominated and Suppressed by Europeans in Church Affairs:" The Nama Secession of 1946 and the Rise of the AME Church in South West Africa.

The Problematic Relationship Between the RMS and the Colonial Government, 1828-1921.

Trans-Atlantic Evangelism and the Rise of the AME Church in the United States and South Africa, 1735-1908.

Background to the Early Interactions Between Namibians and the AME Church, 1904-1945. .251

The Causes and Justifications for the Nama Secession of 1946. .258

The Establishment of AME Church Schools in South West Africa and the Quest for State Recognition, 1948-1960. 
Conclusion

Chapter 6-Forced Land Removals and International Pressure Campaigns: Namibians' Petitions to the United Nations, 1945-1959.

The Transition from the League to the United Nations: A Change in South

West Africa's International Status

The UN Comes to South West Africa: Rev. Michael Scott and the Origins of the Namibian Petition-Writing Campaigns.

The Aminuis Corridor Affair: Hosea Kutako's Petition-Writing Campaign to the United Nations

Imaginary Pelt-Thefts and Arbitrary Police Brutality: The Attempted Forced

Removal at Hoachanas, 1956-1959....

Conclusion

Chapter 7-International Student Politics and the Anti-Apartheid Movement, 1950-1962 _......328

The Development and Foundation of the Global Anti-Apartheid Movement in the 1950 s.

Black Nationalist Politics at the University: Kozonguizi, Fort Hare, and the

Emergence of Namibian Student Activism....

The "Hans Beukes Case" and Covert Student Resistance in 1950s

Southern Africa.

Eyewitnesses to Apartheid: Namibian Students' Testimony Before the

UN General Assembly in October 1959 .366

Conclusion

Chapter 8-Transnational Strategies and Subnational Concessions in the Pre-SWAPO Period: A Conclusion

Embracing Transnational Resistance: Namibians’ Motivations and Reasoning

Finding the Subnational in the Transnational: Subnational Concessions and the Success of Transnational Resistance Strategies in the Police Zone.

Conclusion

Bibliography 


\section{List of Tables}

Table 4.1: Results of Consultations with Non-Europeans in South West Africa

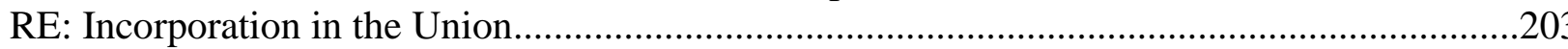




\section{List of Maps}

Map 1: Reproduction of "Map of the Area to be Placed Under Governmental Protection (1907)" '.............................................................................................................

Map 2: The Baster Migration from Amandelboom in 1861 to Rehoboth in 1870 .........................64

Map 3: Hotbeds of UNIA Activity in South West Africa, 1922-1924 ......................................160

Map 4: Locations of Proposed AME Schools in 1950s South West Africa .................................231

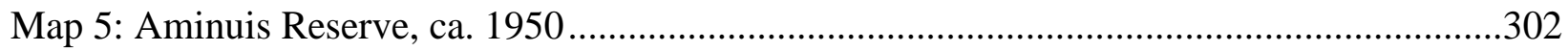

Map 6: The Route of SWAPO Commander Helao Shityuwete into Exile in 1964 as an Example of the "Inevitable Pipeline into Exile". 


\section{List of Abbreviations}

AACRLS -- Archives of Anti-Colonial Resistance and the Liberation Struggle

AAM -- Anti-Apartheid Movement

ACS -- American Colonization Society

AGS -- Africa Groups of Sweden

AME -- African Methodist Episcopal

ANC -- African National Congress

AP -- Afrikaner Party

BBV -- Zuid-Afrikaanse Boeren Beschermings Vereniging

CAF -- Central African Federation

CAO -- Committee of African Organizations

CPSA -- Communist Party of South Africa

DAP -- Deutsche Afrikanische Partei

DSWB -- Deutscher Sudwest Bund

GNP -- Gesuiwerde Nasionale Party

GRA -- Genootskap van Regle Afrikaners

HBCUs -- Historically Black Colleges and Universities

HCC -- Herero Chiefs' Council

HNP -- Herenigde Nasionale Party

ICJ -- International Court of Justice

ICU -- Industrial Commercial Workers' Union

IDAF -- International Defense and Aid Fund

ISF -- International Solidarity Fund

LMS -- London Missionary Society

NAD -- Native Affairs Department

NAMA -- Norwegian Action Against Apartheid

NEUM -- Non-European Unity Movement

NGK -- Dutch Reformed Church in South Africa

NOCOSA -- Norwegian Council for Southern Africa

NP -- National Party

NPSWA -- National Party of South West Africa

NSDAP -- Nationalsozialistische Deutsche Arbeiterpartei

NSM -- New Social Movement

NSA -- United States National Student Association

NSU -- Norwegian National Union of Students

NUSAS -- National Union of South African Students

NUSWAS -- National Union of South West African Students

OB -- Ossewabrandwag

OPO -- Ovambo Peoples Organization

PMC -- Permanent Mandates Commission

RMS -- Rhenish Mission Society

SAK -- Central Organization of Finnish Trade Unions

SANC -- South African Native Congress

SAP -- South Africa Party

SFS -- Swedish National Union of Students 
SRC -- Student Representative Council

SSAK -- Swedish South Africa Committee

SWAA -- South West Africa Administration

SWANC -- South West Africa National Congress

SWANU -- South West Africa National Union

SWAPA -- South West Africa Progressive Association

SWAPO -- South West Africa People's Organization

SWASB -- South West Africa Student Body

SWAUNIO -- South West Africa United National Independence Organization

UCT -- University of Cape Town

UDC -- Union of Democratic Control

UN -- United Nations

UNCIO -- United Nations Conference on International Organization

UNIA -- Universal Negro Improvement Association

UNISA -- University of South Africa

UNSWP -- United National South West Party

UP -- United Party

VCF -- Veterinary Cordon Fence

VP -- Volksparty 


\section{Chapter 1-South West Africa and Its Changing Colonial Context: Historical Background and Methodological Considerations}

The entrenchment of the South African government's illegal occupation of South West Africa, as well as the later development and extension of its apartheid policies, characterized the colonial experience in the territory between 1915 and 1966. Necessarily, Namibians developed complex resistance strategies to the colonial state that mobilized people and resources on the subnational, national, and transnational levels. Resistance by Namibians in the Police Zone during this period centered on political and social autonomy at both the national and subnational levels, overturning forced land expropriations, and increasing economic and educational opportunities. ${ }^{1}$ This dissertation analyzes how these domestically-marginalized actors developed transnational networks, through which they organized strategic resistance campaigns to the extension of segregationist and apartheid policies in South West Africa. The primary focus of this work is how these actors affected subnational political and socioeconomic change through the use of transnational churches, student organizations, and supranational political bodies as a means to temper and alter the behavior and policies of the colonial state. This dissertation argues that transnational resistance strategies were the primary tool used by Namibians in the Police Zone during the first half of the twentieth century and that these strategies were embraced because of the numerous opportunities created by historical linkages connecting Namibians to the international community. Great attention to detail will be paid in discussing the historical actors, key events and transformations in the political and socioeconomic sphere, and the

\footnotetext{
${ }^{1}$ The Police Zone constituted the lower two-thirds of the South West Africa territory. In this area, German and South African colonial police were able to establish police control over the territory constituting the "colonial heartland" and promise South West Africa's white population protection from much larger African populations on the "colonial frontier." For a more in-depth discussion on the Police Zone and the reasons for limiting this dissertation's scope to this area can be found on pages 35-39.
} 
convictions that defined these resistance strategies and shaped Namibian history between 1919 and 1962.

Map 1: Reproduction of "Map of the Area to be Placed Under Governmental Police Protection (1907)"

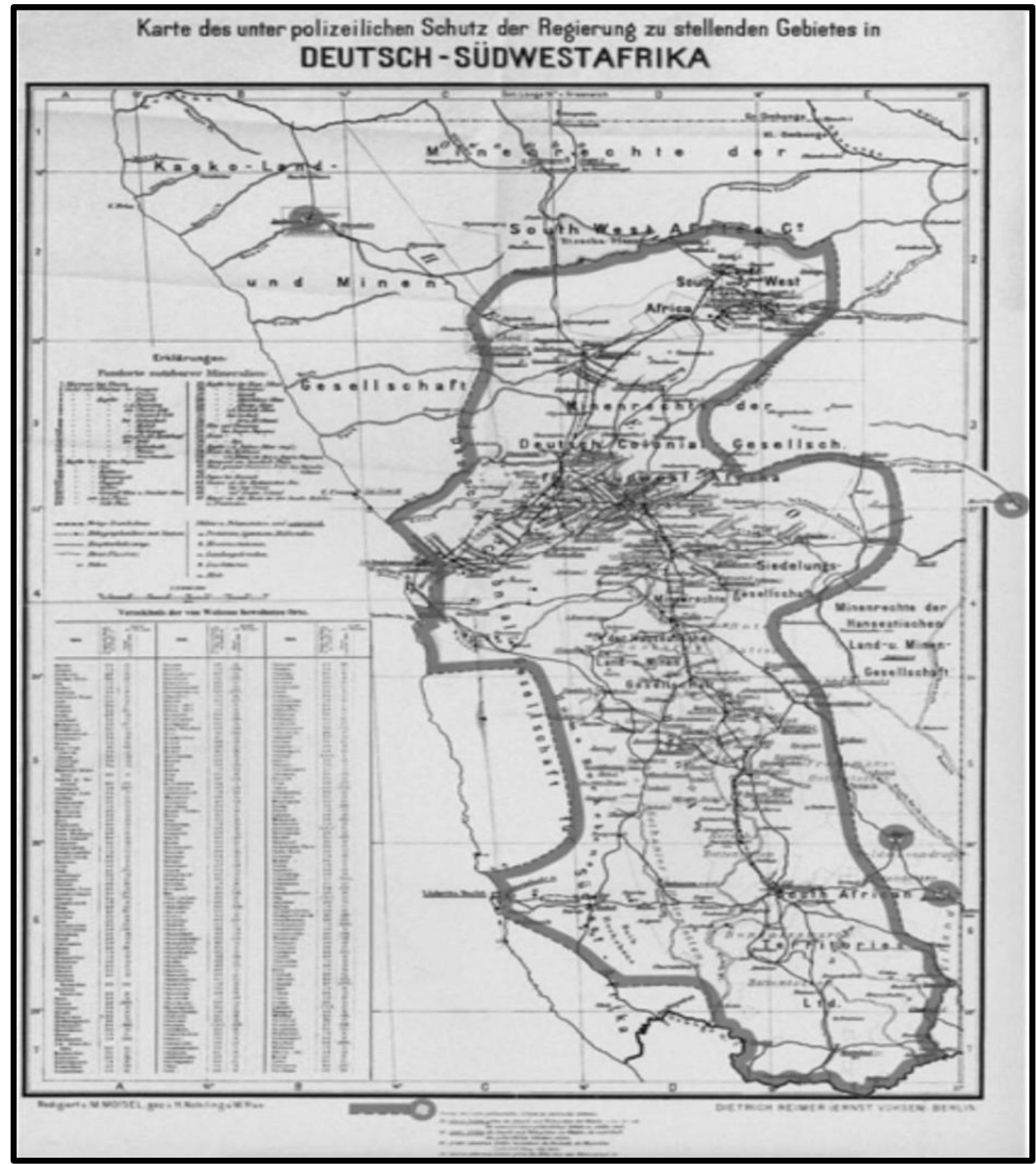

Source: Giorgio Miescher, Namibia's Red Line: The History of a Veterinary and Settlement Border (New York: Palgrave Macmillan, 2012), 45. 
This work examines five key transnational institutions that helped facilitate and aid Namibians' complex resistance strategies to the extension of South African colonial rule. Between 1919 and 1945, the League of Nations and the Universal Negro Improvement Association (UNIA) were the primary transnational bodies that interacted with Namibians in the Police Zone. The League of Nations mandate granted to the South African government in 1921 provided the Rehoboth Basters with a means to legally challenge the loss of their political autonomy and the UNIA provided Herero and Nama leaders with access to an international resource pool and community that lobbied for African independence in the Police Zone. ${ }^{2}$ During the apartheid period in South West Africa, and prior to the formation of the nationalist South West Africa People's Organization (SWAPO) in 1960, several transnational institutions were heavily involved in South West Africa's affairs. The 1940s saw the rise of the African Methodist Episcopal (AME) Church in the predominantly Nama areas of the Police Zone and Namibians used its resources and networks of transnational actors to fight for an improved quality of education for the African population. Likewise, the creation of the United Nations (UN) in 1945 provided Namibian petition-writers with an outlet to express their grievances over forced land expropriations. This gave them an avenue to leverage international political pressure against the South African regime and force it to acquiesce to their demands. Lastly, scholarships provided by foreign colleges and international student organizations created a framework for an intelligentsia in exile and placed critical political actors outside of the reach of the South African government's recourse. These five institutions form the core of this dissertation and are

\footnotetext{
${ }^{2}$ The Nama, Herero, and Basters were the three primary ethnic groups in Namibia's Police Zone. More detail on Herero and Nama ethnicity is provided on pages 39-46 and the Basters are discussed at length on pages 61-71 of this dissertation.
} 
emblematic of the transnational character of Namibians' resistance strategies in the pre-

nationalist period. Each of these resistance strategies is examined in-depth in the following chapters, but first historical context on South West Africa's colonial period under South African rule is summarized.

\section{South African Rule in South West Africa, 1921-1966}

The surrender of the German military to South African forces on 9 July 1915 effectively ended the German government's brutal colonial rule over South West Africa and represented a pivotal moment of hope and potential for political and socioeconomic reform. ${ }^{3}$ German colonial rule began in South West Africa in 1884 with the establishment of a government protectorate over Angra Pequeña and the extension of German jurisdiction into Damaraland and Greater Namaqualand. ${ }^{4}$ Merchants and other agents of the German government concluded uneven land treaties and agreements that, by 1907, effectively granted the German government immense control over the entire territory south of the Ovambo polities at the Angola border. In the face of Herero and Nama resistance to the imposition of German rule, the German government perpetrated the Herero-Nama Genocide between 1904 and 1907. In carrying out the genocide, the German military effectively de-populated south and central Namibia and severely weakened Namibians' ability to successfully rebel against German rule. ${ }^{5}$

\footnotetext{
${ }^{3}$ David Stone, The Kaiser's Army: The German Army in World War One (London: Conway, 2014), 76-77.

${ }^{4}$ Damaraland is the north-central part of South West Africa that stretched from Windhoek in the south to Ovamboland in the north and was bounded by the Kalahari Desert in the east and the Namib Desert in the west. The Orange River divides Namaqualand, with Greater Namaqualand resting to the north of the river and Little Namaqualand to the south.

5 Jeremy Sarkin-Hughes, Germany's Genocide of the Herero: Kaiser Wilhelm II, His General, His Settlers, His Soldiers (Cape Town: University of Cape Town Press, 2011), 137-138. Sarkin-Hughes references a number of studies in his analysis of the demographic impact of the genocide. He references Helmut Bley's Namibia Under German Rule, where he argues that between 75 and 80 percent of the Herero population was killed or went into exile. On those same pages, he points to Horst Drechsler's Let Us Die Fighting: The Struggle of the Herero and Nama Against German Imperialism, which states that nearly 81 percent of the Herero population was killed or
} 
The South African military occupation of the territory between 1915 and 1919 occurred with the use of minimal resources and, as a result, lessened the power of the colonial state to check Namibians' movements and activities. Historian Marion Wallace described this period of minor liberalization, writing "Overall, in the short term the arrival of the South Africans greatly facilitated African access to land and stock, and the tentative repastoralization that had begun in the latter years of German rule was tremendously hastened and reinforced."6 Africans established new pastoral settlements near Windhoek, 139 Namibian stock owners acquired grazing licenses to increase the size of their herds, and new Namibian communities and settlements emerged on crown lands. ${ }^{7}$ Similarly, pre-genocide leadership structures were reconstituted or reformulated in the early years of the South African occupation. For example, Edward Frederick returned to Bethanie, and Isaak Witbooi returned to Gibeon following their imprisonment. ${ }^{8}$

While Namibians worked to re-establish these previous structures and institutions, South West Africa was classified as a "Class-C Mandate" following the signing of the Treaty of Versailles on 28 June 1919 and, despite the initial phase of increased optimism and potential for a return to precolonial sociopolitical structures, the possibility of subnational, or even national, independence quickly faded between 1919 and $1921 .{ }^{9}$ The early years of South African control

displaced. Lastly, Harry Schwirck's study “Law's Violence and the Boundary Between Corporal Discipline and Physical Abuse in German South West Africa," is also mentioned. The figures in Schwirck's work suggest that nearly 85 percent of the Herero population was killed and almost 50 percent of the much smaller Nama population was also exterminated. The term "successfully rebel" is used here to mean the overthrow of the German colonial government in the territory.

${ }^{6}$ Marion Wallace, A History of Namibia: From the Beginning to 1990 (New York: Oxford University Press, 2013), 212.

${ }^{7}$ Ibid.

${ }^{8}$ Ibid. Edward Frederick survived the concentration camps at Shark Island and returned to lead the community at Bethanie in 1916. Isaak Witbooi was the son of Hendrik Witbooi. See Casper W. Erichsen, What the Elders Used to Say: Namibian Perspectives on the Last Decade of German Colonial Rule (Windhoek: Namibian Institute for Democracy, 2008), 32-42 for a fuller discussion of Frederick's treatment.

${ }^{9}$ The mandate system was set forth in Article 22 of the League of Nations Covenant. In reference to Class C Mandates, the text reads, "There are territories, such as South-West Africa and certain of the South Pacific Islands, which, owing to the sparseness of their population, or their small size, or their remoteness from the centers of civilization, or their geographical contiguity to the territory of the Mandatory, and other circumstances, can be best 
mirrored their wartime rule, in that the government lacked the manpower and resources to fully control and subdue the Namibian population. Thus, the martial law period in South West Africa was "in many ways, a time of hope for the African population of the Police Zone, many of whom seem to have genuinely expected that the new colonial masters would return land confiscated by the Germans." ${ }^{10}$ However, this turning of a "blind eye" to the African re-occupation of fertile and productive lands was short-lived and the "new regime had...no intention of returning wellwatered land to the Africans of the Police Zone."11

The South African government ended its military rule over South West Africa on 1 January 1921 and became the mandatory power responsible for overseeing the continued development of the territory. In its capacity as colonial power between 1921 and 1966, the South African government instituted a litany of segregationist and apartheid policies that sought to restrict the mobility of the Namibian population and limit their political, social, and economic opportunities in the territory. ${ }^{12}$ As more resources and manpower were poured into South West Africa in the subsequent decades, the South African government quickly developed a restrictive and highly effective state apparatus to systematically monitor and control the Namibian population. The socioeconomic and political situation for Namibians in the territory rapidly deteriorated as economic and political opportunities disappeared and the standard of living plummeted.

\footnotetext{
administered under the laws of the Mandatory as integral portions of its territory, subject to the safeguards above mentioned in the interests of the indigenous population." The mandate system is described in greater detail on pages 71 through 81 of this dissertation.

${ }^{10}$ Wallace, A History of Namibia, 213.

${ }^{11}$ Ibid.

${ }^{12}$ Specific examples of segregationist policies implemented during the Inter-War Period can be found on pages 81 through 91 of this dissertation, while chapter 4 provides an in-depth analysis of the apartheid policies established after 1948.
} 
The situation in South West Africa was abysmal for its Namibian residents on a number of levels under the South African occupation. During the Interwar Years, the newly appointed South African mandatory government focused primarily on controlling the movement of Namibians and the expropriation of African-inhabited lands. In the early 1920s, the South African government's Native Reserve Commission re-established the former German reserves and created new reserves to displace the Namibian populations from fertile lands, clearing the way for white settlement in the Police Zone. ${ }^{13}$ The new reserves further exacerbated the bleak economic outlook for Namibians during the period, as most of the new reserves were placed on tracts of land that possessed limited water resources and were unable to support the sizable displaced populations. Further compounding the poor economic situation for Namibians in the territory was the drought of the 1920s, the South African government's unwillingness to aid Africans in need of financial assistance, and the coming global economic depression. The drought negatively impacted the agricultural sector of the South West African economy. Whereas whites in the territory had access to loans and state-sponsored subsidies from the Union, Namibians were left to deal with the impending recession on their own. ${ }^{14}$ The result was an intense state of poverty and hardship for South West Africa's African population.

The Namibian population fared even worse under South Africa's apartheid government between 1949 and 1966. The government continued to economically marginalize Namibians by ordering a series of forced land removals in the 1950s and introducing the Wage and Industrial

\footnotetext{
${ }^{13}$ Reinhart Kössler "From Reserve to Homeland: Local Identities and South African Policy in Southern Namibia," Journal of Southern African Studies 26, No. 3 (September, 2000): 447-452.

${ }^{14}$ Wallace, A History of Namibia, 215-232. The term "Union" is used hereafter to refer to the South African government after 31 May 1910. In 1909, the South Africa Act effectively unified the Cape Colony, Natal, Transvaal, and the Orange Free State into one unitary nation. A constitution was created and an entirely white government was formed and headed by a prime minister and a bicameral parliament. The parliament consisted of the 40 -member Senate and the 121-member House of Assembly. The senate possessed eight members from each of the former colonies plus an additional eight members, four of which served as representatives for non-whites in the Union. The House of Assembly was set to expand to 150 members as the Union's population continued to grow.
} 
Conciliation Ordinance of 1952 to bar Namibians from joining trade unions and other organizations that sought to protect workers' legal rights. ${ }^{15}$ Likewise, a pass system was further entrenched during the post-World War II period and Namibian movement was heavily monitored. This new system helped facilitate the implementation of an extensive migratory labor system that sustained South West Africa's white settler economy and continued to pump its revenues into the South African economy.

The apartheid government also delved more deeply into the social sphere. In 1949, whites in South West Africa gained the ability to elect representatives directly to the South African Parliament, while Namibians were still prevented from participation in the election process. The South African government successfully segregated the public sphere by introducing the Prohibition of Mixed Marriages Act of 1949 and the Reservation of Separate Amenities Act of 1953 that required Africans to use separate public facilities than their white counterparts. This enforced segregation carried over into the rural areas as well, with the development of an ethnically-based reserve policy that created ethnic homelands and attempted to divide the Namibian population to make it more manageable. ${ }^{16}$ In all instances, the legal and economic structure imposed on the African population of South West Africa sought to marginalize and impoverish, creating stagnant populations that participated in the monetary economy as a cheap labor pool with few rights and means for recourse.

The deplorable colonial situation that Namibians faced resulted in dynamic resistance campaigns against the implementation and extension of the South African government's restrictive apartheid apparatus. There were undoubtedly a number of domestic resistance

\footnotetext{
${ }^{15}$ Gwyneth Williams and Brian Hackland, The Dictionary of Contemporary Politics of Southern Africa (Abingdonon-Thames: Routledge, 2015), 282.

${ }^{16}$ Kössler, "From Reserve to Homeland," 447-462.
} 
campaigns that attempted to redress violations by the colonial government. In 1922, the

Bondelswarts rebelled against over-taxation and participated in an armed struggle against the colonial regime. In 1923 and 1925, respectively, the Witboois managed to successfully resist a forced removal from Gibeon to Tses, and Hosea Kutako prevented the forced removal of the Herero to inhospitable land at Epikuro. The 1940s and 1950s were likewise characterized by local resistance movements against forced removals and, by the 1960s, regional and national political organizations and workers' unions formed in South West Africa to provide Namibians with an outlet through which they could make claims of the colonial government. ${ }^{17}$

Although Namibians developed domestic resistance campaigns to varying degrees of success, transnational resistance strategies flourished in the Police Zone between 1919 and 1962. During this period, Namibians in the Police Zone fought against the extension of South Africa's colonial rule by drawing on historical linkages and networks with organizations and institutions in Europe and the Americas. In the 1920s, the Rehoboth Basters worked through transnational actors to make claims of both the League of Nations and the South African government to reestablish their political sovereignty at Rehoboth. That same decade, the UNIA sent agents to Lüderitz to develop relationships with Namibian laborers and political and religious leaders in an attempt to gain independence for the South West Africa territory. The 1940s and 1950s saw a continuation of this strategy as well. The AME Church spread to the Nama polities in the mid1940s and quickly became an institution through which Namibians advocated for improved educational opportunities and made claims of permanent settlement on the land. ${ }^{18}$ Nearly a decade later, these same leaders began a petition-writing campaign to the UN that sought aid

\footnotetext{
${ }^{17}$ Wallace, A History of Namibia, 224-225.

${ }^{18}$ Peter Katjavivi, Kaire Mbuende, and Per Frostin, eds. Church and Liberation in Namibia (London: Pluto Press, 2008), 7-9. 
from the international community and requested that they exert pressure on the South African government to temper and halt the forced land removals in the Police Zone.

This dissertation is concerned primarily with the aforementioned transnational resistance strategies that developed between the end of World War I and the formation of the national political parties in the 1960s. At the center of this project are five crucial questions. To what extent and in what ways did Namibians utilize transnational organizations, institutions, and networks in their efforts to dissolve or frustrate the colonial apparatus of the South African regime? Why did Namibians embrace transnationalism as a means of resistance and were these transnational strategies part of a larger coordinated campaign in the territory? How did Namibians develop, use, and maintain these transnational networks across time and space and what were the power dynamics like within these networks? What subnational concessions and reforms did Namibians demand from the colonial state and international community and did these campaigns succeed or fail to achieve the stated goals of the movements' leaders? Lastly, how did subnational geopolitical structures and considerations factor into these resistance strategies and were these strategies inclusive of, or exclusive to, the different groups living in the Police Zone? In answering these questions, this work provides a thorough examination of the transnational resistance strategies employed by Namibian actors and analyzes their varying degrees of success in altering the behavior and policies of the colonial state.

\section{The African Resistance Historiography and the Changing Conception of Resistance}

The historiography surrounding African resistance to colonial rule has evolved significantly as the field of African History has grown over the past 60 years. As the field emerged in the late-1950s and early-1960s, the scholarly conceptualization of resistance centered 
on a dichotomy that labeled African actors as either resistors or collaborators. The publication of Independent African in 1958, an examination of the resistance campaign waged by John Chilembwe against colonial authorities in Nyasaland, set the stage for numerous subsequent works that portrayed African resistors as reactionaries to colonial activity and collaborators as prudent operators that possessed a stronger grasp of the situation at hand.${ }^{19}$ Ronald Robinson and John Gallagher further cemented the two antipoles of resistor and collaborator, the former viewed as romantic and unsuccessful proto-nationalists and the latter as practical and far-sighted actors. $^{20}$

By the late-1960s, after most African nations achieved independence and began the process of nation-building, scholars viewed the aforementioned dichotomy as a gross oversimplification of a nuanced and complex subject. Scholars during this period argued for a middle-path between resistance and collaboration, termed “accommodation." Terrance Ranger's 1969 contribution to The History and Politics of Colonialism in Africa outlined this concept, arguing that the choice to resist or collaborate was often a calculated decision given one's circumstances and that societies could fluctuate between the two positions in quick succession. Ranger contended, "Some resisting societies desperately attempted to avoid the necessity of resistance. Some cooperating societies made it plain that they were ready to resist if their cherished privileges were attacked." 21 Thus, accommodation provided a dynamic, rather than static, analytical tool that could effectively account for African actors' changing agency.

\footnotetext{
${ }^{19}$ George Shepperson and Thomas Price, Independent African: John Chilembwe and the Origins, Setting, and Significance of the Nyasaland Native Rising of 1915 (Edinburgh: Edinburgh University Press, 1958).

${ }^{20}$ Ronald Robinson and John Gallagher, "The Partition of Africa," in The New Cambridge Modern History, ed. F.H. Hinsley, (Cambridge: Cambridge University Press, 1962), 639-640.

${ }^{21}$ T.O. Ranger, "African Reaction to the Imposition of Colonial Rule in East and Central Africa," in The History and Politics of Colonialism in Africa, eds. L.H. Gann and P. Duignan (Cambridge: Cambridge University Press, 1969), 304.
} 
Africans could fluctuate between resistance and collaboration, depending on the given historical context at a particular time.

A common criticism of the resistance scholarship that emerged in the 1970s argued that the historiography centered too much on the political sphere and conceptions of resistance were too closely linked to the nationalist movements. Jonathon Glassman argued in Feasts and Riots that "the historical resistance literature was marred by a teleology that constructed all African protest as leading inexorably to modern nationalism and decolonization." 22 Furthermore, the resistance studies of the 1950s and 1960s focused too intently on armed resistance and rebellion, ignoring various types of resistance that emerged outside of the political sphere. During the 1970s and 1980s, that focus shifted, and the concept of resistance grew and expanded. In these decades, scholars diverted their attention from uncovering the roots of nationalism and instead analyzed the concept of systemic underdevelopment that had occurred in African society. As a result, analysis shifted away from the intelligentsia and heroic nationalist leaders and scholars delved more deeply into the mass movements of the period and the activities of the peasantry.

James C. Scott's Weapons of the Weak, despite its focus on Malaysian peasant resistance, provided one of the most influential theoretical and conceptual shifts in the ways that historians understood and analyzed resistance. Scott's work centered on the dynamics of peasant resistance and moved away from academia's focus on the acts of resistance themselves and, instead, on the intention of the action. In Scott's conception of resistance, everyday activities like arson, sabotage, individual boycotts, and foot-dragging also became acts of resistance. These acts were

\footnotetext{
22 This quote is a summary of Glassman's work found in Klaas van Walraven and Jon Abbink, "Rethinking Resistance in African History: An Introduction," in Rethinking Resistance: Revolt and Violence in African History, eds. Gerrit Jan Abbink, Mirjam De Brujin, and Klaas Van Walraven (Leiden: Brill Publishers, 2003), 2. See Jonathon Glassman, Feasts and Riot: Revelry, Rebellion, and Popular Consciousness on the Swahili Coast, 18561888 (Portsmouth: Heinemann, 2016), 12.
} 
part of a long struggle against the wealthier classes in society that took place "backstage" to avoid outright conflict and win peasants concessions and reform within the existent socioeconomic system. ${ }^{23}$ Weapons of the Weak, and other works published on peasant resistance in Africa during the mid-to-late 1980s, expanded the definition of resistance from rebellion and protest against colonial authority to "include everything from foot-dragging and dissimulation to social banditry, arson, poaching, theft, avoidance of conscription, desertion, migration, and riot." 24

Despite Scott's focus on class relations, the 1990s and 2000s saw an increase in scholarly works that used the now-expanded definition of resistance to analyze its impact on the various spheres of colonial life. Jean and John Comaroff's work on the relationship between symbology, religion, and resistance perhaps best represent this shift in the studies of colonial South Africa. The publication of Body of Power, Spirit of Resistance encapsulated the spirit of Scott's “everyday resistance," but expanded its scope beyond class relations to include issues of symbology, cosmology, and healing. Jean Comaroff contended that the Tshidi construction of an Africanized Christian symbology gave them the ability to confront their lived colonial experiences through the creation of a conscious system of signs and practices, resulting in the ability to manipulate and address their position in the physical world. ${ }^{25}$ Similarly, Of Revelation and Revolution looked at the everyday negotiations that occurred between African social practices and colonial demands of modernity as acts of resistance and accommodation. ${ }^{26}$ In both

\footnotetext{
${ }^{23}$ James C. Scott, Weapons of the Weak: Everyday Forms of Peasant Resistance (London: Yale University Press, 1985).

${ }^{24}$ Donald Crummey, Banditry, Rebellion, and Social Protest in Africa (Suffolk: James Currey, 1986$), 195$.

${ }^{25}$ Jean Comaroff, Body of Power, Spirit of Resistance: The Culture and History of a South African People (Chicago: University of Chicago Press, 1985). The Tshidi are a subgroup of the Barolong cluster of the southern Tswana people. They are located primarily in the Mafeking district in the northern Cape province.

${ }^{26}$ Jean Comaroff and John Comaroff, Of Revelation and Revolution, Volume 1: Christianity, Colonialism, and Consciousness in South Africa (Chicago: University of Chicago Press, 1991) and Jean Comaroff and John Comaroff,
} 
cases, these works represented the coming shifts in historians' definitions of resistance to colonialism in Africa.

Resistance studies of the past decade have picked up this mantle and continue to explore the diverse and nuanced nature of African resistance to colonial rule. For example, Gwen Ansell's Soweto Blues examined the role that jazz played in the South African liberation struggle of the twentieth century and the link it created between South African and African American political activists. ${ }^{27}$ Likewise, Sue Williamson's Resistance Art in South Africa and Glenn Reynold's Colonial Cinema in Africa provide excellent examples of artistic expression as a means through which to challenge the social hegemony that colonial regimes attempted to create. ${ }^{28}$ Further works, like Fassil Demissie's Colonial Architecture and Urbanism in Africa, even analyze the politics of resistance that manifested themselves in city-planning and the aesthetics of colonial architecture. ${ }^{29}$

The gendered dynamics of resistance have also come to the historiographical fore during the past two decades. The publication of Judith Abwunza's Women's Voices, Women's Power and the edited work African Women Writing Resistance are exemplary works that examine women's resistance strategies to not only the colonial society, but the post-colonial world too. Abwunza's work focuses on re-imaging women as "innovative actors, creative and visionary, surviving their oppressive circumstances rather than simply being oppressed," while the edited work examines contemporary issues, like polygamy, environmental degradation, and Sharia law,

Of Revelation and Revolution, Volume II: The Dialectics of Modernity on a South African Frontier (Chicago: University of Chicago Press, 1997).

${ }^{27}$ Gwen Ansell, Soweto Blues: Jazz, Popular Music, and Politics in South Africa (New York: Bloomsbury Academic, 2005).

${ }^{28}$ Sue Williamson, Resistance Art in South Africa (Lansdowne: Double Storey Books, 2010) and Glenn Reynolds, Colonial Cinema in Africa: Origins, Images, Audiences (Jefferson: MacFarland Books, 2015).

${ }^{29}$ Fassil Demissie, Colonial Architecture and Urbanism in Africa: Intertwined and Contested Histories (New York: Taylor and Francis, 2016). 
that women face on a daily basis. ${ }^{30}$ Later works, like Nwando Achebe's The Female King of Colonial Nigeria, continued this multi-dimensional representation of women as crucial resistance figures to colonial rule and examined the way that the Igbo woman Ahebi Ugbabe vacillated between aiding the colonial regime and resisting it for personal gain. ${ }^{31}$ These works, and others like them, added complexity and nuance to historians' use of resistance as an analytical tool, and played varied parts in shaping the Namibian resistance historiography.

\section{The Development of the Namibian Resistance Historiography and this Dissertation's Contribution}

Since Namibia and South Africa experienced late decolonization as a result of the pervasive entrenchment of white minority rule, it follows that its resistance historiography went through many of the aforementioned developments at a later time. ${ }^{32}$ As Namibia emerged as an independent nation in the 1990s, the resistance historiography served a dual purpose as both a field of academic inquiry and a key element in the nation-building process. The former British and French colonies in Africa underwent a similar process in the 1950s and 1960s, when the historiography centered on armed resistance and independence struggles to create a new national identity that focused on African agency and triumph over the colonial oppressors. The early postcolonial resistance historiography in Namibia underwent a similar process as the nation emerged in the 1990s and early-2000s as national political heroes and their activities were re-integrated into the Namibian national consciousness.

\footnotetext{
${ }^{30}$ Judith Mae Abwunza, Women's Voices, Women's Power: Dialogues of Resistance from East Africa (Ontario: Broadview Press, 2008), 3; Anne Serafin, et al., African Women Writing Resistance: An Anthology of Contemporary Voices (Madison: University of Wisconsin Press, 2010).

${ }^{31}$ Nwando Achebe, The Female King of Colonial Nigeria (Bloomington: Indiana University Press, 2011).

${ }^{32}$ See Frederick Cooper, Africa Since 1940: The Past of the Present (Cambridge: Cambridge University Press, 2002), 133-155 for a full discussion on the nature of the late decolonization process that occurred in southern Africa.
} 
The central thematic pursuits of the historiography followed suit and historians focused their inquiries heavily around two subjects: the armed resistance campaigns against the extension of German rule and the armed national liberation struggle undertaken by SWAPO between 1966 and 1991. In 1996, Brigitte Lau translated and published the papers and diary of Hendrik Witbooi in an attempt to bring the writings and ideology of an important resistance figure to the masses. ${ }^{33}$ The 1990 s saw numerous publications of works that examined the activities of the Maharero and Witbooi against German colonial rule as a means to re-integrate the armed resistance activities of these figures into the Namibian independence narrative. ${ }^{34}$ The HereroNama Genocide of 1904-1907 also occupied a prominent space in the post-colonial resistance historiography. Jan-Bart Gewald's Herero Heroes is one of the preeminent works on the genocide and provides an in-depth look at both the internal and external sociopolitical disputes that the Herero faced as the German government strengthened its rule. ${ }^{35}$ The intense academic focus on the German period has been maintained into recent decades with the publication of Jeremy Sarkin-Hughes' Germany's Genocide of the Herero and David Olusoga and Casper W. Erichsen's The Kaiser's Holocaust in $2011 .{ }^{36}$ Although these two studies are far more nuanced in their definition of resistance than the resistance studies of the 1950s and 1960s, they still maintain a clear focus on the armed resistance struggles as the foremost form of resistance to colonial rule.

\footnotetext{
${ }^{33}$ Brigitte Lau, The Hendrik Witbooi Papers, trans. Eben Maasdorp and Annemarie Heywood (Windhoek: National Archives of Namibia, 1996).

${ }^{34}$ Some examples of these works include Gerhardus Pool, Samuel Maharero (Windhoek: Gamsberg Macmillan, 1991); Ludwig Helbig and Werner Hillebrecht, The Witbooi (London: CASS Publishers, 1992).

${ }^{35}$ Jan-Bart Gewald, Herero Heroes: A Socio-political History of the Herero of Namibia, 1890-1923 (Athens: Ohio University Press, 1999).

${ }^{36}$ David Olusoga and Casper W. Erichsen, The Kaiser's Holocaust: Germany's Forgotten Genocide and the Colonial Roots of Nazism (London: Faber and Faber, LLC., 2011); See also Sarkin-Hughes, Germany's Genocide of the Herero.
} 
Likewise, the scholarship created in the post-colonial period is inundated with studies on the activities of SWAPO between 1966 and 1991 and the armed liberation struggle that saw Namibia gain its national independence. Much like the scholarship that examines the armed resistance campaigns against German colonial rule, the scholarship that focuses on SWAPO's war for independence also serves in the building of Namibia's post-colonial national identity. The subject matter examined in studies of SWAPO's activities are diverse, but in most cases the narrative utilizes the colonizer-colonized paradigm and places SWAPO's forces and leadership in a reactionary battle against the activities of the South African government. Only recently have works utilized a more complex analysis of SWAPO's activities. For example, Lauren Dobell's SWAPO's Struggle for Namibia, 1960-1991 examined SWAPO's activities during the liberation struggle primarily through a diplomatic lens. Similarly, Richard Dale's publication of The Namibian War of Independence, 1966-1989 moved beyond the military campaign and looked at the role that economic warfare and diplomatic maneuvering played in Namibia's decolonization process. ${ }^{37}$

The armed struggles against colonial rule provide for a strong nationalistic interpretation that serves the important role of nation-building and creates a useful narrative that celebrates African agency. However, in Jeremy Silvester's recent publication Re-Viewing Resistance in Namibian History, the usefulness of the "nationalistic" interpretation of resistance is critiqued. In the introduction to his work, Silvester takes issues with Peter Katjavivi's belief that independence was the result of a 300-year-long resistance campaign against the German and South African governments and that all acts of resistance against these two governments were

\footnotetext{
${ }^{37}$ Lauren Dobell, SWAPO's Struggle for Namibia, 1960-1991: War by Other Means (Basel: P. Schlettwein Publishing, 1998); Richard Dale, The Namibian War of Independence: Diplomatic, Economic, and Military Campaigns (Jefferson: McFarland \& Company, 2014).
} 
"nationalistic" in nature. ${ }^{38}$ Instead, Silvester warned that such an approach "reduces the dynamics of struggle to a simple dichotomy....The danger is that agency is reduced and the complex political dynamics around issues such as generational conflict, ethnicity, traditional authorities, and gender are ignored." ${ }^{39}$ Silvester recognized one of the more problematic elements of the Namibian resistance historiography: its intense focus on armed resistance and conflict and the potential risk of relying on conventional colonizer-colonized, oppressoroppressed dichotomies.

While Silvester's work identified a key shortcoming in the structure of these early resistance narratives, it serves to highlight a second problem: Namibian resistance to South Africa's colonial rule between 1921 and 1962 is under-researched in comparison to the aforementioned topics. Re-Viewing Resistance, a collection of seventeen chapters presented at the Archives of Anti-Colonial Resistance and the Liberation Struggle's (AACRLS) Moments, Memories and Monuments conference provided nuanced studies of SWAPO's activities through the utilization of new audio-visual sources, interviews with ex-combatants, and music. However, despite developing new directions in the scholarship by using African-created source material, a clear void still persisted with regard to scholarship on resistance to the extension of South Africa's segregationist policies in the pre-SWAPO period.

Few academics have produced comprehensive works of scholarship focusing on resistance campaigns waged by Namibians against the South African state prior to the initiation of the armed national liberation struggle. Tony Emmett was one of the earliest scholars to comprehensively explore the period spanning 1915 to 1966 with the publication of Popular

\footnotetext{
${ }^{38}$ Jeremy Silvester, Re-Viewing Resistance in Namibian History (Windhoek: University of Namibia Press, 2015), 12. ${ }^{39}$ Ibid.
} 
Resistance and the Roots of Nationalism in Namibia in 1999. Emmett's work included an examination of some instances of armed conflict, such as the Bondelswart's Rebellion and the Rehoboth Rebellion, but also included a lengthy analysis of the contract labor system that developed to the north of the Police Zone and the impact that migratory workers had on the independence movement. ${ }^{40}$ Although an important early pioneer in the study of this period, Emmett's work does present some weaknesses. For instance, his work is frequently criticized for its focus of issues that occurred in Windhoek and his complete exclusion of the Black separatist church movements of the 1940s. Emmett's work also falls firmly within the category of works whose main concern is to uncover the roots of the later-nationalist struggle that emerged in the 1960s.

Other academics have also attempted to address the various developments in Namibia that occurred during the South African colonial period. Between 1958 and 1973, Katesa Schlosser's Native Churches in South and Southwest Africa and Theo Sundermeier's But We Were Looking for Fellowship provided in-depth studies of the separatist church movements as they pertain to both theological and practical concerns in the Rhenish Mission Church in the 1940s and 1950s. ${ }^{41}$ Others focused on the legal apparatus surrounding the extension of apartheid in South West Africa in the late-1940s and 1950s. John Dugard's Confronting Apartheid examined the "entrenchment" of discriminatory policies in southern Africa from the viewpoint of UN officials, and international bodies have produced countless reports on the problematic nature of apartheid policies. ${ }^{42}$ Many of the scholars who focused on apartheid polices during this

\footnotetext{
${ }^{40}$ Tony Emmett, Popular Resistance and the Roots of Nationalism in Namibia, 1915-1966 (Basel: P. Schlettwein Publishing, 1999).

${ }^{41}$ Katesa Schlosser, Eingeborenenkirchen in Sud- und Sudwestafrika: Ihre Geschicte und Sozialstruktur (Berlin: Walter de Gruyter, 1958); Theo Sundermeier, Wir aber suchten Gemeinschaft, Kirchenwerdung und Kirchentrennung in Sudwestafrika (Franconia: Erlangen, 1973).

42 John Dugard, Confronting Apartheid: A Personal History of South Africa, Namibia, and Palestine (Johannesburg: Jacana Media, 2018).
} 
period have turned their attention and effort toward understanding apartheid's ability to define space, limit access to said space, and the sociocultural and political consequences of such restrictions.

While many of these studies are comprehensive in their stated scope and address important developments in the pre-SWAPO colonial period under South African rule, they are singular in their subject matter and provide little in the way of understanding the complex, wideranging resistance strategies and networks that developed nearly simultaneously across the Police Zone. Against this backdrop, this study seeks to engage with the resistance strategies of Namibians in the Police Zone between 1921 and 1962 by examining these strategies and efforts as part of a larger transnational process that enveloped the territory. Like most of the studies in the past two decades, this dissertation conceives of resistance as an act and process that extends far beyond armed conflict and the tired colonizer-colonized dichotomies that place all resistance within a nationalistic paradigm. In this work, in agreement with Walraven and Abbink, resistance is defined "not so much by various forms of concrete acts, as by the intent of those performing these acts, aimed usually at the defense of pre-existing and cherished socio-political arrangements, upholding other civilizational ideals, or just defending existing power structures, elite or otherwise." ${ }^{43}$ The resistance of this period need not be conceived merely as an act or action to achieve national independence, but rather as conscious and sustained efforts to carve out spheres of influence and agency within the overarching colonial structure in hopes of improving everyday life.

Whereas most studies of Namibian resistance have focused on political ends, this dissertation examines resistance within its wider spectrum as both a political and socioeconomic

${ }^{43}$ Van Walraven and Abbink, "Rethinking Resistance in African History," 8. 
process that centers not on national independence, but on local and subnational goals and ambitions. Ultimately, this work still addresses political processes much like Emmett's work, and discusses the Rehoboth Rebellion of 1925 . However, a large portion of this dissertation focuses on the social sphere. Among the various social processes discussed are: the growth and eventual dissolution of the UNIA in South West Africa between 1919 and 1924, the rise of the AME Church and its role in both land disputes and advocating for improved education, the socioeconomic-centric petition-writing campaigns to the UN in the 1950s and 1960s, and Namibians' utilization of foreign colleges and student organizations as a means of resistance to the colonial regime.

This work fundamentally differs from previous studies of the time period in that it does not seek to evaluate the resistance campaigns of the era as a predecessor or root cause of the later nationalist movements. Rather, this dissertation examines these various resistance campaigns as part of a larger transnational process that relies on historic linkages and relationships to combat the increasingly aggressive colonial state. These resistance campaigns are, thusly, analyzed as a mechanism to achieve subnational, rather than national, sociopolitical and economic concessions. As is apparent throughout the subsequent chapters, in most cases where transnational institutions were used, the goal of the analyzed political actors was to achieve some type of reform, concession, or improvement for the population in one's specific locale or polity. It was not until the 1950s and early 1960s that true claims of national independence became the focal point of the resistance campaigns in South West Africa. 


\section{Transnational History as a Conceptual Framework for Namibian Resistance Studies}

South West Africa's history under South African colonial rule is defined by the plethora of transnational institutions and organizations that Namibians interacted with between 1919 and 1962. As early as 1919, Namibians accessed historical maritime networks and union connections to spread the Pan-African message of the UNIA and develop local branches tasked with providing social and economic welfare programs to guard Namibians against the harsh realities under the South African colonial regime. Simultaneously, in the Rehoboth Gebiet, the Baster community utilized the legal framework provided by the League of Nations Charter and mandate system to call on the international community to pressure the South African government for restoring local political autonomy at Rehoboth. ${ }^{44}$ The petition-writing campaign legacy would continue into the apartheid period, when new political actors would undertake a similar resistance campaign by writing petitions to the $\mathrm{UN}$ to call for local political autonomy, the protection of land rights, and even national liberation. Some of the same actors that participated in the petition-writing campaign to the UN were also involved with other transnational organizations as a means of resistance to the colonial regime. Throughout the 1940s and 1950s, many Namibians joined the separatist church movements that sought to improve education for Africans and provide Namibians with more authority over their social and religious lives. ${ }^{45}$

In recent decades, transnational history and the examination of transnational institutions as a means of resistance has emerged as an important conceptual framework through which one can analyze developments in African history. Although the term "transnational history" dates

\footnotetext{
${ }^{44}$ Gebiet is the German term meaning "area." Gebiet refers to the Basters' territory in Rehoboth and its surrounding areas. The Gebiet spanned roughly 5,000 square miles and the Baster Raad maintained some level of limited political autonomy and control in the area throughout the German colonial period. The area was not ethnically exclusive however, as both Nama and Herero pastoralists lived in and around the Gebiet with their herds.

${ }^{45}$ Katjavivi, Mbuende, and Frostin, Church and Liberation, 7-9.
} 
back to the 1840s, it has only coalesced into a clearly structured field in the past 20 to 30 years. In 2013, to adequately define the field, Akira Iriye and Pierre-Yves Saunier published books that presented the theoretical considerations, terminology, and methodology of the field. ${ }^{46}$ That same year, Andrew Zimmerman published his article "Africa in Imperial and Transnational History," where he argued that African historians produced transnational histories for decades. Zimmerman viewed these transnational African histories as effective in dismantling previous "borders" between the "colonized" and "colonizer," removing unnecessary dichotomies and problematic paradigms through multi-sited research. ${ }^{47}$ This multi-sited research theoretically diversified the African histories produced by scholars and incorporated multiple perspectives on a historical moment to broaden one's understanding of said event.

Zimmerman believed that Namibia provided fertile ground for transnational African histories because of its rapidly changing colonial context and its peculiar legal standing as both a mandate territory and potential UN trust territory. The historiography provides some support to Zimmerman's assertions, with numerous recent works on southern Africa embracing a transnational perspective. ${ }^{48}$ Robert Vinson's The Americans Are Coming! utilized the transnational and multi-sited approach in its analysis of the movement and development of Garveyist ideas in the United States and South Africa. ${ }^{49}$ Similarly, the work of Robert Houle and James T. Campbell on African Christianity and the Ethiopian movement in southern Africa have incorporated effectively-used transnational frameworks as an explanatory paradigm for the

\footnotetext{
${ }^{46}$ Akira Iriye, Global and Transnational History: The Past, Present and Future (London: Palgrave Macmillan, 2013); Pierre-Yves Saunier, Transnational History: Theory and History (London: Palgrave Macmillan, 2013).

${ }^{47}$ Andrew Zimmerman, "Africa in Imperial and Transnational History: Multi-Sited Historiography and the Necessity of Theory," Journal of African History 54, No. 3 (November, 2013): 331-340.

${ }^{48}$ Ibid., 331-335.

${ }^{49}$ Robert Vinson, The Americans Are Coming!: Dreams of African American Liberation in Segregationist South Africa (Athens: Ohio University Press, 2012).
} 
transfer of peoples and ideas across borders. ${ }^{50}$ This dissertation is largely influenced by these scholars' theoretical frameworks and analyzes the developments of resistance campaigns in Namibia between 1921 and 1962 within their transnational context.

Transnational history emerged in part as a response to the historiographical problem of methodological nationalism, an approach to history "whereby historians explicitly or implicitly produce a tune in which the country, aka the national state, appears as the natural form or organization of societies and the basic unit of historiography." ${ }^{51}$ Saunier acknowledged, however, that a transnational perspective does not eliminate the state as a unit of analysis, writing, "[T]ransnational history is not written against or without nations but simultaneously pays attention to what lives against, between, and through them." ${ }^{, 52}$ In transnational history, the primary focus of analysis is not the state, but rather the multitude of entanglements that exist between nations, communities, economies, and individuals. Thus, those that drive, create, and shape the historical narrative are non-state actors in their variety of forms. In this particular transnational history, those non-state actors include Namibian actors, supranational political organizations, transnational Black separatist churches, and global student organizations that participated in the resistance campaigns against the colonial state.

Through these non-state actors, Namibians created and maintained complex networks that spanned numerous countries. A key unit of analysis for an examination of the transnational resistance strategies developed by these non-state actors is the circuit. Circuits, as defined by Saunier, are "an arrangement of linkages that is consciously installed and maintained in order to

\footnotetext{
${ }^{50}$ James T. Campbell, Songs of Zion: The African Methodist Episcopal Church in the United States and South Africa (London: Oxford University Press, 1995); Robert J. Houle, Making African Christianity: Africans Reimagining Their Faith in Colonial South Africa (Bethlehem: Lehigh University Press, 2011).

${ }^{51}$ Saunier, Transnational History, 2.

52 Ibid., 11.
} 
gain access to resources and possibilities located in different places across national borders. ${ }^{\prime 53}$ Between 1919 and 1962, several different circuits developed across the Atlantic that provided Namibians with access to resources, information, and people that could amplify the effectiveness of their resistance strategies. For example, a circuit developed between North America, the Caribbean, and Namibia as a result of the nineteenth-century commercial maritime trade between the regions. Namibians and Americans maintained this circuit well into the twentieth century, when it served as the foundation for the movement and flow of the UNIA and AME Church. Likewise, circuits that developed in the 1920s as a result of the Rehoboth Basters petitionwriting were maintained and provided pathways for Namibians to undertake a petition-writing campaign to the UN and seek out the aid of international student organizations in North America, Europe, and South Africa during the 1950s.

Undoubtedly, transplantation and migration played an important role in developing these networks. ${ }^{54}$ As chapter 3 will show, the migration of Black Americans to South Africa and Namibia as dockworkers resulted in the development of tightly-knit communities that allowed the UNIA and trade unions to spread and flourish during the 1920s. The travel and migration of missionaries from the United States also made it possible to establish AME Church branches in South Africa that eventually spread to Namibia in the 1940s. Although these actors were frequently required to obtain permission from the colonial state before traveling in the territory, their ambiguous status as non-state actors often provided them with the anonymity and malleability to move on the periphery of the colonial state's gaze. As such, they frequently were

\footnotetext{
53 Ibid., 178.

${ }^{54}$ Ibid., 39. Transplantation refers to the process of the large-scale movement and resettlement of communities to a different location. This does not imply that the entire community moves, rather a diaspora is created. Saunier utilizes the example of the transplantation of Yoruba culture and communities to Brazil as a result of the slave trade to illustrate his point. The same point could be made for the Caribbean and African American communities that emerged near the docks of South West Africa.
} 
the primary developers of the communication infrastructure necessary to maintain the circuits between transnational organizations and Namibian actors.

As the previous two paragraphs suggest, transnational history necessarily deals with the "trends, patterns, organizations, and individuals that have been living between and through [the nation]. ${ }^{555}$ The movement of these ideas, resources, and people along these various circuits had a profound impact on the success and shape of the resistance strategies developed by Namibian actors. In this dissertation the term "circulation," rather than "flow," is frequently used to address the movement of the aforementioned elements. This is an important distinction because within the transnational networks discussed in this work, the exchange of ideas, people, and resources is multi-directional. Saunier noted that this multi-directional circulation is a key part of any transnational history because of the profound impact this has on the shape of one's resistance strategies. He argued that "transnational perspective acknowledges and assesses foreign contributions to the design, discussion, and implementation of domestic features within the communities, polities and societies; and, vice versa, the projection of the domestic features into the foreign. ${ }^{" 56}$ Such multi-directional exchanges and influences are most apparent in the chapters on the UNIA and the AME Church.

The heavy usage of transnational organizations and institutions in Namibians' resistance strategies in the pre-SWAPO period occurred for a number of practical reasons. Chief among these was the fact that as the South African state strengthened its grip on the African populations of South West Africa, fewer avenues of legitimate recourse existed within the state infrastructure. The legal mechanisms instituted by the South African state so profoundly marginalized Namibians' abilities to work through the state to seek reform that they turned to

${ }^{55}$ Ibid., 3.

${ }^{56}$ Ibid. 
transnational organizations that functioned in the territory but existed outside of the recursive purview of the colonial state. While the South African government attempted to regulate and restrict the ability of organizations to maneuver in the territory, the colonial government's obligations to the larger international community allowed transnational organizations to leverage the weight of action by supranational political bodies and the South African government's most important political allies.

Through these transnational networks, Namibians found willing and ready allies that provided the necessary resources to wage resistance campaigns that allowed local leaders to carve out new subnational spheres of political, social, and economic influence within a repressive colonial context. The UNIA provided structural and economic support to create a welfare organization in South West Africa that covered funeral costs, created a socialized medical fund, and advocated for political autonomy. Namibians used the international standing of the League of Nations and the UN and their immense pool of resources to wage a campaign for political autonomy and economic freedom that frustrated the highest echelons of the colonial state. Similarly, Namibians coordinated with the AME Church and used its position as a widelyaccepted global religious institution as a means to advocate for increased education and assert claims to fertile lands in the Police Zone. The development, use, and maintenance of these transnational networks to affect change is the central thrust of this study.

\section{Sources and Methodology}

A sweeping transnational historical study like the one undertaken in this dissertation was time and resource intensive and presented a number of research challenges. First among these many challenges was the disparate nature of the sources and the distribution of relevant materials 
across the globe. As Andrew Zimmerman suggested, one of the keys to overcoming the pitfalls of methodological nationalism and constructing an effective transnational study is the utilization of a multi-sited research approach ${ }^{57}$ The pursuit of historical records across three continents in a variety of archival repositories introduced a number of diverse perspectives that strengthened this work and filled the documentary voids inherent in the collections of a single institution. The multi-sited research approach allowed for the examination of Namibian resistance strategies through interconnected sites which, as a consequence, helped dismantle some of the inherent problems that emerge from focusing solely on records and documents produced by colonial sources. The removal of traditional hierarchies that value European- and white-produced archival materials over those produced by Africans or other non-state international actors was easier to implement by using archival repositories.

A logical starting point for the research in this work was the National Archives of Namibia and its extensive holdings. The National Archives was created through the Archives Act (Act No. 12 of 1992) and the archives assumed responsibility for regulating and supervising all records management activities related to the government and public services. Over the next three decades, the archives accepted numerous documents and collections from the former South African colonial government and international institutions that created records through their interactions with Namibians. The National Archives contains a significant number of historical records spanning from the nineteenth century to the present, with a vast array of collections from both the German and South African colonial periods. One of the primary concerns of this dissertation was to produce a transnational study but still use African voices as the driving force

${ }^{57}$ Zimmerman, “Africa in Imperial and Transnational History,” 336-338. 
in the construction of a historical narrative. Thus, the South West Africa Administration

(SWAA) record group was highly important in extracting the African voices of the period.

The SWAA records span from roughly the 1920 s to the 1980 s with new adoptions and records being added to the collection periodically. Government officials and administrators created this collection over this period. They compiled extensive collections of minutes, memoranda, official and unofficial communications, petitions, and government directives. ${ }^{58}$ It is important to recognize that since these record groups were largely collected and compiled by officials and administrators under the supervision of the colonial government, these actors possessed a significant amount of influence over the types of records collected and, conversely, omitted from the official record. The inclusion and omission of records has a meaningful impact on the historical narrative that emerges from the documentary analysis conducted by scholars and, at times, requires analyzing these silences and glaring absences as clues themselves.

The documents that proved most useful in this collection were, however, those records created by Namibians in their own words and voice. Frequently, the Namibian voice came through most clearly in documents challenging the repressive policies and activities of the colonial state. Letters, petitions, and communications between Namibians and the colonial government were prevalent throughout the SWAA records and, when not in Namibians' own handwriting, were often included as typewritten attachments to official government minutes and communications. These records proved invaluable in the pursuit of extracting the Namibian voice and more deeply understanding their agency, desires, motivations, and the thought process

\footnotetext{
${ }^{58}$ A number of other collections at the National Archives of Namibia also detail the South African colonial period and were useful in the development of this dissertation. The Archives of Anti-Colonial Resistance and the Liberation Struggle, the records accumulated by the Chief Bantu Affairs Commissioner and local magistrates, and the files of the Native Commissioners and Native Affairs Department were equally useful at supplementing the information found in the South West Africa Administration record group.
} 
behind many of their resistance activities and strategies. These types of documents were instrumental in constructing the arguments for chapters 4 through 6. Namibians' discussions and letters with government officials over the issue of incorporation in 1946, correspondence about the construction of AME schools and the attainment of state recognition, and the petitions of Hosea Kutako and Markus Kooper protesting against forced land removals in the 1950s were all found in these archives and helped emphasize the Namibian voice and their agency.

While Namibian-created sources were analyzed carefully, even more discernment was needed when SWAA officials attempted to relay the thoughts and motivations of Namibians that were gleaned from the officials' own understanding of their conversations with Namibian leaders and activists. This was most apparent in chapter 3 and this work's examination of the UNIA in South West Africa. Although the Marcus Garvey papers were published in a multi-volume set in 1983, most of the documents pertaining to South West Africa are amassed in volumes 9 and $10 .{ }^{59}$ In the SWAA records, roughly two boxes contained records produced by Namibians that pertained to the UNIA's activities in the territory. In these boxes, most of the records consisted of SWAA officials' correspondence relating to the monitoring of UNIA agents in the territory and the white response to the association's Pan-African message. There were some documents written by Namibian UNIA members requesting the establishment of branches, handwritten notes in Nama, and correspondence from non-indigenous UNIA members to Namibians and potential recruits. Where only SWAA officials' documents were available, corroborating evidence was sought from other archival institutions and record groups to highlight areas of

\footnotetext{
${ }^{59}$ See Robert A. Hill, ed., The Marcus Garvey and Universal Negro Improvement Association Papers (Hereafter, MGP), Vol. IX Africa for the Africans: June 1921-December 1922 (Berkeley: University of California Press, 1983) and Robert A. Hill, MGP, Vol. X: Africa for the Africans, 1923-1945, ed. Robert A. Hill (Berkeley: University of California Press, 1983).
} 
agreement or incongruity to account for the immense influence that these officials had in compiling the documents and creating an evidentiary record.

In some instances, agreement was easy to find between Namibian sources and SWAA officials. For example, in chapter 5 it was clear that SWAA officials agreed with AME church officials that the RMS embellished accounts of communist infiltration in the AME church movement and were doing so to stem the loss of their congregants and revenues. However, other events examined by this dissertation presented different and often conflicting narratives. In the case of the AME congregations' resistance to the forced removals at Hoachanas in the late 1950s, congregants provided vastly different accounts of the violent encounter with SWAA officials than those records generated by SWAA official Colonel Dorfling. To address these contradictory accounts, and without corroborating evidence elsewhere in the historical record, this work recognized the accounts of the congregants and Colonel Dorfling as differing perspectives on the same event. This also occurred, in part, in this work's examination of the implementation of the vote on incorporation in 1946 and in the correspondence between Hosea Kutako and government officials over the Kuridora Affair in the Aminuis Reserve. In each example, the varying perspectives on the issue were highlighted and then supported by concrete evidence from the archival record.

Aiding in this difficult navigation of archival collections and records produced by the colonial regime were the diverse origins of many of these documents. While government correspondence, minutes, and memoranda made up a significant portion of these collections, there were also record groups present in the SWAA created by Namibians, international actors, and other non-governmental entities. These record groups provided diverse perspectives on overlapping issues and presented adequate source material to either corroborate or contradict the 
official records of the colonial regime. Collections like those detailing the AME church's pursuit of state recognition consisted of a significant number of documents produced by AME actors that provided an important counterbalance to the claims made by the RMS and government officials about the nature of the church movement and the "imaginary" karakul sheep pelt thefts described by the territory's police force. These resources were instrumental in the creation of a more complete historical narrative and allowed for the inclusion of diverse perspectives on the resistance activities of Namibians. Through these varying perspectives, it was easier to see how Namibians viewed the SWAA, how the SWAA viewed Namibian activities, and how Namibians viewed and understood each other's motivations and agency during the period.

Much like this dissertation tracks the flow and circulation of ideas and actors across borders, it was also necessary to track down documents and materials at archival repositories outside of Namibia. South West Africa experienced a series of dramatic political changes throughout its colonial history, moving from German colony to South African mandate territory, and finally to potential UN trust territory. Throughout these changes, and because of South West Africa's changing international legal standing, different national, transnational, and nongovernmental organizations collected and compiled records on the territory and its people. Therefore, many of the records required to construct a more complete historical narrative surrounding Namibian's transnational resistance strategies lay outside of Namibia's present borders.

The clearest examples of the scattered nature of archival records appears in the chapter on the Baster's pursuit of subnational political autonomy and the resistance campaigns waged by Hosea Kutako and Markus Kooper against the SWAA's forced land removals. The Baster's were required to submit their petitions to the League of Nations through the South African mandatory 
government. As a result, there are limited records associated with these petitions in the National Archives of Namibia. Instead, these documents are partially stored in South Africa's National Archives in Pretoria. ${ }^{60}$ Many of the petitions, or copies of the petitions, eventually made their way to the League of Nations Archives in Geneva, Switzerland where they are presently housed as part of the Mandates Section record groups. The petitions were accessed through this archival institution in July 2019 and were influential in drawing out the Baster's own voices and words to highlight their agency and the claims they made to the SWAA.

Similar problems arose with access to the original petitions submitted by Kutako and Kooper to the UN during the 1950s. However, unlike the Baster's petitions to the League of Nations, the National Archives of Namibia secured copies of many of the documents held at the UN and accessioned them as part of the AACRLS in Windhoek. It was necessary to travel to New York City to access the original documents as it was unclear at the time if the copies housed at the National Archives of Namibia were complete in nature. Once again, the petitions sent to the UN were written or dictated directly by influential Namibian political actors and played an important role in using Namibian voices as the driving force in this dissertation.

Despite the primary focus of this work resting on the agency and voices of marginalized Namibian actors, Namibians' transnational resistance strategies involved actors and institutions that moved across borders and resided around the world. These actors played an important role in facilitating the resources, networks, and communicative infrastructure necessary to wage these wide-ranging transnational resistance campaigns. As such, it was important to seek out the voices of these actors to better understand their role in these campaigns and create a more complete picture surrounding the complexity of these transnational resistance strategies. Since

\footnotetext{
${ }^{60}$ The Basters' petitions are held in the Department of Foreign Affairs (Buitilandse Sake [BTS]) record group.
} 
some of these actors were highly influential in global or regional politics, many of their records and writings were published. Several of Reverend Michael Scott's books on his political activism with regard to South Africa are published, as are the records of the UNIA, Marcus Garvey's personal writings, and American Allard Lowenstein's account of his trip to South West Africa. ${ }^{61}$ Yet, other records remained unpublished and provided important insights into the motivations of transnational actors to involve themselves in South West African affairs. Allard Lowenstein's personal records are housed at the University of North Carolina's Wilson Library and unpublished copies of his manuscript for Brutal Mandate provided details of his clandestine trip to the territory that remained out of the public eye for the safety and security of those who helped him. Likewise, the physical copies of audiotapes that contained the spoken testimony of Namibians on their treatment at the hands of the SWAA reside at the library. While edited versions of these accounts were published in UN documents in the late 1950s, the tapes help one understand the tone and exact wording used by Namibian actors. Similarly, one can also hear Lowenstein and his companions on the tapes and hear the various side conversations that did not make it into the written record at the UN.

Other repositories, like Basler Africa Bibliographien in Basel, Switzerland, possessed important copies of records that were compiled by scholars over the course of their research in Namibia and at other relevant archives across the globe. ${ }^{62}$ Here, Theo Sundermeier's collection was most useful in the completion of this dissertation. During his research on German missionary activity in Namibia, Sundermeier successfully compiled immense records on the

\footnotetext{
${ }^{61}$ See Allard Lowenstein, Brutal Mandate: A Journey to South West Africa (New York: MacMillan, 1962); Michael Scott, A Time to Speak (New York: Doubleday, 1958); and Michael Scott, A Search for Peace and Justice, ed. Alexander Paul Hare (London: Rex Collings, 1980).

${ }^{62}$ Basler Afrika Bibliographien is an archival repository in Basel, Switzerland that possesses one of the largest collections on Namibian history outside of the country. The archive houses a rare book collection, documents and collections pertaining to Namibia's colonial history, and has its own publishing house that produces and distributes scholarship on Namibia.
} 
activities of the RMS in South West Africa and several documents pertaining to Herero cultural practices. His tireless work consolidated archival materials from the National Archives of Namibia, the Bundesarchiv, and the records of the Rhenish Mission Society in Wuppertal. ${ }^{63}$ The compilation was essential to the development of the chapter on the activities of the AME church and revealed important archival materials that gave voice and perspective to the RMS missionaries' activities in South West Africa.

These sources located abroad were instrumental in filling important gaps in the historical narrative that could not have happened simply relying on the collections at the National Archives of Namibia. The published records of the UNIA and Reverend Michael Scott, as well as Allard Lowenstein's archival records at the University of North Carolina highlighted the complexity of the networks, connections, and machinations afoot outside of South West Africa's boundaries that Namibians accessed and used to their benefit. Other archival repositories, like the UN Archives and the League of Nations Archives, provided further insight into the inner workings and motivations of transnational organizations and actors to become involved in the South West Africa case and drew attention to the influence that these foreign institutions had over the opportunities, barriers, and restrictions Namibians faced in their engagement with transnational institutions as a means of resistance.

Consequently, this multi-sited approach to transnational history and the use of varied sources created by a vast array of historical actors prevented the writing of an overly nationalistic interpretation of Namibian resistance strategies during the colonial period and avoided many of the pitfalls of methodological nationalism. Through the use of many archival repositories and record types, diverse perspectives are included in the work that highlighted the number of ways

\footnotetext{
${ }^{63}$ The Bundesarchiv is the National Archive of Germany. Its records on the colonial period in Namibia are contained in the Akten des Reichskolonialamtes (RKA) collections.
} 
resistance strategies were understood and interpreted by the various parties involved. Embracing contradictory accounts of an event or seeking out corroborating historical evidence from more than one source illuminated many of the complexities of the colonial situation in South West Africa between 1919 and 1962 and created a historical narrative that was not merely a long, heroic, linear march to national independence. Rather, it shows that Namibians and international actors involved themselves in these transnational resistance strategies for a number of different, and at times competing, reasons. In some instances, they outright resisted the colonial regime and its repressive policies and at other times sought a path of accommodation in an effort to carve out small spheres of influence in the colonial superstructure and improve their everyday standard-of-living.

\section{Temporal and Spatial Limitations of the Study}

This dissertation begins its examination of transnational resistance in 1919 and covers Namibians' resistance strategies up to 1962 . This time frame roughly covers the South African colonial period prior to the emergence of SWAPO as the preeminent national political party and voice of Namibians seeking national independence. The resistance that occurred during this period was characterized by the desire to seek local or subnational sociopolitical changes within the colonial framework. Resistance strategies during this period primarily sought to reform the colonial system and carve out political autonomy or improve socioeconomic conditions on the local or subnational level rather than seek outright national independence for the entire South West African territory. This dissertation focuses on the period up to 1962 because that year represented the emergence of SWAPO as the people's political party and signified a profound shift in Namibians' resistance strategies. No longer were Namibians concerned with merely 
affecting local sociopolitical and economic changes, but instead viewed themselves as inextricably linked in the fight to remove the South African colonial regime from the entirety of the territory. This process, which began in 1962, ultimately culminated in the commencement of an armed liberation struggle in 1966 that sought to remove the South African colonial state by force.

This study is not only temporally restricted to the period spanning 1919 to 1962 , but it is also geographically restricted to those people and communities south of "Namibia's Red Line" that inhabited the "Namibian Police Zone." As a result, this work focuses almost exclusively on the actions and resistance activities of those belonging to the Nama, Herero, and Baster polities. The Red Line began as a veterinary cordon fence (VCF) imposed by the German colonial government in 1896 as a means to control rinderpest outbreaks in South West Africa. However, by the 1910s, the VCF served the dual purpose of preventing the spread of cattle-borne disease, while also physically separating the "colonial heartland [that] had been cartographically defined in 1907" from the Ovambo polities in the north. ${ }^{64}$ The concept of the VCF/Red Line evolved over time and became more politically significant. The German government guaranteed police protection for the European populations inhabiting the lands south of the Red Line and established the basis for the creation of the later Police Zone. Giorgio Miescher's article "Facing Barbarians" best described the dual nature of the Red Line and Police Zone, stating that "The Red Line separated the settler society's heartland, including its African population in central and southern Namibia, from the areas in the far north with their exclusively African population. Seen from a South African perspective the Red Line marked the physical limit of the subcontinent

\footnotetext{
${ }^{64}$ Giorgio Miescher, "Facing Barbarians: A Narrative of Spatial Segregation in Colonial Namibia," Journal of Southern African Studies 38, No. 4 (December, 2012): 770.
} 
claimed to be 'white' settler South Africa, and drew the line against 'dark' or inner Africa." ${ }^{\prime 65}$ In Berlin, the Red Line was simultaneously reconceptualized as a "Blue Line," south of which the German government could guarantee police protection.

The establishment of a Police Zone in 1916 and the restriction of movement across this border effectively separated the Ovambo populations in the north, which constituted the majority of the African population in the territory, from the Nama, Herero, and Baster populations of the south. The Nama and Herero Genocide between 1904 and 1907 made the implementation of colonial rule particularly effective in the south and central parts of the territory. The significantly reduced African populations in the Police Zone allowed for the effective expropriation of land and the transformation of many Africans to the role of farm laborer. Although the boundaries of the Police Zone changed over time, the restrictions on Africans within its boundaries remained similar throughout the transition to South African rule and into the post-World War II period. ${ }^{66}$ Miescher again describes this consistent position of Africans inside the Police Zone, writing:

For the areas inside the Police Zone the South African colonial power now came very close to achieving their goal of ordered segregation of space. In the colonial heartland of the Police Zone, Africans, if not in a reserve, were only tolerated in the form of dependent labor on farms, in mines or in the domestic sphere, keeping out economically independent African entrepreneurs and farmers....By the late 1950s, the territorial segregation of colonial Namibia was successfully completed. Its settler society was now reassured and convinced of its ability to control 'South West Africa proper. ${ }^{67}$

The extensive reach of the South African colonial government in the Police Zone differed greatly from the colonial approach to governing the Ovambo populations that were needed for migrant labor in the mines. ${ }^{68}$

\footnotetext{
${ }^{65}$ Ibid.

${ }^{66}$ Ibid., 769-771.

${ }^{67}$ Ibid., 780-781.

${ }^{68}$ With limited resources in the territory during this period, both the German government and South African colonial regime relied on a form of Indirect Rule to exert control over the Ovambo populations in the north. While the colonial government was still able to impact and affect the lives of the subjugated populations in the region, it did not rise to the same level of control that they possessed in the Police Zone.
} 
The distinct difference between the administration of the "frontier" in the north and the "colonial heartland" in the south of the territory is the primary reason for the spatial demarcations of this study. While a study of transnational resistance strategies in the north would be valuable in its own right, it is the aim of this study to focus on those people and areas that experienced the most intrusive and oppressive effects of the South African colonial regime. Nearly all of the centers of Nama, Herero, and Baster power, including Gibeon, Hoachanas, Bethanie, Warmbad, Okahandja, Gobabis, Omaruru, and Rehoboth, fell south of the Police Zone boundary. These African communities experienced intense restrictions on their religious practices, mobility, economic production, autonomy, and ability to survive in an unforgiving environment. Direct confrontation with segregationist and apartheid policies in these areas, and the ability of the South African government to quickly and effectively enforce those policies in the Police Zone, resulted in the development of specific transnational resistance strategies by the Nama, Herero, and Baster leadership that differed markedly from the more labor-centric movements that emerged in the Ovambo polities to the north. ${ }^{69}$ For these reasons, this dissertation focused on the transnational resistance strategies developed by those communities in the Police Zone between 1919 and 1962.

\footnotetext{
${ }^{69}$ The term "segregationist" refers to those policies and mandates that were passed into law between 1921 and 1949. These policies set out to politically and socioeconomically segregate Africans from white settlers in the public sphere. These were passed while South African control in South West Africa was still expanding but faced limitations due to a lack of manpower. The term "apartheid" is used to refer to the much more expansive and rigidly enforced policies that were passed in 1949 as the National Party came to power in South Africa. The South African government, following a refusal to place South West Africa under the purview of the United Nations, administered South West Africa as an extension of the Union. More resources were poured into the territory during this period and the administration more actively penalized people of all races that violated the legal apparatus of apartheid.
} 


\section{Ethnicity and Geopolitics in Namibia's Police Zone}

Now that the spatial and temporal limits of the study are established, it is important to discuss the nature of ethnicity in the Police Zone and its role in the subnational geopolitical dimensions of the transnational resistance strategies developed by the Nama, Herero, and Basters during this period. In the Police Zone, the Nama, Herero, and Basters were the three primary ethnic groups with significant sociopolitical and economic power. This section deals exclusively with Herero and Nama ethnicity, as Baster ethnicity is dealt with in great detail in chapter 2 . The structuralist interpretation of ethnicity is embraced in this study and the primordial definition of the term is rejected. Thus, ethnicity is conceived as a constructed identity whereby a group of people share cultural traits and historical experiences that are commonly accepted by said group as exclusive or definitive of said ethnicity. Ethnicity is not a biological trait or state of being that is passed from one generation to another. ${ }^{70}$ As such, the following pages look at the shared historical experiences and cultural practices that have come to define an often fluid and changing Herero and Nama ethnic identity.

The Herero are primarily a Bantu subgroup descended from Otjiherero-speakers that arrived in modern-day Namibia from the north and northeast between the sixteenth and eighteenth centuries and settled throughout much of north-central Namibia. While pastoralism was central to the Herero identity, prior to the 1860 s, the Herero were not exclusively cattleherders and frequently supplemented this socioeconomic activity with mercenary work in Angola and less-common hunting and gathering. ${ }^{71}$ As Dag Henrichsen emphasized, before the 1860s stock-owning was not guaranteed in central Namibia and the issue of economic

\footnotetext{
${ }^{70}$ For more on the nature of ethnicity in Southern Africa and the structuralist versus primordial debate, see Leroy Vail, The Creation of Tribalism in Southern Africa (Berkeley: University of California Press, 1991).

${ }^{71}$ Marion Wallace, “'Making Tradition:' Healing, History and Ethnic Identity Among the Otjiherero-Speakers in Namibia, c. 1850-1950," Journal of Southern African Studies 29, No. 2 (June, 2003): 356-357.
} 
impoverishment significantly impacted the Herero. ${ }^{72}$ The 1840 s in central Namibia were characterized by Herero subjugation to Oorlam hegemony, and the 1850s were defined by widespread impoverishment among the Herero. However, in the late-1850s and 1860s, strong Herero leaders emerged in the region and began the process of rebuilding herds, establishing new bases of political power, and creating a new "cattle-based pastoral society which, as such, did not exist before." 73

Following the death of Tjamuaha and Jonker Afrikaner in 1861 and the emergence of his son Maharero as a successful political leader, the 1870s saw the emergence of new ethnic indicators that came to define the Herero identity. ${ }^{74}$ Cattle, guns, the control of land through a network of wells, and the embrace of mission Christianity became characteristic of the Herero. The accumulation of livestock was part of a larger "flexible effort to claim resources and construct an economic, social, and political differentiation in central Namibia." ${ }^{.75}$ The okuruиo, or Holy Fire, was the "ceremonial center of Herero life" and became a defining part of the Herero identity as well. ${ }^{76}$ Kirsten Alnaes, in describing the ceremonial and symbolic importance of the okuruиo to Herero identity, wrote "[I]t is through the Holy Fire that the intricate web of relationships between cattle, forefathers, men, women, children, and extended family is mapped out...[it is the] center around which, and through which, basic factors of Herero life meet, where transformations take place, where misfortune is undone, and where life begins and death is

\footnotetext{
${ }^{72}$ Dag Henrichsen, “Establishing a Precolonial ‘Modern' Cattle-and-Gun Society: (Re-)Pastoralization, Mercantile Capitalism and Power Amongst Herero in Nineteenth-Century Central Namibia," in Pastoralism in Africa: Past, Present and Future, eds. Michael Bollig, Michael Schnegg, and Hans-Peter Wotzka (New York: Berghahn Books, 2013), 203.

${ }^{73}$ Ibid.

${ }^{74}$ Maharero was a powerful Herero chief at Okahandja between 1861 and 1890. Maharero engaged in numerous conflcits with Christian Afrikaner, Jan Jonker Afrikaner, and the Nama in south-central South West Africa to establish political and economic dominance in the region. Maharero's father Tjamuaha was also a Herero chief and ruled mostly from Windhoek under the subordination of Jonker Afrikaner and the Oorlam hegemony of the time.

${ }^{75}$ Ibid., 202.

${ }^{76}$ Wallace, "Making Tradition," 359.
} 
completed." 77 This series of historical, cultural, and structural forces formed the very foundations of a quickly solidifying and exclusive Herero identity in central Namibia.

By the mid 1880s, the Herero had politically restructured themselves, with most of them falling under the political authority of four key leaders with specific geopolitical bases of power. Maharero was based in Okahandja, while Kambazembi, Manasse Tjiseseta, and Kahimemua Nguvauva resided at Waterberg, Omaruru, and Otjihaenena, respectively. ${ }^{78}$ The paramount chieftaincy was frequently contested among the Herero and, with the arrival of the Germans in 1884 and the death of Maharero in 1890, the struggle for this power increased. Maharero's son, Samuel Maharero, underwent a succession dispute and allied with the Germans who named him chief of the Herero and helped him subdue his political rivals. By 1894, Samuel Maharero became the paramount chief of the Herero, agreed to new territorial boundaries with the Germans, and asserted claims over Herero lands not traditionally controlled by the chiefs of Okahandja. In this process, Samuel Maharero expelled many of his rivals, patronized his allies, and consolidated Herero political power in South West Africa. ${ }^{79}$

Samuel Maharero's power was short-lived, however, and the perpetration of genocide against the Nama and Herero by the German government in 1904 was a period of political and socioeconomic devastation for the Herero. Samuel Maharero and many of his followers were forced to flee to the Bechuanaland Protectorate as refugees in 1904 after the Battle of Waterberg. ${ }^{80}$ Many Herero remained in exile until the South African occupation of the territory in 1915, at which most returned to South West Africa and re-established their herds in the north

\footnotetext{
${ }^{77}$ Ibid. Alnaes's quote comes from an unpublished paper titled "The Herero Holy Fire" which is, in turn, quoted by Wallace in this article.

${ }^{78}$ Ibid., 357.

${ }^{79}$ Jan-Bart Gewald ''I Was Afraid of Samuel, Therefore I Came to Sekgoma:' Herero Refugees and Patronage Politics in Ngamiland, Bechuanaland Protectorate, 1890-1914," Journal of African History 43, No. 2 (2002): 217 218.

${ }^{80}$ Wallace, "Making Tradition,” 361-362.
} 
and east-central part of the territory. The crushing loss by the Herero at the hands of the Germans caused many to look for reasons for their failure, with most contending that the abandonment of Herero traditional practices and the embrace of European socioeconomic structures led to their defeat and current state. The death of Samuel Maharero in exile in 1923 served as the spark that led to attempts to return to Herero traditionalism and solidified the twentieth-century Herero identity. ${ }^{81}$

Throughout the 1920s and 1930s, Herero society undertook several actions to return to a more traditional conception of Herero identity. Many actions, like the re-igniting of the okuruиo, the return to male circumcision, and the re-introduction of polygyny were direct responses to mission Christianity which the Herero saw as directly contributing to their downfall in the early twentieth century. ${ }^{82}$ Similarly, some Herero restarted the process of knocking out their lower incisors and filing their upper incisors into an inverted "v" shape. ${ }^{83}$ This process of recreating a "true" Herero identity was only accelerated by the South African government's attempt to reinstitute ethnically-based German reserves in the territory. This process of ethnicization was seen by many Herero as an opportunity to create ethnic spaces and "escape [the dominant colonial order] without leaving it." 84

The term Herero is used frequently in this dissertation and it is necessary to discuss its use with regard to its historicization above. As the previous paragraphs suggest, between the 1920s and 1960s Herero identity became increasingly exclusive and salient and based on a

\footnotetext{
${ }^{81}$ Jan-Bart Gewald, "Coming Through the Slaughter: The Herero of Namibia, 1904-1940," in The Practice of War: Production, Reproduction and Communication of Armed Violence, eds. Aparna Rao, Michael Bollig, and Monika Bock (New York: Berghahn Books, 2007), 96.

${ }^{82}$ Ibid., 97-98.

${ }^{83}$ Ibid.

${ }^{84}$ Gesine Kruger and Dag Henrichsen, “'We Have Been Captives Long Enough. We Want to be Free:' Land, Uniforms, and Politics in the History of the Herero in the Interwar Period" in Namibia Under South African Rule: Mobility and Containment, eds. Patricia Hayes, Jeremy Silvester, Marion Wallace, and Wolfram Hartmann (Athens: Ohio University Press, 1998), 149.
} 
commonly accepted set of characteristics and cultural structures deemed as being "Herero." In the colonial sphere, the South African government had ultimate control over creation and implementation of policy in the territory. However, the Herero chiefs and leaders during this period still maintained a significant amount of power and sway over the political lives of the Herero in South West Africa. While different ethnicities lived in close proximity to one another throughout the territory, the Herero still maintained population centers and traditional nodes of power like Okahandja in central South West Africa. At these nodes of geopolitical power, the Herero leaders played an important role in organizing and structuring the resistance strategies of those who still participated in and followed traditional authority that functioned simultaneously with the colonial political superstructure. Chief Hosea Kutako, who was appointed Herero chief in 1917 by the South African government and later affirmed by Samuel Maharero from exile in 1920, served as one of these important power brokers. ${ }^{85}$ Although he held sway in the larger resistance process of the territory, his primary influence was over the Herero in central South West Africa. Less potent influence was held by other Herero leaders, but the largest concentration of Herero power and control over the resistance decision-making process rested with Kutako. These Herero power brokers frequently coordinated with one another to achieve their subnational goals.

Nama ethnicity, much like Herero ethnicity, centered around common cultural practices, traditional nodes of geopolitical power, and a culturally-accepted lineage that contended the Nama groups descended from a common set of ancestors. The Nama initially lived a nomadic lifestyle with the protection of women and cattle being central to their worldview. The Nama were Khoe-speakers who originated around the Orange River where hunting prowess was valued

${ }^{85}$ Victor L. Tonchi, et al., Historical Dictionary of Namibia (Lanham: Scarecrow Press, 2012), 223. 
and wealth was measured in head of cattle. ${ }^{86}$ The Nama tended to live in small lineage-based groups that consisted of anywhere between five and 30 dwellings, with seniority determining the position of one's home. Common features of Nama society included polygyny, virilocal residence, patrilineal sociopolitical organization, and communal land ownership. ${ }^{87}$

The Nama emerged in South West Africa in two separate waves in the nineteenth century, resulting in a split between two groups called the "Great Nama" or "Pure Nama," and the Oorlam. According to Nama traditional narratives, the "Great Nama" consisted of eight subgroups that descended from a set of five brothers. ${ }^{88}$ The Topnaars settled from Walvis Bay to Okahandja while the Bondelswarts settled in Warmbad. The other six branches of the pure Nama formed an alliance together in south-central Namibia. The Khailkhaun under Oasib established itself at Hoachanas while the Franzmännschen under Simon Kooper emerged at Gochas. The !Kara-!oan of the Chamob River, the Swartboois at Fransfontein, the Groot Doden near the Fish River, and the Feldschuhträgers made up the remaining branches of the Great Nama. ${ }^{89}$

The Nama south of the Orange River ultimately migrated to Namibia later in the 1800 s and were referred to as the Oorlam. These groups mixed with the other Nama groups in the area during this migration and adopted many aspects of their clothing, language, and names, making any distinction between the two groups negligible by the twentieth century. ${ }^{90}$ The Oorlam consisted primarily of five branches with the Afrikaners being the most dominant during this early period. ${ }^{91}$ The Witbooi settled at Gibeon, while the Gei-/Khauan under Amraal Lamberts

\footnotetext{
${ }^{86}$ Alan Barnard, Hunters and Herders of Southern Africa: A Comparative Ethnography of the Khoisan Peoples (Cambridge University Press, 1992), 179-180.

${ }^{87}$ Ibid., $185-187$.

${ }^{88}$ Ibid., 181-182.

${ }^{89}$ Tonchi, et al., Historical Dictionary of Namibia, 270-271.

${ }^{90}$ Ibid.

${ }^{91}$ The term Afrikaner refers here to a specific branch of the Nama and not the Dutch white Boers that lived in South Africa.
} 
established themselves at Naosannabis and Gobabis. The /Kari-Khauan made their home at Berseba and the !Aman at Bethanie. Although there was, at times, conflict between the Great Nama and the Oorlam, ethnic boundaries during this period were porous and frequently traversed. ${ }^{92}$ The Oorlam also found themselves in conflict frequently with the Herero in the area and this led to a period of political instability that spanned from the 1840s through the 1890s.

Following these initial migrations, the Nama settled down and established permanent settlements and hereditary chieftaincies at the aforementioned locations. These settlements and towns became nodes of geopolitical control and power for the ruling families. A kaptein was chosen from the ruling family of a given branch and then his power was limited by a council of elders, from whom the kaptein needed unanimous consent before undertaking a decision. ${ }^{93}$ Thus, the chief was considered a "primus inter pares" whose primary function was to follow and rule by the will of the people. ${ }^{94}$ Some of the most powerful leaders to emerge out of this political system included Hendrik Witbooi, Jonker Afrikaner, Jan Jonker Afrikaner, and Simon Kooper. Likewise, powerful settlements such as Gibeon, Bethanie, Berseba, and Warmbad became influential nodes in the Nama geopolitical system. ${ }^{95}$

Prior to the arrival of the Germans and the perpetration of the genocide in 1904, the various Nama branches undoubtedly came into conflict with one another. However, the genocide proved instrumental in disrupting the sociopolitical organization of the Nama. ${ }^{96}$ Although similar structures would re-emerge during the South African occupation of South West Africa, this period, especially the 1940s and 1950s, saw the emergence of more cohesion between the

\footnotetext{
92 Tonchi, et al., Historical Dictionary of Namibia, 270-271.

93 Ibid., 271.

${ }^{94}$ Barnard, Hunters and Herders of Southern Africa, 183-184.

95 Tonchi, et al., Historical Dictionary of Namibia, 271.

${ }^{96}$ Barnard, Hunters and Herders of Southern Africa, 181-182.
} 
various Nama polities in their attempts to resist the extension of segregationist and apartheid policies by the South African regime. Certain families, like the Witbooi, continued to exert significant influence over Nama social and political life within the confines of the South African colonial system. Much like the Herero, these families and leaders were key power brokers in the development of Nama resistance strategies and although the strategies employed at Hoachanas and Gibeon might be different with regard to the AME Church in the 1940s and 1950s, the strategies across the Nama polities maintained a remarkable cohesiveness and similarity.

When utilizing the terms Herero and Nama in this study, it should not be assumed that the particular resistance strategies were used by all Herero or Nama in the territory in the same way. However, as this section notes, the adoption of particular strategies by powerful families and leaders within a particular ethnic group frequently resulted in the widespread adoption by those who still followed or were beholden to figures and structures of traditional authority within the Police Zone. Although the Nama in Gibeon or Hoachanas, or conversely the Herero in Windhoek or Okahandja, might follow the authority of different chiefs or kaptiens, there was a significant amount of coordination between these leaders that helped create and facilitate coordinated resistance strategies and campaigns with great success. In most cases deviation from these larger subnational strategies was the exception, as in the case of the Swartboois with the UNIA, and not the rule. ${ }^{97}$ Thus, while ethnicity and subnationalism did not exclusively define one's approach to resistance, the geopolitics of ethnicity in the Police Zone did influence Namibians' acceptance and implementation of various resistance strategies.

\footnotetext{
${ }^{97}$ See pages 166 through 168 of this dissertation for more on the Swartboois view of the UNIA in 1920s South West Africa.
} 


\section{Subnationalism and Nationalism in Namibia's Police Zone, 1919-1962}

As the previous pages suggest, ethnicity became more salient and reified under the South African colonial regime as the state actively segregated Namibians from whites and one another. This ethnic structure was highly influential in the way that Namibians resisted between 1919 and 1960, impacting the strategies and goals of these transnational campaigns against South African rule. The resistance strategies developed during this period tended to be highly subnational in nature, with campaigns developing largely along existing ethnic, social, and geopolitical lines. This trend toward seeking subnational concessions through transnational resistance strategies continued through the 1950 s until the more nationalistic resistance movement emerged under the control of SWAPO in the 1960s. Thus, it is crucial to identify the way that the terms "subnationalism" and "nationalism" are used in this dissertation and their role in describing the nature of a particular resistance strategy.

Subnational movements, as defined by Joshua B. Forrest, are "movements by regional actors to pursue greater autonomy within the existing [state], a relatively loose degree of political separatism, or outright secession." ${ }^{98}$ Within subnational movements, the process of political mobilization is often started and controlled by "regionally-based forces" and geared toward the achievement of regionalized territorial autonomy or the redress of specific socioeconomic complaints that center on the achievement of regional political goals. ${ }^{99}$ The regional component of subnationalism often revolves around the rule of traditional authorities that are frequently affixed to a specific geopolitical unit. These traditional authorities and political structures desired the return of political self-autonomy that was usurped by the colonial state. For the masses, the common connective tissue that holds a subnational movement together is ascriptive in nature,

\footnotetext{
98 Joshua B. Forrest, Subnationalism in Africa: Ethnicity, Alliances, and Politics (Boulder: Lynne Rienner, 2004$), 5$.
} ${ }^{99}$ Ibid., 1. 
meaning that a group within a subnational unit perceive themselves as bounded together by common descent, territorial affiliation, or shared historical experiences. Through this group boundedness between the masses and traditional political authorities, subnationalism occurs when this group becomes politically-mobilized with the aim of promoting their collective economic, political, or social interests. ${ }^{100}$

In South West Africa, these subnational movements frequently developed along ethnopolitical and geopolitical lines within the colonial state. Namibians' resistance strategies in the pre-SWAPO period rarely demanded national independence for the entire South West Africa territory. Instead, their transnational resistance strategies and approaches often fought for subnational political autonomy or the achievement of subnational concessions from the colonial state that returned power in the decision-making process to traditional authority figures in a given community or area. For example, during the Rehoboth Basters petition-writing campaign to the League of Nations, the primary concern of the petitioners was the return of the Basters' political autonomy that was enjoyed during the German colonial period. The Basters mobilized politically based on regional factors and their desire to promote their collective interests in the pursuit of subnational political autonomy. Similar processes played out elsewhere in the Police Zone during this period, with the Herero pursuing their own socioeconomic interests through the UNIA and UN and the Nama seeking to re-establish their sociopolitical autonomy through the AME Church and UN.

In these resistance campaigns, the issue of complete territorial independence for the entire South West Africa colony was limited and, at times, not addressed by Namibians' claims. Subnationalism prevailed during this period in part because of the South African state's focus on

${ }^{100}$ Ibid., 9-10. 
promoting the salience of ethnic identity in the creation of reserves in the territory. Another contributing factor was the recent history of conflicts between the Nama, Herero, Damara, and Basters in central Namibia as recently as the 1890s. ${ }^{101}$ Over time, the historical weight of these conflicts lessened as political power brokers turned their attention almost solely to the oppressive behavior of the colonial state. However, during this period subnationalism was one of the defining characteristics of resistance campaigns in the Police Zone that sought to win regional concessions from the colonial government.

In the final chapter of this work, the nature of resistance campaigns waged by Namibians against the South African regime shifted from subnational concerns to those of a more nationalistic nature. African nationalism is different from the subnationalism discussed previously in its territoriality, its social composition, and in its ultimate political and socioeconomic goals. Definitions for African nationalism, or nationalism more broadly, are often elusive and heavily contested in the historiography. The role of colonialism and the lack of true nation-states in colonial Africa are a point of contention among scholars in finding both the antecedents and basis for national movements in Africa. Likewise, academics have deliberated the precise definitions and descriptions of the terms nationality, nationalist, national sentiment, cultural nationalism, and psychological nationalism. ${ }^{102}$ Each of these debates has added nuance to the definition and scope of African nationalism, but the term still remains difficult to concisely conceptualize.

Perhaps it is best to first set forth the territorial dimension of the definition of African nationalism before discussing the movement's composition and goals. The term nationalism, as it

\footnotetext{
${ }^{101}$ See Wallace, History of Namibia, 103-130 for more on the political conflicts that engulfed the central and southern parts of Namibia in the nineteenth century.

102 Arif Hussain, "The Educated Elite: Collaborators, Assailants, Nationalists-A Note on African Nationalists and Nationalism," Journal of the Historical Society of Nigeria 7, No. 3 (December, 1974): 486-488.
} 
is used in this dissertation, differs significantly from subnationalism in its spatial and territorial components. Whereas subnationalism centered on more regional and local political units that often existed in the pre-colonial period, the territorial aspect of African nationalism is inextricably linked to the colonial process and the artificial boundaries that were created and solidified during the nineteenth and twentieth centuries. ${ }^{103}$ Historian Assa Okoth highlighted the role that colonialism played in shaping African nationalist movements, writing "The colonial powers alone created the present bases of [the] nations of independent Africa by arbitrarily dividing the continent into administrative entities and imposing thereupon legal, linguistic, and cultural concepts." 104 These arbitrary colonial borders played an influential role in structuring the legal apparatus, social conditions, economies, and political infrastructure in a given territory during the period. African nationalists, seeking to seize these mechanisms and pry them from European hands, necessarily embraced old colonial boundaries as the territorial limits for the creation of newly independent states. ${ }^{105}$

In the South West Africa example, the nationalist movements of the 1960s represented a marked shift in the territorial conceptualization of resistance movements and resistance strategies. Earlier protest movements and resistance campaigns frequently referenced regional and local ethnopolitical boundaries in seeking concessions from the colonial government. For example, the Basters' petitions in the 1920s pertained exclusively to the lands surrounding Rehoboth while the resistance of the Herero and Nama to forced land removals in the 1940s and 1950s focused almost exclusively on the political and socioeconomic concerns at Aminuis and Hoachanas, respectively. However, in the 1960s the language used in petitions and other forms

\footnotetext{
${ }^{103}$ Toyin Falola, Nationalism and African Intellectuals (Rochester: University of Rochester Press, 2004), 110.

${ }^{104}$ Assa Okoth, A History of Africa: African Nationalism and the De-Colonization Process (Nairobi: East African Educational Publishers, 2006), 2.

105 Toyin Falola, Nationalism, 111.
} 
of protest changed. The student organizations and intellectual elites discussed in the final chapter of this dissertation began to advocate for the independence of the whole South West Africa territory and all of its people from South African control.

In addition to the spatial differences between subnational and nationalist movements, there are also key differences in their composition and stated goals. In historian Arif Hussain's attempt to historicize and explain the general characteristics of African nationalism, he provides a concise definition of nationalism. He contends that nationalism is "a movement for the attainment and maintenance of self-government on behalf of a group of people in a given territory." Thomas Hodgkin espoused a similar understanding of African nationalism, stating the term nationalist referred to "any organization or group that explicitly assert[ed] the rights, claims, and aspirations of a given African society...in opposition to European authority, whatever the institutional form or objective." ${ }^{106}$ While Hussain and Hodgkin clearly focused on political dimensions, other historians have expanded upon the scope of African nationalism and its characteristics. Okoth further argued that nationalism included "opposition to alien control; the consciousness of belonging to a particular African nation...; pride in the nation's culture, traditions, institutions and achievements; awareness of common political rights and responsibilities; an articulate demand for a self-governing nation-state; and especially all forms of persuasion, agitation and concerted action through which such sentiments are expressed and encouraged." ${ }^{107}$ In each of these definitions, it is clear that one of the defining characteristics of the nationalist movements in Africa was the desire of Africans to seize control of the social, political, economic, and legal mechanisms of the state and utilize them for the benefit of Africans, rather than Europeans.

${ }^{106}$ Thomas Hodgkin, Nationalism in Colonial Africa (New York: New York University Press, 1957), 14.

${ }^{107}$ Okoth, History of Africa, 1. 
Several factors contributed to the rise in African nationalism in the 1950s and 1960s. The destructive nature of World War II significantly weakened the global position and capabilities of European powers to maintain their colonial empires. ${ }^{108}$ African veterans' war experiences eliminated the aura of white invincibility that colonial troops and militaries once held and their exposure to concepts of Western nationalism through wartime propaganda only further affirmed their desire for similar rights and opportunities when they returned home. ${ }^{109}$ During the World Wars, hundreds of thousands of African soldiers served in the military and even more laborers were drawn into wartime production. ${ }^{110}$ At the conclusion of World War II a second colonial occupation began, whereby the European colonial powers extended social services, built infrastructure, and encouraged secondary industry to create a small urban-based working class. The European powers hoped to stabilize their colonial possessions through this process and repay their war debts with the profits secured through exploitation of the colonies. ${ }^{111}$ Post-war expectations by Africans for an increased standard of living forced colonial officials to respond to African demands in the hope of avoiding further protest or conflict. Education, in particular, saw a vast expansion during the 1940s and 1950s as new schools were constructed and the level and quality of education increased. Many Africans took advantage of these new opportunities, with a small number of Africans traveling overseas or to other parts of Africa to receive collegelevel educations. ${ }^{112}$ While overseas, African intellectuals were further introduced to Western

\footnotetext{
${ }^{108}$ Cooper, Africa Since 1940, 1-20. Cooper provides a detailed explanation of the impact that World War II had on the ability of European colonial powers to meet the demands of Africans in the post-war period and the general crisis that colonialism faced throughout the 1930s and 1940s. Cooper's work is important in outlining the varied interactions that different classes of Africans had with the colonial state and their changing expectations in the postwar period.

${ }^{109}$ Ndabaningi Sithole, African Nationalism (London: Oxford University Press, 1968), 47-49.

${ }^{110}$ Jean Allman,"Between the Present and History: African Nationalism and Decolonization," in The Oxford

Handbook of Modern African History, eds. John Parker and Richard Reid (London: Oxford University Press, 2013), 226.

${ }^{111}$ Ibid., 227.

${ }^{112}$ Cooper, Africa Since 1940, 24-27.
} 
concepts of nationalism, exposed to political mass mobilization campaigns, and created networks that would provide material and ideological support as their nationalist campaigns in Africa developed. ${ }^{113}$ The early successful decolonization of Ghana, the long-standing independence of Ethiopia, and the emergence of independent nations in formerly colonized Southeast Asia only further increased the demand among Africans for complete independence from colonial and neocolonial forces. ${ }^{114}$

Whereas subnational resistance strategies were often ethnically or linguistically exclusive and led by traditional authority figures or institutions, the nationalist campaigns of the 1950s and 1960s were frequently led by newly-educated political elites who effectively connected with the masses to create inclusive and popular movements. ${ }^{115}$ Okoth's work is again useful at highlighting how the nationalist movements were different from earlier forms of protest. He argued that there were three key characteristics of nationalist movements. First, the movement needed to "aim at the exercise or sharing of power at the colony's political center." 116 Next, the movement is "led by a political elite which is conscious of the aspirations of the masses [and] willing to articulate them." ${ }^{117}$ Finally, the movement must possess a popular following. While earlier forms of protest contained some of these characteristics, Okoth contends that only nationalist movements possessed all three at the same time. ${ }^{118}$ The subnational strategies

\footnotetext{
${ }^{113}$ Allman, "Between the Present and History," 227-228. Allman contended that colonialism and its contradictions helped "produce" the very intellectuals that would lead the African nationalist movements that brought about the end of colonial rule on the continent.

${ }^{114}$ Hodgkin, Nationalism in Colonial Africa, 11. See also, Allman, "Between the Present and History," 233 for a discussion on how nationalist movements in Ghana and Senegal had aims beyond national boundaries. Here, Allman argued that Senghor wished to transform the French Empire rather than escape it and Nkrumah was more focused on creating a "United States of Africa" than simply independence for the Gold Coast.

${ }^{115}$ For more on the connections between Western-or mission-educated elites and their relationship with the masses in the early nationalist movements on the continent, see Allman, "Between Present and History," 228-230.

${ }^{116}$ Okoth, History of Africa, 2.

${ }^{117}$ Ibid.

${ }^{118}$ Ibid.
} 
discussed in this dissertation were frequently led by political elites who were conscious of the aspirations of the masses but frequently lacked the mass popular appeal and sharing of power necessary to classify a movement as nationalistic in nature. The student-led movements of the 1960s and subsequent creation of mass political parties in South West Africa helped solve these glaring weaknesses of the earlier protest movements.

The nationalist movements that emerged across the continent in the 1950s and 1960s were highly effective because of their inclusivity and their ability, for however brief of a time, to overcome internal sociopolitical divisions in pursuit of common goals. The exploitative and oppressive behavior of the colonial regimes in Africa undoubtedly played a role in providing for common cause among the masses. Despite ethnic, linguistic, or subnational political differences, Africans within a particular colonial boundary were often subject to the same types of laws, administrative mechanisms, and sociopolitical controls that frequently advantaged Europeans and the colonial state, while disadvantaging Africans of all different socioeconomic classes. ${ }^{119}$ These experiences, over time, created a sense of common grievances among the different elements of African society and the eradication of the colonial regime was desired, albeit for different reasons, by most. The creation of national political parties became a natural nexus between the political elites and the masses to state these common grievances, give voice to their future aspirations and present them on the national and international stage, and focus the mobilization of resources and energy in a common direction. ${ }^{120}$

The creation of national political parties proved effective messaging tools for this purpose and, through the displacement of traditional authority figures with new Western-educated elites, many of these divisions were overcome in the name of achieving national independence. In

${ }^{119}$ Ibid.

${ }^{120}$ Ibid., 8. 
South West Africa, SWAPO most effectively overcame internal divisions and crafted a popular message that advocated political independence. Unlike in some parts of Africa where traditional authorities were completely displaced, SWAPO actively incorporated more traditional authorities into their power structure to appeal to the masses. ${ }^{121}$ As a result, many of the people bound to these leaders through subnational affiliation also joined the nationalist movement. This brought Baster, Nama, Herero, and Ovambo together for the mutually shared goal of achieving independence from the South African colonial state and eradicating South African rule from the entire territory. Like most entrenched white settler colonies, Namibia's independence ultimately was won by waging a protracted armed liberation campaign that began in $1966 .{ }^{122}$

In this dissertation, particularly in chapter seven, the term "nationalist" is used to describe the resistance campaigns of Namibian students who were educated in European and American universities during the 1950s and 1960s. What is meant by a nationalist resistance strategy in that instance is twofold. First, the resistance strategy was geared toward the complete territorial independence of South West Africa, as defined by the recognized colonial boundaries of the territory. In a national resistance strategy, the desire was the establishment of an independent Namibian state that encompassed the entirety of the South West Africa territory and all of its people. Second, the resistance strategy sought the collective improvement of the economic, social, and political lives of all Namibians, regardless of their ethnic or geopolitical affiliations, through the complete seizure of the political, economic, social, and legal mechanisms of the state that were previously controlled and dominated by South Africans. No longer were political leaders seeking regionally-based concessions for the improvement of their specific group's

\footnotetext{
${ }^{121}$ See Hodgkin, Nationalism in Colonial Africa, 13-16 and Martin Kilson, Political Change in a West African State: A Study in Modernization Process in Sierra Leone (Cambridge: Harvard University Press, 1966), 53-93 for an analysis of the new types of elites leading African nationalist movements and their relationship with the masses.

122 Allman, "Between the Present and History," 230-231.
} 
standard of living within the colonial system, but instead the movement's leaders were concerned about the conditions everywhere in the territory and the complete overthrow of the colonial regime. ${ }^{123}$ In this regard, nationalist movements were socially, politically, and territorially inclusive and used this inclusivity as an instrument of resistance against the colonial state. Although the transnational resistance campaigns involving student organizations and universities initially sought the improvement of individual socioeconomic situations and resistance to the extension of Bantu Education in South West Africa, these campaigns quickly shifted and created an intelligentsia in exile that were motivated by the nationalist concerns of territorial independence, overcoming subnational divisions, and the eradication of South African hegemony in the territory.

\section{Structure of the Dissertation}

This dissertation is divided into two parts consisting of four chapters each. The first part of this study focuses on the period spanning from the signing of the Treaty of Versailles in 1919 to the implementation of the apartheid government in South West Africa in the late-1940s. Chapter 2 examines the petition-writing campaign of the Baster community to the League of Nations and their attempt to retain some semblance of political autonomy in the Gebiet in Rehoboth. Chapter 3 traces the growth of the pan-Africanist UNIA, its role as a protest and social welfare organization, and the disunity that befell the organization following the Herero assumption of leadership in 1922. Finally, chapter 4 analyzes the political climate in South Africa in the late-1930s and 1940s. The development of the apartheid legal apparatus is examined, as are the specific policies that socially, politically, and economically marginalized the Namibian populations of South West Africa until independence.

\footnotetext{
${ }^{123}$ See pages 366 to 376 of this dissertation for more on the nationalistic nature of the Namibian students' resistance campaigns of the late 1950s and early 1960s.
} 
The second half of this dissertation covers a period that begins with the founding of the AME Church branches in 1946 and ends with the emergence of SWAPO and the South West African National Union (SWANU) in the early-1960s. Chapter 5 explores the Nama use of the AME Church to achieve spiritual autonomy from white missionary control and how Namibians utilized the church to call for vast improvements to the African education system in the territory. Chapter 6 draws upon the legacy of the Rehoboth Basters' petition-writing campaign and analyzes how Nama and Herero leaders undertook a similar campaign to the UN to prevent forced land removals in the 1940s and 1950s. The attempted removal of the Nama from Hoachanas and the Kuridora Affair are of crucial importance. The subsequent chapter focuses on the role that foreign universities and international student organizations played in providing scholarships for Namibians, resulting in a vocal political opposition in exile. Finally, the dissertation ends with a conclusion examining the successes and failures of these transnational resistance campaigns, and the larger lessons that can be learned from such efforts. 


\section{Chapter 2-A New Type of Resistance: The Rehoboth Basters' Petition-Writing Campaign to the League of Nations, 1915-1935}

The South African government received the mandate to rule over South West Africa in 1921 as a result of the negotiations at Versailles and the subsequent establishment of the League of Nations and Permanent Mandates Commission (PMC). In the early 1920s, the South African government established its control over South West Africa through the extension of segregationist laws and policies to the territory that limited Namibian mobility, eliminated viable economic opportunities, and institutionalized political oppression. In 1923, the impacts of this process reached the Rehoboth Baster community in southern Namibia when the government passed Proclamation No. 28 of 1923 and curtailed the limited autonomy and political selfdetermination the Basters secured from the German government in 1885. Devoid of legitimate means of legal recourse within the South African colonial system, the Basters focused their efforts on the utilization of post-World War I transnational organizations, like the newly-created League of Nations, to resist the colonial state's attempt to politically repress their community.

In 1923 the Basters responded to the South African encroachment of their limited political autonomy by creating a 13 -year-long petition-writing campaign that employed the language of self-determination and socioeconomic development present in the Covenant of the League of Nations to influence the policy- and decision-making processes of the South African government and express Baster political agency. The Basters sought the aid of the League of Nations in resolving the question of their political autonomy, as well as the resolution of more practical everyday concerns like the uneven issuance of hunting licenses, arbitrary fines, and predatory financial institutions. Although this particular resistance strategy was exclusive to the Basters, the petition-writing campaign opened a period of resistance in South West Africa characterized by the utilization of transnational institutions and organizations as a means of 
resistance against an increasingly aggressive and oppressive colonial state. The campaign proved effective in forcing the South African government to respond to their demands for clarity on policy issues and effectively moderated their abusive behavior toward the Baster community during a period of regional strife and challenges to South African rule.

Whereas previous scholars like Tilman Dedering focused on the Basters' use of Wilsonian language as a tool to place pressure on the South African government, this chapter focuses specifically on the substance of the claims made by the Basters in their petitions and their changing understanding of the League of Nations' role and usefulness in their quest for the return of limited political autonomy in the Gebiet. ${ }^{1}$ The chapter begins with an examination of the development of the Baster community in Namibia and the emergence of a particular AfroEuropean cultural identity defined by its embrace of political autonomy and Christianity. The Baster community's development is traced from its migration from Gordonia in the 1860 s and details the formation of their distinct and exclusive cultural identity. The chapter proceeds to analyze the position of the Basters in Namibian society under German rule and how that position changed throughout the course of World War I and during the South African government's extension of segregationist policies to the territory in the early 1920s. The impact of the Bondelswarts Rebellion on moderating the South African government's behavior in South West Africa is also briefly discussed.

Finally, the chapter concludes with an examination of the petition-writing campaign that began with the early petitions against Proclamation No. 28 of 1923 and ended with petitions

\footnotetext{
${ }^{1}$ Tilman Dedering, "Petitioning Geneva: Transnational Aspects of Protest and Resistance in South West Africa/Namibia After the First World War," Journal of Southern African Studies 35, No. 4 (November, 2009): 785801.
} 
acknowledging the re-unification of the Raads in the 1930s. ${ }^{2}$ Here, the chapter argues that despite the general unwillingness of the League of Nations to intervene in the territory, the petition-writing campaign moderated South African behavior in the territory and brought international attention to the South African government's violations of its position as mandatory power. Perhaps most importantly, it is argued that the ineffectiveness of the League of Nations to restore political autonomy to the Gebiet ultimately led the Baster leadership to develop alternative political strategies that included resolving subnational political disputes in order to make new unified claims of the South African government and League.

The strategies that the Basters developed were subnational in nature and intended to win concessions within the colonial order on issues that pertained exclusively to the Basters at Rehoboth. The express intention of this transnational resistance strategy was to leverage the international political power of transnational organizations to increase the pressure on the South African government to return subnational political autonomy to the Gebiet. During the interwar years, petition-writing became a strategy that was exclusive to the Basters but was adopted after World War II by the different ethnopolitical groups in the Police Zone. This strategy, in part, can be traced back to the historical processes that the Rehoboth Basters underwent during the German colonial period in South West Africa.

\section{Establishment of the Rehoboth Baster Community in Namibia, 1870-1915}

In order to understand the origins of the Baster's petition-writing campaign and the source of their political grievances against the colonial state, one must begin with an examination of the establishment of the Baster community in South West Africa and its distinct political

\footnotetext{
${ }^{2}$ The term Raad refers to the Baster Council, the political body that dealt with internal affairs in the Gebiet in Rehoboth.
} 
standing under German colonial rule. The Rehoboth Baster community originated on the northwestern frontier of the Cape Colony. As Dutch settlers began to trek inland from the Cape Colony in the eighteenth century, many of these settlers married indigenous Khoe women and started mixed-race families, the offspring of which were referred to as "Basters." 3 Baster communities formed in the territory south of the Orange River and north of the Cape Colony. The Basters developed an identity that was rooted in a strong Christian identity and the Afrikaner language, but their African heritage made them distinct from the white and Boer populations of the Cape. ${ }^{4}$

The Basters of the northwestern frontier embraced this distinct identity and wore the name "Baster" as a "badge of honor." The whites and Boers of the Cape rejected the Basters because of their Khoe ancestry and identity. However, the indigenous African populations of the region also rejected the Basters for their European-Christian identity and their use of Afrikaans and Dutch. In this ethnically-fluid space, the Baster community developed an independent cultural identity that leaned on its mixed-race heritage. At this cultural intersection between their European and African heritage, a strong inclination toward political sovereignty and cultural distinctness became a central part of the Baster identity.

Baster families assembled near Amandelboom and Schietfontein in the early nineteenth century and established autonomous settlements thereafter. Missionaries from the London

\footnotetext{
${ }^{3}$ Khoe-speakers are separate from the other Bantu groups in southern Africa. They were nomadic pastoralists that lived in the western part of South Africa and South West Africa. Khoe-speakers were some of the first Africans to come into contact with the Dutch when they arrived in the Cape.

${ }^{4} \mathrm{~J}$ Dahl, The Indigenous Space and Marginalized Peoples in the United Nations (New York: Springer, 2012), 199203. The terms "white" and "Boer" are used separately as a way to make the key distinction between populations of different European origins. The term "white" is used to refer to English-speakers in the Cape, while "Boer" refers to Dutch-speakers in the Cape, particularly those who trekked inland to the South African frontier.

${ }^{5}$ Liesbeth Rosen Jacobson, “The Eurasian Question:” The Colonial Position and Postcolonial Options of Colonial Mixed Ancestry Groups from British India, Dutch East Indies and French Indochina Compared (Hilversum: Uitgeverij Verloren, 2018), 18-19.
} 
Missionary Society (LMS) and Rhenish Mission Society (RMS) began work among these communities in the early-to-mid-nineteenth century and further solidified the group's strong Christian identity. The settlements at Amandelboom and Schietfontein continued to grow into the 1850s when, in 1855, the expanding Boer populations of the Cape encroached on the Baster settlements and forced a Baster exodus. The Basters trekked northward and established new settlements at De Tuin and Pella. ${ }^{6}$

Following the establishment of settlements at De Tuin and Pella, the Cape parliament passed a series of controversial laws in the mid-1860s that required landowners to provide documentary proof that they owned the land on which they resided. The Basters at De Tuin petitioned the Cape parliament in 1865 for the government-sanctioned acquisition of land in the northwestern frontier. However, racial barriers and white complaints over the Basters' request led the Cape parliament to reject the request and this decision forced the Basters to consider a second northward migration. The Basters held a People's Assembly on 24 February 1868 at De Tuin where they elected Hermanus van Wyk as Kaptein and tasked him with leading a migration northward across the Orange River into southern South West Africa. ${ }^{7}$ The Basters left De Tuin in forty ox-pulled wagons on 12 July 1868 , proceeded to Pella, and finally crossed the Orange River on 16 November 1868.

The migration into southern Namibia occurred in three separate groups under the guidance of van Wyk and Klaas Zwarts. Zwarts and his followers established a short-lived settlement at Grootfontein, while van Wyk and his followers continued on to Warmbad near the

\footnotetext{
${ }^{6}$ Martin Legassick, Hidden Histories of Gordonia: Land Dispossession and Resistance in the Northern Cape, 1800 1990 (Johannesburg: Wits University Press, 2016), 12-20.

${ }^{7}$ William Coates Palgrave, The Commissions of W.C. Palgrave: Special Emissary to South West Africa, 1876-1885

(Cape Town: Van Riebeeck Society, 1991), 66-67. Hermanus van Wyk was the first Kaptein of the Basters and responsible not only for their northward migration in the $1860 \mathrm{~s}$, but also secured the Treaty of Protection and Friendship with the German colonial government.
} 
Nama polities. The environmental destruction caused by the party's livestock was immense and van Wyk and his followers were ultimately forced to leave Grootfontein in December 1868.

Nama leadership granted van Wyk sustainable grazing land at Chamis in 1869 after failed settlement attempts at Ganigobis and Keetmanshoop. ${ }^{8}$

Map 2: The Baster Migration from Amandelboom in 1861 to Rehoboth in 1870

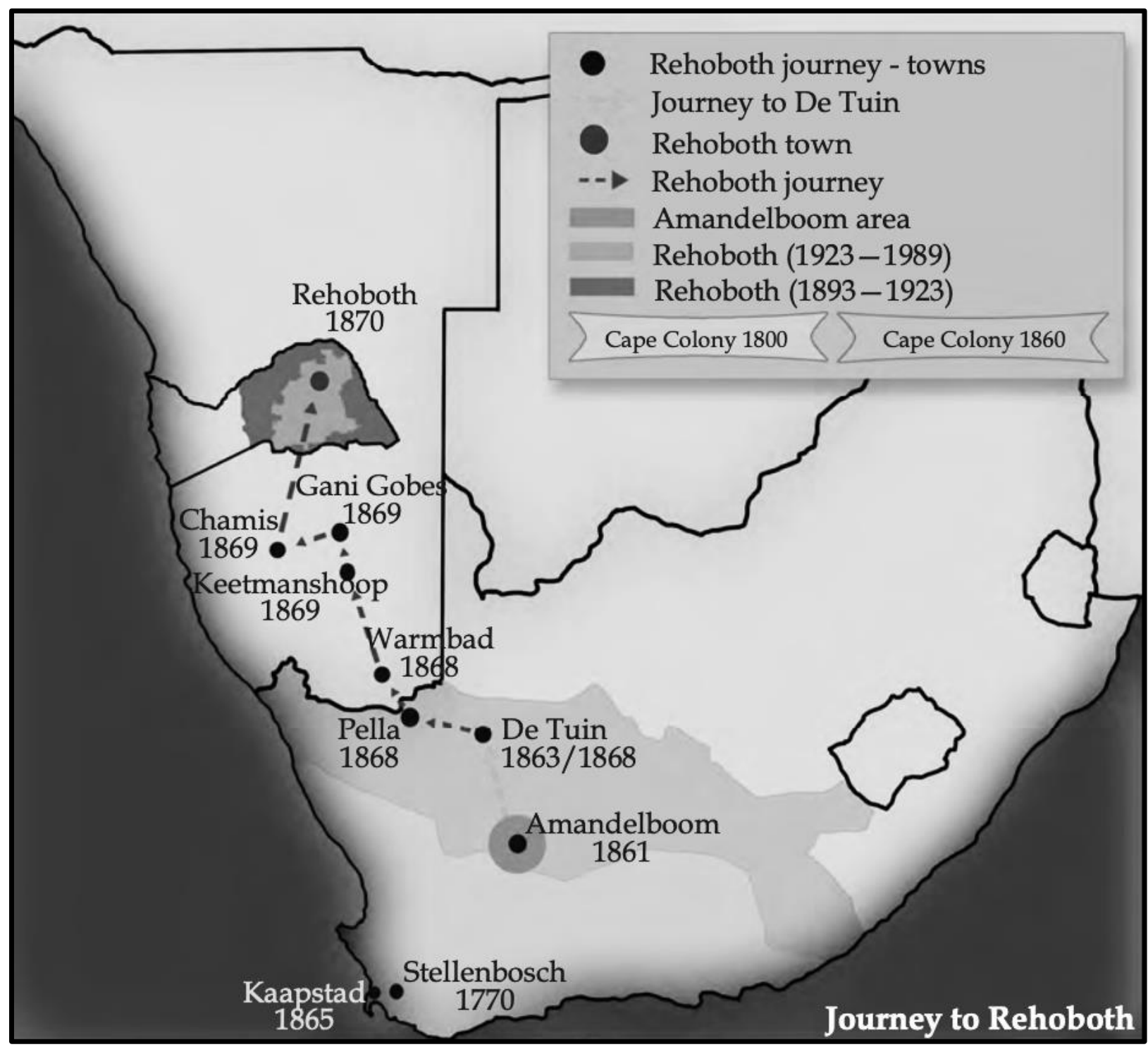

Source: Jeron Zandberg. Rehoboth Griqua Atlas (Morrisville: Lulu Publishers, 2013), 35.

\footnotetext{
8 Jeron Zandberg, Rehoboth Griqua Atlas (Morrisville: Lulu Publishers, 2013), 26-28.
} 
More fertile pastures and reliable water sources lay roughly 230 miles north in the largely-vacant lands surrounding Rehoboth. Oasib of the Khailkhaun granted the Swartboois the land at Rehoboth in the 1840s, but conflicts with Jan Jonker Afrikaner forced the Swartboois to abandon Rehoboth in $1864 .{ }^{9}$ Further conflicts erupted between the Nama and Herero in southern and central Namibia during the 1860s. It was in the peace negotiations between Afrikaner and Maharero that van Wyk and the Basters seized on the opportunity to establish a permanent and sustainable settlement.

Negotiations between the aforementioned parties occurred at Okahandja on 23 September 1870. Carl Hugo Hahn and other missionaries served as intermediaries in the construction of the peace. ${ }^{10}$ Through this agreement, van Wyk and the Basters secured permanent residence at Rehoboth to serve as a "buffer" between the Nama and Herero to reduce future conflicts. ${ }^{11}$ The Basters quickly drafted a new constitution for the governance of the settlement at the start of 1872. On 31 January 1872, the Basters ratified a 30-article constitution that outlined political, socioeconomic, and legal guidelines for the community. ${ }^{12}$ Over the next two decades, disparate Baster populations throughout southern Namibia moved to Rehoboth and facilitated the growth of the settlement. ${ }^{13}$ The Basters faced a number of attacks from the Herero and Nama throughout

\footnotetext{
${ }^{9}$ Alexander Gairiseb, "Swartbooi Traditional Authority in \|Khau-|gôan: !Haos ‡Gaełguis," in Customary Law Ascertained, Volume 3: The Customary Law of the Nama, Ovaherero, Ovambanderu, and San Communities of Namibia, ed. Manfred O. Hinz (Windhoek: University of Namibia Press, 2016), 61-162. Oasib was the leader of the Khailkhaun from 1840 to 1867 . He led numerous raids against the Herero and allowed missionaries to settle at Hoachanas. Jan Jonker Afrikaner was the son of Jonker Afrikaner and served as chief of the Orlam from 1863 to 1889. He was educated by the Rhenish Missionary Carl Hugo Hahn and waged a seven-year war against Maharero. ${ }^{10}$ Carl Hugo Hahn was a prominent Rhenish missionary in South West Africa tasked with introducing Christianity to the Nama and Herero. In addition to brokering the peace agreement at Okahandja, Hahn also established the Augustineum theological seminary at Otjimbingwe in 1866 to educate African missionaries.

${ }^{11}$ Hartmut Lang, "The Population Development of the Rehoboth Basters," Anthropos 93, No 4/6 (1998): 381-382.

12 James Minahan, Encyclopedia of Stateless Nations: Ethnic and National Groups Around the World A-Z (Santa Barbara: ABC-CLIO, 2002), 290-292.

${ }^{13}$ Lang, "Population Development of the Rehoboth Basters," 381-382. The Basters under Klaas Zwarts at Grootfontein moved to Rehoboth in 1881 after facing increased pressure from Nama and Herero raids on the settlement. Basters at Okahandja and Otjimbingwe moved to Rehoboth in 1882 for similar reasons. Finally, roughly fifty-one Baster families from Hoachanas moved to Rehoboth in 1889.
} 
the 1870s, and especially intense conflicts developed between 1880 and 1882 . However, superior firepower helped the Basters maintain their foothold at Rehoboth.

European contacts with Namibians intensified in 1883 when German businessman Adolf Lüderitz secured treaties with local Namibian leaders that procured large swaths of land in the hope of creating a German sphere of influence in southern Africa. On 1 May 1883, with the help of Rhenish missionaries, Lüderitz purchased Angra Pequeña from Joseph Fredericks and the people of Bethanie. ${ }^{14}$ Fear of British annexations in the area ultimately led Lüderitz to request German protection for Angra Pequeña. On 24 April 1884, Otto Von Bismarck placed Angra Pequeña under German protection and began an intensive process of securing more land and treaties with Namibian leaders. The land secured in the Kunene region, Kaoko, and near the Angola border provided the territorial basis for a German colony. ${ }^{15}$

As the Germans extended their colonial rule over their newly procured territory, they faced a shortage of manpower and made use of indigenous populations to strengthen their grip in the colony. Maximillian Bayer and Peter Carstens argued that the German government viewed the Basters as a useful tool in the extension of their colonial rule. The Germans categorized the Basters as an indigenous population, but also acknowledged the distinct position of the Basters in Namibian society. They believed that the Basters' mixed racial heritage indicated a higher level

\footnotetext{
${ }^{14}$ For a full discussion of German land acquisition in South West Africa, see Rayford W. Logan, "German Acquisition of Southwest Africa," The Journal of Negro History 18, No. 4 (October, 1933): 369-395. Lüderitz and other German agents concluded a number of treaties during the 1880s through both legitimate and illegitimate means. In some instances, deception and alcohol were used to facilitate the ratification of these treaties. In other instances, Namibian leaders sought to use the Germans as a powerful instrument to exert influence in local conflicts and power struggles. Missionaries played a key role in these agreements and their participation in these dubious efforts severely impacted their reputation among the African population well into the mid-twentieth century. ${ }^{15}$ Logan, "German Acquisition of Southwest Africa," 369-395. Otto von Bismarck served as the Chancellor of the German Empire from 1871 to 1890 . He was also responsible for organizing the Berlin Conference in 1884-5. At the Berlin Conference, regulations and procedures were established for the procurement and maintenance of European colonial possessions in Africa. At the conclusion of the conference, the German government's claim on South West Africa was confirmed.
} 
of civilizational attainment than their Nama or Herero counterparts. Their perceived intellectual superiority and advanced social development appealed to the German colonial administration and led to overtures for cooperation and collaboration between the two parties. Additionally, the geographical position of the Rehoboth Basters as a buffer between the Herero and Nama polities made the Basters politically useful to the German administration. ${ }^{16}$ The German government agreed that the Basters would retain certain political and legal privileges in exchange for their cooperation.

On 15 September 1885 Hermanus van Wyk agreed to the "Treaty of Protection and Friendship Between the German Empire and the Bastards at Rehoboth" and requested German protection for the Baster community. The treaty explicitly detailed the social, political, and legal privileges granted to the Basters in the Gebiet. And it established the Basters political autonomy, proclaiming "His Majesty the German Emperor acknowledges the rights and the liberty which the [Basters] have acquired for themselves and binds himself to leave undisturbed any treaties which other Nations or subjects thereof have previously entered into with them, and not to prejudice the Chief in the collection of the revenues to which he is entitled according to the laws and usage of his country." ${ }^{17}$ The fifth clause of the treaty expounded upon the Basters political autonomy by permitting them to litigate and try civil and criminal cases in Rehoboth. ${ }^{18}$ The treaty concluded with two clauses that required van Wyk to "[promise] protection, as regards life and property, to all subjects of the German Empire and those under its protection..." and “...assist as much as possible towards the preservation of peace in Great Namaqualand and

\footnotetext{
${ }^{16}$ Maximillian Bayer and Peter Carstens, The Rehoboth Baster Nation of Namibia (Basel: Basler Afrika Bibliographien, 1984), 7-10.

${ }^{17}$ Treaty of Protection and Friendship Between the German Empire and the Bastards at Rehoboth, 15 September 1885, National Archives of Namibia (Hereafter, NAN)/South West Africa Administration (Hereafter, SWAA)/3157.

${ }^{18}$ Ibid. Clause 5 is complex in that it only provides for the trial of cases involving burghers (citizens). A mixed court was required if a case was between a burgher and a non-burgher. In all cases, appeals of a decision to the German government were permitted.
} 
neighboring countries."19 The Basters honored this treaty and fulfilled their obligations from 1885 through the commencement of World War I.

At the beginning of World War I, the German government raised a Baster Corps in Rehoboth to support German forces in Namibia. The German government provided 46 members of the Rehoboth community with uniforms and weapons and sent them to Uitdraai to guard roughly 120 British prisoners of war. The German colonial administration made further attempts to send more members of the Baster Corps north to guard prisoners of war, but this decision provoked protests in Rehoboth. ${ }^{20}$ When the Baster leadership voiced their complaints to Colonel Victor Francke, he presented them with an ultimatum: continue to guard prisoners of war or forfeit their weapons and disarm. ${ }^{21}$

The colonial administration gave the Basters a three-day grace period to respond, but during this time the Basters evacuated unarmed men, women, and children from Rehoboth. When the colonial administration became aware of these actions, disarmament of Baster men at various outposts commenced. The German military proceeded to attack unarmed men, women, and children at Heuras during the Basters' flight from danger. ${ }^{22}$ Perhaps the most significant action taken by the colonial administration was the capture and execution of Cornelius van Wyk's sons. ${ }^{23}$ This act led to increased efforts by the Basters to fight against the German

\footnotetext{
${ }^{19}$ Ibid. Clause 4 also allows for the Rehoboth leadership to determine the conditions under which individuals may remain in the territory.

${ }^{20}$ George Steinmetz, The Devil's Handwriting: Precoloniality and the German Colonial State in Qingdao, Samoa, and Southwest Africa (Chicago: University of Chicago Press, 2008), 238-239.

${ }^{21}$ Ibid. The Basters were assured that their primary role during the war would be the fulfillment of police duties. When they were used to guard white prisoners of war, it laid the groundwork for the Basters to contest their position under German rule. Victor Francke was a German military officer and commander of the Schutztruppe in South West Africa during World War I. Francke led numerous campaigns against the Herero and participated in the Herero and Nama genocide between 1904 and 1907. Francke ultimately surrendered to South African forces on 9 July 1915. ${ }^{22}$ Rudolf G. Britz, et al., A Concise History of the Rehoboth Basters Until 1990 (Windhoek: Klaus Hess Publishers, 1999), 20-27.

${ }^{23}$ Cornelius van Wyk was the son of Hermanus van Wyk. He succeeded his father when he was elected as the second Kaptein of the Basters in 1914.
} 
military. On 22 April 1915, these small skirmishes resulted in the German government's issuance of a declaration of war. ${ }^{24}$

The declaration of war detailed the German government's efforts to disarm the Basters after they refused to fulfill German demands. The German government pointed to the evacuation of families during the three-day grace period, the unwillingness to forfeit their arms, and the alleged "plunder and murder against the whites" as the primary reasons for the conflict. ${ }^{25}$ The government vowed to “...take such measures as it may deem necessary, for the serious consequences of which the [Baster] community of Rehoboth will be answerable" and the "Treaty of Protection and Friendship" was rendered void. ${ }^{26}$ The German Schutztruppe attacked the Basters on 7 and 8 May 1915 at Tsamkhubis and defeat appeared imminent for the Basters. ${ }^{27}$ However, Union forces under the command of General Mackenzie arrived on 9 May 1915 and forced the Schutztruppe to abandon their attack on the Basters. ${ }^{28}$

Prior to General Mackenzie's victory, the Baster community made overtures to Union officials with the aim of preserving their lands and political autonomy in the event of a German defeat in the First World War. On 1 April 1915, Cornelius van Wyk claimed to have met with South African Prime Minister Louis Botha at Swakopmund to assure the general of the Basters

\footnotetext{
${ }^{24}$ Lieutenant-Colonel to the Council of the [Basters] of Rehoboth, 22 April 1915, NAN/SWAA/3157.

${ }^{25}$ Ibid.

${ }^{26}$ Ibid.

${ }^{27}$ The Schutztruppe was the name of the German colonial forces in their African colonies. Although Africans were recruited into the Schutztruppe, the practice waned in South West Africa following the genocide. While a Baster Corps was raised, the Schutztruppe in South West Africa consisted primarily of Germans, with additional support from Afrikaners that lived in the colony.

${ }^{28}$ Karl P. Magyar, "The Campaign in South West Africa," in The European Powers in the First World War: An Encyclopedia,, ed. Spencer C. Tucker (Oxford: Taylor and Francis, 2013), 654. Jan Smuts and Louis Botha answered the request by the British government to join the war effort on 7 August 1914. Smuts and Botha believed that participation in World War I was the best way to lay claim to the territory in the post-war period. Botha took command of the South African forces in February 1915 and arrived in Windhoek by May 1915. Botha controlled the northern forces and Smuts controlled forces in the southern part of the territory.
} 
neutrality. ${ }^{29}$ The Basters believed that this gesture assured them of the retention of their lands and continued self-determination at the conclusion of the war. ${ }^{30}$ The Basters and other Namibians were largely relegated to non-combat roles after the victory at Tsamkhubis, and Botha declared the conflict in South West Africa a "white man's war."31

The South African army quickly dispatched German forces in South West Africa. The German military surrendered to Union forces on 9 July 1915 at Khorab, merely two months after the Rehoboth Basters' stand at Tsamkhubis. ${ }^{32}$ The South African government quickly instituted martial law in South West Africa, which lasted until 1921. The lack of resources available to the South African government during this period allowed Namibians a brief period of reconstituted political power. ${ }^{33}$ The Otruppa movement thrived among the Herero, while Mandume built up his armed support in the north. Fears of rebellion among the white population soared as a result of the perceived military threat that these movements and groups posed, but the South African government did little to alleviate these concerns at the time. ${ }^{34}$ In Rehoboth, there was renewed hope that, at the conclusion of the war, the Baster community would return to its state of political autonomy and regain complete sovereignty. Yet, by 1918 it became clear that the immediate fate

\footnotetext{
${ }^{29}$ Louis Botha was the first prime minister of the Union of South Africa. Botha was a decorated war hero who fought in both the First and Second Boer Wars.

${ }^{30}$ G.J.J. Oosthuizen, "The Military Role of the Rehoboth Basters During the South African Invasion of German South West Africa, 1914-1915," South African Journal of Military Studies 28, No. 1 (1998): 97-98. See also Adam Cruise, Louis Botha's War: The Campaign in German South-West Africa, 1914-1915 (Johannesburg: Penguin Random House South Africa, 2015).

${ }^{31}$ Byron Farwell, The Great War in Africa, 1914-1919 (New York: W.W. Norton \& Company, 1989), 90.

${ }^{32}$ Wallace, History of Namibia, 210-216.

${ }^{33}$ The initial lack of resources and manpower in South West Africa during this period can be directly attributed to the diversion of resources to the German East Africa campaign which spanned from 1914 to 1918. In the immediate aftermath of the South West Africa campaign, Smuts and his forces were sent to German East Africa to subdue general Paul von Lettow-Vorbeck's army. The conclusion of the German East Africa campaign and the end of World War I allowed the South African government to turn its attention more fully toward governing South West Africa.

${ }^{34}$ Mandume was the last of the Kwanyama kings and reigned between 1911 and 1917. He was best known for his attempts to restore the power of the Kwanyama and his refusal to cooperate with Christian missionaries. During World War I, he came into armed conflict with the Portuguese in southern Angola. Upon his death at the hands of South African forces, the Kwanyama kingship ceased to exist.
} 
of the Rehoboth Basters and the rest of South West Africa was directly linked to the activities of transnational actors and the development of a new global post-war political order.

\section{The Creation of the League of Nations and Mandate System in South West Africa, 1916-1920}

The Basters' attempt to regain their political independence began in earnest following the German military's defeat in July 1915. On 2 November 1915 Cornelius van Wyk and four members of the Baster Raad met with the administrator of South West Africa Sir Edmond Howard Lacam Gorges to request the establishment of a new treaty that was similar to the Treaty of Protection and Friendship that the Basters had with the Germans. This overture was rejected and in early 1916 the Basters sent a petition to the British government requesting that Rehoboth be granted its independence. The Basters received no response from the British government and submitted a second petition that would make Rehoboth a British Protectorate. This, too, was rejected by the British in February 1918 because the British government claimed it would not make a decision on the matter while the country was still at war. ${ }^{35}$ One final attempt was made before South West Africa's fate was placed in the hands of the League of Nations and the negotiations at Versailles. In November 1919, the Basters proposed a plan that would place a British representative in Rehoboth and bestow him with immense political power in the town. The British government, once again, rejected the Basters' request. ${ }^{36}$

The political fate of the Basters was ultimately linked directly to the affairs of post-war South Africa and both the domestic and international political maneuvering of Jan Smuts

\footnotetext{
${ }^{35}$ Britz, et al., History of the Rehoboth Basters, 28-29.
}

${ }^{36}$ Zandberg, Rehoboth Griqua Atlas, 45. 
between 1917 and 1924. ${ }^{37}$ In The Failure of South African Expansion, Ronald Hyam posited that South African Prime Minister Louis Botha and General Jan Smuts entered the First World War with an eye toward domestic affairs. The British government requested that Union forces invade South West Africa on 7 August 1914 and the Committee on Imperial Defense set forth a strategic campaign whereby Union forces would capture the harbors at Lüderitz and Swakopmund and the wireless telegraph centers at Windhoek to disrupt German communications. ${ }^{38}$ As the previous pages suggest, South African forces succeeded in their invasion of South West Africa and claimed victory by July 1915. After the Union victory in South West Africa, Jan Smuts led a Union army into German East Africa in 1916 to defeat Paul von Lettow-Vorbeck and his forces. Smuts' offensive proved successful and, by 1917, he confined Lettow-Vorbeck and his German forces to the southern parts of German East Africa. Although German forces continued to operate in the territory until formally surrendering on 25 November 1918, Smuts and the Union military effectively occupied the German colonies in southern and eastern Africa. ${ }^{39}$

Following Smuts' military victories in southern Africa, he was called to London in January 1917 to join the Imperial War Cabinet. Smuts arrived in London in March 1917 and quickly cultivated a close relationship with the British Prime Minister David Lloyd George. Lloyd George relied heavily upon Smuts' military advice during this period and Smuts toured the Western Front, where he supported Field Marshal Douglas Haig's Third Ypres Offensive. An

\footnotetext{
${ }^{37}$ Jan Smuts was a decorated South African general and politician. He served as the Prime Minister of South Africa upon Botha's death in 1919 and held the office for a second time from 1939 to 1948. Smuts proved a highly capable statesman and was essential to the founding of the League of Nations the negotiations at Versailles.

${ }^{38}$ Ronald Hyam, The Failure of South African Expansion, 1908-1948 (New York: Palgrave MacMillan, 1972), 2627.

${ }^{39}$ W.O. Henderson, Studies in German Colonial History (London: Frank Cass, 1976), 134-137. Paul von LettowVorbeck was a German general that commanded the German colonial army in German East Africa. He was able to resist South African forces for nearly 4 years before surrendering in 1918. Lettow-Vorbeck also served in South West Africa and fought against the Herero during the genocide in 1904.
} 
indication of his reputation as a successful general, Smuts was later offered the command over British forces in Egypt, but he rejected the offer. ${ }^{40}$

In addition to Smuts' military acumen and history of success on the battlefield, his abilities as a statesman positioned him to play a prominent role in the creation of the new postwar international political order and provided him with the means to pursue his expansionist domestic political agenda after the war. Smuts' background as an administrator and diplomat, combined with his natural flare for public speaking captured the attention of Lloyd George and his inner circle, of which there were many proponents for the establishment of an international political organization that could facilitate peaceable reconciliation with the German government. Lloyd George, in his role as Prime Minister, created the Phillimore Committee in January 1917 in an attempt to give concrete form to the League of Nations concept that Lord Robert Cecil called for in his 1916 publication Memorandum on Proposals for Diminishing the Occasion of Future Wars. ${ }^{41}$ However, it was Smuts' advocacy and writings between 1917 and 1918 that provided a practical framework for such an organization.

On 14 May 1917, Smuts spoke to the London League of Nations Society and advocated for the creation of an international institution that would secure international rights and general peace at the conclusion of the war. Historian George Curry contended that Smuts' ability to eloquently discuss the future of the British people and the high stakes of the upcoming peace negotiations further ingratiated him to Lloyd George's government. By 1918, the British

\footnotetext{
${ }^{40}$ Spencer C. Tucker, ed., World War I: The Definitive Encyclopedia and Document Collection, (Santa Barbara: ABC-CLIO, 2014), 1474-1475.

${ }^{41}$ Peter Raffo, "The Anglo-American Preliminary Negotiations for a League of Nations," Journal of Contemporary History 9, No. 4 (October, 1974): 155-156. The Phillimore Committee was established in January 1918 at the suggestion of Parliamentary Under-Secretary of State for Foreign Affairs Lord Robert Cecil and Foreign Secretary Arthur Balfour. Lloyd George tasked the Committee with drafting a report that examined the various elements of the proposed League of Nations concept and considering the practicability and viability of such an institution. For more information on Lord Robert Cecil's early conception of the League of Nations, see Lord Robert Cecil, A Great Experiment: An Autobiography (London: Jonathan Cape, Ltd., 1941), 353-357.
} 
government viewed Smuts as a prime candidate to help develop a concrete and structured plan

for the League of Nations that could be presented at later, more formal, peace negotiations. ${ }^{42}$ At the behest of the prime minister, Smuts set forth a practical plan for the League of Nations in 1918 with the publication of The League of Nations: A Practical Suggestion. Smuts' work provided structure and a workable solution to what had previously been a "nebulous" idea. ${ }^{43}$

In the opening pages of his work, Smuts clearly outlined the practical concerns of this endeavor, writing "[T]he discussion of the League of Nations has proceeded far too much on general or academic lines; and this, combined with the inherent difficulties of the subject, has helped to create the impression which is unhappily prevalent, that the League is not really a matter of practical politics. To combat this impression, I have drawn in a rough outline what appears to me a practical, workable scheme." 44 Smuts also addressed the concerns of most at the time that the League of Nations was merely a cautious mechanism created out of fear of future wars. Smuts acknowledged this fact, stating that "a great deal of attention has been given to the idea of the League of Nations as a means of preventing future wars. The discussion of the subject proceeded almost entirely from that one point of view, and as most people are rather skeptical of the possibility of preventing wars altogether, the League has only too often been looked upon as Utopian, as an impracticable ideal not likely to be realized...."45 Smuts attempted to introduce a new "point-of-view" that, at its core, centered on the belief that the League of Nations could act

\footnotetext{
${ }^{42}$ George Curry, "Woodrow Wilson, Jan Smuts, and the Versailles Settlement," The American Historical Review 66, No. 4 (July, 1961): 968-970.

${ }^{43}$ Gertrude Millin, General Smuts, Volume II (London: Simon Publications, 1936), 171. Smuts' use of the word "nebulous" was in reference to the idealistic and unstructured nature of Woodrow Wilson's conception of a League of Nations. Although Wilson initially received overtures from Lord Robert Cecil coldly, he did incorporate the creation of a League of Nations into his "Fourteen Point Plan" in 1918. Despite his support, Wilson provided little in the way of a clear structure for his proposed organization until he appointed Edward M. House to investigate the question of the League and create a preliminary draft of such an organization's structure.

${ }^{44}$ Jan Smuts, The League of Nations: A Practical Suggestion (London: Hodder and Stoughton, 1918), 5.

${ }^{45}$ Ibid., 7
} 
as a stabilizing and guiding force in the creation of a new world order. Smuts' League of Nations was more hopeful than previous iterations. He believed that the League could play a constructive role in the post-war period rather than act as an interventionist monitor of global relations. ${ }^{46}$

One of Smuts' primary concerns about the League was his fear that the post-war political arena would resemble a "scramble among the victors" that equated the territories of the defeated powers to "loot." 47 Smuts argued that if such a situation were to occur, "Europe must indeed be despaired."48 The League of Nations would serve as a mechanism to prevent this problematic post-war reconciliation. He considered the League to be a "reversionary in the most general sense...clothed with the right of ultimate disposal in accordance with certain fundamental principles" and this reversion to the League would function as a substitute for any attempts at national annexation of territory as plunder. ${ }^{49}$

The annexation of territory in the post-war period, in particular the potential annexations of South West Africa and German East Africa, troubled Smuts as it would limit his ability to fulfill his imperial vision of creating a politically and economically strong white dominion in southern Africa. Ronald Hyam and Peter Henshaw argued that Smuts' calls for South African expansion and the creation of Greater South Africa dated back to the mid-1890s and his advocacy for the founding of a South African state that encompassed all territories south of the Zambezi River. ${ }^{50}$ The process of realizing this dream began in 1909 with the passage of the South Africa Act, which created the Union of South Africa from the British colonies of the Cape

\footnotetext{
${ }^{46}$ Ibid., Smuts is quoted as advocating for the League of Nations as "A steadying, controlling, regulating influence...required to give stability to progress....[as the] embodiment and living expression of the moral and spiritual unity of the human race."

47 Ibid., 11.

${ }^{48}$ Ibid. It is clear from his writing that Smuts understood the problematic nature of territorial annexations and believed that such practices would contribute to political instability and potentially future wars.

49 Ibid., 12.

${ }^{50}$ Ronald Hyam and Peter Henshaw. The Lion and the Springbok: Britain and South Africa Since the Boer War (New York: Cambridge University Press, 2003), 103-104.
} 
of Good Hope, Natal, Transvaal, and the Orange River Colony. These four colonies were officially unified on 31 May 1910 and provisions from the South Africa Act of 1909 allowed for the future admittance of Southern Rhodesia into the Union as a fifth province. ${ }^{51}$ Smuts' conception of Greater South Africa also included the incorporation of the British High Commission Territories of Basutoland, Bechuanaland, and Swaziland. German East Africa would be used as a bargaining tool with the Portuguese, ceding parts of southeastern Tanganyika to the Portuguese in exchange for the southern part of Mozambique and, most importantly, possession of the port of Lourenco Marques in Delagoa Bay. ${ }^{52}$

In order for Greater South Africa to come into existence and stretch from coast-to-coast in southern Africa, the incorporation of South West Africa following the First World War was also necessary. The incorporation of South West Africa would give the Union access to the Atlantic ports at Lüderitz, Swakopmund, and Walvis Bay and provide new opportunities for this potential dominion to gain access to gold and diamond mines in the territory. The acquisition of South West Africa by the Union government would also prevent the territory from reverting to German control, an outcome that posed a significant security threat to the Union. Union leadership believed that harsh treatment by the German colonial government would result in significant upheaval in South West Africa and posed the potential to spill over into South African post-war affairs. ${ }^{53}$ The acquisition of South West Africa and proposed exchange for southern Mozambique would theoretically provide South Africa with "a natural frontier and round it off as a compact block of subtropical territory" under white minority rule. ${ }^{54}$ This

\footnotetext{
51 Ibid., 77-78.

${ }^{52}$ Hyam, The Failure of South African Expansion, 23-24.

${ }^{53}$ Ibid., 30. There was a great desire to connect the ports at Lüderitz and Lorenco Marques through the construction of a railway. The railway would increase economic activity in the proposed Dominion and not only connect the two ports, but also connect the interior more effectively to the coast.

54 Ibid., 29.
} 
outward expansion of the Union would fulfill Smuts' imperial vision of creating "one of the greatest future Dominions of the [British] Empire" and ensure the political viability and economic health of whites in southern Africa during the post-war recession and political unrest. ${ }^{55}$

Smuts' desire to utilize the post-war moment as an opportunity to incorporate South West Africa into the Union emerged in The League of Nations in 1918 and became a focal point of his demands during the negotiations at Versailles. In his work Smuts classified the territories of the former Central Powers into three categories, each corresponding to a peoples' perceived modernity and closeness to the Western ideal of "civilization." While the Eastern European nations, the Transcaucasian territories, and the Transcaspian territories fell within the first two categories, the "backward” areas consisting of Germany's former Pacific and African colonies fell into a third category. ${ }^{56} \mathrm{He}$ believed that these territories and people required extensive tutelage, writing:

[T] he German colonies in the Pacific and Africa are inhabited by barbarians, who not only cannot possibly govern themselves, but to whom it would be impracticable to apply any ideas of political self-determination in the European sense. They might be consulted as to whether they want their German masters back, but the result would be so much a foregone conclusion that the consultation would be quite superfluous. The disposal of these Colonies should be decided on the principles which President Wilson has laid down in the fifth of his celebrated Fourteen Points. ${ }^{57}$

Despite Wilson's insistence that the Central Powers' former territories not be annexed as a result of the war, it is clear from Smuts' negotiations at Versailles that he did not conceive of

\footnotetext{
${ }^{55}$ Hyam and Henshaw, The Lion and the Springbok, 105.

${ }^{56}$ Smuts, The League of Nations, 16. Smuts argued that nations like Finland, Poland, Czechoslovakia, and Yugoslavia were "sufficiently capable of statehood [and could] be recognized as independent states of the usual type from the beginning." The second categorization included the Transcaucasian and Transcaspian provinces and were nations that were "perhaps capable of internal autonomy" but "deficient in the qualities of statehood." The Transcaucasian territories included parts of modern-day Georgia, Armenia, and Azerbaijan, while the Transcaspian territories covered Turkmenistan and Southern Kazakhstan.

${ }^{57}$ Ibid., 15. The "Fifth Point" of Wilson's plan argued that "there shall be no annexation of any of these territories to any of the victorious Powers" and "secondly, that in the future government of these territories and peoples the rule of self-determination, or the consent of the governed to their form of government, shall be fairly and reasonably applied."
} 
Germany's former African and Asian colonies as exempt from annexation. While the territories of the first and second kind mentioned above were to be exempt from annexation, Smuts argued that the populations in South West Africa should be guided toward "self-determination, autonomy, or self-government" by a "mandatory" power with close historical ties to the territory in question. ${ }^{58} \mathrm{He}$ believed that "the only successful administration of undeveloped or subject people [would be] carried on by States with long experience, for the purpose and staffs whose training and singleness of mind fit them for so difficult and special a task." ${ }^{, 59}$ Although still subject to the ultimate control of the League of Nations, these mandatory powers, acting on the consent or approval of the governed, lent legitimacy to the League of Nations by avoiding the use of unfamiliar and foreign agents. Furthermore, Smuts suggested that this position was a "sacred trust" bestowed upon the mandatory power and that any violation of this trust could result in the removal of the mandatory power and the appointment of a new mandatory state. ${ }^{60}$ Smuts' publication and delineation of the different types of territories to be administered served as the basis for the "mandate system" created during the negotiations at Versailles.

South West Africa was the prized political and economic asset for Smuts and the South African government at Versailles and represented the next logical step in the creation of Greater South Africa. As discussions surrounding the peace negotiations grew, it became clear that the

\footnotetext{
${ }^{58}$ Alan Sharp, The Versailles Settlement: Peacemaking in Paris, 1919 (New York: Macmillan Publishing, 1991), 166-169. Although Smuts makes vague reference to the idea that "there shall be no annexation of any of these territories," subsequent discussion lays out a plan that quite clearly resembles annexation at worst, and incorporation at best. As Sharp highlights, South West Africa and the Pacific Islands clearly did not factor into the territories of "no annexation."

${ }^{59}$ Smuts, The League of Nations, 19.

${ }^{60}$ Ibid., 20. Smuts discussed his conception of a mandatory power at length. He argued that "In the case of most peoples not yet risen to complete statehood there is some Power which has in the past taken an active interest in their affairs and development. Where such interest has been not merely of a selfish character, old ties of acquaintance or friendship will largely determine the new connection under the regime of the League.... Wherever possible the agent or mandatory [shall] be nominated or approved by the autonomous people or territory." Smuts' reliance on "old ties of acquaintance or friendship" belie his personal motivations for the annexation of South West Africa, as the South African government had the closest ties to the people of the territory.
} 
fate of the former German colonies in Africa was uncertain. Woodrow Wilson believed that the annexation of these former German colonies could result in the same abuses and exploitation that the League of Nations was supposed to safeguard against. ${ }^{61}$ In November 1918, Smuts began his campaign to impress upon British government officials the imperativeness of the "unconditional annexation of the German colonies" under the Treaty of Versailles. ${ }^{62}$ His arguments found the sympathetic ear of Lloyd George who argued Smuts position to the Council of Ten on 24 January $1919 .{ }^{63}$ Through a series of tense negotiations, the various sides settled on a compromise. South Africa was granted the position of mandatory power over South West Africa, but these mandate territories had to be administered as "integral portions" of the mandatory power and not outright annexed. ${ }^{64}$ Such a compromise appeased Wilson and the British radicals and socialists, while also providing a viable path for Smuts and the other Dominion governments to secure economic and political control over their desired territories. ${ }^{65}$

Article 22 of the Treaty of Versailles formalized this compromise and echoed the language of Smuts' League of Nations. Article 22 began:

To those colonies and territories which as a consequence of the late war have ceased to be under the sovereignty of the States which formerly governed them and which are inhabited by peoples not yet able to stand by themselves under the strenuous condition of the modern world, there should be applied the principle that the well-being and development of such peoples form a sacred trust of civilization and that securities for the [formation] of this trust should be embodied in this Covenant. ${ }^{66}$

\footnotetext{
${ }^{61}$ Ray Stannard Baker, Woodrow Wilson and World Settlement: Volume I (New York: G.P. Putnam’s Sons, 1928), 152.

${ }^{62}$ Laurent C.W. Kaela, The Question of Namibia (New York: Springer, 2016), 8.

${ }^{63}$ The Council of Ten consisted of delegates from Britain, France, Italy, Japan, and the United States. Each country had two representatives on the Council. The Council was tasked with establishing the terms of the Treaty of

Versailles.

${ }^{64}$ Kaela, The Question of Namibia, 8-9.

${ }^{65}$ Andrew J. Crozier, "The Establishment of the Mandates System, 1919-1925: Some Problems Created by the Paris Peace Conference," Journal of Contemporary History 14, No. 3 (July, 1979): 483-484.

66 “Article 22," Treaty of Versailles, 1919.
} 
The Treaty proceeded to argue that the tutelage of these populations should fall to "advanced nations who by reason of their resources, their experience, or their geographical position can best undertake this responsibility...."67 It was further recognized that the mandate "must differ according to the stage of the development of the people, the geographical situation of the territory, its economic conditions and other similar circumstances. ${ }^{968}$ In order to account for the different stages of perceived development in these territories, and in an attempt to appease Smuts and his compatriots, a three-tiered mandate system was developed that mirrored Smuts' earlier classifications of territories by their perceived modernity.

South West Africa, like the other former German colonies that were adjacent to, or integral parts of British Dominions, received the classification of a "Class C" mandate. "Class C" mandates were territories with small, heterogeneous, and remote populations that "[could] be best administered under the laws of the mandatory as integral portions of its territory, subject to...the interests of the indigenous population. ${ }^{.69}$ S.D. Meyers contended that, although not outright annexation, Smuts obtained the political and economic access he desired to South West Africa. The PMC was subsequently established in order to provide international oversight on the administration of the mandate territories..$^{70}$ The Commission served as a "consultative body" with the ability to conduct investigations into violations of the mandates and "bring facts to light to influence public opinion." ${ }^{.11}$ In each mandate territory, indigenous populations could submit petitions against the mandatory government to the League of Nations and have their complaints

\footnotetext{
67 Ibid.

68 Ibid.

69 Ibid.

${ }^{70}$ S.D. Meyers, Jr., "The Permanent Mandates Commission and the Administration of Mandates," The Southwestern Political and Social Science Quarterly 11, No. 3 (December, 1930): 217; Article 22 of the League of Nations Covenant stated that the PMC "shall be constituted to receive and examine the annual reports of the Mandatories and to advise the [League of Nations] Council on all matters relating to the observance of the Mandates."

${ }^{71}$ Meyers, Jr., "The Permanent Mandates Commission," 217-219.
} 
debated during the meetings of the PMC. As the South African government extended its rule into South West Africa in the early 1920s and encroached on African lands and communities, the Rehoboth Baster community took full advantage of the ability to submit petitions to the League of Nations as a means to exert international pressure on the South African government and moderate and change repressive colonial policies.

The use of petition-writing as a campaign of transnational resistance against the South African regime was a strategy exclusive to the Basters. For them, petition-writing served as a mechanism through which they could express their sociopolitical and economic agency to great effect. The Basters' resistance efforts represented the early vestiges of an emergent pattern of Namibian actors in the Police Zone accessing transnational networks to circumnavigate the recursive gaze and reach of the colonial state. This began a pattern of transnational resistance in the territory that would continue into the early 1960s, at which time resistance strategies shifted to focus on more inclusive national claims for complete territorial independence.

\section{The Extension of South African Rule and Conflicts in the Police Zone, 1920-1923}

The Rehoboth Baster community, like the rest of South West Africa, fell under the "Class C" categorization and found themselves governed by the mandatory's laws; laws which became highly repressive of the Basters' political autonomy and challenged their very socioeconomic and political survival. South West Africa formally became a mandate territory under the South African government on 1 January 1921, the result of a nearly two-and-a-half-year process. The terms of the Treaty of Versailles were dictated to the German government by the Allied Powers on 7 May 1919. The treaty was subsequently signed on 28 June 1919 , and the former German colonies in Africa and Asia fell under the mandate system of the League of Nations. Soon after, 
the South African government worked rapidly to consolidate its power and authority over South West Africa. $^{72}$

The first piece of legislation that facilitated this transfer of power under the mandate system was the Treaty of Peace and South West Africa Mandate Act (Act No. 49 of 1919) that passed the South African Parliament in September of 1919. The South African Parliament bestowed the Governor-General with the power to "make such appointments, establish such offices, issue such proclamations and regulations, and do such things as appear to him to be necessary for giving effect, so far as concerns the Union, to any of the provision of the said Treaty or to any Mandate issued in pursuance of the Treaty of the Union with reference to the territory of South West Africa...."73 Additionally, Act No. 49 made it possible for the GovernorGeneral to "repeal, alter, amend, or modify any laws in force within the [South West Africa] territory...make new laws applicable to the territory...[and] delegate his authority...."74 South African laws, particularly those that pertained to Crown Lands were retroactively applied to the territory as well. ${ }^{75}$

Following the establishment of its authority to make and repeal laws in South West Africa, the South African government created its civil administration in the territory in January of 1920. Many former South African civil servants manned posts within this new SWAA and enforced the implementation of laws and decisions that emanated both from the South African Parliament and the SWAA. Civil courts, magistrates, native commissioners, and native affairs

\footnotetext{
${ }^{72}$ Heinrich Schnee, The German Colonies Under the Mandates (Berlin: W. Bronner Nowawes, 1922). Heinrich Schnee was the governor of German East Africa from 1912 to 1918 and a strong proponent of Germany reclaiming its colonial possessions in the post-war period.

${ }^{73}$ Union of South Africa, Statutes of the Union of South Africa (Cape Town: Government Printer, 1919), 492.

${ }^{74}$ Ibid., 492-493.

${ }^{75}$ Some of the more important laws that Act No. 49 of 1919 explicitly transferred to South West Africa included the Land Settlement Act of 1912, the Land Settlement Act Amendment Act of 1917, the Crown Land Disposal Ordinance (1903) of the Transvaal, and the Crown Land Disposal Amendment Ordinance (1906) of the Transvaal.
} 
commissioner posts were all created and vested with power in a relatively short period of time.

The SWAA attempted to extend bureaucratic controls over the indigenous populations of the territory and create social, political, and economic order like that which existed in South Africa. $^{76}$

The Council of the League of Nations confirmed the mandate established by the Treaty of Versailles on 17 December 1920 and provided specific terms for the administration of the South West Africa mandate. The official terms of the mandate provided the South African government with the "full power of administration and legislation over the territory subject to the present mandate as an integral portion of the Union of South Africa...."77 Despite this seemingly unlimited authority to administer the territory, subsequent article of the mandate did provide some checks on the South African government's power. The slave trade was to be prohibited in the mandate territory, Africans were not to be trained in the military except for internal policing purposes, and the freedom of conscience and worship was to be protected at all times. Finally, Article 7 explicitly stated that the Council of the League of Nations must approve and consent to any modifications in terms of mandate. Thereafter, military rule was withdrawn from the territory on 1 January 1921 and the period of South African rule in South West Africa officially began. ${ }^{78}$

Prime Minister Jan Smuts and the South African Parliament viewed the addition of South West Africa as a de facto fifth province as a possible solution to the political and socioeconomic unrest occurring in early-1920s South Africa. In May 1921, Smuts' government was forced to

\footnotetext{
${ }^{76}$ Wallace, History of Namibia, 217-218.

${ }^{77}$ See George Louis Beet, African Questions at the Paris Peace Conference: With Papers on Egypt, Mesopotamia, and the Colonial Settlement (New York: Macmillan Publishing, 1923), 545 for the full text of the mandate granted to the South African government.

${ }^{78}$ Wallace, History of Namibia, 218-219.
} 
respond to Enoch Mgijima's growing socio-religious movement in Ntabelanga and the social unrest and economic disruption the movement created. By May 1921, Mgijima and roughly 3000 "Israelites" had amassed at Ntabelanga, occupying white settlers grazing lands and refusing to work on the white farms at Oxkraal. ${ }^{79}$ Facing political pressure, Smuts sent a detachment of 800 armed policemen and gave Mgijima an ultimatum to have his followers leave the area by 23 May 1921. Mgijima and his followers refused and in the subsequent Ntabelanga Massacre, 163 Israelites were killed and another 129 wounded. ${ }^{80}$

Smuts' government faced further unrest as the Rand Rebellion broke out on 28 December 1921. As a result of the post-war recession, gold prices dropped by nearly 27 percent in December 1921. The mining companies, in an effort to remain profitable during the recession, significantly decreased the wages of their white miners. Additionally, the Chamber of Mines proposed a limit to the colour bar that would allow mining companies to hire lower-paid African laborers and displace nearly 2,000 semi-skilled white miners. A workers' strike ensued, and Afrikaner nationalists quickly formed armed para-military commandos. This led to an open insurrection against the South African state in which the strikers took control over most the Rand and some suburbs in Johannesburg. ${ }^{81}$ The formation of the Communist Party of South Africa (CPSA) that same year further complicated matters for the South African government, as the CPSA urged on the strikers' activities. ${ }^{82}$

In response to the Rand Rebellion, Smuts sent 7,000 troops to quell the unrest. These troops were accompanied by bombing planes and tanks. Over the four days of the conflict

\footnotetext{
79 "Israelite" was the term used to refer to Mgijima's followers.

80 “The Bullhoek Tragedy: The Full Story of the Israelite Settlement at Ntabelanga," Daily Dispatch, 1921. For a full examination of the Ntabelanga Massacre, see Robert R. Edgar, Because They Chose the Plan of God: The Story of the Bulhoek Massacre of 24 May 1921 (Pretoria: UNISA Press, 2010).

${ }^{81}$ George M. Frederickson, White Supremacy: A Comparative Study of American and South African History (London: Oxford University Press, 1982), 232-233.

${ }^{82}$ Alex La Guma, A Soviet Journey: A Critical Annotated Edition (Lanham: Lexington Books, 2017), 8-9.
} 
between 150 and 220 people were killed, while another 500 to 600 people were wounded.

Eighteen of the strike's leaders were sentenced to death and four were executed. In the immediate aftermath of the strike, the mining companies proceeded to enforce lower wages, hire cheaper African laborers, and lay off a substantial number of white miners. George Frederickson argued that the extreme use of force against white South Africans and the resultant economic burden faced by white miners soured many South Africans on Smuts' government and the South African Party. ${ }^{83}$

To combat unrest in the Union caused by the post-war recession, the South African government developed plans to encourage white migration to South West Africa for new economic opportunities. The South African government opened up former German crown lands to poor whites in South Africa with the express hope that they would leave South Africa and become prosperous, hard-working farmers in the new territory. Likewise, lands were expropriated from former Nama and Herero reserves and made available for white settlement. The provision of land for white settlement was central to this resettlement scheme, but these new farmers also needed easy access to an immobile and cheap labor source. ${ }^{84}$ Throughout the 1920 s a number of segregationist polices were implemented by the SWAA in the territory and these new laws were used as a means to control the labor of the African populations of the territory and move Namibians into reserves.

\footnotetext{
${ }^{83}$ Frederickson, White Supremacy, 232-233. Scholars attribute the heavy-handed response to the Rand Rebellion as one of the factors that contributed to Smuts' loss to J.B.M. Hertzog in the 1924 South African General Election.

${ }^{84}$ Dennis M.P. McCarthy, International Business History: A Contextual and Case Approach (Westport: Greenwood Publishing Group, 1994), 173-175. See Also Jeremy Silvester et al., “'Trees Never Meet:' Mobility and Containment: An Overview, 1915-1946" in Namibia Under South African Rule: Mobility \& Containment, 19151946, ed. Patricia Hayes (Oxford: James Currey Publishers, 1998), 3-50 and Jeremy Silvester, "Beasts, Boundaries and Buildings: The Survival and Creation of Pastoral Economies in Southern Namibia" in Namibia Under South African Rule: Mobility \& Containment, 1915-1946, ed. Patricia Hayes (Oxford: James Currey Publishers, 1998), 95116.
} 
On 1 July 1920, for example, the administrator of South West Africa passed into force the Vagrancy Proclamation and prohibited Africans from entering or travelling through the Police Zone without employment. If one was found to be "wandering abroad and having no visible lawful means, or insufficient lawful means of support," government officials could deem a person "idle and disorderly" and subject that person to punishment ranging from hard labor to solitary confinement for a period of twelve months. ${ }^{85}$ The restrictions on movement and attempts at the forcible employment of indigenous laborers were aided by the introduction of the Masters and Servants Proclamation, which replaced former German legislation of the same name. This Proclamation focused on civil contracts between an employer (master) and worker (servant) that functioned to bind the indigenous populations to white-owned farms. Namibian workers faced monetary fines, corporal punishment, and incarceration for any offenses that ranged from "withholding full effort" to "unauthorized absences from work." 86 This legislation functioned as a "form of indentured servitude enforced by criminal sanctions" and was only compounded by the implementation of the Vagrancy Proclamation of $1920 .{ }^{87}$ Combined, these two pieces of legislation forced Namibians into the labor force with the threat of extreme criminal punishments for minor infractions and offenses.

In 1922, the movement of Namibians within the Police Zone was further restricted with the introduction of pass laws. The Native Administration Proclamation of 1922 required Namibians to produce a pass when confronted by the police and prohibited them from entering

\footnotetext{
${ }^{85}$ For more on Vagrancy Proclamation No. 25 of 1920, See Suzan Ilcan and Anita Lacey, Governing the Poor: Exercises of Poverty Reduction, Practices of Global Aid (Montreal: McGill-Queen's Press, 2011), 114.

${ }^{86}$ Robert J. Gordon, "Unsettled Settlers: Internal Pacification and Vagrancy in Namibia" in Ethnography in Unstable Places: Everyday Lives in Contexts of Dramatic Political Change, eds. Elizabeth Mertz, et al. (Durham: Duke University Press, 2002), 64-65.

${ }^{87}$ K. Gottschalk, "South African Labour Policy in Namibia, 1915-1975," South African Labour Bulletin 4, No. 1\&2 (January-February, 1978): 83.
} 
or leaving reserves and farms. ${ }^{88}$ If one could not produce a pass accounting for their presence in a given area, arrest and imprisonment were the most likely penalties. A curfew was introduced for Namibians in the Police Zone through Proclamation 33 of 1922 that limited not only the spaces Africans could enter, but the times at which they could travel. ${ }^{89}$ The implementation of the Native (Urban Areas) Proclamation in 1924 provided for residential segregation in South West Africa and limited the ability of Namibians to own and operate businesses or shops, restricting them to locations and reserves. The Native Reserves Regulations of 1924 increasingly entrenched segregation in the territory and gave magistrates and government officials complete control over life on the reserves. Magistrates and government officials had exclusive control over the allotment of land on the reserves and could determine how said land was utilized when given to African laborers. ${ }^{90}$ In combination, these pieces of legislation simultaneously cleared space for white settlers to establish farms and provided them with a stagnant pool of Black labor with limited economic opportunities and little recourse against their employers.

The implementation and enforcement of such policies initially proved difficult in South West Africa. Marion Wallace detailed the limited nature of South African control in 1923, writing that only 503 policemen patrolled the Police Zone at the time. This number only modestly increased over the next sixteen years, rising to 520 policemen in $1939 .{ }^{91}$ The lack of a viable enforcement apparatus provided Namibians with multiple channels through which they could resist the extension of South African rule and the implementation of segregationist policies. Beginning in 1922, the lack of policemen in the Police Zone and the increasingly oppressive nature of South African legislation for the territory resulted in a series of violent

\footnotetext{
${ }^{88}$ Gordon, "Unsettled Settlers," 64-69.

${ }^{89}$ Ibid.

${ }^{90}$ Ibid.

${ }^{91}$ Wallace, History of Namibia, 222-223.
} 
confrontations between Namibian communities and the SWAA. Chief among these occurrences was the Bondelswarts Affair of 1922, which profoundly impacted the South African government's approach to dealing with later confrontations against Namibians when they received unexpected criticism from the international community at the League of Nations.

Although several instances of violent resistance occurred in South West Africa in the early 1920s, few had the international impact of the Bondelswarts Affair. The Bondelswarts, a Nama group located near Warmbad in southern Namibia, experienced the brunt of the extension of South Africa's segregationist policies. The implementation of the aforementioned legislation expropriated the Bondelswarts' lands and subjected them to repeated humiliations, like carrying metal passes to travel within the Police Zone and repeated beatings from employers under the authority of the Masters and Servants Proclamation. ${ }^{92}$ Relations were further strained with the continued implementation of increasingly high taxes during a period when most communities were slowly recovering from the post-war economic recession.

The spark that ignited the Bondelswarts Affair came in April of 1921 when the SWAA implemented a uniform dog tax in South West Africa. The tax specifically targeted "natives and a certain class of European squatter" who the administrator believed used the animals as a dishonest way to obtain a livelihood. ${ }^{93}$ The tax ranged from one pound for a license for the first dog to nearly ten pounds for the fifth dog, an amount that was nearly equivalent to the monthly salary of a herder in the territory. The tax was difficult to enforce throughout the territory and the administrator distributed circulars that lambasted magistrates for uncollected dog taxes.

\footnotetext{
${ }^{92}$ Susan Pedersen, The Guardians: The League of Nations and the Crisis of Empire (London: Oxford University Press, 2015), 113-120.

${ }^{93}$ Union of South Africa, Report of the Administrator to the League of Nations (Cape Town: Government Printer, 1922), 3. The term "dishonest" is used here in reference to Administrator Hofmeyr's belief that the only honest way to earn a living in the territory was through labor, not hunting.
} 
However, the one place that the SWAA enforced the dog tax heavily from its inception was the Bondels Reserve. $^{94}$

Robert J. Gordon's “Fido: Dog Tales of Colonialism in Namibia” provides one of the more detailed analysis of the causes of the Bondelswarts Affair. Between September 1921 and January 1922, the SWAA leveled nearly 140 prosecutions against the members of the Bondelswarts community for violations of the dog tax. Roughly 100 of these proceedings resulted in fines and imprisonment of the perpetrators. In the first half of 1922, nearly 70 percent of all charges brought against the Bondelswarts community directly related to the 1922 dog tax. The seemingly arbitrary enforcement of the dog tax created a volatile environment and increased tensions on the Bondels Reserve. ${ }^{95}$ Gordon argued, "This, coupled with a long legacy of systematic impoverishment, was the final factor which precipitated the Bondelswarts Rebellion in May 1922."96

In May 1922 the Bondelswarts refused to pay the dog tax and failed to hand over five men with arrest warrants, including an armed Abraham Morris, to the SWAA. ${ }^{97}$ Jan Smuts and Gysbert Hofmeyr feared that the rebellion might spill over into South Africa and, as a result, mounted a quick and heavily-armed response to this resistance. ${ }^{98}$ Hofmeyr raised a force of 400 men armed with rifles and machine guns to quell the rebellion. Hofmeyr's forces were also aided

\footnotetext{
${ }^{94}$ Robert J. Gordon, "Fido: Dog Tales of Colonialism in Namibia" in Social History \& African Environments, eds. William Beinart and Joann McGregor (Oxford: James Currey Publishers, 2003), 245.

${ }^{95}$ Ibid., 246

${ }^{96}$ Ibid.

${ }^{97}$ Ibid. Abraham Morris was Jakob Marengo's co-commander during the Herero and Nama campaigns against the Germans between 1904-1907. Morris had re-entered South West Africa illegally during this period and was said to be armed. Concerns of armed rebellion pervaded white society when reports surfaced that Morris attempted to rally Bondelswarts support to rise against the SWAA. In conjunction with the South African government, the SWAA recognized that immediate action was needed.

${ }^{98}$ Gysbert Reitz Hofmeyr was the administrator of South West Africa from 1920 to 1926 and oversaw the government's repression of the Bondelswarts Rebellion. There was a fear that the Bondelswarts Rebellion could lead to further unrest in South Africa and South West Africa. The Union government only recently dealt with the Rand Rebellion and the Ntabelanga Massacre and there was concern that a lackluster response to the Bondelswarts could lead other groups to follow suit.
} 
by South African aircraft that proceeded to indiscriminately bomb the Bondelswarts community. Although short-lived, the conflict resulted in the deaths of 100 Bondelswarts and the wounding or imprisonment of an additional 468 people. When Hofmeyr's forces entered the community, they recovered only 40 weapons, highlighting the fact that the force used against the Bondelswarts was disproportional and violated the mandate bestowed upon the South African government. ${ }^{99}$

The international outcry, especially at the League of Nations, was swift. In May 1922 Haitian delegate Dantes Bellegarde condemned the assault and destruction perpetrated by the South African government against the Bondelswarts and made the international community more fully aware of the atrocity. He appealed to the altruistic and humanitarian covenant of the League of Nations by arguing that "Although there was no act of rebellion and no attempts against life, an expedition was undertaken with all the materials of modern warfare-machine-guns, artillery, and aeroplanes....The natives who were practically unarmed were massacred....That women and children should have been massacred in the name of the League of Nations and under its protection is an abominable outrage which we cannot suffer." ${ }^{100}$ Marcus Garvey was another prominent global figure that railed against the South African government's disproportionate violence against the Bondelswarts and disseminated information about the atrocity to the larger pan-African community through The Negro World in June $1922 .{ }^{101}$

The efforts by these figures and numerous others placed an immense amount of international pressure on Jan Smuts and the South African government. This pressure forced

\footnotetext{
${ }^{99}$ A.M. Davey, The Bondelzwarts Affair: A Study of the Repercussions (Pretoria: University of South Africa Press, 1967), 285-286; The attack on the Bondelswarts resulted not only in the death of 100 combatants, but also the deaths of women and children.

${ }^{100}$ Arnulf Becker Lorca, Mestizo International Law (Cambridge: Cambridge University Press, 2014 ), 256.

101 "Christian Boers of South Africa Use Airplanes to Bomb Hottentots," Negro World, 17 June 1922.
} 
Smuts and the SWAA to adopt a much more cautious approach to dealing with Namibians in the reserves and locations. More violence would only further sway public opinion in Britain, at the League of Nations, and among white liberal opinion in South Africa against the government's mandatory rule. Thus, when similar problems arose in the Rehoboth Baster community between 1923 and 1925, the South African government and SWAA proceeded with a mind toward the impact their actions might have on their position as mandatory power. This was particularly useful for the Basters, who understood that their ability to disseminate information through transnational networks could be leveraged against the state as a means to achieve their subnational goal of local political autonomy.

\section{The Transnational Resistance Strategies of the Rehoboth Basters, 1923-1935}

In the wake of the Bondelswarts Affair, concerns of a general African uprising pervaded southern Africa during the 1920s. South Africa experienced several instances of socioeconomic unrest that made whites fearful of an African uprising, with the Ntabelanga Massacre, the arrest of the prophetess Nontetha, and the introduction of lower-paid African laborers into the mining industry as the most prominent examples. ${ }^{102}$ In South West Africa, the UNIA emerged between 1919 and 1921 in Lüderitz and actively disseminated Pan-Africanist and Black liberation ideologies throughout the Police Zone, finding particular success among the Herero. The active patrolling of quasi-military Otruppa Commandos during the 1920s only added to whites' fears of a rebellion. ${ }^{103}$ Many of the Herero and Nama pastoralists involved in these movements settled

\footnotetext{
${ }^{102}$ Nontetha was a Xhosa priestess in South Africa that led a movement similar to Mgijima's. She advocated that her followers adhere to strict puritanical rules for living without excess. As her movement gained more followers, the Union government arrested her on charges of inciting political unrest and, ultimately, had her committed to a mental hospital.

${ }^{103}$ The Otruppa movement emerged following the German defeat in South West Africa and provided the Herero with an opportunity to reconstitute social and political order in the wake of the destruction caused by the genocide
} 
near Rehoboth in the early 1920s due to the more suitable grazing lands around the settlement and, at the time, to benefit from the Basters' political control of the area. The growing number of “militant” Black Africans in an area where the SWAA's reach was weakened did little to ease the concerns of whites in the territory.

The SWAA, in part, blamed the Basters' practice of leasing land to Nama and Herero herders as one of the primary factors fueling reports from whites that Namibians were arming and preparing for a rebellion. The intense droughts of the early 1920s and the increasingly burdensome post-war economic recession severely impacted the livelihoods of Namibians in the Police Zone. The Baster community, which still possessed the political autonomy to dispense land in the Gebiet without the SWAA's approval, increasingly leased land to Nama and Herero herders as a means to generate additional revenue from the rent and offset the impact of the socioeconomic hardships enveloping the territory. Patrick Pearson stated that this practice led to an influx of Black Namibians into the Gebiet and, to a degree, shielded them from the SWAA's reach in the territory. ${ }^{104}$ At the same time, the SWAA believed that this practice could provide a safe haven for emergent resistance groups in the Police Zone and discouraged Namibians from working on the surrounding white farms.

In an attempt to halt the growing population of Black Namibians in the Gebiet and prevent the possibility of a rebellion, the SWAA attempted to construct an agreement with the Baster Raad that reshaped lease-holding practices and clearly defined the parameters of both criminal and civil jurisdiction in the Gebiet. The SWAA found a willing partner in Kaptein

and German colonial rule. For a more in-depth look at the Otruppa movement, see pages 155 through 158 of this dissertation.

${ }^{104}$ Patrick Pearson, "The Rehoboth Rebellion," in Working Papers in Southern African Studies, Volume 2, ed. P. Bonner, (Johannesburg: Ravan Press, 1981), 33-34. Pearson wrote that by 1925, nearly 2,500 Black Namibians and 3,500 Basters resided in the Gebiet. 
Cornelius van Wyk who desired to create a closer and more favorable working relationship with the SWAA. On 17 August 1923, the Executive Council of the Basters and seven members of the Raad came to an agreement with the SWAA. The framework for this agreement was published in the Official Gazette of South West Africa as Proclamation No. 28 of 1923. ${ }^{105}$

The agreement first established the boundaries of the Gebiet and acknowledged the "right and title" of the Basters to that territory. ${ }^{106}$ The agreement recognized Cornelius van Wyk as the Kaptein of the Rehoboth community and conceded the right of local self-government within the Gebiet in accordance with the laws found in the Law Book of the Raad of Rehoboth. ${ }^{107}$ In order to maintain control over the Gebiet and its populations, the agreement included language in its provision that any laws passed in the Gebiet were to be presented to the administrator for his "assent," and that the laws of the rest of the territory would extend to the Gebiet from that date forward. ${ }^{108}$ Further limits were placed on the Basters' autonomy and sovereignty, when the SWAA prevented the Baster courts from ruling on any cases, civil or criminal, that involved a white party and prevented Basters from selling any land in the Gebiet without the express approval of the new magistrate. ${ }^{109}$

Proclamation No. 28 proved to be one of the key factors that initiated the Basters' 13year-long petition-writing campaign to the League of Nations. A majority of the Basters in the Gebiet believed that van Wyk's agreement with the SWAA effectively forfeited the Basters' sovereignty and vested the SWAA with ultimate decision-making power over the affairs in the Gebiet. In response to the conclusion of this "illegitimate" agreement, the Basters established a

\footnotetext{
${ }^{105}$ Government of the Union of South Africa, Official Gazette of South West Africa, 2 October 1923, 1204-1209.

${ }^{106}$ Ibid., 1352

${ }^{107}$ Ibid.

108 Ibid.

${ }^{109}$ Ibid., 1353-1354.
} 
Provisional Raad under the leadership of the Provisional Kaptein, Nicolas van Wyk. The reasons for the establishment of a Provisional Raad are detailed in Nicolas van Wyk's petition to the League of Nations on 27 June 1924. Van Wyk wrote:

The present situation in our territory is due to the fact that the former Raad of the Rehoboth Burgher Community concluded a Treaty with Mr. Hofmeyr, the Administrator... without the consent of the Community. The Burgher Community consider[s] this Treaty unacceptable, but in spite of protracted negotiations with the Administrator all of our efforts have hitherto been in vain. In view of these circumstances, the [Community] rightly repudiated the former Raad, and a new Provisional Kaptein and Raad were elected by the Burgher Community. The newlyelected Raad has been established to govern the people under the laws of $1870 .{ }^{110}$

Van Wyk continued to argue that the SWAA forced the Basters "against [their] will to conform to the Treaty concluded by the former Raad with the Administrator" and that "[The Baster were] compelled to bring the situation, which is fraught with such dangerous possibilities, to the notice of the League of Nations." 111

The SWAA's unwillingness to respond to the Basters' claims that the agreement in Proclamation No. 28 was illegitimate forced the Basters to seek other means of external legal recourse, since few such avenues existed for Namibians in South West Africa. While it is uncertain exactly how the Basters learned of the League of Nations and why they embraced the process of petition-writing as a means to counter the SWAA's overreach in the Gebiet, historian Tilman Dedering suggested that South African parliamentarian Dewdney Drew played a crucial role in explaining the mandate system and the role of the PMC to the Basters. ${ }^{12}$ The SWAA viewed Drew as an agitator in the Gebiet and argued that he had "no locus standi, and he is [not]

\footnotetext{
${ }^{110}$ Petition from Nicolas van Wyk to the League of Nations, 27 June 1924, League of Nations Archives, United Nations Offices at Geneva (Hereafter LNA)/Mandates Section (Hereafter MS)/ Record Group 11 (Hereafter, R). ${ }^{111}$ Ibid.

${ }^{112}$ Dedering, "Petitioning Geneva," 794.
} 
a resident of the Gebiet...."113 In correspondence between South African Prime Minister J.B.M.

Hertzog and the PMC, Drew's activities in the territory were further explained:

This gentleman has already been the cause of a vast amount of trouble in the Gebiet. From 1917 when he took up the cudgels on behalf of the Rehobothers he has always been ready to impute the basest of motives to the officials responsible for the government of the country, both under the German and Union regimes. Charges of bad faith are made with utter recklessness... Mr. Dewdney Drew's interference in this matter can, I think, only be characterized as mischievous. He has been led away by what he is pleased to regard as the romance attaching to the history of this people and has, I understand, embarked on a series of newspaper articles in the Union papers in which the Bastards' aspirations to remain a separate state under the direct aegis of the Imperial Government... ${ }^{114}$

As Prime Minister Hertzog noted, Drew visited the Basters at Rehoboth in 1917. The Minutes from the PMC's Fourteenth Session elaborate on Drew's visit, stating that he went to Rehoboth to "[speak to the Basters] about the freedom and self-determination of small nations...." that would be guaranteed at the conclusion of the war. ${ }^{115}$ Drew's activities in Rehoboth likely had an impact on the Basters' approach to making claims of the mandatory power, as is evidenced by their specific use of the phrases "self-determination" and "freedom of small nations" in the subsequent petition-writing campaign that developed in the mid-to-late 1920s. Drew's apparent influence over the language and origins of the petition-writing campaign concerned the SWAA that other transnational actors might similarly influence the Rehoboth Basters to take their complaints to a more critical international audience. In 1923, administrator Hofmeyr wrote to then-Prime Minister Jan Smuts that he was concerned that the political activist Dr. Abdullah Abdurahman wanted to visit the Rehoboth Basters and suggested that such a visit

\footnotetext{
113 J.B.M. Hertzog to Secretary General: Observations from the Government of the Union of South Africa to the League of Nations, 23 January 1929, LNA/MS/R2289.

114 Ibid.

115 Ibid.
} 
could lead to increased tensions and added international scrutiny over the SWAA's treatment of the Basters. ${ }^{116}$

The relationships that emerged between the Basters and the aforementioned actors created a circuit through which the Basters developed their later petition-writing resistance strategy. Dewdney Drew's visit to the Basters in 1917 and his subsequent discussions with them surrounding the role of the League of Nations and PMC as it pertained to the territory made the community aware of the potential international influence that could be wielded against the South African government. Likewise, Drew's sympathetic stance toward the Basters required a response from Hertzog to the PMC and brought the government's treatment of the Basters under increased scrutiny. The Basters, aware that the mandate granted to South Africa required the government to submit their petitions to the PMC for review, could levy their accusations against the South African government to the international community and demand that justifiable legal action be taken against the mandatory power. This created a circuit that connected the PMC and League of Nations in Geneva with the mandatory government in South Africa and the petitioners in Rehoboth. Through this circuit, the Basters waged their intensive resistance campaign throughout the Interwar Years.

The Basters' interactions with these transnational actors and their newfound familiarity with the Covenant of the League of Nations and the mission of the PMC served as a foundational moment in the development of the Basters' transnational interwar resistance strategies. Issues of autonomy and self-determination became focal points of the early petitions in 1924 and 1925 as

\footnotetext{
${ }^{116}$ Dedering, "Petitioning Geneva," 792-793. Dr. Abdullah Abdurahman was a South African politician and the first Coloured city councilor in Cape Town. He was also elected President of the African Political Organization, an organization that fought against the South African government's oppressive laws and strove to secure franchise for the Union's Coloured populations. The term "Coloured" was used by the South African government to denote a person of mixed European and African heritage, especially in the Cape Colony.
} 
the Basters sought the League's intervention to enforce its proclaimed mission and settle the dispute between the Basters and the SWAA over Proclamation No. 28. The petitions submitted by the Basters utilized the language of the League's Covenant and South Africa's mandate to make claims of the supranational organization tasked with protecting the development and wellbeing of colonial peoples across the globe. In allusion to the mandate system's proposed goals of guiding colonial peoples toward modernity, the Basters' petitions clearly delineated their social and political position in the territory from that of Black Namibians. ${ }^{117}$ Nicolas Van Wyk historicized the Basters' political autonomy, writing "We, the Burgher Community of the Gebiet of Rehoboth, obtained this territory as our lawful property in the year $1870 \ldots$ bequeathed to us by our forefathers, with its own administration and Government." ${ }^{118}$ Subsequent petitions highlighted that the Basters were not "a conquered people" like the other Black Namibians in the Police Zone, and that the German government afforded their Community and Kaptein Hermanus van Wyk “all the rights appertaining to an independent Chief" and "confirmed [the Basters'] right to live independently under [their] own laws and administration." 119

The Rehoboth Basters' willingness to “...[stand] shoulder to shoulder with the Allies...” during World War I also became a central thrust in the Basters' petitions to the League and their claims of political autonomy as a reward for their service in the war. The Provisional Raad wrote to the League in 1924 that "During the Great World War we had to defend our territory,

\footnotetext{
117 This distinction was emphasized for a number of reasons. First, the Basters believed that their European heritage imbued them with certain rights and characteristics that were absent for the Nama and Herero. Likewise, this delineation was probably a result of ethno-political conflict in the mid-to-late-nineteenth century that saw the Basters fight wars against the Herero and Nama.

${ }^{118}$ Urgent Report from Nicolas van Wyk to the League of Nations, 27 June 1924, LNA/MS/R11.

${ }^{119}$ Petition from Nicolas van Wyk to League of Nations, 1924, LNA/MS/R11; Petition from Nicolas van Wyk to The Secretariat of the League of Nations, 13 November 1924, LNA/MS/R11. It is important to note that the Basters believed that their political sovereignty and autonomy were guaranteed by Botha following their meeting on 1 April 1915. Part of the confusion surrounding the implementation of Proclamation No. 28 was that the Basters believed it violated previous agreements that were supposed to stand in perpetuity.
} 
independently, by the efforts of our Burghers; since we were compelled to take part in the Great War and to incur heavy losses, we are therefore entitled to submit to the League of Nations our claim to possess our own private property, since we understood from the Treaty that we were included, together with all our rights, in the Treaty which was concluded at Versailles on [28 June 1919]." 120

The Basters clearly understood their voluntary participation in World War I as imbuing their community with the same rights granted to other newly-created independent nations at Versailles. The decision made by the administrator to take away part of the Raad's political autonomy and power through Proclamation No. 28 created confusion among the Basters' leadership about their position in South West Africa under the mandate system. Van Wyk continued:

We cannot understand why we should be included by right of conquest or that we should be classified as a conquered people. It is incomprehensible to us since the troops of the Union Government marched freely through the territory of our Republic, which had been fighting independently. All this entitles us to appeal to your Excellencies, for we have done everything in our power, up to the present, to represent to the Administrator our feelings on this subject. The rights which we possess, our opposition to the [Proclamation], and the fact that, as a free and autonomous people, we cannot accept the above mentioned [Proclamation]. ${ }^{121}$

The Basters' expectation that participation in the war on the side of the victors would result in political independence was not unfounded. Namibian wars prior to European encroachment frequently resulted in the capture and expropriation of lands. As argued earlier in this chapter, the mandate system was intended to create an amicable resolution between South African desires to annex Namibia and Wilsonian concepts of self-determination. Likewise, the Treaty of Versailles partitioned former German territories among Allied Powers and created

${ }^{120}$ Petition from Nicolas van Wyk to the League of Nations, 27 June 1924, LNA/MS/R11.
${ }^{121}$ Ibid. 
newly-independent states like Czechoslovakia. Thus, the Basters' belief that their participation entitled them to political autonomy was in line with the political thinking of the period. The Basters' belief that their participation in the war alongside the Allied Powers also likely contributed to their desire to pursue an exclusive and subnational resistance strategy. They viewed themselves separately from the Nama and the Herero in the territory and believed that they had paid the price, through military service, to earn subnational political autonomy in the Gebiet.

In their continued effort to achieve this subnational political autonomy, the Provisional Raad requested the opportunity to appear before the PMC to plead their case about the illegitimacy of Proclamation No. 28; however, the PMC rejected their request. Despite this setback, the petitions from the Provisional Raad continued and the SWAA became more frustrated with the increased scrutiny from the international community about their activities in South West Africa. The recent memory of the Bondelswarts Affair and the intense international scrutiny that the South African government faced at the League of Nations due to its response tempered the SWAA's response to the Rehoboth Basters' demands. The SWAA's attempt to amicably resolve the dispute by establishing a meeting with members of the Traditional Raad and the Provisional Raad failed. On 1 December 1924, the Provisional Raad sent a petition to the Magistrate's Office in Rehoboth effectively ending communication with the SWAA on political matters in the Gebiet. ${ }^{122}$ The petition read:

Hitherto we have done all in our power, but in vain. We now abandon any further attempts and will not apply to you again for counsel or advice; we shall not even make use of the letter from the Administrator, and henceforth we shall remain entirely independent of you. It is clear to us that the magistracy and the Administrator himself still desire to compel the people against their will to submit to the Council which has been

\footnotetext{
${ }^{122}$ Britz, et al., History of the Rehoboth Basters, 33. Britz argued that the letter submitted to the magistrate by the Volksraad on 1 December 1924 served as a unilateral declaration of independence that forced a more aggressive and forceful response from the SWAA.
} 
deposed, and to accept the Agreement....As the elected representatives of the State, it is henceforth our duty to make known the situation in our territory in every newspaper, even in Europe....It is impossible for the present situation in Rehoboth to continue; this population is the only one in the world which is not allowed any right to its own property. We also desire to state that we will not obey any law issued by Nels Klazen; we will only obey authorities who have been elected by the community to enact laws and keep order, and we will only obey the laws so enacted. ${ }^{123}$

The mounting frustrations among the Provisional Raad and its supporters toward the Traditional Raad and the SWAA threatened to spill out into the open. Albert Mouton, the Provisional Kaptein of the Traditional Raad wrote to the Rehoboth magistrate in the week following the break in communication that "the dissensions in Rehoboth have reached a point where it is beyond our power to deal with them...[and] I can see only too clearly the disasters which are before us unless these disorders are speedily brought to a close." ${ }^{124}$ Mouton proceeded to detail how the "opposition" continued to sow the seeds of disaffection toward the Union government among the community and that the possibility existed for members of the Traditional Raad to be imprisoned or physically harmed. Mouton officially requested the SWAA's intervention on his behalf and demanded the "removal of the...leaders and men of the Opposition from the midst of the Community." 125

The prospect of a mutually-agreeable resolution to the dispute no longer existed. As a result, the SWAA took a more direct approach to ending the dispute over Proclamation No. 28. On 10 December 1924, the SWAA issued the Rehoboth Affairs Proclamation No. 31 of 1924 that effectively divested the Kapteins and Raads in the Gebiet of their political powers. Instead, those decision-making powers were vested in the newly-appointed magistrate at Rehoboth. The loss of autonomy in the Gebiet, coupled with mounting frustrations among the Black populations

\footnotetext{
${ }^{123}$ Volksraad to Magistrate's Office, 1 December 1924, LNA/MS/R11.

${ }^{124}$ Albert Mouton to the Magistrate's Office in Rehoboth, 4 December 1924, LNA/MS/R11.

125 Ibid.
} 
around Rehoboth over stock branding proclamations, created a volatile situation that threatened to result in open conflict between Namibians and the SWAA. ${ }^{126}$

On 5 April 1925, these tensions led to the Rehoboth Affair. In the preceding week, the SWAA sent policemen to the Gebiet to arrest three men on charges of failing to appear for summons relating to violations of the stock branding proclamations. The policemen were prevented from arresting the three men and within the week Colonel de Jager sent a police force of 621 men to the Gebiet to carry out these arrests. At 7am on the morning of 5 April 1925, de Jager sent a messenger to the Baster leadership to demand unconditional surrender and to turn the men over. An hour later, before the Basters had the opportunity to evacuate the women and children at Rehoboth, the SWAA flew three airplanes with machine guns over the settlement and the police force charged. ${ }^{127}$ Although no shots were fired during the operation, policemen entered the community members' homes and beat them with sticks and the butts of rifles. ${ }^{128}$

In total, 632 people were arrested in Rehoboth as a result of the police assault. The SWAA confiscated and destroyed another 304 firearms. ${ }^{129}$ Again, the international backlash from the Bondelswarts Affair played a role in tempering the SWAA's response to the Basters perceived disregard for the administration's laws. Despite the SWAA effectively stripping the Baster Raads of any decision-making powers and settling the question of the Basters' selfdetermination, the petition-writing campaign to the League of Nations only intensified. Between 1925 and 1935, the volume of petitions flowing from South West Africa increased. However, during this period the concerns and appeals of the petitioners changed.

\footnotetext{
${ }^{126}$ Emmett, Popular Resistance, 157-161.

${ }^{127}$ Pearson, "The Rehoboth Rebellion," 1.

128 Petition from Nicolas van Wyk to the League of Nations, Geneva, 26 November 1926, LNA/MS/R11.

${ }^{129}$ Emmett, Popular Resistance, 160-161.
} 
The increase in petitions from the Basters to the League between 1925 and 1935 likely came about as a response to the Rehoboth Rebellion. The force used by the SWAA limited the appetite of those at Rehoboth for another violent clash with government forces and, out of necessity, the Baster turned to more diplomatic means to achieve their social and political aims. Due to the government's response and further limitation of the Basters' political rights, it became imperative that Baster leadership seek avenues external to the territory and outside of the jurisdictional reach of the South African government to regain their political autonomy. Earlier interactions with Dewdney Drew and their knowledge of the international outcry over the Bondelswarts Affair made a petition-writing campaign to the League of Nations a logical resistance strategy. The Basters utilized the language of both the League of Nations Covenant and the mandate granted to the South African government as a way to call upon the League to fulfill its mission and force its members to place pressure on the colonial regime.

The claims in the Basters' petitions shifted after the Rehoboth Affair from focusing on political autonomy and self-determination to arguments that centered on practical, everyday claims of underdevelopment and harmful land expropriation practices. In two petitions submitted in November 1926, Nicolas van Wyk and the Rehoboth Basters detailed the SWAA's oppressive treatment toward the community as it pertained to issues of taxation, imprisonment, cattle seizures, and European encroachment. Van Wyk wrote to the League as a result of the Basters' defiance of the SWAA's orders on 5 April 1925, only for administrator Hofmeyr to provide an ultimatum that imposed heavy fines on the community on threat of imprisonment. This action, the petition stated, "heavily taxed [the Basters'] resources" and "forced [them] to sell the little which remained for the subsistence of [their] wives and children." ${ }^{130}$ And this only compounded

${ }^{130}$ Petition from Rehoboth Community to League of Nations, 11 November 1926, LNA/MS/R11. 
the "great set-back[s]" that the Basters experienced since the issuance of Proclamation No. 28 stripped away their political and economic independence. ${ }^{131}$

The Basters' continued to detail their socioeconomic underdevelopment at the hands of the mandatory power, with a particular focus on the laws surrounding cattle in the Gebiet and the predatory practices of white business owners in the area. Cattle and small livestock served as a vital part of the pastoralist existence in Rehoboth and the Police Zone. Following the Rebellion of 1925, the SWAA began to implement legislation known to van Wyk and the community as the "Stock Disease Act." The Basters argued that the new law made the Basters' cattle "subject to strict medical inspection, and if they are found diseased, the owner is summoned or fined and imprisoned, even if he is unaware of the condition of the cattle." ${ }^{132}$ The loss of cattle economically devastated both the Basters and the remaining Black pastoralists in the Gebiet and contributed to their deteriorating circumstances. Subsistence and socioeconomic development became even more difficult in the years following the Rebellion, as the SWAA reduced and limited the number of hunting licenses provided to Basters and Black Namibians. Van Wyk's petitions make it clear that the SWAA significantly increased the number of hunting licenses granted to whites and that they hunted so effectively that it threatened to "exterminate" the game in the Gebiet. ${ }^{133}$ The confiscation and destruction of the Basters' firearms following the Rebellion increased the difficulties faced by hunters in the Gebiet and the inequity in hunting opportunities led van Wyk to comment to the League that "The white man shoots in a month what we could not kill in a year....."134

\footnotetext{
${ }^{131}$ Ibid.

${ }^{132}$ Ibid.

${ }^{133}$ Petition from Nicolas van Wyk to the League of Nations, Geneva, 26 November 1926, LNA/MS/R11.

${ }^{134}$ Ibid.
} 
Finally, van Wyk addressed the increased white encroachment occurring in the Gebiet in 1926 and how the predatory practices of white business owners severely disadvantaged the Basters. Of key concern in these arguments was the fact that the SWAA allowed white shopkeepers and traders to buy land and set up businesses in the Gebiet. ${ }^{135}$ Van Wyk contended that these business owners sold goods to Basters and other Black Namibians on credit, but then quickly brought the Basters to court to settle this debt. Unable to repay the debt in this short time, Basters faced the possibility of steep fines and imprisonment. ${ }^{136}$ This further contributed to the inequity and underdevelopment faced by those the mandatory power was supposed to usher toward development and "civilization."

The focus of these early petitions centered on utilizing the language of the League's Covenant and the mandate to highlight the legal violation committed by the SWA. The mandate granted to the South African government clearly stated that "The mandatory shall promote to the utmost the material and moral well-being and social progress of the inhabitants subject to the mandate" and League's Covenant reaffirmed this, stating "the well-being and development of such peoples form a sacred trust of civilization...."137 In order to bring the League's attention more fully to their demands of local self-determination, the Basters routinely highlighted the lack of social or economic progress that the mandatory's policies created. Thus, van Wyk's petitions pointed to the unscrupulous business practices of whites in the Gebiet that went unpunished by the SWAA and detailed the great difficulty that the Basters faced to obtain hunting licenses that were paramount to their ability to feed themselves. By directly invoking the text of the

\footnotetext{
135 This practice was outlawed by the German government and violated the tenets of the suspended agreement ratified in Proclamation No. 28 of 1923.

136 Ibid.

137 Antony J.M. Zuijdwijk, "The International Court and South West Africa: Latest Phase," Georgia Journal of International and Comparative Law 3, No. 2 (1973): 323.
} 
aforementioned documents, the Basters forced the League of Nations to open inquiries into the abuses of the SWAA and place pressure on the South African government.

Although few laws changed as a result of these November petitions to the League, the petitions forced the SWAA to respond to inquiries by the League of Nations regarding the claims made by the Basters in 1926. In a memorandum addressing the issues raised by the Basters, the SWAA argued that the Basters were subject to the laws of the entire territory and that they no longer possessed rights of limited self-determination in the Gebiet. Furthermore, the SWAA rejected claims that predatory creditors and traders took advantage of the Basters in Rehoboth. The memorandum stated that "Trading licenses [were] restricted to traders who were formerly and continuously carrying on business in the Gebiet," while the issue of credit was to be dealt with in South African judge Justice de Villiers report on Rehoboth. ${ }^{138}$ The issue of whites overhunting in the Gebiet was also addressed briefly in the memorandum and the SWAA made the concession that Basters could "hunt small game without payment of the license fees prescribed by the Game Law, or other restriction, at any time," even as the game laws that related to "royal and big game" remained in effect. ${ }^{139}$

Despite indirect diplomatic pressure from the League's members curtailing the SWAA's willingness to respond violently to colonial resistance, it continued to impact the Basters' development and desire for self-determination through arbitrary arrests and land expropriation. Petitions submitted by the Basters between 1928 and 1929 detailed the increasingly arbitrary nature of arrests in the Gebiet and the use of the police and courts as a means to strip Basters of their property. In January 1928, Jacobus Beukes described the dangerous police state developing

\footnotetext{
${ }^{138}$ South West Africa Administration-Memorandum on Points Raised by Petitioners, undated, LNA/MS/R11. See also, Union of South Africa, Report of the Rehoboth Commission (Cape Town: Government Printer, 1927).

${ }^{139}$ South West Africa Administration-Memorandum on Points Raised by Petitioners, undated, LNA/MS/R11.
} 
in Rehoboth, writing to the Secretariat of the League of Nations that "The Rehoboth District is continually held down by force. It is constantly infested with police who travel about in the district making arrests, thereby causing unrest." ${ }^{" 40}$ The petitioner openly wondered why "there should be police wandering about in an entirely disarmed country" and detailed the establishment of a "prison camp" in Rehoboth. ${ }^{141}$ These aggressive police tactics and activities convinced Beukes that the goal of the SWAA was "to drive [the Basters], the owners of the land, out of [their] own country." ${ }^{142}$ The land could then be dispensed to white farmers and shop owners and encourage both white settlement and economic development in the territory to combat the emergent global depression of the late 1920s. ${ }^{143}$

Imprisonment and the elimination of due process rights proved an effective method for the SWAA to expropriate land from the Basters and redistribute it to white farmers. The Basters' petitions made repeated reference to one particular case in March and May of 1929 that resulted in the expropriation of Hendrik Beukes lands and property. Jacobus Beukes described the pending legal case to the League and argued that the claim made on Hendrik's lands by David Venter was illegitimate. The petition stated that "[the Basters did] not know in what manner Mr. Venter issue[d] summons against Hendrik Beukes," or by what means Venter made claims of possessing Hendrik's lands. ${ }^{144}$ The Basters wrote to the magistrate at Rehoboth and to the SWAA, only turning to the League when they received no reply from either party. While the

\footnotetext{
${ }^{140}$ Petition from Jacobus Beukes to the Secretariat of the League of Nations, 29 January 1928, LNA/MS/R2289. Jacobus Beukes was a leader of the Baster community and fought against the Germans during World War I and was part of the Rehoboth Rebellion in 1925. He petitioned the League of Nations and United Nations on behalf of the Basters in an attempt to regain the community's autonomy. In 1928 he was appointed to the Baster's Advisory Council.

${ }^{141}$ Ibid.

142 Ibid.

${ }^{143}$ Secretary for South West Africa H.P. Smit to Daniel Beukes, et al., 3 October 1929, LNA/MS/R2289.

${ }^{144}$ Urgent Request from Jacobus Beukes to the Secretariat of the League of Nations, 22 May 1929, LNA/MS/R2289.
} 
League failed to act on the petition, Beukes was arrested and removed from his land and his wife and children were forced from the property as well. ${ }^{145}$

The focus on the issue of land is unsurprising as it served as the chief means of survival in the arid parts of the Police Zone. The Basters linked the preservation of their claims to the land as necessary for economic survival and their social and political development under the mandate. Jacobus Beukes questioned the League on the matter in October 1929, positing "How can we keep pace with [development,] seeing that we are completely deprived of our rights? How can we accept offers which have been made to us politically?" He believed that the ease with which the SWAA dispatched Baster lands meant that the Basters were "not property owners" and thus "had no future."146 Since property rights were linked to "foreign laws" and controlled by the SWAA, Beukes contended that, according to the law, "[the Basters were] regarded as belonging to the Union of South Africa," a direct contradiction to the text of the mandate over South West Africa. ${ }^{147}$

It is clear that the continued expropriation of land in the late 1920s created a belief among the Baster community that the SWAA's intention was not the development of the Basters and other indigenous groups in South West Africa, but instead their destruction. The Basters initially made the League aware of their fears that they would be "utterly destroyed and scattered" in January $1928{ }^{148}$ They received no response from the League regarding their concerns surrounding arbitrary detentions and land expropriation, but reaffirmed their concerns about their destruction in March 1930, when they again wrote to the League, "We have still received no

\footnotetext{
145 Ibid.

${ }^{146}$ Petition from Mr. Jacobus Beukes, Rehoboth, South-West Africa to The Honorable Secretariat of the League of Nations, 25 October 1929, LNA/MS/R2289.

147 Ibid.

${ }^{148}$ Petition from Jacobus Beukes to the Secretariat of the League of Nations, 29 January 1928, LNA/MS/R2289.
} 
answer to our previous petition and report submitted through the proper channels, and we are highly apprehensive that if the League hands us over to the present Mandatory Government, we shall quickly be destroyed. We therefore beg you to take pity on us." ${ }^{149}$ The failure of the League to directly respond to the Basters' petitions made the probability of an intervention on the Basters' behalf highly unlikely. Therefore, beginning in 1931 and 1932, the Baster community began the process of resolving their internal disputes and making stronger, unified claims to the SWAA.

Initial attempts were made through Proclamation No. 9 of 1928 to restore some form of local government and self-determination to the Gebiet. This proclamation created an Advisory Council that consisted of three elected officials from the Baster community and three members that the SWAA appointed to the Council. The SWAA's role in appointing three of the Advisory Council's members remained a point of contention among the Basters. Likewise, Proclamation No. 28 of 1923 had yet to be repealed and continued to cause internal tensions and division among the community into the early 1930s and negatively impacted negotiations within the community to end the dispute. On 15 January 1931, Albert Mouton wrote to the League detailing the problematic nature of Proclamation No. 28 in ongoing negotiations:

We do not know how we are to preserve the peace, since the Magistrate of Rehoboth assures us that peace must be concluded under Proclamation 28 of 1923. But Proclamation 28 of 1923 is just the cause of the dissension, and all our petitions to the League of Nations are concerned with Proclamation 28. Honorable Gentlemen, we are anxious to have peace and are actually negotiating for peace, but we [do] not want it under Proclamation 28 of 1923. In case the League of Nations should have approved of Proclamation 28 of 1923, we beg to request you, Honorable Gentlemen, to write us this definitely. ${ }^{150}$

\footnotetext{
149 Jacobus Beukes to the Secretariat of the League of Nations, 7 March 1930, LNA/MS/R2289.
}

150 J. Mouton, et al. to the Secretariat of the League of Nations, 15 January 1931, LNA/MS/R2289. 
Over the course of the next year, Lord Lugard and the PMC implored the Basters to conduct their elections within the guidelines established by Proclamation No. 9 of $1928 .{ }^{151}$ However, Nicolas van Wyk's letter to the administrator at Rehoboth on 5 June 1932 rejected this suggestion. Van Wyk contended that "We, the Burghers who did not adopt the Agreement of 1923, have after long consideration of the letter of the League of Nations of [19] February 1932, decided to hold an election in accordance with the law of our Fathers of 1871-1872."152 The resultant election, according to van Wyk, would allow the elected members to consult with the administrator on the matter of cooperation with the complete backing of the community. Concerned about the nature of the administrator's response to this proposed election and the disregard for Proclamation No. 9, van Wyk also demanded that the Basters be "place[d] under the protection of the League of Nations." ${ }^{" 153}$ Later petitions in 1932 also alluded to potential reprisals against Baster lands in response to proposed elections and the demand for protection by the League was reaffirmed. ${ }^{154}$

By April 1933 opposition to conducting Advisory Board elections under Proclamation No. 9 of 1928 waned. Following the submission of a petition from T. Beukes on 17 June 1932, Nicolas van Wyk and his supporters joined the Minderheids, thus placing them in the majority. ${ }^{155}$ The Minderheids agreed to hold elections under the Proclamation and the members of the

\footnotetext{
${ }^{151}$ Frederick Lugard served as the British representative on the Permanent Mandates Commission. His work on the Commission focused heavily on the issue of slavery.

152 Nicolas van Wyk to Magistrate, Rehoboth, 5 June 1932, LNA/MS/R2289.

153 Ibid.

${ }^{154}$ Petition from T. Beukes and 11 Other Burghers of Rehoboth to the League of Nations, 17 June 1932, LNA/MS/R2289. T. Beukes wrote to the League of Nations that "We fear for our posterity — we already mentioned in 1926 that land belonging to Burghers was sold to Europeans with the consent of the Administrator contrary to our laws. We firmly believe that you, Honourable Gentlemen, will afford us, the Community, protection against the property-rights of the Community at Rehoboth being given to Europeans whether by way of sale or by political means."

${ }^{155}$ Government of the Union of South Africa to the Secretary-General, 19 August 1933, LNA/MS/R4091. Minderheid translates to "minority" and referred to the minority political group in the Rehoboth Gebiet. Meederheid translates to "majority" and referred to the majority political group that was most closely associated with members of the Traditional Raad.
} 
Advisory Council established by Proclamation No. 9 resigned their position, which allowed the administrator to call for elections under Section 2 of the Proclamation. ${ }^{156}$ On 11 April 1933 Nicolas van Wyk and two others were elected to the Advisory Board to serve alongside the three appointed members. While the Meederheids refused to participate in the election, the majority of voters agreed to the appointment of the new Advisory Council and the election, which was largely engineered and made possible by the tri-lateral negotiations of the Baster community represented a restorative step toward the reimplementation of limited self-determination in the Gebiet. ${ }^{157}$ Through Proclamation No. 5 of 1935, the three government-appointed members of the Advisory Council were eventually replaced by elected members. Limited political autonomy and self-determination thus briefly returned to the Gebiet as a result of the Rehoboth Basters' tireless petition-writing campaign and utilization of transnational organizations to make claims to the SWAA and South African government.

\section{$\underline{\text { Conclusion }}$}

The Rehoboth Basters developed and embraced transnational resistance strategies as a means to combat the aggressive extension of South African rule in South West Africa during the 1920s and 1930s. South West Africa's transition from a German colony to a South African mandate territory placed the Basters and other Namibians directly under the legal jurisdiction of the Union. The legal apparatus created by the South African government and implemented by the SWAA provided few viable or legitimate avenues of recourse for Namibians trying to reconstitute political or socioeconomic institutions that existed prior to colonialism. Since only limited concessions could be obtained by working solely through the apparatus provided by the

\footnotetext{
${ }^{156}$ Notice: Election of Elective Members of the Advisory Board for the Gebiet, 1933, LNA/MS/R4091.

${ }^{157}$ Government of the Union of South Africa to the Secretary-General, 19 August 1933, LNA/MS/R4091.
} 
colonial power, the Basters instead turned to transnational actors and institutions that existed outside of the recursive purview of the South African government and could, as a result, provide alternative means of support for the Basters' resistance campaigns. Through a carefully cultivated circuit of interested and sympathetic international actors, the Basters utilized mechanisms of international diplomacy to place pressure on the South African government to acquiesce to their political and socioeconomic demands.

In its earliest phases, the limitations of the Basters' transnational resistance strategies were apparent, and they achieved minimal political change. The Basters' early petitions focused heavily on subnational issue like the reconstitution of their political autonomy in the Gebiet and they believed that their demands would receive full consideration during peace negotiations as a reward for their participation in World War I on the side of the Allies. Despite South African assurances that they would maintain a political position similar to that which existed under German colonial rule, however, the transition from colony to mandate territory and General Smuts' desires to annex South West Africa as a de facto fifth province made the Basters' political sovereignty untenable. As a result of this betrayal, the Basters engaged with the League through a petition-writing campaign intended to apply international pressure on the South African government and moderate its activities against the community.

The focus of these petitions was clearly subnational in nature with limited interest in the independence of the larger South West Africa territory. Instead, the Basters concerned themselves almost entirely with restoring political autonomy in the Gebiet to the Baster Raad. This exclusive approach to resistance to the colonial regime allowed the Basters to focus on a small set of localized problems and avoid embroiling themselves in larger controversies in the territory. Their steadfast concentration on political autonomy and sovereignty during the early 
petition-writing phase had great success in amplifying the Baster voice and expressing Baster agency to the larger international political community. However, that early focus on political autonomy also complicated the League of Nations willingness to intervene in the matter as it tried to restructure the international political order after the war.

The concentration on political autonomy by the petition writers limited the ability of the League to directly intervene. The negotiations at Versailles and the subsequent mandate granted to the South African government clearly placed South West Africa under the legal control of the Union. At the time, the League lacked any type of coercive mechanism or enforcement arm that could have forced South Africa to grant the Basters autonomy. Likewise, the League lacked the appetite to force such a concession from a state that readily participated on behalf of the Allies in World War I. These limitations provided little resolution for the Basters' political demands and forced the Basters to table these complaints and focus on working directly within the legal language of the mandate.

Despite the early limitations of their transnational resistance campaign, the Basters' later resistance efforts proved more successful. As the possibility of obtaining political autonomy in the Gebiet appeared unlikely, the Basters altered their demands and focused more on socioeconomic development than on political sovereignty. The petitions of the mid-to-late-1920s called for reform within the colonial government rather than outright independence. Relying on the language of the League's Covenant and the Treaty of Versailles, the Basters' railed against the lack of progressive development achieved under the colonial regime. Their petitions highlighted the uneven distribution of hunting licenses that adversely affected their ability to feed their families, decried the predatory lending practices of white business owners in the 
Gebiet, and lamented the lack of economic opportunities in the drought- and poverty-stricken territory.

This marked shift in approach by the Basters and their demands for accommodation within the mandate structure allowed the League to more effectively pressure the colonial government. The Basters' demands could be directly linked to the legal language present in the mandate granted to South Africa and recursive measures could be taken. By following the guidelines set forth by the PMC and submitting their petitions to the League, the League compelled responses from the South African government and SWAA regarding the Basters' claims. In order to maintain their mandate over the territory the South African government was forced to respond to the League, further legitimating the Basters' resistance campaign and claims.

The pressure that the Basters were able to leverage against the colonial state by proxy of the League resulted in a number of concessions exclusively for the Basters as the South African government wanted to avoid increased international scrutiny over their actions. The South African government already faced immense backlash as a result of the Bondelswarts Affair and the Rehoboth Rebellion and wanted to avoid similar situations that would require testimony in front of the League. That concern ultimately led to concessions from the colonial regime that improved the socioeconomic situation for the Basters in the Gebiet. For example, the expropriation of lands around the Gebiet temporarily slowed and the Basters were more easily able to obtain hunting licenses to supplement their food production. The petitions effectively forced the South African government to temper its behavior and find more amicable, less violent resolutions to disputes raised by the Basters. 
Despite these victories on socioeconomic issues, the issue of political autonomy simmered well into the early 1930s. The South African government proved unwilling to repeal Proclamation No. 28 of 1923 and the disputes between the Traditional Raad and Provisional Raad continued over this issue. The continued unwillingness of the League to intervene ultimately resulted in the two Raads working internally to resolve their domestic disputes and then, in a unified attempt, made claims of the SWAA to hold elections and restore limited political autonomy in the Gebiet. The approach proved effective and, in 1935, the Basters' Advisory Board consisted entirely of members from the Gebiet.

The success of the Basters in their transnational resistance efforts was part of an emergent pattern in South West Africa that permeated the territory between 1921 and 1962. During the Interwar Years, while the Basters developed and executed their petition-writing campaign, the Herero and Nama simultaneously embraced a transnational resistance strategy that sought to reconstitute their precolonial sociopolitical institutions and traditional authority. Relying on historical maritime linkages that created a circuit between North America, South Africa, and South West Africa, the Herero and Nama readily embraced the Black liberation messages of the UNIA as it spread throughout the territory in the 1920s. The next chapter will examine how the Herero and Nama cultivated and maintained a working relationship with the transnational UNIA and utilized it not for national liberation but, instead, to reconstitute traditional Herero political power and improve the socioeconomic conditions for Namibians living in the Police Zone. 


\section{Chapter 3--"The Herero Claim it for Themselves Alone:" Subnationalism and the Rise and Fall of the UNIA in South West Africa, 1921-1924}

Whereas the Rehoboth Basters turned to the League of Nations to wage their transnational interwar resistance campaign, the Herero and Nama in the Police Zone embraced the UNIA as their primary means of resistance to the South African government's repressive segregationist policies. The UNIA was a transnational organization that originated in the Caribbean and, through Black American diasporic channels, traversed the Atlantic and found fertile grounds in North America and South Africa. The UNIA fostered close relationships with other Black nationalist labor movements in the Union, like the Industrial Commercial Workers' Union (ICU), and shared both leadership and members with these organizations. Unsurprisingly, because of these close relationships, the UNIA came to South West Africa in 1920 by way of the territory's ICU branches and enjoyed popularity among the West Indian and West African dockworkers in the territory. ${ }^{1}$ These West Indians and West Africans spread the UNIA's PanAfricanist message and held positions of immense power within the association for nearly two years, at which time the power dynamics in the territory's UNIA branches shifted.

In late 1922, Herero political leaders wrested power away from the West Indian and West African leadership of the Windhoek branch of the UNIA. This change in power was the result of nearly two years of unkept promises that failed to produce a successful American intervention force and a desire by Namibians to create both old and new structures of power. ${ }^{2}$ As the Herero in Windhoek and Nama in Rehoboth swept into power, the agenda of the UNIA in South West Africa shifted significantly from a focus on racial unity, Pan-Africanism, and complete territorial

\footnotetext{
${ }^{1}$ Tom Lodge, Resistance and Ideology in Settler Societies (Johannesburg: Ravan Press, 1986), 20-23.

${ }^{2}$ See Enclosure: Report of Native Corporal Jacob, 6 November 1922, NAN: SWAA/A50/32 for more on Namibians' disappointment at the lack of American intervention in 1922. The term "intervention force" refers to some Namibians' belief that African Americans would send a military force to liberate the territory from colonial rule.
} 
independence to a message of subnationalism and the achievement of specific subnational ethnopolitical and economic goals. Under its new Herero and Nama leadership, the UNIA became a vehicle for Namibian leaders to redress the political and economic traumas of colonialism and utilize a transnational institution to resist South African colonialism and improve their local socioeconomic circumstances.

This chapter seeks to add further complexity to the historical narrative surrounding the UNIA's activities in South West Africa during the 1920s. Historians have traditionally focused on the role that millenarianism, Black nationalism, and American intervention played in the rise of the UNIA among non-indigenous Blacks in South West Africa's industrial centers. ${ }^{3}$ This chapter instead examines the transnational nature of the UNIA, why the association took root among indigenous Namibians in the early 1920s and what factors, outside of American intervention, facilitated the UNIA's growth as a resistance institution in the Police Zone. In particular, this chapter analyzes how existent cultural frames in Namibian society mirrored the organizational structure of the UNIA and enabled the UNIA's growth as a means to reconstitute Namibians' subnational sociopolitical institutions and challenge the power of the colonial state. In the wake of the Herero's seizure of power, and absent non-indigenous leadership's influence, the focus of the Windhoek branch's activities turned to subnational concerns, with the leadership of other more rural UNIA branches following suit. Lastly, whereas Tony Emmett's work on this

\footnotetext{
${ }^{3}$ For examples of these types of historical studies, see Emmet, Popular Resistance; Tony Emmett, "Popular Resistance in Namibia, 1920-1925," in Resistance and Ideology in Settler Societies, ed. Tom Lodge (Johannesburg: Ravan Press, 1986), 6-49; Robert A. Hill and Gregory Pirio, "Africa for the Africans: the Garvey Movement in South Africa, 1920-1940," in The Politics of Race, Class, and Nationalism in Twentieth-Century South Africa, eds. Shula Marks and Stanley Trapido (New York: Routledge, 2014), 209-253. Gregory Pirio, "The Role of Garveyism in the Making of the Southern African Working Classes and Namibian Nationalism," Paper presented to the Joint Committee on African Studies Conference on South Africa in the Comparative Study of Class, Race, and Nationalism (New York, 1982). These works are discussed in more detail later in the chapter.
} 
topic argues that Garvey's arrest, the preponderant power of the colonial state, and the emergence of the South West Africa National Congress (SWANC) contributed to the collapse of the UNIA in the territory, this chapter instead examines two important aspects of the rise and fall of the association in South West Africa. First, the chapter examines how indigenous Namibians created, accessed, and used the transnational networks provided by the UNIA in order to influence the behavior of the colonial state. Second, unlike Emmett's work, this chapter contends that ethnopolitical rivalry and competing subnational goals played an essential role in the collapse of the UNIA in South West Africa, not external factors overseas. Such an analysis adds further detail and nuance to Emmett's limited discussion on how the "composition and nature of political organizations during this period" contributed to the failure of the UNIA in the $1920 \mathrm{~s} .{ }^{4}$

The historiography surrounding the UNIA in Africa concentrates on the organization's activities in West Africa and South Africa. Within the South African context, scholars focused on the millenarian aspects of Garveyism, how this coincided with similar resistance movements in Southern Africa, and the role that concepts like Black nationalism and providential design played in the association's popularity. Robert Vinson's The Americans Are Coming! is perhaps one of the most thorough examinations of the transnational nature of Garveyism and explored why the UNIA found success in South African industrial centers. Likewise, Robert A. Hill's and Gregory Pirio’s chapter “Africa for the Africans” examined the development of Garvey's movement in South Africa between 1920 and 1940. ${ }^{5}$ Other works, less extensive in scope, analyzed smaller episodes of Garveyism's role as an ideology suited to colonial resistance. For instance, Robert Edgar's “Garveyism in Africa” examined Wellington Buthelezi's activities in

\footnotetext{
${ }^{4}$ Emmett, "Popular Resistance in Namibia, 1920-1925," 31.

${ }^{5}$ Hill and Pirio, "Africa for the Africans," 209-253.
} 
the Transkei in interwar South Africa, and Vinson's "Sea Kaffirs" focused on the role of Black Americans in the spread of Garveyism in Cape Town. ${ }^{6}$

The historiography of the UNIA's activities in South West Africa, unlike its South African counterpart, is more limited. In 1982, Pirio produced one of the early in-depth studies of the UNIA in South West Africa, where he highlighted the connection between the UNIA and the ICU and argued that these two organizations played an instrumental role in the development of a Black working-class nationalism in the territory. ${ }^{7}$ In June 1984, Emmett added to Pirio's work with the presentation of his seminar paper "Popular Resistance in Namibia, 1920-1925." Emmett's paper argued that the UNIA represented the emergence of a new, nationalistic period of resistance in South West Africa's history. His work analyzed the growth of the UNIA as a result of millenarianism and pointed to the association's predominantly non-indigenous leadership, the rise of SWANC, and the preponderant power of the colonial state as major factors in the association's collapse in the territory. ${ }^{8}$ In 1990, Emmett further refined his work on the UNIA in South West Africa and published a shorter version of his seminar paper as part of his larger book Popular Resistance and the Roots of Nationalism in Namibia, 1915-1966. ${ }^{9}$ Other historians, like Jan-Bart Gewald, have briefly analyzed the role of the UNIA in postwar Herero society, but in a more limited manner and within the context of more sweeping historical examinations. ${ }^{10}$

\footnotetext{
${ }^{6}$ Robert Edgar, "Garveyism in Africa: Dr Wellington and the American Movement in the Transkei," Ufahamu 6 (1976): 31-57 and Robert Vinson, "'Sea Kaffirs:' American Negroes and the Gospel of Garveyism in Early Twentieth-Century Cape Town," Journal of African History 47, No. 2 (2006): 281-303.

${ }^{7}$ See Pirio, "The Role of Garveyism."

${ }^{8}$ Emmett, "Popular Resistance," 46-48.

${ }^{9}$ Emmett, Popular Resistance, 126-153.

${ }^{10}$ For examples of these shorter examinations of the UNIA in Namibia, see Jan-Bart Gewald, "We Thought We Would Be Free...." Socio-Cultural Aspects of Herero History in Namibia, 1915-1940 (Koln: Rüdiger Köppe, 2000), 147-50 and Gewald, Herero Heroes, 269-272.
} 
The analysis of the UNIA in South West Africa has focused on two key issues. First, scholars argue that the UNIA's espousal of a Black liberation ideology cultivated an improbable belief among Namibians that American intervention would bring about a millenarian general uprising in the territory. ${ }^{11}$ Second, the UNIA's close links to the ICU created the basis for a Black working-class nationalism that provided the foundation for the national liberation movement of the 1960s. ${ }^{12}$ This approach, although valuable, creates a historiographical issue, whereby there is an overemphasis on the promise of American intervention as the leading cause for the rise and collapse of the UNIA in 1920s South West Africa.

While the possibility of American intervention and territorial liberation undoubtedly aided the spread of the association, it is clear that among indigenous Namibians, particularly the Herero, the success of the UNIA rested on the similarities between Namibian and UNIA sociopolitical structures and their ability to address subnational socioeconomic needs. In the case of the Herero and Nama in the Police Zone, the social welfare programs provided by the UNIA and the opportunity to re-establish earlier sociopolitical structures proved equally enticing and led to the association's growth among Namibians. ${ }^{13}$ Although questions still remained for Namibians around the viability of an American intervention force, the UNIA's new agenda centered on subnational and local problems under indigenous leadership.

This chapter begins its exploration of the UNIA's role in Namibian resistance politics by first detailing Marcus Garvey's early life in the Caribbean and his development of the UNIA in New York. The chapter proceeds with a discussion on the transnational nature of the UNIA and

\footnotetext{
${ }^{11}$ Pirio, "The Role of Garveyism," 1-12.

${ }^{12}$ R.S. Cope, Officer-in-Charge of Native Affairs, Windhoek to J.F. Herbst, Secretary for South West Africa, 21 December 1921, NAN/SWAA/A50/32.

${ }^{13}$ See Molly McCullers, "The 'Truppenspieler Show': Herero Masculinity and the German Colonial Military Aesthetic" in German Colonialism Revisited: African, Asian, and Oceanic Experiences, eds. Nina Berman, et al. (Ann Arbor: University of Michigan Press, 2018), 226-242 for more on Herero attempts to re-establish their ethnopolitical identity after the genocide.
} 
the particular circumstances in South Africa that allowed it to flourish and spread in the early twentieth century. Here, the close relationship that developed between the ICU and UNIA leadership is discussed with a particular focus on the ICU's role in spreading the UNIA to South West Africa. Next, the chapter examines why the UNIA experienced success in South West Africa. The UNIA's similarities with existing Namibian social structures, its popular social welfare message, and spread from urban to rural areas are analyzed. Finally, the chapter concludes with an analysis of the transfer of power that occurred in the UNIA in 1922 and the subsequent collapse that transpired as a result of internal sociopolitical fissures among the UNIA's Namibian leadership and members.

\section{Marcus Garvey: The Development of His Pan-African Thought}

Marcus Garvey was born on 17 August 1887 in St. Ann's Bay, Jamaica to Sarah Jane Richards and Malchus Garvey, Sr. ${ }^{14}$ Richards served as a housekeeper in middle-class households and Garvey, Sr. was a prominent land-owning Black man in St. Ann's Bay who held important positions in the parish and possessed a large private library that provided his son with access to education and inspiration at an early age. ${ }^{15}$ Garvey described the significance of his father's library in his early intellectual development, writing "And in my tender years I went to... [my father's] books and I gathered inspiration, and what inspiration I gathered, changed my outlook from the ambition of wanting to be a wharf-man or a cow-boy, and made me look forward to being a personality in the world. Nobody helped me toward that objective except my

\footnotetext{
14 Judith Stein, The World of Marcus Garvey: Race and Class in Modern Society (Shreveport: Louisiana State University Press, 1991), 24-25.

${ }^{15}$ Marcus Garvey, The Philosophy and Opinions of Marcus Garvey: Africa for Africans, ed. Amy Jacques Garvey (New York: Routledge, 2013), 124.
} 
own mind and God's good will." ${ }^{16}$ Garvey began his formal education at a local elementary school and later enrolled in the Church of England Grammar School in St. Ann's Bay until he completed the sixth standard in $1903 .^{17}$

After leaving the Church of England Grammar School, Garvey became an apprentice in the printing shop of his godfather Alfred Burrowes. During this period, Garvey quickly learned the technical side of the printing process and the importance of the written word. While working in Burrowes' shop, Garvey immersed himself in the printing business and learned of Black Jamaican struggles by listening to Burrowes and his acquaintances discuss historical slave rebellions and the contemporary political happenings on the island. ${ }^{18}$ Upon completion of his apprenticeship with Burrowes, Garvey left St. Ann's Bay in 1904 and travelled to Kingston, Jamaica to obtain work as a printer. In Kingston, Garvey found employment with Jamaica's largest printing firm, P.A. Benjamin Company, and by the age of 20 he became a master-printer and foreman. ${ }^{19}$

During his time at the company, Garvey became deeply involved in the political and economic life in Kingston. The Compositor's Branch of the Printer's Union elected Garvey as its Vice President in 1907, and that same year he led a printers' strike that demanded higher wages and better working conditions for the Union's members. ${ }^{20}$ The strike was broken in 1907 and

\footnotetext{
${ }^{16}$ Robert A. Hill, ed., MGP, Vol. 1:1826-August 1919 (Berkeley: University of California Press, 1983), xl. See Alphonso Pickney, Red Black and Green: Black Nationalism in the United States (Cambridge: Cambridge University Press, 1976), 40-41 for more discussion on the importance of Garvey, Sr.'s library in Garvey's intellectual development.

${ }^{17}$ W.E.B. Du Bois, "Back to Africa," The Century Magazine 105, No. 4 (February, 1923): 540 and Hill, ed., MGP, Vol. 1, cxi.

${ }^{18}$ Adam Ewing, The Age of Garvey: How a Jamaican Activist Created a Mass Movement and Changed Global Black Politics (Princeton: Princeton University Press, 2014), 41. Much like Garvey's father, Burrowes also possessed a sizable private library that Marcus Garvey frequently used to expand his education and knowledge-base. ${ }^{19}$ Amy Jacques Garvey and E.U. Udom, eds., More Philosophy and Opinions of Marcus Garvey (New York: Routledge, 1977), xi-xii.

${ }^{20}$ John McCartney, Black Power Ideologies: An Essay in African American Political Thought (Philadelphia: Temple University Press, 1993), 76. The Printer's Union was the first trade union on the island.
} 
because Garvey did not succumb to the pressure from his employers to defect from his fellow strikers, he was blacklisted from the printing industry in Jamaica. Upon the advice of his mentor and elocution teacher, Dr. Joseph Robert Love, Garvey founded his own publication, Garvey's Watchman, which was based, in part, on Dr. Love's The Advocate. ${ }^{21}$ Love's impact on Garvey's conception and definition of Black consciousness cannot be understated. Garvey was an avid reader of Dr. Love's publication and, through his relationship with Love, he was introduced to the writings of the period's most prominent Pan-African thinkers like Edward Wilmont Blyden, Booker T. Washington, Alexander Crummell, W.E.B. Du Bois, and John Edward Bruce. In response to a letter written by the anonymous "St. Ann" in the 10 February 1930 issue of the Daily Gleaner that described Garvey and Dr. Love's conceptions of race as at odds, Garvey further highlighted the impact of Dr. Love and The Advocate on his conceptions of race. Garvey wrote, “[I]sn't it rather amusing to those who knew Dr. Love for you to refer to him as [someone] to the opposite of Marcus Garvey? Why, much of my early education in race consciousness is from Dr. Love. One cannot read his 'Jamaica Advocate' without getting race consciousness." ${ }^{22}$

Unable to find suitable work in Jamaica and desirous of exploring the Black condition in the rest of the world, Garvey travelled to South and Central America from 1910 to $1912 . \mathrm{He}$ travelled extensively, making stops in Costa Rica, Ecuador, Nicaragua, Venezuela, and Panama where he performed manual labor jobs that provided him with an intimate knowledge of the similar working conditions faced by Black workers in the Americas. ${ }^{23} \mathrm{He}$ attempted to bring this

${ }^{21}$ Karl Putner, The Strange Partnership of George Alexander McGuire and Marcus Garvey (Rockville: Wildside Press LLC., 1986), 8-9.

22 "Garvey to the Daily Gleaner, 10 February 1930," in MGP, Vol. VII: November 1927-August 1940, ed. Robert A. Hill (Berkeley: University of California Press, 1983), 372-373.

23 "Roy T. Davis, US Minister to Costa Rica to Frank Billings Kellogg, Secretary of State, 5 March 1928," in MGP, Vol. 7: November 1927-August 1940, ed. Robert A. Hill (Berkeley: University of California Press, 1983), 136. 
condition of exploitation and oppression to the forefront by publishing La Nacion, a newspaper in which Garvey lamented the burdensome and deadly working conditions faced by Black laborers in Costa Rica. However, the claims and information presented in his paper proved to have little effect on white policy-makers. After two years of seeing the plight of the Black worker, Garvey returned to Jamaica in $1912 .{ }^{24}$

Upon his return, Garvey quickly realized that the lack of employment opportunities still remained and that, in order to find better economic prospects and discern for himself if the treatment of Blacks was better in Europe, he again needed to leave the island. Through the help of his sister Indiana Peart, who was living in London at the time, Garvey secured a passage to England. ${ }^{25}$ In London, Garvey enrolled in Birkbeck College and took courses in philosophy and law while also working at various docks in London. Garvey continued to involve himself in the printing industry and contributed a number of articles to English-language publications, including the African Times and Orient Review. ${ }^{26}$ In this journal, Garvey published his influential article "The British West Indies in the Mirror of Civilization: History Making by Colonial Negroes," which called for a federation in the British West Indies and prophesized that such a federation would make "[West Indians] the instruments of uniting a scattered race who, before the close of many centuries, will found an Empire on which the sun shall shine as

\footnotetext{
${ }^{24}$ Vinson, The Americans Are Coming!, 64-65; and Ronald Harpelle, "Cross Currents in the Western Caribbean: Marcus Garvey and the UNIA in Central America," Caribbean Studies 31, No. 1 (Jan.-Jun., 2003): 39-49. Garvey also found employment with the Panamanian newspaper La Prensa during his time in Colon and likely worked as a printer due to the fact the publication was only printed in Spanish until 1916.

${ }^{25}$ John Henrik Clarke, Marcus Garvey and the Vision of Africa (New York: Vintage Books, 1974), 34-38. Garvey's sister worked in London as a governess to a wealthy family and, through this work, she was able to help supply the fare that allowed Garvey to travel to London.

26 "Mainly About Persons," Jamaica Times, 18 October 1913. The African Times and Oriental Review, run by leading Pan-Africanist Duse Mohamed Ali, was self-described in its first issue in July, 1912 as "a Pan-Oriental, PanAfrican journal at the seat of the British Empire which would lay the aims, desires, and intentions of the Black, Brown, and Yellow Races — within and without the [British] Empire - at the throne of Caesar."
} 
ceaselessly as it shines on the Empire of the North to-day." ${ }^{27}$ Garvey used this concept of "uniting a scattered race," which he developed as a result of his experiences in the Americas and Europe, as the intellectual forerunner to the creation of the United Negro Improvement Association and African Communities League.

\section{The UNIA: Its Structure and Growth in North America}

Garvey returned to Jamaica in 1914 and on 1 August 1914, the anniversary of the emancipation of Jamaican slaves, he founded the UNIA. In its early stages, the UNIA began as a "universal confraternity" with the goal to "promote the spirit of race pride and love,...reclaim the fallen race,... administer to and assist the needy,... [and] establish universities, colleges and secondary schools for the further education and culture of the boys and girls of the [Black] race." ${ }^{28}$ Chapters of the UNIA could be created, with the approval of Marcus Garvey, if the members showed "a commitment to contribute to the UNIA program" and "at least seven Black, dues paying individuals" were present. ${ }^{29}$ The rates of these dues were not to exceed 25 cents per person and included an additional 10 cents that served as a type of insurance that alleviated funeral costs for a deceased UNIA member's family.

Fairly moderate in its early conception, improvement and the provision of education for Black Jamaicans became the early focus of the UNIA. On his return trip from London to Kingston, Garvey read Booker T. Washington's Up From Slavery and firmly embraced Washington's Tuskegee Model and its focus on industrialization and vocational skills as a model to be followed in Jamaica. Garvey initially attempted to create a school for delinquent children in

\footnotetext{
${ }^{27}$ Marcus Garvey, "The British West Indies in the Mirror of Civilization: History Making by Colonial Negroes," African Times and Orient Review 2 (Mid-October, 1913): 158-160.

28 "Membership Application for the Universal Negro Improvement and Conservation Association and African Communities League," in MGP, Vol. 1, ed. Hill, 117.

${ }^{29}$ Vinson, The American Are Coming!, 65-66.
} 
Jamaica, but the government rejected his request for Crown lands to build the school after several complaints from "Coloured" intellectuals and civil servants in Jamaica. ${ }^{30}$ However, it is clear that by September of 1914 Garvey planned to travel to the United States and raise funds for the creation of a school in Jamaica based on the Tuskegee model. He wrote to Booker T. Washington that month, detailing his plan to partake in a lecture tour around the United States to raise awareness about the work of the UNIA in the United States, and he asked Washington to make a donation to their cause. ${ }^{31}$ Although Washington was unable to make a donation to the UNIA or its proposed school, he did reply "I have read what you say with reference to the advance being made in educational facilities for the Negroes of [Jamaica]. I hope that when you come to America you will come to Tuskegee and see for yourself what we are striving to do for the colored young man and woman of the South." ${ }^{32}$ Approximately two years later, and a year after Washington's death, Garvey made the voyage to the United States and arrived in Harlem, New York on 23 March 1916. While Garvey struggled in the early years in New York, late1910s and early-1920s Harlem proved a fertile ground for the Pan-African message and platform of the UNIA.

Two factors that contributed to the eventual popularity of the UNIA in Harlem, and later the United States, were the post-war disillusionment experienced by African Americans and the cultural flourishing of the African American community in Harlem. African Americans that fought in World War I sacrificed their lives for the war effort. Yet, when they returned to the United States they experienced the same humiliation, dehumanization, and violence that thrived under Jim Crowism in the United States South. The production of Birth of a Nation in 1915 led

\footnotetext{
${ }^{30}$ Stein, The World of Marcus Garvey, 33-34.

31 "Marcus Garvey to Booker T. Washington, 8 September 1914," in MGP, Vol. 1, ed. Hill, 141.

32 "Booker T. Washington to Marcus Garvey, 17 September 1914," in MGP, Vol. 1, ed. Hill, 71.
} 
to a revival in the recruitment efforts of the Klu Klux Klan (KKK) and increased violence against

Blacks in the American South. Garvey recognized the peculiar position of African American servicemen and the affected communities and captured the prevailing attitudes of African Americans, writing:

When our interests clash with those of the ruling faction, then we find that we have absolutely no rights. In times of peace, when everything is all right, Negroes have a hard time, wherever we go, wheresoever we find ourselves...but in the time of trouble they make us all partners in the cause, as happened in the last war, when we were partners, whether British, French or American Negroes. And we were told that we must forget everything in an effort to save the nation. We have saved many nations in this manner, and we have lost our lives doing that before. Hundreds of thousands-nay, millions of Black men...we saved this glorious country more than once; and all that we have received for our sacrifices, all that we have received for what we have done, even in giving up our lives, is just what you are receiving now, just what I am receiving. ${ }^{33}$

African American journalist and writer Roi Ottley later wrote of Garvey's ability to connect with the African American sentiment of the time: "Garvey [leapt] into the ocean of Black unhappiness at a most timely moment for a savior. He had witnessed the Negro's disillusionment mount with the progress of the World War. Negro soldiers had suffered all forms of Jim-Crow, humiliation, discrimination, slander, and even violence at the hands of a white civilian population.... Meantime, administration leaders were quite pointed in trying to persuade Negroes that in spite of their full participation in the war effort they could expect no changes in their traditional status in America."34 The unkept promises of the postwar period created an environment where African Americans were particularly receptive to the messages of Garvey and the UNIA.

Despite the broken promises of the period, the Black community in Harlem flourished. The New Negro Movement, which spanned from the 1890s to 1940, provided an intellectual and

\footnotetext{
33 "The Principles of the Universal Negro Improvement Association, 25 November 1922," in Selected Writings and Speeches of Marcus Garvey, ed. Bob Blaisdell (North Chelmsford: Courier Corporations, 2012), 107.

${ }^{34}$ Roi Ottley, A New World A-Coming: Inside Black America (Cleveland: World Publishing, 1943), 69.
} 
philosophical foundation for Black political awareness, citizenship, and power in the postReconstruction Era. Led by Booker T. Washington's “Tuskegee Machine” and W.E.B. Du Bois' “Talented $10^{\text {th }}$," the movement represented a political and social re-awakening for African Americans in the United States. While the New Negro Movement would continue until 1940, in the late 1910s and early 1920s a more radical wing developed in Harlem that centered not on social and political discourse, but instead on Black expression through the arts. This more radical, artistic branch of the New Negro Movement that developed in New York was known as the Harlem Renaissance. ${ }^{35}$

Unapologetically Black and proud, the Harlem Renaissance sought to reclaim the lost identity of Black people from the depths of white oppression. The driving force behind the Harlem Renaissance was the expression of Black identity through the creation of artwork, literature, poetry, and plays that challenged stereotypes and misrepresentations of the Black experience in the United States. For many artists and writers that shaped the Harlem Renaissance, art served as a form of activism. Whereas negative images of African Americans inspired racism, these artists believed that positive representations of Blacks could uplift the race.

Works like Claude McKay’s poem “If We Must Die," Zora Neal Hurston's Their Eyes Were Watching God, and Alaine Locke's The New Negro attempted to capture the feelings of disillusionment that had set in during the post-war years and replace them with feelings of racial pride and optimism. ${ }^{36}$ Such works decried the act of lynching and violence against African

\footnotetext{
${ }^{35}$ See Reiland Rabaka, The Negritude Movement: W.E.B. Du Bois, Leon Damas, Aime Cesaire, Leopold Senghor, Frantz Fanon, and the Evolution of an Insurgent Idea (Lanham: Lexington Books, 2015), 41-88 for a comprehensive examination of the development of the Harlem Renaissance in New York.

${ }^{36}$ Claude McKay, Harlem Shadows: The Poems of Claude McKay (Harlem: Harcourt, 1922), 53; Zora Neale Hurston, Their Eyes Were Watching God: A Novel (New York: Harper Collins, 2010); Alain Locke, The New Negro (New York: Simon and Schuster, 2014).
} 
American, questioned the socioeconomic and political marginalization of Blacks, and challenged African Americans to reconceptualize their position in American society. Other works, like Langston Hughes' The Negro Speaks of Rivers, attempted to connect African Americans with a lost past that included important contributions to the development of Western culture and society ${ }^{37}$ The radical, more militant pro-Black artists of the Harlem Renaissance were critical of the "more conservative bourgeoisie [element] of the New Negro Movement" and, coupled with the disillusionment that many African Americans experienced during this period, their strategies cultivated a receptive audience in New York that was willing to embrace the message that Marcus Garvey prepared to unleash in the United States.

In an attempt to give his idea a lasting organizational foothold in the United States, Marcus Garvey incorporated the New York Branch of the UNIA in June of 1918. Membership in the UNIA began with as few as 13 members. However, by 1920 there were an estimated 300,000 to 2,000,000 members in the UNIA in the Americas and Africa. Likewise, the UNIA established nearly 300 branches across the globe by the mid-1920s. ${ }^{38}$ Garvey's dream of "uniting a scattered race," that he had so eloquently described in "The British West Indies in the Mirror of Civilization" in October of 1913, manifested itself in concrete ways in the 1920s. ${ }^{39}$

As Garvey's movement took root and spread in the United States, the platform and purposes of the UNIA expanded and took shape. At the heart of the UNIA's mission in the United States was the restoration of Black political autonomy and the rescuing of Black humanity and dignity. Unlike other movements which "[sought] to make the Negro a secondary

\footnotetext{
37 Langston Hughes, The Collected Works of Langston Hughes: The Poems, 1921-1940 (Columbia: University of Missouri Press, 2001), 36.

${ }^{38}$ Edward Peeks, The Long Struggle for Black Power (New York: Scribner, 1971), 198-200.

${ }^{39}$ Marcus Garvey, "The British West Indies in the Mirror of Civilization: History Making by Colonial Negroes," African Times and Orient Review 2 (March-October, 1913): 158-160.
} 
part of the existing government" and "subordinate the Negro as a secondary consideration in a great civilization," Garvey and the UNIA advocated for the creation of an African state that African Americans and West Indians could repatriate to and develop. ${ }^{40}$ Garvey acknowledged this desire as a key distinction from other organizations of the period and wrote, "The difference between the [UNIA] and the other movements of this country, and probably the world, is that the [UNIA] seeks independence of government. ${ }^{{ }^{41}}$ From this desire for an independent and blackcontrolled state, albeit controlled by Western blacks, the [UNIA] and Garvey developed their "Back-to-Africa" slogan which became a rallying cry of the Garveyite movement in the United States. $^{42}$

The concept of a "Back-to-Africa" movement was not new in the United States. The American Colonization Society (ACS) supported the repatriation of African Americans to Africa and, in 1822, helped establish the Liberia colony. Garvey was clear that the UNIA was not "seeking to build up another government within the bounds or borders of the United States of America" or "disrupt an organized system of government." ${ }^{\text {"3 }}$ Instead the UNIA was "determined to bring Negroes together for the building up of a nation of their own... because [they] have been forced to it." ${ }^{" 44}$ In this pursuit, Liberia served as a perfect conduit through which the UNIA could carry out its program of re-establishing Black political sovereignty in a world that oppressed, abused, and enslaved its Black populations. Garvey further underlined this point, writing "Yet it is realized that all human beings have a limit to their humanity. The humanity of white America,

\footnotetext{
40 "Speech by Marcus Garvey at Carnegie Hall, 23 February 1923," MGP, Vol. V: September 1922-August 1924, ed. Robert A. Hill, (Berkeley: University of California Press, 1983), 247-251.

${ }^{41}$ Ibid.

${ }^{42}$ See Tamba M'bayo, "W.E.B. Du Bois, Marcus Garvey, and Pan-Africanism in Liberia, 1919-1924,” The Historian 66, No. 1 (Spring, 2004): 22-26 for more on the Back-to-Africa movement's position in Garvey's larger Pan-African ideology.

43 "Speech by Marcus Garvey at Carnegie Hall, 23 February 1923," MGP, Vol. V, 247-251.

${ }^{44}$ Ibid.
} 
we realize, will seek self-protection and self-preservation, and that is why the thoughtful and reasonable Negro sees no hope in America for satisfying the aggressive program of the [National Association for the Advancement of Colored People (NAACP)], but advances the reasonable plan of the Universal Negro Improvement Association, that of creating in Africa a nation and government for the Negro race." 45

Closely related to Garvey's conception of a politically and socially independent Black society was the desire for Black economic self-sufficiency. Garvey believed that "it is only a question of time when the Negro, economically dependent as he is on the white man, [will] be forced to the wall, and that the solution of the problem in the future would not be so much by wholesale killing or wiping out of Negro populations... but by a well-organized plan of economic starvation." 46 He would further write, "The time is coming... when the Negro will have a hard time finding a place in the economic arrangements of the other races of the world, when not only in Europe, but in America, it will become difficult for him to find even the opportunity to work in the most menial occupations." ${ }^{47}$ In order to prepare for and counteract this perceived threat to the viability and stability of the Black race, Milfred Fierce argued that Garvey and the UNIA adopted a platform based on "Black capitalism" and turned its attention toward the creation and support of Black businesses across the United States. ${ }^{48}$

\footnotetext{
45 "Aims and Objects of the Movement for Solution of Negro Problem," in More Philosophy and Opinions of Marcus Garvey, 40.

46 "Will Negroes Succumb to the White Man's Plan of Economic Starvation?" in More Philosophy and Opinions of Marcus Garvey, 44-45.

${ }^{47}$ Ibid., 47.

${ }^{48}$ Milfred C. Fierce, "Economic Aspects of the Marcus Garvey Movement," The Black Scholar 3, No. 7/8 (MarchApril, 1972): 50. Fierce spends part of her article outlining the term "Black Capitalism." She wrote, "Loosely defined, capitalism is principally an economic system which is characterized by freedom of the market for private and corporate ownership of the means of production and distribution that are operated for profit.... Black capitalism means that all of the machinery of capitalism is operated and controlled by black people."
} 
The Black Star Line, one of Garvey's early business ventures, was founded in New York in 1919 and became central to his concept of economic self-sufficiency. The Black Star Line was conceptually a mechanism through which the UNIA could support its "Back-to-Africa" movement and provide African Americans with the opportunity to invest in a Black-run and Black-owned businesses. The Black Star Line was capitalized at \$500,000 and African Americans bought shares of stock in the publicly traded company at $\$ 5$ a share. In addition to the repatriation of African Americans to Liberia, the Black Star Line also served to transport goods, like alcohol, vegetables, and coconuts, to Central and South America, as well as the Caribbean and Africa. This company, the epitome of a Black capitalist venture, provided the UNIA with a means through which to facilitate its followers' dreams of economic opportunity and stability through Black-owned businesses. ${ }^{49}$

In 1920, Garvey and the UNIA also organized and capitalized the Negro Factories Corporation and the Black Cross Navigation and Trading Company. The Negro Factories Corporation's purpose was to "construct and manage factories in the urban or industrial centers of North America, Central America, the West Indies, and Africa" and produce commodities that would guarantee "steady and profitable" employment for black workers. The Negro Factories Corporation served as a way for black producers and manufacturers to sell desired commodities to Black communities, creating a system that increased Black economic power. Similarly, the Black Cross Navigation and Trading Company, a successor of the Black Star Line, chartered trade between Black communities around the Atlantic and facilitated the repatriation of African Americans to Africa. ${ }^{50}$ Garvey intended The Black Cross Navigation and Trading Company to

\footnotetext{
${ }^{49}$ Ibid., 53-55.

${ }^{50}$ E. David Cronon, Black Moses: The Story of Marcus Garvey and the Universal Negro Improvement Association (Madison: University of Wisconsin Press, 1960), 120-122.
} 
"contribute to the transportation of pilgrims to West Africa," which would create the foundation for the development of a Black capitalist society in Liberia devoid of the socioeconomic and political pressures of white society.

In order to develop this Black capitalist society and link it to the larger Pan-African diasporic community, Garvey relied on his background as a publisher, printer, and journalist to disseminate the core concepts of the UNIA across the globe. These core concepts included political sovereignty, economic self-sufficiency, racial pride, and general improvement and upliftment of the Black race. In 1918, with the help of his future wife Amy Euphemia Jacques, Marcus Garvey established The Negro World in New York. The Negro World, a newspaper resembling Hubert Harrison's The Voice, served as the primary propaganda and dissemination organ of the association. The purpose of the Negro World was to connect the African diaspora in North America, South America, the Caribbean, Europe, and Africa with one another and facilitate the exchange of ideas and information. Similarly, Garvey also hoped that The Negro World would encourage other newspapers in the United States to take up international issues that affected the Black community and do so in an honest manner. He argued, "[The Negro World] has rendered a wonderful service to Negro journalism in the United States. It has gradually changed the tone and make-up of some of the papers...today several of the papers are publishing international news and writing intelligent editorials on pertinent subjects. It has been a long and costly fight to bring this about.... I fully realize that very little can be achieved by way of improvement of the race when its press is controlled by crafty and unscrupulous persons who have no pride or love of race." 51

51 “The 'Colored' or Negro Press," in The Philosophy and Opinions of Marcus Garvey, ed. Amy Jacques Garvey, 79. 
Travelling primarily along shipping routes, some estimates place the total global circulation of The Negro World at around 200,000 copies in $1921 .^{52}$ The publication served as a sociopolitical analysis and critique of the Black experience across the globe. And it consequently served as the primary link and line of communication between the UNIA's headquarters in the United States and the separate branches across the world. In many cases, The Negro World not only informed the global Black community about political events, but also distributed information and propaganda about the association that cultivated fertile ground in places where branches of the organization did not already exist. In this way, The Negro World was not only the connective tissue that held the organization together, but also a tool for its growth and expansion in places like West Africa and South Africa.

\section{The UNIA in South Africa}

The historical links that developed a circuit between the United States and South Africa date to the eighteenth century and created a natural channel through which the Garveyist ideology and the UNIA circulated. Garvey's UNIA found a favorable environment in 1920s South Africa as Black South Africans experienced the misfortunes of a poor global economy and the aggressive expansion of segregationist policies by the South African state in the post-war period. The South African government "retained an essentially regressive approach" toward African workers in the 1920 s and limited both their political and socioeconomic opportunities. ${ }^{53}$ The 1913 Land Act, which forced Africans into reserves and prevented them from either buying or renting land that sat outside of these economically unviable reserves, was rigorously enforced

\footnotetext{
52 James N. Gregory, The Southern Diaspora: How the Great Migrations of Black and White Southerners Transformed America (Chapel Hill: University of North Carolina Press, 2006), 127-128.

${ }^{53}$ Nicoli Nattrass and Jeremy Seekings, "The Economy and Poverty in the Twentieth Century in South Africa," CSSR Working Paper No. 276, Centre for Social Science Research: Social Surveys Unit, Cape Town, South Africa, 2010, 11.
} 
and expanded. The 1923 Natives (Urban Areas) Act further restricted the movement of Africans outside of the reserves and practically "provided for the registration and control of employment contracts, and regulated migration into and residence in towns on the basis of the "pass'."54 Africans that violated their labor contracts while in the urban areas were persecuted through the earlier Masters and Servants law and the 1911 Native Labour Regulation Act. ${ }^{55}$ The South African government was, thus, creating an immobile and stagnant labor pool that could be easily controlled and monitored by the state.

For those Africans in the urban areas and cities in South Africa, their economic opportunities were also tightly controlled. As Nicoli Nattrass and Jeremy Seekings suggest, “Trade Unions representing African workers were not recognized, and were not allowed to participate in centralized bargaining," severely limiting Africans' abilities to negotiate better working conditions or higher wages ${ }^{56}$ Although the welfare state in South Africa grew dramatically during the 1920s, African workers were largely excluded from such programs. Many of these programs were meant to promote industrial growth and modernize agricultural practices; however, they were geared largely toward benefiting unskilled poor white laborers as a means to avoid situations similar to the Rand Rebellion of $1922 .{ }^{57}$ In addition to these unfavorable economic conditions, Africans also faced a continuous assault from the South African government on their political rights. Beginning in 1924, J.B.M. Hertzog actively worked to remove Blacks from the South African voting rolls and effectively eliminate their franchise. These efforts culminated in the establishment of the Representation of Natives Act of 1936 that

\footnotetext{
54 Ibid.

55 Ibid.

56 Ibid.

57 Ibid., 13.
} 
placed Black Cape elites with qualified franchise on separate voter rolls and forced them to accept indirect parliamentary representation. ${ }^{58}$

Black South Africans, oppressed by the implementation of the aforementioned segregationist legislation, acutely experienced the dehumanizing effects of the establishment of an early "Color Line."59 The nature of these experiences and the disillusionment it caused South Africans during the previously hopeful post-war period created an environment that craved the Black liberation message at the core of the Garvey Movement. The spread of Garveyism to South Africa, although complex and multi-faceted in nature, can be linked to three specific groups with origins in, and ties to, North America. Crucial to the spread of Garvey's ideology to South Africa were the American Jubilee Singers, West Indian laborers and mariners, and the AME Church.

While American Blacks were historically linked to South Africa through commercial maritime ventures as early as the eighteenth century, one of South Africa's first significant experiences with African Americans occurred in 1862 when the Confederate ship Alabama arrived in Cape Town with a cargo of Black slaves. In The American's Are Coming! historian Robert Vinson wrote of this experience: "The slaves performed minstrel shows for white South Africans sympathetic to the Confederate cause and bitter about Britain's ending of slavery in the Cape Colony; such shows began in the United States in the late 1820s, and they featured white performers in Blackface caricaturing enslaved and free Blacks....Blackface minstrelsy continued

\footnotetext{
58 Johan de Waal, "Constitutional Law," in Introduction to the Law of South Africa, eds. C.G. Van der Merwe and J.E. Du Plessis (Alphen aan den Rijn: Kluwer Law International, 2004), 57.

${ }^{59}$ W.E.B. Du Bois, The Souls of Black Folks (Mineola: Dover Publications, 2012), 9. W.E.B. Du Bois" "Color Line" refers to the "...relation[s] of the darker to the lighter races of men in Asia and Africa, in America and the islands of the sea." Du Bois continues to put the "Color Line" in territorial terms, describing it as a physical division in most cities, countries, or towns, that divides ninety percent of the black population with ninety percent of the white population. The Color Line, in essence is the systematic physical and spatial segregation of the races in a given community.
} 
to circulate negative images of Black Americans in South Africa." ${ }^{60}$ Such shows in South Africa used common American characters and tropes, like Jim Crow and Zip Coon, to re-affirm negative stereotypes about both Africans and American Blacks. These performances were successful in spreading these negative caricatures of Blacks throughout South Africa. However, the relationship between African Americans and black South Africans underwent a fundamental shift in the 1890s with the arrival of the Virginia Jubilee Singers in Cape Town. ${ }^{61}$

Orpheus McAdoo, a former Fisk Jubilee Singer, founded the Virginia Jubilee Singers in 1889 at Hampton Institute in Virginia. The Virginia Jubilee Singers modeled themselves after their Fisk University forerunners and employed biblical imagery, dance, and spiritual songs as a way to critique the racism and horrors of the American South in coded language understood primarily by oppressed Blacks. ${ }^{62}$ The Virginia Jubilee Singers partook in two separate tours of South Africa from 1890 to 1892 and 1895 to 1898 . Counter to the negative anti-Black imagery circulated by the minstrel shows of the previous three decades, the Virginia Jubilee Singers represented the epitome of Booker T. Washington's Up From Slavery. ${ }^{63}$ Rather than displaying the lazy, lustful, and menacing characteristics popularized by caricatures like Jim Crow, the Virginia Jubilee Singers instead represented the possibilities for Black South Africans if they were to follow a program of education similar to that which was provided at the Hampton Institute. Whites understood the achievements of the Virginia Jubilee Singers as a sign of hope that, with time and education, Black South Africans could become civilized like their American

\footnotetext{
${ }^{60}$ Vinson, The Americans Are Coming!, 14.

61 Ibid., 14-15.

${ }^{62}$ Paul Oliver, "Jubilee Singers," in Continuum Encyclopedia of Popular Music in the World, Volume II: Performance and Production, eds. John Shepherd, et al. (London: A\&C Black, 2003), 34-36.

${ }^{63}$ Vinson, The Americans Are Coming!, 13. See also Booker T. Washington, Up From Slavery: An Autobiography (New York: Doubleday, 1907).
} 
counterparts. Black South Africans viewed the successes of the Singers and the "honorary white" status that they received from the South African government quite differently. ${ }^{64}$

In 1896, in the middle of the Virginia Jubilee Singers second tour of South Africa, the AME Church accepted the Ethiopian Independent Church of South Africa as its fourteenth district. ${ }^{65}$ The AME Church was founded in Philadelphia, Pennsylvania in 1816 and preached a Black liberation theology that advocated for the political, social, economic, and spiritual liberation of African Americans. ${ }^{66}$ The interaction between the American members of the church and their new South African counterparts centered on the concept of "Providential Design." "Providential Design" emphasized the idea that diasporic Blacks, who through their enslavement came into contact with Western education and Christianity, would return to Africa and play a key role in civilizing and redeeming the continent. Henry McNeal Turner, a key figure in the founding of the AME Church in South Africa, supported this idea wholeheartedly. ${ }^{67}$ In 1883 he wrote, "I do not believe that American slavery was a divine institution, but I do believe it was a providential institution and that God intends to make it the primal factor in the civilization and Christianization of that dark continent. ${ }^{" 68}$ Pastors and Bishops preached this concept in the AME

\footnotetext{
${ }^{64}$ Veit Erlmann, “'A Feeling of Prejudice.' Orpheus M. McAdoo and the Virginia Jubilee Singers in South Africa, 1890-1898," Journal of South African Studies 14, No. 3 (April, 1988): 332-336; "Honorary whites" is a term used to describe African Americans in South Africa during this period. This designation meant that blacks received most of the privileges experienced by white South Africans during their time in the country.

${ }^{65}$ Daryl M. Balia, Black Methodists and White Supremacy in South Africa (Durban: Madiba Publications, 1991), $75-$ 78. The Ethiopian Independent Church of South Africa emerged in 1892 when Wesleyan minister Mangena Maake Mokone broke away from the church after he became disaffected by the heavily entrenched segregation of the church's clergy. The Ethiopian movement preached an early manifestation of Garvey's concept of "African for Africans" and were openly anticolonial in their messaging. Mokone was eventually introduced to the AME Church by Kate and Charlotte Maneye, two of his relatives studying at Wilberforce University. For more on Mokone and the AME Church, see pages 246 through 250 in this dissertation.

${ }^{66}$ See Campbell, Songs of Zion, 32-63 for a more detailed chronology of the emergence of the AME Church in Philadelphia, Pennsylvania in the 1800s.

${ }^{67}$ Henry McNeal Turner was a preacher and activist in the United States between 1834 and 1915. Following the institution of Jim Crow laws in the American South, Turner more actively promoted the idea of the "Back to Africa" movement and saw African Americans as civilizing agents in this process.

${ }^{68}$ Henry McNeal Turner, "The African Question,” Christian Recorder, 22 February 1883.
} 
Churches of South Africa and Black South Africans projected the Virginia Jubilee Singers, and African Americans more broadly, into this role of liberator and civilizer.

This ideology of Black excellence, racial pride, and liberation from white oppression cultivated an environment primed for the arrival of Garveyism and the UNIA in the 1920s. Garvey and the Black Americans that espoused and transmitted his message, much like the Virginia Jubilee Singers, represented the "American liberators" that had been prophetically foretold in the teachings of the AME Church. UNIA writings and publications used this Biblical and African imagery as a way to convey the message that their organization and members intended to return to Africa and liberate the continent. In 1920, the UNIA adopted "The Universal Ethiopian Anthem" as "the anthem of the negro race" because of its use of this imagery. An excerpt from this poem reads:

Ethiopia, though land of our fathers, Thou land where the gods loved to be, As storm cloud at night suddenly gathers Our armies come rushing to thee. We must in the fight be victorious When words are thrust outward to gleam; For us will the vict'ry be glorious When led by the red, black and green. Advance, Advance to victory, Let Africa be free.... J Jehovah, thou God of the ages Grant unto our sons that lead The wisdom Thou gave to Thy sages When Israel was sore in need. Thy voice thro' the dim past has spoken, Ethiopia shall stretch forth her hand, By Thee shall all fetters be broken, and Heav'n bless our dear fatherland.... ${ }^{69}$

Garvey would likewise use this language in his speeches and publications. On 14 August 1923, during discussions about sending a representative to the League of Nations, he wrote "Let us work and pray for the hastening of the day when 'Ethiopia shall stretch forth her hand unto God' and our race be lifted from the mire of prejudice and injustice to the realm of freedom and true liberty." $" 70$

\footnotetext{
${ }^{69}$ Cary D. Wintz, African American Political Thought, 1890-1930: Washington, Du Bois, Garvey, and Randolph (New York: Routledge, 2015), 213-214.

70 "Sending Representative to League of Nations, 14 August 1923," in The Philosophy and Opinions of Marcus Garvey, ed. Amy Jacques Garvey, 225.
} 
In addition to the contributions of African Americans and their organizations in the United States, the migration of West Indians to South Africa in the early twentieth century also contributed significantly to the rapid spread of Garveyism in Cape Town. American Blacks, and West Indians in particular, had a lengthy history of association with the commercial maritime industry and some estimates suggest that by 1850 nearly 50 percent of all American seamen were Black. The poverty and limited opportunities that accompanied the post-emancipation period in the Caribbean, as well as the economic depression in the sugar industry, forced many West Indians to use migration as a "mechanism of adaptation" and "a symbolic expression of new freedom." ${ }^{71}$ Already proficient in maritime skills, many of these West Indians used the Atlantic trade routes to travel to South America, Africa, and Europe in search of new employment opportunities. These West Indians were often more educated and in possession of more commercial skills than Blacks in other parts of the world. This helped them secure jobs more easily in port towns and cities. ${ }^{72}$

A strong West Indian/Afro-Caribbean community formed in Cape Town as a result of the aforementioned migrations. Alan G. Cobley argued in his article "Far From Home" that "Although a West Indian presence was established in all major ports in southern Africa from Windhoek to Durban, and in the interior as far afield as Bloemfontein, Johannesburg, Kimberley, and Basutoland, the vast majority of West Indians were always to be found in the Cape Colony, and particularly in the great maritime crossroads of Cape Town." ${ }^{93}$ In agreement with Cobley, Robert Vinson contended that most of the West Indians in the Cape "came to the region as

\footnotetext{
${ }^{71}$ Alan Gregor Cobley, "'Far From Home:' The Origins and Significance of the Afro-Caribbean Community in South Africa to 1930," Journal of Southern African Studies 18, No. 2 (June, 1992): 352-353.

${ }^{72}$ Stephen Haber, Political Institutions and Economic Growth in Latin America: Essays in Policy, History, and Political Economy (Palo Alto: Hoover Press, 2000), 174. Most seamen and sailors from the West Indies possessed a basic education. In Barbados elementary education was made compulsory in 1878, St. Lucia in 1889, and the Leeward Islands in 1890. Literacy rates also rose significantly in Jamaica, beginning in the 1890s.

73 Cobley, "'Far From Home'," 357.
} 
sailors who used their maritime skills and their kinship ties to link up with the Trinidadian dock labor recruiter James Wilson to secure readily available, higher paying stevedoring jobs on Cape Town's docks. ${ }^{.74}$ The further discovery of diamonds at Kimberley in 1868 and the discovery of Gold near Johannesburg in 1886 provided a significant financial incentive for West Indians to flock to South Africa.

One of the more attractive features of Cape Town for these West Indian sailors and laborers was that it offered new political possibilities that did not exist in the Caribbean or United States. "Cape Liberalism" was the defining political ideology in Cape Town from the early 1850 s to the early 1890 s. At the core of this ideology were concepts like the non-racial system of Cape Qualified Franchise and the extension of a policy of non-racialism in the social sphere. During this period the Cape's attorney general William Porter, and others like parliamentarian Saul Solomon, embraced an approach to racial relations that was distinct from the other South African provinces. ${ }^{75}$ Such opportunities, coupled with economic opportunities that did not exist in the Caribbean, made Cape Town a hub of diasporic West Indian life.

These newfound opportunities and optimism were short-lived for the West Indian community in Cape Town, however. In 1892, voting restrictions were increased and nonracial franchise was severely limited. Similarly, at the conclusion of World War I, white sailors and maritime workers returned to their jobs and West Indians were subsequently forced to seek other

\footnotetext{
${ }^{74}$ Vinson, "Sea Kaffirs," 284.

${ }^{75}$ Kevin Shillington, Encyclopedia of African History (New York: Routledge, 2013), 214-216. Cape Qualified Franchise and non-racial voter rolls first emerged in the province as part of its 1853 Cape Constitution. Central to this system was the idea that one's access to franchise could be limited by factors such as sex, education, and wealth, but not race. Attempts were made between 1907 and 1909 by Cape Prime Minister John Merriman to extend this system to the other provinces in South Africa, however he proved unsuccessful and non-racial franchise was restricted to the Cape after the 1910 union. African men enjoyed qualified franchise in the Cape until 1936, at which point the Representation of Natives Act of 1936 declared that three white members would be elected to represent the Cape's African population and that Blacks would be moved to separate and limited voter rolls.
} 
forms of employment. ${ }^{76}$ Although many were able to find work on the Cape Town docks, the hopes and aspirations that characterized West Indians post-migration experiences soon evaporated. Instead, restricted franchise rights, more limited economic opportunities, and a general decline in the health of the economy in the 1920s led to a sense of disillusionment akin to that which was experienced by African Americans in the United States during the same period. Whereas African Americans in the United States turned toward the artistic expression that defined the Harlem Renaissance, West Indians in South Africa embraced political and labor activism as a means to cope with their new reality.

Aiding the growth of effective labor organization and Black political consciousness was the arrival of many West Indian and Black veterans to Cape Town. The negative experiences of Black soldiers during World War I is well-documented. Conversely, the interaction of diasporic blacks and the destruction of the myth of white invincibility proved crucial in developing an organized and radical-nationalist sentiment among West Indian troops. ${ }^{77}$ Events like the Taranto Mutiny of December 1918 and the resultant formation of the Caribbean League only further solidified the burgeoning relationship between Black South Africans and Black West Indians that faced similarly oppressive white regimes. The interaction between these two communities led to the creation of a Black nationalist ideology steeped in working-class consciousness. ${ }^{78}$ In 1920 , South African professor and political activist D.D.T Jabavu noted:

\footnotetext{
${ }^{76}$ Richard Smith, Jamaican Volunteers in the First World War: Race, Masculinity and the Development of National Consciousness (Manchester: Manchester University Press, 2004), 152-156. Smith's work describes the difficult and frustrating conditions that Jamaican veterans experienced as they returned home from World War I. Many veterans expected new social and economic opportunities given their sacrifices in the War. Instead, many found employment difficult to obtain.

${ }^{77}$ For more information on the treatment of Black and African soldiers during the World Wars, see Gregory Mann, Native Sons: West African Veterans and France in the Twentieth Century (Durham: Duke University Press, 2006) and Chad L. Williams, Torchbearers of Democracy: African American Soldiers in the World War I Era (Chapel Hill: University of North Carolina Press, 2010).

${ }^{78}$ W.F. Elkins, "A Source of Black Nationalism in the Caribbean: The Revolt of the British West Indies Regiment at Taranto Italy," Science \& Society 34, No. 1 (Spring, 1970): 99-103. The Taranto Mutiny, which lasted four days in
} 
[T] he Native Labor Contingent that did work in France during the Great War has imported into the country a new sense of racial unity and amity quite unknown heretofore among our Bantu races. Common hardships in a common camp have brought them into close relation...some of their white officers, including two chaplains...made themselves notorious by their harsh treatment and slanderous repression of them....All this was carefully noted and published in [South Africa] when they returned. The result is that there is among the diversified Bantu tribes of this land a tendency towards complete mutual respect and love founded upon the unhealthy basis of an anti-white sentiment. They thus provide plastic material for all sorts of leaders and agitators who may use it for good or ill. ${ }^{79}$

The post-war disillusionment experienced by these returning veterans and forcibly unemployed West Indian sailors, combined with the Black nationalist working-class consciousness that they imported, facilitated an unprecedented organizing effort among Cape Town's Afro-Caribbean community. Clements Kadalie, a Malawian schoolteacher, founded the ICU in Cape Town in 1919. The following year a massive strike of 70,000 Black miners and a subsequent strike of Black dockworkers occurred. The ICU proved instrumental in negotiating the wage dispute with Cape Town's dock employers and this success led to a rise in the popularity of the ICU. An article in the Times (London) claimed that "The genuine grievances of the South African Natives provided the hotbed in which the ICU flourished. Rack-rented Natives in the urban locations, underpaid Natives in Government employ, badly treated Natives on

1918, was started by a West Indian regiment and resulted in the arrest and trial of 60 British West Indian soldiers. As a result of the mutiny, nearly 60 Non-Commissioned Officers (NCOs) met on 17 December 1918 to discuss issues of Black rights and self-determination in the West Indies and the Caribbean League was formed to further these goals. The Mutiny served as a cultural rallying cry for diasporic West Indian migrants as they spread across the globe in the post-war years and faced harsh treatment by the white governments in the Americas and South Africa.

${ }^{79}$ Gideon-Cyrus Makau Mutiso and S.W. Rohio, Readings in African Political Thought (Portsmouth: Heinemann, 1975), 91. D.D.T. Jabavu was a Black South African politician, professor, and activist that struggled against the South African government's segregationist policies. He was a founding member of the University of Fort Hare in 1916 where he served as a professor until 1944. He also founded two teachers' organizations, the Cape African Teachers' Association and the South African Native Teachers' Federation and participated in political campaigns that centered on the protection of Black voting rights in South Africa. The above quote is from Jabavu's paper "Native Unrest," which he read before the Natal Missionary Conference in July 1920. Jabavu's paper discussed the mounting anticolonial and anti-white sentiments in South Africa and warned that "it [would] not be very long before the whole white community must deal with a situation overwhelmingly beyond their control." 
European farms, flocked to join the movement." ${ }^{80}$ The ICU spread rapidly in South Africa, establishing branches in East London, Port Elizabeth, Orange Free State, Natal, and the eastern Transvaal. By 1927, membership in the ICU had reached a peak of $100,000 .{ }^{81}$

The lack of consistent leadership and organization within the ICU led to a constant state of ideological change and reformulation. In the 1920s, the ICU focused on traditional trade union activities like workers strikes and union organizing. For a time, the ICU flirted with a Communist ideology and became involved with rural South African workers and their grievances against white employers. Owing to its ethnically and racially diverse base, the ICU proved ideologically fluid during its most influential years. Although the Port Elizabeth Massacre of 1920 is most directly linked with the radical shift in the ICU ideology, the ICU served as an organization focused on Black political, economic, and social justice from its inception. ${ }^{82}$ The state response to the activities of the ICU were fluid over time. In some cases, politicians like J.B.M. Hertzog sought to cultivate friendly relations with the ICU and negotiate with their leadership because of their political influence in the Cape until the late 1930s. ${ }^{83}$ However, as ICU membership crested 100,000 in the late 1920s, the South African government passed legislation to limit the influence of the ICU and hinder its ability to function. The Native

\footnotetext{
${ }^{80}$ This excerpt from the Times was quoted in Denis MacShane, Martin Plaut, and David Ward. Power!: Black Workers, Their Unions and the Struggle for Freedom in South Africa (Boston: South End Press, 1984), 26. ${ }^{81}$ Ibid.

${ }^{82}$ William Beinart and Colin Bundy, Hidden Struggles in Rural South Africa: Politics and Popular Movements in the Transkei and Eastern Cape, 1890-1930 (Berkeley: University of California Press, 1987), 275-280. The Port Elizabeth Massacre, in part, occurred as a result of ICU activities in South Africa. The massacre occurred on 23 October 1920 when demonstrations began outside of Port Elizabeth's Baakens Street Police Station, where protestors demanded the release of union leader Samuel Masabalala. Masabalala had recently established an ICU branch in Port Elizabeth and was seen by government authorities as an agitator. As a result of the demonstrations, police opened fire on the crowd and killed 24 of the demonstrators.

${ }^{83}$ W.E.B. Du Bois, Black Folk Then and Now: An Essay in the History and Sociology of the Negro Race, ed. Henry Louis Gates, Jr., (New York: Oxford University Press, 2014), 190-192. The author noted that "Hertzog himself appealed to the ICU to rally the voters of the Cape behind him in his fight against Smuts in 1924." However, following Hertzog's victory and the increasing alarm of white settlers at the political activities of the ICU, Hertzog's position on the ICU changed in the late-1920s.
} 
Administration Act of 1927 effectively made it "an offense to disseminate "certain doctrines among natives, to say or write anything intended to promote hostility between the races." $" 84$ Likewise, the Riotous Assemblies Act of 1930 targeted organizations like the ICU, the African National Congress (ANC), and CPSA, that the government feared would inflame hostilities between the races. Such "government antagonism" led to the eventual "disintegration" of the ICU in the late 1920 s. $^{85}$

While the ICU thrived in 1920s South Africa, the UNIA also flourished in this environment of newly-emergent Black nationalism and working-class consciousness that the ICU's activities created in Cape Town. Garveyism and the UNIA followed the same transAtlantic shipping routes that carried the Virginia Jubilee Singers and politically active West Indians to South Africa in the 1920s. The UNIA's Black Star Line helped forge these links and facilitated the exchange of people, culture, commercial goods, and knowledge from the Americas to South Africa. Black American sailors carried with them copies of The Negro World, the official information and propaganda organ of the UNIA, and freely disseminated Garveyite ideas to the South African masses without fear of government reprisal. ${ }^{86}$ James Ghazu, a sailor and leader of the UNIA in Cape Town, highlighted the importance of Garveyism in South Africa when he wrote: "Garveyism is a self-protecting system among the blacks to promote the race socially, economically and in the true form which God the creator of all races on this earth meant. The Negro desires to share in every possible thing that other races enjoy and...is just as fit to shape its own destiny as other races are." 87

\footnotetext{
${ }^{84}$ William Minter, King Solomon's Mines Revisited: Western Interests and the Burdened History of Southern Africa (New York: Basic Books, Inc., 1988), 61.

${ }^{85}$ Sonia Bendix, Industrial Relations in South Africa (Cape Town: Juta and Company Publishing, 1989), 60.

${ }^{86}$ Campbell, Songs of Zion, 301-303.

${ }^{87}$ Negro World, 20 November 1926.
} 
The UNIA grew rapidly in Cape Town and the rest of South Africa despite the South African government's fears of a transnational organization contributing to the "Black peril." By 1921, the UNIA founded four separate branches in Cape Town alone. In the following five years, the UNIA reached its peak in South Africa and established at least seven separate UNIA branches by 1926. In 1922 the UNIA established a branch in Claremont, Cape Town. In 1923, five more branches were established in South Africa and in 1924 branches were also established in East London, Pretoria, and Johannesburg. ${ }^{88}$ The South African branches of the UNIA drew its membership across diverse ethnicities and among the various workers in South Africa. However, despite its mass appeal, the UNIA had its largest impact among the trade unionists and manual laborers.

As the UNIA spread across South Africa and among the working-class Black nationalists of the Cape, a close relationship developed between the UNIA and the ICU. The nature of this close relationship is best illuminated through a brief examination of the previously discussed negotiations between the ICU leadership and the dock employers of Cape Town. In August 1920, representatives of the ICU met with the Cape dock employers in an effort to negotiate a wage dispute. Among the ICU leadership that brokered the meeting were Clements Kadalie, J.G. Gumbs, and S.M. Bennet Ncwana. ${ }^{89}$ This represented the first face-to-face meeting between the ICU and Cape Town employers, leading to an increase in membership in the ICU and a rise in its popularity among Black workers..$^{90}$ Membership peaked at over 100,000 members in 1927, drawn mostly from union workers, clergy, traders, and emerging Black political activists. Of the

\footnotetext{
${ }^{88}$ Tony Martin, The Pan-African Connection: From Slavery to Garvey and Beyond (Fitchburg: The Majority Press, 1984), 134.

${ }^{89}$ J.G. Gumbs was a West Indian shipwright, founding member of the ICU in Cape Town, and an ICU office holder. S.M. Bennet Ncwana served many roles in South African politics and society. He was a leader of the ICU, a journalist, trade unionist, and Garveyite. Scholars frequently reference his fluid political identity and his ability to maneuver between these various, and at times competing, roles.

${ }^{90}$ Pirio, "The Role of Garveyism," 14.
} 
three ICU leaders that met with the Cape dock employers, all three were either members of the UNIA or active supporters of the Garveyist agenda in Cape Town.

Clements Kadalie, in particular, had much in common with Marcus Garvey and modeled his union activities on the UNIA. Kadalie admired Garvey's personal charisma and message of Black liberation so much that in a letter to Ncwana, he wrote "My essential object is to be the great African Marcus Garvey and I don't mind of how much I shall pay for the education.." ${ }^{91} \mathrm{He}$ founded the ICU as a mechanism through which Black laborers filed grievances against their employers and organized to effect change in wages and working conditions. Furthermore, he founded The Blackman in Cape Town, a newspaper that simultaneously functioned as the official organ of the ICU and as a conduit for Garvey's propaganda. The Blackman so frequently reprinted stories from The Negro World, Crisis, and The Messenger that Marcus Garvey once described The Blackman as "The Negro World of South Africa."92 The Blackman circulated among the dock workers and laborers of Cape Town and especially among the members of the ICU. Through Kadalie's leadership and publishing efforts the Garveyite ideology was disseminated through the ranks and became a key feature of the labor movement in 1920s South Africa.

S.M. Bennet Ncwana, the other ICU negotiator present at the August 1920 meeting, was also heavily involved in the UNIA in the 1920s. Ncwana's involvement in the ICU saw him rise to the position of "Chairman of Propaganda" and tasked with spreading the message of solidarity and activism to the Black worker. ${ }^{93}$ In 1920 Ncwana became more directly involved in the UNIA

\footnotetext{
${ }^{91}$ Khwezi Mkhize, "Empire Unbound: Imperial Citizenship, Race and Diaspora in the Making of South Africa," (PhD Diss., University of Pennsylvania, 2015), 135.

${ }^{92}$ For a complete understanding of Kadalie's life and involvement in the ICU, see Clements Kadalie, My Life and the ICU: The Autobiography of a Black Trade Unionist in South Africa (London: Cass, 1970).

${ }^{93}$ Emmett, Popular Resistance, 136.
} 
and Garveyist movement. That same year he helped Kadalie create and publish The Blackman. Ncwana often penned articles for the paper that clearly had a Garveyist influence and also began to travel outside of Cape Town and meet with receptive Blacks in other parts of southern Africa to spread the work of the UNIA and ICU. ${ }^{94}$

The activities of the UNIA and ICU became intertwined in South Africa. Historian Gregory Pirio argued that the ICU essentially became the "labor wing of the UNIA/Garveyite Movement in South Africa." ${ }^{" 95}$ The leadership of the ICU in South Africa, as evidenced above, was clearly influenced by Garveyite publications and ideology. In most cases, the language and message of the two organizations overlapped, making them almost indistinguishable from one another. Thus, in 1920s South Africa, the UNIA effectively infiltrated and permeated the ranks of the ICU and its members, leading to the formation of a distinctly Black nationalist and working-class consciousness among the masses. This ideology did not remain confined to Cape Town and South Africa. In the 1920s the UNIA radiated outward from South Africa and established branches in numerous states in southern Africa. One of the UNIA's early successes occurred in South West Africa in the early 1920s.

\section{The UNIA Arrives in South West Africa: Racial Unity and Subnationalism in the Police Zone}

The ICU, which flourished first among the West Indian dockworkers in South Africa and then spread to the other parts of society, ultimately served as the primary vehicle through which Garveyism and the UNIA took root in South West Africa. West Indian and West African seamen, similar to the West Indians that established vibrant and politically-active communities in Cape Town, worked in South West African port cities like Lüderitz, Swakopmund, and Walvis

\footnotetext{
${ }^{94}$ Vinson, The Americans Are Coming!, 98-99
}

${ }^{95}$ Pirio, "The Role of Garveyism," 18. 
Bay. These West Indians and West Africans were well aware of Garveyism, with many having read copies of The Negro World or encountered UNIA members and propaganda in North America or West Africa. ${ }^{96}$ These dockworkers experienced post-war disillusionment and unfavorable working conditions similar to those that arose in the South African ports. Thus, it is unsurprising that agents of the Cape Town ICU, who were also heavily involved in Garvey's movement, spread the UNIA's ideology in the South West African port cities.

The ICU established one of its first branches in South West Africa in December 1920 through the efforts of James La Guma and John de Clue, a member of the UNIA. ${ }^{97}$ Fritz Headley, a West Indian member of the Lüderitz ICU, proceeded the following April to submit an application to the Magistrate of Lüderitz to establish a Lüderitz branch of the UNIA. Headley wrote that the main purpose of creating Branch 294 in Lüderitz was "to establish confraternity among the race, to promote pride and love, to reclaim the fallen and administer and assist the need[y] in the development of the NEGRO RACE." 98 Headley claimed to have a membership roll consisting of 125 people at the time of application and within a month he secured a letter from Marcus Garvey that certified that "Mr. Davis Adams of Lüderitz SWA Division \#294 has been given authority to solicit Convention Funds for the Parent Body of the Universal Negro Improvement Association." 99 Ncwana, the president of the Cape Town division of the UNIA travelled to Lüderitz in June of 1921 and helped facilitate the establishment of this branch. ${ }^{100}$

\footnotetext{
${ }^{96}$ Lodge, Resistance and Ideology, 20-23.

${ }^{97}$ Roger Field, Alex la Guma: A Literary \& Political Biography (New York: Boydell and Brewer, Ltd., 2010), 1315. La Guma had developed a relationship with Clements Kadalie during a strike in the South West African diamond fields in 1910 and this likely contributed to his knowledge of, and participation in, the ICU. Upon its founding, John de Clue served as the Chairman of the ICU's Lüderitz branch and William Adriaanse served as its Secretary.

${ }^{98}$ Fritz Headley to the Magistrate of Lüderitz, 26 April 1921, NAN: SWAA/A50/32.

${ }^{99}$ Marcus Garvey to 'Whom it May Concern,' 5 May 1921, NAN: SWAA/A50/32.

${ }^{100}$ Pirio, "The Role of Garveyism," 4. Ncwana was limited to a fourteen-day stay in Lüderitz because he did not possess the proper paperwork to appease officials as to the purpose of his visit. Ncwana would return to Lüderitz in
} 
Although South Africans facilitated and aided in the establishment of the first UNIA branches in South West Africa, Fritz Headley became the driving force behind the spread of the UNIA and ICU in the territory between 1921 and 1922. He was a West Indian born in Barbados in 1870 and came to Cape Town in 1900 . He served as a cook at the Arthur Seat Hotel and the Kimberley Hospital before becoming a general laborer at Cape Town's docks. In 1909, Headley travelled to Lüderitz as a contract laborer with Metje, Siegler, and Bause until the outbreak of the First World War, at which point he was captured by German forces as a prisoner of war and sent to Namutoni. Upon his release by Union troops, Headley returned to Lüderitz where he found employment with the South African Railway and Harbours Union until 1922. Administrators noted that Headley possessed "sober habits" and that he "[was] much thought of [amongst the Natives]...[and] he demands respect from his fellow Natives."101 Despite statements from his former employer that "he could not say anything detrimental about Headley," administrators still referred to him as an "agitator," especially "amongst the local fishermen."102

Non-indigenous Blacks, like Headley, possessed a significant amount of influence and control in the UNIA during its first year in the territory. The Officer-in-Charge of Native Affairs R.S. Cope recognized the influence of non-Namibian actors in the UNIA as early as September 1921 when he noted that "[The UNIA] does not appear to confine its activities to any particular tribe or sect, but it seems that Kroo Boys are amongst its most active members..."103 Cope reaffirmed this point in the coming months when he wrote, "The most active workers here are

\footnotetext{
July, 1922 under the pseudonym W.O. Jackson to meet with Fritz Headley and J. de Clue on UNIA business and as a way to "revive life" into the ICU and UNIA in South West Africa.

${ }^{101}$ D.C.T. Officer's minute C.27, 10 October 1932, NAN: SWAA/CC/77. The D.C.T. Officer's minute also mentioned that Headley was "convicted by the Magistrate [of] Lüderitz on [19 March 1920] for assault common and was fined 2 pounds or 14 days I.H.L."

${ }^{102}$ Ibid.

${ }^{103}$ R.S. Cope, Officer-in-Charge of Native Affairs, Windhoek, to the Officer-in-Charge of Native Affairs, Lüderitz, 12 September 1921, NAN: SWAA/A50/32. Kroo-Boys was a term used by the SWAA to refer to dockworkers of West African descent.
} 
natives from Monrovia, Liberia, and Togoland and although they are not in confidence of the local natives, the latter are freely joining the society..."104 The initial positions of leadership held by West Indians and West Africans in these formative years is unsurprising given the earlier extensive discussion of the UNIA's historical links to West Africa, migratory West Indian communities, and mobile dockworkers.

The labor union experience of West Indians and West Africans lent itself to effective organizing within the UNIA and allowed for the rapid spread of the organization to urban areas in South West Africa with sizable non-indigenous Black populations. Headley established the Lüderitz branch in June 1921. In October 1921 the UNIA began operations in Windhoek and boasted a "local membership of 311 persons, comprising all native and coloured nationalities, found here, both male and female" by December of that year. ${ }^{105}$ J.D. Abraham, a Cameroonian businessman, also applied to establish a UNIA branch in Swakopmund in April $1922 .{ }^{106}$ Within a year, the UNIA established branches in three of the major population centers in the Police Zone. Copies of the Negro World, which were brought to the territory by West Indian maritime workers, circulated throughout the territory. The Negro World facilitated the spread of Garveyist ideas in the Locations and brought the ideology of the movement to the urban masses. ${ }^{107}$ Other UNIA documents and circulars made their way more slowly to the rural areas by means of

\footnotetext{
${ }^{104}$ R.S. Cope to J.F. Herbst, Secretary for South West Africa, 21 December 1921, NAN: SWAA/A50/32.

${ }^{105}$ Ibid. In January and February of 1922, Aaron Mungunda wrote on behalf of the Windhoek branch to the Mayorin-Council of Windhoek requesting permission to "erect a suitable hall for conducting our meetings."

${ }^{106}$ J.D. Abraham to Magistrate, Swakopmund, 14 April 1922, NAN: SWAA/A50/32. J.D. Abraham argued that the existence of branches in Lüderitz and Windhoek served as enough evidence that the establishment of a branch in Swakopmund would not be troublesome and served only to benefit the local African population.

${ }^{107}$ Secretary for South West Africa to Secretary for Native Affairs, Pretoria. Confidential, 23 December 1921, NAN: SWAA/A50/32. Examples of the Negro World circulating in South West Africa appear as early as 1919. However, references appear much more frequently beginning in December 1921. The publication is frequently referred to by government administrators as a "propaganda organ" of the UNIA and descriptions are often accompanied by concerns that "backward" natives may use the ideology in the publication to cause trouble in the territory for the white populations.
} 
sympathetic actors. For example, W. Scotland, the manager of Liebig's Extract Meat Company in Windhoek, reported to the Secretary of South West Africa that a "Togo boy in the Location office in Windhoek" was the "principal active agent" in spreading these circulars in the city and nearby rural areas. ${ }^{108}$ These ideas spread quickly in the Police Zone and found an audience that was receptive to the UNIA's message.

Tony Emmett argued that the early West Indian and West African leadership of the territory's UNIA branches found it difficult to understand the conditions faced by Namibians throughout South West Africa and focused heavily on the concerns of urban bourgeoisie Black traders, consequently limiting the appeal and spread of the UNIA to the Namibian population. ${ }^{109}$ However, documentary evidence suggests that Namibians embraced the UNIA's message, at least in part, because UNIA leadership and local political leaders were able to connect the organization's ideological underpinnings effectively with the dire political and socioeconomic situation faced by Namibians under two separate colonial regimes. The message that the UNIA disseminated to Namibians and colonial officials alike was that the UNIA was a "humanitarian, charitable, education[al], social, friendly, instructive, and expansive society...founded by [people] desiring to work for the general uplift of the Negro people the world over." ${ }^{110}$ In its early stages, the social welfare message resounded most significantly with Namibians in the Police Zone. These Namibians experienced years of insufficient pay, poor healthcare, a burdensome labor system, and expropriation from ancestral and fertile lands. The eventual

\footnotetext{
${ }^{108}$ W. Scotland, Manager Liebig's Extract Meat Company, Ltd., to the Secretary of South West Africa, Swakopmund, 20 January 1922, NAN: SWAA/A50/32.

${ }^{109}$ Emmett, Popular Resistance, 141-143.

${ }^{110}$ Fitz Herbert Headley to A.C. Warner, Resident Magistrate, Lüderitz, 27 January 1922, NAN: Magistrate Lüderitz (Hereafter, LLU)/4/3/1/1, Ref. C. 14.
} 
embrace of a transnational organization like the UNIA was a calculated response to the limited social and economic opportunities presented to Namibians under colonial rule.

In particular, the UNIA's willingness to provide its members with life insurance, or a “[sick fund]," proved highly popular among Namibians in the Police Zone. The harsh and unforgiving nature of life under German and South African rule provided little assurance that one's family could continue to survive if the primary income earner proved unable to work. R.S. Cope highlighted the importance of the sick fund in recruiting UNIA members, arguing that "The main inducement for natives to become members, is the promise of assistance in time of sickness, funeral expenses in case of death, and an assistance to relatives of deceased members." 111 Where the state and private industry failed to provide any type of social safety net in the event of injury or illness, the UNIA provided a viable alternative and tangible benefits for marginalized Namibians.

The UNIA also drew on Namibian experiences with land expropriation and over-taxation under both the German and South African government as a means to attract followers. Headley's letter to the Negro World in January 1922 referenced the inequitable treatment of Namibians under the segregationist policies of its mandatory power. High taxes on livestock served as a rallying cry for the UNIA in South West Africa and criticism of the transfer of arable land into the hands of white farmers further stoked support for the UNIA in the Police Zone. ${ }^{112}$ In each case that Headley made to the international community and those Namibians reading the

\footnotetext{
${ }^{111}$ R.S. Cope to J.F. Herbst, 21 December 1921, NAN: SWAA/A50/32. The UNIA financed the "sick fund" through the issuance of a "Monthly Death Tax" equal to 1/6. A Sick Benefits book was kept, and evidence suggests that, at least in one branch, "over 37 pounds [were] paid to members for medical, etc. treatment to date."

112 Fitz Herbert Headley to the Negro World, 3 January 1922, NAN: SWAA/A50/32.
} 
circulating copies of the Negro World in the territory, he positioned the UNIA as the primary vehicle for the "salvation" of the Namibian people. ${ }^{113}$

Over time, the scope of the UNIA's message broadened to include more general claims of complete territorial independence and freedom for South West Africa and its residents. Namibian leaders were well aware of Garvey and the UNIA's earlier attempts to lay claim to South West Africa at Versailles in 1919. Headley actively worked to promote this message and its spread within the territory. In the aforementioned letter to the Negro World, Headley wrote that "our fatherland must be freed from the white man's rule, for his reign is simply stifling the talents and progressiveness of our people." ${ }^{114}$ Later that year, in his correspondence with Joseph Hailand on the establishment of a UNIA branch in Usakos, Headley again positioned the UNIA as an organization "working for [South West Africans'] entire freedom and emancipation...for the better conditioning of [South West Africans] as human beings and not as beasts of the fields as we are classed by the other races of mankind." 115

The concept of the UNIA as an organization fighting for the freedom and independence of Namibians reached its pinnacle in July 1922 when Garvey and the UNIA petitioned the League of Nations to assume control over the former German colonies in East and South Africa. Garvey and the UNIA stated that they were "prepared to assume the responsibility of developing [Africa]," and "[desired] to achieve a sympathetic, spiritual, educational, and industrial evangelization of our race in Africa." 116 The Negro World published news of this petition and it circulated throughout the urban locations in Windhoek. News of the petition was well-received

\footnotetext{
${ }^{113}$ Ibid.

${ }^{114}$ Ibid.

${ }^{115}$ F.H. Headley to Joseph Hailand in Usakos, 14 November 1922, NAN: SWAA/A50/32.

${ }^{116}$ Marcus Garvey to the League of Nations: Enclosure-Petition of the Universal Negro Improvement Association and African Communities League to the League of Nations, the Hague, 20 July 1922, NAN: SW AA/A50/32.
} 
in South West Africa and there was an increase in reports of concerning activities coming from whites throughout the Police Zone.

\section{The Rise of Herero Leadership in the UNIA and the Problem of Subnationalism, 1922-1924}

While Garvey's activities on the international political stage increased the association's popularity in the Police Zone, other domestic factors also contributed to the UNIA's rise in South West Africa. Scholars have attributed the successes of the UNIA in South West Africa to the mood of millenarianism enveloping the territory in the 1920s. As Emmett suggested in his paper "Popular Resistance," popular stories of the future arrival of an African American military liberation force appealed to Namibians' desire to see the removal of oppressive colonial rule and the introduction of a new, more liberal political order. The UNIA represented, for many, a new opportunity for African rule in a territory that was economically, politically, and socially damaged by decades of colonial rule. ${ }^{117}$ Likewise, as Pirio suggests in his paper "The Role of Garveysim," an emergent Black working-class nationalism appeared among the West Indian and West African communities in the territory and began, in earnest, to spread to some parts of the Namibian population. ${ }^{118}$ While new possibilities undoubtedly contributed to the UNIA's growth in the territory, the UNIA also served the important function of providing Namibians with an opportunity to reconstitute and re-establish previous sociopolitical and economic institutions. As the allocation of power in the South West African UNIA shifted from the control of nonindigenous Blacks to Namibians, this process of the reconstitution of precolonial sociopolitical institutions played out within the structure and power dynamics of the territory's UNIA branches. When the Herero seized control of the Windhoek branch of the UNIA in late 1922, the

${ }_{118}^{117}$ Emmett, "Popular Resistance," 9-11 and 20-24.

${ }^{118}$ Pirio, "The Role of Garveyism," 3 and 22-32. 
racial unity and Black nationalism discussed in Pirio's "The Role of Garveyism” faded and gave way to subnational resistance strategies that broke, largely, along pre-existing ethnopolitical lines. The leadership of each of these groups understood the role of the UNIA as a transnational resistance institution differently and developed distinct resistance strategies that appropriated the UNIA's organizational infrastructure to further subnational sociopolitical and economic goals.

Undoubtedly, the UNIA experienced its greatest success in South West Africa among the Herero. Robert Edgar argued that the success of the UNIA among the Herero could be attributed to the fact that "it brought together many strands of African thought in the mid 1920s: the linking of European Christianity and mission education with European rule, the attempt to construct alternative institutions for Africans, the desire to overthrow European rule and to control European wealth....and the search for new inspirational leaders who could offer innovative answers and solutions for the traumatic changes which were taking place within African society." 119 Also facilitating the rise of the UNIA among the Herero was the fact that they already possessed cultural institutions that were comparable in structure and function to those of the UNIA. In particular, the Otruppa movement's quasi-military structure and social welfare program were similar to that of the UNIA. These similarities eliminated some cultural obstacles that could have stunted the growth of the organization in the Police Zone and allowed it to flourish in the early 1920 s.

Participation in the UNIA became a logical conduit through which the Herero continued the re-establishment of their important sociopolitical institutions. The Otruppa movement's origins can be traced back to at least the early 1890s and reports of Herero "playing soldier" or mimicking German military practices. The trauma and cultural destruction exacted by the

${ }^{119}$ Robert Edgar, "Garveyism in Africa," 39. 
German military during the genocide in 1904 necessitated the restructuring and reconstitution of Herero identity and cultural practices. ${ }^{120}$ The Otruppa movement provided young Herero with a mechanism to cope with the "emasculating experiences of German colonialism" and an opportunity to "reclaim and renovate Herero manhood in its wake." 121

Performative masculinity, order, and mutual assistance were central to the Otruppa movement and its structure. Molly McCullers, when discussing the rise of the movement in the late 1910s and early 1920s, argued "[The Otruppa movement] recreated the security of military orderliness in a chaotic time through uniforms, ranks, and drilling." ${ }^{" 122}$ The use of military parades, uniforms, insignias, and ranks helped re-affirm the orderliness of the organization and solidified the masculine identity of the movement and newly-reimagined Herero cultural identity. Within this structure, Herero youths created "an alternative masculinity that blended German military aesthetics with aspects of pre-German Herero manhood." ${ }^{123}$ The Otruppa movement thrived and became highly active during the period of martial law and throughout the early 1920s.

The UNIA possessed many similar characteristics in its organizational structure. Much like the Otruppa movement, the various UNIA branches across the globe held parades, developed insignias, and bestowed its members with ranks that resembled a military structure. ${ }^{124}$

\footnotetext{
${ }^{120}$ Wolfgang Werner, “'Playing Soldiers:' The Truppenspieler Movement Among the Herero of Namibia, 1915 to ca. 1945," Journal of Southern African Studies 16, No. 3 (September, 1990): 483-486.

${ }^{121}$ Ibid., 482

${ }^{122}$ Molly McCullers, "The 'Truppenspieler Show'," 232.

${ }^{123}$ Ibid., 227.

${ }^{124}$ Barbara Bair, "True Women, Real Men: Gender, Ideology, and Social Roles in the Garvey Movement," in Gendered Domains: Rethinking Public and Private in Women's History-Essays from the Seventh Berkshire Conference on the History of Women, eds. Dorothy O. Helly and Susan M. Reverby (Ithaca: Cornell University Press, 1992), 158. Bair highlights the important role that the para-military activities of the UNIA's African Legions played in reifying masculine Black political power. Bair wrote, "The African Legions personified the prestige and purpose associated with independent Black manhood. They represented the ideas of power and dominance and the military might necessary to achieve and maintain Negro nationhood. Modeled on U.S. infantry protocol and regimentation.... They provided a dress military function within the UNIA, marching in UNIA parades, supplying bodyguard and crowd-control services in mass meetings, and adding to the pomp and ceremony associated with the
} 
The sale of the UNIA's red, green, and black pins became popular in South West Africa's urban locations, mirroring Otruppa receptions where ox-skin belts were given to soldiers. ${ }^{125}$ The UNIA, in its recruitment efforts, used the pageantry and masculinity of the association and adapted it to its South West African context to appeal to the Herero.

One of the best examples of the UNIA's appeals to masculinity as a recruiting tool appears in F.H. Headley's letter to Herero Headman Barnabas in $1922 .{ }^{126}$ Headley wrote to Barnabas that "in [the UNIA], and [the UNIA] alone, can we as men regain our National Manhood which we have been deprived of for generations before us." ${ }^{127}$ Headley continued to describe the oppressive and "vile" nature of white rule and advocated for "freedom and liberty before it is too late." 128 Clearly drawing on the destructive historical process of genocide and the subsequent emasculation of Herero men under German rule, Headley portrayed the UNIA as a vehicle through which the Herero could continue their process of performative masculinity. Furthermore, Headley closely linked the "[regaining] of National Manhood" with political and social liberation from white colonial rule, a concept that was already popular among the Herero. ${ }^{129}$

Clear connections also existed between the UNIA and the Otruppa's social welfare programs. In its role as a "benefit society," the Otruppa collected subscriptions from members

\footnotetext{
public appearance of UNIA officials - serving in each case as bodily symbols of the movement as a nation within a nation." Such activities and representation appealed to the Herero and aided the UNIAs growth in the Police Zone.

${ }^{125}$ Werner, "Playing Soldier," 482.

${ }^{126}$ Scholars have frequently referenced the importance of masculinity in the structure and presentation of the UNIA. Adam Fairclough, Better Days Coming: Black and Equality, 1890-2000 (London: Penguin Books, 2002) described the UNIA as "a male-dominated organization that exalted masculine values," and James M. Beeby, "Universal Negro Improvement Association," in Race and Racism in the United States: An Encyclopedia of the American Mosaic, eds. Cameron D. Lippard and Charles A. Gallagher, 1277-1279 (Santa Barbara: ABC-CLIO, 2014) argued that the UNIA "was rather masculine and somewhat sexist, though for its time, this was not unusual." Garvey himself lauded the masculine nature of the UNIA in a 1923 speech where he stated, "...we who make up the membership of the Universal Negro Improvement Association reflect the new manhood of the Negro."

${ }^{127}$ Fitz Headley to Mr. Barnabas, Herero Headman, 25 January 1922, NAN: SWAA/A50/32.

${ }^{128}$ Ibid.

${ }^{129}$ Ibid.
} 
for the purposes of "burying paupers, procuring cattle for slaughter on occasion of feasts....to support soldiers' widows, pay court fines, pay for funerals and generally support people in need." ${ }^{130}$ McCullers elaborated on the social aspects of the movement, arguing that "The organization provided Herero youths with a social network and mutual aid, essential qualities of military masculinity." ${ }^{131}$ Members claimed the troops were "designed to foster good fellowship and amusement" and to assist members financially. ${ }^{132}$ This assistance was critical for Herero youths who became detached from families during the genocide and faced social and financial uncertainty during the transition to a new colonial regime. ${ }^{133}$ Similarly, the UNIA's initial popularity in the territory was linked to the sick fund and monthly death tax. The UNIA funded these through the collection of subscriptions among members and claimed to ensure financial security for UNIA members' families in the wake of unforeseen tragedy or difficulty. ${ }^{134}$ As the Negro World and other UNIA circulars spread information about these programs, the movement grew, and more Herero members joined it.

A strong belief grew, among the Herero in particular, that not only could they gain access to these social welfare programs by joining the UNIA, but that Black Americans would inevitably assist in the liberation of Namibians from South African rule. Early graffiti appeared near Okahandja in April of 1922 that read, "This country is not yours, it is that of the Blacks of America and that is the Herero." ${ }^{\prime 35}$ The Herero prophets subsequently foretold of the American arrival after World War I and discussed the liberation of the Herero at the hands of the Americans and English. ${ }^{136}$ The prominent prophetic tradition within Herero culture increased

\footnotetext{
${ }^{130}$ Werner, "Playing Soldier," 484.

${ }^{131}$ McCullers, "The 'Truppenspieler Show'," 232.

132 Ibid.

${ }^{133}$ Ibid.

${ }^{134}$ C. Lewis Warner to Secretary for South West Africa, 20 March 1922, NAN: SWAA/A50/32.

135 Statement by Rev. August Kuhlmann, Rhenish Mission Society," 20 April 1922, NAN: SWAA/A396/13.

${ }^{136}$ Statement by August Kuhlmann to South West Africa," 11 October 1922, NAN: SWAA/A396/13.
} 
expectations of an American liberation force providing the Herero and other Namibians with guns, ammunition, boats, and airplanes. ${ }^{137}$ In some cases, the Herero and members of the Otruppa began the process of procuring guns, ammunition, and horses, while also attending UNIA meetings at night in the "veld."138

The growth of the UNIA among the Herero soon expanded outside of urban Windhoek as Garveyite agents Aaron (John) Mungunda, the brother of local Herero leader Hosea Kutako, and Theodor Hanbanue held meetings to enroll members into the UNIA at Karibib, Usakos, and Okahandja in October 1922. ${ }^{139}$ Mungunda met with Namibians in Karibib on 19 October 1922 and told them that he was "working in conjunction with America, and that they wanted to do away with white teachers, missionaries, and that they want[ed] their own Administration."140 Five new members enrolled at Karibib immediately following the conclusion of the meeting and others asked for the opportunity to consult with their chiefs before making a decision. Over 150 people attended the meeting in Okahandja on 1 November 1922, where an undetermined number of people enrolled in the organization. At the meeting Eduard Maharero was elected chairman of the proposed branch. ${ }^{141}$

\footnotetext{
${ }^{137}$ Fred W. Henley, Acting Magistrate of Okahandja, to A.J. Waters," 1 September 1922, NAN: SWAA/A396/4. See Emmett, "Popular Resistance," 22-29 for a full discussion of white fears about a possible general uprising in the territory.

${ }^{138}$ Enclosure: Statement by Willem Kaapnaar, 16 October 1922, NAN: SWAA/A396/13. While it is unlikely that Namibians were purchasing guns in the territory, accounts reference instances of firearms being stolen or taken from white-owned farms. Kaapnaar recounts during a meeting in Omaruru that "[Herero] also state that they can get guns and ammunition in a day."

${ }^{139}$ C.N. Manning, Secretary for South West Africa, to the Administrator, 14 October 1922, NAN: SWAA/A50/32. Aaron Mungunda and Theodor Hanbanue both applied for travel passes from the South West Africa Administration with the explicit purpose of conducting the work of the UNIA in these areas. In these documents, Mungunda is referred to as "John Hungunda." However, scholars like Jan-Bart Gewald have stated that this is most certainly a misspelling of Mungunda's name.

${ }^{140}$ Enclosure: Post Commander of South West Africa Police, Karibib, to J.J. Dewitt, 19 October 1922, NAN: SWAA/A50/32.

${ }^{141}$ Enclosure: Report of Native Corporal Jacob, 6 November 1922, NAN: SWAA/A396/4
} 
Map 3: Hotbeds of UNIA Activity in South West Africa, 1922-1924

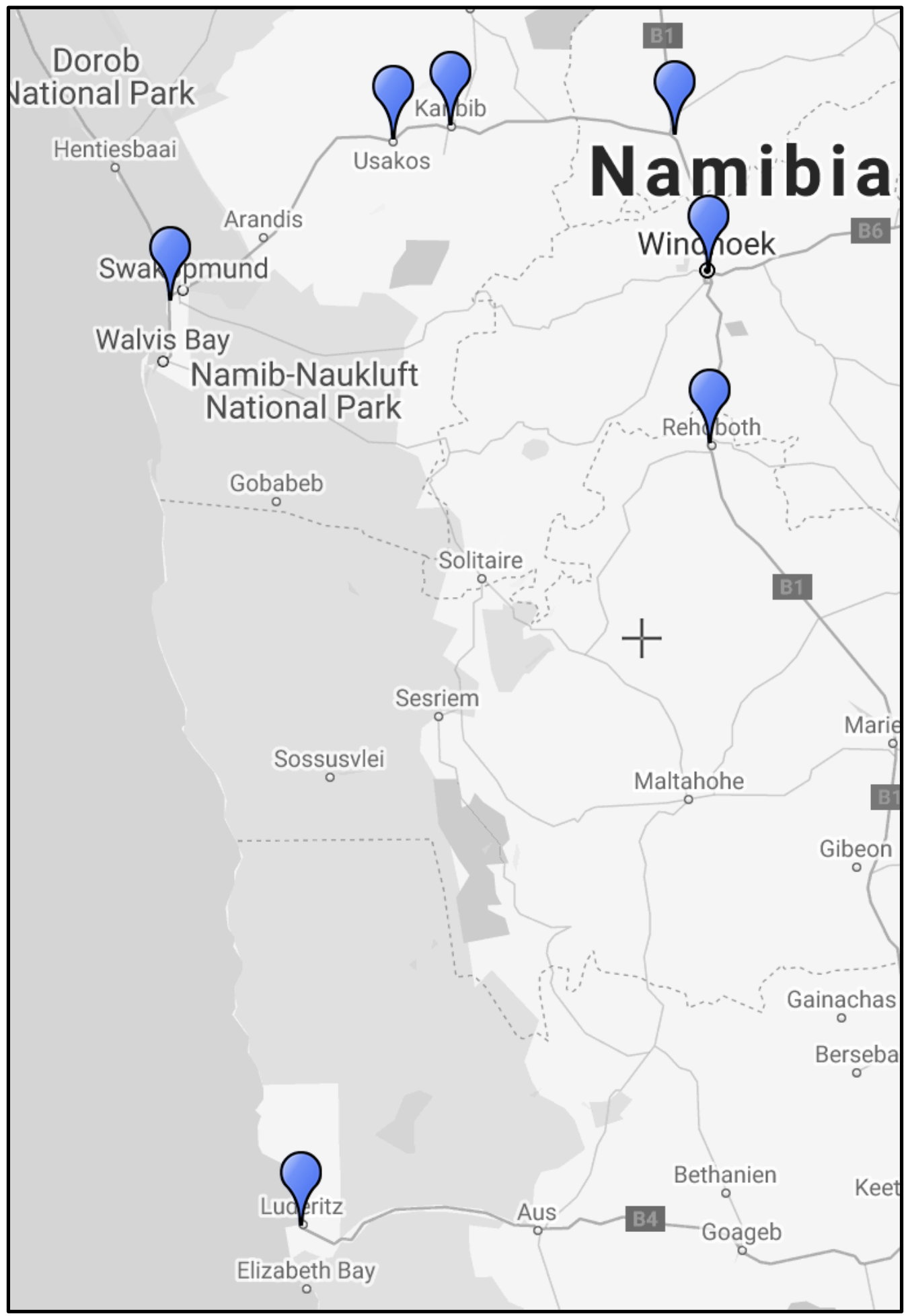

Source: Prepared by Author. 
The burgeoning success of the UNIA in the Police Zone and the spread of rumors about unrest and armed rebellion among the African populations led to numerous complaints from whites in South West Africa. ${ }^{142}$ The South African government took a vested interest the development and movement of the UNIA in the territory and actively monitored the spread of the UNIA branches. On numerous occasions, South West African police intercepted letters between UNIA members, searched members' mail, and surveilled their physical movements. ${ }^{143}$ In some instances, like the UNIA meetings in Karibib, Usakos, and Okahandja, the government used Namibians to infiltrate the meetings. Here, the government's operators pretended to be members of the UNIA and reported back to government officials on the agenda of the association and any future plans for rebellion or unrest in the territory. ${ }^{144}$

Despite the anxieties of white South West Africans, SWAA officials believed that there was little cause for concern. Officials found little evidence to suggest that there was an organized effort among Namibians to execute an armed resistance struggle. Rather, their concern and attention almost exclusively focused on the activities of West Indians and West Africans. Reports included descriptions of the unrest as "engineered by American negroes" and that it was causing "confusion and disorder...in the heads of the natives, especially the Herero minds." 145 However, most official reports concluded that "no trouble [was] anticipated" and that the "matter [was] not serious."146

\footnotetext{
${ }^{142}$ Acting Secretary for South West Africa to Secretary for Native Affairs, Pretoria, 24 April 1922, NAN: SWAA/A50/32.

${ }^{143}$ Gysbert Reitz Hofmeyr, Administrator of South West Africa to Jan Smuts, 18 June 1923, NAN:

SWAA/A312/20.

${ }^{144}$ Enclosure: Post Commander of South West Africa Police, Karibib, to J.J. Dewitt, 19 October 1922, NAN: SWAA/A50/32.

${ }^{145}$ Report by David Ngxiki to South West Africa Police, 3 October 1922, NAN: SWAA/A396/4 and Statement by August Kuhlmann to South West Africa, 11 October 1922, NAN: SWAA/A396/13.

146 AJ Waters to W. Scotland, 30 January 1922, NAN: SWAA/A50/32 and AJ Waters to Major C. Forsbrook, 2 March 1922, NAN: SWAA/A50/32.
} 
In part, the lack of concern by the SWAA toward the UNIA centered on the fact that, despite the UNIA's growth in South West Africa between 1921 and 1922, signs of disunity among the UNIA's American and Namibian leaders also grew. Although Ncwana formed the SWANC in September 1922 to counteract the West Indian and West African influence over the leadership of the UNIA and ICU, within the UNIA itself signs of a growing fracture among the territory's UNIA leadership emerged during that same month. The Officer-in-Charge of Native Affairs in Lüderitz remarked that there was

[D]issatisfaction on the part of [South African] and [South West African] natives with the [ICU] (chiefly dominated by Capeboys) and the [UNIA] (introduced and directed by West Indian and West Coast Natives) which is continually calling for funds for American propaganda purposes. The collection of subscriptions (or dues) for UNIA memberships were intended to provide life insurance and coverage during times of illness. Yet, the funds collected were sent to America and few Namibians ever received payment from the 'sick fund'. ${ }^{147}$

Combined with the lack of action by Americans in the liberation of their Namibian counterparts, the tensions and disappointment in the organization were palpable among the Namibian leadership.

These tensions came to the fore during a meeting between the Herero leadership and UNIA agents at Okahandja on 1 November 1922. During this meeting, a group of young Herero men and women asked Mungunda "when the Americans were coming to release them." 148 Mungunda, surprisingly, openly acknowledged the lack of action by the American branches of the UNIA at a meeting the next day, stating "If I told you that the American negroes were coming to release you, I think you would be satisfied, but it would be a lie. I know nothing about America. The society has been formed through American ideas, but Americans only explained it

\footnotetext{
${ }^{147}$ Annual Report of the Nama Parish, South West Africa, by Rev. Gustav Becker, 9 January 1923, MGP, Vol. X: Africa for the Africans, 1923-1945, ed. Robert A. Hill (Berkeley: University of California Press, 1983$), 8$.

${ }^{148}$ Enclosure: Report of Native Corporal Jacob, 6 November 1922, NAN: SWAA/A50/32.
} 
but will not do the work-we must do that. It is no use holding out false hopes about America, because I do not believe that they will ever be able to come here to help you." ${ }^{149}$ While 30 new members joined the organization following this statement and meeting, Mungunda's willingness to criticize the parent organization during a recruitment drive signaled the eroding patience of not only prospective members, but also the very leadership tasked with spreading and supporting the UNIA's message. ${ }^{150}$ This change in approach heralded the power struggle that occurred within the leadership of the South West African UNIA in the coming months. This struggle ultimately resulted in the Herero taking control of the association in most of the Police Zone.

Colonial officials believed that Hosea Kutako played a crucial role in advocating a change in leadership within South West Africa's UNIA branches. ${ }^{151}$ R.S. Cope wrote to the Secretary for South West Africa that,

[Hosea Kutako] has also got a [program] of the aims and objects of Marcus Garvey, President of the Universal Negro Improvement Association...but I suppose his object is to [show] his Honour that he is at any rate trying to do something, but he is a very plausible individual....He hankers after power similar to that of a great native chief. [I]f he is drawn out it will be observed that this is almost his one aim. [H]e is always deploring his lack of power and finds it so difficult to carry out his duties. ${ }^{152}$

Kutako's campaign for power within the organization, and more broadly control over the UNIA's approach to fighting South African segregationist policies in the territory, succeeded. On 22 November 1922, the Officer-in-Charge of Native Affairs, Windhoek wrote to the Secretary for South West Africa that "the control of the Windhoek Society [had] passed from the hands of the Kroo-Boys and is now vested in the following natives-(John) Aaron Simon Mungunda,

\footnotetext{
${ }^{149}$ Ibid. The reason word "surprisingly" is used to describe Mungunda's statement is that there are few, if any, instances of an active member of the UNIA openly criticizing and acknowledging the shortcomings of the parent organization during recruitment drives.

150 Ibid.

${ }^{151}$ Chief Hosea Kutako was appointed the leader of the Herero in 1917 by the South African government and his position was affirmed in 1920 by Samuel Maharero. Kutako spent most of his life fighting against the South African colonial regime and was instrumental in the development of the later nationalist movement of the 1960s.

152 Memorandum by R.S. Cope to Secretary for South West Africa, 7 November 1922, NAN: SWAA/A50/32.
} 
Herero, President." ${ }^{" 153}$ Mungunda was the brother of Hosea Kutako and colonial officials seemed certain that it was Kutako who was the "controlling spirit" of the change in leadership. Xhosa railway employee Solomon Hosiah Monguya became the Chairman of the Windhoek branch and Clemens Kapuuo served as Secretary following the change. ${ }^{154}$

Whereas the UNIA's ambitions centered on Black liberation, emancipation, and the general uplift of the Black race under West Indian and West African leadership, under indigenous Namibian leadership this Black nationalist creed and racial unity gave way to a more subnational approach. Reverend Gustav Becker noted that the "initial enthusiasm and unity among the [ethnic groups] has disappeared. They gradually [sobered] up. Differences with respect to leadership have arisen....The other [ethnic groups] are dissatisfied with that." ${ }^{155}$ The Herero, as previously mentioned, continued to essentially use the UNIA as an extension of their Otruppa movement. The Windhoek branch focused primarily on Herero concerns, including making claims on expropriated lands and pushing back on excessive livestock taxes. ${ }^{156}$ The shift to Herero leadership in Windhoek also signaled to the Nama leadership further south that they would need to utilize and appropriate the transnational organizational infrastructure of the UNIA in their own way to realize their local political and socioeconomic agenda.

Even prior to the arrival of the UNIA in the territory, many of the Nama leaders felt politically marginalized under the new South African regime and believed that they had not received any "justice" since the South African government took control of the territory. Complicating the matter, it is clear that many Nama believed that members of the other

\footnotetext{
${ }^{153}$ Officer-in-Charge Native Affairs, Windhoek to Secretary for South West Africa, 22 November 1922, NAN: SWAA/A50/32.

${ }^{154}$ Ibid. Kapuuo was the father of Clemens Kapuuo, the future president of the Democratic Turnhalle Alliance who was assassinated in March 1978 by his political rivals.

${ }^{155}$ Annual Report of the Nama Parish, South West Africa, by Rev. Gustav Becker, 9 January 1923, MGP, Vol. X, 8.

${ }^{156}$ Headley, Kutako, W. Jod, Horveka, et al. to Mayor in Council, Windhoek, 23 January 1922, NAN:

SWAA/A50/32.
} 
Namibian ethnic groups received concessions during this period. One of the Nama headmen at

Rehoboth, Vaaluin Lawren, captured the mood among the Nama when he said:

The Bast[ers] got a certain amount of justice, the Germans got justice, the Herero got a little justice but they, the [Nama], got no justice from the Administration, the Europeans and Bast[ers] have farms, the Herero have Reserves but the [Nama] are chased from place to place and have no fixed place to abode. He further stated that the Bastard Government made them pay poll tax in the Gebie[t] and the Administration made them pay Dog Tax in Gebie[t] if they reside on European farms and wished to know why they should pay taxes to two Governments at the same time and be ruled by two Governments at the same time. ${ }^{157}$

The shift to Herero leadership in the UNIA branches at Windhoek and the surrounding areas in November 1922 did little to ease concerns that their voice was fading. Again, pointing to Rev. Becker's statements, they believed that "The Herero claimed the [UNIA] for themselves alone." 158

The Nama at Rehoboth acted quickly and appointed new leadership over their UNIA branch. They elected Vaaluin Lawren and Franz Afrikaner to the positions of Kaptein and Vice Kaptein of the UNIA's Rehoboth branch. ${ }^{159}$ Under their leadership, the UNIA served as a conduit to advocate for Nama independence and as a means to reassert Nama claims to expropriated lands. Lawren and Afrikaner rode around the district collecting subscriptions from members of the UNIA and began telling members that their dues would be used by the UNIA to purchase land and freedom for the Nama members of the district. The magistrate for Rehoboth recalled that Lawren and Afrikaner told members that "this money... would be used to purchase their freedom and the land, at present occupied by the Bastards and Europeans, would be

\footnotetext{
${ }^{157}$ Enclosure: Report by Post Commander of Rehoboth, South West Africa Police, 6 January 1923, NAN: SWAA/A50/32.

${ }^{158}$ Annual Report of the Nama Parish, South West Africa, by Rev. Gustav Becker, 9 January 1923, MGP, Vol. X, 8. ${ }^{159}$ Although a small change, the use of the term "kaptein" to refer to the Nama UNIA leaders represents how Nama appropriated the organizational infrastructure of the UNIA to more closely resemble their own political structures.
} 
returned to them." 160 Upon receiving this news, many Nama at Rehoboth abandoned laboring on white owned farms and began to "congregate" their herds on the Naos and Gurumanas farms. ${ }^{161}$

The activities of Lawren and Afrikaner illustrate how the UNIA leadership near

Rehoboth successfully crafted a Nama-specific message by wedding the desire for the return of ancestral lands to the UNIA's message of Black liberty and emancipation. The magistrate at Rehoboth noted this intense desire for land, contending "The [Nama] appear to be dissatisfied because they have been allocated no reserve, and they say they are chased from place to place, but its only lately that they have come together in a mob; previously they used to work on the [Baster] and European farms, and there was then no necessity to put them in a reserve."162 The message's specificity to the circumstances at Rehoboth differed greatly from the previous approaches of the UNIA that advocated for the emancipation of the entire South West Africa territory. Instead, subnational concerns about Nama independence, and the procurement of the land necessary to make this a reality, took precedent. While there is evidence that communication still existed between the Rehoboth and Windhoek branches and that cooperation was achieved on some territorial matters like the Bondelswarts Rebellion in 1922, the notes of colonial officials make it clear that the leadership of these two branches worked separately toward distinct goals associated with their own ethnopolitical group. ${ }^{163}$

While most branches worked effectively through the UNIA apparatus in the territory, there are some examples that Namibians outright rejected the UNIA and its messaging specific localities. Some preferred instead to pursue other methods to assert their agency and turned

\footnotetext{
${ }^{160}$ J.C. Hofmeyr, Acting Magistrate of Rehoboth, to Secretary for South West Africa, 6 January 1923, NAN: SWAA/A396/6.

${ }^{161}$ Ibid. The Nama chose these farms because they possessed "plentiful water and rand grass" that allowed them to sustain herds of 4,000 small stock and 250 large stock.

162 Ibid.

${ }^{163}$ Emmett, "Popular Resistance," 26-27.
} 
toward the South African colonial state to make claims for aid. For example, even among the Nama the acceptance of the UNIA was not universal. The Swartbooi wrote to the SWAA on 20 November 1922 and dissociated themselves from the movement. David Swartbooi was concerned that the movement was aimed against the SWAA and asked the government to intervene. Members of the UNIA branches in Windhoek and Rehoboth allegedly threatened the Swartbooi for writing to the government and claimed that, for their treachery, the Swartbooi would "lose the blessing which the advent of the [UNIA] government will pour out on Africa."164

The Rehoboth Basters similarly did not pursue great involvement in the spread or utilization of the UNIA as a method to resist the South African government and its policies. Even in the Rehoboth district, where some colonial officials claimed that the Baster Raad was protecting Herero and Nama populations from government policies, it was noted that the Basters desired the removal of Lawren and Afrikaner and were waiting to "see first where [the Garvey movement led]."165 As chapter 2 explained, the Basters instead worked through the South African government and the League of Nations to reaffirm the conditions of the Treaty of Friendship with the Germans that granted them specific legal and political rights in 1895 . Even as the SWAA betrayed the treaty and issued Proclamation No. 28 of 1923, the Basters did not turn to the UNIA to assert their claims to self-determination and land. Rather, they embraced another international institution, the League of Nations, and carried out an ethnically exclusive

\footnotetext{
${ }^{164}$ Enclosure: David Swartbooi, Izaak Swartbooi, Petrus Bois, Hieser Hendrik, and Timotheus Richter, to the Government of South West Africa, 20 November 1922, NAN: SWAA/A50/32.

${ }^{165}$ Enclosure: Report by Post Commander of Rehoboth, South West Africa Police, 6 January 1923, NAN:

SWAA/A396/6 and Annual Report of the Nama Parish, South West Africa, by Rev. Gustav Becker, 9 January 1923, MGP, Vol. X, 8 .
} 
petition-writing campaign that began in 1925 and used international law as a means to stake these claims.

By the middle of 1923, moreover, it became apparent that the UNIA and its resultant Garveyite movement were in decline in South West Africa. The investment failures of Marcus Garvey and his subsequent arrest in 1922 on charges of mail fraud significantly weakened the organization. In the case of South West Africa, the lack of an American liberation force, questions over the use of collected membership dues, and internal fissures led to the collapse of the UNIA in the territory. The UNIA collected over $£ 2,000$ in membership dues, but, by the end of 1922 , only $£ 80$ of this reserve remained. ${ }^{166}$ The failure to administer funeral funds, the sick fund, or establish African-led schools from these dues caused many to become "discontented" and they "dissociated" themselves from the UNIA. The issue of continuing feuds between American and Namibian leadership raged on into early 1924 and the earlier unity that had existed continued to fade, making the UNIA a marginal force in Namibian efforts to assert their agency under South Africa's segregationist system and make claims of subnational independence after 1924.

\section{Conclusion}

The transnational UNIA came to southern Africa by way of historical maritime channels and flourished among union members and dockworkers in South Africa, creating a circuit through which sympathetic anticolonial actors, ideas of Black nationalism, and substantial resources flowed. South Africans believed that the American leadership of the UNIA intended to educate and economically develop Coloureds and Blacks in the Union. The circulation of the

\footnotetext{
${ }^{166}$ Enclosure: Report by Post Commander of Rehoboth, South West Africa Police, 6 January 1923, NAN:
} SWAA/A396/6. 
Negro World disseminated the UNIA's message in South Africa and created a communicative and intellectual link that connected Black trans-Atlantic communities in their efforts against white sociopolitical and economic domination. The UNIA, through its growth and spread, formed valuable relationships with ideologically-similar organizations, like the AME Church and the upstart ICU, that gave way to a larger pan-African resistance strategy in southern Africa.

Beginning in 1919, Garveyist propaganda made its way to South West Africa and circulated in the port city of Lüderitz, establishing another linkage in this transnational resistance circuit. The ICU leadership simultaneously held positions in the UNIA and worked in tandem with West Indian and West African dockworkers in the territory to establish the first branch of the South West African UNIA at Lüderitz between 1920 and 1921. These West Indians and West Africans worked tirelessly to promote the UNIA's message of racial unity and uplift and established subsequent branches at Swakopmund and Windhoek to lobby for their economic and political interests. UNIA agents proceeded to distribute Garveyite propaganda in the rural areas within the Police Zone and establish more branches at Rehoboth, Karibib, Usakos, and Okahandja.

Between 1919 and late 1922, the non-indigenous Black leadership of the South West African UNIA promoted a message of racial unity among Namibians for the purposes of racial development and territorial independence. UNIA agents collected subscriptions throughout the territory and many Namibians joined the UNIA for access to its social welfare program and the guarantees of assistance in their liberation struggle. Unfortunately, few received the benefits from these programs and questions arose over the lack of a promised American liberation force and the limited payouts from the sick fund. In November 1922, these tensions came to a head 
and the Herero members of the UNIA in Windhoek seized control of the branch from its West Indian and West African leadership.

This shift in the power dynamics of the organization weakened the perceived racial unity and inclusivity that existed during the first two years of the organization's existence in South West Africa. Instead, the Nama and Herero appropriated the UNIA as a transnational vehicle to achieve their exclusive subnational and local sociopolitical agendas. The Herero used the UNIA's organizational infrastructure to make claims for lost lands and push back against the SWAA's imposition of dog and livestock taxes. The Nama, unenthused by the shift to Herero leadership, subsequently appropriated the UNIA branch in Rehoboth as a conduit to make claims of subnational independence and establish themselves on land within the Rehoboth district. Meanwhile, other groups like the Swartbooi and the Rehoboth Basters refused to participate in the UNIA's activities and embraced different pathways to challenge the segregationist policies of the South African government in the interwar period.

Although the UNIA essentially collapsed as an organization in South West Africa by 1924, its impact on Namibian resistance during the period was substantial. First and foremost, as Pirio argued in "The Role of Garveyism," the UNIA created the earliest foundations for a Black working-class nationalism in Namibia that contributed to and shaped the approach of the liberation movement in the 1960s. ${ }^{167}$ Perhaps more importantly, the UNIA reified the subnational character of resistance campaigns prior to the 1960s that often broke along ethnic and geopolitical lines in South West Africa. The evidence makes clear that after the Herero seized control of the UNIA in South West Africa, Namibians turned toward their local and traditional

${ }^{167}$ Pirio, "The Role of Garveyism," 3. 
ethnic leadership to make claims to the South African government that were specific to their local situation.

Namibian leadership in the UNIA quickly made use of the resources and transnational infrastructure provided by the UNIA in the territory. Access to the UNIA's network of sympathetic transnational actors, both inside and outside of the territory, proved crucial in Namibians' resistance efforts in the 1920s and allowed them to amplify their voices to a wider audience, thus placing increased pressure on the SWAA to resolve their demands. In concert with agitation from the non-indigenous UNIA leadership for South West Africa's territorial independence, the continued demand by the Namibian UNIA leadership for improved local socioeconomic and political conditions increased tensions with whites in South West Africa. Fears of a larger general uprising and reports that the UNIA's message had encouraged Namibians in the Police Zone to accumulate weapons and ammunition in anticipation of the arrival of an American liberation force permeated the territory only further encouraged the SWAA to interact with the UNIA as a means to peaceably de-escalate post-war tensions in South West Africa. Finally, due to the SWAA's perception of the UNIA's non-indigenous Black leadership as more highly educated agitators than their Namibian counterparts, the SWAA intentionally supported a policy of non-interventionism when Ncwana and his allies established SWANC in September 1922 and siphoned off a significant portion of Namibian support for the UNIA. While this profoundly altered the long-term viability of the UNIA in the 1920s, it also presented disaffected Namibians with a new avenue to pursue the SWAA's unjust policies and provided them with the distinct organizational control missing in the UNIA's leadership structure prior to the Herero seizure of power. 
While the UNIA failed to drastically alter the SWAA's segregationist policies of the early 1920s, the UNIA did have some important successes in its resistance campaign. It provided Namibians with non-state avenues to make claims of the South African government within a system where limited legitimate legal means existed to fundamentally alter the oppressive government apparatus thrust on Namibians. Likewise, the UNIA provided Namibians with an organizational infrastructure that could be used and appropriated to support social welfare programs, encourage mutual aid among Namibians and diasporic Blacks, and actively engage with transnational institutions that could put pressure on the South African government on behalf of Namibian leaders. For example, the use of the UNIA to engage with international actors at the League of Nations and in the Americas slowed the South African government's implementation of harsher segregationist policies prior to World War II.

Perhaps just as significant, Namibian involvement in the UNIA significantly impacted resistance strategies and campaigns in the post-World War II period. The subnational organizing that occurred after November 1922 provided some basis for the lines along which later political parties formed in the early 1960s. The Ovamboland Peoples' Organization (OPO), the South West Africa United National Independence Organization (SWAUNIO), and SWANU developed their early political bases along ethnic lines with some of these parties continuing to give subnational groups a political voice even after SWAPO emerged as the dominant political party in 1962. Yet, underneath the clear distinctness in political demands during the early political party years existed the concept of cooperation and Black nationalist consciousness that the UNIA helped develop in the territory under non-indigenous leadership.

Similarly, the experience of interacting with a transnational organization like the UNIA shaped Namibians' resistance strategies in the post-World War II era. The AME Church became 
a central institution among the Nama resistance efforts in the Police Zone and had close organizational and ideological linkages to the UNIA. The Nama leadership used the AME Church to make claims of spiritual and political autonomy, as well as promote socioeconomic development and educational improvements. The UN also served as a transnational means of resistance and Namibian leadership used a petition-writing campaign, a method the UNIA and Rehoboth Basters helped popularize in the Police Zone in the 1920s, to place pressure on the South African government when few other legitimate means existed. Later involvement with student organizations and sympathetic international actors also had its foundation in these early interactions with these transnational organizations. In essence, perhaps the UNIA's greatest impact in Namibia was that it helped form the basis for future resistance strategies that would have a much larger impact on facilitating concrete changes to South African colonialism in the territory. 


\section{Chapter 4-Comparative White Politics and Apartheid in Southern Africa, 1919-1964}

The interwar transnational resistance campaigns of the Basters and the South West African UNIA proved moderately successful in achieving their political and socioeconomic ends. The Basters advocated to the League of Nations for the re-establishment of their political sovereignty and autonomy and achieved a fairly small concession of limited self-government from the SWAA in the 1930s. Meanwhile, the UNIA provided the necessary transnational resources to develop a basic social welfare program among the Herero and Nama in the 1920s. However, as they resisted colonial expansion and the implementation of segregationist policies, white politics in South Africa and South West Africa rapidly changed. The battle for the heart of Afrikanerdom came to represent the core struggle of the interwar period and, by 1948, D.F. Malan's National Party (NP) emerged victorious over Jan Smuts' United Party (UP) and began to construct and implement the more rigid and harshly enforced apartheid in South Africa and South West Africa. The emergence of apartheid as the primary governing ideology in postWorld War II South Africa and South West Africa placed increasingly more difficult barriers and obstacles in front of Africans seeking to regain political and socioeconomic independence.

With this background in mind, the purpose of this chapter is not to examine a particular transnational resistance institution, but instead to trace the evolution of apartheid in southern African politics in the 1930s and 1940s. This chapter contends that apartheid grew and developed simultaneously in South West Africa and South Africa, albeit at different rates and with different intensity, as a result of the changing dynamics in white politics and interracial relations in post-World War II southern Africa. The chapter begins with an examination of the evolution of twentieth-century Afrikaner nationalism in South Africa and South West Africa, and the process of political samsmelting that led to fissures in Afrikanerdom and the radicalization of 
some elements of the volk. Both global and domestic South African politics are examined within the political and socioeconomic context of the interwar period, with a particular emphasis on Smuts' international political focus and D.F. Malan's internal political warfare with his Afrikaner rivals. Malan's and the NP's rise to political prominence in 1940s southern Africa is central to the chapter and the dueling Fagan and Sauer Commission reports are discussed within their apartheid context. Finally, the chapter concludes with an examination of the entrenchment and extension of apartheid in South Africa beginning in 1948 and how apartheid was installed in South West Africa by the SWAA through a series of legislation that sought to politically, socially, and economically segregate Namibians. In its totality, this chapter serves to provide a contextual foundation for the remainder of the dissertation, which examines Namibians' transnational resistance strategies in the late-1940s and 1950s in the face of an ever expansive and rigid apartheid apparatus.

\section{Samsmelting and Changes in Late-Nineteenth- and Twentieth-Century Afrikaner Politics}

The transformations that occurred to Afrikaner identity during the 1930s and 1940s facilitated the creation of an apartheid apparatus that severely limited Namibians' prospects for subnational or national independence after World War II. Historian Hermann Giliomee traced the development of late-nineteenth- and twentieth-century Afrikaner identity to the economic crisis in 1870s South Africa. There, Giliomee contended, fears of "cultural degeneration" took priority among the Afrikaner upper classes. Dutch-Afrikaner farmers were forced from their farms into a state of squalor, illiteracy, and into close proximity with Africans. ${ }^{1}$ The "Anglicization" of Dutch-Afrikaner intellectuals led to a cultural crisis that resulted in the

\footnotetext{
${ }^{1}$ Hermann Giliomee, "The Beginnings of Afrikaner Ethnic Consciousness, 1850-1915," in The Creation of Tribalism in Southern Africa, ed. Leroy Vail (London: James Currey, 1989), 32-34.
} 
creation of two contradictory Afrikaner nationalist organizations: the Genootskap van Regte Afrikaners (GRA) and Zuid-Afrikaanse Boeren Beschermings Vereniging (BBV). The GRA and BBV worked simultaneously to construct a true "Afrikanerdom," with the GRA working among the "true Afrikaners" and the BBV working almost exclusively with the wealthier elements of Dutch-Afrikaner society. ${ }^{2}$

This early movement to re-invent Afrikaner traditions and an imagined Afrikaner community focused on three crucial elements: language, race/ethnicity, and religion. The issue of language was of chief importance to the GRA and S.J. du Toit wrote in 1874 that he wanted to make Afrikaans "the cardinal ethnic symbol which encapsulated the history and the singularity of the Afrikaner people." ${ }^{3}$ The language not only served as a political tool with particular importance to "Afrikaner ethnic self-awareness," but also served the important purpose of educational uplift for poor white Dutch-Afrikaners and became a symbol of resistance to the perceived threat of British imperialism in South Africa. ${ }^{4}$ The First Language Movement and Second Language Movement of the late nineteenth and early twentieth centuries created an ethnonational identity that repurposed words to convey a certain political and cultural belief system that provided Dutch-Afrikaners with a way to resist the Anglicization of South Africa during this period. ${ }^{5}$

\footnotetext{
${ }^{2}$ Joanne L. Duffy, The Politics of Ethnic Nationalism: Afrikaner Unity, the National Party, and the Radical Right in Stellenbosch, 1934-1948 (New York: Routledge, 2006), 4-5.

3 "Articles by 'A True Afrikaner'," Zuid-Afrikaan, 8, 15, 22 July 1874. S.J. du Toit was a pastor, politician, and newspaper publisher living in the Cape Colony in the mid-to-late nineteenth century. Du Toit was an avowed Afrikaner nationalist and founded the Afrikaner Bond, one of the first political parties in the Cape that sought to create a pan-Afrikaner organization in southern Africa.

${ }^{4}$ Duffy, Politics of Ethnic Nationalism, 5.

${ }^{5}$ Gerhard Schuttle, What Racists Believe: Race Relations in South Africa and the United States. (Thousand Oaks: Sage Publications, 1995), 33-35; For a full discussion on the relationship between the Afrikaans language and Afrikaner cultural identity, see Johan van Wyk, “Afrikaans Language, Literature, and Identity," Journal of Social and Political Theory, No. 77 (May, 1991): 79-89 for a full discussion on the relationship between the Afrikaans language and Afrikaner cultural identity.
} 
While one's whiteness played a role in the definition of Afrikaner identity, the concept of whiteness in South Africa was complex and multi-layered. Afrikaners viewed themselves as white in the sense that they were a clearly distinct racial group from the Black Africans who lived in close proximity. However, both Dutch-Afrikaners and English-speaking South Africans viewed themselves as racially and ethnically separate. English-speakers viewed the Afrikaners as culturally backward and did not view them as civilized whites like themselves. Likewise, the Dutch-Afrikaners did not view themselves as racially, ethnically, or culturally similar to Englishspeaking South Africans. This concept of distinctness is best described by Giliomee when he detailed the GRA's conception of Afrikaner identity: "[The GRA] divided the Afrikaner people into three groups - those with English hearts, those with Dutch hearts and those with Afrikaner hearts, and only the latter were considered the true Afrikaners."

Lastly, nineteenth- and twentieth-century Afrikaner nationalism rested on Christianity and, in particular, the teachings of the Dutch Reformed churches in South Africa. As Joha LouwPotgieter crudely wrote in 1988, “[A] typical Afrikaner...[is] supposed to be white, an Afrikaans-speaker of West European descent, who votes for the NP, belongs to one of the three Dutch Reformed churches and shares distinctive history with the rest of the Afrikaner group."” Mission leaders in the Dutch Reformed churches espoused, over time, a neo-Calvinist message that "consort[ed] naturally with conceptions of racial superiority and of national separateness" and found a place in "the spiritual home of the vast majority of Afrikaners." " Pastors in the

\footnotetext{
${ }^{6}$ Giliomee, "Afrikaner Ethnic Consciousness," 34.

${ }^{7}$ Joha Louw-Potgieter, Afrikaner Dissidents: A Social Psychological Study of Identity and Dissent (Cleverdon: Multilingual Matters, 1988), 50. While scholars have criticized Louw-Potgieter for simplifying Afrikaner identity as a static monolith, his argument that the Dutch Reformed churches played a crucial role in defining and shaping Afrikaner identity from the 1870s-1950s proves important in understanding the religious influence on Afrikaner culture.

${ }^{8}$ Richard Elphick, The Equality of Believers: Protestant Missionaries and the Racial Politics of South Africa (Charlottesville: University of Virginia Press, 2012), 222. Neo-Calvinism provided Afrikaner Trekboers with the theological underpinnings to legitimate white supremacy and racial inequality in South Africa's interior. The
} 
Dutch Reformed Church were involved with the "color question" as early as the 1920s and espoused a missiology that focused on the civilization, but separateness of, Black churches and congregations. ${ }^{9}$ The vast majority of self-identified Afrikaners embraced the missiology and neoCalvinist teachings of the Dutch Reformed Church and, especially in the 1930s and 1940s, this particular conceptualization of Christianity was central to Afrikaner identity and political policies.

Aiding the constructive process of the reformulation of twentieth-century Afrikaner identity, Afrikaner intellectuals returned to South Africa from doctoral programs in Europe where they were exposed to German Romantic Philosophy and concepts of organic nationalism rooted in natural law. Neo-Fichtean ideas and Kuyperian theology combined to provide a new type of nationalism that further solidified Afrikaners as a volk (people) that was socially separate and distinct from other elements of South African society. ${ }^{10}$ Exposure to other philosophers, like Johann Herder and August Wilhelm von Schegel, only further integrated the concepts of shared culture, language, and history into the evolution of the Afrikaner identity. ${ }^{11}$ While language, ethnicity, and religion still remained crucial to Afrikaner identity, the shared history of the Great Trek of the 1830s took prominence in the creation of an imagined community with a distinct

\footnotetext{
Trekboers interpreted the Bible literally and viewed themselves as akin to the Israelites, or God's "Chosen People." Conversely, in this frontier theology, they viewed Africans as possessing the "Curse of the Son of Ham." Through this "Curse," Afrikaners deduced that their purpose in the interior was the conquest of Africans and the preservation/spread of the Christian community. The Chosen People/Heathen dichotomy that Afrikaners created and ground in Christian theology further legitimated racial disparities and provided a clear foundation of white supremacy that came to define Afrikaner-African relations well into the $20^{\text {th }}$-century. For a full discussion on the relationship between Afrikaner identity, Calvinism, and white supremacy, see Andre Du Toit, "No Chosen People: The Myth of the Calvinist Origins of Afrikaner Nationalism and Racial Ideology," American Historical Review 88, No. 4 (October, 1984): 920-952.

${ }^{9}$ Hermann Giliomee, “The Making of the Apartheid Plan, 1929-1948," Journal of Southern African Studies 29, No. 2 (June, 2003): 373-374 and 380-384.

${ }^{10}$ T. Dunbar Moodie, The Rise of Afrikanerdom: Power, Apartheid and the Afrikaner Civil Religion (Berkeley: University of California Press, 1975), 153-158. Moodie provides a thorough examination of the impact of German Romantic Philosophy on Afrikaner intellectuals in the 1930s.

${ }^{11}$ Duffy, Politics of Ethnic Nationalism, 3.
} 
anti-British imperialist identity. ${ }^{12}$ As World War II approached in the mid-to-late 1930s, Afrikaner identity was ever more contested among the volk, most prominently in the political sphere.

The contestation of Afrikaner political identity and policy reached a climax in 1933 and 1934 over the issues of political samsmelting (fusion). Beginning in 1933, heated debates occurred over the issue of Afrikaner political and economic cooperation with Britain and English-speaking South Africans as a result of the Great Depression. The proposed plan called for a samsmelting between the South Africa Party (SAP), first led by Boer generals Louis Botha and Jan Smuts, and the Afrikaner-led NP under Prime Minister J.B.M. Hertzog. The SAP was more sympathetic toward cooperation with the British government and English-speaking South Africans and found that, as a result of the NP's increasingly unpopular position among Afrikaners in the Transvaal and Orange Free State, Hertzog and the party's moderates were willing to consider samsmelting out of economic and political necessity. ${ }^{13}$

The Great Depression and its resultant economic impact played an influential role in the fusion process between the SAP and the NP. Prior to the depression, however, deep fractures existed within Afrikaner politics based on class conflicts and geographic rivalries. The Afrikaner members of the NP in the Cape consisted of skilled professionals and "prosperous farmers who were relatively unaffected by the Depression" that controlled Afrikaner capital and financial ventures of the period. ${ }^{14}$ Conversely, the Afrikaners in the Transvaal and Orange Free State consisted primarily of farmers and manual laborers who "constituted the lowest socioeconomic

\footnotetext{
${ }^{12}$ For more on the concept of "imagined communities" and their role in promoting the growth and spread of nationalist sentiments, see Benedict Anderson, Imagined Communities: Reflections on the Origins and Spread of Nationalism (New York: Verso Books, 1991).

13 Aletta J. Norval, Deconstructing Apartheid Discourse (New York: Verso, 1996), 35-37.

${ }^{14}$ Shamira M. Gelbman and Jesse H. Rhodes, "Ideology Construction, Grassroots Mobilization, and Party Strategy in South Africa and the United States, 1934-1948," Polity 43, No. 2 (April, 2001): 161-162.
} 
strata of South Africa's white population."15 These differences resulted in "considerable interregional resentment" that fueled socioeconomic rivalries between northern and Cape Afrikaners that characterized their political relationship into the 1930s and 1940s. ${ }^{16}$

As the Great Depression persisted and expanded, it only further exacerbated these tensions and fissures, which disproportionately affected Afrikaners in the Transvaal and Orange Free State. As global trade slowed, the demand for agricultural goods and mineral exports, the heart of northern Afrikaner economic production, dropped drastically. This dramatic decrease in demand for South African agricultural exports caused the prices for these goods to similarly fall and deprived Afrikaner farmers of their main source of income. As a result of these changes to the global and domestic economy, numerous Afrikaner farmers defaulted on the loan payments for their farms and lost their livelihood. ${ }^{17}$

Likewise, the Gold Standard Crisis of 1931 adversely impacted the South African economy during the Great Depression. Speculative attacks on sterling led the British government to abandon the Gold Standard in September 1931 and New Zealand and Australia soon followed. The South African government under Hertzog, however, remained on the Gold Standard until 1932. ${ }^{18}$ Hertzog faced immense pressure from the Gold Producer's Committee and the leaders of the mining companies to remain on the Gold Standard, as they viewed sterling as "unstable."19 Additionally, these interest groups feared that abandoning the Gold Standard would threaten the

\footnotetext{
15 Ibid., 162.

16 Ibid.

${ }^{17}$ See C.G.W. Schumann, The World Depression, South Africa, and the Gold Standard (Johannesburg: Juta and Company, 1932) for a discussion on the impact of the Great Depression on the prices Afrikaner farmers received for their produce. Scholars have criticized Schumann's work for some of his conclusions regarding whether the South African government should abandon the Gold Standard, but he provides great detail on some of the more general economic mechanisms impacting South African society in the early-1930s.

${ }^{18}$ H.S. Jones and Andre Muller, The South African Economy, 1910-90 (London: Palgrave Macmillan, 2016), 150152 .

${ }^{19}$ Keith Breckenridge, “'Money with Dignity': Migrants, Minelords and the Cultural Politics of the South African Gold Standard Crisis, 1920-33,” Journal of African History 36, No. 2 (1995): 297.
} 
viability of the mining industry in Witwatersrand and that maintaining this standard was “economically and psychologically imperative." ${ }^{20}$ In November 1931, only after closely studying the positive impact that the abandonment of the Gold Standard had on the Australian mining industry, the Gold Producer's Committee lobbied the South African government to abandon the Gold Standard. They believed that the devaluation of the South African currency offered the opportunity to increase profits and undermine the costs of labor, leading them to officially demand the linking of South African currency to sterling on 13 November $1931 .^{21}$

Hertzog initially refused to succumb to this pressure and, much like the consequences of the United States government's refusal to abandon the Gold Standard until 1933, the impact of the depression continued to grow. Hertzog intended to stay on the Gold Standard as a way to show his supporters that the Union was independent of British influence, but this move was viewed as "widely unpopular," even among his political base. ${ }^{22}$ Northern Afrikaner farmers were disproportionately affected by the deepening depression and held the NP, and the manufactureroriented Cape NP in particular, responsible for their plight. The 1930 and 1932 by-elections emphasized their growing political discontent as the election results showed a clear shift away from the NP toward the SAP. ${ }^{23}$

In the face of the negative economic impact discussed above and its potential political consequences, Hertzog abandoned the Gold Standard in 1932. Upon doing so, the South African economy recovered, albeit slowly, and the country saw an improvement in its economic

\footnotetext{
${ }^{20}$ Ibid.

${ }^{21}$ Ibid., 297-299. In addition to the reasons listed above, the South African government embraced the abandonment of the Gold Standard more broadly because they believed it would make their exports, particularly agricultural exports, more competitive on the world market. They believed that this move would eliminate some of the political tensions that had emerged with agriculturalists, an important base of support for the party.

${ }^{22}$ Newell Maynard Stultz, Afrikaner Politics in South Africa, 1934-1948 (Berkeley: University of California Press, 1974), 25.

${ }^{23}$ Ibid.
} 
situation. The South African gold mining industry was highly advanced for the time period and, when global gold prices began to rise in 1932-33, the health of the South African economy improved. As Keith Breckenridge observed, revenue from the sale of gold jumped by nearly $£ 20$ million after 1932 and the mining companies’ gold revenues approached $£ 50$ million for the first time. The increase in the demand and price of gold also increased mining companies' dividends to more than $£ 13.5$ million. The positive shift in the gold mining industry doubled the workforce and led to rapid expansion for the mining industry in West Rand and the Orange Free State. ${ }^{24}$

While the mining sector experienced positive growth in 1932, the South African government continued to face pressure from Afrikaner farmers who still experienced the negative effects of the Great Depression. After the British government left the Gold Standard, South African farmers continued to see their incomes drop because the sterling price of their exports had not risen to a level that compensated them for the devaluation of sterling. Concerns mounted that Afrikaner farmers, and to a degree mine laborers and manufacturers, would seek economic reprieve by challenging the government that failed to resolve these issues. These disillusioned Afrikaner farmers found an ally in Jan Smuts and the SAP, who took up the farmers' complaints in 1933 and tried to find a way to make the South African economy more profitable for this important political constituency. ${ }^{25}$

In 1933, Smuts and his party crafted a plan that advocated for the devaluation of the South African pound that would bring it into closer parity with the British sterling. This plan posited that such a devaluation and entrance into the sterling area would benefit both the mining and agricultural sectors in South Africa. Such a devaluation would, in theory, directly benefit the

\footnotetext{
${ }^{24}$ Breckenridge, “'Money with Dignity'," 300.

25 Peter J. Henshaw, "Britain, South Africa and the Sterling Area: Gold Production, Capital Investment and Agricultural Markets, 1931-1961,” Historical Journal 39, No. 1 (March, 1996): 205.
} 
mining sector by raising the domestic price of gold ${ }^{26} \mathrm{~A}$ rise in the domestic price of gold would consequently increase the mines' profitability and lead to expansion in the industry. A more stable currency would also consequently increase British interest in supplying new capital and investment for said expansion and growth. ${ }^{27}$

For Afrikaner farmers, devaluation and entrance into the sterling area was necessary because Britain remained the dominant customer of South African agricultural goods. Entering into the sterling area essentially "concluded a wide-ranging bargain" that drastically benefited Afrikaner farmers. ${ }^{28}$ For example, under this plan and "bargain," South African farmers received higher prices for their exports. The British, as a result, received a beneficial "ruling price" on much needed agricultural goods. British encouragement of this deal ultimately also made the pound sterling more stable, increased the prestige of sterling in the global market, and provided British capitalists with a new area for investment. ${ }^{29}$

Hertzog and Smuts both believed that one of the primary ways to maintain the positive economic growth experienced by the South African economy was the development and maintenance of cooperative trade agreements with the British government. Unfortunately, a significant portion of the Cape members of the NP maintained their long-held skepticism that cooperation between the South African and British governments would prove beneficial to their interests. Farmers and manufacturers in the Cape NP ardently opposed British imperialism, as they despised the ability of a foreign government to influence the prices paid for their exports. ${ }^{30}$ The general unwillingness of the Cape NP to support cooperation with the British government

\footnotetext{
${ }^{26}$ The term "sterling area" refers to a group of countries that stored most of their exchange reserves at the Bank of England. In doing so, these countries were provided with access to the London capital and money markets. The sterling area consisted mostly of then-current and former Commonwealth countries.

${ }^{27}$ Henshaw, "Sterling Area," 205-206.

${ }^{28}$ Ibid., 206.

${ }^{29}$ Ibid., 206-207.

${ }^{30}$ Gelbman and Rhodes, "Identity Construction," 162.
} 
posed a clear threat to the economic interests of Afrikaners in the Transvaal and Orange Free State who benefitted from Hertzog's earlier political maneuvering with regard to the Gold Standard. As such, the appeal and popularity of the NP weakened in the early 1930s and created an opening for negotiations surrounding the formation of a coalition government and fusing part of the NP with the SAP. ${ }^{31}$

As Hertzog and Smuts developed the structure and platform of the proposed UP in 1933 and 1934, it was clear that one of the major hurdles the new party faced was Afrikaner suspicions that the English-speaking whites in South Africa held a deep-seated loyalty to the British government and would never truly place the interests of the Union first. Unlike those suspicious Afrikaners, Hertzog embraced the concept of a "two-stream policy." Hertzog based the twostream policy on "an absolute equality between Afrikaners and English-speaking whites [that resulted] in an emphasis on white unity and the protection of white civilization in the face of a 'Black peril'." 32 The UP supported this position and adamantly believed that English-speakers in South African society would put the interests of South Africa first, even if these interests came into conflict with the interests of the British government. Belief in this policy portended a belief that Afrikaners and English-speakers could come together in support of the best economic and political interests of the white race. ${ }^{33}$ Additionally, the two-stream policy allowed for separate development and for the retention of some key elements of the Afrikaner identity, most significantly Afrikaans. The UP's willingness to adopt and support this policy ultimately led to Hertzog throwing his support behind the samsmelting of the SAP and NP.

\footnotetext{
${ }^{31}$ Stultz, Afrikaner Politics, 25.

${ }^{32}$ Norval, Deconstructing Apartheid, 37.

33 Ibid.
} 
While Hertzog sought compromise, the more right-leaning anti-imperial elements of the Cape NP saw Hertzog's negotiations as a betrayal. D.F. Malan, a political opponent of Hertzog, believed that the very premise of the two-stream policy was flawed and unrealistic. Newell Stultz described Malan's position as “[seeing] no evidence of a change in nature of the Englishspeaking population, and, moreover, [Malan] was deeply suspicious of the willingness of Smuts to unite with Hertzog, vaguely seeing some treacherous motive beneath Smuts' sanguine pronouncements on national unity." 34 Furthermore, Malan argued that "the English[-speaking] South African would never voluntarily relinquish his un-Afrikaner associations with Great Britain; he would remain, until persuaded or compelled to change, an 'unassimilated' element in the white population of the Union." ${ }^{35}$ There were only two viable solutions to the two-stream policy issue. He argued that the connection to Britain must be severed through the creation of a republic, and that this would force English-speaking South Africans to embrace Afrikaans as their primary language. In essence, Malan advocated that "South Africa [would] have two equal languages, but [they] shall be one People!"36

Malan's position, following the initial successes of Smuts' and Hertzog's economic plan to cooperate with the British on trade deals, proved unpopular and placed Afrikaners, who still strongly supported the NP's protection of Afrikaner culture, in a challenging electoral position. In 1934, Afrikaners faced the difficult decision of following Hertzog into the UP or voting to remain a separate political party. The vote split nearly 60-40 and clear divisions emerged along regional lines. The Cape served as an NP stronghold for those in support of rejecting

\footnotetext{
${ }^{34}$ Stultz, Afrikaner Politics, 38.

${ }^{35}$ Ibid.

${ }^{36}$ Die Burger, 23 December 1933. D.F. Malan was a South African politician who served as Minister of the Interior, Education, and Public Health between 1924 and 1933. He was the head of the GNP between 1935 and 1939 and led the HNP from 1940 to 1948 . He became Prime Minister in 1948 and held this position until 1954.
} 
samsmelting, while the Orange Free State and Transvaal, Afrikaner regions that benefitted significantly from Smuts' and Hertzog's political maneuvers, voted heavily in favor of fusion. ${ }^{37}$ When Hertzog left for the UP, he took many of the northern Afrikaners and Afrikaner moderates with him. The more right-wing elements of Afrikaner society instead joined D.F. Malan's newlycreated Gesuiwerde Nasionale Party (GNP). Multiple factions within the GNP vied for political power in a battle for the heart of Afrikanerdom. This struggle resulted in a concentration of power around Malan, clear ideological shifts in Afrikaner nationalism, and the eventual emergence of competing Afrikaner political parties.

The relationship between Malan and Hertzog was contentious in the years immediately following the split. However, the centenary celebrations in 1938 to commemorate the Great Trek served as an important moment that led to a heightened cultural self-awareness among Afrikaners and led to demands for a political reunion between the two figures. ${ }^{38}$ While Hertzog was initially receptive to the idea, Malan outright rejected it and squandered an important opportunity that had important political implications in the coming years. World War II commenced in 1939 and the UP-led South African government declared war on Germany. Hertzog, a strong opponent of South Africa joining the war, ultimately left the UP on this point and created the Volksparty (VP), which drew support from Afrikaners to Malan's political left. That same year, Malan faced an internal ideological challenge from his political right with the formation of the radical right-wing Ossewabrandwag (OB) on 4 February $1939 .{ }^{39}$ Thus, Malan faced challenges from both sides of the political spectrum during World War II.

\footnotetext{
${ }^{37}$ Dan O'Meara, Volkskapitalisme: Class, Capital and Ideology in the Development of Afrikaner Nationalism, 19341948 (Cambridge: Cambridge University Press, 2009), 43-48. The Cape National Party voted 164 to 18 to reject fusion, while the Free State and Transvaal voted for fusion by a count of 107 to 27 and 281 to 38, respectively.

38 Dan O'Meara, “The Afrikaner Broederbond 1927-1948: Class Vanguard of Afrikaner Nationalism,” Journal of Southern African Studies 3, No. 2 (April, 1977): 178-180.

${ }^{39}$ For an analysis of the OB's radical right-wing policies and role in South African politics in the 1930s and 1940s, see Christoph Marx, "The Ossewabrandwag As A Mass Movement, 1939-1941," Journal of Southern African
} 
While the GNP vocally supported the concept of republicanism and tacitly supported anti-Semitic immigration policies, the OB came out in full support of the German government during the war. Although the South African Parliament voted to support the war effort on the side of Britain, the OB took explicit steps to sabotage the war effort and even created paramilitary units called Stormjaers. ${ }^{40}$ The OB's ambiguous appeal to volkseenheid (national unity) allowed the party to develop into a mass movement, as it intentionally failed to elaborate on specific policy distinctions that weakened broad popular support for earlier Afrikaner political movements. The OB embraced radical right-wing politics of the time and "articulate[d] the disgust which many people felt in view of the delicacies of party politics. It proudly showed itself as a movement of 'doers' rather than 'talkers'....For everyone hoped to find his or her 'salvation' there, rather than in politics." ${ }^{41}$ Within its first year, the OB effectively peeled away 300,000 supporters from Malan's political right and forced him to contend with their popular policy agenda. ${ }^{42}$

In the 1940s, another shift occurred that challenged Malan's control over Afrikaner politics. In 1941, a split within Hertzog's VP led H.C. Havenga to create the Afrikaner Party (AP), a party consisting of those opposed to following Hertzog into the Herenigde Nasionale Party (HNP) under Malan's control. ${ }^{43}$ Thus, prior to the 1943 General Elections, three primary political parties battled for control over political Afrikanerdom. The UP under Smuts drew its support from Afrikaner moderates and maintained its support of the two-stream policy and its

Studies 20, No. 2 (June, 1994): 195-219 for an analysis of the OB's radical right-wing policies and role in South African politics in the 1930s and 1940s.

${ }^{40}$ Ibid., 207-208. Stormjaers served as the para-military wing of the OB and committed numerous acts of sabotage against the South African state during World War II, including dynamiting post offices and railway lines, cutting telephone lines, and destroying power lines.

${ }^{41}$ Ibid., 198.

42 Ibid., 195-200.

${ }^{43}$ Gilbert William Frederick Dold and Christian Petrus Joubert, The Union of South Africa: The Development of Its Laws and Constitution (Astoria: Stevens, 1955), 117-119. 
intentions to cooperate with English-speakers in the Union. Malan's HNP formulated its political agenda based on the promotion of Afrikaans, its rejection of South African participation in World War II, and its strong desire for a republic. Finally, the OB continued to pull its support from the far-right and those that, in many cases, supported the German government and embraced much of the National Socialist sociopolitical agenda. ${ }^{44}$

The division created in Afrikaner politics between 1939 and 1942 made Smuts' and the UP's victory in the 1943 elections a certainty. In 1942, Afrikaner political leaders made last-gasp efforts to unite Afrikanerdom and challenge the UP's political dominance. In March, L.J. du Plessis wrote a piece in Die Vaderland that proposed a new Unity Movement to facilitate cooperation between Afrikaner leaders with disparate interests. ${ }^{45}$ Johannes Van Rensburg also tabled a proposal that sought to mitigate the disagreements between the OB and HNP by agreeing to "put up mutually acceptable volk candidates" in the 1943 General Election. ${ }^{46}$ Malan viewed the political maneuvering by the OB leadership as a sign of weakness and concluded that such an arrangement benefited members of the OB far more than it helped the HNP.

\footnotetext{
${ }^{44}$ Daniel Coetzee, "Fires and Feathers: Acculturation, Arson and the Jewish Community in Oudtshoorn, South Africa, 1914-1948," Jewish History 19, No. 2 (2005): 143-187. Scholars still debate how closely the OB embraced the National Socialist political agenda. Some have argued that the OB fully embraced National Socialism and supported their political agenda. Others have argued that this support for German political policies served merely as a stand-in for their hopes that a German victory could bring about the collapse of the British Empire and the emergence of a South African republic; See also, Marx, "The Ossewabrandwag," 202. He pointed to the defeat of the Netherlands in World War II as a "sobering moment" for many in the OB and resulted in a number of political defections from the party.

${ }^{45}$ Die Vaderland, 20 March 1942.

${ }^{46}$ Stultz, Afrikaner Politics, 83-84. This failure to come together on an agreement had dramatic impacts on the 1943 General Election. In the South African political system during this period the Union was divided into 150 electoral divisions, with an additional three officials chosen to represent the "Natives" in the Union. An official won one of these seats by receiving the most votes in a constituency. In the 1943 General Election, with the Afrikaners divided, this benefited the UP who won $49.7 \%$ of the vote and 89 out of 153 seats. However, with a more united National Party in the 1948 General Election, this system proved detrimental to the UP. The UP won $49.2 \%$ of the total vote to the National Party's $37.7 \%$. Despite winning a higher percentage of the vote, the UP secured most of their vote in urban constituencies and only won 65 seats. The National Party, conversely, won a number of smaller districts and secured 70 seats. They then formed a coalition government with the Afrikaner Party and their nine seats to form a government. The UP formed a coalition with the remaining parties but were outnumbered in total seats 79 to 74 . This unrepresentative political system allowed the National Party to entrench its control in the coming decades and develop its apartheid policies.
} 
Instead of coming together in the interest of defeating Smuts and the UP, Malan devised a political campaign that guaranteed short-term losses in Afrikaner political power but laid the foundation for the consolidation of Afrikaner politics under his control. Rather than attack the UP, Malan instead waged a campaign against his Afrikaner political rivals. Malan's internal crusade focused on portraying the $\mathrm{OB}$ as extremists with an unworkable political agenda and abandoning republicanism for a more widely-accepted parliamentarianism grounded in populism and authoritarianism. ${ }^{47}$ The strategy proved successful as the OB became defunct and the AP offered little in terms of a true political rival. The HNP gained 16 seats during the election and received roughly 36.7 percent of the vote, but Smuts and the UP retained 89 seats in Parliament and captured 49.68 percent of the vote ${ }^{48}$ Smuts' victory and Malan's consolidation of Afrikaner political power proved significant developments for the post-war trajectory of South African politics.

\section{Interwar White Politics in South West Africa, 1919-1939}

While nineteenth- and twentieth-century Afrikaner identity was re-invented in the Union, white politics in South West Africa underwent a similarly contentious and volatile reformulation during the Interwar Years. White politics in South West Africa generally broke along lines pertaining to language and culture and consisted of three separate spheres: English-speakers, German-speakers, and Afrikaans-speakers. The English-speaking element of society was relatively small and consisted primarily of civil servants and government administrators who came from the Union to serve in the SWAA. The Germans, as described by historian Christo Botha, "tended to be generally enterprising, inquisitive and already possessed a self-image that

${ }^{47}$ Ibid., 85-91.

${ }^{48}$ Ibid. 
depicted them[selves] as being a distinctly localized German entity. ${ }^{\circ 9}$ Lastly, the Afrikaners "comprised the predominantly rural element amongst the white population.... Religion played a vital role everywhere for Boer rural communities.... [And] religion was closely associated with education and imparting moral values required to cope with what was perceived as at best a foreign world encroaching upon them." ${ }^{, 50}$ Although there were conflicts between Englishspeakers and the other two groups, the main tensions arose between the German-speakers and Afrikaans-speakers, as they were the largest two non-indigenous groups in South West Africa.

Prior to 1915, tensions between the Germans and Afrikaners in the territory centered on a rural-urban divide that created negative stereotypes of each group among their counterpart.

Christo Botha described this rural-urban dichotomy:

Contact between these rural Afrikaners and Germans in the pre-1915 era was therefore between representatives of a rapidly industrializing country in the grip of a profoundlydislocating modernization process and representatives of a rural lifestyle whose way of thinking was essentially shaped by generations of volatile engagement with African communities and the British in South Africa, as well as the German-speakers in the former German South West Africa. ${ }^{51}$

The German's self-fashioned identity as urban, industrial, and modernizing was supported by the fact that they dominated the business and finance sectors in the territory. Conversely, Afrikaners were largely rural-based and availed themselves to the agricultural sector. Germans, and even English-speakers, in the territory viewed the Afrikaners as culturally-backward and slow to accept the modernization process underway in the colonial world. ${ }^{52}$

\footnotetext{
${ }^{49}$ Christo Botha, "Internal Colonization and an Oppressed Minority? The Dynamics of Relations Between Germans and Afrikaners Against the Background of Constructing a Colonial State in Namibia, 1884-1990," Journal of Namibian Studies 2 (2007): 15-16.

50 Ibid., 15.

51 Ibid., 16.

${ }^{52}$ Ibid.; Wallace, History of Namibia, 240. Wallace highlighted the class-element of this dichotomy, arguing "To some extent class divisions followed this divide. German farmers formed a wealthy elite in relation to the incoming Afrikaner pastoralists, and (despite declining economic influence in many areas) Germans continued to dominate the retail trade."
} 
Despite the existence of tensions between the territory's Germans and Afrikaners prior to World War I, this conflict inevitably exacerbated the enmity between the two groups. As the conclusion of the war approached, the South African government, keen to assert its power and control over South West Africa, used the Blue Book as a mechanism to collect damning information on the German treatment of the territory's African populations and discredit German colonial rule in the process. ${ }^{53}$ The Blue Book ultimately allowed the South African government to portray the German government as "unfit to exercise control over [its] colonies." ${ }^{54}$ Coupled with Germany's impending defeat and the internment of large numbers of German males in the territory during the war, Germans in the territory viewed the Blue Book as "add[ing] injury to the humiliation of defeat." ${ }^{, 5}$ The territory's Germans, still loyal to the German government and their deeply embedded cultural identity, continued to rail against the administration of the Blue Book well into the mid-1920s.

A second factor that contributed significantly to the tensions between Germans and Afrikaners in post-war South West Africa was the issue of citizenship and immigration. Germany's defeat in the war, and its subsequent loss of its colonial possessions, left South West Africa's German population in a peculiar position with regard to their legal status in the territory. During a trip to London in 1923, Prime Minister Smuts unsuccessfully attempted to persuade German government officials to assent to a plan that would see the nearly 8,000 Germans in South West Africa apply for citizenship in the Union. In an attempt to resolve the Germans' legal

\footnotetext{
${ }^{53}$ The 1918 Blue Book was a report that documented the German treatment of Namibians in South West Africa. The report collected Namibians' oral testimony under sworn oath about the atrocities committed under German colonial rule. The Union government viewed this document as crucial to their attempts to secure South West Africa as a de facto Fifth Province during the later peace negotiations. The depiction of the German colonial regime was so problematic for relations between German-speakers and the SWAA that the Blue Book was ordered destroyed in June 1926, following the UNSWP's victories in the election.

${ }^{54}$ Botha, "Internal Colonization," 13.

${ }^{55}$ Ibid.
} 
status, Smuts ratified the London Agreement of 1923 and provided citizenship to all Germans in the territory within a specified time. This agreement was upheld by the League of Nations in April 1923 and "as a result of the London Agreement [Germans in South West Africa were] made [Union] citizens unless they refuse[d]: but, in accordance with the German nationalization law, they still remain[ed] German citizens since they...made no application to change their status." 56 Thus, Germans in the territory "[had] rights and duties within the Union" but were exempt from military service for a period of 30 years. ${ }^{57}$

It is clear that, through the London Agreement, the Union government wanted to cultivate a positive working relationship with the German-speakers as a means to solidify and expand their control in the territory. In order to achieve this positive relationship, the Union government agreed to a number of concessions that allowed German-speakers to maintain their cultural and political identity. Per the agreement, Germans in the territory were permitted to retain the "free use of the German Language," an important concession given the role language played in creating tensions between the German-speaking and Afrikaans-speaking elements of white South West African society. ${ }^{58}$ Likewise, the Union government also agreed to provide support to German schools in the territory and maintain a friendly relationship with German churches and missionaries. Finally, former German officials were granted access to their retirement pensions. ${ }^{59}$

There were initial attempts to work closely with the territory's German-speaking population, however, German-speakers were uneasy about the Union government's land settlement schemes and immigration policies that directly impacted the composition of the white

\footnotetext{
${ }^{56}$ Arthur Lyon Cross, “The British Empire,” Current History 20 (April-September, 1924): 308.

${ }^{57}$ Ibid. Military service became a key point of the London Agreement, as German-speakers were adamant that they would not fight against the German government if future conflicts were to arise. It gave many German-speakers pause before assenting to citizenship.

${ }_{58}^{5}$ Ibid.

${ }^{59}$ Ibid.
} 
population in South West Africa. As chapter 2 argued, Smuts and the South African government offered whites in the Union favorable loan deals and easy access to relatively fertile lands in South West Africa as a way to deal with the poor white problem in the Union and avoid recurrences of revolts like the Rand Rebellion of $1922 .{ }^{60}$ German-speakers believed that these government policies constituted an active attempt by the Union government to increase the size of the Afrikaner population in the territory and, ultimately, further dilute the political power of German-speakers in South West Africa. These suspicions were only further confirmed when, in 1929, "it was decreed that German immigrants would henceforth need to reside for five years in [South West Africa] before they could claim citizenship, in contrast to British (i.e., South African residents) who required only two." ${ }^{61}$ That same year plans were made to resettle nearly 1,200 Boers from Angola, a move that would have further politically marginalized Germanspeakers in the territory. ${ }^{62}$

As a result of the tensions that emerged among South West Africa's whites, a flurry of ethnically- and linguistically-based political parties formed throughout 1924 in an attempt to safeguard the interests of the various sectors of the territory's white population. Frikke Jooste founded The National Party of South West Africa (NPSWA) in Mariental on 26 July 1924 and the party aligned its platform with Hertzog's aforementioned NP in the Union. In September 1924, Andries de Wet, A.P. Olivier and F. van Der Heever founded the Union Party, another predominately Afrikaner political party that aligned itself ideologically with Smuts' SAP. ${ }^{63}$

\footnotetext{
${ }^{60}$ See pages 83 through 85 of this dissertation for a more in-depth discussion on the economic issues facing poor whites in the Union during the early-1920s.

${ }^{61}$ Botha, "Internal Colonization," 18.

${ }^{62}$ Ibid., The Dorsland Treks were a series of four treks that occurred between 1874-75 and 1905. Boers in the Transvaal were concerned about impending British encroachment and, as a result, began a northwestward migration through the Kalahari. The Dorslandtrekkers wound their way through the soon-to-be-established South West Africa colony before finally settling in the Humpata Plateau of Portuguese Angola in 1881.

${ }^{63}$ Wallace, History of Namibia, 239-240 and Tonchi, et al., Historical Dictionary of Namibia, 289-290 and 433-434.
} 
Outside of counteracting German political influence in the territory, a key point of ideological agreement between these two parties was their desire to seek the incorporation of South West Africa into the Union as a fifth province. ${ }^{64}$ In contrast, Dr. Fritz Brenner founded the primarily German-speaking Deutscher Bund on 3 September 1924 to advocate for the 11,000 Germans in the territory and fight against the other two parties' demands for incorporation. ${ }^{65}$

Beginning in 1925, these political parties became the electoral mechanism through which white South West African society influenced policy and territorial decision-makers. That year, the South African Parliament passed the South West African Constitution Act which helped tighten their control on the territory. This act allowed for limited rights of political participation for the white population and created a representative Legislative Assembly that crafted legislation for the territory. Executive powers in South West Africa were shared jointly by the SWAA and the Executive Committee. Meanwhile, the South African Parliament and the territory's Governor-General maintained the ability to overrule any piece of legislation or executive decision that it deemed not in accordance with the Union's political agenda. ${ }^{66}$ Although they were not provided direct representation in the South African Parliament, whites in South West Africa possessed the necessary political infrastructure to pursue their ambitions and agenda in the territory.

The first elections in 1926 proved a success for the Deutscher Bund, as Afrikaners and English-speakers in the territory remained divided between the NPSWA and the South West

\footnotetext{
${ }^{64}$ Daniel Joseph Walther, Creating Germans Abroad: Cultural Policies and National Identity in Namibia (Athens: Ohio University Press, 2002), 162. Walther provides a detailed table that outlines each of the territory's parties' stances on the issue of incorporation.

65 Tonchi, et al., Historical Dictionary of Namibia, 79.

${ }^{66}$ Martin Cai Lockert, "Transplanting and Customizing Legal Systems: Lessons from Namibian Legal History," Richmond Journal of Global Law and Business 13, No. 2 (2014): 190.
} 
Party (formerly the United Party). ${ }^{67}$ The Deutscher Bund secured seven of the 18 Legislative Assembly seats, while the NPSWA and the South West Party won a combined three seats. ${ }^{68}$ The Deutscher Bund's victory, however, was somewhat blunted when Administrator Werth appointed four Afrikaans-speakers and two German-speakers to fill the six appointed seats on the assembly. ${ }^{69}$ This essentially meant that Afrikaners controlled seven seats, German-speakers controlled nine seats, and two seats were held by independent candidates, preventing any one party from dominating the territory's first Legislative Assembly.

The NPSWA and South West Party recognized that swift action must be taken to find common cause among the territory's Afrikaners and prevent successive Deutscher Bund electoral victories. Therefore, on 31 January 1927 the NPSWA and South West Party merged to form the United National South West Party (UNSWP) and pursue their joint goal of securing the incorporation of South West Africa into the Union. The newly-merged party experienced almost immediate success. In the 1929 Legislative Assembly elections, the UNSWP procured eight of the 12 elected seats by campaigning on a pro-incorporation platform. The Deutscher Bund won the other four seats while supporting an agenda focused on German cultural rights and upholding the terms of the mandate. ${ }^{70}$ Werth again limited the impact of the election by appointing more German-speaking members to the Legislative Assembly to provide balance. ${ }^{71}$ However, the 1929 election signified an important shift in the territory's white politics that saw a rise in influence of South West Africa's Afrikaans-speaking whites.

\footnotetext{
${ }^{67}$ Walther, Creating Germans, 162. The United Party dissolved on 28 January 1926 and rebranded itself as the South West Party.

${ }^{68}$ Andre Du Pisani, SWA/Namibia: The Politics of Continuity and Change (Johannesburg: J. Ball Publishers, 1985), 73-74

${ }^{69}$ Ibid., 74. Administrator Werth is quoted in this work as justifying his appointments by stating "No party will be allowed to dominate."

${ }^{70}$ Wallace, History of Namibia, 240.

${ }^{71}$ Klaus Dierks, Chronology of Namibian History: From Pre-Historic Times to Independence (Windhoek: Namibia Scientific Society, 1999), 105.
} 
Following the 1929 elections, sectional divisions were further enflamed as Germanspeakers continued to lose political influence in South West Africa. As was previously mentioned, in 1929 barriers were put in place that required German immigrants to reside in the territory twice as long as their South African counterparts in order to receive citizenship and political representation. Similarly, plans were devised to repatriate nearly 1,200 Angola-Boers, a move viewed by German-speakers as a ploy to solidify the Afrikaners population advantage. ${ }^{72}$ If successful, the UNSWP would be further entrenched as the dominant political party in the territory and the likelihood of incorporation, something vehemently opposed by the Deutscher Bund, increased. This led the Deutscher Bund to fight for German language rights and, more importantly, against automatic naturalization during the late 1920s and early 1930s. ${ }^{73}$

Further compounding the dire sociopolitical position for German-speakers, internal fractures appeared in the early-1930s. The Nationalsozialistische Deutsche Arbeiterpartei (NSDAP) was founded by Ernst Wilhelm Bohle in South West Africa in 1932, a year prior to Hitler and the National Socialist Party's rise to power in Germany. ${ }^{74}$ The NSDAP was heavilysupported by the younger elements of German-speaking society and, in light of Hitler's rise in 1933 and his strong denunciation of the provisions of the Treaty of Versailles, they demanded the return of South West Africa to German control. This inevitably led to conflict with the Deutscher Bund, which maintained popularity among the older German-speakers in the territory

\footnotetext{
72 Botha, "Internal Colonization," 18.

${ }^{73}$ Dierks, Chronology, 110.

${ }^{74}$ A. Kum'a N'dumbe, Relations Between Nazi Germany and South Africa (New York: United Nations Centre Against Apartheid, 1976), 8. Bohle was one of the leaders of the NSDAP in Germany. When he lived and studied in South Africa, he spent a significant amount of time in South West Africa, where he worked to establish NSDAP "cells" before his return to Germany. The party possessed strong socialist leanings and worked vigorously to defend German language rights to prevent the incorporation of the territory into the Union. This created a solid foundation for the spread of Nazism in South West Africa following the rise of Hitler in Germany in 1933.
} 
and supported a more moderate political agenda. ${ }^{75}$ The founding of the Deutsche Afrikanische Partei (DAP) under Martin Mauer in February 1939, an anti-Nazi party that emerged from the Deutscher Sudwest Bund (DSWB), only further added to the multitude of internal fissures that enveloped German political life in the territory and increasingly weakened their influence in South West African politics. ${ }^{76}$

The rise of Nazism also led to increased cooperation between the Union government and SWAA, resulting in the UNSWP actively working to limit the spread and influence of Nazism in the territory. In 1933 and 1934, the UNSWP, through the Legislative Assembly, banned the NSDAP and Hitlerjugend (Hitler Youth) in the territory. ${ }^{77}$ The NSDAP held three demonstrations in South West Africa in 1934 to demand the reinstatement of the party in South West Africa and the return of their expelled leader Major Weigel. However, the demonstrations proved unsuccessful and subsequently resulted in UNSWP raids on the NSDAP's offices and the headquarters of the Hitler Youth. The volatile and problematic activities of the Nazi organizations in South West Africa proved beneficial for the UNSWP, as the 1934 elections showed a significant shift away from the Deutscher Bund and toward the Afrikaner-dominated political parties. ${ }^{78}$

The UNSWP continued its political dominance in South West Africa well into the early 1940s. However, in 1939 the NPSWA re-emerged as a separate political party in the territory. Although the UNSWP and NPSWA shared a desire for incorporation of South West Africa into the Union, their primary point of differentiation centered on South African participation in World

\footnotetext{
${ }^{75}$ Reinhart Kossler, Namibia and Germany: Negotiating the Past (Windhoek: University of Namibia Press, 2015), 104-105.

${ }^{76}$ Zedekia Ngavirue, Political Parties and Interest Groups in South West Africa (Namibia): A Study of a Plural Society (Basel: P. Schlettwein Publishing, 1997), 138-139.

${ }^{77}$ Dierks, Chronology, 108.

${ }^{78}$ Ibid. The UNSWP won eight seats compared to the Deutscher Bund's one seat in the Legislative Assembly during the 1934 elections.
} 
War II. The UNSWP, much like Smuts and the UP in South Africa, supported joining the war effort on the side of the Allied Powers. This decision created tensions between the UNSWP and German-speakers in South West Africa, as they were steadfastly against participation in the war. The NPSWA, despite its support for incorporation into the Union, was against South African or South West African participation in World War II. ${ }^{79}$ The NPSWA sought electoral support from the likeminded members of the DAP in their challenge of UNSWP hegemony in the 1939 Legislative Assembly elections. Nonetheless, given the anti-German sentiment among the territory's Afrikaans- and English-speakers, this move caused the NPSWA to lose each of its contested seats and the party only received two seats through administerial appointment following the election. ${ }^{80}$ The NPSWA remained a minor political party during the course of World War II and it only rose to prominence in South West Africa after the NP gained popularity under D.F. Malan in the Union as a result of his pro-apartheid agenda.

\section{The Incorporation of South West Africa and the}

\section{Failed Referendum of 1946}

The UP's victory in the 1943 election and Malan's subsequent consolidation of Afrikaner political power proved significant developments for the post-war trajectory of South African politics. One issue of political importance for South West Africa in the post-World War II period was Smuts' renewed attention on incorporating South West Africa into the Union and determining the fate of the other High Commission Territories in southern and eastern Africa. Conversely, Malan and the HNP focused on reformulating their political agenda and message in an attempt to appeal to the more moderate elements of Afrikanerdom. The post-war years were

\footnotetext{
${ }^{79}$ Ibid., 111; See Du Pisani, SWA/Namibia, 83-84 for more information on why German-speakers turned toward the NPSWA in the late-1930s and 1940s instead of the UNSWP.

${ }^{80}$ Dierks, Chronology, 111.
} 
significant in paving the way for the development of apartheid policies in South Africa and providing a legal justification for their extension and entrenchment in the 1940s and 1950s.

The European conclusion of World War II in May 1945 presented Smuts and the South African government with renewed opportunities for the incorporation of South West Africa as a de facto fifth province. Smuts believed that joining the war effort on the side of Britain provided a clear path to the incorporation of the three High Commission Territories in southern Africa, allowed for the annexation of South West Africa, and brought his concept of a Greater South Africa to fruition. ${ }^{81}$ W.K. Hancock suggested that "not a dog would have barked during the Second World War if [Smuts] had simply annexed South West Africa," but Smuts' “oldfashioned respect for the legal fabric of the society of nations restrained him. ${ }^{\prime 82}$ Smuts, instead, intended to secure "full sovereignty" over South West Africa through the newly-formed UN. ${ }^{83}$

Delegates of the Allied Powers met in San Francisco at the United Nations Conference on International Organization (UNCIO) between April and June 1945 to charter a new international organization with a more robust enforcement arm than the League of Nations. ${ }^{84}$ The delegates opened the UN Charter for signatures, and they ratified the document on 26 June 1945. After a minor delay, the UN began its operation on 24 October 1945 and existed simultaneously with the League of Nations until April 1946. It was clear that, with an effective enforcement arm, the UN would soon replace the League of Nations. ${ }^{85}$ The transfer of powers from the League of Nations

\footnotetext{
${ }^{81}$ For more on the role of the High Commission Territories in Smuts' concept of Greater South Africa, see pages 76 and 77 of this dissertation.

${ }^{82}$ W.K. Hancock, Smuts: The Fields of Force, 1919-1950, Vol. II (Cambridge: Cambridge University Press, 1968), 467.

${ }^{83}$ Michael Crowder, "Tshekedi Khama, Smuts, and South West Africa," The Journal of Modern African Studies 25, No. 1 (March, 1987): 25-26.

${ }^{84}$ International Peace Research Association, The Future of the United Nations System: Potential for the TwentyFirst Century (Tokyo: United Nations University Press, 1998), 156-159.

${ }^{85}$ Ibid.
} 
to the UN was complex, but no issue created a lengthier and more intense debate than the proposed status of the mandate territories that existed under the League's purview.

Chapter 12 of the UN's Charter attempted to resolve this issue. Article 75 of the Charter “establish[ed] under its authority an international trusteeship system for the administration and supervision of such territories as may be placed thereunder by subsequent individual agreements." 86 The "territories now held under mandate" were included under the purview of the trusteeship system. ${ }^{87}$ The trusteeship system laid out a program designed to "encourage respect for human rights and for fundamental freedoms," as well as "promote the political, economic, social, and educational advancement of the inhabitants of the trust territories, and their progressive development toward self-government." ${ }^{88}$ The mandatory powers continued to administer these territories under the guidelines laid out in the Covenant of the League of Nations until such time as an agreement could be reached to place these territories under the trusteeship system. ${ }^{89}$

Smuts believed that, based on the wording of the proposed trusteeship system, Namibians' consent to incorporation would facilitate the process and ease any potential concerns or objections that might be brought against the South African government at the General Assembly. The need for Namibians' consent was emphasized at a confidential conference of Native Commissioners in Windhoek on 19 January 1946. Smuts tasked the attendees of the conference with carrying out a referendum to determine whether Namibians living in the territory "wish any other Government or people to rule [them]" and if they "would like [their]

\footnotetext{
${ }^{86}$ United Nations, Charter of the United Nations, 24 October 1945, 1 UNTS XVI, Article 75.

${ }^{87}$ Ibid., Article 77.

${ }^{88}$ Ibid., Article 76.

${ }^{89}$ Ibid., Article 80.
} 
country to become part of the Union of South Africa." ${ }^{90}$ Smuts instructed the Native Commissioners that "incorporation will depend on whether the United Nations is satisfied that the Natives want it."91 The South African government needed consent because they believed that "the mandate was originally set up for the protection of the Natives and therefore the Natives' willingness to stand under the Union government [would] contribute to the inclusion of South West Africa with the Union."92 Thus, an affirmative response from Namibians toward incorporation was essential to Smuts' larger plans for southern Africa.

To ensure that the referendum result was favorable, the Native Commissioners received detailed instructions at the aforementioned confidential meeting on how to carry out the referendum. Native Commissioners in Ovamboland had already made initial contacts with Ovambo leaders on the referendum and ascertained that there was "unanimous" support for the referendum. ${ }^{93}$ In the Police Zone, the fate of the referendum was much less clear. While some believed that if "the Ovambos [are] affiliated with incorporation, the Herero and the Basters will also agree," others questioned whether the Herero would consent to incorporation. ${ }^{94}$ The Native Commissioners from central Namibia recounted throughout the meeting that the Herero political process necessitated discussion and debate, often requiring additional time to come to a decision. Concerns existed that the Herero would question why a document must be signed and approach the referendum with suspicion. ${ }^{95}$

The Native Commissioners agreed to carry out the referendum in a confidential manner to avoid any potential outside influence on the process. The Native Commissioner at Karasburg,

\footnotetext{
${ }^{90}$ Referendum Template, 1 February 1946, NAN: SWAA/GL/37/V1.

${ }^{91}$ Native Commissioners' Conference: South West Africa, 19 January 1946, NAN: SWAA/GL/37/V1.

${ }^{92}$ Ibid.

${ }^{93}$ Ibid.

${ }^{94}$ Ibid.

${ }^{95}$ Ibid.
} 
J.S.J. Grobler, feared that if the administration of the referendum took too long and lengthy deliberations ensued, the "Natives [could] run to the German Fathers and Priests and...be wrongly influenced" against the Union government on the issue of incorporation. ${ }^{96}$ The commissioners thought that some of the missionaries in South West Africa might still be bitter about the South African government supporting Britain in the war and that they might stoke negative sentiments among Africans. Chief Native Commissioner for South West Africa P.R. Botha concurred with this assessment and reiterated that "it was not the idea to advertise the [referendum] because priests and missionaries would advise the natives to vote against the incorporation of South West Africa with the Union. ${ }^{997}$ Uniform statements about the purpose of the referendum were created to avoid potential contradictions among Native Commissioners that could be exposed during meetings between the various groups in the Police Zone.

The Native Commissioners travelled to the locations in February 1946, prior to putting the referendum to a vote, to consult with Namibian leaders and ensure that an affirmative vote could be obtained. Commissioners visited each reserve and consulted with leaders, explaining the nature of the referendum and its consequences. It was clear during these consultations that a "Yes" vote on the referendum was a certainty. A total of 168,491 Namibians, consisting mostly of Ovambos, informed the Commissioners that they intended to vote for incorporation. Another 7,176 Namibians indicated that they would vote against incorporation, while 11,246 remained uncertain of their stance on the issue. The table on the next page highlights how these consultations determined how each reserve intended to vote after the meetings.

\footnotetext{
${ }^{96}$ Ibid.

${ }^{97}$ Ibid.
} 
Table 4.1

Results of Consultations with Non-Europeans in South West Africa RE: Incorporation in the Union

\begin{tabular}{|l|l|l|}
\hline \multicolumn{2}{|c|}{ In Favor Of. } \\
\hline \multicolumn{1}{|c|}{ Native Territory or Reserve } & \multicolumn{1}{c|}{ [Ethnic Group] } & \multicolumn{1}{c|}{ Population } \\
\hline Bondels & {$[$ Nama] } & 700 \\
\hline Western Caprivi Zipfel & Okavangos & 2,797 \\
\hline Franzfontein & {$[$ Nama] } & 433 \\
\hline Hoachanas & {$[$ Nama] } & 280 \\
\hline Kaokoveld & {$[$ Nama and Herero] } & 6,294 \\
\hline Kranzplatz & {$[$ Nama] } & 422 \\
\hline Okavango & Okavangos & 17,682 \\
\hline Ovamboland & Ovambos & 129,763 \\
\hline Okombahe & [Damara] & 1,744 \\
\hline Otjimbingwe & [Damara] (excluding Herero) & 400 \\
\hline Otjituo & Herero & 1,976 \\
\hline Rehoboth & Coloured & 6,000 \\
\hline & & 168,491 \\
\hline
\end{tabular}

\begin{tabular}{|l|l|l|}
\hline \multicolumn{3}{|c|}{ Against. } \\
\hline Aukeigas & {$[$ Damara] } & 519 \\
\hline Berseba & {$[$ Nama $]$} & 2,472 \\
\hline Otjimbingwe & {$[$ Nama $]$} & 530 \\
\hline Otjohorongo & {$[$ Nama $]$} & 2,204 \\
\hline Ovitoto & Herero & 1,020 \\
\hline Soromas & {$[$ Nama $]$} & 431 \\
\hline & & 7,176 \\
\hline
\end{tabular}

\begin{tabular}{|l|l|l|}
\hline \multicolumn{2}{|c|}{ Doubtful. } \\
\hline Aminius & Herero & 2,287 \\
\hline Epukiro & Herero & 3,087 \\
\hline Waterberg East & Herero & 4,493 \\
\hline Tses & Herero & 1,379 \\
\hline & & 11,246 \\
\hline
\end{tabular}

\begin{tabular}{|l|l|}
\hline In Favor of & 168,491 \\
\hline Against & 7,176 \\
\hline Doubtful & 11,246 \\
\hline
\end{tabular}

Source: Results of Consultations with Non-Europeans in South West Africa, RE: Incorporation in[to] the Union, 1946, NAN: Native Commissioner Ovamboland (Hereafter, NAO)/47/1/1.

In April 1946 the Native Commissioners travelled to the locations, read the statements on the referendum, allowed for deliberations, and then put the issue of incorporation into the Union 
to an official vote. The results of the referendum returned overwhelmingly in favor of the incorporation of South West Africa into the Union. Namibians allegedly voted in favor of the referendum, with 208,850 voting in the affirmative and 33,520 voting against incorporation. These results provided Smuts with the statistical evidence he believed was necessary to convince the UN that South West Africa should become the fifth province of the Union. ${ }^{98}$

Smuts formally submitted his request for the incorporation of South West Africa into the Union at the first meeting of the UN General Assembly in October 1946. The request was poorly received and the Indian delegate Mrs. Pandit used the request as an opportunity to attack Smuts and the South African government for the institution of the Asiatic Land Tenure and Indian Representation Act earlier that year. ${ }^{99}$ Smuts later wrote that Pandit's attacks were a "bitter experience" that exposed the author of the preamble of the UN Charter as a "hypocrite and double-faced time server!" ${ }^{100}$ Smuts and his government never recovered from this humiliation with regard to the South West Africa question. After a few months of debate, the UN General Assembly rejected Smuts' proposal for incorporation in December 1946. UN Resolution 65-1 of 14 December 1946 acknowledged that the General Assembly was "unable to accede to incorporation" because the "African inhabitants of South West Africa [had] not yet secured political autonomy or reached a stage of political development enabling them to express a considered opinion which the assembly could recognize on such an important question as

\footnotetext{
${ }^{98}$ E. Ike Udogu, Liberating Namibia: The Long Diplomatic Struggle Between the United Nations and South Africa (Jefferson: McFarland, 2011), 41-43.

${ }_{99}$ Saul Dubow, "Smuts, the United Nations, and the Rhetoric of Race and Rights." Journal of Contemporary History 43, No. 1 (January, 2008): 67. Also known as the "Ghetto Act," the Asiatic Land Tenure and Indian Representation Act sought to "restrict or 'peg' the rights of Indians to purchase land in return for a modicum of indirect political representation."

100 "Smuts to M.C. Gillett, 14 January 1947," in Selections from Smuts Papers: Volume VII, August 1945-October 1950, eds. Jean van der Poel and William Keith Hancock (Cambridge: Cambridge University Press, 2007), Document 764.
} 
incorporation of their territory." ${ }^{101}$ Instead, the General Assembly recommended that the mandate territory be placed under the trusteeship system and allowed for the South African government to "continue to administer the territory... in the spirit of the principles laid down in the $[\mathrm{m}]$ andate." 102

Numerous factors contributed to the failure of Smuts' proposed plan for the incorporation of South West Africa, the most prominent of which was the perceived illegitimacy of the referendum of 1946. Three key factors contributed to the perception of the referendum's illegitimacy. First, delegates at the General Assembly believed that the wording and language of the proposed referendum was ambiguous and misleading. Second, the Native Commissioners' conversations with Namibian leaders on the Union's plans to remain a part of the British Commonwealth were believed to be misleading at best and were thought to have influenced their votes during the referendum. Finally, the delegates of the General Assembly believed that the South African government manipulated the process of the referendum and utilized questionable tactics to achieve their desired result.

The phrase "that we do not wish any other Government or people to rule us" was a central focus of the referendum's critics. The wording of this phrase and the manner in which it was presented to Namibian leaders led them to believe the choice presented in the referendum was binary in nature, an exclusive choice between remaining under Union governance or returning to German rule. ${ }^{103}$ Many leaders feared the possibility of being placed under an

\footnotetext{
${ }^{101}$ UN General Assembly Resolution 65/1, A/RES/The Future Status of South West Africa, A/RES/65/1 (14 December 1946).

102 Ibid.

${ }^{103}$ Officer-in-Charge, Native Affairs, Ohopoho, Kaokoveld to the Secretary for South West Africa, 22 January 1946, NAN: NAO/47/1/1. The fact that some Namibian leaders believed that a return to German rule was a possibility further underlines critics' point that some Namibian leaders possessed a limited understanding of the complex transfer process that accompanied the establishment of the trusteeship system. This lack of understanding is unsurprising as the Native Commissioners provided little in the way of guidance or a genuine explanation of the nature and functions of the newly-created United Nations Organization.
} 
unknown government and the nature of the trusteeship system and its focus on guiding populations to political self-determination went unexplained. Benjamin Kido and Ovahimba Headman Youyouruka's conversations with the Officer-in-Charge of Native Affairs in Kaokoveld in January 1946 highlight this issue. The Officer-in-Charge asked "whether they would prefer any other Government to the present Administration" and Kido responded, "I have heard what you have told us, and I understand. I cannot wish for a Government that I know nothing about or that I have never seen. The Government I have now I know. With it I am satisfied, and I would like to remain under this Government to the last."104 Headman Youyouruka concurred: "I do not want to talk a lot. All the Governments you told me about, I do not know. I know the Government we have at present. It is our Government. We have been under it for a long time. We are satisfied with it and do not want any other."105

Further confusion surrounded the position of the Union of South Africa within the British Commonwealth and the South African government's intention to remain in the Commonwealth. Major Hahn's recollection of conversations with the Witboois at Krantzplatz in 1946 highlight the unclear nature of this issue. Kaptein David Witbooi was hesitant about the prospect of incorporation, stating "I do not know about joining the Union; we are under the English and we always [said] this." ${ }^{\prime 06}$ He further pointed to Hendrik Witbooi's words from the late-nineteenth century, relaying that "If [the gentleman] is the administrator of the English Government I would like to say that old Hendrik Witbooi, who died, told us that we also joined the English Government. It was before the German government came here. I now understand that there are other nations who want to rule [South West Africa]. Our Kaptein said he was under the English

\footnotetext{
104 Ibid.

105 Ibid.

${ }^{106}$ Major Hahn to the Secretary for South West Africa, 10 February 1947, NAN: SWAA/GL37/V1.
} 
Government. The Union Government is also under the English Government and if we say we are under the English Government, we reckon we are under it." ${ }^{\text {"107 }}$ Similar questions arose in the Otjohorongo Native Reserve and at Grootfontein about the nature of the Union's relationship with the British Commonwealth. ${ }^{108}$

The assurances provided to Namibian leaders at the time, that the Union would remain part of the British Commonwealth, proved disingenuous. An excerpt from an administrator in the Omaruru district read, "After about an hour had elapsed they sent for me and told me that they wanted to 'remain' under the English flag. I explained to them that they were being administered by the Union Government, through the South West African Administration, and not by the British Government. I also explained to them that the Union of South Africa was a member of the British Commonwealth of Nations, and that as far as could be foreseen it would continue to remain a member." 109 The impending rise of Malan's NP in the immediate post-war years was a primary concern of Namibian leaders in the territory and there were well-founded fears that incorporation entailed potential oppression under a hostile Afrikaner-led government. The aforementioned administrator in Omaruru recalled that "there seemed to be a fear amongst a section [of Namibians] that the extreme element amongst the Afrikaners in the Union would come into power and would then break away from the British Commonwealth." ${ }^{110}$ Assurances were given to Namibian leaders, but long-standing debates about the "two-stream policy" made it impossible to provide such assurances with any certainty and, given the rise of Malan's antiBritish HNP after the war, such assurances proved untenable.

\footnotetext{
${ }^{107}$ Ibid.

${ }^{108}$ Incorporation... Reply from the Otjohorongo Native Reserve, District Omaruru, 1946, NAN: SWAA/GL37/V6/11.

${ }^{109}$ Ibid.

${ }^{110}$ Ibid.
} 
Coupled with disingenuous information and limited explanations of the true nature of the trusteeship system, delegates were rightly concerned about the South African government's manipulation of the referendum process through nefarious means. While largely speculation at the time, documentary evidence suggests that the General Assembly's delegates' skepticism about the veracity of the referendum was well-founded. A transcript of the confidential Conference of Native Commissioners on 19 January 1946 details how Smuts, the South African government, and the SWAA initially planned to avoid "Natives... unless it was certain that a favorable response would be obtained from them." ${ }^{111}$ Furthermore, concrete efforts were made to monitor potential dissidents and limit their influence within the Police Zone. For example, Fritz Kasuto's activities in Windhoek were closely observed and the SWAA used "native detectives" to track his movements and secretly read his mail. They believed that he was a member of the "red bands" and involved in "...making adverse propaganda amongst the Herero regarding incorporation of the territory." ${ }^{112}$ Despite claims of holding a vote of "free will" among Africans in South West Africa, the South African government actively manipulated the results of the vote and created the most favorable conditions for a "Yes" vote.

These acts of manipulation occurred most frequently in the Police Zone among the populations with the closest ties to sympathetic international actors who could amplify their case for self-determination on the global stage. It should not, however, be assumed that all Namibians who voted "Yes" on the referendum were manipulated or misled by the SWAA. For example, a history of conflict and famine in the Ovambo areas north of the Police Zone led many to believe

\footnotetext{
${ }^{111}$ Conference of Native Commissioners, 19 January 1946, NAN: SWAA/GL37/V1.

${ }^{112}$ Private Secretary, On Her Majesty's Service (O.H.M.S.) to Fritz Kasuto on Incorporation of South West Africa in the Union of South Africa, 1946, NAN: SWAA/GL37/V5. In Werner, "'Playing Soldier"," 502 Kasuto is described as "the leader of the Herero Red-Band Organization...[and] was engaged in advising the old traditional leaders against incorporation."
} 
that incorporation into the Union was socioeconomically beneficial. They believed that becoming the fifth province of the Union ensured protection against cattle raids from populations across the Angola border and that, additionally, there was a real opportunity for legal rights and protections to be extended to Namibians in South West Africa. ${ }^{113}$ This geographical divide in terms of the referendum likely occurred because Ovamboland's colonial experience centered on indirect rule, while the experiences of the Nama, Herero, Damara, and Basters were directly influenced by daily experiences of government/police brutality in the Police Zone. ${ }^{114}$

\section{The Rise of D.F. Malan and the Implementation of Apartheid in South Africa, 1945-1955}

Concerns over the legitimacy of the referendum caused the South African government's attempts at incorporation to fail and, as a consequence, the political position of Jan Smuts and the UP weakened. His opponents seized on this momentum and attacked Smuts' 'temporizing equivocation and perceived weakness on the Colour Question." 115 This tactic was successfully utilized in the 1924 elections when Hertzog used the threat of a "Black peril" to defeat Smuts. The NP repurposed this approach as efforts ramped up for the 1948 General Election. This strategy made it clear that the issue of racial segregation, apartheid, and safeguarding

\footnotetext{
${ }^{113}$ Native Commissioner, Ovamboland to the Secretary for South West Africa, Swakopmund, 7 January 1946, NAN: NAO/47/1/1. The transcript of meeting with Ovambo leaders provides great detail into their motivations for voting "Yes" on the referendum. They point to the constant threats of "famine," "cattle raids," and "death" prior to the Union government arrival, and the comparative period of peace that has ensued north of the Police Zone after the Union's arrival, as primary motivating factors in their decisions.

${ }^{114}$ See collection NAN: NAO/47/1 for a full explanation of the policy of indirect rule that governed Ovamboland during the colonial period.

${ }^{115}$ Saul Dubow, Apartheid, 1948-1994 (London: Oxford University Press, 2014), 7. Following the 1948 election, the HNP merged with the AP and resumed using the shorter "National Party" name. For the purpose of consistency and clarity, this section will refer to both the HNP and NP as the NP for the period covering 1943-1955.
} 
Afrikanerdom from this perceived threat played a crucial role in the outcome of the 1948 election and South Africa's plan to manage race relations in the future. ${ }^{116}$

Malan's approach to South African politics changed markedly after the 1943 General Elections, and he shifted his attention toward a political agenda that the larger white South African electorate embraced. In November 1943, Malan gave a conciliatory speech at Stellenbosch where he recognized the importance of changing the NP's stance on the question of the "two-stream policy" to appeal to more moderate Afrikaners. Whereas in the past Malan and the NP fully-embraced the "Afrikaans-heart” definition of Afrikaner nationalism, Malan's new approach argued that the Afrikaner and English-speaking South African were socially, politically, and economically equal. ${ }^{117}$ While such a stance alienated some of the extremist elements of Afrikanerdom, Malan believed that this position attracted far more Afrikaners from his political left.

Malan's post-election political maneuvering was on full display in May 1944 during the Wakkerstroom by-election. In previous elections, most notably the 1943 General Election, Malan and the NP reached out to their political rivals in an attempt to cooperate and defeat the UP's candidates. A coalition formed between the Greyshirt Movement, the New Order Movement, the $\mathrm{AP}$, and the $\mathrm{OB}$. The coordination between these Afrikaner organizations resulted in the victory of NP candidates over the UP with a majority of 221 votes. ${ }^{118}$ The unity displayed during this election and the fruitful results of the election opened a new chapter in Afrikaner politics and provided a clear blueprint for defeating the UP in future post-war elections.

\footnotetext{
116 Ibid.

${ }^{117}$ Michael Roberts and A.E.G. Trollip, The South African Opposition, 1939-45 (London: Longman's, Green and Co., 1947), 163-165.

118 William Barry White, "The South African Parliamentary Opposition, 1948-1953” PhD diss., (University of Natal, 1989), 321-341. Each of the four parties in this coalition possessed far-right Afrikaner political ideologies or were sympathetic to National Socialism.
} 
The achievement of volkseenheid became the central thrust of Malan's policy formulation in the post-war era. ${ }^{19}$ Afrikaners believed that the only way to achieve volkseenheid was to establish a republic and rid themselves of British influence that was rife in the Union. However, since more moderate Afrikaners still desired a close relationship with Britain for its beneficial trade agreements, Malan, a republican at heart, embraced a more pro-parliamentary approach in the post-war period to attract those moderate Afrikaners that left for the UP in the 1930s and 1940s. The Union functioned essentially as a republic regardless of its label, and Malan's more conciliatory approach to this issue served as an olive branch to the more moderate elements of Afrikanerdom in the hopes of finally unseating Smuts and the UP in the 1948 General Election. $^{120}$

The policy to promote volkseenheid heading into the 1948 General Election consisted of three particular elements meant to appeal to Afrikaners across the political spectrum. First and foremost, the NP's political platform advocated the establishment of schools taught solely in Afrikaans. The goal of these Afrikaans-language schools was clearly the promotion, development, and entrenchment of Afrikaner cultural identity in South Africa. It served to redress many of the ills that plagued Afrikanerdom throughout its history. They believed that "Mother-tongue schools" would reduce illiteracy rates among the poorer elements of Afrikaner society and protect against feared cultural degeneration in the face of a perceived "Black peril."."121

\footnotetext{
119 "National Unity" refers to unity among the whites in South Africa and, in particular, unity among the various branches and ideological strains of South African Afrikanerdom.

${ }^{120}$ G.H. Calpin, "South Africa in Afrikaner Hands," Foreign Affairs 29, No. 3 (April, 1951): 417-420.

${ }^{121}$ Meredith Martin, In the Name of Apartheid: South Africa in the Postwar Period (London: Penguin Books, 1988), $112-114$
} 
In the aftermath of World War II, concerns over the spread of communism were pervasive in South Africa and Malan used fears of both a Red and Black peril to his political advantage to attract support from moderates. The NP included a strong anti-communist platform in their political agenda in order to appeal to the English-speaking whites in South Africa who believed communist infiltration in schools, labor unions, and Black nationalist groups could lead to violence or rebellion. ${ }^{122}$ Similarly, the rise of the Youth League in the ANC was monitored by the South African government as their more militant approach to fighting white oppression increased fears of a Black or Red peril. ${ }^{123}$ The Non-European Unity Movement (NEUM), a Trotskyist organization based on non-racialism and non-collaboration with the South African government emerged most prominently in Cape Town among Coloured activists. ${ }^{124}$ Although the NEUM was highly critical of the ANC and CPSA, their stance of non-collaboration made them a perceived threat to white hegemony in the Union as well. ${ }^{125}$ Malan understood this fear well and manipulated the situation to his political benefit.

Lastly, the NP embraced the concept of apartheid as a key component of its political campaign and efforts to reunite the disparate elements of Afrikaner society. During World War II, factories in South Africa expanded to meet the production demands of the Union government for the war effort. The increase in factory jobs ultimately drew Africans from rural areas to the cities and brought them into close contact with whites. This close proximity increased competition for jobs and impacted the wages whites could obtain. The labor strikes and clashes

\footnotetext{
${ }^{122}$ Gail M. Gerhart, Black Power in South Africa: The Evolution of an Ideology (Berkeley: University of California Press, 1979), 45-84.

${ }^{123}$ Iris Berger, South Africa in World History, (London: Oxford University Press, 2009), 112. The Youth League's manifesto was highly critical of the ANC and the role of elites in the organization. They supported a message of strong African-nationalism and self-determination. Although some have pointed to the Youth League and ANC as harboring Communist sympathies, Berger contends that the Youth League rejected the Communists' focus on class conflict and believed that oppression in South Africa was based largely on one's race.

${ }^{124}$ Ibid., 112-113.

${ }^{125}$ Ibid., 113.
} 
that ensued following increased African urbanization in the 1940s only added to these fears, as nearly half of the population lived in urban areas. The government was fearful that the races living in such close proximity could result in the collapse of white hegemony over the economy and industrial labor in particular. ${ }^{126}$

The increased urbanization of Africans in the 1940s brought Blacks and whites into ever closer proximity, re-igniting fears of cultural degeneration that permeated the Afrikaner discourse between the 1870s and 1940s. ${ }^{127}$ Apartheid, the Afrikaans word for "separateness," sought to segregate the white, Coloured, Asian, and Black parts of society and allow them to develop separately along different lines. In its practical implementation, the implications were clear. Apartheid provided a perceived safeguard for white society and Afrikaner culture against a Black peril represented by the influx of Black Africans into the urban areas of South Africa. ${ }^{128}$

The centrality of apartheid to the political landscape was reinforced in 1946 and 1947 when the dueling Fagan and Sauer Commissions were appointed to tackle the problems of African urbanization. The UP-led government created the Fagan Commission in 1946 and sought to resolve the problem of African urbanization through liberal means. The Fagan Report recommended an approach of limited state intervention through the creation of advisory labor bureaus that made recommendations to facilitate the regulation of African urbanization. The report found the concept of "total territorial segregation" to be impractical and instead sought to

\footnotetext{
${ }^{126}$ Nancy L. Clark, "South Africa: Industry, Labor, Urbanization, 1940-1946," in Encyclopedia of African History, Volume I, ed. Kevin Shillington (Oxfordshire: Taylor and Francis, 2013), 1439-1440.

${ }^{127}$ David M. Smith, The Apartheid City and Beyond: Urbanization and Social Change in South Africa (New York: Routledge, 2003), 1-10.

128 J. Kevin Livingston, A Missiology of the Road: Perspectives in David Bosch's Theology of Mission and Evangelism (Cambridge: James Clarke \& Co., Ltd., 2013), 4-7.
} 
implement less rigid pass laws that allowed for the creation of a reliable and stable African labor source in the urban areas. ${ }^{129}$

Unsurprisingly, the NP created the Sauer Commission in 1947 to counteract the claims of the UP and the Fagan Commission Report. The Sauer Commission Report argued for the eventual implementation of "total apartheid" and for a complete separation of whites and Africans. This approach also employed labor bureaus but relied on heavy state intervention and control of these institutions as a means to reverse African urbanization completely. Such a process called for the creation of ethnically-based governments in the reserves and the complete removal of African laborers from white industries. ${ }^{130}$ These two approaches to racial relations came to define the UP and NP platforms heading into the 1948 General Election and provided voters with a distinct choice on the future of the Union.

The 1948 General Election pitted Malan’s Afrikaner-dominated NP against a weakened Smuts and his UP. The NP's cooperation with its former adversaries, namely the AP, the OB,

\footnotetext{
${ }^{129}$ Ivan Evans, Bureaucracy and Race: Native Administration in South Africa (Berkeley: University of California Press, 1997), 58-59. The Fagan report was more inclusive in its approach to the problem of African urbanization and the solutions it proposed. The Fagan report contended that total territorial segregation was impractical and also contended that heavy state intervention in urban native administration was unnecessary. Instead, the Fagan report called for municipalities, rather than the central government to regulate urban contacts and encounters. The goal was ultimately to find an appropriate balance between resident Africans and migrant Africans in the city and use labor bureaus to regulate, rather than completely halt the urbanization process. In theory, this would introduce a transitional segregation, whereby "race would erode away as an organizing principal in South Africa." The Sauer report conversely approached the issue of apartheid from an exclusive perspective. The Sauer report argued for strong state intervention and the complete reversal of African urbanization. Rather than finding ways to manage contacts and urbanization, the goal of the Sauer report was, over a lengthy period, to remove African laborers from white industries and socially, spatially, and politically remove urban Africans from the cities. Thus, one report advocated for regulation and participation by Africans in the urban areas while the other pushed for their complete removal.

${ }^{130}$ Ibid., 60-61. The South African reserve policy emerged with the ratification of the Natives Land Act of 1913 and the Native Trust and Land Act of 1936, which allocated 7.1\% and 13.6\% of South Africa's total land to the Black majority that constituted nearly $75 \%$ of the total population. The introduction of the 1959 Promotion of Bantu SelfGovernment Act re-designated the reserves as "homelands" or Bantustans, which forced Blacks onto ethnicallydesignated tracts of lands. This allowed for the forcible removal of Blacks from "white areas" in South Africa and solidified the separateness of apartheid in the Union. The later Bantu Homelands Citizenship Act of 1970 effectively placed Blacks under "tribal" governance structures and stripped them of their South African citizenship and civil rights.
} 
and now-sympathetic Afrikaner moderates, proved successful in the General Election. The NP won 70 seats in the election and the allied AP won another nine seats. Conversely, the UP lost 24 seats during the election and ended up with only 65 seats. Likewise, the Labor Party managed to win six seats. ${ }^{131}$ The results of the election provided the NP with a mandate to further implement the recommendations of the Sauer Report and install the necessary government infrastructure to create the "total apartheid" the Report envisioned.

The NP implemented apartheid beginning in the late 1940s, crafting new legislation to deal with the fluid issue of race relations in the Union and amending or adding to current segregationist legislation. These apartheid policies simultaneously attempted to create total separation between whites and Africans in three spheres: territorially, socially, and politically. Attempts to institutionalize the physical and territorial separation began with the implementation of the Population Registration Act in 1950. This act classified the South African population into four separate racial categories based on their physical appearance. The South African government issued identity cards that listed a person's race, as well as their physical description, an identity number, and "the tribe to which he belongs."132 The Group Areas Act was implemented later that year and combined with the identity cards created by the Population Registration Act, worked to territorially segregate the South African population. This act limited transactions in land between whites and Blacks and separated Blacks and Coloureds into their own separate reserves to allow for separate development. ${ }^{133}$ Furthermore, in 1951 the NP-led

\footnotetext{
${ }^{131}$ Ian Loveland, By Due Process of Law: Racial Discrimination and the Right to Vote in South Africa, 1855-1960 (London: Bloomsbury Publishing, 1999), 229.

${ }^{132}$ Elizabeth S. Landis, "South African Apartheid Legislation I: Fundamental Structure," The Yale Law Journal 71, No. 1 (November, 1961): 1-14.

${ }^{133}$ Alan Mabin, "Comprehensive Segregation: The Origins of the Group Areas Act and Its Planning Apparatuses," Journal of Southern African Studies 18, No. 2 (June, 1992): 405-429. Mabin's work details the role that urbanization played in the formulation of the Group Areas Act and the role it played in entrenching strict segregation in South African society.
} 
government passed the Prevention of Illegal Squatting Act. The NP sought to fulfill its promise of eliminating African urbanization by allowing for the forcible removal of squatter communities and the demolition of Black shanty towns in urban and rural areas. ${ }^{134}$

The apartheid legislation for the social sphere sought to safeguard Afrikaner cultural purity by protecting against the pervasive Black peril and the accompanying "cultural degeneration" that came with close proximity between the races. The South African government passed the Prohibition of Mixed Marriages Act in 1949 and made it illegal for any white person to enter into a marriage with a Black or Coloured person. Additionally, the Immorality Act of 1927 was amended in 1950. The new amendment to the act extended the prohibition on interracial intercourse between whites and Africans to encompass all "non-Europeans," including Coloureds and Asians. ${ }^{135}$ These policies sought to prevent not only biological "degeneration," but also the perceived implications that interracial marriages and offspring would have on South Africa's cultural fabric.

Finally, the South African government sought to further disenfranchise Coloureds and Indians in an attempt to create a white monopoly on South African politics. In 1950, the government passed the Suppression of Communism Act and outlawed the CPSA and any other organizations that aimed to "[encourage feelings] of hostility between the European and nonEuropean races of the Union." ${ }^{136}$ This act gave the government the ability to "[declare]...organizations promoting communistic activities to be unlawful and [prohibit] certain

\footnotetext{
${ }^{134}$ T. Davenport and C. Saunders, South Africa: A Modern History (New York: Springer, 2000), 599-601.

${ }^{135}$ Pierre L. van den Berghe, "Miscegenation in South Africa," Cahiers d'Etudes Africaines 1, No. 4 (December, 1960): 71-82. Van den Berghe provides a detailed examination of the Immorality Act's evolution over a period of three decades. In 1957 this Act was amended another time and included a penalty of up to 7 years in prison for anyone who engaged in interracial intercourse or prostitution, as well as any other immoral or indecent acts between whites and non-whites.

${ }^{136}$ Union of South Africa, Statutes of the Union of South Africa (Cape Town: Government Printer, 1950), 549.
} 
periodical or other publications [and] to prohibit certain communistic activities." ${ }^{137}$ The specter of communism played an important role in winning moderate Afrikaners to the side of Malan's NP. However, in its South African context, the act was aimed at the numerous Black revolutionary groups that embraced aspects of a communist or socialist ideology. The aforementioned Youth League of the ANC and the NEUM proved particularly worrisome to the South African government and this act provided them with the opportunity to label people engaged in political activism as communists. African calls for political participation and for changes in the political, economic, or social spheres would be dismissed as attempts to cause disharmony between the races.

Coloureds were further disenfranchised by the NP-led government. Malan introduced the Separate Representation of Voters Bill in 1951. The act effectively removed all non-whites from the voter roll and revoked the Cape Qualified Franchise system. ${ }^{138}$ Although ruled unconstitutional in 1952, the South Africa Act Amendment Act was passed in March 1956 and overturned the Supreme Court's ruling. ${ }^{139}$ Under this system, Coloured voters in the Cape Province participated in segregated elections and were only allowed to elect four members to Parliament. Blacks were still barred from participation in elections at this time, and there were numerous debates surrounding the participation of South Africa's sizable Indian population during this period. Through all of these separate pieces of legislation, the South African government was able to create a highly-sophisticated and all-encompassing system of apartheid that physically, socially, and politically isolated the various races of South Africa.

\footnotetext{
137 Ibid.

${ }^{138}$ Loveland, Due Process, 260-274. Cape Qualified Franchise first appeared in the Cape in 1853. It was premised on non-racial voter rolls and the political participation of men irrespective of race.

139 The South Africa Act Amendment Act, Act No. 9 of 1956 overturned the Court's previous decision that the Separate Representation of Voters Bill was unconstitutional. It read, "The Separate Representation of Voters Act, 1951 (Act. No 46 of 1951), published under Government Notice No. 1498 of the eighteenth day of June, 1951, shall have the force of law with effect from the date of commencement of this Act..."
} 


\section{De Facto Incorporation and the Introduction of Apartheid in South West Africa, 1949-1964}

While apartheid was entrenched in South Africa during the late 1940s and 1950s, it developed and emerged more slowly in South West Africa. Due to the close political links between South Africa and South West Africa, the NPSWA saw an increase in popularity and power following the Malan-led NP's victory in the 1948 General Election and, as a result, the issue of the implementation of apartheid in South West Africa came to the fore. Since its reemergence in 1939, the NPSWA actively courted the territory's sizable German-speaking population to increase its political influence. The NPSWA initially fared much better than the UNSWP among South West Africa's German-speakers because, much like its counterpart in the Union, the NPSWA vehemently opposed participation in World War II on the side of the British government. Also, in a move similar to the Union NP, the NPSWA opposed the expulsion of the territory's Germans in 1948 and, instead, advocated that these Germans be granted South African citizenship. The NPSWA also proved markedly more sympathetic to German-speakers' demands for German Language rights than the UNSWP, thus contributing to the NPSWA's improved political standing among the territory's white population. ${ }^{140}$

Germans in South West Africa viewed Malan and the Union NP as accommodating to the needs and demands of German-speakers in both the Union and South West Africa. Since the NPSWA was, for all intents and purposes a branch of the Union NP, Germans viewed the NPSWA as a mechanism through which they could safeguard Germans' racial privileges in the territory and simultaneously preserve their cultural-linguistic profile. ${ }^{141}$ Smuts' failure to successfully incorporate South West Africa as a fifth province in 1946 and the UNSWP's

\footnotetext{
${ }^{140}$ Kossler, Namibia and Germany, 108-110.

${ }^{141}$ Ibid., 108.
} 
subsequent opposition to incorporation only further weakened the position of the UNSWP among Afrikaners who whole-heartedly supported, and even demanded, incorporation into the Union. In 1949, Malan moved to solidify the standing of the NP in South West Africa by granting the territory's whites direct representation in the South African Parliament and de facto incorporating the territory into the Union.

De facto incorporation was finally achieved in 1949 with the passage of the South West Africa Affairs Amendment Act. Under this Act, the Advisory Council was abolished, and South West Africa's white electorate was granted the right of direct representation to the South African Parliament. The Union granted the territory's whites six seats in the South African House of Representatives and another four seats in the Senate. Only Europeans over the age of eighteen could participate in the elections and, furthermore, issues pertaining to Native Affairs were reserved for the Union government. ${ }^{142}$ The move further repudiated the UN's demands for the territory to be placed under the trusteeship system and facilitated the implementation and entrenchment of the apartheid apparatus in South West Africa. The introduction of the aforementioned act also proved a successful political maneuver for Malan because he provided the territory's whites with the close political linkage to the Union that they desired and, as a result, essentially gained 10 reliable NP seats across the Senate and House of Representatives. ${ }^{143}$ The immediate impact of the passage of the South West Africa Affairs Act on domestic South West African politics was readily apparent in the 1950 Legislative Election. In 1945, the

\footnotetext{
${ }^{142}$ Carol Anderson, “International Conscience, the Cold War, and Apartheid: The NAACP's Alliance with the Reverend Michael Scott for South West Africa's Liberation, 1946-1951," Journal of World History 19, No. 3 (September, 2008): 313-315.

${ }^{143}$ These six South West African seats were important to the NP and strengthened their majority in the government. In 1953 the NP won a total of 86 of the 159 seats and 96 of the 159 in 1958. The six South West African seats ensured the NP had an absolute majority in the House of Assembly and gave the party some room to maneuver if any party members defected. Additionally, this meant that the NP did not need to form a coalition in order to run the government and they could pursue their party platform more vigorously.
} 
NPSWA failed to win a single seat in the election and only secured two seats by administerial appointment. However, with its newfound popularity and close links to the Union's NP, the NPSWA won $55 \%$ of the vote and secured 15 of the 18 seats in the Legislative Assembly. Conversely, the UNSWP received $45 \%$ of the vote and only procured three seats in the Assembly. ${ }^{144}$ This significant majority would continue until the 1978 Legislative Election, with the NPSWA never losing more than three seats in any election during that period.

The success of the NPSWA in the territory allowed for Afrikaners and German-speakers to work cooperatively on their most significant point of agreeance: apartheid. As the previous section detailed, the Union government passed a robust amount of apartheid legislation in South Africa to combat the perceived threats of rapid African urbanization, popular resistance, and white cultural degeneration. However, in South West Africa, apartheid developed much more slowly as a result of a different socioeconomic context. As Marion Wallace argued in A History of Namibia, African urbanization occurred to a lesser degree in South West Africa than in South Africa. Likewise, there were less robust challenges to the state in South West Africa during the interwar years. ${ }^{145}$ The segregationist policies discussed at length in chapter 2 mostly remained in place into the 1940s. This meant that "de facto control was already applied through informal segregation," and that allowed for formal apartheid to develop more slowly in South West Africa since effective mechanisms were already in place to limit and control interaction between the races. ${ }^{146}$

Although the South African government reserved the right to extend any piece of apartheid legislation to South West Africa, the existence of informal segregation meant that not

\footnotetext{
144 Ngavirue, Political Parties, 302.

${ }^{145}$ Wallace, History of Namibia, 251. Wallace contended that between 1946 and 1955, South West Africa's urban Black population grew from 30,000 to 49,000 .

146 Ibid., 252.
} 
all legislation created in the Union needed to transfer to South West Africa to maintain control over the Black population. The Population Registration Act of 1950 is perhaps the best example of South African apartheid legislation not extending to the territory. In the Union, the act required people to be registered under one of the four races from birth based on their appearance. Such a system already existed in South West Africa and, as a result, such legislation was not extended as part of the formal apartheid apparatus. ${ }^{147}$ However, such informal practices still played a significant role in promoting and maintaining the racial separateness demanded of the apartheid system.

Instead of direct transference, apartheid in the territory was implemented through three types of legislation: constitutional laws, security legislation, and ordinances imposing racial segregation. ${ }^{148}$ One of the key pieces of apartheid legislation passed in South West Africa during the 1950s was the Natives (Urban Areas) Proclamation of 1951, which effectively limited African mobility through the creation of segregated towns and attempted to create reliable and controllable labor pools for whites. ${ }^{149}$ The Prohibition of Mixed Marriages Ordinance of 1953 was similar to the Mixed Marriages Act passed in the Union in 1949 and prevented marriage between whites and non-whites in the territory. The Education Ordinance of 1962 essentially institutionalized Bantu education in South West Africa and was quite similar to the Bantu Education Act of 1953 that was passed in the Union. ${ }^{150}$ This type of education intended to provide Namibians with just enough knowledge to successfully participate in low-level skilled labor, while simultaneously excluding them from enough education to significantly improve their

\footnotetext{
${ }^{147}$ Ibid., 251-252.

148 Ibid.

${ }^{149}$ Similar legislation was passed earlier in South West Africa with the Native (Urban Areas) Proclamation of 1924.

${ }^{150}$ The Bantu Education Act of 1953 legalized the segregation of schools and educational facilities. This act centralized the power of the state over schools and a number of missionary schools lost their relative autonomy. State funding of Black schools became contingent upon acceptance of the government-sponsored racist curriculum intended to educationally underdevelop Africans and funnel them into unskilled low-wage labor jobs.
} 
socioeconomic standing. ${ }^{151}$ These pieces of legislation worked to socially segregate South West Africa's Black population from whites and preserve the cultural identity that was so valued by both the Germans and Afrikaners.

Legislation focused on territorial and spatial segregation also proved essential to the extension of apartheid in South West Africa. Town planning ordinances played a crucial role in the segregation of urban spaces. Wallace, again, highlighted this process, writing, "The urban areas legislation and subsequent town planning ordinances also set up new means of enforcing spatial apartheid in the towns, using the title deeds of individual properties to prevent land in 'white' and 'Coloured' areas being sold to Africans.". ${ }^{152}$ In effect, this type of legislation "created a very small African urban elite with rights to remain in the towns, while the majority of the Black population were conceived as a transient proletariat." ${ }^{153}$ Further limiting Namibians' physical and economic mobility, the SWAA passed the Industrial Conciliation Act in 1952 and prevented Namibians from joining labor and trade unions. This move limited Namibians' abilities to resist unfair and exploitative working conditions imposed by the territory's white business class and worsened the socioeconomic condition of most Namibians in South West Africa. ${ }^{154}$

The rural parts of South West Africa also experienced the heavy hand of apartheid in the 1950s. In 1954, the Union government passed the South West Africa Native Affairs Administration Act which vested the Minister of Native Affairs with decision-making power

\footnotetext{
${ }^{151}$ For a more in-depth discussion of the Education Ordinance of 1962 and its relation to Bantu Education, see A. Mauno Mbamba, A Diagnostic Analysis of the Education System in Namibia (Paris: UNESCO International Institute for Educational Planning, 2011), 30-33.

152 Wallace, A History of Namibia, 252.

${ }^{153}$ Ibid.

${ }^{154}$ Ibid., For more on apartheid legislation in South West Africa, see Ngavirue, Political Parties, 235-236 and Muriel Horrell, South-West Africa (Johannesburg: South Africa Institute of Race Relations, 1967).
} 
over issues concerning South West Africa's Namibian population. ${ }^{155}$ The Act was placed into effect in the territory through the South West Africa Native Affairs Administration Ordinance of 1955. ${ }^{156}$ The Native Affairs Department (NAD) under H.F. Verwoerd quickly implemented a plan that re-established reserves in South West Africa and used forced removals to clear fertile land and urban spaces for new white settlement. Whereas reserves in South West Africa initially consisted of various ethnic groups to prevent the re-constitution of precolonial political structures, the NAD constructed new reserves based on ethnic identity to more closely mirror the "homeland" policy in the Union. ${ }^{157}$ In their totality, these efforts funneled South West Africa's sizable rural population onto small arid pieces of land that were agriculturally poor, thus forcing them into the migrant labor system to work on white-owned farms and in mines.

The extension of apartheid in South West Africa became more salient in 1963-64 with the issuing of the Odendaal Commission's Report of the Commission of Enquiry into South-West Africa Affairs, 1962-1963. The Commission's goal was to find the most effective way to promote the separate development of Namibians in the territory and to extend its "homeland" policy to South West Africa. ${ }^{158}$ The Odendaal Commission recommended in 1964 that a homeland "must be created for each population group, in which it alone had residential, political, and language rights to the exclusion of other population groups." ${ }^{\prime 159}$ Such a policy necessitated the use of

\footnotetext{
${ }^{155}$ Union of South Africa, Statutes of the Union of South Africa (Cape Town: Government Printer, 1954), 559-564. The text of this act reads, "To provide for the transfer of the administration of native affairs and matters specially affecting natives from the Administrator of the territory of South-West Africa, acting under the direction and control of the Governor-General, to the Minister of Native Affairs, for the reservation or setting apart of land for the use and occupation of natives in that territory in substitution for any other land so reserved or set apart, and for matters incidental thereto."

${ }^{156}$ SWAA, Official Gazette Extraordinary of South West Africa, No. 1899, 28 April 1955, 346-358.

${ }^{157}$ Reinhart Kossler, "From Reserve to Homeland," 447-462. Kossler provides a thorough examination of the theoretical and legislative shifts that occurred in Namibia during the 1950s and 1960s that transformed Namibia's Reserves to more closely resemble the South African homelands and bantustans.

${ }^{158}$ Amy Vandenbosch, South Africa and the World: The Foreign Policy of Apartheid (Lexington: University Press of Kentucky, 1970), 222-223.

${ }^{159}$ Republic of South Africa, Report of the Commission of Enquiry into South-West Africa Affairs, 1962-1963

(Pretoria: Government Printer, 1964), 55.
} 
forced removals of Namibian populations from fertile and desired lands and led to the development of eleven separate ethnic homelands in South West Africa. Although apartheid was de facto extended to South West Africa through the aforementioned policies and legislation, the Odendaal report officially extended the strict legal apparatus of apartheid to the territory and entrenched socioeconomic and spatial segregation. This set the stage for a series of confrontations between the South African government, Namibians, and transnational actors in the post-World War II era.

\section{$\underline{\text { Conclusion }}$}

Malan's political maneuvering during the 1940s led to the NP's dominance in post-war South Africa and South West Africa. While Smuts looked outward in an attempt to fulfill his vision of Greater South Africa, Malan turned inward and exerted all of his effort to unite the disparate and ideologically-opposed parts of Afrikanerdom under the ideology of apartheid. Following the recommendations of the Sauer Commission report, Malan and the NP established and implemented an apartheid legal apparatus. The NP blunted the rapid African urbanization occurring in the Union by developing legislation to separate whites, Africans, Coloureds, and Asians in the political, social, and economic spheres. Legislation like the Bantu Education Act of 1953 and the Immorality Act of 1950 severely disadvantaged South Africa's Black population and entrenched the apartheid system at all levels of life.

Malan's victory in the 1948 General Election and his accommodationist stance toward German-speakers in South West Africa led to a rise in popularity for the NPSWA as well. The NPSWA's success in the 1950 Legislative Elections and the ratification of the South West Africa Affairs Amendment Act of 1949 de facto incorporated the territory into the Union and cleared 
the way for the entrenchment of apartheid in South West Africa. Apartheid developed more slowly in South West Africa than in the Union and it relied heavily on the segregationist policies implemented during the interwar years under the League of Nations mandate. Yet, it proved highly effective at separating the races and limiting the political, educational, economic, and social opportunities for Namibians in the territory.

Conversely, the South African government's repudiation of the UN's demand that South West Africa be placed under the trusteeship system only increased international interest and scrutiny in the treatment of Namibians at the hands of the SWAA and Union government. Whereas apartheid legislation closed off official and legitimate channels for Namibians to make claims of the Union government, Namibians found new opportunities in the relationships they cultivated with sympathetic transnational actors. Namibian leaders called upon historical linkages and networks to use transnational institutions and actors to pressure the colonial regime and seek recourse for the state's abuses of the Namibian population. The following chapters examine the role of three particular transnational organizations in the development of Namibians' resistance strategies in the post-war period: the African Methodist Episcopal Church, the United Nations, and international student organizations. These organizations, much like those engaged with the Basters and Herero during the interwar years, functioned on the margins of South African governmental recourse and provided Namibians with alternative strategies for moderating and changing oppressive policies implemented between 1946 and 1960. 


\section{Chapter 5-"They Do Not Want to be Dominated and Suppressed by Europeans in Church Affairs:" The Nama Secession of 1946 and the Rise of the AME Church in South West Africa}

The victory of the South African NP in the 1948 General Election allowed the government to implement and expand its apartheid policies throughout the 1950s and 1960s. The extension of some South African apartheid policies to South West Africa began in the late 1940s as the NP government in both South Africa and the territory sought to protect white society from the perceived threat of cultural degeneration and African urbanization. This protection was achieved through the strict enforcement of territorial, social, political, and economic segregation. The NP's apartheid government espoused the development of different racial groups along separate lines and entrenched a system of homelands and reserves in both South Africa and South West Africa. This policy often meant inadequate facilities and services for Africans and it severely limited their socioeconomic and political opportunities in the post-war years.

Throughout the 1950s, for example, the NP government attempted to create a minimallyskilled and immobile Black labor force that would provide cheap wage labor for white-owned farms, mines, and businesses. ${ }^{1}$ As a result, Namibians faced chronic and systemic educational underdevelopment. This educational underdevelopment entailed limited class schedules devoid of courses related to non-labor occupations, a restriction on classes above Standard II, a lack of

\footnotetext{
${ }^{1}$ The Ovambo that lived in South West Africa were forced into the migratory labor system and funneled to the mines and industrial centers in the territory and South Africa. In the Police Zone, the primary goal of educational underdevelopment was to provide Namibians with the necessary vocational skills to perform basic agricultural labor on white farms. The intent was to control Namibian movement and labor, harness it toward the colonial state's ends, and force Namibians into the capitalist economy through legislation like the Vagrancy Proclamation and the Masters and Servants Act that criminalized those who refused. The NP's legislation effectively reified an already operational industrial color bar that was brought into existence in South Africa through the Industrial Conciliation Acts of 1924 and 1934. The color bar prevented Africans from securing skilled industrial jobs, protected white employees from undercutting and competition from Africans in the labor market, and established industrial boards and trade unions that allowed whites to negotiate in favor of their own interests. Africans were not allowed to participate in these boards or unions as they were not recognized as workers. The industrial color bar effectively worked in Namibia as well, funneling Africans into systems of migratory mine labor and manual agricultural labor.
} 
African teachers, and minimal government investment to improve the educational environment. This systemic underdevelopment of the education system and infrastructure in South West Africa first occurred at the hands of the RMS, which had a longstanding reputation as oppressors and state collaborators in the territory. As apartheid became more entrenched, educational underdevelopment happened through the introduction and standardization of Bantu Education in South West Africa by the SWAA. To resist this social underdevelopment, an extension of apartheid, Namibian leaders in the Police Zone turned to the AME Church in 1946, a transnational institution grounded in an Ethiopianist Black liberation theology and emancipatory ethos.

The AME Church's determination to achieve racial uplift and economic self-sufficiency through Black-led education matched the needs and demands of Namibians in the territory at the time. Through the AME Church, its Black liberation theology, and transnational resource pool, Namibians recognized the opportunity to improve their own socioeconomic position and gain back some of the control in their daily lives that was wrested from them by the RMS and the SWAA. Mission educated Namibians, who often served as communities' political leaders, continued to face mission- and state-sanctioned limitations to their upward mobility within the church and, more broadly, limits to their larger socioeconomic and political mobility under the SWAA and RMS. These Namibians were barred from being ordained within the RMS, unable to tend to the financial and spiritual needs of their Namibian congregations and restricted in their opportunities to teach at the mission-run schools. The AME Church's arrival in the territory provided new avenues, outside of the colonial state and RMS, to seek some level of personal and community autonomy in both worldly and spiritual matters to resist the crushingly dehumanizing effects of the apartheid apparatus. 
This chapter argues that due to the state's persistence in its policies of educational underdevelopment and its lack of responsiveness to Namibians' claims for increased educational standards, Namibians turned to transnational actors and institutions to leverage international resources and political pressure to alter the colonial state's behavior. In the Police Zone the primary transnational institution with the international reputation, resources, and familiarity with the South African government to effect change was the AME Church. The AME Church, renowned for its establishment of Black-led schools and its espousal of a message of racial uplift, was known to the Nama in the early nineteenth century. It is argued that these early relationships, established by Hendrik Witbooi, created the necessary channels and circuits through which transnational actors and resources circulated from the United States to South Africa, and finally into South West Africa to give the Nama the ability to resist the colonial state's attempts at educational and economic underdevelopment. Although the AME Church's activities in the territory were inclusive of all Namibians, by the 1950s the resistance strategy surrounding the AME Church became an almost exclusively Nama undertaking. Thus, the transnational resistance strategies involving the AME Church in South West Africa took on a fundamentally subnational character during this decade and presented the Nama with new avenues to make claims to the colonial state for the improvement of their everyday material and spiritual lives.

These resistance strategies, although subnational and largely exclusive to the Nama congregations, sought inclusion in the colonial sphere. Despite seeking independence in church and spiritual affairs, the Nama congregations and their leaders pursued improvements to colonial education standards within the existent framework. Likewise, in order to more effectively create, staff, and maintain schools, AME leaders pursued state recognition for the AME schools so that funds could be secured for the "feeding schemes" and permits obtained to legally construct 
schools and churches. Although a long and trying process, by the 1950s the AME congregations in the Police Zone received a number of permits to construct schools and experienced some success in their efforts to secure state recognition for their schools and mitigated the educational underdevelopment caused by nearly 70 years of colonial rule.

\section{The Problematic Relationship Between the RMS and the Colonial Government, 1828-1921}

The origins of the Nama Secession of 1946 are found in the problematic and often tense relationship that developed between Namibians and missionaries in South West Africa from 1828 to 1946. Tracking the development of missionary activity in South West Africa during this period highlights the complex nature of the relationships created between the RMS and the Nama and illuminates the weaknesses in the missionaries' approach that led to a rise in internal dissatisfaction among the Nama congregations. The RMS was founded in Germany in 1828 when three missionary societies merged. John Philip, the superintendent of the LMS in South Africa, submitted a request for missionaries to come to South Africa shortly after the RMS's inception in Germany. The RMS responded to this request and established its first mission in South Africa in $1832 .^{2}$

The RMS received a boost in its missionary efforts when Jonker Afrikaner requested a missionary from the RMS and Wesleyan Missionary Society in $1840-41 .{ }^{3}$ Heinrich Vedder

\footnotetext{
${ }^{2}$ G.L. Buys and S.V.V. Nambala, History of the Church in Namibia, 1805-1990 (Windhoek: Gamsberg Macmillan, 2003), 17.

${ }^{3}$ The LMS established a mission at Bethanie, but in 1840, transferred the rights for the mission to the RMS. The Wesleyans also conducted missionary work in Bethanie beginning in 1834. Jonker Afrikaner became the fourth captain of the Oorlam after succeeding his father Jager Afrikaner in 1823. Afrikaner and his followers were highly active in raiding cattle from the Nama and Damara but he was particularly effective against the Herero. In 1840, he established Windhoek as his capital further challenging the Herero. Afrikaner's military and political success provided him with significant influence in the region and, as a result, missionaries needed to curry his favor in order to operate in the central part of the territory.
} 
recounted this important moment, writing, "[O]n the [4 March 1841], the Society passed a unanimous resolution to send the missionary, Hugo Hahn...with instructions that he should settle in Bethanie... with Heinrich Kleinschmidt." ${ }^{4}$ The missionaries arrived in Windhoek on 9 December 1842 and involved themselves immediately in local Namibian politics. One of the missionaries' earliest political entanglements involved the provision of aid to Afrikaner in order to secure a peace treaty in $1842 .{ }^{5}$ Despite this help, Afrikaner initially refused to allow the RMS and its missionaries to penetrate into Nama and Herero lands. However, in 1844 Afrikaner chose to retain the Wesleyan missionaries at Windhoek and allow the RMS missionaries to continue onward to work among the Nama populations. ${ }^{6}$ RMS mission stations proliferated in Great Namaqualand in the aftermath of this decision. ${ }^{7}$

RMS missionaries focused on the religious sphere during these early years despite some inevitable involvement in political affairs. For example, Johann Krolein studied the Nama language extensively at Berseba in the 1850s and successfully generated religious texts, textbooks, and dictionaries in Khoekhoe. Another missionary, Johannes Olpp, built a church at Gibeon and worked to convert the Nama to Christianity with success among the Witbooi. ${ }^{8}$ Regardless of the particular missionary or mission station, the missionary enterprise in South

\footnotetext{
${ }^{4}$ Heinrich Vedder, South West Africa in Early Times: Being the Story of South West Africa Up to the Date of Maharero's Death in 1890 (London: CASS Publishing, 1966), 220-221.

${ }^{5}$ The Christmas Peace of 1842 was crafted and signed by two agents of the RMS. The successful years following the peace resulted in a rise in the activities of the Wesleyan missionaries and increased RMS activity in Windhoek. Despite their role in the peace, the RMS missionaries experienced difficulties establishing themselves among Afrikaner's followers.

${ }^{6}$ Buys and Nambala, History of the Church, 17-18. Afrikaner and missionary Carl Hugo Hahn of the RMS had an often contentious relationship. When the Wesleyans and the RMS came into conflict in Windhoek in the 1840s, Afrikaner backed the Wesleyans to remain.

${ }^{7}$ Wallace, History of Namibia, 59-67. RMS missions appeared at Rehoboth and Rooibank (1845), Berseba (1850), Gibeon (1863), Keetmanshoop (1866), and Warmbad (1867). Great Namaqualand was the term used by South Africans to refer to the southern half of South West Africa that was largely inhabited by the Nama. It was divided from Little Namaqualand by the Orange River.

${ }^{8}$ Buys and Nambala, History of the Church, 22-23.
} 
West Africa possessed a common goal: to "civilize" the African populations of South West Africa.

Map 4: Locations of Proposed AME Schools in 1950s South West Africa

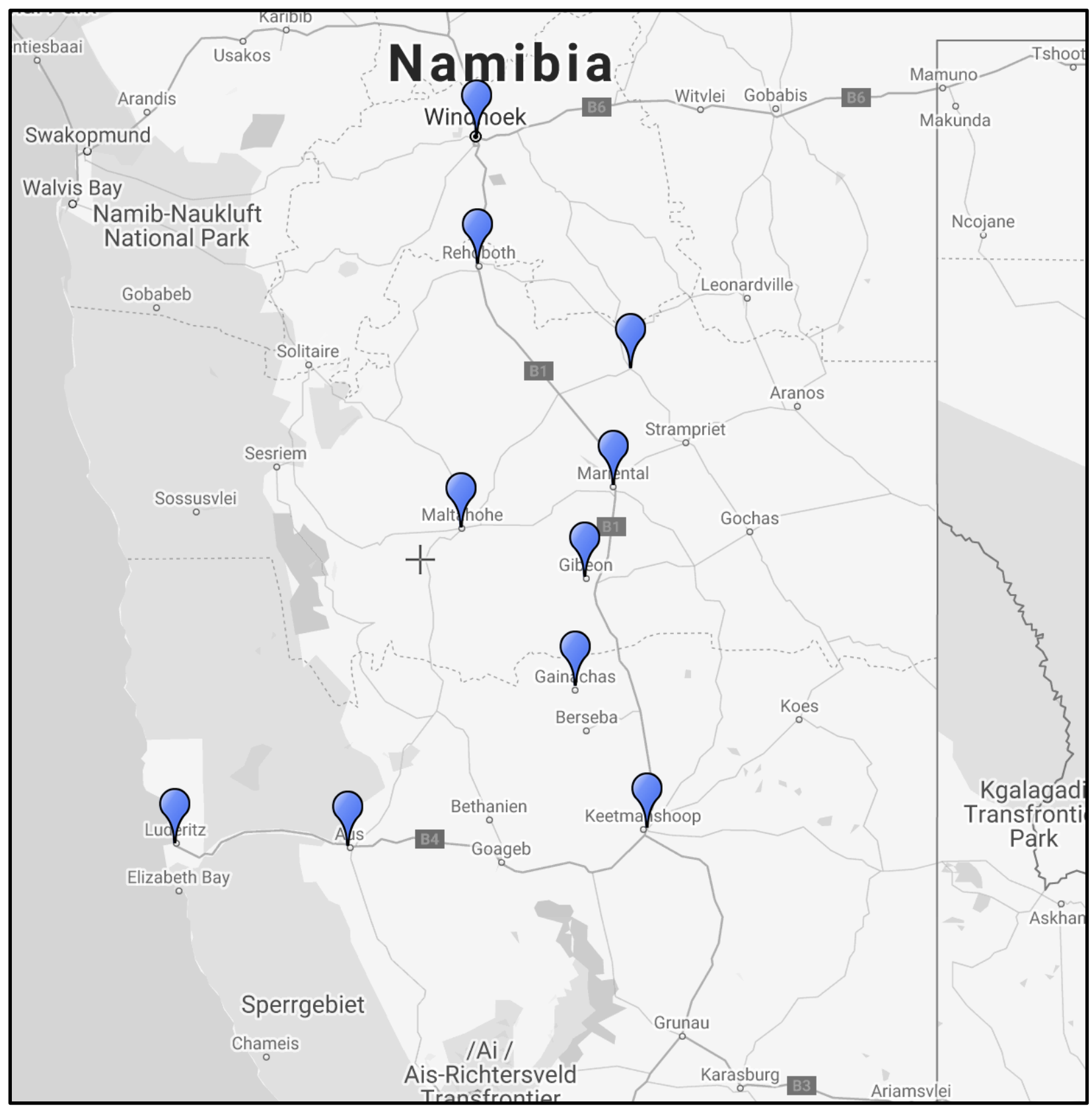

Source: Prepared by Author. 
Historian Marion Wallace laid out the ideological foundations of this "civilizing mission" as follows: "[T]he new RMS and Wesleyan stations made active attempts to reshape the societies in which they lived... according to a specific Christian and European model of godliness....[M]issionaries promoted a salvation that lay not only in faith, a rigid sexual morality and the abandonment of...'heathen' practices, but also in the adoption of the features of an idealized, orderly, European peasant society. ${ }^{9} "$ Missionaries espoused Western-style dress, literacy to read the scriptures, and strict adherence to patriarchal gender roles. They also introduced important economic innovations, like the plough in 1848, to promote a more Western-style agriculture among the converts. The objective was clear: to restructure African society in the image of a Western agricultural settler culture and eliminate the mobile pastoralist lifestyle that thrived in south and central Namibia. ${ }^{10}$

The services that missionaries and mission stations provided in times of warfare and food insecurity allowed for increased, albeit slow, rates of conversion among the Nama and Herero. Increases in followers created mission stations that "constituted alternative nodes of power" for disenchanted Africans and created new possibilities for challenging traditional political authority. ${ }^{11}$ Missionaries also developed large mission colonies that participated in regional and international trade to increase the appeal of the RMS among the Nama and Herero. Carl Hugo Hahn described the process of constructing a mission colony in 1858 :

I recommended that an industrial and farming colony be established.... There must be no lack of iron for the smith, or of wood for the wagon-maker, and they must be provided with the proper tools. The stock-farming operations ought to begin with 100 and 150 head of cattle; between 500 and 1,000 sheep will be required.... If the Missionary Society should see its way clear to establish a mission colony of this kind, it can have some expectation of the Herero mission becoming a success. ${ }^{12}$

\footnotetext{
${ }^{9}$ Wallace, History of Namibia, 63-64.

${ }^{10} \mathrm{Ibid}$.

${ }^{11}$ Ibid., 62.

12 Vedder, South West Africa, 288.
} 
Although Hahn's statement pertained to the creation of an RMS mission among the Herero, it was illustrative of the structure subsequently used among the Nama.

The new missions functioned, to a degree, as outposts in a southern African trade network. Traders like Sidney Dixon and James Morris successfully traversed routes that connected the Cape with South West Africa in the 1840s, with Windhoek being the central hub of this trade. The discovery of guano at Ichabo Island and concessions for mining rights further sparked trade. ${ }^{13}$ RMS missionaries were active in this trade and, ultimately, participated in the firearms trade as well. The firearms trade not only served to protect mission stations from potential cattle raids but also provided the means for some missionaries to curry favor with Nama and Herero leaders in search of firearms and ammunition for local political conflicts. ${ }^{14}$ Trade initially allowed mission stations to remain viable. However, the influx of firearms from these routes exacerbated long-standing tensions between the Nama and Herero and made for a volatile political situation in the region.

Missionaries also significantly contributed to the unstable political environment in 1880 s and 1890s south and central South West Africa through the provision of firearms and the sociopolitical upheaval caused by the growth of Christianity. ${ }^{15}$ The missionaries did play a role in the peacemaking process to end these conflicts, but it is clear from subsequent events that they failed to craft equitable treaties that satisfied all parties. For example, in 1870 missionary Hugo Hahn helped create and secure the Peace Treaty of Okahandja to put an end to the Nama-Herero

\footnotetext{
${ }^{13}$ Wallace, History of Namibia, 65-67.

${ }^{14}$ Briggite Lau, "Conflict and Power in Nineteenth Century Namibia," Journal of African History 27, No. 1 (1986): 29-31.

${ }^{15}$ In 1863 and 1864 Rhenish missionaries supported Maharero’s “war of liberation” from the Oorlam and Afrikaners, which resulted in his procurement of Windhoek through a treaty in 1870. Likewise, the 1880s and 1890s saw Hendrik Witbooi consolidate power among the Nama and come into conflict with the Herero. Not only did missionaries provide firearms in these disputes, but the Christian doctrine also led to generational conflict whereby younger men challenged traditional leadership structures.
} 
War of 1863-1870. However, the treaty further dispossessed Jan Jonker Afrikaner of his lands and increased his distrust in the RMS missionaries. ${ }^{16}$ Jan Jonker Afrikaner accused missionaries and traders of contributing to the growing power of his rival Chief Maharero and threatened punishment against the missionaries by means of expulsion or through the price-fixing of firearm sales. The failures of the treaty and the missionaries' inability to create an equitable resolution to this conflict led to resumed hostilities within the decade. ${ }^{17}$

The missionaries' most profound failures, in terms of the deteriorating MissionaryNamibian relationship, occurred in 1868 and 1884. Inspector Fabri of the RMS submitted a letter to the British Parliament on 9 November 1868 in which he "[prayed] that British protection might be afforded to the German Missionaries in Namaqualand... who are grievously oppressed by the natives." ${ }^{18}$ Fabri's attempts to secure British protection resulted in a subsequent race to establish a colonial presence in the territory. As a result, Adolf Lüderitz sent his request for German protection in August 1884 and initiated the colonial period in South West Africa. Rather than strongly rebuke colonial intervention, many RMS missionaries embraced colonialism and welcomed the presence of the German government. ${ }^{19}$

Missionaries actively facilitated the spread of colonialism, functioning as translators who convinced Nama and Herero leaders to sign uneven peace treaties that reduced their power, dispossessed their lands, and forced people to settle ever closer to RMS mission stations. The

\footnotetext{
${ }^{16}$ Die Friedenskonferenz zu Schmelens Erw. (Okahandja), Basler Afrika Bibliographien (Hereafter, BAB): Personal Papers of Theo Sundermeier (Hereafter, PA.73)/VI.2.2.

${ }^{17}$ John H. Wellington, South West Africa and Its Human Issues (London: Clarendon Press, 1967), 154-155.

${ }^{18}$ Great Britain Establishment of a German Protectorate at Angra Pequeña and Along the Neighboring Coast, Cmnd. 4265 (London: HMSO, 1884), 11. This conflict is also referred to in various sources as the Third NamaHerero War, the Herero War of Liberation, and the Herero War of Freedom.

${ }^{19}$ Nils Ole Oermann, Mission, Church and State Relations in South West Africa Under German Rule, 1884-1915 (Stuttgart: Franz Steiner Verlag, 1999), 99-158; While many RMS missionaries embraced their role as translators and intermediaries, many took these positions because of their experiences with frequent raids on the mission stations. Not all missionaries worked as agents of colonialism. Missionaries like Gottlieb Viehe frequently questioned the viability of the treaties constructed between the German government and Africans.
} 
clearest example of these uneven treaties included the negotiations between Lüderitz and Josef Frederiks over the land at Angra Pequeña and protection treaties. ${ }^{20}$ The view of missionaries as complicit in the dispossession of Namibian lands and power, as well as the perception that missionaries were responsible for the German annexation of South West Africa, solidified many Namibians' negative perceptions of RMS missionaries as colonial collaborators.

In the South West African context, the flag undoubtedly followed the cross. The relationship between missionaries and the colonial state, and the debate over which preceded the other, has been contested by historians. Edith Miguda attempted to describe this close relationship in its Nigerian context, arguing:

When missionaries came to Africa, the close following by and connection with colonial administrators and colonial occupation led to the phrase 'the Flag Follows the Cross.' Once colonial administrators occupied Africa, a number of missionaries relied heavily on colonial military might for their own survival and continued missionary work. As a result, the cross followed the sword inland into areas brought under effective colonial administration and control. At decolonization, churches did not pack and leave with the outgoing colonialists, as a result of which the cross remained behind the flag. ${ }^{21}$

The symbiotic, and at times undifferentiable, relationship between the missionaries and colonial state created lingering perceptions of missionary complicity in the abuses of the colonial regime. This issue persisted throughout Africa and was not exclusive to the South West African context. In Joseph Kirsop's book on the activities of the missionary Robert Moss Ormerod in East Africa, this troubling relationship is laid bare in its Kenyan context. After quoting Ormerod as describing the position of missionaries in East Africa "as the friend of both parties, and...in no

\footnotetext{
${ }^{20}$ Steven Press, Rogue Empires (Cambridge: Harvard University Press, 2017), 140-147. Frederiks served as the chief of the Nama at Bethanie in the 1880s. He is responsible for "selling" land at Angra Pequeña to F.A. Lüderitz on 1 May 1883. The sale of this land to Lüderitz effectively led to the German colonial period and the subsequent purchase of more Nama land around the Orange River. Fredericks was also responsible for signing a protection treaty with the representative for Chancellor Otto von Bismarck on 28 October 1884.

${ }^{21}$ Edith A. Miguda, "Encountering History: Christianity and Identity in Nigerian Diaspora Churches," in Religion, History, and Politics in Nigeria: Essays in Honor of Ogbu U. Kalu, eds. Chima Jacob Korieh and G. Ugo Nwokeji (Lanham: University Press of America, 2005), 217.
} 
way connected with [the] Government," Kirsop added "This disclaimer was very prudent and very necessary. Missionary memoirs... show the evil that results when the missionary is identified with the civil powers. The case is an example of how the flag follows the missionary, not the missionary the flag."22 Although Miguda and Kirsop's arguments show that this relationship differed in the various colonial spheres, the late establishment of an official colonial power in South West Africa created the perception that the brutal German state followed the missionaries who had arrived decades earlier.

This perception became ever more salient in South West Africa in the early twentieth century when the Nama and Herero experienced the full weight and destruction of German colonialism. In 1904, after nearly two decades of mounting tensions, war broke out between the German colonial government, Samuel Maharero, and Hendrik Witbooi. ${ }^{23}$ Over the course of three years, German General Lothar von Trotha committed an act of genocide against the Herero and Nama. ${ }^{24}$ It is estimated that 40 -to-60 percent of the Nama and Herero populations perished as a result of the genocide. ${ }^{25}$ In the aftermath of the physical, social, and political destruction caused by German colonialism, survivors were pushed toward the RMS mission stations as a means of survival. The belief that missionaries were partially responsible for the destruction wrought upon the Namibian population prevailed in subsequent decades and, ultimately, sowed

\footnotetext{
${ }^{22}$ Joseph Kirsop, Life of Robert Moss Ormerod, Missionary to East Africa (London: Andrew Crombie, 1901), 9293.

${ }^{23}$ See G.M. Gugelberger, ed., Nama/Namibia: Diary and Letters of Nama Chief Hendrik Witbooi, 1884-1894, (Boston: African Studies Center, 1984).

${ }^{24}$ Von Trotha was a German General, and he was in charge of German forces in South West Africa after assuming control on 11 June 1904. He was sent to the territory to deal with the growing unrest among the Nama and Herero. Under his leadership, the German military carried out a genocide by forcing the Nama and Herero fighters into the desert and then poisoning and patrolling watering holes. When the Nama or Herero returned from the desert to secure water, German soldiers killed men, women, and children on sight. Von Trotha is infamous for issuing the extermination order on 2 October 1904 that called for the killing of all Herero within the colony's borders whether they were "with or without a gun."

${ }^{25}$ Jan-Bart Gewald, Herero Heroes, 141-191.
} 
the seeds for the later Nama Secession in 1946. Namibians viewed the RMS as an oppressor of the African populations of South West Africa, not merely bringers of a Christian "civilizing" mission. Jan Jonker Afrikaner summarized the attitudes cultivated toward the RMS over the preceding century, stating that "Missionaries were traitors to the country...[I] would rather go to hell with [my] whole people than ever again receive a missionary amongst [my] people."26

The relationship between the RMS and Namibians continued to deteriorate, but the destruction experienced during the genocide limited their ability to resist in a way that truly threatened German hegemony in the territory. This condition persisted until the outbreak of the First World War and the declaration of martial law by the South African government on 12 October 1914. ${ }^{27}$ Between 1914 and 1921, the South African invasion of South West Africa "greatly facilitated [Namibian] access to land and stock, and [tentative] re-pastoralization....The South African invasion thus intensified the movements of people and stock and the rebuilding of herds.... On the political level, this movement meant the (re)constitution of leadership that had been broken or banished by the defeat in 1904." ${ }^{28}$ Leaders like Edward Fredericks and Isaak Witbooi returned to their communities at Bethanie and Gibeon and, in some cases, quasi-military activities re-emerged among some Nama and Herero groups. ${ }^{29}$ The re-emergence of space for African social and political agency as a result of diminished government and missionary control

\footnotetext{
${ }^{26}$ Vedder, South West Africa, 256. Jan Jonker Afrikaner was the son of Jonker Afrikaner and became the leader of the Oorlam after succeeding his brother Christian Afrikaner in 1863. Jan Jonker Afrikaner, like his father, viewed the missionaries as problematic and contributing to the conflicts and instability in central South West Africa. Afrikaner frequently came into conflict with the Herero. On 22 June 1864, he was soundly defeated by Maharero and the Oorlam under his leadership lost their position of dominance in the territory as a result.

${ }^{27}$ Gewald, Herero Heroes, 220-231.

${ }^{28}$ Wallace, History of Namibia, 212-214.

${ }^{29}$ Gewald, Herero Heroes, 231-262.
} 
was, however, short-lived because, as explained earlier in the dissertation, the League of Nations classified the territory as a "Class C" Mandate under South African control in $1921 .{ }^{30}$

\section{Trans-Atlantic Evangelism and the Rise of the AME Church in the United States and South Africa, 1735-1908}

While missionaries were busy spreading Christianity in South West Africa, Blacks in the United States grew the AME Church, an Ethiopianist church focused on racial uplift, selfimprovement, and Black ecclesiastical control of the church. The origins of African Methodism in the United States can be traced to the eighteenth century and the First Great Awakening that occurred in England and its American colonies. ${ }^{31}$ Evangelist John Wesley arrived in the Georgia colony in 1735 and tried to convert Native Americans to Christianity with little success. Wesley returned to England two years later and, aware of the failings of his missionary activities in the colonies, sought a deeper connection and understanding with his Christian faith. At a service in Aldersgate in May 1738, Wesley underwent a profound and personal experience relating to God's salvation. Soon after, Wesley and his companions preached in open fields and churchyards about crucial Methodist concepts like salvation through faith alone, the fallacy of the Calvinist belief in pre-destination, spiritual rebirth, and Christian perfection. ${ }^{32}$

As Methodist communities formed in the 1760s American colonies, the issues of slavery and abolition were central to the greater Methodist theological debate. Eighteenth-century

\footnotetext{
${ }^{30}$ See pages 3 through 5 of this dissertation for more on South West Africa's transition from German colony to South African mandate territory.

${ }^{31}$ The Great Awakening was a spiritual renewal that occurred across the American colonies in the $18^{\text {th }}$ century. The movement focused on individual piety and spirituality that was characterized by emotional and fervent prayer and a new questioning of religious authority. For a full description of the First and Second Great Awakening, see John Fea, "In Search of Unity: Presbyterians in the Wake of the First Great Awakening," The Journal of Presbyterian History 86, No. 2 (Fall/Winter, 2008): 53-60 and Joseph Conforti, "The Invention of the Great Awakening, 17951842," American Literature 26, No. 2 (1991): 99-118.

${ }^{32}$ David T. Morgan, “John Wesley's Sojourn in Georgia Revisited," The Georgia Historical Quarterly 64, No. 3 (Fall, 1980): 253-262.
} 
Methodists believed that the institution of slavery represented a great hypocrisy within the Christian doctrine and was "inconsistent" with the teaching of church founder John Wesley. ${ }^{33}$ Methodist preachers and clergy displayed a keen interest in the salvation of Black souls and, as early as 1766, accepted African American converts into their church. ${ }^{34}$ While the issues of abolition and slavery were heavily contested and led to a split between northern and southern Methodists, the anti-slavery message of the church and its participation in institutions like the Underground Railroad led to a rise in popularity for the church among African American communities in both the northern and southern United States. ${ }^{35}$

African Americans flocked to the Methodist Episcopal Church in the United States, with slaves and free Blacks serving as some of the primary propagators of the faith. African Methodism emerged and developed primarily within the context of American slavery and this historical experience ultimately shaped the character and nature of the AME Church of the nineteenth and twentieth centuries. James H. Cone argued that within this context, Methodism was "re-interpreted for and adapted to the life-situation of Black people's struggle for justice in a nation whose social, political, and economic structures [were] dominated by a white racist ideology." 36 African Methodism was not merely an identical recreation of white American's church theology, but rather a newly created syncretic religion that utilized both African and

\footnotetext{
${ }^{33}$ See Kenneth J. Collins, The Scripture Way of Salvation: The Heart of John Wesley's Theology (Nashville: Abingdon Press, 2010.

${ }^{34}$ Dennis C. Dickerson, "Liberation, Wesleyan Theology and Early African Methodism, 1766-1840," Wesley and Methodist Studies 3 (2011): 109-111. In 1766, a slave named Betty became Methodism's first African American convert.

${ }^{35}$ C.C. Goen, Broken Churches, Broken Nation: Denominational Schisms and the Coming of the American Civil War (Macon: Mercer University Press, 1985), 65-69. The Underground Railroad was a network of secretive routes that led from the American South, which supported an enforced legal slavery, to the northern United States where slavery was abolished by 1804 . Abolitionists utilized this network of people and resources to lead runaway slaves to these northern states where southern slave owners' reach was more severely limited.

${ }^{36}$ James H. Cone, "Black Theology in American Religion," Journal of the American Academy of Religion 53, No. 4 (December, 1985): 755.
} 
white Christian practices to develop a religious worldview that more closely linked to one's lived experiences. As slavery and racial injustice dominated many aspects of the African American lived experience, it is unsurprising that the issues of equality, racial justice, and spiritual salvation dominated the newly-emergent theology of African Methodism. ${ }^{37}$

African American Methodists developed a Black liberation theology that served as the ideological core of the eventual AME Church, and they utilized the language of freedom and equality that pervaded the American Revolutionary War discourse enshrined in the Declaration of Independence. The Black liberation theology that defined Black religious thought during the period of American slavery rested on five key themes: justice, liberty, hope, love, and suffering. ${ }^{38}$ Black liberation theology argued that the "Justice of God" was inescapable, and that God's justice ensured that African Americans' wicked oppressors would be punished and the oppressed liberated. Although many held onto the belief that this liberation would occur in the physical world, Black liberation theology generally advocated that Blacks' liberation from their oppressors would come in the next life. Thus, the concept of Heaven acted as a beacon of hope within this theological worldview and served as a way to reaffirm God's love and one's humanity, while also simultaneously ending the suffering experienced by enslaved Africans and oppressed free Blacks. ${ }^{39}$ Frequently, to affirm the belief that God would redeem the African race and free Blacks from their white oppressors, Psalm 68:31 was referenced in sermons: "Princes shall come out of Egypt; Ethiopia shall soon stretch out her hands unto God." ${ }^{40}$

\footnotetext{
${ }^{37}$ Ibid., 760.

${ }^{38}$ Ibid.

${ }^{39}$ Ibid., 757. See also James H. Cone, The Spirituals and the Blues: An Interpretation (Ossining: Orbis Books, 1992) for a full discussion on the importance of heaven in the Black liberation theology.

${ }^{40}$ Psalm 68:31 King James Version (KJV).
} 
One of the most important propagators of African Methodism in the United States was Richard Allen. Allen was born into slavery on 14 February 1760 in Delaware and was introduced to Methodism during his enslavement. Allen eventually secured enough money to purchase his manumission from slavery in 1780 when his slave master experienced an "awakening" to the ills of slavery after listening to the Methodist preacher Freeborn Garrettson. ${ }^{41}$ Allen proceeded to qualify as a preacher at the Christmas Conference in Baltimore in 1784 and began his work as a Methodist clergyman and proponent of the Black liberation theology. ${ }^{42}$

The Methodist Episcopal Church in America was founded at the Christmas Conference in Baltimore in 1784 and, within two years, Allen moved to Philadelphia to spread the message of the Methodist Episcopal Church among one of the largest free Black communities in the United States. ${ }^{43}$ The event that sparked the subsequent separation between the Methodist Episcopal Church and its Black congregants occurred in 1787 at St. George's Methodist Church in Philadelphia. Allen served as a preacher at St. George's and proved particularly popular among African American congregants during the morning services, when he quickly accumulated followers at his sermons. The white church leadership at St. George's segregated their services, forcing Allen to preach only in the mornings and in separate areas of worship. Furthermore, at other services the congregation's seating was segregated, and Black parishioners were barred

\footnotetext{
${ }^{41}$ Freeborn Garrettson was a Methodist clergyman. Garrettson became an ardent abolitionist and even emancipated several slaves that he inherited. Garrettson preached as he traveled in Delaware and Maryland and his lessons did lead a number of slave owners in these places to emancipate their slaves.

${ }^{42}$ Albert J. Raboteau, A Fire in the Bones: Reflections on African-American Religious History (Boston: Beacon Press, 1995), 79-102. The Christmas Conference was a ten day meeting at Lovely Lane Chapel in Delaware in December 1784. The purpose of the conference was the founding and organization of a new Methodist Episcopal Church in the United States. At the conference, the hierarchy of the church was created, and several positions filled. ${ }^{43}$ Daniel De Vinne, The Methodist Episcopal Church and Slavery: A Historical Survey of the Relation of the Early Methodists to Slavery (London: Francis Hart, 1857), 20-28.
} 
from sitting in the front pews of the church. ${ }^{44}$ Allen and his colleague Absalom Jones believed that white Wesleyans no longer possessed the fortitude or desire to support the church's egalitarian teachings and, in November of 1787, Allen, Jones, and the Black congregants of St. George's walked out of the church service and sought to establish their own Black-led church. ${ }^{45}$

Allen and Jones initially founded the Free African Society as an "ethical and beneficial association" that served to "promote orderly and sober living," as well as advocate for the education and socioeconomic support of the African American community in Philadelphia. ${ }^{46}$ The Free African Church of St. Thomas was established in the summer of 1794 and the Bethel Methodist Church was also founded that same year. Allen remained affiliated with the Methodist Episcopal Church for nearly two decades, but continued conflict between white church oversight and the needs of the Black congregation and clergy created tensions. Therefore in 1816, Allen and five other African American Methodist congregations founded the AME Church. ${ }^{47}$

Allen and the AME Church readily embraced Black liberation theology and institutionalized an emancipatory ethos in Black Methodism. Much like Garvey’s later Negro World, the AME Church used its publication, the AME Recorder, as an organ for the dissemination of Black liberation theology and a means to attract followers to the denomination. Cornelius Bynum argued that the AME Recorder "deliberately worked to refine and forcefully

\footnotetext{
${ }^{44}$ For a complete examination of the events surrounding the walk out and the founding of the AME Church, see Richard S. Newman, Freedom's Prophet: Bishop Richard Allen, the AME Church, and the Black Founding Fathers (New York: New York University Press, 2009).

${ }^{45}$ Ibid., 64-69. Absalom Jones was one of the United States' first African American pastors. He was born into slavery in Delaware. He received his manumission in 1784 and became a minister at St. George's Methodist Episcopal Church with Richard Allen. In 1792, he played a role in founding the First African Church in Philadelphia.

${ }^{46}$ Cornelius L. Bynum, Philip Randolph and the Struggle for Civil Rights (Champaign: University of Illinois Press, 2010), 25-26. Richard Allen and Absalom Jones founded the Free African Society in Philadelphia in 1787. The Free African Society endeavored to provide support and aid to newly-emancipated Blacks and functioned as a mutual aid society. The Free African Society helped support African American widows and orphans and provided aid to those struck with illness.

${ }^{47}$ Lynn Bridgers, The American Religious Experience: A Concise History (Lanham: Rowman \& Littlefield Publishers, 2006), 47-48.
} 
articulate a specific liberation theology that challenged the fundamental moral underpinnings of white supremacy and unequivocally affirmed the equality of all people." ${ }^{48}$ The AME Recorder frequently questioned the moral and legal legitimacy of white supremacy and frequently highlighted the hypocritical relationship between Christianity and slavery that Wesley's theology made so readily apparent decades earlier. The spread of the AME Church's message proved successful in terms of recruitment during the early-to-mid nineteenth century and was aided by the Second Great Awakening. ${ }^{49}$ At the time of Allen's death in 1831, the AME church "boasted congregations in every northern state and several southern ones, with a total membership of more than ten thousand." ${ }^{, 50}$ Membership had increased to over 50,000 congregants by 1861 and the AME Church possessed the requisite numbers and resources to send missionaries to the southern United States after the American Civil War to seek out converts and admit new church members. $^{51}$

The core premises of Black liberation theology in the AME Church during the period of American slavery focused on spiritual liberation and salvation. However, with the issuance of the Emancipation Proclamation in 1863 and the period of Reconstruction that followed the American Civil War, the AME Church's Black liberation theology soon shifted to deal with more practical issues. ${ }^{52}$ Intellectuals in the AME leadership subscribed to the belief that "[God helps] those who

\footnotetext{
${ }^{48}$ Bynum, Philip Randolph, 27.

${ }^{49}$ The Second Great Awakening was a Protestant religious revival that occurred roughly between 1795 and 1835 . Methodist and Baptist churches experienced surges in new membership and resulted in the creation of new colleges and seminaries associated with the faith. During this revival, there was a pronounced shift away from Calvinism and toward Arminianism and several new reforms were introduced.

${ }^{50}$ Campbell, Songs of Zion, 32.

${ }^{51}$ Ibid.

${ }^{52}$ The Emancipation Proclamation was issued by Abraham Lincoln on 1 January 1863 and declared "that all persons held as slaves" within the Confederate States "are, and henceforward shall be free." The term "Reconstruction" refers to the post-American Civil War period that spanned from 1865 to 1877. During the Reconstruction period, the United States government worked to effectively dismantle the slavery apparatus and ensure African Americans' civil rights. Although well-intentioned, the period is largely viewed as a failure and increased instances of racial violence and intimidation in the United States South. Following its failure, segregation and systemic racism were further entrenched in southern social, political, and economic institutions.
} 
help themselves" and, therefore, advocated the need for "racial self-sufficiency." ${ }^{53}$ This new focus on matters of the material world centered on issues of the socioeconomic realm, with later thinkers like Henry McNeal Turner shifting their attention to political matters. These intellectuals developed a doctrine that supported a clear social and political program that vehemently criticized and challenged the ills of laissez-faire economics where the rich devour the weak. Instead, the new practical Black liberation theology of the AME Church argued in support of an economic program that was simultaneously socialist in nature but allowed for African Americans and former-slaves to pull themselves up in the capitalist classes of society. ${ }^{54}$

To achieve the necessary economic advancement to improve one's material life and overcome trials that the white supremacist systems in the United States inflicted on African American communities, AME thinkers considered education to be of paramount importance. Allen believed that members of his congregation should be provided with a moral and religious education to fulfill their potential in society. Literacy was essential to aid in the reading of scriptures, and Allen also believed that it was necessary to teach free Blacks a technical trade so that they could secure stable employment and pull themselves out of poverty. ${ }^{55}$ In combination with a strong moral education that advocated the avoidance of vices like drinking, gambling, and idleness, Allen believed that education through the AME Church could limit the impact of structural inequalities faced by free Blacks in Philadelphia and "lift his congregation out of poverty." ${ }^{, 56}$ In doing so, he hoped that Black-led education would provide more social and

\footnotetext{
${ }^{53}$ Benjamin Tucker Tanner, "The Present and Future," Christian Recorder, 4 January 1877.

${ }^{54}$ Bynum, Philip Randolph, 37-38.

${ }^{55}$ Elise Kammerer, "Uplift in Schools and the Church: Abolitionist Approaches to Free Black Education in Early National Philadelphia," Historical Social Research 42, No. 1 (2017): 299-309.

${ }^{56}$ Ibid., 311.
} 
economic opportunities for his congregation, while simultaneously "gaining respect from white Philadelphians." 57

While many AME intellectuals focused on the promotion of racial self-sufficiency through economic opportunities and education, the early "Back to Africa" concept became more salient among the politically-minded leaders of the church. The "Back to Africa" movement emerged as early as 1773 when theologian Samuel Hopkins advocated for African Americans to serve as a civilizing force in Africa. ${ }^{58}$ The subsequent creation of the Sierra Leone colony in 1787 and the founding of the ACS in 1817 produced further momentum behind the concept of repatriating freed Blacks from the United States to Africa. ${ }^{59}$ The concept of emigration to Africa became a point of contestation between AME intellectuals and the larger African American community despite the establishment of a permanent AME mission in Africa as early as 1787.

In one camp sat African American leaders that opposed the repatriation of Blacks to the continent. The intellectuals in this camp believed that the actions of the ACS and the supporters of a repatriation scheme merely sought to weaken the gains of racial uplift organizations in the United States like the AME Church. Richard Allen and Absalom Jones were notably against the emigration schemes proposed by the ACS. They and the congregation of the Bethel Church asserted their right to remain in America and continued to strive for the goals of egalitarianism and abolition espoused in the Wesleyan doctrine. ${ }^{60}$ Later thinkers like Edward Blyden and

\footnotetext{
${ }^{57}$ Ibid., 314.

${ }^{58}$ Joseph A. Conforti, Samuel Hopkins and the New Divinity Movement: Calvinism and Reform in New England Between the Great Awakenings (Eugene: Wipf and Stock Publishers, 2008), 148-149 and 151-155. Samuel Hopkins was an American theologian and critic of American slavery. Hopkins' theology became highly popular and helped facilitate the spread of the religion to Africa. He created a school with the intention to train African American preachers for missionary work in Africa.

${ }_{59}$ Monday B. Abasiattai, "The Search for Independence: New World Blacks in Sierra Leone and Liberia, 17871847," Journal of Black Studies 23, No. 1 (September, 1992): 107-116.

${ }^{60}$ Campbell, Songs of Zion, 68-71. Allen and Jones initially threw their support behind the ACS. However, once their congregations voiced their opposition to the repatriation schemes, the two withdrew their support
} 
Alexander Crummell, as well as influential AME Bishop Henry McNeal Turner, believed in Providential Design and the concept that American Blacks were particularly well-suited for Christian civilizing work in Africa. ${ }^{61}$ The work of AME missionaries on the continent increased in the mid-to-late nineteenth century with the continued growth of the movement and the emergence of an increasingly global Pan-African movement.

The 1890s represented a particularly successful decade for the spread of the AME Church, specifically within the South African context. The history of the Wesleyan involvement in South Africa dated back to the arrival of missionary Reverend J. McKenny at Cape Town in August 1814 and the spread of Wesleyan Methodism to the Highveld by the 1820 s. $^{62}$ The Wesleyan Church experienced a period of growth in South Africa during the nineteenth century that saw the establishment of a number of churches in Cape Town. The Wesleyans gained more popularity among African congregants because of the Church's willingness to accept Black ministers "on trial" and their support for egalitarianism and the education of its congregations. However, by the 1880 s the church experienced a series of internal disputes that led to a few break-away movements. As it pertains to the establishment and spread of the AME Church in

\footnotetext{
${ }^{61}$ Robert Vinson, "Providential Design, American Negroes, and Garveyism in South Africa," in From Toussaint to Tupac: The Black International Since the Age of Revolution, eds. Michael O. West, William G. Martin, and Fanon Che Wilkins (Chapel Hill: University of North Carolina Press, 2009), 131-134. Vinson defines Providential Design as a civilizing concept that "assigned diasporic Blacks a divinely ordained role in the 'redemption' of Africa." Edward Blyden was born in the Virgin Islands in 1832 and later became a minister. He emigrated to Liberia in 1851 and was ordained by the Presbyterians in 1858. Blyden served many roles in Liberia and Sierra Leone, where he functioned as a preacher, educator, and politician. He was a strong supporter of the idea that African Americans would play an important role in bringing Christianity and Western Civilization to the continent. Alexander Crummell was an African American minister who moved to Liberia in 1853. There he worked primarily to convert Africans to Christianity and provide Africans with a Western-style education. He, much like Blyden, believed in Providential Design and the role of African Americans as civilizing agents. He spent nearly 20 years in Liberia before returning to the United States.

${ }^{62}$ Paul S. Landau, Popular Politics in the History of South Africa, 1400-1948 (Cambridge: Cambridge University Press, 2010), 22-24.
} 
southern Africa, Mangena Mokone's withdrawal from the Wesleyan Methodist Missionary

Society in 1892 proved crucial. ${ }^{63}$

The Wesleyan Methodist Church ordained Mokone in 1887 and he served as both a minister and educator to his congregations in Pretoria, South Africa. Mokone became disenchanted with the discriminatory treatment he and other Black ministers suffered at the hands of Wesleyan Church leadership. He believed that African ministers received far more limited financial support than their white counterparts and were often arbitrarily deemed unfit to serve as ministers to their congregations by church elders. He created a list of grievances against missionaries and, in November 1892, he resigned from the Wesleyan Church ministry and established the Ethiopian Church in South Africa. In the process, Mokone brought a number of African ministers and congregants with him into his newly-formed church. ${ }^{64}$

Mokone's breakaway from the Wesleyans was merely one of several secession movements in southern Africa characterized as "Ethiopian." The people attracted to the Ethiopian movement were frequently "those who had received a certain amount of education at the hands of missionary bodies and who felt their newly-created aspirations blocked by the dominant European ruling class." 65 The leadership of the Ethiopian movement commonly consisted of these disillusioned Black clergymen who felt socioeconomically and spiritually

\footnotetext{
${ }^{63}$ For more on Mokone's role in the rise and spread of Ethiopianism in South Africa, see Hendrik Rudolf Tjibeba, “The AMEC Schism in Namibia, 1946," Alternation 2 (2005): 329-333. Mangena Mokone was an ex-Wesleyan minister who founded the Ethiopian Church in 1892. Mokone and his followers had become increasingly disillusioned and discontented with the Wesleyans and resented the lack of mobility available to Blacks within the church's hierarchy. The type of Christianity developed by Mokone and his followers essentially created an Africanized form of Christianity that more directly appealed to Blacks feeling the burden of white oppression in South Africa.

${ }^{64}$ Jeffrey W. Barbeau, The Spirit of Methodism: From the Wesleys to a Global Communion (Westmont: InterVarsity Press, 2019), 123-124.

${ }^{65}$ George Shepperson, “Ethiopianism and African Nationalism," Phylon 14, No. 1 (1953): 12.
} 
oppressed by the white church hierarchy. Mammo Muchie and Hailemichael Demissie described the role of these Black clergymen in propelling the movement forward, writing:

The Ethiopian movement was first a reaction to the discrimination in ecclesiastical administration and the outright marginalization of Black clergymen. Black clergymen underwent demeaning acts of de-selection for ordination and promotion to the clerical echelons. They were denied deserved promotion to the higher ranks of the clergy for no other reason than the color of their skin. The white mission churches had an unwritten bylaw that the ordination of Blacks was to be avoided. Even when a Black clergyman was ordained, he was stripped of authority and privilege that he was supposed to have by virtue of his ordination. ${ }^{66}$

Black clergymen quickly realized that any chance to rectify the church's shortcomings and wrong-doings would be impossible under the white-dominated church hierarchy. ${ }^{67}$ Mokone, like Nehemiah Tile nearly a decade before him, withdrew from the white churches and created an independent African church that ultimately "associate[ed]...with kindred bodies amongst [the] American Negro churches." 68

Mokone first became aware of the AME Church through letters sent by his niece Charlotte Manye, who was studying at Wilberforce University in Ohio. In the middle of 1895 Mokone began a correspondence with Henry McNeal Turner and the AME leadership in the United States to discuss the goals and aims of the movement, as well as the possibility of joining the AME Church. ${ }^{69}$ At the Third Annual Conference of the Ethiopian Church in 1896, Mokone and the various branches of the church held a vote to seek affiliation with the AME Church. The

\footnotetext{
${ }^{66}$ Mammo Muchie and Hailemichael Demissie, "Re-discovering and Re-vitalizing the Neglected Roots of PanAfricanism: Ethiopianism for African Renaissance and Unity," in Unite or Perish: Africa Fifty Years After the Founding of the OAU, eds. Mammo Muchie, et al. (Pretoria: Africa Institute for South Africa, 2015), 28.

${ }^{67}$ Ibid., 29.

${ }^{68}$ Shepperson, "Ethiopianism," 10. Nehemiah Tile seceded from the Wesleyan Methodist Church in 1884. Tile's secession is considered one of the earliest of the Ethiopian movement in South Africa. Tile fell out with the Wesleyans when he faced a reprimand for his involvement in Thembu politics. Tile's new church combined elements of Christianity and Thembu religion and politics to create a new form of syncretized African Christianity. ${ }^{69}$ Jay Riley Case, An Unpredictable Gospel: American Evangelicals and World Christianity, 1812-1920 (London: Oxford University Press, 2012), 183-187. Case contends that Mokone discovered Turner through a family friend who traveled to the United States and interacted with Turner.
} 
vote passed in the affirmative and that same year the AME Church formally incorporated Mokone and the Ethiopian Church of South Africa into the movement. ${ }^{70}$ Even with the successful vote, however, the first years of this association provided a number of difficulties for the growth and structure of the church.

Upon J.M. Dwane's return from a meeting with the AME leadership in the United States in 1897, he convened a meeting of 20 former Ethiopian Church ministers and "re-obligated" them to the AME ministry. ${ }^{71}$ His stories of AME promises to build a "South African college" resulted in a "revival" that led to the rapid spread of the AME Church across the eastern Cape and into Transkei. This "revival" led to the admittance of thousands of new congregants and spurred on the early growth of the AME Church in South Africa. ${ }^{72}$

Despite the success of the church in its early years in South Africa, the rapid growth of the congregations caused Dwane and Mokone concern that this growth could potentially put strain on an inadequate church infrastructure. Thus, in 1898, Dwane called upon Henry McNeal Turner to travel to South Africa and aid in structuring the South African AME Church to support its rapid growth. Turner arrived in South Africa in March 1898 and ordained new ministers and streamlined the church's infrastructure. Within the first six weeks of his arrival, Turner successfully incorporated three more congregations into the South African AME Church and increased the size of the congregation by more than 11,000 members. To deal with this influx of new members, he also ordained roughly 60 deacons and church elders. By the time Turner

\footnotetext{
${ }^{70}$ Campbell, Songs of Zion, 134-135.

71 J.M. Dwane was a Methodist preacher and educator in South Africa. He was ordained at the Russell Road Methodist Church in Port Elizabeth in 1881. In 1896 he joined Mokone's Ethiopian Church after becoming disillusioned with the segregation in the Methodist Church and the limited opportunities for Black preachers. Dwane traveled to the United States in 1897 to discuss an "amalgamation" between the Ethiopian Church and AME Church. In 1888, he was appointed Vicar-General of the AME Church in South Africa and remained one of the highest ranking church officials upon Turner's return to the United States.

72 Ibid., 136.
} 
returned to the United States in the middle of 1898, he had doubled the size of the AME Church in South Africa and provided the church with improved means to support its growth. ${ }^{73}$

In 1900, the AME Church sent Bishop LJ Coppin to South Africa to serve as the church's first bishop in the country. ${ }^{74}$ Within the year, the Cape Government "acknowledged" the AME Church, one of only three African Independent Churches to receive this recognition at the time. ${ }^{75}$ Following Coppin's arrival, the AME Church in South Africa went through another period of growth. During this time, the AME Church successfully ordained numerous African ministers and admitted students from South Africa into Wilberforce University in the United States where they would train to become ministers in South Africa. ${ }^{76}$ In 1908, the church leadership took their commitment to the education of a successful ministerial force another step and established the Wilberforce Institute in Evaton, South Africa. The church's commitment to education, racial self-sufficiency, and the general principles of egalitarianism facilitated its entrenchment as a critical social institution among Black South Africans in the late nineteenth and early twentieth centuries. ${ }^{77}$ In South Africa, the AME Church developed a positive reputation among Blacks for its focus on ordaining Black pastors and promoting an atmosphere among the congregation of ecclesiastical and social equality. This reputation travelled along transnational channels and preceded the arrival of the AME Church in South West Africa in the early twentieth century.

\footnotetext{
${ }^{73}$ Ibid.

${ }^{74}$ Levi Coppin was an educator, missionary, and Bishop of the AME Church. He became a minister at Bethel AME Church in 1877. In 1902 he traveled to Cape Town where he played an important role in establishing mission houses throughout South Africa and providing structure to the church as it spread in the Union.

${ }^{75}$ Hendrik Rudolf Tjibeba, "The History of the Rhenish Mission Society in Namibia with Particular Reference to the African Methodist Episcopal Schism, 1946-1990” (PhD diss., Paulinum Theological Seminary, 2003), 66-67.

${ }^{76}$ Ibid.

${ }^{77}$ Ingrid Patricia Babb-Bracey, The Development of Educational Policy for Black Africans in South Africa, 16521948 (Amherst: University of Massachusetts Press, 1984), 188-195. Many South Africans studying at Wilberforce University in the United States returned to South Africa in the 1890s to spread the faith and improve the educational infrastructure of the AME Church in South Africa.
} 


\section{Background to the Early Interactions Between Namibians and the AME Church, 1904-1945}

Although the earliest interactions between Namibians and the Methodist church can be traced back to the Moravian missions in Namaqualand in the 1810s, the first prolonged and meaningful interactions between Namibians and the AME Church are undoubtedly linked to Hendrik Witbooi, his theology, and his interactions with the Union Ethiopianist prophet Shepherd Stuurman during the genocide between 1904 and $1907 .{ }^{78}$ The mission-educated Witbooi rose to prominence as a leader among the Nama in the 1880 s when he claimed to have received a vision that "instructed him to lead his followers north on a mission from God."79 Combining Christian elements of an Exodus story with Nama ancestor-worship, Witbooi claimed the "sole right to tread a path which he saw as having been determined by the ancestors of the group, which led to a strategically well-situated redoubt in the mountains" and sanctioned armed raids and conflicts against other Africans to fulfill this vision. ${ }^{80}$ Witbooi's komando, the Witkam, believed that Witbooi was a prophet and followed his commands with an almost "blind obedience." ${ }^{81}$ Witbooi's belief that his mission was ordained by God lent him religious and moral authority among his followers.

Witbooi led his followers north in a series of three ill-fated attacks on the Herero living in the fertile land he believed was promised to his followers by God. In 1888, during a leadership dispute among the Witbooi at Gibeon, Hendrik and his followers migrated to Hoornkrantz where they established a fairly successful settlement with an effective central administration and a

\footnotetext{
${ }^{78}$ J. Whiteside, History of the Wesleyan Methodist Church of South Africa (Eugene: Stock Publishers, 1906), 35-36. ${ }^{79}$ Christine Hardung, "God, the Warlord and the Way of the Ancestors: On the Intertwinement of Christianity and Ancestry in Hendrik Witbooi's Politico-Religious Mission of the 1800s (Southwest Africa)," Civilizations 63, No. 1\&2 (2014): 82. Witbooi was first introduced to Christianity by Paul Visser but received a more formal Christian education under Johannes Olpp and the RMS between 1868 and 1878.

${ }^{80} \mathrm{Ibid}$. The komando was a quasi-military sociopolitical unit frequently consisting of approximately 50 armed men mounted on horses or oxen. The komando was used for hunting and cattle-raiding, as well as defense 81 Ibid.
} 
church. He and his followers resided at Hoornkrantz until April 1893 when German Captain Curt von Francois attacked Witbooi and his followers to secure his signature on a treaty of protection. ${ }^{82}$ Von Francois killed 88 of Witbooi's followers, 78 of whom were women and children. Von Francois' heavy-handed tactics resulted in a change in German leadership in South West Africa and Theodor Leutwein became the Commander of the Schutztruppe. ${ }^{83}$ Witbooi signed a treaty of protection on 15 September 1894 and allied with Leutwein in a series of military campaigns that sought to quell potential rebellions in the territory. Witbooi returned to Gibeon and, from 1894 to 1904, he helped the German government maintain the "Ten-Year Peace." 84

Witbooi's activities in the late nineteenth century embodied the nuanced nature of resistance and accommodation under German colonial rule. Within the span of a decade, Witbooi went from vehemently resisting the German government at every turn to working through them to achieve his subnational sociopolitical and economic goals. However, in 1904 a changing sociopolitical context and Witbooi's new relationship with the Ethiopianist prophet Stuurman led the Nama back into direct conflict with the German colonial military. Administration officials believed that Stuurman was a Cape Presbyterian functioning as an agent of the Ethiopian Church in the Union during his time in South West Africa. Stuurman arrived at Rehoboth in February 1904 after his arrest by Cape police in Rietfontein for giving "riotous speeches." 85 While at Rehoboth, Stuurman preached to Namibians that the time had come to redeem Blacks from the

\footnotetext{
${ }^{82}$ Von Francois was an officer in the Schutztruppe and served as the Reichskommissar of South West Africa from 1891 to 1894. On 12 April 1893 he led an assault on Hendrik Witbooi and his men at Hoornkrant..

${ }^{83}$ Leutwein served as the commander of the Schutztruppe beginning in 1894 and served as the Governor of South West Africa from 1895 to 1904, at which time he was replaced because of his ineffective handling of simultaneous uprisings among the Nama and Herero.

${ }^{84}$ Hendrik Bosman, "A Nama 'Exodus'?: A Postcolonial Reading of the Diaries of Hendrik Witbooi," Scriptura 108 (2011): 330-331.

85 Tilman Dedering, “The Prophet's 'War Against Whites': Shepherd Stuurman in Namibia and South Africa, 19041907," Journal of African History 40, No. 1 (1999): 5.
} 
oppressive rule of German white supremacy in the territory. He detailed a prophetic vision that he received from God, telling Rhenish missionary Carl Wandres, "I was a stable groom in Kimberley. One day I cleaned the horse stable and I saw a fire in front of me. In the fire, there was a figure that looked at me with piercing eyes. I realized it was Jesus Christ. Next to that figure I noticed Black people. The Lord in the fire gave me the order to go west in order to preach to the Black people. ${ }^{.86}$

During his westward journey, Stuurman encountered Hendrik Witbooi at Gibeon and told the Witboois that he had been sent by God to "drive all the whites out of Africa." ${ }^{87}$ At the time, Witbooi still maintained a friendly relationship with Leutwein and the German forces in South West Africa. However, increased German aggression and violent interrogations made Witbooi sour on German racial and political policies toward the Nama and other Blacks in South West Africa. Stuurman's threats to seek out the Herero to participate in this emancipatory campaign and his prophecy that "a little king" was chosen by God to liberate the Black people of South West Africa appear to have altered Witbooi's willingness to engage against the German military. ${ }^{88}$

In part, Stuurman's self-identification as a Christian prophet appealed to Witbooi because he too experienced prophetic visions and messages that led to his migration northward from Gibeon in the 1880s. Witbooi saw himself much in the same vein as other historical "Black Moses" figures and as the person responsible for leading his followers to physical, socioeconomic, and political liberation from oppressive forces. Initially these oppressive forces came from within his own family. However, as German colonialism became more entrenched in

\footnotetext{
${ }^{86}$ Ibid., 6.

${ }^{87}$ Ibid., 5 .

${ }^{88}$ Ibid., 6.
} 
South West Africa, Witbooi's desire for liberation from his oppressor became inherently intertwined with a Black liberation theology.

In October of 1904 Witbooi and the other Nama polities rebelled against the German government. Witbooi and Stuurman led an intense and violent resistance campaign to end German hegemony over the Nama. Stuurman utilized prophecy and mysticism within a larger Christian Black liberation narrative to lead a unit of 30 "sacred warriors" and roughly 200 other men against the German Schutztruppe. As the conflict dragged on and the Nama experienced a series of desertions and defeats, Stuurman's personal influence among the Witbooi eroded and he no longer enjoyed a high status among his followers. Open challenges to Stuurman's authority forced him to abandon the Witbooi, whom he accused of losing faith in his prophecy. ${ }^{89}$ Witbooi's subsequent death in 1905 effectively removed the Nama from the conflict against the German government and solidified feelings of racial animosity and distrust against the German population in Namibia that lasted long after Witbooi's death.

Despite his waning personal influence, Stuurman's Black liberation theology maintained a particular appeal in the collective Nama historical memory. Witbooi, in part, entered the conflict based on his growing belief and acceptance of the Ethiopian-style message espoused by Stuurman. ${ }^{90}$ Witbooi's martyrdom and resultant position as a lauded anticolonial resistance figure in twentieth-century South West Africa inextricably tied Ethiopianism, Black liberation theology, and anticolonial struggle together. The inability of the missionaries to prevent the genocide of the Nama and Herero and their role in crafting the ineffective Treaty of Protection that left Namibians vulnerable to German aggression ultimately soured the relationship between

\footnotetext{
${ }^{89}$ Ibid., 9.

90 Bosman, "Nama Exodus," 31. Bosman wrote that Witbooi did not consider his entry into the conflict in 1904 as a violation of the protection treaty. Instead, he placed his entry into the conflict within the context of it being ordained by God as part of his prophecy.
} 
the Nama and the RMS. This relationship only became further strained as RMS influence in the Police Zone weakened following World War I and the AME Church, an Ethiopianist institution associated with Witbooi's anticolonial and anti-white campaigns of the early twentieth century, became increasingly active in is proselytization efforts in the territory.

Nama experiences after the genocide and Witbooi's continued popularity in the Nama historical memory further weakened the position of the RMS in the Police Zone and cultivated fertile ground for the emergence of the AME Church in South West Africa. Between 1907 and 1945, some cracks formed in the relationship between the Nama and the RMS missionaries. The commencement of World War I and World War II during this period severely curtailed the ability of the RMS to function at full capacity in the territory. A few mission stations closed, some German missionaries were expelled or arrested, and many of the benefits that drew Nama practitioners to the mission stations disappeared. Schools closed and economic activity decreased around a number of mission stations. ${ }^{91}$

The socioeconomic and political experiences of the Nama after the First World War only further strained an already tense relationship. The socioeconomic prospects for the Nama failed to improve and these issues were exacerbated by the global depression of the late 1920s and 1930s. Likewise, fears of potential rebellions and the alleged accumulation of weapons by Africans weighed heavily on the minds of the newly-instituted South African mandatory government. Pass laws were implemented to control the movement of Namibians in the territory, investment in social programs for Namibians was severely limited, and the constant threat of the expropriation of African lands hung over the 1920s and 1930s. ${ }^{92}$ Missionaries played a limited

\footnotetext{
${ }^{91}$ Margit Resch, trans., The Church in the Industrial Age (London: Burns and Oates, 1981), 557-559.

${ }^{92}$ See pages 209 through 217 of this dissertation for more on the economic situation in South West Africa during the interwar period.
} 
role in the implementation of these policies and laws, but the perception of missionaries as colonial agents remained strong among Namibians even as a new colonial regime took control. As World War II approached and further restraints were put on the capabilities of the RMS as those with German heritage were viewed with suspicion, Nama church and community leadership seriously considered the establishment of an independent African church and the severing of ties with the RMS. The establishment of such a church would serve as the foundation of the Nama's subnational resistance campaigns of the 1950s.

A letter from Petrus Jod to Heinrich Vedder in 1939 provided some of the reasons that Nama leadership desired to sever ties with the RMS. Chief among the reasons for the formation of a breakaway church was the belief among the Nama that the RMS failed to fulfill a number of its promises with regard to schooling and education. Jod wrote:

We only want us and our people to get on. All we got, however, was promises and our own hope, all of those years....I do not do this work because of some white missionary pushing us but to help our people to advance.... Now the school has been closed again, without us getting to know this. We were not even told a single word about it, but nevertheless, it will be us whose fault it is that it has been closed. Even with all this I was committed to the work of the Rhenish Mission....This is why-in the time, which I will still live, if the Lord will give me this - I am looking for my people and me somewhere else for the things...you have promised to me, to us, to our people, but which you have kept until today. ${ }^{93}$

The lack of commitment by the RMS to schooling and education, combined with their unwillingness to ordain African pastors and protect their congregations' economic interests, led the Nama leadership to leverage the threat of a secession against the RMS.

In contrast, the AME Church's reputation of ordaining African ministers and its intense focus on education and schooling, coupled with the historical links between the AME Church, Hendrik Witbooi, and the Nama polities, ultimately made the AME Church an attractive option

${ }^{93}$ Petrus Jod to Heinrich Vedder, 1939, NAN: SWAA/A216/6. See also, Tjibeba, "Rhenish Mission Society,” 100. 
when a breakaway church movement formed among the Nama congregations. Information about the AME Church was readily available to the Nama leadership and their congregations. The AME attempted on numerous occasions to send missionaries to the territory and establish a presence in South West Africa, resulting in the spread of AME literature and teachings. Furthermore, South African newspapers and publications frequently discussed the problems and successes that accompanied the spread and growth of the AME Church in the Cape. ${ }^{94}$ Nama leaders had access to a vast transnational network of information because of these earlier experiences, and that helped shape their approach to dealing with the oppressive nature of their relationship with the RMS and SWAA leading up to 1945.

The resistance campaign that developed among the Nama during the period was simultaneously subnational and transnational. Their strategies sought to leverage the resources of the transnational AME Church to avoid working through the colonial state, which merely wanted to use Namibians as agricultural laborers in the Police Zone Through the AME Church, the Nama were able to pursue their subnational goals of obtaining a more advanced Western-style education to resist the colonial state's efforts to socioeconomically underdevelop the Nama. While the movement initially started inclusively and drew some followers among the Herero, the rise of the Oruuano Church siphoned off most of the AME's Herero congregants and made the AME Church in the territory a nearly exclusive vehicle of the expression of Nama agency and resistance. ${ }^{95}$

\footnotetext{
94 Tjibeba, "Rhenish Mission Society," 72. Here, Tjibeba highlights how evangelist Zacheus Thomas was an avid reader of the South African newspapers in order to "[follow] current socio-political issues in [South Africa and South West Africa].

${ }^{95}$ For more on the history of the Oruanno Church, see Ehrenfried Kandovazu, The Origin and History of the Oruuano Church in Namibia (Windhoek: Klaus Hess Publishers, 2009).
} 


\section{The Causes and Justification for the Nama Secession of 1946}

The Nama's subnational resistance campaign against educational underdevelopment began when an article in the South African Afrikaans-language publication Die Burger on 31 October 1945 revealed negotiations between the Superintendent of the RMS, Heinrich Vedder, and the Dutch Reformed Church of South Africa (NGK). Financial trouble in the RMS led Vedder to negotiate the transfer of 23 RMS churches and congregations to the control of the NGK, and this sparked the Nama Secession of $1946 .{ }^{96}$ Nama leaders viewed the NGK as a segregationist church that embodied the very structures from which the Nama sought to liberate themselves. In response to the article, Zacheus Thomas, an Evangelist from Keetmanshoop, convened the Nama Teachers and Evangelists Association on 12 January 1946 to formulate a plan of action to deal with this perceived betrayal. The summary of the minutes from this meeting are referred to as the Protokoll uber die bei der Evangelistenzusammenkunft festgelegten Punkte, or Minutes on the Specified Points of the Evangelist's Meeting. ${ }^{97}$

An examination of these notes revealed the motivations for the meeting, the goals of the association, and provided insight on Nama agency during the period. Thomas began the meeting with a discussion that covered the article in Die Burger and the prospect of the NGK incorporating 23 RMS stations. Next, the Protokoll showed that those in attendance agreed to resist any attempt to hand over control of the churches to the NGK. If the RMS refused to change their leadership and ordination practice, Black congregants threatened to leave the church entirely. Several references were made at the meeting to the deteriorating relationship between RMS missionaries and their African congregants, the lack of consultation between congregations

\footnotetext{
96 Tjibeba, "Rhenish Mission Society," 72.

${ }_{97}$ Protokoll uber die bei der Evangelistenzusammenkunft festgelegten Punkte, 12 January 1946, BAB: PA.73/VI.5.a.5.
} 
and missionaries in the church's decision-making process, and the contempt missionaries displayed toward their Black practitioners. ${ }^{98}$ Finally, the document concluded with references to the education process and the need for new textbooks for Standard II students. ${ }^{99}$

As a result of this conference, Zacheus Thomas, Petrus Jod, and Markus Witbooi wrote a public letter titled the Agitasie teen die Blanke Genootskappe, or Protest Against the White Societies. The letter opened with a statement that argued non-white congregations in South West Africa would no longer accept spiritual guidance or ministry from whites in the RMS or NGK. The letter read, "On behalf of the non-whites and non-white church members from the southern part of South West Africa, that so far served under the spiritual ministry of the Rhenish Mission Society, we wish to state that the congregations refuse to further serve under the governance of any white Society, the Rhenish Mission Society, or the Dutch Reformed Church. Our motivation will be clear from [what follows]." 100 The subsequent paragraphs in the Agitasie laid forth the historical argument that the leadership of the RMS had failed in its duties to successfully administer and develop their Nama congregations.

The authors of the letter lamented the slow progress made by the RMS and their failure to provide adequate spiritual and practical guidance. The authors contended:

[After] one hundred years under the spiritual ministering of the [Rhenish Mission Society] ...we are today described as incompetent, weak, [and] heathens. The question is, how long will it be so? When will we become proficiently strong and become Christians? Time has revealed that the spiritual disposition of the white population is not better, but worse. Clearly, conditions today are anything but desirable.... The spiritual education and the social conditions are deplorable. This is all due to the policy of the RMS in South West Africa. ${ }^{101}$

They continued their lamentation:

\footnotetext{
98 Ibid.

${ }^{99}$ Ibid.

${ }^{100}$ Agitasie teen die Blanke Genootskappe, 12 January 1946, BAB: PA.73/VI.5.a.6.

${ }^{101}$ Ibid.
} 
It seems clear that upliftment and development will never happen, because a hundred years have passed, and we are still where we were at that time. From our own experience, in some books we learned that it was not the RMS's endeavor to do constructive and enduring work among us, compared to the work done by the Finnish Mission under the Ovambos, but to use us to support constructive things elsewhere. The only intrinsic interest that has been shown so far is that the members must fulfill their ecclesiastical duties, especially the financial ones.... Even in the material state such as improvements and repairs, there is no interest. There are many other clear evidences that seem to prove that revenue play the main role, not the spiritual well-being of the congregations that are being targeted. ${ }^{102}$

The Agitasie also further reaffirmed the belief among Black congregants that whites, including teachers and pastors, possessed "degrading and humiliating” attitudes toward their congregations. There appears to be an attempt by the authors of the letter to avoid arguing that African members of these congregations should be treated as equals to their white counterparts. However, there was a strong belief that their humanity and human dignity should be recognized by the RMS leadership. The letter reads "[W]e are nevertheless human beings, people with eternal souls, human beings who, as far as it concerns the temporal [world], form a definitive part of society." 103

The final point of contention addressed in the Agitasie clearly laid out that the Nama leaders and their congregations would no longer accept the spiritual guidance of the RMS if it continued to refuse the ordination of Black ministers and betrayed the will of its congregants. The authors demanded that congregations, in the form of a Church Council, possess significant influence over the decision-making process, especially in terms of church finances. The Nama leaders advocated:

Finally, [if] we have to remain under [the RMS's] spiritual governance...current policy and management [must] change....All church matters must be discussed and dealt with at semi-annual church council meetings. We may elect a secretary and treasurer who will be responsible for the control of all institutional activities and income and expenses. No

102 Ibid.

103 Ibid. 
income will be accepted, and no expenses paid without the knowledge and approval of the church council. ${ }^{104}$

Through these demands, the Nama leaders sought to limit the unilateral power of the white ministers and restore authority and power over the decision-making process to the congregations. Within two days of these demands becoming public, the demands were disregarded and RMS missionary W. Neumeister was appointed pastor at Keetmanshoop instead of ordaining Zacheus Thomas to fill the position. ${ }^{105}$

While letters were exchanged between the RMS and Nama leaders between January and June of 1946, the Nama leaders officially broke away from the RMS on 3 July 1946. After the secession, Thomas gathered further information about the AME Church in the Cape from Keetmanshoop policeman Jonas Katjirungu. Through this network, Thomas contacted Francis H. Gow in South Africa. Gow, the General Inspector of the AME Church, agreed to provide aid for the Nama secessionists until they could independently run their church. The AME Church ordained a number of the secession's leaders, including Thomas, Jod, and Witbooi, making them leaders of their churches and communities. ${ }^{106}$

The Nama secession was wholly Ethiopian in its nature and different from the creation of more radical African Independent Churches that sought to completely remove the Western influences from the church. Whereas other breakaway churches in Africa expressed open hostility toward the colonial administration, the Ethiopian churches, though anticolonial at heart, instead emphasized "self-improvement and political rights" as a key part of their spiritual and

\footnotetext{
${ }^{104}$ Ibid.

${ }^{105}$ Buys and Nambala, History of the Church, 179.

106 Tjibeba, "Rhenish Mission Society," 67-72 and 213-215.. Francis H. Gow was born in Cape Town in 1887 and educated in the United States where he earned degrees at Wilberforce, Miami (Ohio), and a Doctorate in Divinity at Morris Brown University. He served as the Headmaster at Wilberforce Institute in Evaton and became a Bishop of the AME Church in South Africa in 1956. He played an influential role in bringing the AME Church to South West Africa and was responsible for the founding of numerous church schools throughout the territory.
} 
worldly ideology moving forward. ${ }^{107}$ Likewise, while many Ethiopian and breakaway churches often "incorporate[d] a [large] measure of African beliefs and practices into Christian life than was permitted in churches under missionary control," the Nama instead turned to already existent Ethiopian churches to provide structure and a path forward. ${ }^{108}$ Tabona Shoko described the Ethiopian churches in southern Africa as "exhibiting anti-racist and Pan-African tendencies, while retaining the organization and doctrines of white dominated Protestant Churches they broke away from." 109 The AME Church in particular provided the necessary structure to be simultaneously anticolonial and Pan-African, while maintaining the Christian doctrine that many of the secessionist leaders supported as a result of their mission education. In the AME Church's Protestantism and advocacy for racial uplift and equality within the church hierarchy, the Nama found a "place to feel at home" that provided "spiritual, mental, and material security" from the "paternalistic attitudes and cultural superiority of [the] mission churches."110

The secession and the incorporation of the movement into the AME Church represented an important step in the development of an almost exclusively Nama-led transnational resistance campaign against the further encroachment of the SWAA into Nama socioeconomic and political affairs. Through information gathered from a South African Afrikaans-language publication, Nama leadership undertook a letter writing campaign to demand institutional reform by the RMS for the rectification of their troubled relationship. When the RMS refused to seriously consider ordaining Nama ministers or to consult congregations more thoroughly in church matters, Nama leaders accessed their networks in South Africa. The Nama successfully allied themselves with

\footnotetext{
${ }^{107}$ K. Asare Opoku, "Religion in Africa During the Colonial Era," in General History of Africa, Volume 7: Africa Under Colonial Domination, 1880-1935, ed. A. Adu Boahen (Suffolk: James Currey, 1990), 529.

109 Tabona Shoko, Karanga Indigenous Religion in Zimbabwe: Health and Well-Being (Oxford: Taylor and Francis, 2016), 110.

${ }^{110}$ Ibid.
} 
Francis H. Gow and the AME Church, a church with its origins in Philadelphia and a wellestablished presence in South Africa. The relationship that developed between Nama political leaders and the AME Church proved crucial in Nama leaders' later resistance campaigns to fight for subnational concessions like high quality Black-led education in the territory and a halt to forced land removals in the Police Zone.

\section{The Establishment of AME Church Schools in South West Africa and the Quest for State Recognition, 1948-1960}

Due to the AME Church's successes in the United States and South Africa, the foundation of the AME Church in South West Africa presented Namibians with renewed hopes that this transnational organization would provide the machinery for improved education and increased socioeconomic opportunities in the territory. News of the relative successes of the AME schools in the United States and South Africa during the early-to-mid twentieth century circulated in South West Africa by means of AME publications and sympathetic transnational actors. Government officials believed that the AME clergy's success in cultivating the aforementioned breakaway movement relied primarily on the promises of the organization to create and staff Black-led schools in South West Africa. In 1953, for example, the Magistrate of Maltahöhe emphasized the vital relationship between the church and Black education in government communications and went as far as to argue that he "[did not] think that [Namibians] will want to establish a church if they cannot have a school." 111

Namibians' desire for Black-led education in the territory came as a natural by-product of the poorly-funded and unsatisfactory education provided by the RMS prior to the Nama Secession of 1946. The Western-styled education offered by white missionaries prior to the

${ }^{111}$ Note to Mr. Allen from the Magistrate at Maltahöhe, 13 April 1953, NAN: SWAA/A489/25/2. 
implementation of apartheid allowed converts to partake in the colonial economy, but in a limited capacity. The RMS educational system delivered low-quality education to Namibians in an effort to provide them with enough skills to work for and benefit the white farmers and businessmen, while simultaneously limiting upward mobility for Blacks and funneling them into low-wage labor-intensive work. ${ }^{112}$ This type of education created low-level artisans, domestic servants, and agricultural laborers who could serve the economic purposes of the missionaries, white farmers, and the state. ${ }^{113}$

The RMS curriculum at the mission schools played a critical role in the systematic educational underdevelopment of South West Africa's African population. The course schedules and grade sheets for the RMS school at Hoachanas provide insight into how exactly the missionaries administered education to Namibians and its inherent shortcomings. Prior to 1960, the RMS curriculum listed a number of courses including Reading, Recitation, Speaking, Composition, Arithmetic, Grammar, and Bible Study. Likewise, these course offerings also listed classes in Geography, History, Natural Studies, and Hygiene; all courses offered to white students. In some instances, a limited number of schools also offered courses in metalworking and woodworking. However, an examination of the grade sheets prior to the 1960s revealed that courses were not provided, nor were grades submitted for any of the social or natural science

\footnotetext{
${ }^{112}$ Martha Akawa, The Gender Politics of the Namibian Liberation Struggle (Basel: Basler Afrika Bibliographien, 2014), 155-156.

${ }^{113}$ Ivan Raymond Wills, “The History of Bantu Education: 1948-1994,” (Master's Thesis, Australian Catholic University, 2011), 84-86. The RMS perpetuated this type of education throughout the 1940s and into the 1950s, at which point the state played a more prominent role in shaping educational policy. This type of underdeveloped education became official SWAA policy after the Bantu Education Act was passed in 1953. Under this act, the education of Africans was intended to "produce subservient individuals with the skills needed to minister to the needs of the white economy rather than to develop critical thinkers. Its aim was to maintain - if not actually createa state of intellectual underdevelopment and dependency." As such, education became a mechanism to reproduce "unequal social relations" and provide labor geared toward the needs of white farmers and businessmen.
} 
classes listed on the course schedules. ${ }^{114}$ Instead, missionaries emphasized the cultivation of the basic skills of reading, writing, and arithmetic, as well as the promotion of the Afrikaans language.

While the offered courses provided Namibians with the basic education needed to fill menial labor jobs, they found themselves at a competitive disadvantage in the labor market because their education was limited. A common complaint that arose among the Namibian population in the Police Zone in the late 1940s centered on the fact that missionary schools only offered Blacks education up to the level of Standard II. Standard II provided a minimal primary school education for Blacks and few opportunities existed in the territory for secondary and postsecondary education. Nama leaders, seeking inclusion in the colonial economy and the equitable provision of education, pressured the SWAA as early as 1948 with calls for an increase in the level of education provided to Africans intensified in the early 1950s. ${ }^{115}$ In 1952 Joseph Kahuika, an AME-affiliated teacher at Gainachas in the Berseba Reserve, pointed to the limits placed on Namibians' education and the desire for education up to the level of Standard VI. In his communications with the Director of Education in Windhoek he argued:

The Rhenish Mission [has led] our Native schools for more than a century. Still, the styles of education are laughable and ridiculous compared to today's modern times. We have made unsuccessful efforts in the past, to get a better education. So, we trust the Administration and politely ask the Education Department to take this school at Gainachas completely [under] its direct supervision [and allow us to teach school to Standard VI]. There are 70 students here at this school [and] it is undesirable to continue with Standard II if there are skilled and suitable teachers. ${ }^{116}$

\footnotetext{
${ }^{114}$ Rhenish Native Schools_-Hoachanas-Inspections-Class Schedules, Undated, NAN: South West Africa Administration: Education Branch (Hereafter, EDU)/18/17/4/4.

115 Manager/Administrator/Head Fr. Mayer to Director of Education, Windhoek, 21 January 1948, NAN: EDU/18/17/4/5.

116 J. Kahuika and D. Isaak to Director of Education, Windhoek, 14 February 1952, NAN: EDU/742/7.
} 
Although secondary education developed in the territory as the standardization of Bantu Education occurred in the 1950s, missionaries failed to meet the growing desires of Namibian leaders for improved education and social progress.

Namibian leaders were also concerned with the treatment of Black educators at the mission schools in the Police Zone. A limited number of RMS-affiliated Blacks taught at the mission schools prior to the secession, but the conditions and opportunities for these teachers were poor. Opportunities for promotion within the RMS were non-existent and the pay that these few Black teachers received was not comparable to their white counterparts. Black teachers repeatedly advocated for increased pay and opportunities for advancement within the RMS's existing structure. ${ }^{117}$ However, as these prospects continued to dim, the Black teachers and members of the RMS started to look elsewhere for the opportunities they were denied.

As many of the Black congregants and educators in the RMS left to join their local AME congregations, the RMS exacted retribution on the Black educators and their schools for leaving the denomination. Gow relayed to government officials that the RMS schools demoted and removed teachers that left the denomination to join the AME church. Johannes Ludwig served as the principal at the RMS school in Mariental for a number of years before he was demoted for joining the AME Church. Similarly, the RMS removed Jeremiah Fleermuis as the principal of the RMS school at Hoachanas after his nine years of service because he too abandoned the RMS for the AME Church. ${ }^{118}$ Gow urged the government to take action to stop these retributions as he believed the denomination of a teacher should play no role in their employment given that the state funded most of the mission schools by 1945. The "intimidation and victimization" against

\footnotetext{
${ }^{117}$ Peter Katjavivi, A History of Resistance in Namibia (Trenton: Africa World Press, 1990), 28.

${ }^{118}$ Francis H. Gow to Chief Native Commissioner, South West Africa, 8 July 1947, NAN: SWAA/A489/25.
} 
the AME teachers resulted in increased feelings of dissatisfaction toward the RMS and its schools and led other teachers to further abandon the RMS altogether. ${ }^{119}$

The growing number of AME Church schools in predominantly Nama areas provided these disaffected teachers and congregants with opportunities for socioeconomic mobility lacking under the RMS. Gow and AME agents in the territory continued the AME's Cape tradition of promoting Black pastors and advocating for the use of Black educators in their proposed schools in the territory. This led to the exodus of influential Black teachers from the RMS and, as an expression of their anticolonial agency, their participation in the AME schools. Reverend Daniel Dausab taught at the RMS school in Rehoboth for nearly 20 years before leaving for the AME Church and its schools in December of $1947 .{ }^{120}$ Reverend Markus Kooper, who similarly trained at the Augustinium in Okahandja, left the RMS in Hoachanas and proceeded to further his education at Wilberforce in the Cape before returning to Hoachanas to serve as a pastor and a teacher in the AME Church. ${ }^{121}$ Finally, Markus Witbooi also abandoned the RMS and its schools after being demoted from his position of principal at Gibeon after 10 years of service for nothing more than the possibility of "a conflict in religious differences that [arose] between himself and his Manager."122

The parents of the Nama schoolchildren supported the shift from missionary education under the RMS to the AME's new Black-led education system as a means of resistance to colonial rule. When the AME Church first formed and broke away from the RMS parents pulled their children out of classes and enrolled them in the AME schools. ${ }^{123}$ The Director of Education

\footnotetext{
119 Ibid.

${ }^{120}$ J.H. Schar, Windhoek to the Secretary for South West Africa, 17 February 1948, NAN: SWAA/A489/25.

${ }^{121}$ Inspector of the Rhenish School, Hoachanas Report on Markus Kooper, NAN: SWAA/410/4

${ }^{122}$ Francis H. Gow to the Native Commissioner, South West Africa, 8 July 1947, NAN: SWAA/A489/25

123 Ibid.
} 
in Windhoek described the parents' strong desire to leave the RMS even if there was not a viable alternative school. Writing to the Chief Native Commissioner in 1951, he stated: "Although some parents will be prepared to send their children to Rhenish Mission schools, and some have already done so, the majority are still far from being in a mood to consider such a step. Many will probably prefer doing without a school for their children [rather] than make use of facilities provided by what they have come to consider an enemy Church Mission." 124 The parents' willingness to rebel against the RMS schools led to a reduction in enrollment in the RMS schools, particularly among the Nama schoolchildren. ${ }^{125}$

The school enrollment statistics for the RMS school at Hoachanas between 1947 and 1952 highlight the precipitous drop in Nama enrollment as the AME-minded parents enrolled their children in the Black-led AME schools. In December of 1947, 71 Nama schoolchildren enrolled in the school at Hoachanas and constituted roughly 79 percent of the total students. By 1951, only 24 Nama school children were enrolled at Hoachanas, making up barely 30 percent of the student population. ${ }^{126}$ A similar trend occurred at Gibeon and Gainachas among Nama schoolchildren as enrollment numbers continued to drop at the RMS school in favor of an AME education. ${ }^{127}$

The decreased enrollment in the Nama areas challenged the viability of the RMS schools in the 1940s and 1950s. State funding for teachers' pay and the "feeding scheme" were contingent upon enrollment numbers and fewer students threatened to decrease RMS revenues in the territory. In an attempt to stunt the growth of the AME and its schools, RMS missionaries

\footnotetext{
${ }^{124}$ Director of Education, Windhoek to the Chief Native Commissioner, 11 April 1951 NAN: SWAA/A489/25/4

125 The AME Schools were frequently referred to in government documents as "Nama Schools" because most of the student bodies in these institutions came from the Nama communities in the Police Zone.

${ }^{126}$ Quarterly Statement for Rhenish Mission School, Hoachanas, 1947-1964, NAN: SWAA/EDU/410/4.

${ }^{127}$ Hendrik S. Issak and 46 others to the Director of Education, Windhoek, undated, NAN: SWAA/EDU/21/1.
} 
filed complaints to the SWAA against the AME Church that sought to influence the government's perception of the school's intentions. Teachers and missionaries argued that the arrival of the AME Church in South West Africa resulted in an increase in "idleness, promiscuity, immorality" and social degeneration. ${ }^{128}$ The missionaries continued to portray the AME Church as an organization with "political goals that they pursued under the guise of religion." 129 The RMS described the AME schools' curriculum as promoting "anti-white resistance" and causing "struggle and strife among the non-whites." 130 These alleged anti-white attitudes were subsequently used to paint the church as anticolonial in nature and as an institution that hindered the general progress of Namibians in South West Africa.

The development of the global Cold War political context in the immediate post-war years, especially the South African government's attempts to prevent the spread of communism, provided new fodder for RMS missionaries and teachers to use against their AME counterparts. The Magistrate in Keetmanshoop detailed a common RMS complaint in a 1948 letter to the Chief Native Commissioner, writing "I have been informed that the [AME] movement is communism under the cloak of religion but have never been able to get any concrete or real evidence to substantiate this allegation." ${ }^{131}$ Other allegations of the distribution of communist propaganda circulated in the Police Zone during the late 1940s. However, much like the complaint received by the Magistrate in Keetmanshoop, concrete evidence of communist influence among the AME congregants never materialized. ${ }^{132}$

\footnotetext{
${ }^{128}$ Report by C.J. Rossouw, Superintendent, Kransz-Platz Reserve, 14 November 1948, NAN: SWAA/A489/25

129 Ibid.

${ }^{130}$ Hendrik S. Issak and 46 others to the Director of Education, Windhoek, undated, NAN: SWAA/EDU/21/1.

${ }^{131}$ Magistrate, Keetmanshoop to Chief Native Commissioner, Windhoek, 20 December 1948, NAN: SWAA/A489/25.

${ }^{132}$ Report by C.J. Rossouw, Superintendent, Kransz-Platz Reserve, 14 November 1948, NAN: SWAA/A489/25
} 
The skepticism of SWAA officials mounted as unsubstantiated complaints continued to pile up in administrative offices throughout the Police Zone. Magistrates noted that most of the accusations against the AME Church originated with members of the RMS and NGK. The questionable motivations of these two organizations did not go unnoticed by SWAA officials. In 1948, the Magistrate at Keetmanshoop posited that "The loss of revenue to the [RMS and Dutch Reformed Church] has therefore been considerable....[I]t is only natural that the Rhenish Mission, whose membership has been so depleted...should feel antagonistic towards [the AME Church]. Their pockets have been touched." ${ }^{133}$ The magistrate drew upon the South African government's experience with the AME Church in the Union and went on to argue, "I do not think that the AME Church is responsible for the propaganda that is afoot. It is worldwide and common to all non-European peoples. The RMS is as far as I know the chief complainant but as stated before they are not disinterested as the AME has deprived them of a large source of income." 134

In the early 1950s, Gow submitted applications to the SWAA for state recognition of the AME Church schools in South West Africa to receive government funding and solidify the survival of the church in the territory. The SWAA's intervention in South West Africa had increased over the previous three decades, beginning with the issuance of Proclamation 16 of 1926 that provided for separate classifications of mission schools into "Coloured" and "Native" schools and placed the burden of "control and management" of all of the schools in the territory on the SWAA. Proclamation 31 of 1932 vested the SWAA with the power to grant permission for the construction of church sites for schools and mission purposes. ${ }^{135}$ Control over funding

\footnotetext{
${ }^{133}$ Magistrate, Keetmanshoop to Chief Native Commissioner, Windhoek, 20 December 1948, NAN: SWAA/A489/25.

${ }^{134}$ Ibid.

${ }^{135}$ Permit Issued by AJR Van Rhijn, Administrator, Windhoek, 24 June 1953, NAN: SWAA/A489/25/2.
} 
and oversight was further granted to the SWAA through the Native Education Finance Act of 1945 which provided for the "financing of Native Education out of general revenue."136 This legislation culminated in the further extension of Bantu Education to South West Africa by way of the Van Zyl Commission in 1958 and the establishment of a government-sponsored apartheid-style education system.

To gain state recognition for the AME Church schools, Francis Gow, Bishop I.H. Bonner, and Rev. Zacheus Thomas met with the Secretary for South West Africa on 3 August 1951 to discuss the various requirements that had be met in order for the AME schools to be recognized by the SWAA. The secretary pointed to three specific requirements. First, the conditions of Proclamation 16 of 1926 must be observed. Second, each school must operate under a European manager or supervisor during a probationary period of unspecified length. ${ }^{137}$ Finally, the AME Church needed to restore faith and confidence in the church by "allaying" white suspicions that the church aimed for non-ecclesiastical goals. ${ }^{138}$ The Secretary detailed how reports of "certain statements made by irresponsible members of the [AME] Church caused [the church] to be regarded with very grave suspicion by Europeans in the Territory" and how this had led the SWAA to refuse to provide the same level of assistance to the AME church as was provided to other schools. $^{139}$

Bonner and Gow assured the Secretary and the Director of Education that the accusations were unfounded. Over the course of the next three years, Gow repeatedly wrote to the SWAA and the Director of Education to assure them that the conditions set forth in the August 1951

\footnotetext{
136 Thomas Karis, et al., From Protest to Challenge: Hope and Challenge, 1935-1952 (Palo Alto: Hoover Institution Press, 1972), 93.

${ }^{137}$ Francis H. Gow to the Secretary for South West Africa, Windhoek, 3 November 1952, NAN: EDU/742/7.

138 Ibid.

${ }^{139}$ Notes on Interview Accorded to Bishop I.H. Bonner of the AME by the Secretary, 3 August 1951, NAN: SWAA/A489/25.
} 
meeting were met. ${ }^{140}$ In May and June 1955 the SWAA received applications for recognition from AME representatives at Keetmanshoop, Aus, Maltahöhe, Mariental, and Windhoek. ${ }^{141}$ The SWAA cautiously reviewed the applications for the establishment and construction of AME churches and schools and were initially slow to approve the necessary permits. In several government documents, this delay in approval was directly linked to the 1953 South African General Elections and the possibility that approval for the construction of "Coloured" or "Native" churches and schools could impact the NP's electoral prospects in the territory and further weaken the NPSWA in the 1955 elections. ${ }^{142}$ Despite the slow process, it is clear that government officials believed that little harm would come to the territory through the state's recognition of the AME schools and that, in many cases, administrators wanted more time to assess the long-term viability and ambitions of the AME Church in South West Africa. ${ }^{143}$ Some concerns existed over internal political strife in Omaruru in 1953 and the aforementioned "irresponsible members" spreading communist and anti-white propaganda. Although the Nama used the AME Church as an anticolonial resistance institution to advocate for better educational standards, most SWAA officials pointed to the lack of tensions and problems the church caused

\footnotetext{
${ }^{140}$ Native Schools, General: Applications for Recognition, NAN: SWAA/EDU/21/1

${ }^{141}$ Ibid.

142 The 1953 South African General Elections were important as the NP attempted to gain more control over the government. In the 1948 General Elections, the NP managed to secure a five-seat advantage over the UP. The NP proved victorious in the 1953 General Election and secured 94 seats to the UP's 57. The South West African Legislative Elections were to be held in 1955 and the 6 seats afforded to direct representatives of the territory to the South African Parliament were reliably won by the NPSWA. The recognition and approval of Black-led schools in the territory could have threatened the NPSWA's dominance in the territory and siphoned off white votes to another opposition party. Thus, the slow process of approval was a practical political maneuver by the NP and NPSWA to maintain their political dominance in the upcoming elections.

${ }^{143}$ Report of C.J. Rossouw, Superintendent, Kransz-Platz Reverve, 14 November 1948, NAN: SWAA/A489/25. In this document, the Magistrate of Rehoboth stated that "none of the farmers are in a position to support the allegations of incitement of Natives against Whites." The Magistrate of Lüderitz similarly pushed back against the claims against the AME Church, writing "[I] disagree with the allegations against the AME. I never noticed any misconduct on the part of this church." Lastly, the Magistrate at Keetmanshoop also rejected allegations of communist activity, relaying that "There is no evidence to support the claim that the AME is communist."
} 
in the Union in the previous half-century and believed that the AME would cause few problems in South West Africa outside of limited conflicts with the RMS for congregants and influence. ${ }^{144}$ As the Van Zyl Commission contemplated non-European education in South West Africa in 1958, Gow and the AME secured recognition of two AME schools at Duwisib and Keetmanshoop, but experienced great difficulty elsewhere as the commission recommended the entrenchment of apartheid-style education in the territory. ${ }^{145}$ Gow described these difficulties in a letter to the Director of Education in 1958:

Once again I am making an urgent earnest appeal for the registration of our schools. In a number of cases we have gone to considerable expense, and even sacrifice to meet the requirements as suggested to us by your office in the expectation that our petition might commend itself to your favorable consideration. I need to point out of what tremendous help it would be to our missionary efforts if we could be accorded the same or similar benefits granted to like bodies in South West Africa. If we are still lacking in essential requirements please point them out to us and we will seek further avenues through which to meet your wishes. ${ }^{146}$

The acceptance and implementation of the suggestions contained in the Van Zyl Commission report made the state recognition of additional AME schools unlikely and constructed barriers to the Nama quest for socioeconomic inclusion within the restrictive colonial state. ${ }^{147}$

Regardless of the failures faced in achieving state-sponsored funding and recognition, the AME Church received several permits in the 1950s that secured sites for the construction of churches and school buildings. AME leaders at Hoachanas received a permit to construct a church in 1952 and requested the expansion of their school building in 1953. ${ }^{148}$ Markus Witbooi

\footnotetext{
${ }^{144}$ Chief Native Commissioner, Windhoek to the Magistrate/Native Commissioner, Omaruru, 11 September 1953, NAN: SWAA/A489/25/9.

${ }^{145}$ G.D. Scholtz, Director of Education to Francis H. Gow, 1958, NAN: SWAA/EDU/20/1

${ }^{146}$ Francis H. Gow to Director of Education, 31 May 1958, NAN: SWAA/EDU/20/1.

${ }^{147}$ Katjavivi, History of Resistance, 28. The author states that AME schools were not recognized by the South African regime. However, correspondence between the Administration and Francis Gow shows that the schools at Duwisib and Keetmanshoop received state recognition. The state's position on the schools at Gibeon and Hoachanas is disputed.

${ }^{148}$ Permit-Hoachanas, Issued by Administrator AJR Van Rhijn, 13 March 1952, NAN: SWAA/A489/25/6; See also, Markus Kooper to Chief Native Commissioner, Windhoek, 19 September 1952, NAN: SWAA/A489/25/6.
} 
secured a permit for a church site in Gibeon in 1951 and expanded the AME school there in 1953 as well. Additional AME Churches and schools emerged in Keetmanshoop, Rehoboth, Lüderitz, Maltahöhe, Mariental, and Windhoek throughout the late 1940s and 1950s. ${ }^{149}$

The increase in the number of available AME schools led to a growth in enrollment despite the lack of state support and funding. Between 1948 and 1950, Keetmanshoop's AME Church saw school enrollment rise from 260 pupils to 286, while Maltahöhe's school enrollment increased from approximately 140 pupils to 170 over the same period. Hoachanas and Gibeon likewise saw increased involvement in the AME schools with their enrollment number moving from 90 to 165 and 50 to 92, respectively, between 1949 and 1951. Similar trends of increased school enrollments continued in Lüderitz, Rehoboth, and Mariental during the same time. ${ }^{150}$ The statistics suggest that the AME's Black liberation theology appealed to Namibian parents and that Black-led education possessed a particular value as an anticolonial strategy to resist the extension of Bantu Education in the early years of apartheid in South West Africa.

The increased level and quality of education provided by the AME schools also facilitated its growth in the late-1940s and 1950s. As the previous pages argued, one of the primary reasons that the AME Church's schools appealed to Namibians was that it promised to provide education above a Standard II level. The desire for education up to the level of Standard VI became a central rallying cry for the AME leadership throughout South West Africa, and they quickly achieved this goal. In March 1952, Joseph Kahuika argued that the AME possessed a teacher capable of offering education to Standard V, and he placed pressure on the SWAA at the

\footnotetext{
${ }^{149}$ Permit - Gibeon, Issued by Administrator AJR Van Rhijn, 28 July 1951, NAN: SWAA/A489/25/4.

150 The statistics provided above are a compilation taken from NAN: SWAA/A489/25/1-9. Contradictory enrollment numbers are provided for the time period in various locations. The numbers above utilize the most conservative estimates provided for each school between 1949 and 1951.
} 
Berseba Reserve to make that a reality. ${ }^{151}$ By 1958, AME Church schools began to offer English as a second language. ${ }^{152}$ The most successful of the AME schools proved to be the school at Keetmanshoop which, by January of 1959, enrolled students from Sub-Standard A through Standard VI. ${ }^{153}$ Over time, most of the AME schools in the territory achieved similar levels of educational quality.

The early successes of the AME Church and its schools in the Police Zone served as a means of resistance to the increasingly segregated and deteriorating level of education provided to Namibians by the SWAA and the missionaries. The RMS and other Lutheran-based mission schools provided low-level education with a limited curriculum designed to create a cheap and immobile labor force to be used by white farmers, businesses, and the state in its economic endeavors in the Police Zone. The AME Church schools offered a less vocational and more traditional Western-style education that, by the 1960s, extended from Sub-Standard A to Standard VI. AME congregants pulled their children out of the RMS schools and enrolled their children in the AME schools in droves to obtain the type of education that provided Namibians with the education, spiritual freedom, and limited socioeconomic opportunities that the RMS schools could not provide.

\section{Conclusion}

The AME Church became an invaluable resistance institution against the extension of the SWAA's apartheid policies in the 1950s and 1960s because the AME's Black liberation

\footnotetext{
${ }^{151}$ Extract from the Minutes of the Quarterly Meeting Held in the Berseba Native Reserve, 18 March 1952, NAN: SWAA/A489/25/7.

${ }^{152}$ Untitled Document, NAN: EDU/20/2/4/4.

${ }^{153}$ Director W. Rover to the Director of Education, Windhoek, 22 January 1959, NAN: EDU/20/2/4/5. In January 1959, the AME School at Keetmanshoop possessed the following enrollment numbers: Sub. Std. A (26), Sub. Std. B (15), Std. I (25), Std. II (14), Std. III (25), Std. IV (8), Std. V (10), and Std. VI (5) for a total enrollment of 128 students. The total enrollment at Keetmanshoop would increase to 218 students by 1963.
} 
theology responded to the socioeconomic and political conditions faced by Namibians of the period. The colonial state's policies effectively worked to create a minimally-educated and stagnant Black labor pool that existed to meet the economic needs of white society. The SWAA limited Namibians' mobility through the implementation of pass laws and vagrancy laws, preventing them from freely seeking employment in the territory's industrial centers. Instead, through the use of systemic educational underdevelopment and the territory's apartheid legal apparatus, the colonial state funneled Blacks into the wage-based economy either as poorlycompensated migrant laborers or agricultural workers on white-owned farms.

The lack of economic opportunities for Namibians was inextricably linked by Nama leaders to the failed educational system facilitated by the missionaries and SWAA. State- and missionary-led education provided Namibians with basic technical skills necessary to fulfill menial-labor jobs that were of value to the territory's white population. However, this type of education was limited to the level of Standard II in order to prevent competition between the territory’s white and Black populations that might result in incidents similar to the Rand Rebellion of 1922. The limits placed on education by the colonial government also served the purpose of preventing the rise of a Namibian intelligentsia that could challenge white hegemony and colonial dominance in the future. In both cases, Namibians faced poor socioeconomic prospects as a result of educational underdevelopment.

In contrast to white-led schools and churches, the AME Church, from its inception in Philadelphia in the 1810 s, believed that education was the key to racial uplift and self-sufficiency and served as a means to change white opinions of the Black race. The Nama leaders' desires for subnational concession like improved education and the historical linkages created between Hendrik Witbooi and the Ethiopianist evangelist Stuurman in the early twentieth century 
generated a channel through which Francis H. Gow and the AME Church established a foothold in the Police Zone in the 1940s and 1950s. Gow worked tirelessly in the 1940s and 1950s to obtain state recognition for the AME Church and its schools, which would result in increased state-sponsored funding and the issuance of permits for the construction of durable AME school sites. Through these state channels, Gow ensured that Black educators filled positions at the AME schools, even if it meant that they had to operate under white government supervision. This ultimately fulfilled Nama parents' desires for Black-led education and reduced student interactions with white teachers who parents deemed condescending and oppressive.

Thus, education was viewed as a way for the Nama to seek inclusion in the colonial economy, decision-making process, and social sphere. AME leaders recognized that the SWAA placed barriers in the way of African-led institutions in order to maintain strict control over Namibian economic, social, and political mobility. The AME schools represented a chance to break through these barriers and increase the standard-of-living for the Nama congregants and families. The quest for state recognition was aimed at pacifying the concerns of the SWAA and gaining access to state funds to feed, house, and educate students, in exchange for the acceptance of white oversight. AME congregants accepted this fact to receive higher standards of education that could potentially lead to inclusion in the colonial economy and access to occupations of higher prestige and wages in the Police Zone, like teachers or pastors.

The AME Church proved to be one of the most successful transnational resistance institutions in South West Africa between 1946 and the 1960s, as it was able to achieve a number of its stated goals. The AME Church increased the number of Black teachers and schools in the Police Zone and gave previously marginalized Black clergymen and mission-educated teachers an opportunity to receive decent wages for their work. New courses were also introduced to class 
schedules, and Namibian school children were able to take some classes that did not directly contribute to their ability to perform technical or menial labor jobs. Likewise, the AME Church was able to increase the standard of learning in the territory by providing students with an education that ranged from Sub-Standard A to Standard VI. Finally, in spiritual matters, the church also achieved its goal of ordaining Black pastors in the territory. This allowed Namibians to reassert some level of autonomy and control over their congregations' spiritual and financial lives and reduced their interactions with sermons and services that the Namibian congregations deemed dehumanizing and oppressive. 


\section{Chapter 6-Forced Land Removals and International Pressure Campaigns: Namibians' Petitions to the United Nations, 1945-1959}

The 1950s and 1960s in South West Africa were characterized by the rapid expansion of the apartheid system and the systemic social, political, and economic underdevelopment of Namibian communities. Transnational institutions provided opportunities for Namibians to work outside of official government channels and leverage the influence of these international organizations against the Union government and the SWAA to limit the continued abuse of vulnerable Namibians. As chapter 5 showed, the AME Church proved to be a viable transnational institution for Nama communities to make subnational claims of the SWAA for improved educational standards and newly-constructed schools. However, as the mid 1950s approached, the issue of land expropriation and forced removals came to the fore in South West African politics. The Union government's refusal to place South West Africa under the UN's trusteeship system effectively placed Namibians at the mercy of the exploitative colonial state.

Prior to the emergence of SWAPO in 1960 and the creation of a more unified nationalist front, Namibians looked outside territorial boundaries and engaged with sympathetic transnational actors to place international pressure on the Union government and combat the government's aggressive land expropriation schemes. While the Katutura Massacre in Windhoek in December 1959 became the central thrust of the nationalist petitions at the UN in the early 1960s, the attempted removals at Aminuis and Hoachanas between 1956 and 1959 dominated the early meetings of the Committee on South West Africa. In these small rural reserves, Namibian community leaders called upon historical networks and relationships to make the international community more aware of the Union government's violation of the principles of its mandate. Through a lengthy petition-writing campaign, Chief Hosea Kutako and Reverend Markus Kooper called upon the UN to intervene in South West African affairs and fulfill its international 
duty to provide for the development and progress of the indigenous people in the mandatory and trusteeship territories.

The historiography surrounding Namibians' petitions to the UN in the post-World War II period focused extensively on the nationalist petitions submitted by SWAPO and SWANU representatives as part of a larger strategy to achieve national independence for the South West Africa territory. ${ }^{1}$ In this process the petitions submitted throughout the $1950 \mathrm{~s}$, a decade prior to the emergence of the nationalist movements, have gone largely unexamined and the historical importance of their content not analyzed. This chapter argues that before the emergence of SWAPO and a united nationalist front, the UN petitions from Namibians in the Police Zone were subnational in nature and mostly concerned with halting the SWAA's land expropriation schemes in the 1950s. Although each petition was subnational and geopolitically exclusive in its formulation, they occurred nearly simultaneously and drew upon one another's experiences to make their case. As a result of these resistance strategies and their access to politically influential transnational networks, the Nama and Herero leadership in the Police Zone were able to wage a public opinion campaign against the SWAA that led to UN resolutions which halted Namibians' removal from socioeconomically important lands. Through this campaign, Nama and Herero leaders sought further inclusion in the colonial decision-making process and a halt to those exclusionary policies and actions which sought to further segregate and marginalize Namibians in the Police Zone.

\footnotetext{
${ }^{1}$ See Udogu, Liberating Namibia as a prime example of the works examining SWAPO's role at the United Nations between the 1960s and 1980s.
} 


\section{The Transition from the League to the United Nations: A Change in South West Africa's International Status}

The earliest origins of Namibians' UN petition-writing campaign can be traced to the establishment of the UN in 1945 and the re-ordering of international politics after World War II. The commencement of World War II in 1939 made clear that the ambitious League of Nations concept had failed. Criticism against the idealism of the League's covenant and its inability to fulfill its stated mission emerged as early as the 1920s and mounted with each of the organization's missteps. Despite the international community's criticisms of the League, a dialogue in support of a supranational successor organization emerged by the middle of the Second World War. Cooperation among the world's political powers was believed to be a necessary endeavor to prevent future wars and the development of a more peaceable global political order.

Scholars and politicians of the period considered the League of Nations a failure because of the stark contrast between its idyllic and utopian message of democratic idealism and its inability to fulfill its central political goal of collective security that was outlined in Articles 10, 11 and 16 of the League's Covenant. ${ }^{2}$ The organization failed to maintain order within the international community and proved incapable of protecting the rights of people and property from aggression and abuse. M. Patrick Cottrell argued that the events of the late 1930s and early 1940s only further highlighted the limits of the League's "naïve utopianism" and delegitimated it in a multitude of ways. ${ }^{3}$ Chief among these was the lack of support from the Great Powers, the

\footnotetext{
${ }^{2}$ C.G. Fenwick, "The 'Failure' of the League of Nations," The American Journal of International Law 30, No. 3 (July 1936): 506-509.

${ }^{3}$ M. Patrick Cottrell, "Lost in Transition? The League of Nations and the United Nations," in Charter of the United Nations: Together with Scholarly Commentaries and Essential Historical Documents, eds. Ian Shapiro and Joseph Lampert (New Haven: Yale University Press, 2004), 91.
} 
League's inability to check German aggression in central Europe, and the ineffectiveness of economic sanctions levied by the League as a result of the Italo-Ethiopian Crisis in $1935 .{ }^{4}$

From its inception, the League faced challenges to its legitimacy and struggled to attract the dominant political powers of the period to its side. Although American President Woodrow Wilson played a fundamental role in conceptualizing the League and its purpose, he failed to convince Congress that the United States should join the League. The Japanese government withdrew from the League of Nations in February 1933 when the League's assembly adopted the Lytton Report that accused the Japanese government of violating Chinese sovereignty and called for the immediate withdrawal of Japanese forces from Manchuria. ${ }^{5}$ The German government withdrew that same year and the USSR was expelled from the League in 1939. Without resounding support among global political power brokers, the provision of adequate collective security appeared unlikely. The defection of smaller nations like Guatemala, Honduras, Nicaragua, Hungary, and Spain in the 1930s only further weakened the League's ability to fulfill its charter. ${ }^{6}$

The German governments' withdrawal from the League of Nations in 1933 proved crucial in the delegitimization of the League. Germany's increased aggression toward the League's member states provided direct evidence that the League possessed no coercive mechanism to ensure collective security. In 1936, Hitler's Germany reoccupied and remilitarized the Rhineland and then, in 1938, he imposed the Anschluss in Austria and occupied the

\footnotetext{
4 Ibid.

${ }^{5}$ In 1931, the League of Nations tasked the Lytton Commission with the investigation and evaluation of Japan's role in the Mukden Incident and the Japanese government's seizure of Manchuria. In October 1932, the commission found that Japan had invaded and seized Manchuria under false pretenses and recommended that Manchuria be returned to the Chinese government.

${ }^{6}$ James T. Watkins IV, "International Affairs: Democracy and International Organization-The Experience of the League of Nations,” The American Political Science Review 36, No. 6 (December, 1942): 1140.
} 
Sudetenland in Czechoslovakia. ${ }^{7}$ Each of these matters was vigorously debated in the League's assembly, but no resolution was achieved and no preventative actions taken. These failures only contributed to the League's negative post-war reputation and presented Hitler's government with no consequences to dissuade it from its future aggressive actions against Poland in 1939.

The League's inability to successfully prevent, and later punish, the Italian government's aggressive actions in Ethiopia in 1935 solidified the image of the League as a failure. To redress the failures of Italian forces in 1896 and recreate the glories of its Roman past, dictator Benito Mussolini sent Italian forces to invade Ethiopia in October $1935 .{ }^{8}$ Ethiopian Emperor Haile Selassie initially turned to the League for aid in enforcing its doctrine of collective security. The League implemented economic sanctions against the Italian government and implored its member states to refrain from selling arms to warring nations. However, the League failed to institute an embargo on oil to Italy and the Italian military was able to continue its assault on Ethiopia largely unimpeded. ${ }^{9}$ The ineffectiveness of the League was viewed as a significant failure in the international community and eventually led Mussolini to withdraw from the League in 1937.

Hitler's invasion of Poland in 1939 represented a physical manifestation of the League's failure and, by 1941, discussion commenced on the termination of the League and its replacement by a more effective successor organization. The Declaration of St. James' Palace

\footnotetext{
${ }^{7}$ Peter J. Beck, "The League of Nations and the Great Powers, 1936-1940," World Affairs 157, No. 4 (Spring, 1995): 175-189. Anschluss is the term that refers to Nazi Germany's annexation of Austria on 12 March 1938. The Sudetenland is a territory that was part of the former Czechoslovakian state. The territory contained a high population of ethnic Germans. The occupation of the Sudetenland by Hitler's forces in 1938 was viewed as a way to redress the humiliations of the Treaty of Versailles.

${ }^{8}$ James H. Meriwether, Proudly We Can Be Africans: Black Americans and Africa, 1935-1961 (Chapel Hill: University of North Carolina Press, 2002), 28. Emperor Menelik II defeated invading Italian forces at the Battle of Adwa on 1 March 1896. The Italian defeat served as a humiliation that severely damaged Italy's prestige in European circles.

${ }^{9}$ Ibid., 29.
} 
was signed in 1941 and advocated for "the willing cooperation of free peoples in a world in which, relieved of the menace of aggression, all may enjoy economic and social security" as a means to develop "enduring peace." 10 The Atlantic Charter was issued two months later and set the foundation for the cooperative principles that guided post-war international relations. ${ }^{11}$ By January 1942, representatives of the 26 countries fighting the Rome-Berlin-Tokyo Axis signed the Declaration of the United Nations and committed to the "maximum war effort" against the Axis Powers and agreed to make a singular peace supported by each signatory power. ${ }^{12}$ The need for a cooperative successor organization was again affirmed in November 1943 when paragraph four of the Declaration of the Four Nations on General Security recognized "the necessity of establishing at the earliest practicable date a general international organization, based on the principle of the sovereign equality of all peace-loving states, and open to membership by all such states, large and small, for the maintenance of international peace and security."13

While the concept of a successor organization remained in the abstract during the early years of the war, the Dumbarton Oaks Conference in 1944 produced some of the earliest concrete proposals for the League's successor, the UN. On 7 October 1944, representatives from the United States, USSR, Great Britain, and China met at a private mansion in Washington, DC to create proposals for the organizational structure of the UN. The conference proposed that the UN would consist of four bodies: the General Assembly, the Security Council, the International

\footnotetext{
${ }^{10}$ Royal Institute of International Affairs, "Declaration of St. James Palace," in United Nations Documents, 1941 1945 (New York: Royal Institute of International Affairs, 1947), 9.

${ }^{11}$ The Atlantic Charter served as a framework for a post-World War II order. The concept of international cooperation, self-determination, and the restoration of self-government pervaded the Charter. It played an important role in influencing inter-European relations, US-European relations, and the relationship between the colony and metropole in the post-war period.

${ }^{12}$ Royal Institute of International Affairs, "Declaration of the United Nations," in United Nations Documents, 19411945 (New York: Royal Institute of International Affairs, 1947), 11-12.

${ }^{13}$ Royal Institute of International Affairs, "Declaration of the Four Nations on General Security," in United Nations Documents, 1941-1945 (New York: Royal Institute of International Affairs, 1947), 13-14.
} 
Court of Justice, and the Secretariat. The General Assembly consisted of representatives from all member states and was tasked with the promotion of international cooperation through research and recommendations for action. The Security Council, perhaps the most important new innovation of the UN, consisted of 11 members, with five permanent members and six rotating members from the General Assembly. The Security Council was tasked with the prevention of future wars and granted the power to demand armed forces from member states to fulfill this duty. Such capabilities sought to redress the League's lack of a coercive mechanism for the enforcement of its decisions. ${ }^{14}$

These proposals were debated at the San Francisco Conference of 1945, where representatives of 50 nations met to establish a charter for the UN based on the work completed at Dumbarton Oaks. ${ }^{15}$ On 24 October 1945 the five permanent members of the Security Council ratified the charter and brought the UN into existence. The following April, the League's assembly voted to take the necessary steps to terminate its existence and transfer its properties and assets to the newly-created UN. On 1 August 1946, this transfer was carried out during a small ceremony in Geneva. ${ }^{16}$

In its early years, one of the key questions that the UN was forced to consider was the status of the mandate territories created under the League of Nations. This issue arose at the San Francisco Conference since such concerns were not addressed at the Dumbarton Oaks Conference. At the center of the debate over the mandate territories was whether the UN should

\footnotetext{
${ }^{14}$ For a full discussion of the Dumbarton Oaks Conference, see Robert C. Hilderbrand, Dumbarton Oaks: The Origins of the United Nations and the Search for Postwar Security (Chapel Hill: University of North Carolina Press, 2001).

15 The 46 nations that declared war on Germany and Japan received invitations to the San Francisco Conference in March of 1945. A subsequent four nations were invited to the conference at a later date. The 50 nations represented at the Conference represented roughly 80 percent of the world's population.

${ }^{16}$ Leland M. Goodrich, "From League of Nations to United Nations," International Organization 1, No. 1 (February, 1947): 3.
} 
promote outright independence among the mandates, or whether it would be better suited to pursue a policy of self-determination in these territories. ${ }^{17}$ After much debate, the San Francisco Conference settled on the promotion of "the progressive development" of the people of these territories and their direction toward either independence or self-government. ${ }^{18}$ The mandate territories would be reclassified under this new system as "Trusteeships" and placed under the purview and collective administration of the UN.

Chapter twelve of the UN charter provided for the establishment of a Trusteeship Council that consisted of representatives from the five permanent members of the Security Council and both administering and non-administering member states. ${ }^{19}$ The primary role of the Trusteeship Council was to oversee the administration of these new "trust territories" and ensure that each territory was administered in a manner consistent with the promotion of the best interests of the indigenous people in each territory. Political scientist Huntington Gilchrist argued that the Trusteeship Council's established standards for the treatment of non-self-governing peoples provided a "yardstick throughout the entire colonial world" for how indigenous inhabitants should be treated under the new global political order. ${ }^{20}$

It was clear that a new system of administration was needed as the mandate system possessed inherent weaknesses that led to its failure. The mandate territories that existed under the League were primarily viewed in negative terms by those who supported the shift to the trusteeship system. Under the League, the mandate system merely "sought to protect the peoples

\footnotetext{
${ }^{17}$ The use of the term self-determination implies here that the mandate territories would have the right to determine the path of their own statehood and have the ability to develop international relationships as they saw fit.

${ }^{18}$ William C. Johnstone, “The San Francisco Conference,” Pacific Affairs 18, No. 3 (September, 1945): $220-221$.

${ }^{19}$ In addition to the five permanent members of the UN Security Council, the UN charter called for the Trusteeship Council to include all UN member states administering a trust territory and an additional number of nonadministering member states so that the number of administering and non-administering members were equal.

${ }^{20}$ Huntington Gilchrist, "Trusteeship and the Colonial System," Proceedings of the Academy of Political Science 22, No. 2 (January, 1947): 96.
} 
under its charge...from abuses which had arisen in dependent territories in the past." ${ }^{21}$ Prolonged enquiries on abuses committed by mandatory powers frequently took years to produce and often relied on information provided by the abusive state itself. The PMC provided little protection against these abuses and few consequences existed for the responsible party. Coupled with its lack of concrete plans for the economic and social development of the people under its charge, the mandate system was fraught with incoherency and contradiction. ${ }^{22}$

Conversely, the trusteeship system was viewed primarily in positive and proactive terms. Social and economic development of the indigenous people entrusted to the UN became the driving impetus of the Trusteeship Council. The "trust territories," unlike their predecessors, also had a "constitutional status recognized under international law" which permitted the Trusteeship Council to send representatives to trust territories instead of relying on the reports of the administering powers when claims of abuse arose. ${ }^{23}$ This theoretically allowed for quicker resolution of disputes and limited the ability of the administering power to hide such abuses. Likewise, the protective measure provided for under the mandate system would be enforced in the new trust territories to ensure the promotion of "progressive development" of the indigenous people in a territory.

Despite the more positive conception of the trusteeship system, however, one clear weakness emerged that directly impacted the international status of South West Africa in the post-war period. In order for a territory to be placed under the trusteeship system, the mandatory power had to willingly place the territory under the purview of the Trusteeship Council and the UN. Gilchrist described the process, stating "All former Mandatories which are now members of

\footnotetext{
${ }^{21}$ Ibid., 98.

${ }^{22}$ Ibid., 98-99.

${ }^{23}$ Ibid., 100.
} 
the United Nations...have drawn up Trust Agreements in consultation with other interested states and these agreements are now receiving attention at Lake Success in the Trusteeship Committee of the General Assembly." ${ }^{24}$ The only exception to this process was the Union government, which actively sought to retain its exclusive control over South West Africa and incorporate it into the Union.

As chapter 4 discussed in detail, Smuts and the South African government still possessed plans of outright annexation for South West Africa and desired to incorporate it as a fifth province into the Union. Attempts were initially made to convince the General Assembly that annexation was a more productive path forward rather than placing South West Africa under the trusteeship system. Smuts held a referendum in 1946 asking the indigenous people of South West Africa whether they wanted to be ruled by the South African government or "any other Government or people." ${ }^{25}$ Despite the referendum returning resoundingly in favor of incorporation, reports emerged that brought the method of the referendum's administration into question. The UN subsequently rejected Smuts' plan of incorporation and demanded that South West Africa be placed in trust of the UN. ${ }^{26}$ Smuts and the South African government rejected the demands of the UN and proceeded with their plan of de facto incorporation of South West Africa as a fifth province. The rapid expansion of the apartheid apparatus and the continued social, economic, and political underdevelopment of Namibians in South West Africa would continue, despite the changing position of all other mandate territories within the international political order.

\footnotetext{
${ }^{24}$ Ibid., 101.

${ }^{25}$ Referendum Template, 1 February 1946, NAN: SWAA/GL37/V1. For more information on the referendum on incorporation, see pages 198 to 208 of this dissertation.

${ }^{26}$ Emmett, Popular Resistance, 250-255.
} 
The refusal of the South African government to willingly place South West Africa in trust of the UN caused international tensions between the two. Legally, the UN could not force the South African government to place South West Africa under the trusteeship system and its primary legal recourse was to demand the enforcement of the League's earlier mandate, which was deemed to still be in effect. Although the UN considered South West Africa still under its purview and believed that it still had monitoring responsibilities over the indigenous Namibian population, the South African government ruled the territory as a fifth province and continued the extension of the apartheid apparatus relatively unimpeded. Thus, while 10 other territories were under the administration of the UN Trusteeship Council, the South African government maintained largely unfettered access to South West Africa as a colonial possession. This placed Namibia in a precarious international legal situation, whereby the UN and South African government were vying for control in the territory. Although the South African government would not assent to placing South West Africa under the trusteeship system, UN efforts to push for trust status spread knowledge and information about the organization among Namibians in the territory. Whereas the Basters relied on Dewdney Drew to gather information about the League of Nations for their petition-writing campaign, the Nama and Herero instead relied on transnational actors from Britain and the United States to formulate their resistance campaigns.

\section{The UN Comes to South West Africa: Rev. Michael Scott and} the Origins of the Namibian Petition-Writing Campaigns

While the South African government hoped to limit the impact of the UN in South West Africa by refusing to place the territory in its trust and instead incorporate it as a fifth province, the contest between the two for influence introduced many Namibians to the true power and influence of the organization. In the administration of its controversial referendum, the South 
African government failed to adequately explain the role of the $\mathrm{UN}$ in international politics and its potential role in the administration of South West Africa. Discussions about the trusteeship system were avoided altogether in consultations with Namibian leaders. The concept of the UN as an institution of resistance to fight against the Union government's implementation of its apartheid policies did not emerge until 1947. In 1947, Chief Frederick Maharero, upon the urging of the Tswana chiefs, established contact with the Reverend Michael Scott. ${ }^{27}$ It was through this contact with Reverend Scott that knowledge of the UN and its purpose grew among Namibians during the 1940s and 1950s. By the middle of the 1950s, Scott petitioned the UN on behalf of Namibians as their representative.

To understand Scott's role in the formulation of the Namibian petition-writing campaigns to the UN, it is first necessary to look at his early activism and the role he played in southern African protest movements. Following his ordination as an Anglican priest in 1930, Scott spent his first years at a parish in Sussex and then moved to a parish in West London. He lasted only a year in West London, which he believed was too removed from the real struggles of the world experienced by the everyday man. Scott moved to another parish in East London the next year where he believed "the evils of the world were being fought or endured." ${ }^{28}$ In East London, he came to view religion as a "divine instrument of change rather than a divine sanction of the status quo." ${ }^{29}$ During this time he became sympathetic to communism and had dealings with the

\footnotetext{
${ }^{27}$ Ibid., 253. The Tswana chiefs sent a memorandum to the British government stating their opposition to the incorporation of South West Africa into the Union and asking for their own representation at the United Nations. The Tswana chiefs believed that if South West Africa was incorporated and the Bechuanaland Protectorate was surrounded by white settlement, then the Protectorate could be "economically strangulate[ed]." Frederick Maharero was the son of Samuel Maharero, the former paramount chief of the Herero. Frederick and his father were forced into exile in Bechuanaland in 1904 at the conclusion of the Herero-Nama Genocide. He actively petitioned the UN in the late-1940s to stop the incorporation of South West Africa into the Union.

${ }^{28}$ Scott, A Time to Speak, 53-54.

${ }^{29}$ Ibid., 55.
} 
hunger marchers from Tyneside and Scotland. ${ }^{30}$ Through these experiences, Scott reconciled his religious beliefs to follow a more humanitarian and activist ethos.

Scott took a post as the chaplain at St. Joseph's Orphanage in South Africa in 1943 and also served at the St. Alban's Coloured Mission. ${ }^{31}$ While in South Africa, he likewise participated in the Campaign for Right and Justice. The campaign was an extra-parliamentary movement focused on seeking out both racial and class injustices in South Africa. Scott recalled that "[The campaign's] aim was to form a vigorous and realistic movement in opposition to the growth of Dr. Malan's form of Afrikaner Nationalism and 'apartheid' and to uncover the menacing ramifications of the Afrikaner Broederbond, which was stretching its tentacles into all forms of economic, social, and political life, and was becoming so powerful as to be almost a state within a state." ${ }^{\prime 2}$ The campaign was active in its messaging and called for the "provision of social services for all races," as well as "full and direct representation for all sections of society," the "abolition of all legislation discriminatory on grounds of colour, race, or sex," and "the provision of land for the landless people of South Africa." ${ }^{33}$ By 1946, Scott's activities were well-known, and he was approached by the Council for Human Rights and asked to travel to Durban to observe the violence meted out against the Passive Resistance Movement. ${ }^{34}$ Scott witnessed immense violence against members of the movement following the passage of the

\footnotetext{
${ }^{30}$ Scott never considered himself to be a communist in the truest sense. He stated, "I had a lot of serious misgivings about the communists' attitudes and wondered what was really inspiring their action. I admired their courage and the intensity with which they worked night and day for the cause they believed in. But I had a great hesitation about actually joining their party because it seemed to me that their whole attitude towards life was limited." Hunger Marchers protested periods of high unemployment in twentieth-century Britain. They frequently protested outside of Parliament over the impact unemployment had on their ability to feed their families. The Tyneside and Scottish hunger marchers came from the area around Newcastle and the northern United Kingdom.

${ }^{31}$ Scott, A Search for Peace and Justice, 18.

${ }^{32}$ Ibid., 38.

${ }^{33}$ Ibid., 36.

${ }^{34}$ The Passive Resistance Movement in 1940s South Africa was based on the non-violence movement led by Gandhi in the early-twentieth century. It sought peaceable solutions to the increasingly violent and abusive way that Afrikaner nationalists dealt with South Africa's Indian population.
} 
Asiatic Land Tenure and Indian Representation Act, and his own participation in the resistance only further solidified his desire to incorporate social activism into his personal life. ${ }^{35}$

In 1946, Tshekedi Khama invited Scott to the Bechuanaland Protectorate to meet with Frederick Maharero and discuss his anxiety over the 1946 referendum and the Union's desire to incorporate South West Africa ${ }^{36}$ When he met with Maharero, Maharero told Scott about the numerous "letters of distress" he had received from the Herero in South West Africa over the issue of land expropriation. ${ }^{37}$ Maharero asked Scott to travel to Windhoek to meet with some Herero and question them about the issues afflicting his followers in the territory. During this discussion, the young Herero determined that Scott should meet with the Herero headmen in Windhoek and took him to the Aminuis Reserve to meet with Chief Hosea Kutako. ${ }^{38}$

Kutako called a number of his councilors to meet with Scott that night and discuss Maharero's concerns about incorporation and the treatment of the Herero in the territory. During these discussions, information about the newly-formed UN was disseminated and its potential role in South West Africa detailed. Scott recalled that there was a "curious tenseness about these Africans hearing of the UN," but by the end of the conversation the UN was regarded as "the answer to their prayers" and "God's instrument of justice and freedom for their people." ${ }^{39}$ Molly McCullers affirmed that the Herero readily embraced the vision of the UN described by Scott,

\footnotetext{
${ }^{35}$ Scott, A Time to Speak, 133-134. The Asiatic Land Tenure and Indian Representation Act of 1946 attempted to further segregate and marginalize South Africa's Indian community. The Act stripped Indians of their right to own property without a permit and attempted to limit the land they could occupy. Furthermore, it placed limits on South African Indians' occupational opportunities.

${ }^{36}$ Tshekedi Khama was the Regent-King of the Bamangwato in Bechuanaland. Like the chiefs, Khama feared that the incorporation of South West Africa would eventually lead to the surrounding of Bechuanaland by hostile white governments. If this were to occur, he believed that the Protectorate could face "economic strangulation" and ruin. For an examination of the role of Bechuanaland in the southern African liberation movements, see Johann Muller, The Inevitable Pipeline into Exile: Botswana's Role in the Namibian Liberation Struggle (Basel: Basler Afrika Bibliographien, 2012).

${ }^{37}$ Scott, A Time to Speak, 216-217.

${ }^{38}$ Scott was granted a one-day pass by Chief Native Commissioner H.J. Allen to travel to Aminuis and meet with Kutako.

${ }^{39}$ Scott, A Time to Speak, 219.
} 
writing, "Rural Herero conceived of the UN in terms of leadership, loyalty, and deliverance....Rural Herero placed considerable, almost religious, hope in the UN and overestimated the degree, speed, and kind of assistance it might provide.....[N]o one knew the exact parameters of the UN's jurisdiction or how much power it would wield." 40

During Scott's visit with Kutako, the two constructed a petition to be submitted through the Union government to the UN. In the petition, Kutako called for the "return of [Herero] lands in South West Africa, and for the return from exile in Bechuanaland of our Paramount Chief Frederick Maharero together with the Herero people at present living in Bechuanaland." ${ }^{41}$ The issue of Herero representation at the UN also permeated this first petition. Kutako asserted:

So long as the League of Nations existed [the Herero] retained the right to petition the League, and, as has been pointed out...the Native inhabitants of South West Africa did not become Union Nationals when the Union assumed the mandate of South West Africa....Also we must beg to call your attention to the fact that despite the assurance of the representatives of the Union government that our case would be fully represented by the Union government's spokesmen at the United Nations' Assembly, we do not feel confident that this was adequately done. It is our opinion that the Union government by reason of its treatment of the African people, both in the Union and in South West Africa, has now forfeited all moral right and claim to continue exercising the mandate over South West Africa. ${ }^{42}$

He then requested the Union government's support to send Herero representatives to the UN to state their case in person. Kutako's petition represented one of the early attempts by Namibians to demand the placement of South West Africa under the trusteeship system and purview of the $\mathrm{UN}$.

\footnotetext{
${ }^{40}$ Molly McCullers, "Lines in the Sand: The Global Politics of Local Development in Apartheid-Era Namibia, 1950-1980," (PhD diss., Emory University, 2012), 72.

${ }^{41}$ Chief Hosea Kutako to the Parliamentary Secretary for Commonwealth Relations, 7 August 1947, NAN: Archives of Anti-Colonial Resistance and the Liberation Struggle (Hereafter, AACRLS)/006. See Gewald, "'I Was Afraid of Samuel," and Boammaruri Bahumi Kebonang, "The History of the Herero in Mahalapye, Central District: 19221984," Botswana Notes and Records 21 (1989): 43-60 for more on the Herero experience in Botswana. ${ }^{42}$ Ibid.
} 
At the conclusion of this meeting with Kutako, Scott returned to Bechuanaland to discuss the future of South West Africa with Maharero and Khama to write another petition to the UN. The petition, in Maharero's name, made similar demands of the Union government. He, too, requested the return of his followers from exile in Bechuanaland. Maharero asserted that he wanted to return to productive and healthy lands and that, upon agreement with Tshekedi Khama, he would bring his cattle with him from the protectorate. ${ }^{43}$ At the conclusion of the meetings with Maharero and Kutako, Scott was asked to serve as the Herero's representative at the UN. In 1949, he was granted a hearing before the Fourth Committee and presented testimony on behalf of the Herero. ${ }^{44}$

Scott continued to present and submit petitions from the Herero as their official representative into the $1950 \mathrm{~s}^{45}$ The petitions frequently demanded that South West Africa be placed under the trusteeship system and reiterated that the South African government repeatedly and flagrantly violated the principles and integrity of the mandate system established by the League of Nations. In most cases, the petitions detailed the horrid living conditions in the reserves and the socioeconomic hardships that Namibians faced in the wake of the extension of South African apartheid policies. ${ }^{46}$ Over time, these early petitions had the cumulative effect of keeping the South West Africa question at the fore of the General Assembly's proceedings and

\footnotetext{
43 “Frederick Maharero to Chief Hosea Kutako," 15 August 1947, NAN: AACRLS/006.

${ }^{44}$ Carol Anderson, Bourgeois Radicals (London: Cambridge University Press, 2015), 114-160.

${ }^{45}$ Over time, the South African government became more restrictive of Rev. Scott's access to Kutako and the Herero. In 1958, due to these limitations and difficulties, Fanuel Kozonguizi was appointed the permanent UN petitioner of the Herero Chief's Council. He served in this role until 1966 and was also the president of the South West Africa National Union during that time.

${ }^{46}$ See Hosea Kutako to the Chairman of the Ad Hoc Committee on South West Africa, 11 May 1956, United Nations Archives (Hereafter, UNA): S-0443-0061-9786/ Petitions Concerning South West Africa (Hereafter, TR240)/1957-1959; Kutako to Chairman of the Ad Hoc Committee on South West Africa, 30 October 1956, UNA: S0443-0061-9786/TR-240/1957-1959; and Mr. W. Kaukuetu to Secretary General, Dag Hammarskjoeld, 21 November 1956, UNA: S-0443-0061-9786/TR-240/1957-1959.
} 
forced the General Assembly to find more effective methods for checking the Union government's attempts to incorporate the territory into the Union.

Scott's testimony and activity also proved instrumental in popularizing the South West Africa question and bringing the weight of international political pressure on the South African government. Stories about Scott's testimonies in front of the UN appeared frequently in the press in the United States and were particularly popular among the African American press. Reports of his role as the representative of the Herero, and the conditions that the Herero faced under the South African government, appeared in the Philadelphia Tribune in November $1947 .{ }^{47}$ In December 1951 the New Journal and Guide published a story about Scott and Kutako, emphasizing Kutako's deteriorating health and his desire to testify in front of the UN in Paris on the state of the Herero and other Namibians in South West Africa ${ }^{48}$ Likewise, a similar story ran that month in the Philadelphia Tribune of Kutako's desire to testify as a "last service...to his people. ${ }^{\circ 9}$ More general appeals about the UN constructively intervening in Africa appeared in the New York Amsterdam News in 1952 and reference was once again made to Kutako and his desire to testify in person at the UN. ${ }^{50}$ The continuous circulation of reports about Kutako and the Herero in South West Africa kept the issue in front of sections of the American public and

\footnotetext{
47 "South African Cleric Tells of Fight for Native's Rights," Philadelphia Tribune, 11 November 1947. The Philadelphia Tribune was first published in 1884 by Christopher J. Perry and is the oldest continuously published African American newspaper in the US.

48 "United Nations Told of Woes of African Tribes," New Journal and Guide, 15 December 1951. The New Journal and Guide was originally published as the Gideon Safe Guide in 1900 by the Supreme Lodge Knights of Gideon and became one of the pre-eminent Black newspapers in the United States. It was primarily distributed in Norfolk, Virginia and temporarily halted publication in April 2020. Stories about Scott also appeared in the Times in the early 1950s. See Michael Scott, "Racial Equality," Times, 7 August 1950.

49 "UN Hears Priest Make Fervent Plea For Protesting Tribesmen," Philadelphia Tribune, 18 December 1951.

50 "Rev. Scott Asks UN to Hear S. African," New York Amsterdam News, 8 November 1952. The New York Amsterdam News is a weekly African American publication that was first distributed in New York City in 1909.
} 
placed pressure on diplomats, activists, and government officials to find a resolution to this issue. $^{51}$

The stories pertaining to South West Africa in the Black press coincided with an uptick in African American anticolonial activity in the 1940s and late 1950s. Ebere Nwaubani contended “American Black leaders from 1943 to 1947 raised a vigorous protest against European colonialism and against the American foreign policy which they found in support of that colonialism." 52 Although some negative images of Africa persisted among the African American community in the United States, many saw their own destinies deeply intertwined with those facing colonial oppression on the continent. Thus, African American intellectuals worked to actively shape American foreign policy and, as a result of the Cold War, found some success. For example, between 1957 and 1960 many of these intellectuals were enlisted by the State Department to attend African independence celebrations and show support for new governments that American foreign policy hoped to win to the causes of democracy and capitalism. ${ }^{53}$ Given the African American role in this decolonization process, the circulation of these stories likely had some impact on American political decision-makers and, consequently, the UN.

In light of this international pressure in 1950, substantial progress was made at the UN in its attempt to check the Union government's exploitation and abuse of Africans in the territory.

\footnotetext{
51 "UN Hears Priest Make Fervent Plea For Protesting Tribesmen," Philadelphia Tribune, 18 December 1951. This story, in particular, highlights the impact that such stories were having on public opinion and the decision-making process of US government officials. The story quotes Francis B. Sayre, the United States' representative to the Trusteeship Council, imploring the UN to "show the world that it rested on the moral force and judgement of mankind."

${ }_{52}$ Ebere Nwaubani, The United States and Decolonization in West Africa, 1950-1960 (Rochester: University of Rochester Press, 2001), 233.

${ }^{53}$ Ibid., 234. Also, see Brenda Gayle Plummer, In Search of Power: African Americans in the Era of Decolonization, 1956-1957 (Cambridge: Cambridge University Press, 2013) and Erik S. McDuffie, "Black and Red: Liberation, the Cold War, and the Horne Thesis," Journal of African American History 96, No. 2 (Spring, 2011): 236-247 for more information on the impact that African Americans had on American foreign policy during the period of African decolonization.
} 
On 11 July 1950, the International Court of Justice (ICJ) issued an advisory opinion that attempted to resolve the tensions between the UN and the Union on the issues of incorporation and the international status of South West Africa. In its advisory opinion, the ICJ ruled that neither the court nor the UN could compel the Union to place the territory under a trusteeship agreement since the term "agreement" implied the consent of both parties involved. However, the ICJ did rule that despite the termination of the League of Nations, the principles of the mandates issued during its existence must continue to be enforced. ${ }^{54}$ Additionally, the ICJ determined that the Union was obligated to continue to transmit Namibians' petitions to the General Assembly, as this right was granted by the Council of the League under the mandate and maintained by Article 80, paragraph 1 of the charter of the United Nations. ${ }^{55}$ Thus, the General Assembly maintained an important and influential role in monitoring the abuses meted out by the South African government and SWAA. Over the next three years, the General Assembly worked to find a solution to the international status of South West Africa and develop a method for dealing with South African abuses in the territory.

On 28 November 1953 the General Assembly passed Resolution 749(VIII)/A, which "Establish[ed] until such time as an agreement is reached between the United Nations and the

\footnotetext{
${ }^{54}$ The Advisory Opinion further argued that "The obligations of the first group represent the very essence of the sacred trust of civilization. Their raison d'etre and original object remain. Since their fulfillment did not depend on the existence of the League of Nations, they could not be brought to an end merely because this supervisory organ ceased to exist. This view is confirmed by Article 80, paragraph 1, of the Charter, maintaining the rights of States and peoples and the terms in question are placed under the trusteeship system. Moreover, the resolution of the League of Nations of April 18, 1946, said that the League's functions with respect to mandated territories would come to an end; it did not say that the mandates themselves came to an end....Therefore, South West Africa is still to be considered a territory held under the mandate of December $17^{\text {th }}, 1920 . "$

${ }^{55}$ Article 80, paragraph 1 of the UN Charter reads, "Except as may be agreed upon in individual trusteeship agreements, made under Articles, 77, 79, and 81, placing each territory under the trusteeship system, and until such agreements have been concluded, nothing in this Chapter shall be construed in or of itself to alter in any manner the rights whatsoever of any states or any peoples or the terms of existing international instruments to which Members of the United Nations may respectively be parties."
} 
Union of South Africa, A Committee on South West Africa, consisting of seven members. ${ }^{\Perp 56}$ The Committee on South West Africa's primary role was the analysis of "such information and documentation as may be available in respect to the Territory of South West Africa" and to "Examine, as far as possible, in accordance with the procedure of the former mandate system, reports and petitions which may be submitted to the Committee or to the Secretary-General." The General Assembly also tasked the Committee with the transmission of reports on the conditions in the territory. Although Namibians submitted petitions to the General Assembly, the creation of the Committee provided them with a direct liaison at the UN tasked specifically with evaluating and resolving Namibians' complaints against the Union government. In the coming years, the Committee on South West Africa faced an influx of petitions as the South African government more aggressively entrenched its apartheid system and more firmly instituted its reserve policy.

The committee proved crucial to Namibians' attempts to resist the extension of apartheid while the UN attempted to find a resolution to the South West Africa question. As stated above, the Committee on South West Africa wrote and distributed reports to the General Assembly on the conditions faced by Namibians in the territory and also received and considered petitions from Namibians. On several occasions, plans were made by the Committee to send an envoy to South West Africa to examine the conditions firsthand, but the South African government frequently rebuffed these attempts. Perhaps the most important success for the committee, and boon to Namibian resistance efforts against the SWAA, occurred with the ICJ's issuance of the Advisory Opinion of 1 June 1956. This advisory opinion provided the Committee with the ability

\footnotetext{
${ }^{56}$ General Assembly Resolution 749(VIII)A, The Question of South West Africa, A/RES/749(VIII)A (28 November 1953).

${ }^{57}$ Ibid.
} 
to grant oral hearings to petitioners on matters concerning South West Africa. ${ }^{58}$ Although the SWAA and Union government actively tried to prevent Namibians from testifying at the UN, the prospect of having their case heard in front of the General Assembly led many Namibians to flee into exile and make their way to the United States.

Namibians in the territory faced an increasingly harsh socioeconomic reality at the hands of the SWAA while the UN attempted to more fully bring South West Africa under its trusteeship system and the Committee on South West Africa kept the General Assembly informed of the situation in South West Africa. The issue of land came to define the tense relationship that developed between the SWAA and Namibians in the Police Zone during the 1950s. The early-to-mid 1950s were characterized by a drought that placed strain on Namibians' abilities to securely live in the environmentally-challenging Police Zone. Similarly, white farmers in the Police Zone became increasingly frustrated with some Namibians' continued residence on agriculturally valuable land and land near water sources that could be used to maintain herds of cattle. These white farmers placed immense amounts of pressure on the SWAA to remove Namibians and place them in reserves. ${ }^{59}$

In response to white farmers pressure, the SWAA implemented a series of forced land removals in the early 1950 s and tried to free up this desired land. In 1954, the government removed roughly 200 Hai |lom from the Etosha Game Reserve and plans were developed to remove Namibians from the Old Location in Windhoek. The following year, the Department of Native Affairs brought the territory's reserve strategy under its direction and started to turn the

\footnotetext{
${ }^{58}$ Admissibility of Hearings of Petitioners by the Committee on South West Africa: Advisory Opinion of 1 June 1956, ICJ Reports 1956.

${ }^{59}$ Gido G. Weigend, "Economic Activity Patterns in White Namibia," Geographical Review 75, No. 4 (October, 1985): 463-470.
} 
reserves into "homelands." ${ }^{60}$ Between 1952 and 1959, two of these attempted forced removals defined the petition-writing campaigns of Namibians to the UN: Aminuis (1952-1958) and Hoachanas (1956-1959). Through these petition-writing campaigns, Namibian leaders sought to employ the newly-empowered Committee on South West Africa and the General Assembly to express Namibian agency and exert pressure on the Union government to halt their proposed removals. The petition-writing campaign that ensued represented perhaps the largest network of transnational actors and institutions employed by Namibians as a means of anticolonial resistance. These campaigns focused on utilizing transnational resources to stake subnational socioeconomic claims of the SWAA, halt the SWAA's implementation of harsh spatial and economic segregation, and seek inclusion and an influential voice in the colonial decisionmaking process.

\section{The Aminuis Corridor Affair: Hosea Kutako's Petition-Writing Campaign to the United Nations}

The first post-war petition-writing campaign to be examined involved Hosea Kutako and the Herero at the Aminuis Reserve. They undertook one of the early petition-writing campaigns to the UN in an attempt to resist the annexation of parts of the Aminuis Reserve for white farmers and prevent a proposed land swap involving Kuridora. ${ }^{61}$ In 1923 , the South African Native Reserves Commission established the Aminuis Reserve to further control the mobility of Namibians and reduce the spread of livestock disease into the Bechuanaland Protectorate.

Throughout the territory, over 2 million hectares were set aside for the further creation of

\footnotetext{
${ }^{60}$ Wallace, History of Namibia, 253.

${ }^{61}$ Kuridora was a narrow strip of land placed between the Aminuis Reserve's eastern border and the western border of the Bechuanaland Protectorate. This piece of land is also frequently called "the Corridor" by SWAA officials, however the Herero referred to it as Kuridora.
} 
reserves. ${ }^{62}$ The Herero were first forcibly moved to reserves in the Police Zone following their role in the Rehoboth Affair in $1925 .{ }^{63}$ The conditions in the reserves were burdensome and unsustainable for settlement, with Kutako remarking "[I]t is a desert where no human being ever lived before. It is a country only good for wild beasts. On top of that it is not healthy for the people or the cattle...You should rather bring the Europeans here and let us stay where we are. ${ }^{64}$

${ }^{62}$ Gertrud Boden, "Mapping Culture, Representing Boundaries and Politicizing Difference: Reflection on two San Cases in Namibia," in Atlas of Cultural and Environmental Change in Arid Africa, eds. Olaf Bubenzer, et al. (Koln: Heinrich-Barth-Institut, 2007), 112-113.

${ }^{63}$ See Chapter 2, pages 101 and 102 for a full discussion on the Rehoboth Affair.

${ }^{64}$ Wolfgang Werner, "No One Will Become Rich": Economy and Society in the Herero Reserves in Namibia, 1915 1946 (Basel: P. Schlettwein Publishing, 1998), 105. 
Map 5: Aminuis Reserve, ca. 1950

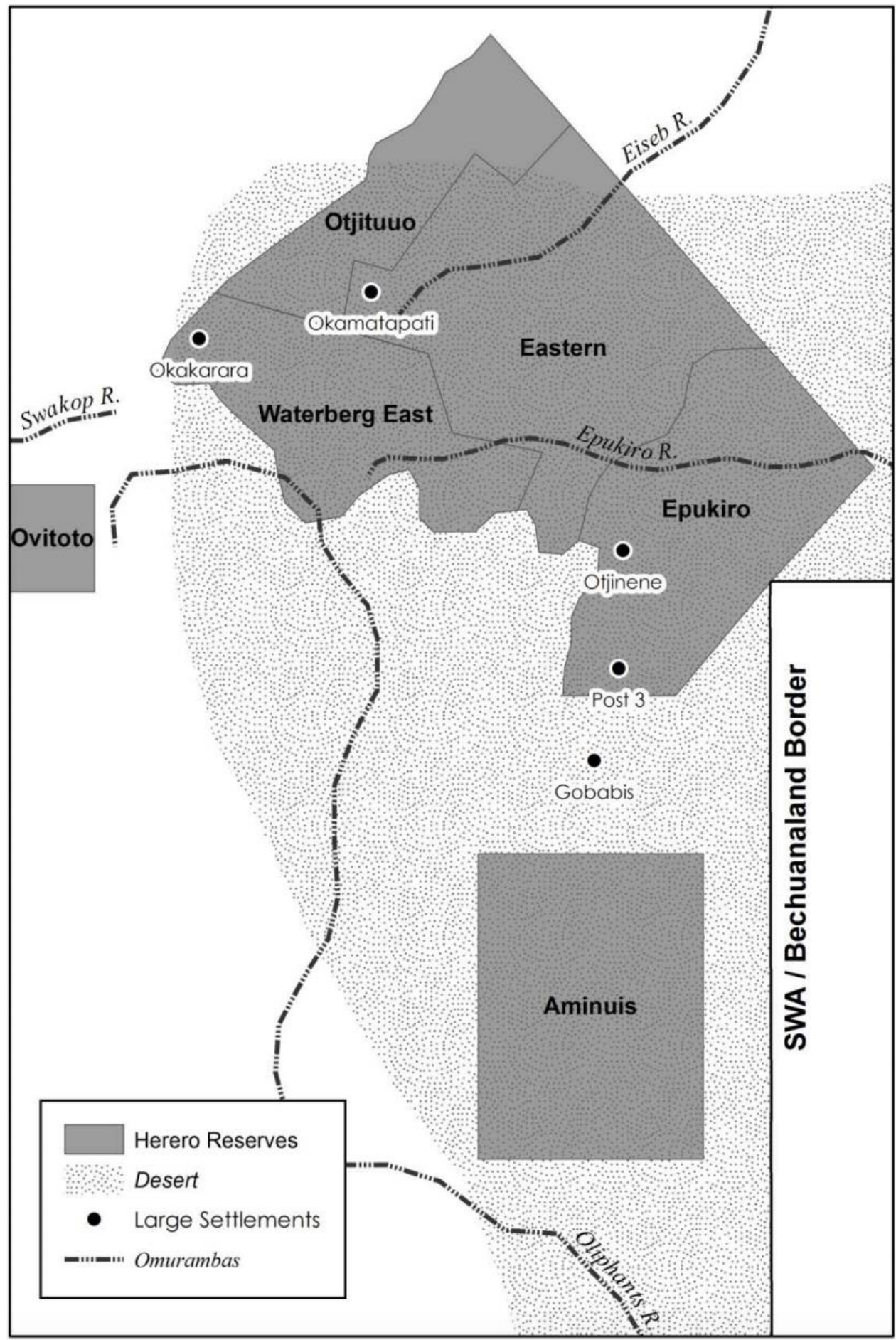

Source: Molly McCullers, "Lines in the Sand: The Global Politics of Local Development in Apartheid-Era Namibia, 1950-1980," (PhD diss., Emory University, 2012), 6. 
Nevertheless, the SWAA forced Kutako and his followers to Aminuis in 1925, where they experienced the ecological hardships of the reserves. Aminuis, in particular, possessed a severely compromised water supply, that veterinary reports described as "poisonous." 65 One of the superintendents at Aminuis went as far as to lament the situation at the reserve, writing "Grazing is poor. The oxen that were in fair condition when I was last there [have] fallen considerably in condition and are quite unfit for market. How the women and children exist is beyond my poor comprehension. At all events they are all thin and appear to be half starved."66 Although the conditions in the reserve could not support an increase in population, plans still existed to send more Namibians to Aminuis.

Historically, the Herero at Aminuis believed that a solution to improving their socioeconomic position at the reserve resided in the opening up of Kuridora for Herero use and settlement. In 1928, the Herero petitioned the SWAA to add Kuridora to the Aminuis Reserve, but Kuridora was instead turned into a quarantine zone to protect against the spread of livestock diseases from Bechuanaland. Another failed attempt was made in 1939 to see Kuridora attached to Aminuis. ${ }^{67}$ The debate over Kuridora subsided until 1952 and 1953, when white farmers placed increased pressure on the SWAA to open Kuridora to alleviate the hardships created by the drought in the territory.

In 1952 the Herero at Aminuis, as a result, petitioned Chief Native Commissioner, H.J. Allen, to add Kuridora to the Aminuis Reserve. However, the SWAA's Executive Committee rejected Allen's request and instead placed Kuridora under the control of the Department of

\footnotetext{
65 “Stock Inspector Macpherson's Report on Aminuis," 23 July 1925, NAN: Native Affairs Windhoek (Hereafter, NAW)/28/68.

66 “Letter to Cope," 15 November 1925, NAN: NAW/28/68.

${ }^{67}$ McCullers, "Lines in the Sand," 60.
} 
Native Affairs for the purpose of "emergency grazing." ${ }^{68}$ When the Executive Committee faced similar requests from the white farmers for access to Kuridora, the Executive Committee commenced borehole projects and developed a plan to alleviate the effects of the drought in the area ${ }^{69}$ The Executive Committee proposed the settlement of white farmers in Kuridora and promptly drilled more boreholes. Allen was highly critical of the Executive Committee's decision, and in 1955, he proposed a new plan that sought to annex the northern and western parts of the Aminuis Reserve for white farmers, while granting the Herero access to part of Kuridora for farming and grazing. ${ }^{70}$ Allen believed that such a plan would appease white farmers, assent to Herero demands for the extension of the reserve and prevent the emergence of a "Black island.","1

Despite Allen's assurances, the Executive Committee failed to follow his suggestion that the approval of the Herero must be obtained if such a proposal were to go forward. ${ }^{72}$

Unsurprisingly, Kutako and the Herero at Aminuis rejected the proposed land exchange when the Executive Committee announced the plan. Kutako possessed few legitimate paths of recourse with the SWAA to prevent the plan from moving forward and, instead, utilized his familiar transnational network to petition the proposed removal of the Herero from Aminuis. On 30 October 1956, Kutako petitioned the UN and detailed Allen's proposed exchange. Kutako wrote, "We also wish to inform you that the Chief Native Commissioner of South West Africa, Mr. H.J. Allen held a meeting with the Herero Chief and Headmen in September 1956 in the Aminuis

\footnotetext{
68 Ibid., 61.

69 Ibid.

70 "H.J. Allen to C.B. Young, Secretary for Native Affairs," 16 April 1955, NAN: Chief Bantu Affairs

Commissioner Windhoek (Hereafter, BAC) 4/HN/1/1/7/4. H.J. Allen was the Chief Native Commissioner of South West Africa until 1958 and was an advisor to the Odendaal Commission.

71 The creation of a "Black island" among white settlement ran counter to the apartheid ethos utilized in South Africa and South West Africa. If the initial plan to settle white farmers in Kuridora were followed, the Herero at Aminuis would have been surrounded by white settlement on all sides.

${ }^{72}$ McCullers, "Lines in the Sand," 67.
} 
Native Reserve... he informed us that a portion of the Aminuis Reserve was to be given to the European farmers and that a small part of land called Kuridora to the southeast of Aminuis Native Reserve was to be given to the Herero in exchange for their land." ${ }^{, 3}$ Kutako proceeded to "object" to the removal of the Herero to the southeastern portion of Kuridora and informed the chairman that "We concluded our meeting with the Chief Native Commissioner by saying to him that the government should keep Kuridora for European farmers and we would keep our reserve and would not exchange one for the other." ${ }^{, 74}$

Kutako elaborated on his reasoning for rejecting the proposed move in a second petition to the Secretary General at the UN the following year. He highlighted the point that the proposed exchange of land was uneven, arguing "That part of Aminuis Reserve which the government proposed to give to the white farmers is the best grazing area in that Native Reserve and there are five boreholes with strong water, and they are 500 feet and 700 feet deep. In Kuridora which the government proposed to give to us in exchange for our land... a kind of grass called suurgras grows in the largest area, but only during the rainy season and lasts...from January to June, while Kuridora itself is in the Kalahari Desert and is therefore subject to scanty rainfall...the result [is] unsuitable for grazing., ${ }^{75}$ Thus, the proposed exchange threatened to place the already strained Herero population in an even more untenable situation. The exchange would siphon off the best parts of the Aminuis Reserve for the use of white farmers, while providing the Herero with an inconsistent supply of grass for grazing and limited boreholes with faulty engines and equipment.

\footnotetext{
${ }^{73}$ Chief Hosea Kutako the Chairman of the Ad Hoc Committee on South West Africa, 30 October 1956, UNA: S0443-0060-9783/TR-240/1955-1957.

${ }^{74}$ Ibid.

${ }^{75}$ Chief Hosea Kutako to the Secretary General, United Nations, 28 May 1957. UNA: S-0443-0061-9786/TR240/1957-1959.
} 
Union Minister of Native Affairs H.F. Verwoerd and the SWAA attempted throughout late 1956 and early 1957 to persuade Kutako to assent to the land exchange. ${ }^{76}$ A series of failed meetings and negotiations during this period were only compounded by an environmental crisis in Kuridora during March 1957 that was characterized by an influx of Bovine Malignant Catarrhal Fever and inconsistent rainfall that had devastating consequences for both agriculture and cattle herding. The only portion of land that remained viable for both agriculture and herding was the northern part of the Aminuis Reserve; the portion of the reserve intended to be expropriated as part of the proposed land exchange. ${ }^{77}$ The combination of these factors only strengthened the resolve of Kutako and the Herero at Aminuis to reject any loss of their lands. The petitions submitted by Kutako exhibited a tangible effect on the decision-making process of the SWAA and concerned Verwoerd. Verwoerd questioned the viability of the land exchange at Aminuis as early as August 1956, as Kutako became increasingly vocal and defiant in his resistance to the plan. Verwoerd wanted to prevent the "unpleasantness and foreign noise" that might accompany Kutako's petitions to the UN, as his close relationship with influential international actors was well known to Verwoerd and the SWAA. ${ }^{78}$ As was previously mentioned, African American newspapers continued to publish stories about Kutako's desire to testify in person at the UN as early as 1950 and several of Reverend Scott's speaking engagements in the United Kingdom, South Africa, and the United States kept Kutako's case in the minds of transnational activists.

\footnotetext{
${ }^{76}$ Dr. H.F. Verwoerd was the Minister of Native Affairs from 1950 to 1958 under prime ministers Malan and Johannes Strijdom in the NP government. In 1958, Verwoerd was appointed to the position of Prime Minister and facilitated the entrenchment of apartheid in South Africa and South West Africa.

${ }^{77}$ McCullers, "Lines in the Sand," 77. BMCF is a lymphoproliferative disease that is highly fatal to cattle and other ungulates. Cattle usually die within a week after being infected and the chance of recovery is limited once symptoms appear.

${ }^{78}$ D.F. Verwoerd to Viljoen, 24 August 1956, NAN: BAC4/HN/1/1/7/4. See McCullers, "Lines in the Sand," 73-74 for a more complete discussion on the changing thought of Verwoerd on the Aminuis land exchange.
} 
In an attempt to halt Kutako's petitions to the UN and alleviate the international pressure and scrutiny directed at the Union government, the Acting Secretary for Native Affairs wrote to Kutako on 31 August 1957 to clarify perceived points of confusion about the exchange. The Secretary framed his argument in quantifiable terms and focused on the monetary value of the land involved, as well its development potential. He reiterated the SWAA's position that "the land to be added to the reserve is both larger and better prepared for development than the land to be excised therefrom," and that there was "no less than 15 successful boreholes and the carrying capacity of the area is in the vicinity of 10,000 cattle units as compared with about 3,000 units in the area to be excised, which has only 3 satisfactory boreholes." ${ }^{.79} \mathrm{He}$ valuated the proposed land of Kuridora at $£ 312,440$, whereas the land to be excised at Aminuis was valued at $£ 155,100 .{ }^{80}$

In that same letter, the Acting Secretary informed Kutako that "Minister [Verwoerd] does not wish to force any exchange upon you and the [Herero], although he and the department are still convinced that you and the [Herero] are extremely foolish and shortsighted in rejecting the offer....The possibility of any exchange and any acquisition of part of the 'corridor' is therefore now for all time at an end." ${ }^{\prime 1}$ Though Kutako had temporarily prevented the expropriation of land in the Aminuis Reserve, the Secretary informed him that Kuridora would not be added to the Aminuis Reserve for Herero use. The SWAA rejected Kutako's claim that Kuridora was already part of the Aminuis Reserve and the property of the Herero. ${ }^{82}$ Instead, he wrote that "The

\footnotetext{
${ }^{79}$ Acting Secretary for Native Affairs to Chief Hosea Kutako, 31 August 1957, UNA: S-0443-0061-9786/TR240/1957-1959.

${ }^{80}$ Ibid.

81 Ibid.

${ }^{82}$ See Chief Hosea Kutako to Dr. H.F. Verwoerd, Minister of Native Affairs, 28 October 1957, UNA: S-0443-00619786/TR-240/1957-1959 for more on Kutako’s historical analysis of the Herero's land rights to Kuridora.
} 
[SWAA] is at liberty to allot the 'Corridor' to European farmers and will immediately proceed to do so. .83

Kutako proved that the specter of foreign interference by the UN was enough to undoubtedly change the behavior and decision-making process of the Union government and the SWAA. Kutako's petitions successfully resisted the expropriation of economically important portions of the Aminuis Reserve and thwarted the aforementioned land exchange proposal. However, as the Acting Secretary's letter suggests, the reach of the UN and the ability of Namibians to leverage the UN's power was limited. The SWAA still proceeded to shirk its responsibility to develop and protect the indigenous inhabitants of South West Africa and, rather than add Kuridora to the Aminuis Reserve as a means of alleviating economic and environmental pressure mounting on the Herero settled at the reserve, the SWAA instead attended to the needs of white farmers first. ${ }^{84}$ Despite the desire to work within the existent colonial framework and be included in the decision-making process, the SWAA unwillingness to acquiesce to Kutako's demands forced him to seek alternative means to protect Herero interests in South West Africa.

Kutako's petition-writing campaign epitomized the subnational focus of many of the transnational resistance strategies employed by Namibians in the Police Zone. Rather than focus on complete territorial independence, Kutako attempted to obtain concessions from the SWAA on matters of great subnational importance. Preserving control of the land at Aminuis was of

\footnotetext{
${ }^{83}$ Acting Secretary for Native Affairs to Chief Hosea Kutako, 31 August 1957, UNA: S-0443-0061-9786/TR240/1957-1959. Kutako would later write to Verwoerd on 28 October 1957 that "We still maintain that Kuridora is part of our land and it ought not to be given to white farmers. Even the whole world knows that it is our land because the Union Government informed the League of Nations in 1933 that Kuridora was to be added to Aminuis." ${ }^{84}$ The forced land removals coincided with similar attempts in South Africa. The passage of the Group Areas Act of 1950 initiated a large-scale and intensive process in the Union whereby Africans were removed from "white areas" and placed in residential townships or Bantustans. The forced removals at Aminuis and and Hoachanas were a natural extension of the Union's policies.
} 
paramount importance for the continued survival of the Herero under his leadership and, as such, he focused many of his petitions on this attempted removal. Despite simultaneous forced land removals elsewhere, Kutako's primary obligation remained to the Herero at Aminuis and their socioeconomic interests. It is clear that Kutako's initial resistance strategies pursued Herero inclusion in the economic and political decision-making process with regard to issues of land settlement and forced removals. Kutako did not want to be further marginalized in this process through the implementation of evermore restrictive apartheid policies and schemes. Once it was apparent that this approach would not work, he instead turned to more exclusionary means of resistance that called on the international community to safeguard and consider the economic needs of the Herero under the repressive SWAA policies.

\section{Imaginary Pelt-Thefts and Arbitrary Police Brutality: The Attempted Forced Removal at Hoachanas, 1956-1959}

As the Herero faced the full weight of the SWAA's apartheid policies at Aminuis, similar forced removal plans proceeded elsewhere in the Police Zone. Beginning in 1956, the SWAA initiated a forced removal at Hoachanas to appease white farmers seeking more fertile lands and more reliable sources of water in the southern part of the territory. Whereas the Herero at Aminuis relied on the relationship developed between Michael Scott and Hosea Kutako to fight the expropriation of land, the Nama residents at Hoachanas turned first to the familiar AME Church to stake a claim to their land and then, in subsequent years, also developed an extensive petition-writing campaign to the UN to express their agency and resist the SWAA. The SWAA's attempted removal of the AME pastor Markus Kooper and his congregation from Hoachanas between 1956 and 1959 served as the basis of the Nama petitions that were submitted to the Committee on South West Africa. 
An examination of the case study at Hoachanas provides a clear example of how the support provided by two transnational institutions, the AME Church and the UN, dovetailed together and formed the foundation of a successful resistance strategy against land expropriation in the Police Zone. Over the course of 10 years, the Nama congregation at Hoachanas secured an application for a church, constructed said church, and prevented their forced removal from the land at the hands of the SWAA. Throughout the process, Nama leadership at Hoachanas submitted petitions to the UN detailing the arbitrary arrest of Markus Kooper and the SWAA's attempts to move his congregation to a less hospitable reserve at Itsawisis. As a result, the UN exerted international pressure on the SWAA to mitigate its aggressive behavior toward the Hoachanites and prevent the removal of the AME congregation at the reserve. The following pages examine these developments and the resistance strategies employed at Hoachanas as part of a larger Nama strategy to win subnational concessions from the SWAA.

In response to land expropriation and increased forced removals in the Police Zone, Namibians looked for any possible means to establish legal claims to their land and thwart the government's actions in court. The construction of AME churches in rural Nama communities were viewed as a means to resist this process and affirm Namibian ownership of the land. It is clear that the AME congregations understood the construction and presence of a church on the land provided the community with a strong claim to possession of, and continued residence on, the land. ${ }^{85}$ Many of the Nama communities had also provided labor, funds, and materials for the construction of the RMS churches and schools. When the Nama Secession occurred in 1946, AME leaders repeatedly petitioned the SWAA and made claims that their students, teachers, and

\footnotetext{
${ }^{85}$ See Abraham Frederik to Chief Native Commissioner, Windhoek, 25 November 1948, NAN: SWAA/A489/3 for an example of the disputes that arose over possession and ownership of school buildings and property in the early years of the AME Church's growth in the territory.
} 
congregants had a right to use the buildings and repurpose them for the AME's functions.

Through the series of accepted permits and applications for AME schools and churches in the 1950s, these congregations believed that they had staked a legal claim to their continued residence in their communities. ${ }^{86}$

The Khailkhaun initially staked their claim at Hoachanas when they settled near the freshwater springs in the area in $1695 .^{87}$ The missionary enterprise arrived there in 1853 , and the Khailkhaun continuously resided at Hoachanas until 1904. At the conclusion of the Herero and Nama genocide, Governor Leutwein guaranteed the Khailkhaun 50,000 hectares of land at Hoachanas for their permanent residence. ${ }^{88}$ The South African government honored this agreement between 1921 and 1956. However, the implementation of apartheid policies starting in the late 1940s led to a lengthy legal battle between the Khailkhaun and SWAA to resist their forced removal from Hoachanas. While the Nama Secession in 1946 laid the foundation for this legal conflict, tensions between the Nama and white residents of Hoachanas increased significantly, beginning in 1952.

The AME's rapid expansion in the Police Zone and the desire of its congregants to remain on the land close to their church sites, frequently fertile agricultural lands, alarmed the whites in the area. The congregations and communities in the AME strongholds fully embraced the Black liberation theology advocated by the church and lived its message of racial uplift, industriousness, and racial self-sufficiency. ${ }^{89}$ Adherents viewed white farmers and missionaries

\footnotetext{
${ }^{86}$ Acting Secretary for Native Affairs to Chief Hosea Kutako, 31 August 1957, UNA: S-0443-0061-9786/TR240/1957-1959.

${ }^{87}$ Manfred O. Hinz, Customary Law Ascertained Volume 3: The Customary Law of the Nama, Ovaherero, Ovambanderu, and San Communities of Namibia (Windhoek: University of Namibia Press, 2016), 89.

${ }^{88}$ Theodor Leutwein, Elf Jahre Gouverneur in Deutsch-Sudwestafrika (Hamburg: E.S. Mittler und Sohn, 1906), 272 and Tilman Dedering, Hate the Old and Follow the New: Khoekhoe and Missionaries in Early Nineteenth-Century Namibia (Berlin: Franz Steiner Verlag, 1997), 98.

${ }^{89}$ See chapter 4 , pages 240 through 244 for an analysis of Black liberation theology.
} 
as an extension of the SWAA and, consequently, as oppressors. AME preachers demanded that their congregations focus on maintaining their own flocks and small agricultural plots and limiting their employment on white farms. Namibians' control over fertile lands and some freshwater springs, as well as their increasing refusal to participate in farm labor, significantly increased tensions between rural Namibians and the adjacent white farmers. The forced land removals served as a means to reduce and eliminate these tensions, but many AME congregations grew entrenched and refused to willingly abandon their lands and churches.

In February 1952, AME officials began construction of a church at Hoachanas and established a permanent AME presence at the reserve. That month, Reverend Markus Kooper submitted an application for temporary residence at Hoachanas and permission to construct an AME Church. On 31 July 1952, Welfare Officer Balt travelled to Hoachanas to examine the site for the church and issue a construction permit to the Khailkhaun..$^{90}$ To complete construction of the church, Kooper and his congregation navigated the restrictive apartheid apparatus and tapped into local business networks to secure supplies. The only business owners who possessed the supplies and materials to facilitate the church's construction were white businessmen. After an exhaustive search, Kooper found a white general store owner in Lidfontein, referred to in the documents as Mr. Frank. Frank provided cement, building lime, roofing materials, doors and windows for the construction of the church. Additionally, he granted the congregation access to his lorry for the transport of these materials from Lidfontein to Hoachanas. Over the next four years, Kooper and his congregation built the Emmanuel AME Church. ${ }^{91}$ During this process,

\footnotetext{
90 Johannes Dausab to the Committee on South West Africa, 12 October 1957, UNA: S-0443-0061-9786/TR240/1957-1959.

91 Ibid.
} 
Kooper was ordained as a deacon of the AME Church in 1954 and began preaching to the congregation. $^{92}$

The construction of the Emmanuel AME Church occurred in the midst of the aggressive extension of apartheid in South West Africa. The aforementioned removal of the Hail|om at Etosha occurred the same year that Kooper began preaching and, as tensions increased, the SWAA undertook removals at Aukeigas Reserve in 1958. The Khailkhaun found themselves the target of forced removal in 1956. The white farmers in South West Africa desired the agriculturally-conducive land and springs at Hoachanas. However, the Black liberation theology preached at Emmanuel AME Church proved ill-suited for the SWAA's goal of creating stagnant labor reserves. ${ }^{93}$ To avoid further confrontations and inquires by the UN into the forced removals in the territory, the SWAA sought legal justification for the removal of the Khailkhaun.

Ultimately, the government decided to remove Kooper from Hoachanas in hopes that his loyal congregation would follow. ${ }^{94}$

Later petitions and interviews with the Namibian residents of Hoachanas claimed that the SWAA conspired with the police at Derm and white Hoachanites to provide false legal grounds for the eviction of Kooper. In 1956, these parties manufactured what Kooper and Johannes Dausab referred to as a "fake karakul-pelt theft" to justify the removal..$^{95}$ The karakul-pelt-theft plot alleged that AME congregants at Hoachanas illegally obtained and sold karakul pelts to accumulate money for the construction of the Emmanuel Church. ${ }^{96}$ The Derm police travelled to farms near Hoachanas to coerce falsified statements implicating African members of the AME

\footnotetext{
${ }_{92}$ Markus Kooper to the United Nations, 16 May 1960, UNA: S-0443-0063-9787/TR-240/1960.

${ }^{93}$ In addition to the tenets of Black liberation theology, white Hoachanites reduced employment opportunities for the Khailkhaun to force them from the arable land and onto other reserves in the Police Zone.

${ }^{94}$ Markus Kooper to the United Nations, 16 May 1960, UNA: S-0443-0063-9787/TR-240/1957-1959.

95 Johannes Dausab, 12 October 1957, UNA: S-0443-0061-9786/TR-240/1957-1959

${ }^{96}$ If the SWAA proved that the funds for the Church were gained illegally, it would weaken the claims of the AME congregants to remain on the land in the face of the government's removal attempts.
} 
and NGK churches. Kooper and his congregation recounted these attempts in petitions and audio recordings obtained by activist Allard Lowenstein, stating "When the church building was about to be completed in February 1956 they manufactured a make-believe karakul-pelt theftplan....The state-police [were] the executives of the horrible, barbaric, and unchristian devil's business. The members of the [NGK were] their tools. They were beaten by the police, tortured, and strangled and dictate[d] to say what is not true.... They were instructed by the police to say that they have stolen karakul-pelts of their respective farm-masters and sold the same [pelts] to us the members of the persecuted [AME Church]." ${ }^{, 97}$

Hoachanites victimized by the Derm police refused to affirm the SWAA's manufactured narrative, and the police could not secure the necessary witnesses to evict Kooper. The police subsequently raided the houses of the AME congregants at Hoachanas to find evidence supporting this false narrative. One witness recalled, "[The police searched] the house of the [Rev. Kooper], the resident elder of the [AME Church] at Hoachanas... a man whose career and record is clean as far as court cases and any other kind of irregularities are concerned...."98 The Derm police were unable to recover any sheep pelts and the "make-believe" plot appeared doomed.

The SWAA made one final attempt to find legal justification for the eviction of the Khailkhaun. On 7 February 1956, the police arrested Mr. Frank of Lidfontein and accused him of purchasing stolen karakul pelts from the Khailkhaun. Frank procured the representation of the

\footnotetext{
${ }^{97}$ Johannes Dausab to the Committee on South West Africa, 12 October 1957, UNA: S-0443-0061-9786/TR240/1957-1959. See also, Tape 10: Markus Kooper, University of North Carolina (Hereafter, UNC): Allard K. Lowenstein Collection (Hereafter, C04340)/S10.2/Audiotapes (Hereafter, T-4340). Allard Lowenstein was an American student activist and politician. He was the president of the National Student Association and received his J.D. from Yale Law School in 1954. In 1959, Lowenstein undertook a secretive trip to South West Africa where he collected audio recordings and testimony from Namibians detailing the abuses they faced at the hands of the SWAA. These recordings became the basis of his testimony at the UN later that year.

${ }^{98}$ Johannes Dausab to the Committee on South West Africa, 12 October 1957, UNA: S-0443-0061-9786/TR240/1957-1959.
} 
law firm of Harry Bloch \& Co. and brought a case of slander against the SWAA. The magistrate ruled in Frank's favor and found the accusations to be unsubstantiated. ${ }^{99}$ The judge awarded Frank $£ 3,000$ to repay the damages made to his reputation and dealt another blow to the SWAA's pelt-theft narrative. ${ }^{100}$ Despite the collapse of the plot and a lack of legally-sound evidence for removal, the SWAA issued a notice of eviction for the Khailkhaun on 3 December 1956. The SWAA planned to remove the Khailkhaun to the inhospitable reserves at Berseba, Aminuis, and Tses. The Khailkhaun believed the eviction order violated their legal ownership of the land and refused to willingly leave Hoachanas. ${ }^{101}$

On 12 October 1957, Johannes Dausab petitioned the members of the Committee on South West Africa to place South West Africa under the trusteeship system to resist these forced removals and abuses meted out by the SWAA. He meticulously detailed the developments at Hoachanas that placed the Khailkhaun's continued residence in the reserve in jeopardy. Furthermore, Dausab reiterated that, "In case the United Nations learned that we the inhabitants of Hoachanas are no [longer] at Hoachanas, the United Nations Organization are already told that [this] will happen only by force, because we are totally [determined not] to go away from Hoachanas, our inheritance. Nobody should have the right to assert that we have moved voluntarily and on our consent. Hoachanas is [a] fertile agricultural place, if only we [were] helped to improve our irrigation."102 Dausab ensured that the SWAA's continued attempts to forcibly remove the Khailkhaun would be understood as an act against the will of the residents at Hoachanas and tried to leverage this information to increase international pressure from the UN.

\footnotetext{
${ }^{99}$ Johannes Dausab and Daniel Dausab to the United Nations, 10 October 1956, UNA: S-0443-0060-9784/TR240/1955-1957.

100 Johannes Dausab to the United Nations, 13 July 1958, UNA: S-0443-0061-9786/TR-240/1957-1959.

${ }^{101}$ Ibid.

102 Johannes Dausab to the Committee on South West Africa, 12 October 1957, UNA: S-0443-0061-9786/TR240/1957-1959.
} 
The eviction notice for the entire AME congregation at Hoachanas failed in December 1956 as the AME congregants refused to heed the government order. Throughout the 1950s, Francis Gow and AME officials from South Africa and the United States continued to work with the government to receive approval and recognition for the construction of AME churches and schools in the Police Zone, a move that was viewed by congregants as a way to further entrench the AME Church and its followers on the land. As a result, the SWAA created a new plan that focused solely on the eviction of Markus Kooper as a way to get the congregation to follow. In 1958, Administrator D.T. du Plessis Viljoen brought an eviction case against Kooper that claimed he was an illegal resident at Hoachanas. Kooper knew that the trial lacked integrity and believed he would not receive a fair trial in the High Court of Windhoek. He refused to appear before the High Court, and the case against him proceeded in his absence, concluding with the High Court finding in favor of the SWAA. In July 1958, Kooper received his notice of eviction but refused to relocate to Itsawisis. ${ }^{103}$ This final refusal to relocate set the stage for the events of 29 January 1959, when an armed police detachment committed acts of violence against the resisting Khailkhaun to forcibly remove Kooper.

A series of petitions submitted by Dausab and Kooper to the UN in 1960 detail the events that unfolded at Hoachanas. Kooper and his congregation's refusal to leave Hoachanas necessitated action by Viljoen to appease the white Hoachanites and open up arable land. Viljoen deployed a division of the South African police force to Hoachanas to ensure the removal of Kooper. The Magistrate of Rehoboth, A.C. Chatwind, District Commander of Police Major Lombard, Adjunct Commissioner of the South West Africa Police, Colonel N.J. Dorfling, and

103 "Ejection Order Against Natives in [Hoachanas] Reserve: Alternate Ground Offered," Windhoek Advertiser, 22 July 1958. 
Derm policeman Oliver accompanied the detachment deployed to Hoachanas. ${ }^{104}$ The detachment arrived at Hoachanas in the early morning hours of 29 January 1959. The sun had not yet risen, but AME member Jonas Nakom recalled, "[On 29 January 1959] these officials [came] in seven motor cars under the leadership of [Chatwind and Dorfling] with 15 Europeans and 12 Native African policemen." ${ }^{" 105}$ Oliver led the police into Hoachanas from the east and halted before reaching the congregants' houses. ${ }^{106}$ Accounts suggest that the police force was heavily armed and militarized. Many petitioners claimed that the police brought a machine gun with them and that they carried "guns on points of which bayonets were fixed." 107 In addition to substantial firepower, police carried an array of handheld weapons, including assegais, kieries, police batons, and knives. ${ }^{108}$

Kooper awoke as the police detachment entered Hoachanas and went to speak to Chatwind. He recalled that the magistrate, who introduced Colonel Dorfling, said that as a result of the so-called High Court decision the previous year, they came to eject him from Hoachanas. ${ }^{109}$ Kooper's primary concern was whether the police came to remove only him, or all Khaillkhaun residents from Hoachanas. These concerns were rooted in the spread of recent rumors that claimed the white residents near Hoachanas held a meeting in conjunction with the police to conspire about land removals. Kooper feared that the removal of his congregation to inhospitable lands would force the Khaillkhaun to participate in the migrant labor system or work

\footnotetext{
104 Tape 10: Markus Kooper, UNC: C04340/S10.2/T-4340.

105 Tape 14: Jonas Nakom, UNC: C04340/S10.2/T-4340.

${ }^{106}$ Markus Kooper to South West Africa Committee, 29 April 1959, UNA: S-0443-0061-9786/TR-240/1957-1959. ${ }^{107}$ Ibid.

${ }^{108}$ Tape 10: Markus Kooper, UNC: C04340/S10.2/T-4340 and Tape 14: Jonas Nakom, UNC: C04340/S10.2/T-4340; For more information on the militarization of the South African police, see International Defense and Aid Fund, Apartheid's Army in Namibia: South Africa's Illegal Military Occupation (London: IDAF, 1982). An assegai is a long wooden spear with an iron tip that is common to southern Africa. A kierie is a club-like weapon that can serve the dual purpose of a walking stick. This weapon is also common in southern Africa.

109 Tape 10: Markus Kooper, UNC: C04340/S10.2/T-4340.
} 
on white-owned farms. When Kooper asked Dorfling who they planned to evict, Dorfling responded, “[T] oday [we are] removing only [Reverend Kooper], but [you can] tell the others that they will be ejected one day." ${ }^{110}$ Upon learning his fate, Kooper requested the opportunity to return to his home and change clothing and Dorfling assented. Dorfling's own account suggests that Kooper appeared ready to peaceably leave Hoachanas. ${ }^{111}$

Khaillkhaun and SWAA sources corroborate that Kooper returned to his house to change and that a number of the residents at Hoachanas emerged from their homes. However, the Khailkhaun and SWAA narratives surrounding the subsequent events of 29 January 1959 contradict one another. Khaillkhaun accounts claim that they presented no threat to the police. One UN petitioner wrote that they shouted at the police that Reverend Kooper was a minister and "[he is] in no way responsible for [our] refusal to move from Hoachanas!" 112 Colonel Dorfling's account contradicted Khailkhaun sources. His account stated that between 150 and 200 people, including school children, purposefully marched up from the school, "jeered" at police and demanded they leave. Dorfling further contended that the actions of the residents of Hoachanas moved beyond shouting, with some residents hurling rocks at the police and, in one instance, a resident was seen carrying "a bicycle chain fastened to a piece of wood."113

Tensions continued to mount while Kooper changed, and the situation outside deteriorated. Local leader Matheus Kooper asked Dorfling the purpose of the police presence and Dorfling replied that the police came "in peace" to carry out the eviction notice. Matheus Kooper and the Khailkhaun residents knew, based on previous experiences with police brutality, that the claim was disingenuous. The crowd's shouts that "[the police] have come to attack us" belied the

\footnotetext{
110 Ibid.

111 Ibid.

112 Tape 16: Markus Kooper, UNC: C04340/S10.2/T-4340.

113 "Police Chief Explains Police Action at [Hoachanas]," Windhoek Advertiser, 30 January 1959.
} 
strained nature of this precarious relationship. ${ }^{114}$ Dorfling recognized that the situation had become increasingly dangerous and that the Khaillkhaun would not allow the police to remove Kooper. During these conversations, a small group of residents entered Kooper's home and managed to barricade the door in an attempt to thwart the police's attempt to evict the reverend. ${ }^{115}$ In response to this "subversive" act, Dorfling instructed his policemen to fix their bayonets to their rifles and ordered his white policemen to form a protective ring around the lorry designated to transport Kooper to Itsawisis. He further commanded his African policemen to use their batons and weaponry to disperse the crowd and gain entry to Kooper's home. ${ }^{116}$

When the crowd refused to disperse, Dorfling ordered his policemen to charge the people with their bayonets and batons. A bloody confrontation ensued, resulting in the injury of 18 men. Policemen beat several residents so badly with their batons that during an interview with Allard Lowenstein nearly five months later, a man presented his injured leg and still-bandaged arm. He described the events of 29 January 1959, recounting that "[the residents] were made to see our blood run down on the ground." ${ }^{\text {"117 }}$ Another interviewee echoed this sentiment and stated, "the police [fought] the people so that the blood was running down the bodies of the people."118

The policemen inflicted severe injury on an additional seven women during their attack at Hoachanas. One resident provided an account of the injuries his pregnant wife sustained. He recalled that the policemen under Dorfling's command "bodily assaulted" his wife and caused her to have a miscarriage. ${ }^{119} \mathrm{UN}$ petitioners noted that police attacked more than one pregnant woman and, in some cases, "the police stabbed people, including women, on their stomachs with

\footnotetext{
114 Ibid.

115 “Ejection Order Carried Out Against Pastor Kooper," Windhoek Advertiser, 30 January 1959.

${ }_{116}$ Markus Kooper to the United Nations, 16 May 1960, UNA: S-0443-0063-9787/TR-240/1960.

${ }^{117}$ Lowenstein, Brutal Mandate, 101.

118 Tape 5: Markus Kooper, UNC: C04340/S10.2/T-4340.

119 Tape 14: Jonas Nakom, UNC: C04340/S10.2/T-4340.
} 
bayonets." ${ }^{120}$ Additionally, some of the policemen were even accused of using their knives to threaten the children who marched up from the AME school. ${ }^{121}$ One petitioner even went as far as to beg the UN to intervene on their behalf and stop the violence, crying out "I am praying that the United Nations will dry my tears for me." 122

Kooper provided the most vivid accounts of his removal, telling Lowenstein, "From my house I was guided by three policemen.... When I was brought to the lorry, I was taken by my right hand by a Coloured policeman [and an] Ovambo policeman took my left hand....I was in my full [clerical] uniform." ${ }^{123}$ After the policemen successfully removed Kooper from his home, two African policemen threw Kooper into an old road construction lorry originally designed to transport livestock. ${ }^{124}$ Petitioner Jonas Nakom recalled the unbearable sight, "We saw our poor minister being thrown on one of the government's lorries like a thief... without food and without water." ${ }^{125}$ Policemen then proceeded to throw his wife, teenage daughter, and four sons, all under the age of 10 , into the same lorry. ${ }^{126}$

On the morning of 29 January 1959, police successfully removed Kooper from Hoachanas. After stops at Tses and Derm, the SWAA dumped Kooper at barren Itsawisis. There, Kooper joined the Khaillkhaun NGK congregants who evacuated Hoachanas in 1956 in compliance with the first eviction order. The environment at Itsawisis proved difficult for Kooper and his family. He described the lack of food in a petition sent to the United Nations, writing, "Sirs, while I do not know the present situation of my people at Hoachanas whom I have been serving and from whom I was depending for my meals and salary. I, together with my wife

\footnotetext{
${ }^{120}$ Markus Kooper to the United Nations, 29 April 1959, UNA: S-0443-0061-9786/TR-240/1957-1959.

${ }^{121}$ Ibid.

122 Tape 14: Jonas Nakom, UNC: C04340/S10.2/T-4340.

123 Tape 10: Markus Kooper, UNC: C04340/S10.2/T-4340.

${ }^{124}$ Tape 14: Jonas Nakom, UNC: C04340/S10.2/T-4340.

125 Ibid.

${ }^{126}$ Ibid.
} 
and children are in a miserable situation of hunger....I fed my children on gum since we have been [thrown] away in these lifeless stones....I am closing the petition so far for today because I am going to fetch gum...our only diet to quiet my children crying for food." ${ }^{127}$ Despite Kooper's removal and his family's suffering, he still demanded that the congregation remain at Hoachanas and continue to resist the SWAA's eviction order. Kooper attempted to keep the spirits and morale of the congregation high by stealthily returning to preach to them at Hoachanas each month.

During Kooper's time at Itsawisis he came into contact with sympathetic transnational actors interested in exposing the oppressive nature of South African rule in the territory. Kooper resolved to expose the abuses and injustices the Khaillkhaun faced at the hands of the SWAA and utilized these transnational networks to send petitions and accounts to the United Nations.

Reverend Scott learned of Kooper's resistance campaign through his communications with Chief Kutako and AME leaders in the Union. Through information garnered from meeting Scott, Allard Lowenstein proceeded to travel to South West Africa and secure testimony from Kooper about the eviction attempts. Kooper provided an oral account of the violence at Hoachanas while Lowenstein ferried him from Itsawisis to Hoachanas to preach. ${ }^{128}$

Upon Lowenstein's return to the United States, the oral accounts provided by Kooper and his congregants were transcribed, and plans were made to enter the accounts into evidence against the South African government. When Lowenstein and two of his companions provided oral testimony before the UN in late 1959 , copies of the tapes were distributed to members of the General Assembly and entered into the record. The compelling testimony provided by Lowenstein and the taped petitions of Kooper and his followers resulted in the passage of a series

${ }^{127}$ Ibid.

${ }^{128}$ Lowenstein, Brutal Mandate, 95-100. 
of resolutions by the General Assembly. The General Assembly referred to the Union government's actions as a "violation of fundamental human rights and the sacred trust assumed by the government" and as "not in conformity with the mandate or the Charter of the United Nations... [and] contrary to the obligation undertaken by the mandatory power to promote to the utmost the material and moral well-being and the social progress of the 'Native' inhabitants of the Territory." 129 The resolution then "Urge[d] the Government of the Union of South Africa to desist from carrying out the removal of other residents of the Hoachanas Reserve and to arrange for the return of the Reverend Markus Kooper and his family to that reserve."130

The petitions presented by Lowenstein and his companions in 1959 and 1960 received the most attention by the press, as his influential network of activist supporters promoted his testimony and subsequent book in the newspapers. Once again, the Black press in the United States most actively carried stories about the testimony provided at the UN. In October 1959, the Afro-American ran a brief story about the various petitioners that were heard by the General Assembly and quoted activist teacher Emory Bundy as describing the conditions in South West Africa as "near-slavery." ${ }^{131}$ A much lengthier story ran the subsequent week in the New York Amsterdam News that provided significantly more detail about the living conditions faced by Namibians in the territory and included numerous quotes from the testimony of Namibians who previously fled South Africa and South West Africa to come to the United States. ${ }^{132}$ Hans Beukes, a Namibian student bound to study in Oslo who had his passport revoked by the South African government, also received significant press coverage in the United States and in Cape

\footnotetext{
${ }^{129}$ General Assembly Resolution 1357(XIV), The Hoachanas Native Reserve: Resolution, A/RES/1357(XIV) (17 November 1959).

${ }^{130}$ Ibid.

131 “Group Urges UN to Act in S.W. Africa," Afro-American, 24 October 1959.

132 Wilmer F. Lucas, Jr., "Has the UN Ignored South West Africa?” New York Amsterdam News, 31 October 1959.
} 
Town. ${ }^{133}$ Newspapers would continue to cite Lowenstein's and Scott's testimony in the United States press in the coming years, keeping discussions on the South West Africa question in the public sphere and continuing to influence public opinion against the South African state. ${ }^{134}$

Lowenstein actively worked to secure funds from sympathetic actors in the United States. Meanwhile, Kooper wrote to the UN from exile in Bechuanaland and requested an oral hearing to provide his own testimony before the General Assembly. Kooper received a cable from the UN on 3 June 1960 that granted him an oral hearing on 5 July $1960 .{ }^{135} \mathrm{He}$ faced great difficulty in securing a passport to travel to the UN to provide his testimony and, as a result, his oral hearing was pushed back to the Fall of 1960 . When Kooper finally arrived at the UN, he provided compelling testimony in his own words to alert the General Assembly that the Union government was still engaged in efforts to remove his congregation from Hoachanas and reaffirm that the congregation was still unwilling to go to Itsawisis. Although the SWAA continued in its attempts to remove the Khailkhaun, the recognition of their right to reside at Hoachanas by the UN only bolstered their resolve to remain at the reserve, and they successfully resisted these future removal attempts. Whereas the Herero's petitions ultimately forced the SWAA to make the internal decision to halt its forced land expropriation schemes at Aminuis, the Khailkhaun resistance campaign held even more international significance. Their successful use of the UN's transnational networks and infrastructure forced the UN General Assembly to issue resolutions condemning the South African government's activities. This signified the

\footnotetext{
${ }^{133}$ See Cape Times, January 1959-June 1959 for examples of how Hans Beukes' testimony and the testimony of Lowenstein were treated in the South African press.

${ }^{134}$ See Charles Loeb, “'Where Africa Goes, So Goes Humanity...,', Cleveland Call and Post, 11 February 1961 as an example of later newspaper articles that discussed Lowenstein's testimony and fact-finding trip to South West Africa.

${ }^{135}$ UN Cable to Markus Kooper, 3 June 1960, UNA: S-0443-0063-9787/TR-240/1960.
} 
sweeping reach and success that resistance campaigns waged by small groups, for subnational concessions, could succeed in the larger international political order.

\section{Conclusion}

The petitions submitted between 1947 and 1959 brought intense international scrutiny on the Union government for its treatment of Namibians in the Police Zone. Namibian leaders like Chief Hosea Kutako and Reverend Markus Kooper recognized that any attempt to halt the forced land removals and seek recourse through the apartheid state would prove futile. What initially began as a process of seeking inclusion in the colonial decision-making process necessarily evolved into a resistance campaign demanding exclusion from the SWAA's repressive apartheid policies. The Union government's refusal to willingly place South West Africa under the control of the UN Trusteeship Council limited the ability of the UN to stop abusive and oppressive practices aimed at Namibians. South West Africa remained directly under the control of the SWAA and was governed as a de facto fifth province of the Union. This resulted in the continued, and often unimpeded, expansion of apartheid state in South West Africa and reinforced the importance of looking outside of South West Africa's territorial boundaries in order to resist the colonial state.

As a result, Namibians accessed long-standing transnational networks sympathetic to the demands of the indigenous people of South West Africa. Supportive transnational actors like the Reverend Michael Scott and Allard Lowenstein aided in the transmission of these petitions to the United Nations. There, the petitions were analyzed by state actors and representatives who could exert external pressure on the apartheid state. The numerous and continued reports coming out of South West Africa resulted in tangible victories for Namibians, like the creation of the 
Committee on South West Africa in 1953 in order to handle the growing volume of petitions coming from the territory. This Committee, the result of the intense petition-writing campaign waged by Namibians, wrote and distributed reports on the worsening situation in the territory for Namibians. By 1956, the Committee, via the ICJ's Advisory Opinion, secured a ruling that permitted oral hearings for South West African petitioners at the UN.

Most of these petitions dealt with subnational socioeconomic issues prominent in the 1950s Police Zone and concerns over the treatment of Namibians in the reserves. Kutako petitioned the United Nations to make them aware of a proposed land exchange scheme at the Aminuis Reserve that sought to take away the reserve's most valuable land for white farmers and give Namibians undesirable lands. Further south in Hoachanas, similar pressures from white farmers during a time of drought and agricultural hardship led the SWAA to develop plans for the removal of the AME congregation at that reserve. In each case, Namibian leaders drew on their historical linkages to the reserves and claimed the right to legal and continued residence at these locations to resist the SWAA plans. Both campaigns pursued inclusion in the face of exclusionary policies that attempted to further marginalize the territory's African populations.

This resistance strategy and use of the United Nations as a mechanism for recourse against the apartheid state clearly had an impact on the state's decision-making process and their ability to arbitrarily carry out forced removals. Letters between Verwoerd and the administrator in South West Africa reveal a minister astutely aware of the problems increased scrutiny at the UN could cause in the territory. He feared that Kutako's petitions could cause just such a disturbance and thus, he reluctantly abandoned the plan to siphon off part of the Aminuis Reserve in 1958. At Hoachanas, Kooper's resistance activities and subsequent international pressure also proved successful in dissuading the SWAA from removing the AME congregation. 
His petitions and audio recordings provided enough evidence of the Union government's wrongdoing that, in November of 1959, the General Assembly passed a resolution demanding the actions of the Union government be investigated and that the Khailkhaun be permitted to remain at Hoachanas. In each case Namibian leaders were successful, even if only temporarily, in preventing the arbitrary removal of their followers.

Discussions of subnational issues like forced removals and land expropriation dominated the petitions of leaders in other parts of the territory as well. For example, Johanne Beukes continually submitted petitions to the UN to resolve disputes over land in Rehoboth in the postWorld War II period. Likewise, petitions from outside of the Police Zone in Ovamboland also complained about environmental crisis, land issues, and the abusive migratory labor system. The Damara also submitted petitions over their concerns about their increasingly burdensome situation. In each case, leaders sought to resolve their subnational issues and mitigate the abuses committed by the SWAA against Namibians through the use of transnational actors and institutions, rather than pursue outright territorial independence for South West Africa.

More violent forced removals also occurred in the urban areas, with the attempted removal of Namibians from the Old Location in Windhoek being the most problematic. Protests and women's marches erupted in Windhoek as the SWAA attempted a forced removal of Namibian residents of the Old Location to the newly-created township in Katutura. Among these protests and marches, unrest outside of a beer hall in Windhoek resulted in the police opening fire and killing 12 people. ${ }^{136}$ Whereas the UN was swift to action in the cases above, their unwillingness and inability to reprimand the Union government following the Windhoek Massacre led to a prolonged and voluminous petition-writing campaign from Namibians,

${ }^{136}$ Wallace, History of Namibia, 254. 
particularly during SWAPO's and SWANU's infancy. However, that petition-writing campaign took on a more nationalist tone, something largely missing in the earlier petitions of Kutako and the congregants at Hoachanas. 


\section{Chapter 7-International Student Politics and the Anti-Apartheid Movement, 1950-1962}

The transnational resistance strategies implemented by Namibians in the Police Zone between 1919 and the late 1950s developed largely along subnational ethnopolitical lines, which at times became ethnically exclusive or developed specific characteristics depending on where the strategy was employed in the territory. For example, the Rehoboth Basters' use of transnational networks and supranational political institutions during their petition-writing campaign in the 1920s and 1930s pertained specifically to the Basters' desire to re-establish political autonomy in the Gebiet. Similarly, Namibians' embrace of the UNIA as a means to resist the SWAA's implementation of segregationist policies in the 1920s illuminated subnational fissures when the Herero seizure of power in the Windhoek branch led the Nama members of the UNIA at Rehoboth to pursue their own sociopolitical ends through the association's framework. In the post-World War II period, the use of the AME Church as a transnational resistance mechanism was likewise defined by its ethnic exclusivity, with the Nama most vigorously incorporating the church into its strategies in the 1940s and 1950s.

As the 1950s unfolded, however, a new generation of social and political leaders from the Police Zone emerged and sought new strategies to resist the apartheid state. These new leaders were younger and more radical than their predecessors. Previous generations lacked many of the educational opportunities that emerged during the 1950s, with Namibian students having new opportunities to attend high schools and universities in South Africa and beyond. As this new youthful intelligentsia developed and moved between South West Africa and South Africa for their education, their approach to resistance took on a more nationalistic nature than its earlier 
iterations as they demanded not only educational reforms, but also complete territorial independence. $^{1}$

This new generation of Namibian leaders' educational experiences in South Africa were key to the formulation of new nationalist resistance strategies that sprung up at the end of the 1950s. In South Africa, a select number of Namibian students at the University of Fort Hare and the University of Cape Town (UCT) were introduced to the ANC's Youth League, with Fort Hare serving as one of the Youth League's main branches from 1948 onward. Here, Namibian students were re-introduced to concepts of Black nationalism that had faded in popularity in South West Africa after the collapse of the UNIA in 1924. At South Africa's open universities and pre-dominantly Black institutions like Fort Hare, Namibian students also engaged with sympathetic transnational actors, student organizations, and university faculty with access to extensive resource networks that possessed in-depth knowledge of the apartheid state. ${ }^{2}$

Namibian students' use of these networks as a means of resistance to the apartheid state centered on tapping into global resources to facilitate the creation of a Namibian intelligentsia in exile that could wage a campaign of resistance against the South African government with limited fear of the recursive power of the state. Essential to this approach at the end of the 1950s was the desire of these Namibian students to present a political front that was united in its desire to secure the territory's independence from South Africa and seize control of the mechanisms of

\footnotetext{
${ }^{1}$ For more on the difference between nationalism and subnationalism, see pages 47 to 56 of this dissertation.

${ }^{2}$ Elizabeth Le Roux, A Social History of the University Presses in Apartheid South Africa (Leiden: Brill Press, 2015), 15. Le Roux described open universities as follows: “The designation 'open' implied that these universities' admission criteria were intended to be purely academic, and applied without regard to considerations of race, colour or creed." Le Roux also noted that the Vice-Chancellor of UCT, Dr. T.B. Davie, contended that there were "four essential freedoms" for the open universities: to determine for itself on academic grounds who may teach, what may be taught, how it shall be taught, and who may be admitted to study." This flew directly in the face of the apartheid policies espoused by the NP in South Africa and led to contentious interactions between the government and these institutions. In South Africa the English-speaking universities of UCT, Natal, Rhodes, and the Witwatersrand received this designation.
} 
state. Over the course of the 1950s, students like Jariretundu Fanuel Kozonguizi, Mburumba Kerina, and Hans Beukes found themselves at the center of this new nationalist strategy when they used student organizations and universities across the globe, like the United States National Student Association (NSA), the National Union of South African Students (NUSAS), the Norwegian National Union of Students (NSU), and the Swedish National Union of Students (SFS) to escape South Africa in pursuit of more expansive educational opportunities abroad. During this flight and formation of a Namibian intelligentsia in exile, Namibian students embraced the suggestion by the leadership of the aforementioned student organizations to appear in person before the UN and provide testimony on the abuses meted out by the South African state. The following pages examine the role that these networks and student organizations played in facilitating the appearance of Kozonguizi, Kerina, and Beukes before the UN in October 1959 and how these students attempted to sway public and international political opinion against the apartheid state to frustrate and temper the extension of apartheid policies over Namibians in South West Africa.

This chapter argues that there was no clean break between the subnational resistance strategies of the past four decades and the new nationalistic resistance strategies that emerged in the 1960s and advocated for national independence. The use of student organizations and universities across the globe was initially intended to address subnational concerns of educational and economic underdevelopment in South West Africa. However, over time, Namibian students' interactions with Pan-Africanist and nationalist organizations across the globe introduced Namibians to new unified nationalistic means of resistance. While these students still pursued their education for individual socioeconomic reasons, they used these 
experiences with Western-styled education and transnational organizations to open a new phase in Namibians' fight against the South African colonial regime.

\section{The Development and Foundation of the Global Anti-Apartheid Movement in the 1950s}

Many of the educational opportunities secured by Namibian students that ultimately led to their testimony at the UN in October 1959 were made possible by the rising tide of antiapartheid sentiment in parts of the Western world in the 1950s. The global anti-apartheid movement began in earnest in the 1950s among a small, educated intelligentsia, but rapidly expanded as more people became aware of the South African government's policies towards Africans and had direct interactions with those who experienced the brunt of these policies. Mobility undoubtedly played an essential role in the spread and growth of the movement. International student conferences and meetings of political institutions created the necessary space for the liberal elements of Western society to network, debate, and coordinate both national and transnational campaigns of resistance against the South African government. South Africans in exile frequently attended these meetings, gave speeches, and provided a necessary "face" that humanized the abstract "other" that often seemed so distant to Europeans and Americans. Through these interactions with South Africans and by hearing their personal stories, sympathetic actors and activists created an emotional connection to the anti-apartheid movement that hardened their commitment to the eradication of these oppressive policies in southern Africa. $^{3}$

\footnotetext{
${ }^{3}$ Håkan Thörn, "Solidarity Across Borders: The Transnational Anti-Apartheid Movement," Voluntas: International Journal of Voluntary and Nonprofit Organizations 17, No. 4 (December, 2006): 297.
} 
The transnational anti-apartheid networks that developed between the 1950s and 1994 effectively connected thousands of disparate groups that spanned cross-sections of society, including solidarity organizations, churches, labor unions, youth organizations, and student organizations in over 100 countries. In this way, the global and transnational anti-apartheid movement truly was a "New Social Movement (NSM)." The movement transcended the boundaries of economic class, social status, or organizational affiliation and represented the emergence of a new "transnational political culture." Driven heavily by the production and dissemination of knowledge to the masses, public opinion became a key ideological battleground of the anti-apartheid movement and played a key role in reaffirming the solidarity and goals of the movement as a whole. ${ }^{6}$ While in 1956 the international attitude and opposition to apartheid could best be described as a "diffuse moral condemnation of [the South African government]," the nearly 100 arrests and subsequent Treason Trial served to "[accelerate] the growth of international campaigns against apartheid."7

Although the anti-apartheid movement began in South Africa, the movement quickly spread in the 1950s and developed epicenters of activity in Britain, Scandinavia, and the United States. At the heart of the early anti-apartheid movements were the student organizations that possessed a fairly liberal sociopolitical ideology and a vast network of connections across the globe. Although the involvement of student organizations in the 1950s varied by country, by the

\footnotetext{
${ }^{4}$ Ibid., 286.

5 Ibid.

6 Ibid.

${ }^{7}$ Robert Skinner, "The Dynamics of Anti-Apartheid: International Solidarity, Human Rights and Decolonization" in Britain, France, and the Decolonization of Africa: Future Imperfect?, eds. Andrew W.M. Smith and Chris Jeppesen (London: UCL Press, 2017), 115. The "Treason Trial” was the coordinated government arrest of approximately 156 members of the Congress Alliance on 5 December 1956 on charges of treason against the South African government. The arrests were intended to diminish the power and influence of South African resistance leaders. However, the Treason Trial received significant attention in the international press and resulted in the acquittal of the remaining defendants in March 1961.
} 
1960s the aforementioned countries possessed numerous student organizations that took a highly active role in coordinating and participating in the global anti-apartheid movement. In order to understand how exactly these student organizations played a role in aiding the transnational resistance strategies of Namibians in the Police Zone, one must first examine how the antiapartheid movement developed in South Africa and then spread to student organizations in countries far outside of the recursive reach of the South African government.

As the third chapter detailed, the NP came to power in South Africa through the 1948 South African General Elections and implemented their apartheid policies to segregate South African society in all spheres of life. The African intelligentsia in South Africa quickly developed resistance strategies meant to frustrate the South African state and slow the implementation of apartheid. In the 1940s, South Africa saw a rise in instances of grassroots urban protest against the government's restrictive policies. Political Scientist Brendan D. Works contended that roughly 300 workers' strikes occurred between 1939 and 1945. While more militant resistance became popular during this period, moderate tactics of petition-writing and public organizing were frequently used to place pressure on the government to secure concessions that resolved minor local problems. Frequently, the division between these two approaches in South Africa broke along class lines. Elite Africans and those in charge of the ANC tended to embrace the more moderate approach to anti-apartheid protest, while the masses embraced the more militant organizing that flourished among the trade and workers' unions. ${ }^{8}$

The divergent approaches of these two groups were primarily reconciled when the ANC Youth League organized in 1944 and a "new generation of more assertive leaders" encouraged a

\footnotetext{
${ }^{8}$ Brendan D. Works, "Popular Opposition to Apartheid, 1950-1990," (PhD diss., University of California-Berkeley, 1998), 47-49.
} 
more militant shift within the ANC that led to "elite-led mass action." ${ }^{.9}$ This change in approach came to a climax in 1949 when the ANC adopted its "Programme of Action," which advocated for the more militant approach embraced by the masses. Key to this strategy were campaigns of civil disobedience, worker strikes, economic boycotts, and other acts of non-violent resistance. This ultimately marked the beginning of "mass-based opposition" toward the South African government that came to define the resistance campaigns of the $1950 \mathrm{~s} .{ }^{10}$

Throughout the 1950s, the ANC's strategy also focused on undermining white support, both domestically and internationally, for the South African apartheid regime by "revealing its anti-democratic charter." 11 Works described the ANC's approach as a "war of position" that sought to undermine the NP's "moral legitimacy" and "engage the state almost exclusively on an ideological level." ${ }^{12}$ ANC leadership believed that the most effective way to splinter white support for the NP-led government was to embrace non-violent forms of mass protest in the early 1950s. Following the violence meted out during the May Day protests on 1 May 1950, the ANC called for a National Day of Protest and Mourning on 26 June 1950 to protest the issuance of a series of six unjust laws that Black South Africans viewed as further entrenching the apartheid system. ${ }^{13}$ ANC leadership believed that African workers formed the backbone of the South African economy and issued a "nationwide stay-at-home" on the Day of Protest as an act of civil disobedience and economic resistance. ${ }^{14}$ Two years later, the ANC proceeded to launch their Campaign of Defiance of Unjust Laws where volunteers "violate[d] petty apartheid laws, [got]

\footnotetext{
${ }^{9}$ Ibid., 49.

${ }^{10}$ Ibid., 49-51.

${ }^{11}$ Ibid., 45.

${ }^{12}$ Ibid.

${ }^{13}$ E.C. Webster and Eddie Webster, “'Stay-Aways' and the Black Working Class: Evaluating a Strategy,” Labour, Capital and Society 14, No. 1 (April, 1981): 14. The May Day protest in 1950 was organized by the Communist Party of South Africa to protest against the Suppression of Communism Act of 1950. The strike and mass protests led to police violence that resulted in the death of 18 Africans in Johannesburg.

${ }^{14}$ Meriwether, Proudly We Can Be Africans, 94.
} 
arrested, and fill[ed] the prisons" in an attempt to overturn apartheid laws and overwhelm the South African prison system. ${ }^{15}$ The Campaign of Defiance commenced on 26 June 1952 and resulted in the arrest of nearly 8,000 South Africans; though it did not overturn the apartheid system, the campaign received recognition by the UN and a commission was started to investigate the matter. ${ }^{16}$

While the ANC waged its campaign of political and economic resistance against the apartheid state, student organizations in South Africa fought against the extension of these policies into the academic sphere. NUSAS played an instrumental role in coordinating antiapartheid resistance among the South African open universities and, perhaps more consequentially, spread the anti-apartheid movement to sympathetic student organizations across the globe that would play an influential role in aiding Namibian resistance to the South African government's colonial rule. NUSAS was founded in 1924 with the intent to "represent all students at white and open universities in South Africa." 17 Yet, NUSAS failed to uphold this lofty ideal until 1945 when Black African students from the University of Fort Hare and the Hewat Training College were admitted to the organization. ${ }^{18}$ At this time, NUSAS amended its constitution and included the defense of democracy and the "[encouragement and promotion] of educational and economic opportunity to all South Africa with special attention to the underprivileged." ${ }^{19}$ However, until the mid 1950s, NUSAS focused primarily on issues of apartheid that directly impacted student life and the halls of academia.

\footnotetext{
${ }^{15}$ Hoda M. Zaki, "From Montgomery to Tahrir Square: The Transnational Journeys of Nonviolence and Utopia," Utopian Studies 26, No. 1 (2015): 204.

${ }^{16}$ Ibid., 204-205.

${ }^{17}$ Julian Brown, The Road to Soweto, (Suffolk: Boydell and Brewer Publishers, 2016), 22.

${ }^{18}$ Benjamin Kline, "The National Union of South African Students: A Case-Study of the Plight of Liberalism, 192477," The Journal of Modern African Studies 23, No. 1 (March, 1985): 140.

19 Ibid.
} 
Beginning in 1953, the ever-increasing encroachment of the government into academia accelerated NUSAS's anti-apartheid activism and resistance. In 1953, the Bantu Education Act was instituted and the government's intention to introduce apartheid to South African universities was apparent. ${ }^{20}$ In March 1956, NUSAS and the faculty at UCT and the University of Witwatersrand (Wits) became aware of the early manifestations of the future Extension of University Education Act that would formally introduce apartheid in the university. ${ }^{21}$ Throughout 1956 and 1957, the faculty and student body at these universities passed a number of resolutions and statements that opposed academic segregation and led protest marches against the implementation of the act. ${ }^{22}$ While NUSAS's activities were initially viewed as a minor threat in the early-to-mid 1950s, their participation in protests alongside alternative, more militant white liberal opposition groups like the Black Sash and the Torch Commando in the late 1950s and early 1960 s soon drew the ire of the apartheid government. ${ }^{23}$

While NUSAS and white liberal student groups played an important role in the South African anti-apartheid movement of the 1950s, the anti-apartheid movement in 1950s Britain consisted of little involvement from student organizations and universities. Although the

\footnotetext{
${ }^{20}$ Ibid.

${ }^{21}$ The Extension of University Education Act of 1959 segregated institutions of higher learning in a number of ways. The act effectively criminalized the enrollment of non-white students at the open universities and also created separate institutions for Blacks, Coloureds, and Indians.

22 Paul Maylam, "Rhodes University: Colonialism, Segregation, and Apartheid, 1904-1970," African Sociological Review 9, No. 1 (2005): 17.

${ }^{23}$ Brown, The Road to Soweto, 22-23. The Black Sash was initially founded on 19 May 1955 as the Women's Defense of the Constitution League. The Black Sash's initial membership consisted of six women and emerged primarily as a result of the disgust English-speaking white women felt toward the NP's disenfranchisement of Coloureds in the Cape. The Black Sash extended its activities in the 1950s and 1960s to fight against the entrenchment of apartheid in South Africa and provide legal counsel to those affected by these policies. The Torch Commando emerged in 1951 as the Springbok Legion faded in influence. The Torch Commando consisted mostly of anti-fascist and left-leaning white military veterans and the organization participated in torch-lit marches to demonstrate mass opposition to the government's apartheid policies. The rise of the Torch Commando concerned the South African government, as many judges, military officials, and veterans flocked to the organization. For more on these two organizations, see Cherry Michelman, The Black Sash of South Africa: A Case Study in Liberalism (Oxford: Oxford University Press, 1975) and Michael Fridjon, "The Torch Commando and the Politics of White Opposition: South Africa, 1951-1953," Paper Presented at the University of Witwatersrand African Studies Institute (March, 1976).
} 
involvement of student organizations featured more prominently in the 1960s and 1970s, liberal white intellectuals and activist priests defined the direction of Britain's early anti-apartheid movement. Initially, this movement was confined to small white elite circles in Britain.

However, the activities of the Reverend Michael Scott and his address to the UN in November 1949 served as a catalyst for the growth of British anti-apartheid activism and resulted in increased media coverage for the already-existent movements occurring in South Africa. ${ }^{24}$ In between his appearances at the UN as a representative on behalf of the Herero Chiefs' Council (HCC) and Chief Hosea Kutako, Scott worked tirelessly to promote the anti-apartheid cause in Britain and bring it to the masses. Scott attended a number of public meetings across Britain throughout the 1950s to speak on his experiences in South Africa with the apartheid regime and, more importantly, appealed to political organizations like the Union of Democratic Control (UDC) and the National Peace Committee that more directly pressured the government on issues of foreign policy. ${ }^{25}$

Despite Scott's best efforts, British public opinion against the South African apartheid regime was slow to turn. In 1952, Scott and his associates founded the Africa Bureau to create an organization that disseminated information about the African political situation and the struggles for independence to the British public. The founding of the Africa Bureau and subsequent organizations like the Movement for Colonial Freedom "helped stimulate public interest in African affairs during the early 1950s." ${ }^{26}$ This, much like earlier attempts to generate anti-

\footnotetext{
${ }^{24}$ Robert Skinner, "The Moral Foundations of British Anti-Apartheid Activism, 1946-1960," Journal of Southern African Studies 35, No. 2 (June, 2009): 401-403.

${ }^{25}$ Ibid., 404. The UDC was established by E.D. Morel in 1914. The UDC pressured the British government to pursue a more liberal and anti-fascist foreign policy and became heavily involved in propaganda campaigns to sway British public opinion from the 1930s onward.

${ }^{26}$ Ibid. The Movement for Colonial Freedom was established in Britain in 1954. The organization became popular among the British Labour Party's rank-and-file members and the movement focused on providing support to leaders fighting for national independence in Africa and Asia. The Movement for Colonial Freedom was particularly active on the issues of the Suez crisis and Portuguese decolonization in the 1970s.
} 
apartheid sentiment among the British public, was confined primarily to "establishment circles" that served as important voices of dissent and laid the foundation for the anti-apartheid movement that flourished in the late 1950s and 1960s. ${ }^{27}$

In addition to Scott's activities, other Christian activists became involved in antiapartheid protest in the 1950s out of a fear that remaining silent on the issue of apartheid "fatally undermine[d] Christianity within Africa." ${ }^{28}$ Historian Robert Skinner described the problem faced by these British church activists: "For church and missionary circles, apartheid raised an acute dilemma: on the one hand, very few argued that South African government policy was reasonable (and it was unlikely that British clergy would run the risk of perceived association with the state as they were elsewhere in Africa), while on the other, any criticism risked undermining church activities." ${ }^{29}$ To distinguish themselves from those who remained silent on the issue of apartheid, activist priests like Bishop Trevor Huddleston published works and treatises that invoked theological arguments to condemn the immorality of the apartheid system and highlight the danger that silence on the issue presented to society. Works like Huddleston's Naught For Your Comfort publicized the anti-apartheid cause in 1950s Britain and brought the issue to a much wider audience. ${ }^{30}$

These early efforts to grow the British anti-apartheid movement in the 1950s provided tangible results when new institutions and strategies were established to place pressure on the South African government. In 1956, the same year the Treason Trials in South Africa began, Anglican priest John Collins established the International Defense and Aid Fund (IDAF) to

\footnotetext{
${ }^{27}$ Ibid.

${ }^{28}$ Ibid., 407.

${ }^{29}$ Ibid., 409.

${ }^{30}$ Ibid. See also, Trevor Huddleston, Naught for Your Comfort (Glasgow: William Collins Sons and Co., 1956.) Huddleston's work drew on his personal experiences with the apartheid government in Johannesburg and roundly condemned these policies as immoral and un-Christian. Huddleston focused in particular on issues surrounding African education, reserves, and pass laws.
} 
provide legal and financial support to those in South Africa accused of violating apartheid laws. Subsequently, in June 1959 the Committee of African Organizations (CAO) formed a Boycott Committee at a meeting in London. This movement evolved over time into the Independent Boycott Movement, the forerunner to the Anti-Apartheid Movement (AAM) created in Britain by South African exiles. ${ }^{31}$

While the British anti-apartheid movements of the 1950s were largely devoid of substantial influence from student organizations, elsewhere in Europe, particularly in Scandinavia, student organizations formed the backbone of the early anti-apartheid movement. The two Scandinavian countries most active in the anti-apartheid movement of the 1950s were Norway and Sweden. Norwegian Historian Tore Linné Eriksen described the Norwegian government and public as "silent through most of the 1950s," contending that there was a limited public interest in the issue of South African apartheid. ${ }^{32}$ Similarly, despite Norway having a permanent mission to the UN, the government was hesitant to openly criticize the South African government and the permanent mission frequently avoided the denouncement of the South African government with the belief that they would be more open to listening to a "friendly" voice. $^{33}$

Eriksen credits the "internationally-inclined student organizations" for increasing the Norwegian public's attention to the South African apartheid regime in the late $1950 \mathrm{~s} .{ }^{34}$ After Bantu Education passed in South Africa in 1953 and threatened the academic integrity of the English-speaking open universities in South Africa, the NSU created a scholarship fund as an act

\footnotetext{
31 Thörn, "Solidarity Across Borders," 288-292.

32 Tore Linné Eriksen, “The Origins of a Special Relationship: Norway and Southern Africa, 1960-1975," in Norway and National Liberation in Southern Africa, ed. Tore Linné Eriksen (Uppsala: Nordic Africa Institute, 2000$)$, 12.

33 Ibid.

34 Ibid.
} 
of resistance against the apartheid regime. ${ }^{35}$ The scholarship fund was used to sponsor the study of African students at the University of Oslo for a period of three months. The scholarship program experienced limited success until it expanded the length of the scholarship to three years in 1959 to allow students to complete their education at a Norwegian institution. Beginning in 1959 with the "Beukes Affair," the scholarship fund experienced more success. ${ }^{36}$

In 1959, as a result of the Norwegian students' efforts to bring more attention to the abuses committed by the South African government, other elements of Norwegian society joined the anti-apartheid movement. In October 1959, the Norwegian South Africa Committee formed with the explicit purpose to internationally oppose the South African government, continue to fund scholarships for African students to attend Norwegian universities, and explore the idea of a consumer boycott on South African goods. ${ }^{37}$ Likewise, in 1959 Norwegian trade unionists and students organized the aforementioned consumer boycott to directly impact the South African economy and pressure the South African government to change its apartheid policies. ${ }^{38}$

Swedish society was similarly slow to grapple with South Africa's apartheid regime. Anti-apartheid activist Tor Sellström belied this point, writing “As Swedish society in general, students at the universities of Gothenburg, Lund, Stockholm, and Uppsala were largely isolated

\footnotetext{
${ }^{35}$ See Le Roux, A Social History of the University, 15 and Ian Bunting, "The Higher Education Landscape Under Apartheid," in Transformation in Higher Education: Global Pressures and Local Realities, eds. N. Cloete, et al. (New York: Springer, 2006), 42 The open universities viewed the implementation of apartheid policies in higher education as threatening academic integrity for a number of reasons. First and foremost, the open universities prided themselves on being liberal educational institutions with full control over the faculty, student body, and curriculum on their campuses. Although they were public institutions and entitled to funding from the apartheid state, they viewed their commitment to "universal academic freedom" as a direct conflict with the state. Despite the funding they received from the state, open universities were hostile to any attempt to infringe upon their educational authority and resented the idea of becoming "servants of the state." This conflict between the open universities and the apartheid state were only further exacerbated by the Bantu Education Act of 1953 and the Extension of University Education Act of 1959.

${ }^{36}$ Eriksen, "The Origins of a Special Relationship," 13-14.

${ }^{37}$ Ibid., 15.

${ }^{38}$ Ibid.
} 
from the colonized world until after the Second World War." ${ }^{39}$ However, in the 1950s, with increasing interaction between the SFS, South African students, and NUSAS, the Swedish student unions became more involved in anti-apartheid activities. In the early 1950s the SFS started a scholarship fund for international students geared toward bringing African students to Swedish universities. This continued until 1955 when the South African government informed the SFS that only white South African students could participate in the program. Despite this setback and the SFS sending a delegation to South Africa to ascertain why this restriction was placed on the program, it only steeled their resolve to provide scholarships for students who were "working for freedom from colonialism and segregation." 40

In 1958 and 1959, with the impending implementation of the Extension of University Education Act in South Africa, the SFS responded to NUSAS's call for increased scholarship funds for African students. Between 1950 and 1958, the SFS raised nearly 25,000 SEK to fund the study of African students at Swedish universities. In 1958, the SFS attempted to further increase its scholarship fund by appealing to the Swedish universities to fully finance a six-year scholarship for a Black student. The cost of such a scholarship was roughly 30,000 SEK. Students embraced this challenge and raised money through blood donations, successfully raising approximately 7500 SEK annually from 1958 to 1964 . In 1959, the SFS attempted to influence Swedish politics by convincing the Swedish foreign minister to raise the issue of the worsening situation for African students in South Africa at the UN General Assembly. The SFS succeeded in having their request conveyed to the General Assembly and this represented the

\footnotetext{
${ }^{39}$ Tor Sellström, "Forerunners of a Popular Opinion," in Sweden and National Liberation in Southern Africa, Volume I: Formation of a Popular Opinion, 1950-1970, ed. Tor Sellström (Uppsala: Nordic Africa Institute, 1999), 85 .

${ }^{40}$ Bengt Säve-Söderbergh and Pekka Peltola, "The Scandinavian Anti-Apartheid Movement: International Solidarity in Action," in The Future We Chose: Emerging Perspectives on the Centenary of the ANC, ed. Busani Ngcaweni (Pretoria: Africa Institute of South Africa, 2013), 156.
} 
first time the Swedish government brought a matter pertaining to apartheid to the attention of the $\mathrm{UN}^{41}$

Although the global anti-apartheid movement developed more robustly as a NSM in the 1960s and 1970s, transcending class and social divisions, the origins of this transnational movement emerged in the 1950s and was spurred forward by the collaborative efforts of student organizations, universities, religious activists, and government officials. In South Africa, NUSAS spearheaded white liberals' and students' anti-apartheid activities and served as an important link between non-white South Africans and sympathetic actors in Scandinavia, Britain, and the United States. While activist priests and government officials led the movement in Britain, student organizations in Norway and Sweden established scholarship funds as an act of open resistance against the introduction of anti-liberal apartheid policies, like the Bantu Education Act and the Extension of University Education Act, in South African higher education. Similarly, NUSAS acted as intermediaries to engage with the NSA and other American student organizations, who were comparatively late to the anti-apartheid movement, to secure crucial funding and diplomatic support to facilitate the movement of African students across borders. These collaborative efforts in the early-to-mid 1950s created the foundation for a sprawling transnational network that was essential to the creation of a Namibian intelligentsia in exile. These efforts provided students with the resources and means to flee southern Africa to pursue a liberal Western-style education and, perhaps more importantly, testify in person before the UN as part of a more united nationalist resistance strategy.

${ }^{41}$ Sellström, “Forerunners of a Popular Opinion,” 86-88. 


\section{Black Nationalist Politics at the University: Kozonguizi, Fort Hare, and the Emergence of Namibian Student Activism}

While white liberal student organizations across the globe solidified collaborative resistance networks to openly contest South Africa's apartheid policies in the 1950s, Namibian students took advantage of a limited number of opportunities to pursue higher education in South Africa. A select few places existed at predominantly-white open universities like UCT in South Africa for Namibian students. However, the predominantly-Black Fort Hare University became a breeding ground for a more militant Black student activism in the 1940s and 1950s and served as a training ground for Namibian students to organize and network among their peers. Namibian student Jariretundu Fanuel Kozonguizi, a Herero from Windhoek, was essential to Namibian students' organizing activities and played a crucial role in the establishment of formal Namibian student organizations like the South West Africa Student Body (SWASB) and South West Africa Progressive Association (SWAPA), which sought to connect the Namibian intelligentsia at universities across southern Africa. These formal student bodies constituted the backbone of the Namibian intelligentsia's anti-apartheid resistance strategies in the 1950s and facilitated the emergence of more nationalist political organizations in the 1960s.

Any examination of the impact that international universities and transnational student organizations had on both Namibians' subnational and national resistance campaigns against the South African government must start at Fort Hare University and explore how this university developed and awakened the political consciousness of the select few Namibian students who gained admission to a university outside of South West Africa. Prior to the late 1950s, tertiary education for non-white Namibians in South West Africa consisted merely of four teacher 
training colleges. ${ }^{42}$ Therefore, it was necessary for those Namibians who had exceeded the limitations of the mission schools, teacher training schools, and government-run secondary schools to leave the territory in order to advance their education. This primarily meant that Namibians had to seek out educational opportunities in South Africa since the government desired to maintain relative control over the education of its African populations. Fort Hare University maintained a significant amount of autonomy from the government prior to the late 1950s and, as a result, became an intellectual training ground for many future African nationalist leaders across southern, eastern, and central Africa. Among its most distinguished alumni were Nelson Mandela, Oliver Tambo, Robert Mugabe, Seretse Khama, and Robert Sobukwe. ${ }^{43}$ The same was true of Fort Hare's impact on Namibia's earliest nationalists, with the university having a particularly powerful influence on the political thought and activities of Jariretundu Fanuel Kozonguizi, one of the founders SWASB, SWAPA, and the political party SWANU. The first institutions of higher learning appeared in South Africa in the early nineteenth century with the founding of the South African College in Cape Town in 1829, the Dutch Reformed Church theological seminary in 1859, and University of the Cape of Good Hope in

\footnotetext{
${ }^{42}$ Wallace, A History of Namibia, 248. Wallace acknowledges that government-run secondary schools were established in the territory throughout the 1940s and, by 1962, there were 12 government schools for Black pupils in South West Africa.

${ }^{43}$ Nelson Mandela and Oliver Tambo were influential members of the ANC, with Mandela becoming the President of South Africa in 1994 and Tambo serving as President of the ANC from 1967 to 1991. Mugabe was a freedom fighter and became Zimbabwe's president in 1987. Lastly, Robert Sobukwe held the office of President of the Pan Africanist Congress from 1959 to 1963, while Fort Hare graduate Seretse Khama became the president of Botswana. Seretse Khama is particularly important in southern African and Namibian history. Khama married Ruth Williams, a white British woman, in 1948. This marriage caused significant internal divisions within the Bechuanaland Protectorate between Seretse and his uncle Tshekedi. Seretse prevailed over his uncle in the dispute and his position as kgosi was confirmed by the Bamangwato elders. His ruling position and interracial marriage caused relations to sour with the South African government as the existence of the Khama's relationship threatened the ideological underpinnings of their apartheid policies. Seretse Khama actively thwarted the South African governments apartheid rule throughout the 1950s and 1960s by supporting those Africans and activists that sought to escape white-minority rule and testify before the UN.
} 
1873. ${ }^{44}$ These institutions catered to the needs of their white students, and opportunities for Black South Africans to receive a secondary or tertiary education centered almost entirely on the efforts of transnational African American actors who were able to connect Africans to educational opportunities and available funding in the United States. Mission educated Africans frequently attended Historically Black Colleges and Universities (HBCUs) or predominately Black religiously-affiliated institutions in the United States during this period. Institutions like Lincoln College, Wilberforce College, and the Tuskegee Institute were active in this student exchange. Other colleges, like the Hampton Institute and Fisk University, had historical links to South Africa that dated to the late nineteenth century. ${ }^{45}$

The education that Black South Africans received at these foreign institutions was often incompatible with the segregationist policies of the nineteenth and twentieth century South African government, as these institutions frequently advocated for an educational ethos steeped in race pride and racial self-sufficiency. This produced the necessary seeds for an African intelligentsia with hopes of substantial sociopolitical and economic change in South Africa. There was fear among South African leadership that these ideas of social, racial, and economic equality would filter down from this educated elite as they returned from their studies abroad and potentially spread among the masses, causing large-scale unrest among Black South Africans. ${ }^{46}$ In order to prevent this from happening, proposals emerged at the beginning of the twentieth century for the establishment of an African university with a curriculum under the purview of the South African government.

\footnotetext{
${ }^{44}$ Rico Devara Chapman, Student Resistance to Apartheid at the University of Fort Hare (Lanham: Lexington Books, 2016), 8. The South African College in Cape Town became the University of Cape Town and the Dutch Reformed Church theological seminary was instituted as a university in 1866.

${ }^{45}$ Ibid., 9.

${ }^{46}$ Ibid., 9-10.
} 
Two proposals for an African university emerged in the first decade of the twentieth century with competing ideas of how much control whites should have in running such an institution. In 1901, Mfengu leader and South African Native Congress (SANC) member Horatio Isaiah Bud-Mbelle began a fundraising campaign to establish an African university. His proposal was taken up at the SANC Annual Conference in September 1902, and the Queen Victoria Memorial Fund was established to raise the necessary funds. The SANC's ultimate ambition was the establishment of an African university in the Eastern Cape that was largely devoid of white control. ${ }^{47}$ Unsurprisingly, this proposal failed to generate sufficient support among South African authorities.

Conversely, the South African Native Affairs Commission's proposal for an African university in 1905 garnered more support from missionaries and government officials in the Cape. Following a "native convention" held at Lovedale in 1905, where the Cape government was encouraged to accept the newly-named Inter-State Native College scheme, the SANC was implored to merge their Queen Victoria Memorial Fund with the Inter-State Native College scheme to fund a new university. The SANC refused out of a fear that this new scheme injected an element of white control into the African university that they so desperately wanted to avoid. The mission-sponsored Inter-State Native College scheme continued to grow in popularity as influential Africans, like John Tengo Jabavu, threw their support behind the scheme and more African organizations embraced the concept at the Inter-State Native College convention in July $1908 .^{48}$

\footnotetext{
${ }^{47}$ Les Switzer, Power and Resistance in an African Society: The Ciskei Xhosa and the Making of South Africa (Madison: University of Wisconsin Press, 1994), 179.

${ }^{48}$ Ibid., 180-181. See also, Cecil Seethal, Gustav Visser, and Ronnie Donaldson, The Origin and Growth of Geography as a Discipline at South Africa Universities (Cape Town: African Sun Press, 2016), 190. Missionaries and religious institutions were heavily involved in the early funding at Fort Hare. The Transkeian Territories General Council donated $£ 10,000$ in 1907 to fund the creation of an African institution. Likewise, the United Free Church of Scotland offered the site for the university as part of a $£ 5,000$ donation and purchased adjoining lands for
} 
Following the founding of the Union of South Africa in 1910, the government embraced the Inter-State scheme and the South African Native College at Fort Hare was established on 8 February 1916. Although no official religious affiliation existed, Fort Hare maintained a close relationship with the Methodist and Presbyterian missionaries who originally supported the plan and required their staff to "be professing Christians and of missionary sympathies." ${ }^{49}$ In its attachment to the University of South Africa (UNISA), Fort Hare served as a college preparatory institution that prepared students for matriculation exams and university entrance until it was incorporated under the Higher Education Act in 1923. Upon its incorporation in 1923, Fort Hare students took UNISA's examinations "for degree purposes and for diplomas in the Arts, Agriculture, and Commerce. ${ }^{" 50}$ This affiliation with UNISA continued until 1951, at which time the re-named University of Fort Hare severed ties and affiliated instead with Rhodes University by way of the Rhodes University (Private) Act of $1949 .{ }^{51}$

As the student body grew during these years, so too did the political consciousness and activism of the student population at Fort Hare. The 1930s are generally referred to as a "period of calm" at the university, with the university's principal submitting a report on student activity from 1916 to 1935 that described students as commendable for their discipline and educational progress. ${ }^{52}$ However, beginning with the enrollment of Nelson Mandela and Oliver Tambo at the

the growth and construction of the campus. John Tengo Jabavu was the father of D.D.T. Jabavu and a Xhosa political activist, editor, and publisher and railed against the treatment of Black Africans in Southern Africa.

${ }^{49}$ Chapman, Student Resistance, 10.

${ }^{50}$ Seethal, Visser, and Donaldson, The Origin and Growth of Geography, 190.

${ }^{51}$ Ibid., 191.

52 Zolane Ngwane, "The Politics of Campus and Community in South Africa: An Historical Historiography of the University of Fort Hare, Volume 1," (PhD diss., University of Chicago, 2001), 121. This "period of calm” likely came as a result of the ANCs internal struggles and divisions during the 1930s. In January 1927 ANC president J.T. Gumede went to the first international conference of the League Against Imperialism in Belgium. At this conference Gumede met a number of communists, visited Berlin as a guest of the German Communist Party and met Joseph Stalin in Moscow. Gumede's infatuation with the communist cause led him to neglect parts of his role as ANC president and bred dissent within the ANC's ranks. He was ultimately replaced as ANC president by Pixley ka Isaka Seme. The dissention and fissures caused by this chapter in the ANC's history caused many to abandon the ANC and left the party small and in disarray throughout the 1930s. As the 1940s approached, the party re-imagined itself 
university in 1939, there was a marked and clear shift in student political activity and the emergence of a new, more radical political consciousness. ${ }^{53}$ The first iterations of this new more militant student ideology emerged in 1941 and 1942 when the students at Fort Hare organized to protest against the deteriorating quality of food offered by the university. Yet, it was the establishment of the ANC Youth League in September 1944 that "[brought] in fresh blood and a new radicalism within the ANC" and among the students at the University of Fort Hare. ${ }^{54} \mathrm{By}$ 1948, the main branch of the ANC Youth League was established at Fort Hare by Robert Sobukwe, Joe Matthews, Ntsu Mokhehle, and Godfrey Pitje, further increasing the political activities and radicalization of the student body. ${ }^{55}$

The emergence of the ANC Youth League was significant for Black student politics in South Africa and African politics at-large because it represented a clear shift away from more conservative and traditional old-guard politics to a more confrontational and radical style of organizing. The leaders of the ANC Youth League criticized the ANC's leadership for using

as a more radical mass-led movement with a strong activist inclination. The 1940s presented the radical elements of the ANC with an opportunity to grow their base of support. The 1940s in South Africa was characterized by rapid industrialization, mass African urbanization, and the failure of municipalities or the government to provide services, jobs, or economic opportunities for Africans. Previously, the ANC lost membership to the communist party because of their unwillingness to focus on economic and subsistence issues. However, the new radical youthful leadership of the ANC embraced these issues and sought to make the dire economic situation for Africans in the 1940s a centerpiece of their program.

${ }^{53}$ Ibid. Also see Chapman, Student Resistance, 11-12. Chapman noted that there were other instances throughout the 1930s that portended the coming radical shift among the student body. Throughout the 1930s, J.B.M. Hertzog passed a series of segregationist policies that restricted the economic, social, and physical mobility of the non-white populations in South Africa. The African People's Organization (APO) held a series of conventions in the Eastern Cape in the late 1920s and early 1930s that debated the legitimacy of these policies. Similarly, African American missionary Max Yergan and Communist Party member Edward Roux openly discussed the communist ideology with students at Fort Hare and in the Cape during the 1930s. Chapman contends that all of these activities contributed to the increased radicalism of Fort Hare students in the 1940s and 1950s.

${ }^{54}$ Ngwane, "The Politics of Campus and Community," 122.

${ }^{55}$ Joe Matthews was the son of the influential Z.K. Matthews. Matthews studied law at Wits in the 1950s and was politically active in the Defiance Campaign in 1952 and the CPSA in 1957. Matthews was also one of the defendants in the Treason Trial in 1956. Ntsu Mokhele formed the Basutoland Congress Party with Potlako Leballo in 1952. He became the third Prime Minister of Lesotho in 1993 and again between 1994 and 1998. Similarly, Pitje was active in the ANC Youth League before becoming a member of the ANC National Executive Committee in 1949. 
conservative resistance strategies like petitions and complaints. Instead, the Youth League embraced more visible and direct strategies that centered on civil disobedience, strikes, boycotts, and stay-at-homes. Additionally, the ANC Youth League was much more vocal in its weariness of white liberal institutions and those Africans that collaborated with them, instead preferring a resistance strategy for, and controlled by, Blacks. These strategies flourished at the universities where the ANC Youth League had a strong foothold, but also emerged in national politics in the early 1950s with the Day of Protest in 1951 and the Defiance Campaign in 1952. ${ }^{56}$

The radical student politics that developed at Fort Hare during the 1940s profoundly impacted and shaped Namibians' approaches to challenging the South African government throughout the 1950s and 1960s, with Jariretundu Kozonguizi emerging as one of the leading Namibian student intellectuals studying in the Cape. At Fort Hare, Kozonguizi immersed himself in African nationalism and came into contact with influential actors, groups, and resistance campaigns that he and his fellow Namibians re-purposed and retooled for the Namibian context. Kozonguizi was born in South West Africa in 1932 and attended primary school in Windhoek before being sent by his family to South Africa where he worked for the Department of Native Affairs. In South Africa, he matriculated at Fort Hare in the early 1950s, at which time he became highly active in campus political organizing. ${ }^{57}$

At the University of Fort Hare, Kozonguizi and fellow Namibian student Zedekia Ngavirue were active in the ANC Youth League in the 1950s and, in 1952, endeavored to establish a similar organization that represented the interests of Namibian students at universities in South Africa. In 1952, with the help of fellow Namibian students Ottilie Schimming, Kenneth

\footnotetext{
${ }^{56}$ Ngwane, "The Politics of Campus and Community," 122-124.

${ }^{57}$ Sam Nujoma, Where Others Wavered: My Life in SWAPO and my Participation in the Liberation Struggle for Namibia (Bedford: PANAF Books, 2001), 49.
} 
Abrahams, Emil Appolus, and Lincoln University student Mburumba Kerina, Kozonguizi and Ngavirue established SWASB.$^{58}$ SWASB was an experimental organization that served as "one of the first major organizational expressions of political opposition to colonial domination in [South West Africa]. ${ }^{.59}$ The membership of the organization consisted only of those students studying abroad in South Africa and, as such, the organization concerned itself primarily with promoting and protecting the interests of Namibian students. ${ }^{60}$ Since so few Namibian students studied in South Africa at this time, SWASB was unable to grow and extend beyond its student base like the ANC Youth League. ${ }^{61}$

To rectify SWASB's shortcomings and expand into a more nationalist cultural organization with a wider support base, Kozonguizi, Uatja Kaukuetu, and other students returning from their studies in South Africa formed SWAPA in Windhoek in late $1955 .^{62}$ The support base for SWAPA was slightly larger than SWASB, yet SWAPA was still geared primarily toward teachers, clerical workers, and educated Namibians. SWAPA initially concerned itself mostly with issues of African education and providing guidance for Namibian students looking to leave South West Africa and study at universities in South Africa. Unlike SWASB, SWAPA was concerned with founding a more nationalistic movement and believed that it was necessary to aid in the creation of a Namibian intelligentsia that could wage a

\footnotetext{
${ }^{58}$ Ottilie Schimming and her future husband Kenneth Abrahams were students at UCT in the 1950s and highly active in Black politics. Schimming was an integral part of the OPC and SWAPO while she was in exile in Sweden. Abrahams was also active in SWAPO and received his MD while in exile in Sweden. Emil Appolus was one of the founding members of the OPC and later served on SWANU's Executive Committee. Ngavirue was likewise an active member in SWANU in the late 1950s and also created The South West News, a multi-lingual publication. He went on to receive his bachelor's degree from Uppsala University and his doctorate from Oxford.

${ }^{59}$ Gasan Omar, et al, “An Introduction to Namibia's Political Economy," SALDRU Working Paper (Cape Town: Southern Africa Labour and Development Research Unit, 1990), 19.

${ }^{60}$ Kaela, The Question of Namibia, 63.

${ }^{61}$ Du Pisani, SWA/Namibia, 19.

${ }^{62}$ Uatja Kaukuetu received a scholarship to study at Lund University in 1960. Kaukuetu was involved in nationalist politics while studying abroad. Kaukuetu served as the President of SWAPA and became the Vice President of SWANU when it merged with the HCC in 1959.
} 
resistance campaign against the South African government and run a nation once independence was achieved. ${ }^{63}$

While in South Africa as a student, Kozonguizi was heavily involved in not only student politics, but also in broader political movements in both South Africa and South West Africa. Shortly after founding SWASB with other Namibian students attending high school and university in South Africa, Kozonguizi joined the HCC in 1954 as an advisor to Chief Kutako. ${ }^{64}$ As a student, Kozonguizi submitted his first petition to the UN on 5 August 1954 lamenting the inadequate state of education in South West Africa. He argued that the introduction of the Bantu Education Act "would virtually eliminate African education in [South West Africa]" and that "no more than six non-Europeans [had] progressed beyond high school standard." 65 Kozonguizi detailed the obstacles put in place by the SWAA to prevent the establishment of student organizations like SWASB. ${ }^{66}$ This, and subsequent petitions to the UN caused issues for Kozonguizi during his studies, with his scholarship eventually pulled because of his engagement with the international body. ${ }^{67}$

Kozonguizi completed the first phase of his studies at Fort Hare in 1956 when he became the first Namibian to graduate from the institution with a bachelor's degree. In 1957, he enrolled at UCT where he studied law for a brief time. ${ }^{68}$ However, he returned to Fort Hare in 1958 to

\footnotetext{
${ }^{63}$ Du Pisani, SWA/Namibia, 146 and Tonchi, et al., Historical Dictionary of Namibia, 404-405.

${ }^{64}$ David Soggot, Namibia: The Violent Heritage (London: Rex Collings, Ltd., 1986), 25. The Herero Chiefs' Council was the authoritative political body of the Herero and developed an active resistance campaign against the South African government to frustrate the implementation of its apartheid policies. Those on the council acted in an advisory role to Chief Hosea Kutako. Although it is not entirely clear why Kozonguizi joined the Herero Chiefs' Council, lawyer David Soggot stated that Kozonguizi "was co-opted onto the Council," implying that the HCC identified his political activity and extensive education in South Africa as a potential asset for their petition-writing campaign to the UN.

${ }^{65}$ Official Records of the General Assembly, Ninth Session, Annexes, Agenda Item 34, Document A/2666/Add.1, Annex III.

${ }^{66}$ Ibid.

${ }^{67}$ George M. Houser, No One Can Stop the Rain: Glimpses of Africa's Liberation Struggle (Leiden: Pilgrim Press, 1989), 113.

${ }^{68}$ Colin Legum, Africa: A Handbook to the Continent (Santa Barbara: Praeger, 1966), 370.
} 
secure his Diploma in Education. At this time, Chief Kutako made contact with Kozonguizi and asked him to go into exile in order to testify in person before the UN. Kutako believed that sending a Herero like Kozonguizi to the UN to provide eyewitness accounts of his experiences with the apartheid government in southern Africa would revive the interest of the UN and the international public in the South West Africa question. Thus, Kozonguizi was appointed the official representative of the HCC and was set to join Reverend Scott at the UN the following year. $^{69}$

Therefore, in 1959 Kozonguizi abandoned his studies and fled from South Africa without the permission of the South African government. His route into exile first began in the Bechuanaland Protectorate, a territory placed under the protection of the United Kingdom in 1885 with an extensive network of resources that earned it the nickname the "Pipeline into Exile." ${ }^{70}$ From Bechuanaland, Kozonguizi continued his journey through Northern Rhodesia, eventually arriving in Tanganyika where he was able to secure the necessary funding to fly to the UN in New York in $1959 .^{71}$

\footnotetext{
${ }^{69}$ Robert I. Rotberg, Suffer the Future: Policy Choices in Southern Africa (Cambridge: Harvard University Press, 1980), 204-205.

${ }^{70}$ See Johann Alexander Müller, “The Inevitable Pipeline Into Exile:” Botswana's Role in Namibia's Liberation Struggle (Oxford: African Books Collective, 2012) for more on Botswana's exile network. Botswana's position as a British Protectorate and the Khama's willingness to help Namibians in their resistance campaigns proved instrumental in the liberation struggle. In the 1950s and early 1960s, this "Pipeline into Exile" played an essential role in helping Namibian students, pastors, activists, and politicians escape the SWAA and South African government's watchful eye. These actors frequently travelled to the UN to provide testimony against the South African colonial state or, as in the case of Hans Beukes and numerous others, continued their education abroad to prepare to run an independent Namibia. In the 1960s and 1970s, as the armed liberation struggle commenced, this pipeline through Botswana served as an important mechanism for Namibian liberation fighters to enter and exit the territory to fight in small armed conflicts against the South African government. This type of guerilla warfare, aided by the porousness of the border with the protectorate, continued to frustrate the South African Defense Forces and caused the South African government to slowly exhaust its resources in the conflict.

${ }^{71}$ Houser, No One Can Stop the Rain, 113-114.
} 
Map 6: The Route of SWAPO Commander Helao Shityuwete into Exile in 1964 as an Example of the "Inevitable Pipeline into Exile"

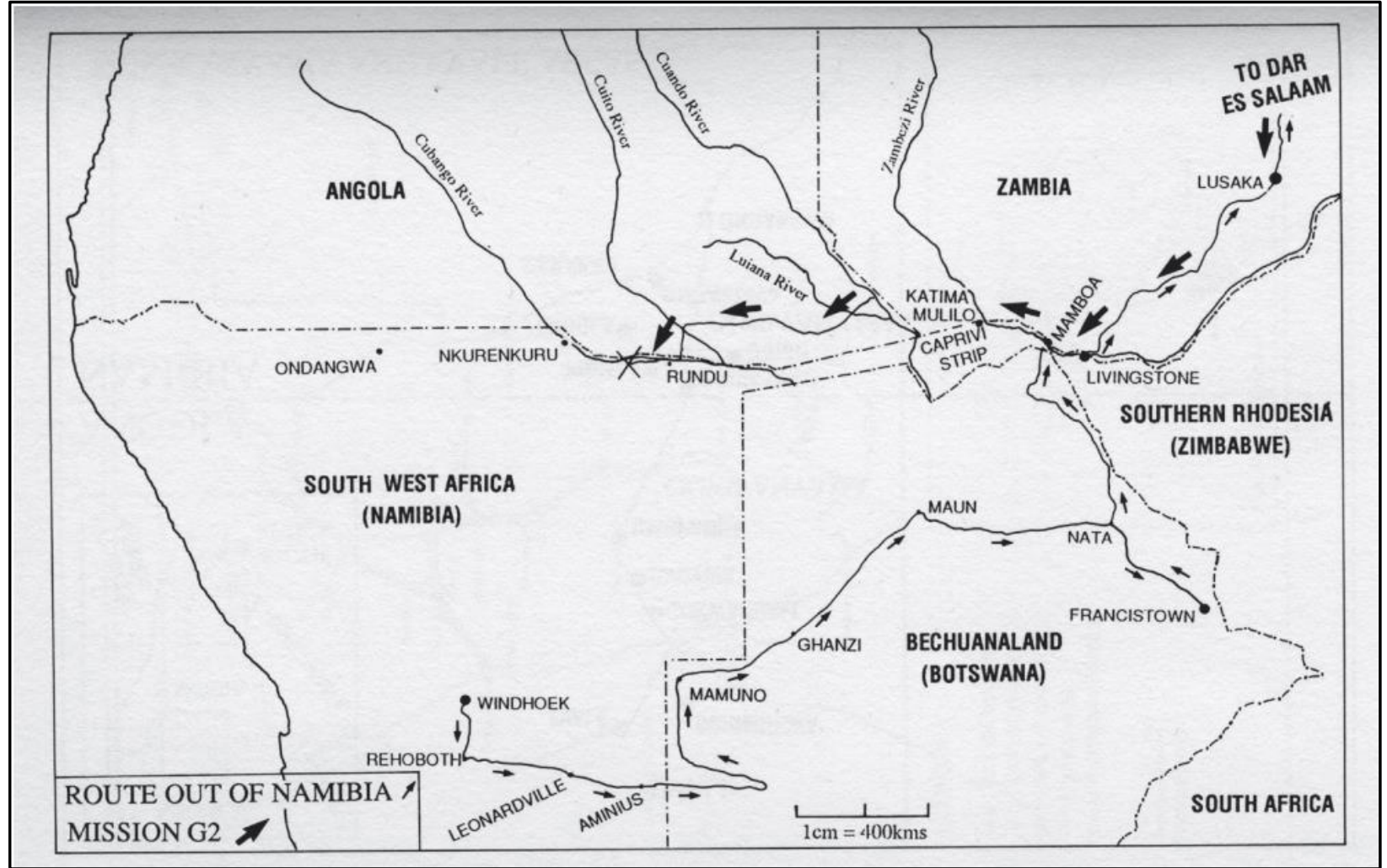

Source: Johann Alexander Müller, "The Inevitable Pipeline Into Exile:" Botswana's Role in Namibia's Liberation Struggle (Oxford: African Books Collective, 2012), 103.

Once in New York, Kozonguizi became part of a small group of Namibian students set to testify before the UN at the end of the year. Fellow student and co-founder of SWASB, Mburumba Kerina, had already petitioned the UN in the early 1950s while a student at the Pennsylvaniabased HBCU Lincoln University. Although the two later became rivals jockeying for power among the Namibian intelligentsia in exile, in 1959 they had the common goal of waging an intense pressure campaign against the South African government for control over South West Africa and its people. In the months that followed, another student from South West Africa's Police Zone used similar transnational networks, universities, student organizations, and 
sympathetic actors to flee southern Africa and provided eyewitness testimony at the UN. These three students formed the heart of a public pressure campaign that continued into the 1960s and caused the South African government legal difficulties and embarrassments on the international stage.

\section{The "Hans Beukes Case" and Covert Student Resistance in 1950s Southern Africa}

Kozonguizi's flight into exile and subsequent political activity was the result of years of higher education and complete immersion into the radical Black politics at Fort Hare practiced by the ANC Youth League, SWASB, and SWAPA. However, his exile and appearance at the UN in 1959 was principally undertaken of his own volition to represent the HCC and Namibians before the international community to openly challenge the South African regime. Conversely, in 1959 , following the seizure of his passport and the blockade placed on his study abroad in Norway by the South African government, Hans Beukes was forced into exile so that he could continue his legal studies and fulfill the scholarship granted to him by the University of Oslo. Educated at the predominantly-white UCT, Beukes was largely viewed as apolitical and the seizure of his passport reverberated among the liberal white elements of Cape society and the Norwegian press. Beukes' subsequent flight into exile introduced him to the more radical student politics and anti-apartheid views present at Fort Hare and espoused by the NSA in the United States.

The Hans Beukes case is perhaps one of the best examples of how universities and student organizations worked collaboratively across national borders with national governments, supranational governmental institutions, and sympathetic transnational actors to challenge the South African apartheid regime's claims over South West Africa. Beukes' lengthy education, 
subsequent flight into exile, and testimony before the UN's General Assembly in 1959 was made possible by an extensive transnational network comprised of the University of Oslo, NUSAS, American political activist Allard Lowenstein, Seretse Khama, and the NSA. These actors and institutions provided the necessary resources, funds, and information to successfully smuggle Beukes, a Namibian student, out of South Africa to pursue his degree at the University of Oslo and provide in person testimony at the UN. Once outside of the recursive reach of the South African government, Beukes and his fellow Namibians waged a public opinion campaign against the apartheid regime and increased international pressure and scrutiny on the way that the South African government exerted its control over the South West Africa territory.

Hans Beukes was the son of influential Baster political leader Hermanus Christoffel Beukes and grandson of Johannes Timotheus Beukes. ${ }^{72}$ Although the family possessed modest financial means, education was of paramount importance and Hans was educated from an early age. His first experiences with the education system in South West Africa began when he enrolled at a newly-created school in Tsumis Park. However, during his second year at Tsumis Park, and at the urging of his grandfather, Hans was sent to a school in Rehoboth that was created for the education of the children of the Methodist congregations. The school was run primarily by South Africans and had a reputation for being much stricter and academically rigorous than either of the neighboring Catholic or Lutheran schools. ${ }^{73}$

Upon graduating from the Methodist primary school, Beukes attended the Dr. Lemmer Secondary School in Rehoboth, the first middle school in South West Africa that catered to the

\footnotetext{
${ }^{72}$ Hermanus Beukes frequently petitioned the League of Nations throughout the 1920s and 1930s in an attempt to restore limited political sovereignty to the Basters at Rehoboth. He remained politically active in Namibia until he was forced to flee to Botswana in 1963 due to his recruitment of soldiers for SWAPO's military wing. Johannes Timotheus Beukes was equally involved in political life. He was a veteran of Tsamkhubis and also fought against the Germans following their extermination order in 1904.

${ }^{73}$ Hans Beukes, Long Road to Liberation: An Exiled Namibian Activist's Perspective (Johannesburg: Porcupine Press, 2014), 19-20.
} 
"mixed-race population" in the territory. ${ }^{74}$ Beukes proved a successful student and passed his final examinations at the school, but he faced the harsh reality that the lack of traditional institutions of higher education for Namibians presented a significant obstacle for his continued education. At the urging of his grandfather, Beukes applied for admission to the Wesley Teachers' Training School in Cape Town, an institution geared toward Coloured students from the Cape and South West Africa that provided students with a teaching certification. ${ }^{75}$ After two years at the Wesley Teachers' Training School, Beukes returned to South West Africa and reenrolled at Dr. Lemmer Secondary School which, during his absence in South Africa, was elevated to the status of a high school. Following a year at the school, Beukes proceeded to enroll at the William Pescod High School in Kimberley where most of the students were Coloured and a large majority of the teachers were educated at the University of Fort Hare. Beukes successfully graduated from William Pescod at the top of his class. ${ }^{76}$

Despite his academic success in South Africa, Beukes still faced financial impediments that prevented him from immediately enrolling at a South African university upon his graduation. He returned to Rehoboth where the SWAA's Department of Education assigned him a position as both a teacher and principal at a new school in Karasburg created for the education of the Baster children of the Dutch Reformed Church congregation. Beukes intended to save enough money while teaching that he could apply and attend an open university in South

\footnotetext{
${ }^{74}$ Ibid., 23.

${ }^{75}$ Francois Cleophas, "A Historical Exploration of Physical Education at the Wesley Teachers' Training School , Cape Town (1915-1966)," Southern African Review of Education: A Review of Comparative Education, History of Education and Educational Development 19, No. 1 (2013): 43-44. The Wesley Teachers' Training School was added to the Wesley Mission School in 1915. The Wesley Teachers' Training School was recognized by the Cape Education Department in 1915 as a "teacher training center for Coloured students" and, upon this recognition, Coloured and African students were no longer allowed to register at Cape Town's Teachers' Training College. In 1941, the Wesley Teachers' Training School stopped admitting African students and exclusively trained Coloured students. For more on the process of teacher education in South Africa, see Linda Chisholm, Teacher Preparation in South Africa: History, Policy, and Future Decisions (Bradford: Emerald Publishing Group, 2019).

${ }^{76}$ Beukes, Long Road to Liberation, 24-28.
} 
Africa. ${ }^{77}$ However, the specter of the implementation of legislation intended to entrench apartheid at South African universities expedited this process. To secure the necessary funding to pursue a law degree at UCT, Beukes drove to his grandfather's house in Narabes and asked him to "support an application for a loan to the Rehoboth community chest." ${ }^{\text {"78 }}$ Given that Hans had completed teacher training school and wanted to pursue a legal degree to "be able to defend the interests of [his] less fortunate countrymen," his grandfather supported the application. Hans was accepted to UCT and, upon this acceptance, the loan from the Rehoboth community chest was granted with minor stipulations. ${ }^{79}$

Beukes began his studies at UCT and enrolled in a number of law courses that would lead to the conferment of a Bachelor of Arts and of Laws (BA-LLB), a degree that would allow him to practice law as an advocate. At UCT, Beukes came into contact with a number of students who became influential members in South African politics and society and was acutely aware of the effects of apartheid even at open universities where the student body was generally opposed to the extension of apartheid in the country. It was not lost upon him that, despite this opposition to apartheid, only five percent of the student body was African, and he was only aware of approximately two Black teachers at the university. In any case, Beukes successfully navigated his first year of enrollment at the university. ${ }^{80}$

In April 1959, a seemingly innocuous event outside of the student cafeteria on campus changed the trajectory of Beukes' life and thrust him into the middle of the ongoing struggle between the South African government, the international community, and Namibians over

\footnotetext{
${ }^{77}$ Ibid., 37.

${ }^{78}$ Ibid., 39.

${ }^{79}$ Ibid. Beukes recalled that the loan was obtained "on the condition that it be secured with a third of Grandfather's farm as surety. In addition, should I happen to fail any subject at the end of the year, the loan would immediately become repayable."

${ }^{80}$ Ibid., 39-45.
} 
control of South West Africa. On his way from the library to the student cafeteria, Beukes was handed a flyer by a member of the Student Representative Council (SRC). ${ }^{81}$ The flyer was posted on campus by NUSAS and it implored African students at the South African open universities to apply for a three-year scholarship at the University of Oslo to study in any academic field, excluding medicine. ${ }^{82}$ The scholarship was issued as part of a student exchange program established by the NSU following the introduction of the Bantu Education Act in 1953. The program was partly established as an act of protest against the South African apartheid regime and its attempts to segregate institutions of higher education. Initially the NSU scholarships were only for a period of three months, but in 1959 the length of the scholarship was extended to three years in order for students to complete their education in its entirety in Oslo. Prior to 1959, only two students were invited to participate in the exchange program, but with increased funding from the Norwegian Ministry of Foreign Affairs, the University of Oslo, and student societies in Oslo, Bergen, and Trondheim, the exchange program expanded. ${ }^{83}$

Beukes submitted an application for the scholarship with the backing of some law faculty and, within a month, he was awarded the bursary scholarship to attend the University of Oslo to study law. Per the terms of the scholarship, Beukes was set to begin his study in August of that year. Although Beukes was frequently described in the historiography as apolitical during his early academic career, in the months before leaving for Oslo he participated in a number of meetings with influential political leaders and activists in southern Africa who anticipated that Beukes' position as an international student would allow him to amplify an anti-apartheid

\footnotetext{
${ }^{81}$ Student Representative Council was an elected body that advocated for the interests of the entire UCT student body and participated in the university's decision-making process on issues that impacted their studies and student life on campus.

82 Beukes, Long Road to Liberation, 46.

${ }^{83}$ Eriksen, "The Origins of a Special Relationship," 13-14.
} 
message to a global audience. ${ }^{84}$ Beukes recalled that on a car ride from the train station back to his home, his father remarked "It's a good thing you will be going abroad. You should be using the opportunity to make [the South West Africa] case known." ${ }^{95}$ Once in Rehoboth, Beukes traveled to Windhoek where a meeting was arranged with Clemens Kapuuo and Chief Hosea Kutako to further avail Hans of the circumstances in South West Africa and provide him with their viewpoints on the situation, so that he could credibly speak on their behalf if the opportunity arose abroad. A subsequent meeting with Albert Luthuli following his press conference at the Parade Grounds in front of the City Hall in Pretoria in 1959 only further encouraged Beukes' budding political activism and reified the importance of his future position outside of the reach of South African government. ${ }^{86}$

With the help of South African senator Leslie Rubin, the father of NUSAS president Neville Rubin, Beukes secured the necessary passport to study abroad in Oslo. He was to depart from Port Elizabeth aboard a Norwegian ship that would take him to Oslo. After arriving by train from Cape Town, the Port Elizabeth police and Major Heiberg of the Special Branch stopped Beukes and commenced a search of his luggage and papers. An immigration officer accompanying the police seized Beukes' passport and the subsequent discovery of a copy of Ronald Segal's journal Africa South and Adlai Stevenson's Call to Greatness among Beukes' belongings gave the South African police the desired justification to withhold Beukes' passport and prevent him from travelling to Norway. ${ }^{87}$ Although the government claimed that Beukes

\footnotetext{
${ }^{84}$ Lowenstein, Brutal Mandate, 43.

${ }^{85}$ Beukes, Long Road to Liberation, 48.

${ }^{86}$ Ibid., 48-49 and 52-53. Albert Luthuli was a South African political activist and President of the ANC from 1952 to 1967 . He won the Nobel Peace Prize in 1960 for his use of non-violent resistance strategies to combat the South African government's apartheid policies.

${ }^{87}$ Ibid., 53-58. Adlai Stevenson, Call to Greatness (Cambridge: Atheneum, 1966). Segal's Africa South dealt with contemporary issues of religion, politics, and economics in South Africa. Segal was a self-claimed socialist and antiapartheid activist in 1950s South Africa. The discovery of works by Segal and Stevenson would have been
} 
participated in "subversive activities" and possessed communist propaganda, it was posited that the South African government became aware of his meetings with Namibian and ANC activists prior to his departure for Port Elizabeth and that the government was concerned that he may try to testify before the UN on behalf of the Rehoboth Basters. ${ }^{88}$ The seizure of his passport forced Beukes to return to Cape Town, where he was greeted by a public outpouring of anger at the government and a series of publications and student marches that sought the return of his passport. ${ }^{89}$

Not only did the seizure of Beukes' passport stir the liberal parts of Cape society to action, it also drew the attention of a vast network of transnational actors that viewed Beukes' case as an opportunity to strike a blow at the heart of the South African apartheid regime by showing the international community the human side impacted by repressive apartheid policies. Few transnational actors played a more important role in the Beukes case than the American Allard Lowenstein. Lowenstein was heavily involved in student politics throughout his early career and, while an undergraduate at the University of North Carolina, he served as the president of the NSA. In this role he focused on "winning over developing nations to Westernstyle democracy and the cause of anti-communism. ${ }^{.90}$ Lowenstein continued to focus on student politics throughout his academic career and after he received his law degree from Yale in 1954. Between 1956 and 1957 Lowenstein spent time organizing campuses for the College Association

categorized as communist propaganda and was used by police as a justification for preventing Beukes from leaving southern Africa.

${ }^{88}$ Eriksen, "The Origins of a Special Relationship," 14.

${ }^{89}$ Lowenstein, Brutal Mandate, 43 and Beukes, Long Road to Liberation, 62. Beukes' passport seizure was wellreported in parts of the South African press. For more on this press coverage, see "Student's Passport Seized: City Man was to Take Up Norwegian Bursary," Cape Times, June 1959; "Passport Protest," Cape Times, 26 June 1959; and "Seized Passport: Teachers Appeal to Naude," Cape Times, 26 June 1959.

${ }^{90}$ William H. Chafe, Never Stop Running: Allard Lowenstein and the Struggle to Save American Liberalism (New York: Basic Books, 1993), 132. 
of the UN and then returned to the University of North Carolina for a subsequent year of graduate study. ${ }^{91}$

In the summer of 1958, Allard Lowenstein embarked on a trip at the request of the NSA's international vice president to obtain answers to a series of questions about student life in Africa and Asia. The journey spanned roughly 20 different cities across 17 countries and led Lowenstein to spend a significant amount of time in Rhodesia and South Africa. During this trip, Lowenstein stopped at the University of Fort Hare and gave an impassioned speech that defended American ignorance to South Africa's apartheid policies and attempted to absolve the American public of responsibility for the South African government's actions. It was during this heavily-criticized speech and subsequent discussion that night, that Lowenstein became familiar with the extent to which the apartheid government exerted control over the political, social, and economic lives of Namibians in South West Africa. The aforementioned Kozonguizi attended Lowenstein's speech and called out from the back of the room, "You say your people do not see that they are responsible for the things that are done to the Black man in South Africa. Well, I come from a place for which your country and the UN are directly responsible, and there things are so much worse that I must come here to get a breath of fresh air."92 Initially stunned by the story, Lowenstein spoke with Kozonguizi through the night about "the anomaly of a nation being protected by a world organization dedicated to human rights, but exemplifying in the most glaring ways the suppression of all those rights." 93

At the conclusion of their conversation, Kozonguizi encouraged Lowenstein to seek out Reverend Michael Scott upon his return to the United States to further discuss the issue of South

\footnotetext{
${ }^{91}$ Ibid.

${ }^{92}$ Lowenstein, Brutal Mandate, 3-4.

${ }^{93}$ Chafe, Never Stop Running, 134.
} 
West Africa. During this meeting, Reverend Scott impressed upon Lowenstein the importance of having a fresh set of eyes report on the conditions in South West Africa, and he detailed a plan that saw Lowenstein travel to South West Africa to undertake a clandestine fact-gathering mission that would result in his own in person testimony before the UN's General Assembly. Lowenstein used his connections from his time in national student politics to find reliable companions who accompanied him on this mission. He chose Emory Bundy, a student at the University of Washington who was the student body president when Lowenstein spoke at the university in 1957, and Sherman Bull, a Yale graduate and Columbia medical student with a scientific background that made his cover story about studying the various forms of wildlife in South West Africa more plausible. ${ }^{94}$

In the summer of 1959, the three Americans travelled to South Africa under the auspices of attending the annual NUSAS Congress at Wits in Johannesburg, where Lowenstein would deliver the meeting's greeting. While Lowenstein and his companions were in South Africa preparing to undertake their fact-finding mission, Beukes' passport was seized. ${ }^{95}$ Lowenstein's attendance at the NUSAS Congress and Beukes' close relationship with NUSAS members at UCT, combined with NUSAS awarding the Norwegian scholarship to Beukes, made a meeting between Lowenstein and Beukes highly likely. Upon Beukes' return to Cape Town via plane, he was picked up by NUSAS president Neville Rubin and Adrian Leftwich and whisked away to an impromptu meeting with Lowenstein. ${ }^{96}$ At this meeting, Lowenstein impressed upon Beukes the importance of sending a cable to the UN detailing the nature of his passport seizure and he

\footnotetext{
${ }^{94}$ Ibid., 135-136.

${ }^{95}$ Lowenstein, Brutal Mandate, 41-42.

${ }^{96}$ Beukes, Long Road to Liberation, 60. Adrian Leftwich was a white South African student activist who served as the President of NUSAS from 1961 to 1962 and participated in increasingly radical resistance strategies, including strategic infrastructural bombings.
} 
suggested that Beukes should request a hearing before the UN on the matter. In concert with Beukes' cable, Lowenstein also instructed Rubin to send a cable on behalf of NUSAS covering similar subject matter.

Following this initial meeting in Cape Town, Beukes and Lowenstein both attended the annual NUSAS Congress in Johannesburg where Lowenstein provided a brief greeting to the crowd and Beukes gave a much longer speech detailing the seizure of his passport and the conditions faced by Namibians in South West Africa. After these speeches, Beukes asked Lowenstein to talk in a more private setting and, once the two were alone, he asked Lowenstein to help him escape South Africa so that he could present his testimony at the UN in person. Lowenstein and his two companions mulled over the request for nearly two days because helping Beukes jeopardized the time-scale they established for their clandestine trip to South West Africa at the conclusion of the NUSAS Congress. However, Beukes' persistence won the day and the three Americans agreed to smuggle him into the Bechuanaland Protectorate where they could more freely find a way to get Beukes to New York to testify. ${ }^{97}$

This unexpected addition to their trip undoubtedly required more resources and Lowenstein looked for sympathetic actors in South Africa to help smuggle Beukes out of the country. Lowenstein first turned to the ANC which, as the chapter previously discussed, was the most active anti-apartheid political organization in South Africa. Lowenstein and Beukes travelled to the law offices of Nelson Mandela and Oliver Tambo to attend a meeting and ask for their help in this endeavor. However, Tambo informed Lowenstein that the ANC possessed a limited infrastructure to help political dissidents escape the country. Lowenstein left the offices

\footnotetext{
${ }^{97}$ Lowenstein, Brutal Mandate, 47-48.
} 
in disbelief that the ANC was not more prepared in this regard and, in his indignant outrage, agreed to personally smuggle Beukes out of the country. ${ }^{98}$

Beukes' escape from South Africa began in Johannesburg following the NUSAS Congress, where Bundy and Bull had secured a Volkswagen Beetle for the journey. Despite a series of miscues and miscommunication about where to meet one another, Beukes and the three Americans began their journey to the Bechuanaland Protectorate by traveling through the Northern Transvaal and heading north of Pretoria. ${ }^{99}$ The group made it within 30 miles of the Bechuanaland Protectorate border before experiencing car trouble when an accelerator cable was damaged. During the brief time in which Bull successfully fixed the car, Beukes and Lowenstein debated the best way to cross the border since it was highly likely that the bridges that crossed the Limpopo River were well-guarded by the South African police. ${ }^{100}$ It was during this conversation that the Americans recalled a part of Rudyard Kipling's poem “The Elephant's Child" that detailed the Limpopo's crocodile-infested waters. ${ }^{101}$ As this conversation unfolded, and before the Volkswagen was fixed, another car approached on the road and the Americans hurriedly hid Beukes in the space between the back seat of the car and its rear window and covered him with suitcases and documents to hide him from sight. Although this encounter came to nothing, it did provide them with a method for hiding Beukes as they crossed into the Bechuanaland Protectorate. ${ }^{102}$

Their crossing into the protectorate succeeded with little trouble and the foursome continued onward until they arrived at a hotel near the Palapye, a small town roughly 30 miles

\footnotetext{
${ }^{98}$ Beukes, Long Road to Liberation, 64-65.

${ }^{99}$ Lowenstein, Brutal Mandate, 51-52.

100 Ibid., 54.

${ }^{101}$ Rudyard Kipling, The Elephant's Child (Binghamton: Platt and Munk, 1988).

102 Lowenstein, Brutal Mandate, 55-56.
} 
outside of Serowe. The hotel in Palapye served as a makeshift base for Lowenstein and his friends as they shuttled Beukes back and forth to the house of Seretse and Ruth Khama in Serowe where plans were made for Beukes' immediate future. Except for a small incident in which the manager of the hotel stormed into Lowenstein's room in the middle of the night with a spotlight looking for Beukes, this process went smoothly, and it was eventually agreed that Beukes would stay with the Khamas while Lowenstein, Bundy, and Bull completed their trip to South West Africa to collect audio-recordings of Namibians' testimonies on their treatment under the apartheid regime. ${ }^{103}$

Beukes stayed with the Khamas in Serowe for approximately one month while transnational actors worked to secure his safe passage to New York to testify. Kozonguizi and Kerina worked tirelessly to secure a US visa for Beukes and obtain the necessary clearances that allowed him to travel through countries that had their own restrictive racial policies. In one letter to Beukes, Kerina claimed that he had called upon Kwame Nkrumah to write to the Prime Minister of the Central African Federation (CAF) to clear Beukes' path to Salisbury. ${ }^{104}$ Kozonguizi and Kerina eventually succeeded in securing a US visa and received clearance for Beukes to travel through the CAF. Beukes embarked on a train that took him to Salisbury where he received notification from Seretse Khama that Lowenstein had secured funding of $\$ 750$ to cover the cost of his airfare to the UN. ${ }^{105}$ Beukes eventually flew from Nairobi to London where he was met at the airport by Reverend Scott's secretary, Doris, who took him to meet Kozonguizi and Scott in London. Beukes subsequently participated in a brief tour across Norway that was followed closely by the press. This publicity tour was intended to draw the attention of the

\footnotetext{
${ }^{103}$ Beukes, Long Road to Liberation, 70-75.

${ }^{104}$ Ibid., 79.

${ }^{105}$ Ibid., 81.
} 
Scandinavian people, and more broadly the global public, to Beukes' experiences with the apartheid regime and increase public attention for the future hearing before the UN. At the conclusion of this brief tour, Beukes flew to New York in preparation for his in person testimony alongside Lowenstein, Kozonguizi, and Kerina. ${ }^{106}$

Beukes' arrival in New York in 1959 was a result of the collective collaborative power of student organizations in the United States, Norway, and South Africa and embodied the transnational nature of anti-apartheid activism in the 1950s. The initial scholarship provided by the NSU was advertised on the UCT campus by NUSAS and presented Beukes with an opportunity to escape the South African government's control over his education and study at the University of Oslo so that he could potentially return to South West Africa and defend the legal interests of the Rehoboth Basters. The seizure of his passport by the South African government in 1959 resulted in further student collaboration that saw NUSAS call upon its relationship with former NSA leaders who now adorned positions of political repute in the United States. From these positions of power, Beukes was able to access the necessary resources and funding to flee to Bechuanaland in 1959 and fly to New York to testify in person at the UN in an act of open resistance toward the apartheid state.

\section{Eyewitnesses to Apartheid: Namibian Students' Testimony Before the UNGA in October 1959}

The tireless work of Namibian students to collaborate with foreign universities, student organizations, government agencies, and networks of sympathetic transnational activists resulted in the first testimonies of what developed into a lengthy and sustained legal campaign waged by the international community at the UN against the apartheid government. In October 1959, some

106 Ibid., 90-94. 
of the first Namibian students appeared before the UN to give in person testimony on the conditions in South West Africa in an attempt to sway public opinion, give the South African government's occupation of South West Africa a human face, and secure concrete legal action and resolutions to temper or dissuade the South African government's oppressive policies. Lowenstein, Bull, and Bundy returned to the United States from their trip to South West Africa in the summer of 1959 and prepared their testimony for the UN, while also soliciting funds to ensure that Beukes made it to New York later that year. Kerina, who already attended university in the United States, similarly faced limited obstacles in his preparation to travel to New York. Meanwhile, Beukes had successfully navigated the early stages of his exile in the Bechuanaland Protectorate and Southern Rhodesia and used funds secured by Lowenstein through the NSA to fly to London, Oslo, and then New York. ${ }^{107}$

Over a 10-day period in the middle of September 1959, Kerina, Kozonguizi, Beukes, Lowenstein, and Bundy officially requested oral hearings at the Fourteenth Session of the Fourth Committee of the UN General Assembly. ${ }^{108}$ Hearings were granted to these petitioners and scheduled for the second week of October 1959. ${ }^{109}$ The testimonies between the aforementioned parties were well-coordinated and each touched on a different aspect of life in South West Africa and the impact that the South African government's policies had on Namibians across the globe. To avoid overlapping testimonies, Kozonguizi and Kerina focused on broader issues outside of Namibia’s Police Zone. Kerina provided a lengthy statement that detailed the several legal failings of the South African government to uphold the terms of its mandate over the territory.

\footnotetext{
107 Chafe, Never Stop Running, 143.

${ }^{108}$ United Nations' General Assembly, Question of South West Africa: Request for Hearings, Ninth Session, Fourteenth Committee, Annexes, Agenda Item 38, 22 September 1959, (A/C.4/410).

${ }^{109}$ Ibid. These requests for oral hearings were only a few of the many demanded in 1959. Chief Hosea Kutako submitted a request for an oral hearing on 4 March 1959. The aforementioned Reverend Kooper requested an oral hearing on 10 April 1959.
} 
He focused extensively on the South African government's unwillingness to negotiate with the South West Africa Committee, restrictions placed on petitioners who wished to appear before the UN, the apartheid government's disregard for the ICJ's advisory opinions, and their failure to place South West Africa under a trusteeship agreement with the UN. ${ }^{110}$ Conversely, Kozonguizi's testimony covered the poor conditions and circumstances faced by the territory's Ovambo populations to the north of the Police Zone. He contended that the SWAA intentionally underdeveloped the educational infrastructure in Ovamboland to provide a consistent stagnant pool of labor necessary to maintain the Ovambo migrant labor system that was essential to the southern African mining sectors. ${ }^{111}$

Beukes and Lowenstein, unlike their fellow petitioners, testified specifically about the conditions that they personally witnessed in the Police Zone and in South Africa. Beukes discussed the appalling state of the educational infrastructure in the Police Zone and larger territory by relaying his own experiences looking outside of South West Africa to pursue a college degree. He lamented the South African government's implementation of apartheid at South Africa's open universities and the South African government's great efforts to maintain control over Black education, as evidenced by the confiscation of his passport and the prevention of his continued legal studies in Norway. ${ }^{112}$ Beukes concluded with an appeal to the UN and general public to halt the apartheid regime's oppressive policies:

Sir, we have too much faith in the sincerity of the countries who have an anti-slavery history and the establishment of human rights to their credit to believe that you are acquiescing in the outrages against human beings in South West Africa out of cynicism.... Can we hope, Sir, that the nations of the world will feel free to undertake their obligations in regard to the people of our country, by removing us from the bondage

\footnotetext{
${ }^{110}$ Michael Scott, et al. “The South West Africa Story,” Africa Today 6, No. 6 (December, 1959): 9-10.

${ }^{111}$ Ibid.

${ }^{112}$ Ibid., 6-7.
} 
of South Africa and granting us the opportunities denied us for so long, to live and develop in dignity, as human beings, in our country of birth? ${ }^{113}$

Beukes' appeal to the inhumanity and immorality of apartheid in South West Africa echoed much of the language that came to dominate the anti-apartheid movement in Britain, which was led by activist Christian priests and pastors like Scott and Huddleston.

Finally, Lowenstein's testimony and the recounting of his journey to South West Africa served not only to present the UN with a detailed summary of the audiotapes and statements he secured that summer, but his popularity among American liberals, student activists across the globe, and within government circles served to grab the attention of member states' representatives and the wider American and European public. South Africa's Minister of Foreign Affairs Eric Louw was acutely aware of the potential legitimacy that the testimony of a white man could give to the claims and demands of the other Namibian witnesses and worked to undermine Lowenstein with questions of his credibility and his motivations for his visit to South West Africa. ${ }^{114}$ Anticipating such a tactic, Lowenstein provided the UN General Assembly with written letters from Eleanor Roosevelt, Frank Porter Graham, Senator Hubert H. Humphrey, and Adlai Stevenson that attested to his high moral character and credibility as a witness. ${ }^{115}$ Lowenstein's subsequent testimony directly targeted the legitimacy of South Africa's mandatory rule over South West Africa and outlined the impact of their oppressive policies on Namibians.

Lowenstein denounced the conditions in South West Africa, arguing:

We have concluded that the Government of South Africa is unfit to continue as the Trustee for the conscience of the world and should be stripped of its rights as a Mandatory Power....It is hard to find any evidence that, despite the clear injunctions of the Mandate, the Mandatory Power in thirty-nine years has done anything significant to help the

\footnotetext{
${ }^{113}$ Ibid., 7.

${ }^{114}$ Richard Cummings, The Pied Piper: Allard K. Lowenstein and the Liberal Dream (New York: Grove Press, 1985), 99-101.

${ }^{115}$ Ibid.
} 
indigenous population of South West Africa to develop towards self-government or to improve its living conditions. ${ }^{116}$

It was not lost on Lowenstein that the general global public knew very little about the situation in South West Africa. In an apparent attempt to grab the attention of the public and ensure that parts of his testimony received attention in the press, Lowenstein made a direct comparison between the South African apartheid government and Adolf Hitler's Nazi Germany. Lowenstein proceeded to describe the unacceptable behavior of the South Africa government, writing "The simple, unavoidable fact is that a sacred trust of all of us now rests in the hands of the only government on earth that dares to exalt the same types of laws that united humanity against Hitler, and that have been repudiated alike by science and by all religions, by the spokesmen of democracy, of communism, and of all gradations and styles of government between."117 Although the similarities between the two regimes may have been overstated by Lowenstein, the intention of his statement to highlight how out of line South Africa's policies were with the mainstream international community proved effective.

While Kerina, Kozonguizi, and Beukes were some of the first Namibians to testify in person before the UN, they were not the last. Kozonguizi and Kerina, alongside Allard Lowenstein and Reverend Scott, continued to submit petitions and appear before the General Assembly throughout the 1960s and highlighted the increasingly worse conditions experienced by Namibians in the territory. Other Namibians fled the territory in the coming years, often in an attempt to provide in person testimony at the UN of horrible atrocities that occurred in South West Africa at the hands of the SWAA. In 1960, Reverend Markus Kooper appeared before the UN to detail his forcible removal from Hoachanas and the bodily injury meted out against his

${ }^{116}$ Scott, et al. "The South West Africa Story," 8.
${ }^{117}$ Ibid., 9. 
AME congregation by the territory's police force. ${ }^{118}$ Sam Nujoma, one of the leading members of SWAPO, similarly testified before the UN's Committee on South West Africa on 5 July 1960 and admonished the SWAA for the use of violent and deadly police tactics that resulted in the Windhoek Massacre on 10 December 1959. ${ }^{119}$

Undoubtedly, the testimony provided by Namibians at the UN in 1959 and 1960 tempered and frustrated the attempts of the South African government to administer and control South West Africa and its Namibian population. The testimonies of Lowenstein and Beukes in particular were popular in the world press at the time and, for many in the general public, served as an early introduction to the activities of the South African government in the territory. ${ }^{120}$ Likewise, following the testimony of so many Namibian students and those that aided their flight into exile, the UN General Assembly passed a series of resolutions in November 1959 that rebuked the South African government. Resolution 1358 stated that the General Assembly viewed the withdrawal of Beukes' passport "to be an act of administration contrary to the mandate for South West Africa" and called upon the South African government to reconsider their decision so that Beukes could "take advantage of the scholarship offered him to study at the University of Oslo in circumstances permitting him to maintain normal relations with his family

\footnotetext{
${ }^{118}$ See pages 309 to 324 of this dissertation for more on the violence at Hoachanas and Reverend Kooper's flight into exile.

${ }^{119}$ Nujoma, Where Others Wavered, 102-103. The Windhoek Massacre occurred as a result of a planned demonstration by SWANU to protest the forced removal of Namibians from Windhoek's Old Location to the municipally-owned Katutura. During the protest, police opened fire and killed 11 Namibians. The Windhoek Massacre received significant attention in the press and was one of the leading causes of the formation of SWAPO in April 1960.

${ }^{120}$ These testimonies and the Hans Beukes story in particular were well covered in the press. For examples of press coverage of the October testimonies and their later appearances in December on the Windhoek Massacre, see "U.N. Hearing to African: Student Blocked on Going to Norway to Make Plea," New York Times, 24 July 1959; "African Student Gets A U.S. Visa," The Times, 9 September 1959; McCandlish Phillips, "U.N. Group Hears Plea on Africans: 3 Americans Tell Trustee Unit of 'Hope' of People of South-West Area," New York Times, 14 October 1959; "Group Urges UN to Act in S.W. Africa," Afro-American, 24 October 1959; "South-West Africans' Night Plea Asks U.N. to Intervene in Strife," New York Times, 12 December 1959; and "Ask UN Study African Crisis," Daily Defender, 22 December 1959.
} 
and his country." ${ }^{121}$ In the subsequent Resolutions 1359 and 1360, the assembly continued to exert pressure on the South African government to place South West Africa under the Trusteeship Council's supervision to ensure the economic and political development of the Namibian people. ${ }^{122}$ In Resolution 1360, the assembly even made specific reference to Namibians' petitions and in person testimony on the "concerning political, social, economic, and educational conditions prevailing in the territory" as a contributing factor to the their recommendation that the South African government begin negotiations with the appropriate committees to ensure that the South African government "administer the mandate territory in accordance with the principles and purposes of the mandate." ${ }^{123}$ Despite the flurry of resolutions, little changed legally in the territory as the South African government continued to expand its apartheid policies into South West Africa.

The largest impact that the testimony of these students had on pressuring the South African government to temper its activities in the territory was in the awareness that their actions raised across most of the Western world about the conditions in the territory. The circulation in the press about the testimony of these students and their better-known white counterparts served as a spark for a more global and transnational anti-apartheid movement between the 1960s and 1994. Hans Beukes' case before the UN and the deep involvement of the Nordic student associations led to a flurry of anti-apartheid activity in Norway, Sweden, and Finland. ${ }^{124}$

\footnotetext{
${ }^{121}$ United Nations General Assembly Resolution 1358, Withdrawal of a Passport from Mr. Hans Johannes Beukes, A/RES/1358(XIV) (17 November 1959).

${ }^{122}$ United Nations General Assembly Resolution 1359, Status of the Territory of South West Africa, A/RES/1359(XIV) (17 November 1959).

${ }^{123}$ United Nations General Assembly Resolution 1360, Question of South West Africa, A/RES/1360(XIV) (17 November 1959).

${ }^{124}$ Finland developed one of the closest relationships with anti-apartheid activities as it related to South West Africa. In the 1970s, the Central Organization of Finnish Trade Unions (SAK), the Finnish-Namibian Society, and the International Solidarity Fund (ISF) all formed to place pressure on the South African government over its control of the territory. In Norway, Norwegian Action Against Apartheid (NAMA) and the Norwegian Council for Southern Africa (NOCOSA) were formed to help coordinate a boycott of South African goods. Similarly, in Sweden the
} 
Similarly, Britain saw the rise of the AAM in 1960, although the impact of the Namibian students and Reverend Scott were much less influential in this instance. In the United States, the Sharpeville Massacre in March 1960 served as a moment of awakening for many American student organizations. However, for the NSA, some of their earliest involvements in antiapartheid activities came through their close relationship with Allard Lowenstein and the provision of funds to ensure that Beukes could fly from Nairobi to New York to appear before the General Assembly. These actions by student organizations and sympathetic transnational actors across the globe ultimately culminated in a sustained effort to boycott South African goods in the 1970s and led to a Student Divestment Movement against the South African government in the 1980s. ${ }^{125}$

Namibian students' testimony in 1959 was merely the beginning of the Namibian intelligentsia's engagement with student politics and the start of a protracted resistance campaign from exile. Namibian students in exile continued to wage a number of different resistance campaigns against the South African government that did not include the UN and transcended national boundaries. In August 1959, two months before testifying in person at the UN, Kozonguizi played an influential role in the establishment of one of the first truly nationalist political parties in South West Africa. Kozonguizi, who was both a founding member of SWAPA and acting as a representative of the HCC at the UN, successfully aided in the negotiation of a merger between the two organizations and the creation of SWANU. The formation of SWANU was seen as an attempt to bring together the traditional Herero authority

formation of the Swedish South Africa Committee (SSAK) in 1961 and the Africa Groups of Sweden (AGS) in 1974 also coordinated on issues of the boycott and worked to disseminate information about apartheid to the larger public.

${ }^{125}$ See Sarah A. Soule, "The Student Divestment Movement in the United States and Tactical Diffusion: The Shantytown Protest," Social Forces 75, No. 3 (March, 1997): 855-882 for more on American student resistance strategies against the South African apartheid state in the 1980s and 1990s. 
with the more radical activist youth and intelligentsia that constituted SWAPA's membership.

These youths wanted to find a less sectional approach to resisting the SWAA and viewed SWANU as the bridge between these two groups and a move to cultivate a broader base of support that transcended ethnopolitical boundaries. ${ }^{126}$ Kozonguizi worked effectively to include many of the Herero students who received scholarships to Nordic universities in the hierarchy of SWANU and, more importantly, included leading members of other South West African political organizations, like the OPO's Sam Nujoma, in the organization's leadership. ${ }^{127}$ Despite Kozonguizi's efforts to create a nationalist organization while in exile, he was unable to maintain unity between the diverse groups under the organization's purview.

In April 1960, SWANU experienced its first major setback when the HCC withdrew from the organization over disagreements about the diminished role of traditional ethnic authorities that was espoused in SWANU's radical post-independence vision. ${ }^{128}$ Similarly, a personal rivalry between Kozonguizi and Kerina handicapped the organization's appeal. SWANU was largely founded without input from Kerina, and he feared that his influence as a significant political force in post-independence Namibia would be diminished under Kozonguizi's SWANU. Therefore, in 1959 and 1960, Kerina advocated with Sam Nujoma to focus the OPO's efforts on expanding beyond their large Ovambo base and to actively recruit leaders throughout South West Africa, regardless of their political or ethnic affiliations. ${ }^{129}$ In April 1960, Nujoma

\footnotetext{
${ }^{126}$ Dobell, SWAPO's Struggle for Namibia, 30-32.

${ }^{127}$ Ronald Dreyer, Namibia and Southern Africa: Regional Dynamics of Decolonization, 1945 -1990 (New York: Routledge Press, 2016), 32-34.

128 Dobell, SWAPO's Struggle for Namibia, 31-32.

129 J.H.P. Serfontein, Namibia? (Randburg: Fokus Suid Publishers, 1976), 146-147. See also, Katjavivi, A History of Resistance in Namibia, 50 for more on the rivalry between Kozonguizi and Kerina. Another reason for the division that emerged between SWAPO and SWANU was SWANU's perceived leftward lurch and the development of closer relations with communist world powers. SWAPO had positioned itself more closely with WesternDemocratic nations and Kozonguizi's "Peking Speech" that railed against the imperialism of the West threatened this relationship. Kerina circulated the speech at the UN and this action solidified the perception of SWANU as a communist organization.
} 
founded SWAPO, the political party recognized by the UN General Assembly in 1972 as the "sole legitimate representative" of the Namibian people in their liberation struggle. ${ }^{130}$

Beukes, on the other hand, confined his political activities largely to student politics while he studied law in Oslo. In 1966, in an attempt to mend the rift that had emerged between SWAPO and SWANU, student representatives from each group met in Uppsala under the auspices of an SFS conference to craft the constitution for a National Union of South West African Students (NUSWAS). Beukes, then considered a political independent, was chosen to chair the meeting that included influential figures like Zedekia Ngavirue, Sam Nujoma, Andreas Shipanga, and Solomon Mifima. ${ }^{131}$ NUSWAS was founded at this meeting to create an organization that could coordinate the education of Namibian students in exile, so that they received the necessary training and degrees to run an independent nation. Beukes tried to create a database of NUSWAS membership that tracked each member's specific field of study so that they could identify and fill the academic voids necessary for an independent nation to run effectively. Unfortunately for Beukes and NUSWAS, the task proved too great and few students responded to the requests for information sent out by NUSWAS. Additionally, concerns over NUSWAS's political orientation put off students from both SWAPO and SWANU, leading to the organization's quick collapse.

\section{$\underline{\text { Conclusion }}$}

\footnotetext{
${ }^{130}$ Pierro Gleijeses, Visions of Freedom: Havana, Washington, Pretoria, and the Struggle for Southern Africa, 1976-1991 (Chapel Hill: University of North Carolina Press, 2013),449.

${ }^{131}$ Shipanga and Mifima were two of the founding members of the OPC, the forerunner to the OPO. They both served in various positions within SWAPO until the "Shipanga Rebellion" in 1976. During this rebellion, Shipanga called for SWAPO to hold a congress in Lusaka, Zambia for the purpose of electing new officials and rooting out perceived corruption within the organization. Nearly 1000 youths marched in Lusaka in protest of this corruption, which ultimately led to mass arrests and the detention of Shipanga and Mifima for a period of two years. Upon their release, Shipanga formed the SWAPO-Democrats in Sweden as an opposition party to SWAPO.
} 
The actions of Namibian students during their early resistance campaigns in the late 1950s represented their most complete transnational resistance strategies in the years prior to the formation and expression of a solidified nationalist movement in the 1960s. For these Namibians, international student organizations and foreign universities represented an entry point into a larger transnational network that possessed the financial and infrastructural resources, mobility, and necessary distance from the recursive power of the South African state to facilitate an effective resistance campaign. Unlike previous resistance campaigns between 1919 and 1960 that mostly required Namibians to work with transnational institutions and actors that were able to penetrate into South West Africa's borders, the student-led campaign of 1959 saw Namibian activists traverse national boundaries and move beyond the punitive reach of the state. Once in exile, Namibian students were more able to directly and openly challenge the South African government on its policies.

These students successfully navigated emergent channels of communication that provided them with the resources necessary to improve their own educations and form the beginnings of an intelligentsia in exile that could effectively make the case for independence to the international community. The foundations for their access to higher education were built by South African activists in the early $20^{\text {th }}$ century with the creation of the University of Fort Hare, a university for the education of non-Europeans across southern, eastern, and central Africa. Here, Namibian students were re-introduced to the concepts of Black nationalism and radical mass protests espoused by the ANC Youth League that had waned in South West Africa after the fall of the UNIA in the 1920s. This immersion in Black nationalist resistance strategies and rhetoric provided Namibian students like Kozonguizi with the requisite experiences to form 
Namibian student organizations like SWASB and SWAPA in the 1950s, organizations of paramount importance in the creation of the nationalist movements of the 1960s.

Namibians worked strategically and collaboratively within the context of 1950s southern Africa, harnessing the rising tide of white liberalism in the Cape and using their disgust at government interference in South Africa's open universities to advance their own agenda. NUSAS in particular became an important tool for Namibian students seeking educational opportunities outside of South Africa, where scholarships and bursaries could be rescinded for "subversive" political activities. NUSAS's links to other student organizations in the Western world presented Namibians with new opportunities to obtain scholarships and funding to pursue college degrees in the United States, Britain, and Scandinavia. Hans Beukes was one of the earliest students to take advantage of the scholarships offered by Scandinavian universities via NUSAS. However, throughout the 1950s and 1960s, other influential Namibians who played important roles in SWANU, SWAPO, and SWAPO-Democrats, like Uatja Kaukuetu, Charles Kauraisa, Ottilie Schimming, Kenneth Abrahams, and Zedekia Ngavirue, similarly took advantage of scholarships and academic opportunities outside of southern Africa.

In exile and outside of the reach of the South African state, educated Namibians could openly debate issues of national independence and subnational resistance within colonial boundaries. Student-based organization emerged throughout the 1960s as the Namibian intelligentsia prepared for the territory's future independence. In addition to numerous student testimonies at the UN and the submission of petitions on behalf of those Namibians still in South West Africa, Beukes created an organized network of student information intended to facilitate a quick and effective transition to independence. These exiled students and political activists ultimately came to populate the highest ranks of the Namibian government in the post- 
independence period. The opportunities created by these students, in conjunction with the resources provided by transnational actors and institutions, proved instrumental in the transition from one phase of resistance in South West Africa and began a new phase of armed resistance by a relatively united nationalist front.

As the argument set forth at the beginning of the chapter states, this campaign should not be seen as a clean or distinct break from the subnational resistance strategies that characterized most of the pre-SWAPO period, but more of a slow evolution that portended the nationalist campaigns that emerged in the 1960s. The actors discussed in this chapter initially went into exile to pursue their own personal and subnational goals. For example, Kozonguizi initially went into exile at the request of the $\mathrm{HCC}$ to provide personal testimony about the conditions facing the Herero under the SWAA. Similarly, Beukes initially wanted to pursue his education at UCT and in Norway to secure a law degree so that he could protect the rights and interests of the Baster community at Rehoboth. In both cases, these actors pursued paths aimed at improving the standard-of-living and conditions in specific localities where they had a vested interest.

However, over time and through interactions with other activists free of the recursive powers of the South African government, the aforementioned Namibians developed campaigns that simultaneously pursued subnational goals and complete territorial liberation for South West Africa. It was clear to these savvy political operators that national independence meant an improved standard-of-living in each locality and the dissolution of the apartheid apparatus that so gravely underdeveloped and repressed Namibian communities. Kerina, Kozonguizi, Nujoma, and to a lesser degree Beukes, were all involved in the nationalist politics that emerged in exile in the 1960s as a result of the transnational resistance strategies discussed in this chapter. The 1960s, again, represented an evolution in Namibian resistance strategies that remained 
transnational in nature, but instead shifted their attention toward national liberation instead of subnational concessions within the colonial framework. 


\section{Chapter 8-Transnational Strategies and Subnational Concessions in the Pre-SWAPO Period: A Conclusion}

In September 1959, Jariretundu Kozonguiz founded the political party SWANU. In April 1960, Sam Nujoma and Andimba Toivo ya Toivo founded SWAPO. The establishment of these two national political parties represented a shift in Namibians' resistance strategies against the colonial state and opened a new chapter in Namibians' anticolonial activities. Although continuity existed between the pre- and post-SWAPO periods, Namibians turned their focus from securing subnational concessions from the colonial state to the complete eradication of white rule in the territory and an end to white hegemony. ${ }^{1}$ In this new nationalist approach, the inclusion of all Namibians and overcoming subnational segmentation was of critical importance. That temporary unity was then leveraged as an instrument of resistance itself. National liberation was the main aim of the nationalist movement and merely carving out spheres of influence within the colonial structure was no longer acceptable. In 1966, as part of this larger national liberation struggle, SWAPO began an armed liberation struggle against the South African state that resulted in national independence in $1991 .^{2}$

Despite the clear successes of the armed liberation struggle and SWAPO's larger nationalist movement, Namibians' transnational resistance strategies in the pre-SWAPO period also proved remarkably effective at winning Namibians concessions from the colonial state. Throughout these resistance campaigns Namibians expressed their agency, frustrated the colonial state, and won important subnational concessions that improved the standard of living for many Namibians in the Police Zone and relieved some of the abuses meted out by the colonial regime. This chapter serves as a conclusion for this work and analyzes the overall effectiveness of

\footnotetext{
${ }^{1}$ Victor Tonchi and Albertina N. Shifotoka. Parties and Political Development in Namibia (Johannesburg: Electoral Institute for Sustainable Democracy in Africa, 2005), 10-20.

${ }^{2}$ Dale, Namibian War of Independence, 73-110.
} 
Namibians' transnational resistance strategies. Of paramount importance here is an examination of how and why these transnational networks were developed and maintained, how Namibians utilized these networks to resist the colonial state, and in what ways these strategies succeeded or failed in their stated aims. This analysis will concisely answer the crucial questions set forth in the dissertation's introduction on page 9 .

\section{Embracing Transnational Resistance: Namibians' Motivations and Reasoning}

Between 1921 and 1962, transnational resistance strategies flourished in the Police Zone and became one of the primary modes of anticolonial resistance to the extension, intensification, and entrenchment of South African rule in the territory. Other approaches to resistance existed elsewhere in the territory. North of the Police Zone, the repressive migratory labor system was an ever-present fact of life for the Ovambo and, as such, they adopted labor-centric resistance strategies that centered on work stoppages, strikes, and smaller exclusionary acts of resistance like refusing to participate in the system. ${ }^{3}$ Elsewhere, even in the Police Zone, it is clear that alternative strategies existed. The Bondelswarts Affair of 1922 and the Rehoboth Rebellion of 1925 showed that many Namibians still embraced the idea of physical confrontation with the colonial state as a mechanism to alter the behavior of the South African regime. However, despite these diverse approaches to resistance, the Nama, Baster, and Herero embrace of transnational institutions and organizations as vehicles for change in South West Africa dominated the anticolonial activities of the period.

\footnotetext{
${ }^{3}$ For more on the migrant labor system in Ovamboland, see Jan-Bart Gewald, "Near Death in the Streets of Karibib: Famine, Migrant Labour and the Coming of Ovambo to Central Namibia," Journal of African History 44, No. 2 (2003): 211-239 and Alland D. Cooper, "The Institutionalization of Contract Labour in Namibia," Journal of Southern African Studies 25, No. 1 (March, 1999): 121-138.
} 
Three of the central questions posited in this dissertation were why Namibians embraced transnationalism as a means of resistance, how and to what extent did they develop transnational networks across time and space, and was this part of a larger coordinated effort in the Police Zone? A primary reason that Namibians readily embraced transnational institutions and organizations as a means of resistance to the colonial state was that Namibians and the larger South West Africa territory developed extensive networks in the Americas and Europe through historical processes and relationships developed over the course of nearly 200 years. One of the more influential circuits that developed linked South West Africa with the United States, the Caribbean, and Black American seamen. As a result of the poverty and economic exclusion that Black Americans faced after emancipation, many turned to commercial maritime industries as a way to adapt to their circumstances. As chapter 3 illuminated, by 1850 Black Americans accounted for nearly 50 percent of all American seamen travelling this developing circuit. ${ }^{4}$ As these seamen traversed the Atlantic seaboard, they established Afro-Caribbean and West Indian communities with some emerging in South West Africa's industrial port towns. Combined with South African experiences with singing groups from American HBCUs and the larger historical process of post-emancipation Black migration, a circuitous network was created between the Americas and southern Africa that allowed people, resources, and information to be circulated multi-directionally across the Atlantic.

This transnational network was further developed and maintained throughout the twentieth century by Namibians and Black Americans and was essential to Namibian resistance efforts during the period. The earliest example of this network's success at introducing sympathetic transnational actors and institutions to Namibians occurred in the early 1900s as

\footnotetext{
${ }^{4}$ Cobley, "Far From Home," 352-353.
} 
Garveyite agents came to South Africa and developed practical relationships with Black protest nationalist organizations in South Africa like the ICU. The UNIA established its own branches in South Africa during this period and shared some of its leadership and members in South Africa with the ICU. The subsequent movement of ICU and UNIA agents from South African industrial centers to those in South West Africa brought this transnational organization to urban Namibians in the early twentieth century. Namibians developed their own relationships with these agents, opened and maintained channels for information and resources to travel across national boundaries, and ultimately repurposed the infrastructure of the UNIA in the territory to resist the colonial state and achieve their own subnational goals. ${ }^{5}$

Much like the UNIA, the rise of the AME Church as a transnational resistance institution in South West Africa was linked to a historical process that created a Black Atlantic circuit that introduced Namibians to Black Americans with a keen interest in the African continent. ${ }^{6}$ Often, American interest in the continent was for a particular actor's or organization's own ambitions and interests. The rise of the ACS in the nineteenth century and the increased salience of the "Back-to-Africa" movement under Garvey in the early twentieth century saw Black American actors travel to places like Liberia and South Africa to escape white hegemony or act as civilizing agents seeking to redeem the African continent. The AME Church, much like it had in Liberia, emerged in South West Africa as a result of this trans-Atlantic process and its links to Pan-Africanist and evangelical movements in the Americas.

\footnotetext{
${ }^{5}$ Ibid.

${ }^{6}$ For more on the concept of the "Black Atlantic," see Paul Gilroy, The Black Atlantic: Modernity and Double Consciousness (New York: Verso Books, 1993) and Karen Sotiropoulos, "James and Rose Aggrey and the Black Atlantic Gestations of African Nationalism," International Journal of African Historical Studies 53, No. 2 (2020): 239-264.
} 
Another global historical process that dramatically impacted Namibians' embrace of, and introduction to, transnational resistance institutions was the period of warfare and political reordering that occurred in Europe between 1915 and 1945. The European powers, which actively worked to subjugate, exploit, and control African populations through colonial administrations and enterprises since the nineteenth century, went through their own period of warfare and turmoil during World War I and World War II. These wars ultimately brought many of their colonial populations into the war. During the Interwar Years and after World War II, the global powers set about re-ordering and re-organizing European political institutions and structures to prevent these conflicts from enveloping the world again. Necessarily, this meant that a similar restructuring took place in the colonial sphere and reshaped the relationship between the colony and the metropole.

As this historical process of global political re-organization played out it had a direct impact on Namibians and the South West Africa territory, which became a proverbial political football whose international legal status was hotly contested by several states and supranational institutions. The League of Nations was established in 1919 as an organization to prevent future wars and oversee the modernization and development of the territories and colonies divided up through the Treaty of Versailles. South Africa, because of its wartime service during the First World War on behalf of the victors, received the mandate to rule over South West Africa and quickly began the de facto incorporation of South West Africa as a fifth province. ${ }^{7}$ This entailed the extension of South Africa's segregationist policies to the territory, policies that were in direct contradiction to the League of Nations mandate granted to the South African government and ran

\footnotetext{
${ }^{7}$ Hyam and Henshaw, The Lion and the Springbok, 103-105.
} 
counter to the Wilsonian language and spirit that characterized international politics in the immediate aftermath of the war.

The anger and contempt felt by more liberal transnational actors toward the South African government's disregard for the League's mandate focused attention on South West Africa and, in some instances, even brought sympathetic transnational actors to the territory to impede this de facto incorporation of the territory. In the early years of mandatory rule, South African parliamentarian Dewdney Drew, who had travelled to Rehoboth in 1917 to speak to the Basters about the issue of post-war self-determination, continued to communicate with the Basters on the role of the newly-created League and PMC. This information, which came to the Basters as part of this larger global political re-organization, served as their first introduction to the League of Nations and created deeper understanding of its function in global politics and its ability to alter the behavior of an oppressive colonial state. ${ }^{8}$ As a result of this process and transnational actors' responses to violations of this political reconfiguration, the Basters developed their petition-writing campaign to fight for subnational self-determination and the return of political autonomy in the Gebiet.

A similar process occurred at the conclusion of World War II after the League of Nations failed and another round of global political re-ordering commenced. The UN was established in 1945 to provide for the collective security and colonial modernization and development that the League failed to produce. The South African government once again attempted to incorporate South West Africa as a fifth province and came into direct conflict with the UN over placing the territory in the trust of the UN. Given the rising tide of anticolonialism, nationalism, and human rights across the globe in the 1940s and 1950s, it is unsurprising that sympathetic transnational

\footnotetext{
${ }^{8}$ J.B.M. Hertzog to Secretary General: Observations from the Government of the Union of South Africa to the League of Nations, 23 January 1929, LNA/MS/R2289 and Dedering, "Petitioning Geneva," 794.
} 
agents who embraced more liberal sociopolitical positions, like anti-apartheid or humanitarianism, turned their attention to South West Africa and worked to frustrate the South African colonial regime. For example, this second round of global political reconfiguration led the Reverend Michael Scott, who abhorred the South African government's racial policies because of his experiences with the Campaign for Right and Justice in 1943, to travel to South West Africa and discuss the role of the UN in global politics with Herero chief Hosea Kutako. ${ }^{9}$ Similarly, American political activist Allard Lowenstein travelled to South West Africa in 1959, in part at the behest of Reverend Scott and in part because of his student political activism across the globe in the 1950s, to secretly record Namibians' testimonies about the abuses perpetrated by the SWAA and distribute them to a wider public audience. ${ }^{10}$ In each of these cases, historical processes played an important role in the development and creation of the transnational networks that Namibians maintained and used to wage their resistance campaigns against the SWAA.

While Namibians readily embraced transnational institutions for their resistance campaigns because of the historical linkages that existed between Namibians, Americans, and Europeans, Namibians also pursued this specific style of resistance because transnational agents and institutions could more easily traverse national borders and evade the recursive power of the South African state. Whereas the South African state controlled the movement of Namibians through a series of segregationist pass laws and vagrancy proclamations, more limited mechanisms of control existed for transnational actors who visited the territory. While outright refusal of entry was a possibility for the South African government, language in South Africa's mandate for the territory allowed for observers and external agents to visit South West Africa. Thus, refusal of entry often led to increased problems for the South African state that resulted in

\footnotetext{
${ }^{9}$ Scott, A Search for Peace, 36-38.
}

${ }^{10}$ Lowenstein, Brutal Mandate, 1-10. 
the government facing increased pressure from the League, UN, or general public over why they prevented these seemingly innocuous actors from entering the territory.

Namibians recognized the problems that transnational agents caused for the South African government with the international community and sought out sympathetic actors to serve as vehicles and conduits through which they could express their agency and resist the colonial regime. Namibians were acutely aware that some international figures received deference because of their occupation or position. For example, the Reverend Michael Scott and Francis H. Gow were able to cross the South West African border largely because of their positions as Christian pastors and priests. Despite their activist inclinations and activities in resistance movements elsewhere, the South African government was slow to limit their access to Namibians because of the close ties the two had with influential religious and political communities in Europe and the United States. In other instances, one's occupation or position made them less noticeable to the SWAA. Although Allard Lowenstein was monitored and known to have embraced anticolonial causes during his time in global student politics, he and his companions' stated goal of speaking to student groups at South African universities only moderately drew the interest of the South African state in 1959 and likely aided in his ability to evade detection and arrest in South West Africa during his fact-finding mission. ${ }^{11}$

Namibians also recognized that transnational actors and institutions could more easily enter and leave South West Africa. Rather than fully take on the colonial state and experience the full weight of its recursive powers, Namibians instead turned to transnational agents as vehicles of resistance because those actors could leave the territory and evade harsh punishment from the colonial regime. The inability of the South African state to take action against these figures once

\footnotetext{
${ }^{11}$ Lowenstein, Brutal Mandate, 133-136 and 145-148.
} 
they left the territory made them particularly difficult to monitor and control. If there was no recourse once one left the territory, these actors could help facilitate Namibian resistance to the South African state more vociferously and without the concern of punitive action. Likewise, any attempts to punish these actors would further draw the attention of the international community to the government's segregationist and apartheid policies, a problem that the colonial government surely wanted to avoid.

To further answer the second question posited at the outset of this dissertation, transnational resistance appealed to Namibians for the several reasons above, but most importantly, Namibians turned to this resistance strategy because it was one of the most effective ways to frustrate the colonial state and slow the implementation of its segregationist and later apartheid policies. Chief among the reasons that Namibians turned to transnational resistance was that these networks and actors proved most effective at amplifying their voices, expressing their agency, and getting their demands to the widest possible audience. While writing to a newspaper or challenging South African segregationist policies in a South African court may have wielded small successes, more well-known American and European activists and institutions had a much wider reach and following. Namibians understood the importance of amplifying their message and garnering as much global support as possible to influence the colonial state. This made the colonial regime deliberate potential policies more extensively and sometimes alter decisions based on the perceived optics of a policy. In a number of cases cited in this dissertation, this pressure helped mitigate or halt the negative impacts that accompanied such policies and their implementation. This amplification is perhaps best embodied by the activities of the Reverend Michael Scott, Allard Lowenstein, and those Namibians who travelled to the UN in 1959 and 1960 to state their case before the UN General Assembly. The popularity of these 
actors led to several media stories that were read and digested by intellectual elites and influential politicians across the globe. ${ }^{12}$

Similarly, Namibians embraced these types of institutions because they understood that organizations like the UN and League of Nations could leverage their international political standing and resources to alter or temper the behavior of the colonial state. Namibians knew that the colonial state possessed disproportionately more power than themselves and that by utilizing transnational institutions and actors as conduits for their own agency and resistance, Namibians could alter the power dynamics of their relationship with the colonial state to their benefit. The Basters had minimal success with this approach during their petition-writing campaign in the Interwar Years, but the use of international pressure as an instrument of resistance proved more successful in the 1950s and 1960s as Namibians accessed the power and influence of the UN through their petitions and testimonies. Following a petition-writing campaign to the UN, the General Assembly issued a series of UN resolutions in the 1950s that halted forced land expropriations at Hoachanas and Aminuis and condemned the South African government's pursuit of these apartheid-based removals. ${ }^{13}$ Combined with the Namibian students' testimonies at the UN and another series of UN resolutions, the use of international political pressure as leverage against the colonial regime belied why Namibians turned to transnational institutions during this period.

Finally, and perhaps most importantly, Namibians also embraced transnational resistance for the access that this strategy provided to immense international pools of resources. After experiencing nearly four decades of socioeconomic and political underdevelopment at the hands

\footnotetext{
${ }^{12}$ See pages 294-296 and 305-307 of this dissertation for a more in-depth look at the circulation of newspapers reporting on Namibians' testimonies to the international public in 1959 and 1960.

${ }^{13}$ General Assembly Resolution 1357(XIV), The Hoachanas Native Reserve: Resolution, A/RES/1357(XIV) (17 November 1959).
} 
of the German government, Namibians faced similar underdevelopment by the South African colonial regime that was made more salient by the state's hardline segregationist and apartheid policies. As a result, Namibians possessed a limited number of resources in South West Africa that could be used to resist the colonial state. Thus, access to the resources possessed by transnational actors and institutions were crucial to Namibians' ability to effectively resist the state's policy of underdevelopment and oppression. The UNIA and AME Church presented Namibians with access to important actors and institutions that provided economic and political support that resulted in the construction of numerous school buildings intended to fight economic underdevelopment, and the creation of a social welfare program meant to limit the devastating impacts of socioeconomic disaster. Likewise, the League and the UN provided Namibians with access to extensive networks connecting students, priests, politicians, and others, for the purpose of fighting the South African government's legal claims to the territory. Scholarships served as an important form of aid to facilitate the development of a Namibian intelligentsia in exile and brought the South West Africa case to the international forefront. In each of these instances, transnational institutions and actors presented Namibians with access to resources, people, and networks that were used to challenge the colonial state more effectively.

One question posed in the introduction was whether these transnational resistance campaigns were part of some larger preconceived resistance strategy in the Police Zone between 1919 and 1962. It is clear that there was never an explicit agreement by the actors referenced in this work to coordinate and embrace transnational institutions as a way to resist the colonial state's oppressive policies. Rather, Namibians turned to transnational forms of resistance when the opportunity presented itself and made logical sense in the achievement of Namibians' broader subnational sociopolitical and economic goals. While some of the resistance campaigns 
overlapped on subject matter, shared historical actors, and at times coordinated on specific issues like the forced land removals of the 1950s, there was no territory-wide effort to simultaneously or exclusively pursue transnational institutions to frustrate the colonial state. In most instances, transnational resistance strategies were used alongside more territorially-bounded campaigns that involved labor strikes, work stoppages, or boycotts.

\section{Finding the Subnational in the Transnational: Subnational Concessions and the Success of Transnational Resistance Strategies in the Police Zone}

While the creation and nature of the transnational networks and strategies employed by Namibians in the Police Zone make up a bulk of this work, questions were also posed in the first chapter about the way that Namibian sociopolitical systems impacted the resistance campaigns and what types of subnational concessions and reforms were demanded. The aims of these transnational resistance strategies and the concessions they sought to win from the South African state were mostly subnational in nature, despite the networks spanning continents, oceans, and national boundaries. Historically, the scholarship on this time period focused on tracing the roots of nationalism and connecting these resistance campaigns to the activities of the national political parties and armed liberation struggle of the 1960s and 1970s. ${ }^{14}$ This dissertation, conversely, contends that most of the resistance strategies and actions taken by Namibians were not part of some long linear progression toward nationalism and national independence, but instead formulated as a response to particular subnational, regional, and local everyday concerns in the Police Zone.

\footnotetext{
${ }^{14}$ See Emmett, Popular Resistance and Pirio, "The Role of Garveyism" for examples of works that aim to uncover the roots of nationalism in Namibia.
} 
The subnational concerns of Namibians' transnational resistance campaigns, and the very way that specific campaigns developed and grew, often broke along existing ethnopolitical and geopolitical lines, all with the express purposes of carving out spheres of influence, challenging the colonial state, and improving Namibians' quality of life in the territory. One of the key subnational concerns that Namibians addressed through the use of transnational actors and institutions was the re-establishment of subnational political autonomy in the Police Zone. At times, Namibians' political ambitions during this period are portrayed as seeking the complete overthrow of the colonial state and the removal of white hegemony over the entire South West Africa territory. Despite this depiction, most resistance campaigns in the Police Zone during this time centered on achieving subnational political autonomy or concessions for one's own group, since modern forms of African nationalism were still in their infancy in the territory.

In the 1920s, these subnational desires were most apparent with the Rehoboth Basters and their petition-writing campaign to the League of Nations. Rather than call for complete territorial independence for all Namibians, they instead focused their energies and resistance on re-establishing the political autonomy in the Gebiet that they secured under German colonial rule. The Basters worked through the transnational League of Nations and used its vast international resources and legal mechanisms to challenge the control that the SWAA exerted over Rehoboth, but their claims centered almost exclusively on the Gebiet and mentioned only other "small nations" in Europe receiving independence as a result of their participation in World War I instead of other groups in Namibia's Police Zone. The Nama at Rehoboth also sought the re-establishment of their subnational political autonomy through the UNIA in the 1920s and laid claim to the formerly Nama areas surrounding Rehoboth. Although their claims failed, it highlights the role those transnational institutions played in Namibians' attempts to resist the 
colonial state and win subnational concessions around political autonomy and exclusion from the colonial state.

The campaigns surrounding the Basters and Nama in 1920's South West Africa represent the clearest examples of transnational resistance campaigns that were exclusionary in their political goals. Ethnically, these approaches were exclusive to the Basters and Nama and sought localized concessions and reforms. Whereas later strategies sought to be more involved in the colonial political process, these two campaigns instead demanded exclusion from colonial rule and policies and the return of political autonomy in the decision-making process. The Basters, specifically, frequently differentiated themselves from other Namibians in the territory and contended that they should not be subjected to German or South African colonial rule because of the various treaties they constructed and their military service during World War I. Likewise, the Nama members of the UNIA did not demand concessions within the colonial framework, but instead demanded the complete return of ancestral lands and exclusion from the colonial government's repressive policies.

In addition to subnational concerns on the restoration of political autonomy, other resistance strategies focused on the socioeconomic instability of the time and the improvement of living conditions in one's particular region or town. In the 1920s, the UNIA emerged in South West Africa espousing its Pan-African message and calls for national independence for the territory. This message proliferated in the Police Zone during the association's early years, but as Namibians became more familiar with its structure and machinations, they repurposed the infrastructure and resources of the UNIA to achieve their own subnational goals. Following the Herero's rise to power within the South West African UNIA, the association's messaging and activities shifted from one of Pan-African unity and national independence and focused more on 
improving the economic conditions for Namibians in the Police Zone. In those areas where the Herero controlled the UNIA branch, the association called for the re-establishment of herds, the return of Herero lands, and use of the "sick fund" to alleviate the economic pain and burden felt by those who became ill or faced an unexpected death in the family. ${ }^{15}$ In those areas where the Nama controlled the UNIA branch, like Rehoboth for example, the association was used to press Nama claims on expropriated lands. While the association did not succeed in achieving many of these economic claims, through the Herero's interactions with this transnational association, a new masculine Herero cultural identity formed, became more salient, and impacted the Herero's resistance strategies between the 1930s and 1950s.

The example of the UNIA in the 1920s provides another fine example of how subnational strategies differed and changed over time. While non-indigenous Namibians maintained control over the UNIA in 1921, the association demanded exclusion from the colonial state's repressive policies and relied on claims of territorial liberation as a recruitment technique. Yet, when it was clear that territorial liberation would not be achieved by the UNIA, Namibians quickly changed their strategies and, instead, sought inclusion in the colonial decision-making process. The Herero used the UNIA and its international audience as a way to demand the restoration of social programs and herds that would improve their standard-of-living in the territory. The Herero viewed inclusion and a seat at the table as a more practical way to carve out a sphere of influence within the colonial superstructure.

This concern with winning subnational socioeconomic concessions continued after World War II and was a prominent feature of Namibians' transnational resistance strategies during the extension of apartheid to the territory in the 1940s and 1950s. Although the petition-writing

${ }^{15}$ R.S. Cope to J.F. Herbst, 21 December 1921, NAN: SWAA/A50/32. 
campaigns to the UN took on a more nationalistic nature in the 1960 s, during the 1950 s

Namibians used the UN and the international political pressure it wielded as a way to stop the forced land expropriations that became commonplace in the 1940s and 1950s. In the early 1950s, rather than focus on national liberation, Herero chief Hosea Kutako wrote to the UN on behalf of his followers to prevent the expropriation of valuable arable lands at Aminuis. The Reverend Markus Kooper undertook a similar campaign in 1959 when the SWAA attempted to remove the AME congregation at Hoachanas. The nature of the petitions submitted by Kooper and his followers explicitly asked for the UN to halt their removal from lands that were held by their ancestors for nearly two centuries. Unlike the UNIA's failure to dramatically impact socioeconomic change on the subnational level, the UN issued a series of resolutions that effectively halted the forced removals at Hoachanas and Aminuis and allowed Namibians to remain on comparatively more arable land than the SWAA intended. ${ }^{16}$

Although these two petition-writing campaigns were ethnically exclusive and demanded concessions that were localized at Aminuis and Hoachanas, their ultimate goal was inclusion in the colonial decision-making process and to have a larger influence and voice in their socioeconomic affairs. Kutako, for example, initially attempted to go through official government channels to explain to the SWAA why their resettlement scheme at Aminuis was flawed. Markus Kooper and the AME congregation at Hoachanas similarly navigated the state apparatus to apply for permits to construct a church and school at Hoachanas with state recognition. When they did finally petition the UN in the 1950 s, they still attempted to carve out their own spheres of influence within the colonial structure by demanding that the UN force the SWAA to consider their objections to the forced removals and follow established international

${ }^{16}$ General Assembly Resolution 1357(XIV), The Hoachanas Native Reserve: Resolution, A/RES/1357(XIV) (17 November 1959). 
legal precedents set forth by the transnational bodies. It was only after the SWAA refused to heed these demands that both men demanded national liberation in their petitions and sought exclusion from colonial rule and policies.

Lastly, the transnational resistance strategies of Namibians during this period also aimed to win concession from the colonial state on the matter of improved educational standards. Namibians turned to the AME Church and its extensive network of activist pastors across the globe to win subnational concession on this matter. The Nama benefitted substantially from the relationship that they cultivated with the AME Church agents from South Africa and used the church's good standing in the Union to construct churches and school buildings in central South West Africa. Through transnational agents like Francis H. Gow, the Nama worked through the AME Church and colonial state to raise the level of education in the Nama areas from Standard II to Standard VI. This provided Nama schoolchildren with a more advanced education and served as a mechanism through which the Nama directly resisted the colonial regime's systemic underdevelopment of the Namibian population.

The Nama's use of the AME Church, although mostly ethnically-exclusive, sought further inclusion in colonial life. Nama parents desired to have the same opportunities and educational standards that were compulsory and guaranteed to the territory's white populations. They viewed improved educational standards as a way to combat educational and economic underdevelopment. If Nama schoolchildren received improved standards of education, many believed that this would lead to better and more prestigious jobs, like clergymen, clerical workers, or schoolteachers, and improve the socioeconomic standing and standard-of-living for one's family or community. In a more long-term view, this would also provide a basis for a 
Namibian intelligentsia that could more aptly carve out spheres of subnational influence within the colonial structure and, at a later date, help lead the nationalist movement.

All of these transnational resistance strategies were developed with the express goal of achieving subnational concessions to improve the standard-of-living for Namibians in the Police Zone, carving out new spheres of influence for Namibians, and frustrating the colonial state's extension of South African apartheid policies. Some of these resistance strategies were ethnically-exclusive in nature. The Rehoboth Basters' petition-writing campaign is perhaps the best example of an exclusive transnational resistance strategy because it was only the Basters themselves who submitted petitions and made official subnational claims of political autonomy from the League of Nations. Other strategies, like Namibians' use of international student organizations and foreign universities in the 1950s, were more inclusive and involved Namibian students of various ethnic and class backgrounds. This more inclusive movement was led by Basters, Nama, and Herero alike.

Most of the transnational resistance strategies during this period, however, fell somewhere between completely ethnically inclusive or exclusive. The UNIA for example was embraced by both the Nama and Herero in the 1920s and was ethnically-inclusive in nature. However, by 1922 it was apparent that the Herero held the most power within the territory's association and exerted a significant amount of influence over the resistance strategies surrounding the UNIA. The AME Church's role in Namibians' resistance strategies followed a similar path. When it first emerged in South West Africa, the AME Church was an inclusive organization that served Nama and Herero congregants alike. Yet, when the Oruuano Church appeared and siphoned off Herero support from the AME Church, it became almost exclusively a Nama institution and served the Nama as a mechanism for resistance to the colonial state. A 
similarly blurred line between ethnically exclusive and inclusive also appeared in the UN petition-writing campaigns of the 1950s. Both the Nama and Herero participated in this form of resistance, but there was limited coordination between the two and each set of petitions sought to secure its own subnational concessions from the colonial state. ${ }^{17}$ Although there was no clear pattern on the inclusivity or exclusivity of Namibians' transnational resistance campaigns, they all shared a similar goal: secure subnational concessions from the colonial state to improve Namibians' standard of living in the Police Zone and alter the behavior of the oppressive colonial state.

While ethnic exclusivity was common to many of these transnational resistance strategies, most of the campaigns deployed by Namibians sought some form of inclusion in the colonial sphere or the colonial decision-making process. The Herero used the UNIA to demand concessions from the SWAA that brought them more fully into the colonial economy and provided them with access to land and herds that could improve their standard-of-living. The Nama undertook a similar quest with the establishment of AME schools in the Police Zone. They believed that the provision of compulsory and high-level education represented the best path toward greater inclusion in the colonial economy, improved occupational opportunities, and an increased standard-of-living. Similar arguments could be made about Kutako's and Kooper's petitions to the UN and their demands to halt forced land removals that would further weaken their voice in the colonial decision-making process and socio-economically marginalize their communities. Perhaps the only resistance strategy covered in this dissertation that was truly exclusionary in its subnational goals was the petition-writing campaign of the Rehoboth Basters. They demanded exclusion from oppressive colonial policies and the return of their complete

\footnotetext{
${ }^{17}$ See pages 300 through 324 of this dissertation for more on the UN petition-writing campaigns of Hosea Kutako
} and Markus Kooper. 
political autonomy in the Gebiet. The Nama made similar territorial demands through the Rehoboth branch of the UNIA and likewise sought exclusion from the colonial sphere.

\section{Conclusion}

Despite their variety of forms and manifestations, transnational resistance campaigns became the primary way of frustrating the colonial state in South West Africa prior to the emergence of the national political parties and the commencement of the armed liberation struggle in the 1960s. Rather than looking at these resistance campaigns as part of some longer linear trajectory toward nationalism, they should be viewed as characteristically distinct strategies that were developed for a particular colonial circumstance and, in most cases, obtaining some level of concessions within the colonial framework for the improvement of their standard-of-living. The South African colonial administration worked tirelessly to expand its segregationist policies and apartheid apparatus in South West Africa between 1921 and 1962 and attempted to actively monitor and control Namibians' movements and activities in the territory. Under the watchful eye of the state, Namibians developed effective resistance strategies that frustrated this state apparatus, slowed the extension of these detrimental policies, and carved out spaces of influence on the subnational level where subnational political and socioeconomic concessions were won.

The employment of transnational resistance strategies and the use of transnational actors and institutions to wage these campaigns was a calculated decision by Namibians that shielded them from the recursive power of the SWAA. Transnational actors could cross national boundaries more freely, escape the jurisdiction of the South African state, and bring more attention to the claims and complaints of Namibians stuck within the colony's borders. The 
power dynamics in these relationships were fluid, with transnational actors and Namibians both having different motivations for participating in these networks. However, both worked effectively together between 1921 and 1962 to leverage international pressure against the colonial state that ultimately tempered and altered its behavior toward Namibians in the territory. Through these campaigns, Namibians won numerous concessions including improved educational quality and standards, the halt of forced removals at Aminuis and Hoachanas, the slower implementation of apartheid policies, more tempered and less violent responses from the SWAA to perceived acts of resistance, and a few instances of local political autonomy. 


\section{Bibliography}

\section{Archival Materials}

\section{National Archives of Namibia, Windhoek, Namibia}

Archives of Anti-Colonial Resistance and the Liberation Struggle, AACRLS, 1884-1990.

Chief Bantu Affairs Commissioner Windhoek, BAC,1953-1979.

Magistrate Lüderitz, LLU, 1914-N/A.

Native Affairs Windhoek, NAW, 1919-1954.

Native Commissioner Ovamboland, NAO, 1919-1955.

South West Africa Administration: Education Branch, EDU, 1916-1972.

South West Africa Administration Records, SWAA, 1915-1990.

\section{League of Nations Archives, Geneva, Switzerland}

League of Nations Mandates Section, R10, 1919-1927

League of Nations Mandates Section, R11, 1919-1927

League of Nations Mandates Section, R2289, 1928-1932

League of Nations Mandates Section, R4091, 1933-1946

\section{Basler Afrika Bibliographien, Basel, Switzerland}

Research Archives of Theo Sundermeier, VI.2: Carl Hugo Hahn II: Letters and Curriculum Vitae of Carl Hugo Hahn to Heinrich Richter

Research Archives of Theo Sundermeier, VI.5: Breakaway Movements I: 1934-1968

\section{United Nations Archives, New York, United States}

United Nations Registry Section TR-240, Petitions Concerning South West Africa, 1955-1960

\section{Wilson Special Collections Library, University of North Carolina, Chapel Hill, United}

\section{$\underline{\text { States }}$}

The Allard K. Lowenstein Papers, 1924-1995: Sound Recordings, 1950-1982-Audiotape T04340/5-18. 


\section{Published Primary Sources}

\section{Government Publications}

\section{Government Gazettes}

SWAA. Official Gazette Extraordinary of South West Africa, No. 1899, 28 April 1955.

SWAA. Official Gazette of South West Africa, 2 October 1923.

\section{Government Reports}

Great Britain. Establishment of a German Protectorate at Angra Pequeña and Along the Neighboring Coast. Cmnd. 4265. London: HMSO, 1884.

Great Britain. Report on the Natives of South West Africa and Their Treatment by Germany. London: HMSO, 1918.

Republic of South Africa. Report of the Commission of Enquiry into South-West Africa Affairs, 1962-1963. Pretoria: Government Printer, 1964.

Union of South Africa. Report of the Administrator to the League of Nations. Cape Town: Government Printer, 1922.

\section{Statutes}

Union of South Africa. Statutes of the Union of South Africa. Cape Town: Government Printer, 1919.

Union of South Africa. Statutes of the Union of South Africa. Cape Town: Government Printer, 1950.

Union of South Africa, Statutes of the Union of South Africa. Cape Town: Government Printer, 1954.

\section{UN Documents and Reports}

Official Records of the General Assembly, Ninth Session, Annexes, Agenda Item 34, Document A/2666/Add.1, Annex III. 
United Nations. Charter of the United Nations. 24 October 1945. 1 UNTS XVI.

United Nations' General Assembly, Question of South West Africa: Request for Hearings, Ninth Session, Fourteenth Committee, Annexes, Agenda Item 38, 22 September 1959, (A/C.4/410).

\section{UN Resolutions and Advisory Opinions}

Admissibility of Hearings of Petitioners by the Committee on South West Africa: Advisory Opinion of 1 June 1956, ICJ Reports 1956.

United Nations General Assembly Advisory Opinion. Admissibility of Hearings of Petitioners by the Committee on South West Africa, A/RES/1047. 1 June 1956.

United Nations General Assembly Resolution 65/1. The Future Status of South West Africa, A/RES/65/1. 14 December 1946.

United Nations General Assembly Resolution 749. The Question of South West Africa, A/RES/749(VIII)A. 28 November 1953.

United Nations General Assembly Resolution 1357. The Hoachanas Native Reserve, A/RES/1357(XIV). 17 November 1959.

United Nations General Assembly Resolution 1358. Withdrawal of a Passport from Mr. Hans Johannes Beukes, A/RES/1358(XIV). 17 November 1959.

United Nations General Assembly Resolution 1359. Status of the Territory of South West Africa, A/RES/1359(XIV). 17 November 1959.

United Nations General Assembly Resolution 1360. Question of South West Africa, A/RES/1360(XIV). 17 November 1959.

\section{$\underline{\text { Books }}$}

Beukes, Hans. Long Road to Liberation: An Exiled Namibian Activist's Perspective. Johannesburg: Porcupine Press, 2014.

Cecil, Lord Robert. A Great Experiment: An Autobiography. London: Jonathan Cape, Ltd., 1941.

Garvey, Amy Jacques and E.U. Udom, eds. More Philosophy and Opinions of Marcus Garvey. New York: Routledge Press, 1993. 
Garvey, Marcus. The Philosophy and Opinions of Marcus Garvey: Africa for Africans, edited by Amy Jacques Garvey. New York: Routledge Press, 2013.

Gugelberger, G.M., ed. Nama/Namibia: Diary and Letters of Nama Chief Hendrik Witbooi, 1884-1894. Boston: African Studies Center, 1984.

Hill, Robert A., ed. The Marcus Garvey and Universal Negro Improvement Association Papers, Vol. I: 1826-August 1919. Berkeley: University of California Press, 1983.

. The Marcus Garvey and Universal Negro Improvement Association Papers, Vol. V: September 1922-August 1924. Berkeley: University of California Press, 1983.

. The Marcus Garvey and Universal Negro Improvement Association Papers, Vol. VII: November 1927-August 1940. Berkeley: University of California Press, 1983.

. The Marcus Garvey and Universal Negro Improvement Association Papers, Vol. X: Africa for Africans, 1923-1945. Berkeley: University of California Press, 1983.

Houser, George M. No One Can Stop the Rain: Glimpses of Africa's Liberation Struggle. Leiden: Pilgrim Press, 1989.

Huddleston, Trevor. Naught for Your Comfort. Glasgow: William Collins Sons and Co., 1956.

Hughes, Langston. The Collected Works of Langston Hughes: The Poems, 1921-1940. Edited by Arnold Rampersad. Columbia: University of Missouri Press, 2001.

Kadalie, Clements. My Life and the ICU: The Autobiography of a Black trade Unionist in South Africa. London: Cass, 1970.

La Guma, Alex. A Soviet Journey: A Critical Annotated Edition. Lanham: Lexington Books, 2017.

Lau, Brigitte. The Hendrik Witbooi Papers. Translated by Eben Maasdorp and Annemarie Heywood. Windhoek: National Archives of Namibia, 1996.

Leutwein, Theodor. Elf Jahre Gouverneur in Deutsch-Sudwestafrika. Hamburg: E.S. Mittler und Sohn, 1906.

Locke, Alain. The New Negro. New York: Simon and Schuster, 2014.

Lowenstein, Allard. Brutal Mandate: A Journey to South West Africa. New York: Macmillan, 1962.

Nujoma, Sam. Where Others Wavered: My Life in SWAPO and my Participation in the Liberation Struggle for Namibia. Bedford: PANAF Books, 2001. 
Ottley, Roi. A New World A-Coming: Inside Black America. Cleveland: World Publishing, 1943.

Palgrave, William Coates. The Commissions of W.C. Palgrave: Special Emiisary to South West Africa, 1876-1885. Cape Town: Van Riebeeck Society, 1991.

Schlosser, Katesa. Eingeborenenkirchen in Sud- und Sudwestafrika: Ihre Geschicte und Sozialstruktur. Berlin: Walter de Gruyter, 1958.

Scott, Michael. A Search for Peace and Justice. Edited by Alexander Paul Hare. London: Rex Collings, 1980.

. A Time to Speak. New York: Doubleday, 1958.

Smuts, Jan. The League of Nations: A Practical Suggestion. London: Hodder and Stoughton, 1918.

Stevenson, Adlai. Call to Greatness. Cambridge: Atheneum, 1966.

Van der Poel, Jean and W.K. Hancock, eds. Selections from Smuts Papers: Volume VII, August 1945-October 1950. Cambridge: Cambridge University Press, 2007.

Vedder, Heinrich. South West Africa in Early Times: Being the Story of South West Africa Up to the Date of Maharero's Death in 1890. London: CASS Publishing, 1966.

Washington, Booker T. Up From Slavery: An Autobiography. New York: Doubleday, 1907.

\section{$\underline{\text { Book Chapters }}$}

Royal Institute of International Affairs, eds. "Declaration of St. James Place." In United Nations Documents, 1941-1945. New York: Royal Institute of International Affairs, 1947.

. "Declaration of the United Nations." In United Nations Documents, 1941-1945. New

York: Royal Institute of International Affairs, 1947.

. "Declaration of the Four Nations on General Security." In United Nations Documents, 1941-1945. New York: Royal Institute of International Affairs, 1947. 


\section{Unpublished Secondary Sources}

\section{Dissertations and Theses}

McCullers, Molly. "Lines in the Sand: The Global Politics of Local Development in ApartheidEra Namibia, 1950-1980.” PhD diss., Emory University, 2012.

Mkhize, Khwezi. "Empire Unbound: Imperial Citizenship, Race and Diaspora in the Making of South Africa.” PhD diss., University of Pennsylvania, 2015.

Ngwane, Zolane. "The Politics of Campus and Community in South Africa: An Historical Historiography of the University of Fort Hare, Volume I.” PhD diss., University of Chicago, 2001.

Tjibeba, Hendrik Rudolf. "The History of the Rhenish Mission Society in Namibia with Particular Reference to the African Methodist Episcopal Schism, 1946-1990." PhD Diss., Paulinum Theological Seminary, 2003.

White, William Barry. "The South African Parliamentary Opposition, 1948-1953." PhD diss., University of Natal, 1989.

Willis, Ivan Raymond. “The History of Bantu Education: 1948-1994.” Master's Thesis, Australian Catholic University, 2011.

Works, Brendan D. "Popular Opposition to Apartheid, 1959-1990." PhD diss., University of California Berkeley, 1998.

\section{Presented Papers and Working Papers}

Fridjon, Michael. "The Torch Commando and the Politics of White Opposition: South Africa, 1951-1953." Paper Presented at the University of Witwatersrand African Studies Institute, Johannesburg. March, 1976.

Nattrass, Nicoli and Jeremy Seekings. "The Economy and Poverty in the Twentieth Century in South Africa." CSSR Working Paper No. 276, Centre for Social Science Research: Social Surveys Unit. Cape Town: South Africa, 2010.

Omar, Gasan, et al. "An Introduction to Namibia's Political Economy." SALDRU Working Paper. Cape Town: Southern Africa Labour and Development Research Unit, 1990.

Pirio, Gregory. "The Role of Garveyism in the Making of the Southern African Working Classes and Namibian Nationalism." Paper presented to the Joint Committee on African Studies Conference on South Africa in the Comparative Study of Class, Race, and Nationalism. New York, 1982. 


\section{Published Secondary Sources}

\section{$\underline{\text { Books }}$}

Abwunza, Judith Mae. Women's Voices, Women's Power: Dialogues of Resistance from East Africa. Ontario: Broadview Press, 2008.

Achebe, Nwando. The Female King of Colonial Nigeria. Bloomington: Indiana University Press, 2011.

Akwa, Martha. The Gender Politics of the Namibian Liberation Struggle. Basel: Basler Afrika Bibliographien, 2014.

Anderson, Benedict. Imagined Communities: Reflections on the Origins and Spread of Nationalism. New York: Verso Books, 1991.

Anderson, Carol. Bourgeois Radicals. London: Cambridge University Press, 2015.

Ansell, Gwen. Soweto Blues: Jazz, Popular Music, and Politics in South Africa. New York: Bloomsbury Academic, 2005.

Babb-Bracey, Ingrid Patricia. The Development of Educational Policy for Black Africans in South Africa, 1652-1948. Amherst: University of Massachusetts Press, 1984.

Balia, Daryl M. Black Methodists and White Supremacy in South Africa. Durban: Madiba Publications, 1991.

Barbeau, Jeffrey W. The Spirit of Methodism: From the Wesleys to a Global Communion. Westmont: Inter Varsity Press, 2019.

Barnard, Alan. Hunters and Herders of Southern Africa: A Comparative Ethnography of the Khoisan Peoples. Cambridge: Cambridge University Press, 1992.

Bayer, Maximillian and Peter Carstens. The Rehoboth Baster Nation of Namibia. Basel: Basler Afrika Bibliographien, 1984.

Beet, George Louis. African Questions at the Paris Peace Conference: With Papers on Egypt, Mesopotamia, and the Colonial Settlement. New York: Macmillan Publishing, 1923.

Beinart, William and Colin Bundy. Hidden Struggles in Rural South Africa: Politics and Popular Movements in the Transkei and Eastern Cape, 1890-1930. Berkeley: University of California Press, 1987.

Bendix, Sonia. Industrial Relations in South Africa. Cape Town: Juta and Company Publishing, 1989. 
Berger, Iris. South Africa in World History. London: Oxford University Press, 2009.

Blaisdell, Bob, ed. Selected Writings and Speeches of Marcus Garvey. North Chelmsford: Courier Corporations, 2012.

Bley, Helmut. Namibia Under German Rule. Munster: LIT Verlage Munster, 1996.

Bridgers, Lynn. The American Religious Experience: A Concise History. Lanham: Rowman \& Littlefield Publishers, 2006.

Britz, Rudolf G., et al. A Concise History of the Rehoboth Basters Until 1990. Windhoek: Klaus Hess Publishers, 1999.

Brown, Julian. The Road to Soweto. Suffolk: Boydell and Brewer Publishers, 2016.

Buys, G.L. and S.V.V. Nambala. A History of the Church in Namibia, 1805-1990. Windhoek: Gamsberg Macmillan, 2003.

Bynum, Cornelius L. Philip Randolph and the Struggle for Civil Rights. Champaign: University of Illinois Press, 2010.

Campbell, James T. Songs of Zion: The African Methodist Episcopal Church in the United States and South Africa. London: Oxford University Press, 1995.

Case, Jay Riley. An Unpredictable Gospel: American Evangelicals and World Christianity, 1812-1920. London: Oxford University Press, 2012.

Chafe, William H. Never Stop Running: Allard Lowenstein and the Struggle to Save American Liberalism. New York: Basic Books, 1993.

Chapman, Rico Devara. Student Resistance to Apartheid at the University of Fort Hare. Lanham: Lexington Books, 2016.

Chisholm, Linda. Teacher Preparation in South Africa: History, Policy, and Future Decisions. Bradford: Emerald Publishing Group, 2019.

Collins, Kenneth J. The Scripture Way of Salvation: The Heart of John Wesley's Theology. Nashville: Abingdon Press, 2010.

Comaroff, Jean. Body of Power, Spirit of Resistance: The Culture and History of a South African People. Chicago: University of Chicago Press, 1985.

Comaroff, Jean and John Comaroff. Of Revelation and Revolution, Volume I: Christianity, Colonialism, and Consciousness in South Africa. Chicago: University of Chicago Press, 1991. 
. Of Revelation and Revolution, Volume II: Dialectics of Modernity on a South African Frontier. Chicago: University of Chicago Press, 1997.

Cone, James H. The Spirituals and the Blues: An Interpretation. Ossining: Orbis Books, 1992.

Conforti, Joseph A. Samuel Hopkins and the New Divinity Movement: Calvinism and Reform in New England Between the Great Awakenings. Eugene: Wipf and Stock Publishers, 2008.

Cooper, Frederick. Africa Since 1940: The Past of the Present. Cambridge: Cambridge University Press, 2002.

Cronon, E. David. Black Moses: The Story of Marcus Garvey and the Universal Negro Improvement Association. Madison: University of Wisconsin Press, 1960.

Crummey, Donald. Banditry, Rebellion, and Social Protest in Africa. Suffolk: James Currey, 1986.

Cummings, Richard. The Pied Piper: Allard K. Lowenstein and the Liberal Dream. New York: Grove Press, 1985.

Dahl, J. The Indigenous Space and Marginalized Peoples in the United Nations. New York: Springer, 2012.

Dale, Richard. The Namibian War of Independence: Diplomatic, Economic, and Military Campaigns. Jefferson: MacFarland, 2014.

Davenport, T. and C. Saunders. South Africa: A Modern History. New York: Springer, 2000.

Davey, A.M. The Bondelzwarts Affair: A Study of the Repercussions. Pretoria: University of South Africa Press, 1967.

De Vinne, Daniel. The Methodist Episcopal Church and Slavery: A Historical Survey of the Relation of the Early Methodists to Slavery. London: Francis Hart, 1857.

Demissie, Fassil. Colonial Architecture and Urbanism in Africa: Intertwined and Contested Histories. New York: Taylor and Francis, 2016.

Dierks, Klaus. Chronology of Namibian History: From Pre-Historic Times to Independence. Windhoek: Namibia Scientific Society, 1999.

Dobell, Lauren. SWAPO's Struggle for Namibia, 1960-1991: War by Other Means. Basel: P. Schlettwein Publishing, 1998.

Dold, Gilbert William Frederick and Christian Petrus Joubert. The Union of South Africa; The Development of Its Laws and Constitution. Astoria: Stevens, 1955. 
Drechsler, Horst. Let Us Die Fighting: The Struggle of the Herero and Nama Against German Imperialism (1884-1915). London: Zed Press, 1980.

Dreyer, Ronald. Namibia and Southern Africa: Regional Dynamics of Decolonization, 19451990. New York: Routledge Press, 2016.

Du Bois, W.E.B. Black Folk Then and Now: An Essay in the History and Sociology of the Negro Race, edited by Henry Louis Gates, Jr. New York: Oxford University Press, 2014. . The Souls of Black Folks. Mineola: Dover Publications, 2012.

Du Pisani, Andre. SWA/Namibia: The Politics of Continuity and Change. Johannesburg: J. Ball Publishers, 1985.

Dubow, Samuel. Apartheid, 1948-1994. London: Oxford University Press, 2014.

Duffy, Joanne L. The Politics of Ethnic Nationalism: Afrikaner Unity, the National Party, and the Radical Right in Stellenbosch, 1934-1948. New York: Routledge, 2006.

Dugard, John. Confronting Apartheid: A Personal History of South Africa, Namibia, and Palestine. Johannesburg: Jacana Media, 2018.

Edgar, Robert R. Because They Chose the Plan of God: The Story of the Bulhoek Massacre of 24 May 1921.

Elphick, Richard. The Equality of Believers: Protestant Missionaries and the Racial Politics of South Africa. Charlottesville: University of Virginia Press, 2012.

Emmett, Tony. Popular Resistance and the Roots of Nationalism in Namibia, 1915-1966. Basel: P. Schlettwein Publishing, 1999.

Erichsen, Casper W. What the Elders Used to Say: Namibian Perspectives on the Last Decade of German Colonial Rule. Windhoek: Namibian Institute for Democracy, 2008.

Evans, Ivan. Bureaucracy and Race: Administration in South Africa. Berkeley: University of California Press, 1997.

Ewing, Adam. The Age of Garvey: How a Jamaican Activist Created a Mass Movement and Changed Global Black Politics. Princeton: Princeton University Press, 2014.

Fairclough, Adam. Better Day Coming: Blacks and Equality, 1890-2000. London: Penguin Books, 2002.

Farwell, Byron. The Great War in Africa, 1914-1919. New York: W.W. Norton \& Company, 1989. 
Field, Roger. Alex la Guma: A Literary \& Political Biography. New York: Boydell and Brewer, Ltd., 2010.

Frederickson, George M. White Supremacy: A Comparative Study of American and South African History. London: Oxford University Press, 1982.

Gerhart, Gail M. Black Power in South Africa: The Evolution of an Ideology. Berkeley: University of California Press, 1979.

Gewald, Jan-Bart. Herero Heroes: A Socio-political History of the Herero of Namibia, 18901923. Athens: Ohio University Press, 1999.

. "We Thought We Would Be Free...:." Socio-Cultural Aspects of Herero History in Namibia, 1915-1940. Koln: Rüdiger Köppe, 2000.

Gilory, Paul. The Black Atlantic: Modernity and Double Consciousness. New York: Verso Books, 1993.

Glassman, Jonathon. Feasts and Riot: Revelry, Rebellion, and Popular Consciousness on the Swahili Coast, 1856-1888. Portsmouth: Heinemann, 1995.

Gleijeses, Pierro. Visions of Freedom: Havana, Washington, Pretoria, and the Struggle for Southern Africa, 1976-1991. Chapel Hill: University of North Carolina Press, 2013.

Goen, C.C. Broken Churches, Broken Nation: Denominational Schisms and the Coming of the American Civil War. Macon: Mercer University Press, 1985.

Gregory, James N. The Southern Diaspora: How the Great Migrations of Black and White Southerners Transformed America. Chapel Hill: University of North Carolina Press, 2006.

Haber, Stephen. Political Institutions and Economic Growth in Latin America: Essays in Policy, History and Political Economy. Palo Alto: Hoover, Press, 2000.

Hancock, W.K. Smuts: The Fields of Force, 1919-1950, Vol. II. Cambridge: Cambridge University Press, 1968.

Helhig, Ludwig and Werner Hillebrecht. The Witbooi. London: CASS Publishers, 1992.

Henderson, W.O. Studies in German Colonial History. London: Frank Cass, 1976.

Hilderbrand, Robert C. Dumbarton Oaks: The Origins of the United Nations and the Search for Postwar Security. Chapel Hill: University of North Carolina Press, 2001. 
Hinz, Manfred O. Customary Law Ascertained Volume 3: The Customary law of the Nama, Ovaherero, Ovambanderu, and San Communities of Namibia. Windhoek: University of Namibia Press, 2016.

Hodgkin, Thomas. Nationalism in Colonial Africa. New York: New York University Press, 1957.

Horrell, Muriel. South-West Africa. Johannesburg: South Africa Institute of Race Relations, 1967.

Houle, Robert J. Making African Christianity: Africans Reimagining Their Faith in Colonial South Africa. Bethlehem: Lehigh University Press, 2011.

Hurston, Zora Neale. Their Eyes Were Watching God: A Novel. New York: Harper Collins, 2010.

Hyam, Ronald. The Failure of South African Expansion, 1908-1948. New York: Palgrave Macmillan, 1972.

Hyam, Ronald and Peter Henshaw. The Lion and the Springbok: Britain and South Africa Since the Boer War. New York: Cambridge University Press, 2003.

Ilcan, Suzan and Anita Lacey. Governing the Poor: Exercises of Poverty Reduction, Practices of Global Aid. Montreal: McGill-Queen's Press, 2011.

International Defense and Aid Fund, Apartheid's Army in Namibia: South Africa's Illegal Military Occupation. London: International Defense and Aid Fund, 1982.

International Peace Research Association. The Future of the United Nations System: Potential for the Twenty-First Century. Tokyo: United Nations University Press, 1998.

Iriye, Akira. Global and Transnational History: The Past, Present and Future. London: Palgrave Macmillan, 2013.

Jacobsen, Lisebeth Rosen. "The Eurasian Question:” The Colonial Position and Postcolonial Options of Colonial Mixed Ancestry Groups from British India, Dutch East Indies and French Indochina Compared. Hilversum: Uitgeverii Verloren, 2018.

Jones, H.S. and Andre Muller. The South African Economy, 1910-90. London: Palgrave Macmillan, 2016.

Kaela, Laurent C.W. The Question of Namibia. New York: Springer, 2016.

Kandovazu, Ehrenfried. The Origin and History of the Oruuano Church in Namibia. Windhoek: Klaus Hess Publishers, 2009. 
Karis, Thomas, et al., From Protest to Challenge: Hope and Challenge, 1935-1952. Palo Alto: Hoover Institution Press, 1972.

Katjavivi, Peter. A History of Resistance in Namibia. Trenton: Africa World Press, 1990.

Katjavivi, Peter, Kair Mbuende, and Per Frostin, eds. Church and Liberation in Namibia. London: Pluto Press, 2008.

Kilson, Martin. Political Change in a West African State: A Study in Modernization Process in Sierra Leone. Cambridge University Press, 1966.

Kipling, Rudyard. The Elephant's Child. Binghamton: Platt and Munk, 1988.

Kirsop, Joseph. Life of Robert Moss Ormerod, Missionary to East Africa. London: Andrew Crombie, 1901.

Kossler, Reinhart. Namibia and Germany: Negotiating the Past. Windhoek: University of Namibia Press, 2015.

Landau, Paul S. Popular Politics in the History of South Africa, 1400-1948. Cambridge: Cambridge University Press, 2010.

Le Roux, Elizabeth. A Social History of the University Presses in Apartheid South Africa. Leiden: Brill Press, 2015.

Legassick, Martin. Hidden Histories of Gordonia: Land Dispossession and Resistance in the Northern Cape, 1800-1990. Johannesburg: Wits University Press, 2016.

Legum, Colin. Africa: A Handbook to the Continent. Santa Barbara: Praeger, 1966.

Livingstone, J. Kevin. A Missiology of the Road: Perspectives in David Bosch's Theology of Mission and Evangelism. Cambridge: James Clarke \& Co., Ltd., 2013.

Lodge, Tom. Resistance and Ideology in Settler Societies. Johannesburg: Ravan Press, 1986.

Lorca, Arnulf Becker. International Law. Cambridge: Cambridge University Press, 2014.

Louw-Potgieter, Joha. Afrikaner Dissidents: A Social Psychological Study of Identity and Dissent. Cleverdon: Multilingual Matters, 1988.

Lovedale, Ian. By Due Process of Law: Racial Discrimination and the Right to Vote in South Africa, 1855-1960. London: Bloomsbury Publishing, 1999.

Macshane, Denis, Martin Plaut, and David Ward. Power!: Black Workers, Their Unions and the Struggle for Freedom in South Africa. Boston: South End Press, 1984. 
Mann, Gregory. Native Sons: West African Veterans and France in the Twentieth Century. Durham: Duke University Press, 2006.

Martin, Meredith. In the Name of Apartheid: South Africa in the Postwar Period. London: Penguin Books, 1988.

Martin, Tony. The Pan-African Connection: From Slavery to Garvey and Beyond. Fitchburg: The Majority Press, 1984.

Mauno Mbamba, A. A Diagnostic Analysis of the Education System in Namibia. Paris: UNESCO International Institute for Educational Planning, 2011.

McCarthy, Dennis M.P. International Business History: A Contextual and Case Approach. Westport: Greenwood Publishing Group, 1994.

McKay, Claude. Harlem Shadows: The Poems of Claude McKay. Harlem: Harcourt, 1922.

Meriwether, James H. Proudly We Can Be Africans: Black Americans and Africa, 1935-1961. Chapel Hill: University of North Carolina Press, 2002.

Michelman, Cherry. The Black Sash of South Africa: A Case Study in Liberalism. Oxford: Oxford University Press, 1975.

Miescher, Giorgio. Namibia's Red Line: The History of a Veterinary and Settlement Border. New York: Palgrave Macmillan, 2012.

Millin, Gertrude. General Smuts, Volume II. London: Simon Publications, 1936.

Minahan, James. Encyclopedia of Stateless Nations: Ethnic and National Groups Around the World A-Z. Santa Barbara: ABC-CLIO, 2002.

Minter, William. King Solomon's Mines Revisited: Western Interests and the Burdened History of Southern Africa. New York: Basic Books, Inc., 1988.

Moodie, T. Dunbar. The Rise of Afrikanerdom: Power, Apartheid and the Afrikaner Civil Religion. Berkeley: University of California Press, 1975.

Müller, Johann Alexander. "The Inevitable Pipeline Into Exile:” Botswana's Role in Namibia's Liberation Struggle Oxford: African Books Collective, 2012.

Mutiso, Gideon-Cyrus Makau and S.W. Rohio. Readings in African Political Thought. Portsmouth: Heinemann, 1975.

N'dumbe, A. Kum'a. Relations Between Nazi Germany and South Africa. New York: United Nations Centre Against Apartheid, 1976. 
Newman, Richard S. Freedom's Prophet: Bishop Richard Allen, the AME Church, and the Black Founding Fathers. New York: New York University Press, 2009.

Ngavirue, Zedekia. Political Parties and Interest Groups in South West Africa (Namibia): A Study of a Plural Society. Basel: P. Schlettwein Publishing, 1997.

Norval, Aletta J. Deconstructing Apartheid Discourse. New York: Verso, 1996.

Nwaubani, Ebere. The United States and Decolonization in West Africa, 1950-1960. Rochester: University of Rochester Press, 2001.

Oermann, Nils Ole. Mission, Church and State Relations in South West Africa Under German Rule, 1884-1915. Stuttgart: Franz Steiner Verlag, 1999.

Olusoga, David and Casper W. Erichsen. The Kaiser's Holocaust: Germany's Forgotten Genocide and the Colonail Roots of Nazism. London: Faber and Faber, 2011.

O'Meara, Dan. Volkskapitalisme: Class, Capital and Ideology in the Development of Afrikaner Nationalism, 1934-1948. Cambridge: Cambridge University Press, 2009.

Pedersen, Susan. The Guardians; The League of Nations and the Crisis of Empire. London: Oxford University Press, 2015.

Peeks, Edward. The Long Struggle for Black Power. New York: Scribner, 1971.

Pickney, Alphonso. Red Black and Green: Black Nationalism in the United States. Cambridge: Cambridge University Press, 1976.

Plummer, Brenda Gayle. In Search of Power: African Americans in the Era of Decolonization, 1956-1957. Cambridge: Cambridge University Press, 2013.

Pool, Gerhardus. Samuel Maharero. Windhoek: Gamsberg Macmillan, 1991.

Press, Steven. Rogue Empires. Cambridge: Harvard University Press, 2017.

Putner, Karl. The Strange Partnership of George Alexander McGuire and Marcus Garvey. Rockville: Wildside Press, LLC, 1986.

Rabaka, Reiland. The Negritude Movement: W.E.B. Du Bois, Leon Damas, Aime Cesaire, Leopold Senghor, Frantz Fanon, and the Evolution of an Insurgent Idea. Lanham: Lexington Books, 2015.

Raboteau, Albert J. A Fire in the Bones: Reflections on African-American Religious History. Boston: Beacon Press, 1995.

Resch, Margit, trans. The Church in the Industrial Age. London: Burns and Oates, 1981. 
Reynolds, Glenn. Colonial Cinema in Africa: Origins, Images, Audiences. Jefferson: MacFarland Books, 2015.

Roberts, Michael and A.E.G. Trollip. The South African Opposition, 1939-45. London: Longman's, Green and Co., 1947.

Rotberg, Robert I. Suffer the Future: Policy Choices in Southern Africa. Cambridge: Harvard University Press, 1980.

Sarkin-Hughes, Jeremy. Germany's Genocide of the Herero: Kasier Wilhelm II, His General, His Settlers, His Soldiers. Cape Town: University of Cape Town Press, 2011.

Saunier, Pierre-Yves. Transnational History: Theory and History. London: Palgrave Macmillan, 2013.

Schnee, Heinrich. The German Colonies Under the Mandates. Berlin: W. Bronner Nowawes, 1922.

Schumann, C.G.W. The World Depression, South Africa, and the Gold Standard. Johannesburg: Juta and Company, 1932.

Schuttle, Gerhard. What Racists Believe: Race Relations in South Africa and the United States. Thousand Oaks: Sage Publications, 1995.

Scott, James C. Weapons of the Weak: Everyday Forms of Peasant Resistance. London: Yale University Press, 1985.

Serafin, Anne, et al. African Women Writing Resistance: An Anthology of Contemporary Voices. Madison: University of Wisconsin Press, 2010.

Sharp, Alan. The Versailles Settlement: Peacemaking in Paris, 1919. New York: Macmillan Publishing, 1991.

Seethal, Cecil, Gustave Visser and Ronnie Donaldson. The Origin and Growth of Geography as a Discipline at South Africa Universities. Cape Town: African Sun Press, 2016.

Serfontein, J.H.P. Namibia? Randburg: Fokus Suid Publishers, 1976.

Shepperson, George and Thomas Price. Independent African: John Chilembwe and the Origins, Setting, and Significance of the Nyasaland Native Rising of 1915. Edinburgh: Edinburgh University Press, 1958.

Shillington, Kevin. Encyclopedia of African History. New York: Routledge, 2013. 
Shoko, Tabona. Karenga Indigenous Religion in Zimbabwe: Health and Well-Being. Oxford: Taylor and Francis, 2016.

Silvester, Jeremy. Re-Viewing Resistance in Namibian History. Windhoek: University of Namibia Press, 2015.

Sithole, Ndabaningi. African Nationalism. London: Oxford University Press, 1968.

Smith, David M. The Apartheid City and Beyond: Urbanization and Social Change in South Africa. New York: Routledge, 2003.

Smith, Richard. Jamaican Volunteers in the First World War: Race, Masculinity and the Development of National Consciousness. Manchester: Manchester University Press, 2004.

Soggot, David. Namibia: The Violent Heritage. London: Rex Collings, Ltd., 1986.

Stein, Judith. The World of Marcus Garvey: Race and Class in Modern Society. Shreveport: Louisiana State University Press, 1991.

Steinmetz, George. The Devil's Handwriting: Precoloniality and the German Colonial State in Qingdao, Samoa, and Southwest Africa. Chicago: University of Chicago Press, 2008.

Stone, David. The Kaiser's Army: The German Army in World War One. London: Conway, 2014.

Stultz, Newell Maynard. Afrikaner Politics in South Africa, 1934-1948. Berkeley: University of California Press, 1974.

Sundermeier, Theo. Wir aber suchten Gemeinschaft, Kirchenwerdung und Kirchentrennung in Sudwestafrika. Franconia: Erlangen, 1973.

Switzer, Les. Power and Resistance in an African Society: The Ciskei Xhosa and the Making of South Africa. Madison: University of Wisconsin Press, 1994.

Tonchi, Victor L., et al. Historical Dictionary of Namibia. Lanham: Scarecrow Press, 2012.

Tonchi, Victor L. and Albertina N. Shifotoka. Parties and Political Development in Namibia. Johannesburg, Electoral Institute for Sustainable Democracy in Africa, 2005.

Tucker, Spencer C., ed. World War I: The Definitive Encyclopedia and Document Collection. Santa Barbara: ABC-CLIO, 2014.

Udogu, E. Ike. Liberating Namibia: The Long Diplomatic Struggle Between the United Nations and South Africa. Jefferson: MacFarland, 2011. 
Vail, Leroy. The Creation of Tribalism in Southern Africa. Berkeley: University of California Press, 1991.

Vandenbosch, Amy. South Africa and the World: The Foreign Policy of Apartheid. Lexington: University of Kentucky, Press, 1970.

Vinson, Robert. The Americans are Coming!: Dreams of African American Liberation in Segregationist South Africa. Athens: Ohio University Press, 2012.

Wallace, Marion. A History of Namibia: From the Beginning to 1990. New York: Oxford University Press, 2013.

Walther, Daniel Joseph. Creating Germans Abroad: Cultural Policies and National Identity in Namibia. Athens: Ohio University Press, 2002.

Wellington, John H. South West Africa and Its Human Issues. London: Clarendon Press, 1967.

Werner, Wolfgang. "No One Will Become Rich": Economy and Society in the Herero Reserves in Namibia, 1915-1946. Basel: P. Schlettwein Publishing, 1998.

Whiteside, J. History of the Wesleyan Methodist Church of South Africa. Eugene: Stock Publishers, 1906.

Williams, Chad. Torchbearers of Democracy: African American Soldiers in the World War I Era. Chapel Hill: University of North Carolina Press, 2010.

Williams, Gwyneth and Brian Hackland. The Dictionary of Contemporary Politics of Southern Africa. Milton Park: Routledge, 2015.

Williamson, Sue. Resistance Art in South Africa. Lansdowne: Double Storey Books, 2010.

Wintz, Cary D. African American Political Though, 1890-1930: Washington, Du Bois, Garvey, and Randolph. New York: Routledge, 2015.

Zandberg, Jeron. Rehoboth Griqua Atlas. Morrisville: Lulu Publishers, 2013. 


\section{$\underline{\text { Book Chapters }}$}

Allman, Jean. "Between the Present and History: African Nationalism and Decolonization." In The Oxford Handbook of Modern African History, edited by John Parker and Richard Reid, 224-239. London: Oxford University Press, 2013.

Beeby, James M. "Universal Negro Improvement Association." In Race and Racism in the United States: An Encyclopedia of the American Mosaic, edited by Cameron D. Lippard and Charles A. Gallagher, 1277-1279. Santa Barbara: ABC-CLIO, 2014.

Blair, Barbara. "True Women, Real Men: Gender, Ideology, and Social Roles in the Garvey Movement." In Gendered Domains: Rethinking Public and Private Women's HistoryEssays from the Seventh Berkshire Conference on the History of Women, edited by Dorothy O. Helly and Susan M. Reverby, 154-166. Ithaca: Cornell University Press, 1992.

Boden, Gertrud. "Mapping Culture, Representing Boundaries and Politicizing Difference: Reflection on two San Cases in Namibia." In Atlas of Cultural and Evironmental Change in Arid Africa, edited by Olaf Bubenzer, et al., 112-115. Koln: Heinrich-Barth-Institut, 2007.

Bunting, Ian. "The Higher Education Landscape Under Apartheid." In Transformation in Higher Education: Global Pressures and Local Realities, edited by N. Cloete, et al., 35-52. New York: Springer, 2006.

Clark, Nancy L. "South Africa: Industry, Labor, Urbanization, 1940-1946." In Encyclopedia of African History, Vol. I, edited by Kevin Shillington. Oxfordshire: Taylor and Francis, 2013.

Cottrell, M. Patrick. "Lost in Transition? The League of Nations and the United Nations." In Charter of the United Nations: Together with Scholarly Commentaries and Essential Historical Documents, edited by Ian Shapiro and Joseph Lampert, 91-106. New Haven: Yale University Press, 2004.

De Waal, John. "Constitutional Law," In Introduction to the Law of South Africa, edited by C.G. Van der Merwe and J.E. Du Plessis, 55-106. Alphen aan den Rijn: Kluwer Law International, 2004.

Emmett, Tony. "Popular Resistance in Namibia, 1920-1925." In Resistance and Ideology in Settler Societies, edited by Tom Lodge, 6-48. Johannesburg: Ravan Press, 1986. 
Eriksen, Tore Linné. “The Origins of a Special Relationship: Norway and Southern Africa, 19601975." In Norway and National Liberation in Southern Africa, edited by Tore Linné Eriksen, 9-87. Uppsala: Nordic Africa Institute, 2000.

Gairiseb, Alexander "Swartbooi Traditional Authority in \|Khau-Igôan: !Haos łGaełguis." In Customary Law Ascertained, Volume 3: The Customary Law of the Nama, Ovaherero, Ovambanderu, and San Communities of Namibia, edited by Manfred O. Hinz, 157-194. Windhoek: University of Namibia Press, 2016.

Gewald, Jan-Bart. "Coming Through the Slaughter: The Herero of Namibia, 1904-1940." In The Practice of War: Production, Reproduction and Communication of Armed Violence, edited by Aparna Rao, Michael Bollig, and Monika Bock, 89-110. Oxford: Berghahn Books, 2007.

Giliomee, Hermann. "The Beginnings of Afrikaner Ethnic Consciousness, 1850-1915." In The Creation of Tribalism in Southern Africa, edited by Leroy Vail, 21-54. London: James Currey, 1989.

Gordon, Robert J. "Fido: Dog Tales of Colonialism in Namibia." In Social History \& African Environments, edited by William Beinart and Joann McGregor, 240-254. Oxford: James Currey Publishers, 2003.

. "Unsettled Settlers: Internal Pacification and Vagrancy in Namibia." In Ethnography in Unstable Places: Everyday Lives in Contexts of Dramatic Political Change, edited by Elizabeth Mertz, et al., 61-84. Durham: Duke University Press, 2002.

Henrichsen, Dag. “Establishing a Precolonial 'Modern' Cattle-and-Gun Society: (Re)Pastoralization, Mercantile Capitalism and Power Amongst Herero in NineteenthCentury Central Namibia." In Pastoralism in Africa: Past, Present and Future, edited by Michael Bollig, Michael Schnegg, and Hans-Peter Wotzka, 201-229. New York: Berghahn Books, 2013.

Hill, Robert A. and Gregory Pirio. "Africa for the Africans: the Garvey Movement in South Africa, 1920-1940." In The Politics of Race, Class, and Nationalism in TwentiethCentury South Africa, edited by Shula Marks and Stanley Trapido, 209-253. New York: Routledge, 2014.

Kruger, Gesine and Dag Henrichsen. "'We Have Been Captives Long Enough. We Want to be Free:' Land, Uniforms, and Politics in the History of the Herero in the Interwar Period." In Namibia Under South African Rule: Mobility and Containment, edited by Patricia Hayes, Jeremy Silvester, Marion Wallace, and Wolfram Hartmann, 149-174. Athens: Ohio University Press, 1998.

Magyar, Karl P. "The Campaign in South West Africa." In The European Powers in the First World War: An Encyclopedia, edited by Spencer C. Tucker, 654. Oxford: Taylor and Francis, 2013. 
McCullers, Molly. "The 'Truppenspieler Show': Herero Masculinity and German Colonial Military Aesthetic.” In German Colonialism Revisited: African, Asian, and Oceanic Experiences, edited by Nina Berman, et al., 226-242. Ann Arbor: University of Michigan Press, 2018.

Miguda, Edith A. "Encountering History: Christianity and Identity in Nigerian Diaspora Churches." In Religion, History, and Politics in Nigeria: Essays in Honor of Ogbu U. Kalu, edited by Chima Jacob Korieh and G. Ugo Nwokeji, 216-229. Lanham: University Press of America, 2005.

Muchie, Mammo and Hailemichael Demissie. "Re-discovering and Re-vitalizing the Neglected Roots of Pan-Africanism: Ethiopianism for African Renaissance and Unity." In United or Perish: Africa Fifty Years After the Founding of the OAU, edited by Mammo Muchie, et al., 26-45. Pretoria: Africa Institute for South Africa, 2015.

Oliver, Paul. "Jubilee Singers." In Continuum Encyclopedia of Popular Music in the World, Volume II: Performance and Production, edited by John Shepherd, et al., 34-36. London: A\&C Black, 2003.

Opoku, K. Asare. "Religion in Africa During the Colonial Era." In General History of Africa, Volume 7: Africa Under Colonial Domination, 1880-1935, edited by A. Adu Boahen, 508-538. Suffolk: James Currey, 1990.

Pearson, Patrick. "The Rehoboth Rebellion." In Working Papers in Southern African Sutdies, Volume 2, edited by P. Bonner, 31-51. Johannesburg: Ravan Press, 1981.

Ranger, T.O. "African Reaction to the Imposition of Colonial Rule in East and Central Africa." In The History and Politics of Colonialism in Africa, edited by L.H. Gann and P. Duignan, 293-324. Cambridge: Cambridge University Press, 1969.

Robinson, Ronald and John Gallagher. "The Partition of Africa.” In The New Cambridge Modern History, edited by F.H. Hinsley, 593-640. Cambridge: Cambirdge University Press, 1962.

Säve-Söderbergh, Bengt and Pekka Peltola, "The Scandinavian Anti-Apartheid Movement: International Solidarity in Action." In The Future We Chose: Emerging Perspectives on the Centenary of the ANC, edited by Busani Ngcaweni, 154-167. Pretoria: Africa Institute of South Africa, 2013.

Sellström, Tor. "Forerunners of a Popular Opinion." In Sweden and National Liberation in Southern Africa, Volume I: Formation of a Popular Opinion, 1950-1970, edited by Tor Sellström, 85-117. Uppsala: Nordic Africa Institute, 1999.

Silvester, Jeremy. "Beasts, Boundaries and Buildings: The Survival and Creation of Pastoral Economies in Southern Namibia." In Namibia Under South African Rule: Mobility \& 
Containment, 1915-1946, edited by Patricia Hayes, 95-116. Oxford: James Currey Publishers, 1998.

Silvester, Jeremy et al., “'Trees Never Meet:' Mobility and Containment: An Overview, 19151946." In Namibia Under South African Rule: Mobility \& Containment, 1915-1946, edited by Patricia Hayes, 3-50. Oxford: James Currey Publishers, 1998.

Skinner, Robert. "The Dynamics of Anti-Apartheid: International Solidarity, Human Rights and Decolonization." In Britain, France, and the Decolonization of Africa: Future Imperfect?, edited by Andrew W.M. Smith and Chris Jeppesen, 111-130. London: UCL Press, 2017.

Van Walraven, Klaas and Jon Abbink, "Rethinking Resistance in African History: An Introduction." In Rethinking Resistance: Revolt and Violence in African History, edited by Gerrit Jan Abbink, Mirjam De Brujin, and Klaas van Walraven, 1-40. Leiden: Brill Publishers, 2003.

Vinson, Robert. "Providential Design, American Negroes, and Garveyism in South Africa.” In From Toussaint to Tupac: The Black International Since the Age of Revolution, edited by Michael O. West, William G. Martin, and Fanon Che Wilkins, 130-154. Chapel Hill: University of North Carolina Press, 2009.

\section{Journal Articles}

Abasiatti, Monday B. "The Search for Independence: New World Blacks in Sierra Leone and Liberia, 1787-1847.” Journal of Black Studies 23, No. 1 (September, 1992): 107-116.

Anderson, Carol. 'International Conscience, the Cold War, and Apartheid: The NAACP's Alliance with the Reverend Michael Scott for South West Africa's Liberation, 19461951.” Journal of World History 19, No. 3 (September, 2008): 297-325.

Beck, Peter J. "The League of Nations and the Great Powers, 1936-1940." World Affairs 157, No. 4 (Spring, 1995): 175-189.

Bosman, Hendrik. “A Nama 'Exodus'?: A Postcolonial Reading of the Diaries of Hendrik Witbooi." Scriptura 108 (2011): 329-341.

Botha, Christo. "Internal Colonization and an Oppressed Minority? The Dynamics of Relations Between Germans and Afrikaners Against the Background of Constructing a Colonial State in Namibia, 1884-1990." Journal of Namibian Studies 2 (2007): 7-50.

Breckenridge, Keith. “'Money with Dignity': Migrants, Minelords and the Cultural Politics of the South African Gold Standard Crisis, 1920-33." Journal of African History 36, No. 2 (1995): 271-304. 
Calpin, G.H. "South Africa in Afrikaner Hands." Foreign Affairs 29, No. 3 (April, 1951): 417423.

Cleophas, Francois. "A Historical Exploration of Physical Education at the Wesley Teachers' Training School , Cape Town (1915-1966)," Southern African Review of Education: A Review of Comparative Education, History of Education and Educational Development 19, No. 1 (2013): 38-58.

Cobley, Alan Gregor. "'Far From Home:' The Origins and Significance of the Afro-Caribbean Community in South Africa to 1930." Journal of Southern African Studies 18, No. 2 (June, 1992): 349-370.

Coetzee, Daniel. "Fires and Feathers: Acculturation, Arson and the Jewish Community in Oudtshoorn, South Africa, 1914-1948.” Jewish History 19, No. 2 (2005): 143-187.

Cone, James H. "Black Theology in American Religion." Journal of the American Academy of Religion 53, No. 4 (December, 1985): 755-771.

Conforti, Joseph. "The Invention of the Great Awakening, 1795-1842." American Literature 26, No. 2 (1991): 99-118.

Cooper, Allan D. "The Institutionalization of Contract Labour in Namibia." Journal of Southern African Studies 25, No. 1 (March, 1999): 121-138.

Cross, Arthur Lyon. “The British Empire.” Current History 20 (April-September, 1924): 306309.

Crowder, Michael. "Tshekedi Khama, Smuts, and South West Africa." The Journal of Modern African Studies 25, No. 1 (March, 1987): 25-42.

Crozier, Andrew J. "The Establishment of the Mandates System, 1919-1925: Some Problems Created by the Paris Peace Conference." Journal of Contemporary History 14, No. 3 (July, 1979): 483-513.

Curry, George. "Woodrow Wilson, Jan Smuts, and the Versailles Settlement." The American Historical Review 66, No. 4 (July, 1961): 968-986.

Dedering, Tilman. "Petitioning Geneva: Transnational Aspects of Protest and Resistance in South West Africa/Namibia After the First World War." Journal of Southern African Studies 35, No. 4 (November, 2009): 785-801.

. "The Prophet's 'War Against Whites': Shepherd Stuurman in Namibia and South Africa, 1904-1907." Journal of African History 40, No. 1 (1999): 1-19.

Dickerson, Dennis C. "Liberation, Wesleyan Theology and Early African Methodism, 17661840." Wesley and Methodist Studies 3 (2011): 109-120. 
Du Bois, W.E.B. "Back to Africa.” The Century Magazine 105, No. 4 (February, 1923): 539549.

Du Toit, Andre. "No Chosen People: The Myth of the Calvinist Origins of Afrikaner Nationalism and Racial Ideology." American Historical Review 88, No. 4 (October, 1984): 920-952.

Dubow, Samuel. "Smuts, the United Nations, and the Rhetoric of Race and Rights." Journal of Contemporary History 43, No. 1 (January, 2008): 45-74.

Edgar, Robert. "Garveyism in Africa: Dr. Wellington and the American Movement in the Transkei." Ufahamu 6 (1976): 31-57.

Elkins, W.F. "A Source of Black Nationalism in the Caribbean: The Revolt of the British West Indies Regiment at Taranto Italy." Science \& Society 34, No. 1 (Spring, 1970): 99-103.

Erlmann, Veit. “'A Feeling of Prejudice.' Orpheus M. McAdoo and the Virginia Jubilee Singers in South Africa, 1890-1898." Journal of South African Studies 14, No. 3 (April, 1988): 331-350.

Fea, John. "In Search of Unity: Presbyterians in the Wake of the First Great Awakening." The Journal of Presbyterian History 86, No. 2 (Fall/Winter, 2008): 53-60.

Fenwick, C.G. "The 'Failure' of the League of Nations." The American Journal of International Law 30, No. 3 (July: 1936): 506-509.

Fierce, Milfred C. "Economic Aspects of the Marcus Garvey Movement." The Black Scholar 3, No. 7/8 (March-April, 1972): 50-61.

Garvey, Marcus. "The British West Indies in the Mirror of Civilization: History Making by Colonial Negroes." African Times and Orient Review 2 (March-October, 1913): 158-160.

Gelbman, Shamira M. and Jesse H. Rhodes. "Ideology Construction, Grassroots Mobilization, and Party Strategy in South Africa and the United States, 1934-1948." Polity 43, No. 2 (April, 2001): 154-178.

Gewald, Jan-Bart. “'I Was Afraid of Samuel, Therefore I Came to Sekgoma:' Herero Refugees and Patronage Politics in Ngamiland, Bechuanaland Protectorate, 1890-1914." Journal of African History 43, No. 2 (2002): 211-234.

. "Near Death in the Streets of Karibib: Famine, Migrant Labour, and the Coming of Ovambo to Central Namibia.” Journal of African History 44, No. 2 (2003): 211-239.

Gilchrist, Huntington. "Trusteeship and the Colonial System." Proceedings of the Academy of Political Science 22, No. 2 (January, 1947): 95-109. 
Giliomee, Hermann. "The Making of the Apartheid Plan, 1929-1948." Journal of Southern African Studies 29, No. 2 (June, 2003): 373-392.

Goodrich, Leland M. "From League of Nations to United Nations." International Organization 1, No. 1 (February, 1947): 3-21.

Gottschalk, K. "South African Labour Policy in Namibia, 1915-1975." South African Labour Bulletin 4, No. 1\&2 (January-February, 1978): 75-106.

Hardung, Christine. "God, the Warlord and the Way of the Ancestors: On the Intertwinement of Christianity and Ancestry in Hendrik Witbooi's Politico-Religious Mission of the 1800s (Southwest Africa)." Civilizations 63, No. 1\&2 (2014): 81-98.

Henshaw, Peter J. "Britain, South Africa and the Sterling Area: Gold Production, Capital Investment and Agricultural Markets, 1931-1961." Historical Journal 39, No. 1 (March, 1996): 197-223.

Johnstone, William C. "The San Francisco Conference." Pacific Affairs 18, No. 3 (September, 1945): 213-228.

Kammerer, Elise. "Uplift in Schools and the Church: Abolitionist Approaches to Free Black Education in Early National Philadelphia." Historical Social Research 42, No. 1 (2017): 299-319.

Kebonang, Boammaruri Bahumi. "The History of the Herero in Mahalapye, Central District: 1922-1984." Botswana Notes and Records 21 (1989): 43-60.

Kline, Benjamin. "The National Union of South African Students: A Case-Study of the Plight of Liberalism, 1924-77." The Journal of Modern African Studies 23, No. 1 (March, 1985): $139-145$.

Kössler, Reinhart. "From Reserve to Homeland: Local Identities and South African Policy in Southern Namibia." Journal of Southern African Studies 26, No. 3 (September, 2000): 447-462.

Landis, Elizabeth S. "South African Apartheid Legislation I: Fundamental Structures." The Yale Law Journal 71, No. 1 (November, 1961): 1-52.

Lang, Hartmut. "The Population Development of the Rehoboth Basters." Anthropos 93, No. 4/6 (1998): 381-391.

Lau, Briggite. "Conflict and Power in Nineteenth Century Namibia." Journal of African History 27, No. 1 (1986): 29-39. 
Lockert, Martin Cai. "Transplanting and Customizing Legal Systems: Lessons from Namibian Legal History." Richmond Journal of Global Law and Business 13, No. 2 (2014): 174216.

Logan, Rayford W. "German Acquisition of Southwest Africa." The Journal of Negro History 18, No. 4 (October, 1933): 369-395.

M'bayo, Tamba. "W.E.B. Du Bois, Marcus Garvey, and Pan-Africanism in Liberia, 1919-1924." The Historian 66, No. 1 (Spring, 2004): 19-44.

Mabin, Alan. "Comprehensive Segregation: The Origins of the Group Areas Act and Its planning Apparatuses.” Journal of Southern African Studies 18, No. 2 (June, 1992): 405-429.

Marx, Christoph. "The Ossewabrandwag as a Mass Movement, 1939-1941." Journal of Southern African Studies 20, No. 2 (June, 1994): 195-219.

Maylam, Paul. "Rhodes University: Colonialism, Segregation, and Apartheid, 1904-1970." African Sociological Review 9, No. 1 (2005): 14-22.

McDuffie, Erik S. "Black and Red: Liberation, the Cold War, and the Horne Thesis." Journal of African American History 96, No. 2 (Spring, 2011): 236-247.

Meyers, Jr., S.D. "The Permanent Mandates Commission and the Administration of Mandates." The Southwestern Political and Social Science Quarterly 11, No. 3 (December, 1930): 213-246.

Miescher, Giorgio. "Facing Barbarians: A Narrative of Spatial Segregation in Colonial Namibia." Journal of Southern African Studies 38, No. 4 (December, 2012): 769-786.

Morgan, David T. “John Wesley's Sojourn in Georgia Revisited.” The Georgia Historical Quarterly 64, No. 3 (Fall, 1980): 253-262.

O’Meara, Dan. "The Afrikaner Broederbond, 1927-1948: Class Vanguard of Afrikaner Nationalism.” Journal of Southern African Studies 3, No. 2 (April, 1977): 156-186.

Oosthuizen, G.J.J. "The Military Role of the Rehoboth Basters During the South African Invasion of German South West Africa, 1914-1915." South African Journal of Military Studies 28, No. 1 (1998): 91-110.

Raffo, Peter. "The Anglo-American Preliminary Negotiations for a League of Nations." Journal of Contemporary History 9, No. 4 (October, 1974): 153-176.

Schwirck, Harry. "Law's Violence and the Boundary Between Corporal Discipline and Physical Abuse in German South West Africa." Akron Law Review 36 (2002): 81-132. 
Scott, Michael, et al. “The South West Africa Story.” Africa Today 6, No. 6 (December, 1959): 4-10.

Shepperson, George. "Ethiopianism and African Nationalism." Phylon 14, No. 1 (1953): 9-18.

Skinner, Robert. "The Moral Foundations of British Anti-Apartheid Activism, 1946-1960." Journal of Southern African Studies 35, No. 2 (June, 2009): 399-416

Soule, Sarah A. "The Student Divestment Movement in the United States and Tactical Diffusion: The Shantytown Protest." Social Forces 75, No. 3 (March, 1997): 855-882.

Sotiropoulos, Karen. "James and Rose Aggrey and the Black Atlantic Gestations of African Nationalism." International Journal of African Historical Studies 53, No. 2 (2020): 239264.

Tanner, Benjamin Tucker. “The Present and Future.” Christian Recorder (4 January 1877).

Thörn, Håkan. "Solidarity Across Borders: The Transnational Anti-Apartheid Movement." Voluntas: International Journal of Voluntary and Nonprofit Organizations 17, No. 4 (December, 2006): 285-301.

Tjibeba, Hendrik Rudolph. "The AMEC Schism in Namibia, 1946.” Alternation 2 (2005): 329362.

Van den Berghe, Pierre L. "Miscegenation in South Africa." Cahiers d'Etudes Africaines 1, No. 4 (December, 1960): 68-84.

Van Wyk, Johan. "Afrikaans Language, Literature, and Identity." Journal of Social and Political Theory, No. 77 (May, 1991): 79-89.

Vinson, Robert. 'Sea Kaffirs:' American Negroes and the Gospel of Garveysim in Early Twentieth-Century Cape Town.' Journal of African History 47, No. 2 (2006): 281-303.

Wallace, Marion. ““'”Making Tradition:' Healing, History and Ethnic Identity Among the Otjiherero-Speakers in Namibia, c. 1850-1950.” Journal of Southern African Studies 29, No. 2 (June, 2003): 355-372.

Watkins IV, James T. "International Affairs: Democracy and International Organizations-The Experience of the League of Nations." The American Political Science Review 36, No. 6 (December: 1942): 1136-1141.

Webster, E.C. and Eddie Webster. "'Stay-Aways' and the Black Working Class: Evaluating a Strategy." Labour, Capital and Society 14, No. 1 (April, 1981): 10-38.

Weigend, Gido G. "Economic Activity Patterns in White Namibia." Geographical Review 75, No. 4 (October, 1985): 462-481. 
Werner, Wolfgang. “'Playing Soldiers:' The Truppenspieler Movement Among the Herero of Namibia, 1915 to ca. 1945." Journal of Southern African Studies 16, No. 3 (September 1990): 476-502.

Zaki, Hoda M. "From Montgomery to Tahrir Square: The Transnational Journeys of Nonviolence and Utopia.” Utopian Studies 26, No. 1 (2015): 203-219.

Zimmerman, Andrew. "Africa in Imperial and Transnational History: Multi-Sited Historiography and the Necessity of Theory." Journal of African History 54, No. 3 (November, 2013): 331-340.

Zuijdwiik, Antony J.M. “The International Court and South West Africa: Latest Phase.” Georgia Journal of International Comparative Law 3, No. 2 (1973): 323-343.

\section{$\underline{\text { Newspapers }}$}

Afro-American, 1959

Cape Times, 1959

Christian Recorder, 1883

Cleveland Call and Post, 1961

Daily Defender, 1959

Daily Dispatch, 1921

Die Burger, 1933

Die Vaderland, 1924

Negro World, 1922-1926

New Journal and Guide, 1951.

New York Amsterdam News, 1952-1959

New York Times, 1959

Philadelphia Tribune, 1947-1951

The Times, 1950-1959 
Windhoek Advertiser, 1959

Zuid-Afrikaan, 1874 